GEOLOGICAL SURVEY CIRCULAR 861

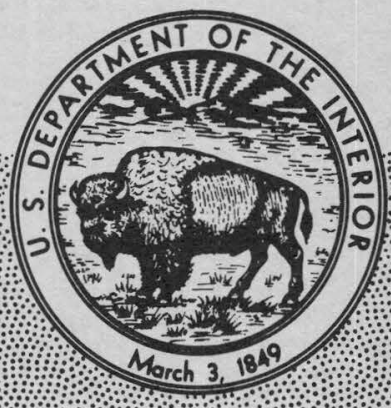

Geological Studies of the

COST Nos. G-1 and G-2 Wells,

United States North Atlantic

Outer Continental Shelf 

Geological Studies of the

COST Nos. G-1 and G-2 Wells,

United States North Atlantic

Outer Continental Shelf

By Peter A. Scholle and Chiye R. Wenkam, Editors

GEOLOGICAL SURVEY CIRCULAR 861 
United States Department of the Interior

JAMES G. WATT, Secretary

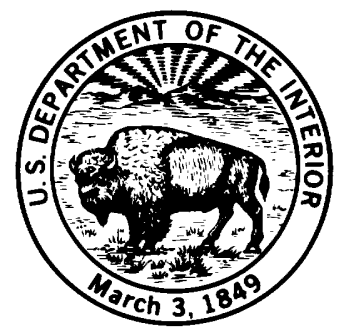

Geological Survey

Dallas L. Peck, Director 


\section{CONTENTS}

Page

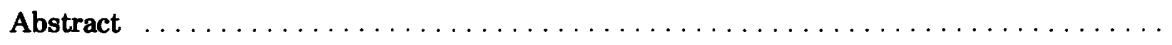

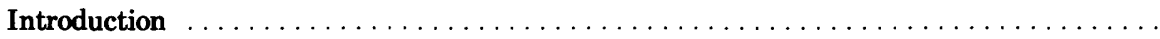

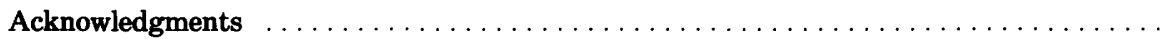

Geologic setting of the Georges Bank basin, by John S. Schlee and Kim D. Klitgord . . . . .

Lithology and petrography of COST Nos. G-1 and G-2 wells, by Michael A. Arthur . . . . . .

Calcareous nannofossil biostratigraphy and paleoenvironment of the COST Nos. G-1 and G-2 wells in the Georges Bank basin, by Page C. Valentine . . . . . . . . . . . . . . . . .

Foraminiferal and seismic stratigraphy, paleoenvironments, and depositional cycles in the Georges Bank basin, by C. Wylie Poag . . . . . . . . . . . . . . . . . . . . . . .

Significance of the Mesozoic carbonate bank-reef sequence for the petroleum geology of the Georges Bank basin, by Robert E. Mattick . . . . . . . . . . . . . . . . . . . . . . . .

Organic geochemistry of the Georges Bank basin COST Nos. G-1 and G-2 wells, by R. E. Miller, H. E. Lerch, G. E. Claypool, M. A. Smith, D. K. Owings, D. T. Ligon, and S. B. Eisner

Thermal history of the Georges Bank basin, by Michael A. Arthur . . . . . . . . . . . . . . . . Geophysical studies of the COST Nos. G-1 and G-2 wells, by David J. Taylor and R. C. Anderson

Basement structure, sedimentation, and tectonic history of the Georges Bank basin, by Kim D. Klitgord, John S. Schlee, and Karl Hinz . . . . . . . . . . . . . . . . . . . . .

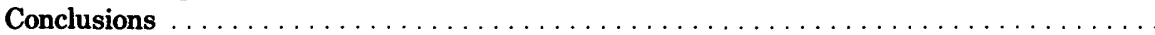

References cited

1

1

3

4

11

43

93

105

143

153

160

187

188

Figures 1-4. Maps showing:

1. Locations of Georges Bank and COST wells Nos. G-1 and

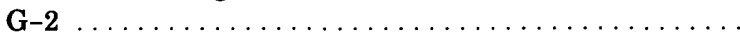

2. Locations of COST wells Nos. G-1 and G-2, USGS core hole 6001, and multichannel seismic reflection profiles $\ldots \ldots \ldots \ldots \ldots \ldots \ldots \ldots \ldots \ldots \ldots \ldots \ldots \ldots \ldots \ldots \ldots$

3. Isopachs of Upper Triassic and younger sedimentary rocks in the Georges Bank basin . . . . . . . . . . . . . . . .

4. Tectonics and structure of the Georges Bank area . . . . . . . 5-7. Charts showing:

5. Lithologic logs of COST Nos. G-1 and G-2 wells and the Nantucket Island well $\ldots \ldots \ldots \ldots \ldots \ldots \ldots$

6. Geophysical logs, lithology, and ages for the COST No. G-1 well $\ldots \ldots \ldots \ldots \ldots \ldots \ldots \ldots \ldots \ldots \ldots \ldots \ldots \ldots \ldots \ldots \ldots$

7. Correlation between rocks of COST Nos. G-1 and G-2 wells $\ldots \ldots \ldots \ldots \ldots \ldots \ldots \ldots \ldots \ldots$

8-9. Graphs for the COST No. G-1 well showing:

8. Porosity versus depth $\ldots \ldots \ldots \ldots \ldots \ldots \ldots \ldots$

9. Porosity versus permeability $\ldots \ldots \ldots \ldots \ldots \ldots \ldots \ldots$

10. Chart showing geophysical logs, lithology, and ages for the COST No

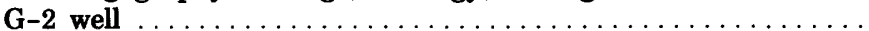


Figures 11-12. Graphs for the COST No. G-2 well showing:

11. Porosity versus depth $\ldots \ldots \ldots \ldots \ldots \ldots \ldots \ldots$

12. Porosity versus permeability

13-14. Charts showing calcareous nannofossil biostratigraphy and paleoenvironments in:

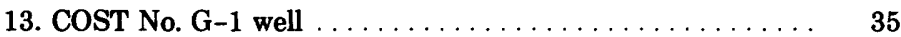

14. COST No. $\mathrm{G}-2$ well $\ldots \ldots \ldots \ldots \ldots \ldots \ldots \ldots \ldots \ldots$

15. Map of well and core sites and reflection profiles $\ldots \ldots \ldots \ldots \ldots \ldots \ldots$

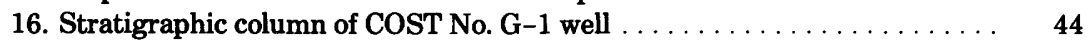

17. Geologic column of COST No. G-1 well $\ldots \ldots \ldots \ldots \ldots \ldots \ldots \ldots \ldots$

18. Diagram showing interpreted structure and stratigraphy along seismic

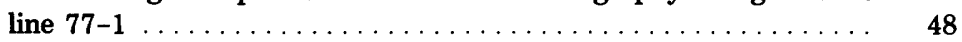

19. Stratigraphic column of COST No. G-2 well $\ldots \ldots \ldots \ldots \ldots \ldots \ldots \ldots$

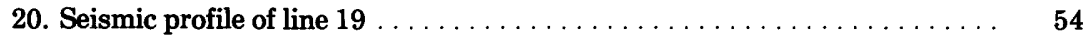

21. Diagram showing interpreted structure and stratigraphy along seismic

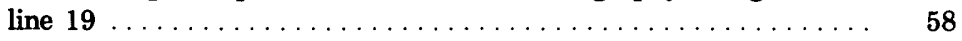

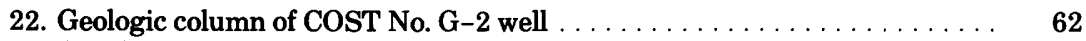

23. Graph showing sediment accumulation rates for the G-1, G-2, and other COST wells $\ldots \ldots \ldots \ldots \ldots \ldots \ldots \ldots \ldots \ldots$

24. Chart showing correlation between Shell Mohican I-100 and COST No.

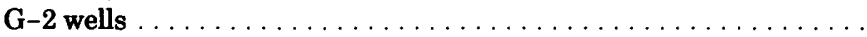

25. Diagram showing interpreted structure and stratigraphy along seismic

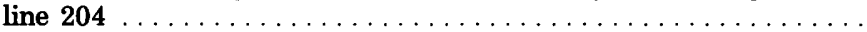

26. Geologic column of ASP corehole $18 \ldots \ldots \ldots \ldots \ldots \ldots \ldots \ldots$

27. Paleoenvironments of COST Nos. G-1 and G-2 wells, compared with relative sea level and global supercycles ......

28. Comparative stratigraphy of Georges Bank and the adjacent North American Basin . . . . . . . . . . . .

29. Map showing locations of CDP profiles on the northern and central U.S. Atlantic margin

30. Chart showing COST No. G-2 well data plotted alongside seismic data from profile 15

31-34. Parts of seismic profiles across the outer shelf and slope in the Georges Bank basin:

31. Seismic profile 1

32. Seismic profile 20

33. Seismic profile 8

34. Seismic profile 5

35. Part of seismic profile 22 across the Long Island platform

36. Diagrammatic sketch showing construction of continental shelf during the Jurassic

37. Map of shelf margin positions during Middle Jurassic, Late JurassicEarly Cretaceous, and present time $\ldots \ldots \ldots \ldots \ldots \ldots$ 10

38. Diagrammatic sketch of carbonate reef and bank facies . . . . . . . . $10 \AA$

39. Gas chromatograms of saturated paraffin-naphthene hydrocarbons in lignosulfonate and in an asphalt-like substance and a solid black hydrocarbon from the COST No. G-2 well

40-41. Charts summarizing organic-richness analyses of:

40. COST No. G-1 well

116

41. COST No. G-2 well

42-50. Gas chromatograms of saturated paraffin-naphthene hydrocarbons of:

42. Cretaceous rocks of the COST No. G-1 well . . . . . . . .

43. Upper Jurassic through Tertiary rocks of the COST No. G-2 well

44. Upper Jurassic rocks of the COST No. G-1 well . . . . . .

45. Upper and Middle Jurassic rocks down to $12,540 \mathrm{ft}$ $(3,822 \mathrm{~m})$ in the COST No. G-2 well . . . . . . . . . .

46. Middle Jurassic rocks from 13,500 to $17,540 \mathrm{ft}(4,115$ to $5,346 \mathrm{~m}$ ) in the COST No. G-2 well 
Figures 42-50. Gas chromatograms-Continued

47. Middle Jurassic rocks from 17,470 to $20,010 \mathrm{ft}(5,325$ to $6,099 \mathrm{~m}$ ) in the COST No. G-2 well . . . . . . . . .

48. Middle Jurassic rocks from 20,480 to $21,540 \mathrm{ft}(6,242$ to $5,565 \mathrm{~m}$ ) in the COST No. G-2 well . . . . . . . . .

49. Middle Jurassic rocks from above $13,000 \mathrm{ft}(3,962 \mathrm{~m})$ in the COST No. G-1 well . . . . . . . . . . . . . . . . . . .

50. Middle Jurassic, Lower Jurassic, and Cambrian rocks of the COST No. G-1 well . . . . . . . . . . . . . .

51-57. Summary profiles showing:

51. Types of organic matter versus depth in COST No. G-1 well $\ldots \ldots \ldots \ldots \ldots \ldots \ldots \ldots \ldots \ldots \ldots \ldots \ldots$

52. $C_{1}$ to $C_{7}$ hydrocarbon analyses for COST No. G-1 well . . . .

53. Maturation versus depth in COST No. G-1 well . . . . . .

54. Types of organic matter versus depth in COST No. G-2

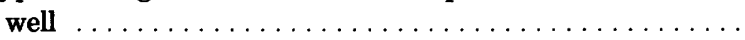

55. Maturation versus depth in COST No. G-2 well . . . . . . .

56. $\mathrm{C}_{1}$ to $\mathrm{C}_{7}$ hydrocarbon analyses for COST No. G-2 well ....

57. Temperature, vitrinite reflectance, and thermal alteration indices versus depth for COST Nos. G-1 and G-2 wells ...

58-59. Charts showing:

58. History of basement subsidence and sedimentation at COST No. G-2 well . . . . . . . . . . . . . . . . .

59. Model of thermal history at COST No. G-2 site . . . . . . .

60-62. Graphs showing vitrinite reflectance for samples from COST Nos. G-1 and G-2 wells:

60. Versus thermal alteration indices . . . . . . . . . 151

61. Versus present temperature gradient (linear plot) . . . . . . 151

62. Versus present temperature gradient (semilog plot) . . . . . 152

63-64. Graphs of average velocity and root-mean-square velocity versus twoway traveltime for:

63. COST No. G-1 well

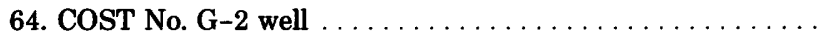

65. Graph showing two-way traveltime as a function of depth for COST Nos. G-1 and G-2 wells . . . . . . . . . . . . . . . . .

66. Map showing locations of seismic lines 77-1 and 77-2 . . . . . . .

67. Seismic profile of line 77-1 and synthetic seismogram from COST No. G-1 well $\ldots \ldots \ldots \ldots \ldots \ldots \ldots \ldots \ldots \ldots \ldots \ldots \ldots \ldots \ldots \ldots \ldots \ldots \ldots$

68. Seismic profile of line 77-2 and synthetic seismogram from COST No. G-2 well

69-70. Charts showing core log data and synthetic seismograms versus time for:

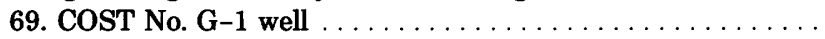

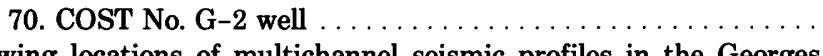

71. Map showing locations of multichannel seismic profiles in the Georges Bank region . . . . . . . . . . . . . . . . . .

72. Cross-section and magnetic anomaly profile for the Georges Bank basin based on CDP line 19

73-74. Maps of the Georges Bank area showing:

73. Magnetic anomalies . . . . . . . . . . . . . . . 164

74. Depth to magnetic basement . . . . . . . . . . 166

75. Magnetic anomaly and seismic reflection profiles across Step \#1 . . . . . 167

76. Maps of gravity anomalies in the Georges Bank area . . . . . . . . . 168

77. Two-dimensional gravity model for CDP line $5 \ldots \ldots \ldots \ldots \ldots \ldots$

78-79. Seismic profiles of:

78. Part of CDP line 19 showing landward-dipping reflectors . . 171

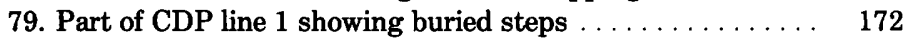

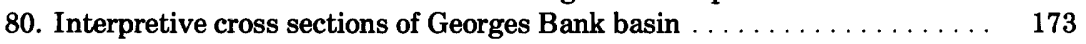

81-86. Seismic profiles of parts of:

81. CDP line 5 across prerift or synrift basins . . . . . . 175

82. CDP line 1 across the Jurassic shelf edge showing buried benches 
Figures 81-86. Seismic profiles-Continued

83. CDP line 5 across the Jurassic shelf edge . . . . . . . .

84. BGR line 209 across central Georges Bank basin (with interpretation)

85. Line 20 across west central Georges Bank basin (with inter-

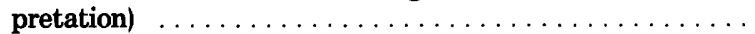

86. Line 18 between shot points 1360 and $1900 \ldots \ldots \ldots \ldots . \ldots 180$

87-88. Isopach maps of the Georges Bank basin showing:

87. Synrift deposits

88. Cretaceous and Jurassic postrift sediments . . . . . . . .

89. Paleogeographic maps showing Early and Middle Jurassic reconstruc-

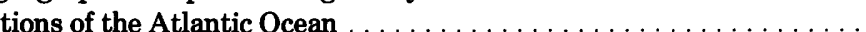

Plate 1. Thin-section photomicrographs of carbonate rocks from COST No. G-2 well .... 2. Thin-section photomicrographs of clastic rocks from COST Nos. G-1 and G-2 wells

\section{TABLES}

Table 1. Lithologic descriptions of COST No. G-1 well cuttings used for organic geochemical analyses $\ldots \ldots \ldots \ldots \ldots \ldots \ldots \ldots \ldots \ldots \ldots \ldots \ldots \ldots \ldots \ldots$

2. Lithologic descriptions of COST No. G-2 well cuttings used for organic

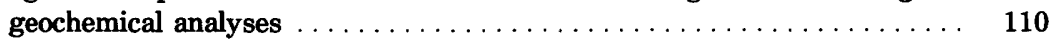

3. Organic carbon and extractable organic matter, COST No. G-1 well . . . . . . . 112

4. Organic carbon and extractable organic matter, COST No. G-2 well . . . . . . . 113

5. Organic carbon and thermal analysis data for samples from the COST No. G-1

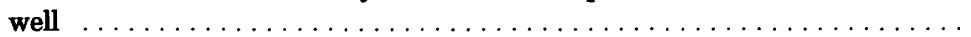

6. Organic carbon and thermal analysis data for samples from the COST No. G-2

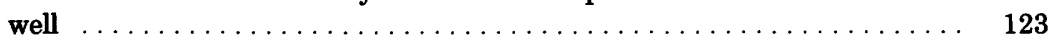

7. Geothermal gradients on passive continental margins $\ldots \ldots \ldots \ldots \ldots \ldots$

8. Data used and results of calculations of basin subsidence at the COST No. G-2

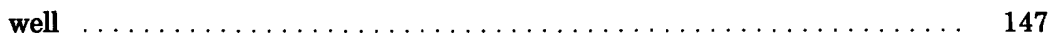

9. Time-temperature indices for representative horizons in the COST No. G-2 well . . 150

Use of brand names in this report is for descriptive purposes only and does not constitute endorsement by the U.S. Geological Survey. 


\title{
Geological Studies of the COST Nos. G-1 and G-2 Wells, United States North Atlantic Outer Continental Shelf
}

\author{
By Peter A. Scholle and Chiye R. Wenkam, Editors
}

\begin{abstract}
The COST Nos. G-1 and G-2 wells (fig. 1) are the second and third deep stratigraphic test wells drilled in the North Atlantic Outer Continental Shelf of the United States. COST No. G-1 was drilled in the Georges Bank basin to a total depth of $16,071 \mathrm{ft}(4,898 \mathrm{~m})$. G-1 bottomed in phyllite, slate, and metaquartzite overlain by weakly metamorphosed dolomite, all of Cambrian age. From approximately 15,600 to $12,400 \mathrm{ft}(4,755$ to $3,780 \mathrm{~m})$ the strata are Upper Triassic(?), Lower Jurassic(?), and Middle Jurassic, predominantly red shales, sandstones, and conglomerates. Thin, gray Middle Jurassic beds of shale, sandstone, limestone, and dolomite occur from 12,400 to $9,900 \mathrm{ft}(3,780$ to $3,018 \mathrm{~m})$. From 9,900 to $1,030 \mathrm{ft}(3,018$ to $314 \mathrm{~m})$ are coarse-grained unconsolidated sands and loosely cemented sandstones, with beds of gray

poor reservoir rocks. Above $10,000 \mathrm{ft}(3,000 \mathrm{~m})$ the porosities range from 16 to 39 percent, and the permeabilities are highly variable, ranging from 0.01 to $7,100 \mathrm{mD}$.

Measurements of vitrinite reflectance, color alteration of visible organic matter, and various organic geochenical properties suggest that the Tertiary and Cretaceous strata of the COST Nos. G-1 and G-2 are not prospective for oil and gas. These sediments have not been buried deeply enough for hydrocarbon generation, and the kerogen and ertractable organic matter in them are thermally immature. However, the Jurassic rocks at the G-1 site do contain smal amounts of thermally mature gas-prone kerogens. The Jura-sic rocks at COST No. G-2 are also gas-prone and are slightly richer in organic carbon and total extractable hydrocarbons than the G-1 rocks, but both sites have only poor to fair oil and gas source-rock potential.
\end{abstract} shale, lignite, and coal. The microfossils indicate the rocks are Upper Jurassic from $10,100 \mathrm{ft}(3,078 \mathrm{~m})$ up to $5,400 \mathrm{ft}$ $(1,646 \mathrm{~m})$ and Cretaceous from that depth to $1,030 \mathrm{ft}(314 \mathrm{~m})$. No younger or shallower rocks were recovered in the drilling at the COST No. G-1 site, but an Eocene limestone is inferred to be disconformable over Santonian strata. The Jurassic strata of the COST No. G-1 well were deposited in shallow marine, marginal marine, and nonmarine environments, which changed to a dominantly shallow marine but still nearshore environment in the Cretaceous.

The COST No. G-2 well was drilled 42 statute miles (68 km) east of the G-1 site, still within the Georges Bank basin, to a depth of $21,874 \mathrm{ft}(6,667 \mathrm{~m})$. The bottom $40 \mathrm{ft}(12 \mathrm{~m})$ of salt and anhydrite is overlain by approximately $7,000 \mathrm{ft}(2,134 \mathrm{~m})$ of Upper Triassic(?), Lower Jurassic(?) and Middle Jurassic dolomite, limestone, and interbedded anhydrite from 21,830 to $13,615 \mathrm{ft}(6,654$ to $4,153 \mathrm{~m})$. From 13,500 to $9,700 \mathrm{ft}(4,115$ to $2,957 \mathrm{~m}$ ) are Middle Jurassic limestones with interbedded sandstone. From 9,700 to $4,000 \mathrm{ft}(2,957$ to $1,219 \mathrm{~m})$ are Upper Jurassic and Cretaceous interbedded sandstones and limestones overlain by Upper Cretaceous unconsolidated sands, sandstones, and calcareous shales. Pliocene, Miocene, Eocene, and Paleocene strata are disconformable over Santonian rocks; uppermost Cretaceous rocks are missing at this site, as at G-1. The sedimentary rocks in the COST No. G-2 well were deposited in somewhat deeper water, farther away from sources of terrigenous material than those at $G-1$, but still in marginal marine to shallow marine environments.

Data from geophysical logs and examination of conventional cores, well-cuttings, and sidewall cores show that below $10,000 \mathrm{ft}(3,048 \mathrm{~m})$, the strata in both wells have moderate porosities $(<20$ percent) and low to moderate permeabilities $(<100 \mathrm{mD})$ and are thus considered adequate to

\section{INTRODUCTION}

Until the COST Nos. G-1 and G-2 wells were drilled, the only subsurface information on the geology of Georges Bank came from multichannel seismic lines and extrapolation of the stratigraphy from wells on the Scotian shelf, eastern Canada. Although rocks recovered from the COST Nos. G-1 and G-2 wells are earily correlated with named formations on the Scotian shelf, there are differences in the development of the sedimentary section on Georges Bank that affect petroleum source and reservoir poten tials.

The COST No. G-1 well was drilled between April 6 and July 26, 1976, by Ocean Prcduction Company acting as operator for 31 participating companies. The well was drilled by the somisubmersible rig SEDCO-J in $157 \mathrm{ft}(48 \mathrm{~m})$ of water in the southwestern part of the Georges Bark basin at lat $40^{\circ} 55^{\prime} 52.108^{\prime \prime}$ N., long $68^{\circ} 18^{\prime} 18.917^{\prime \prime}$ W. A total section of $16,071 \mathrm{ft}(4,898 \mathrm{~m})$ was drilled.

The COST No. G-2 well was drilled 42 statute miles $(68 \mathrm{~km})$ east of COST No. G-1 between January 6 and August 30, 1977, by Oceæn Production Company acting as operator for 19 participating companies. G-2 was drilled ir $272 \mathrm{ft}$ 


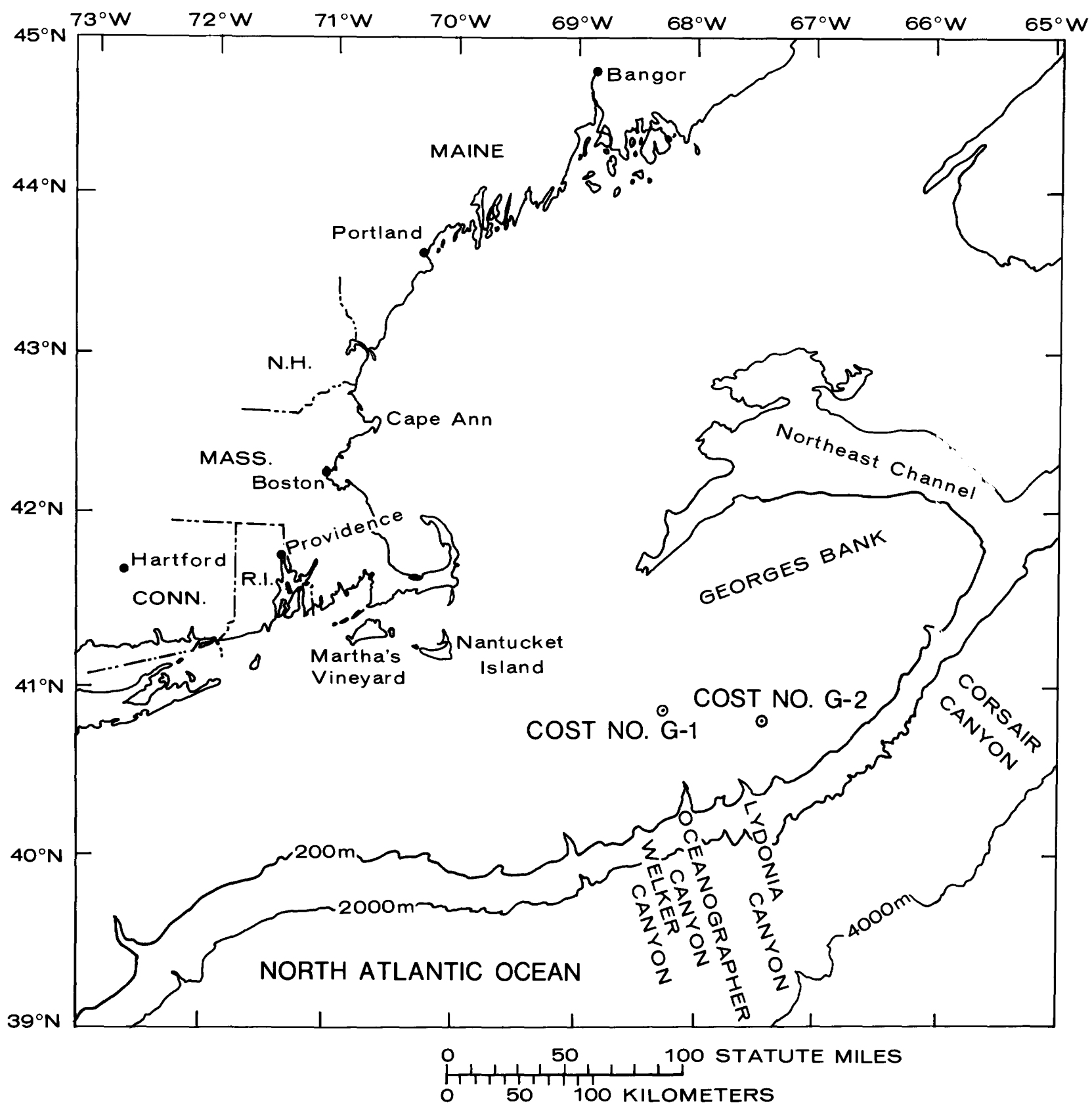

FIGURE 1.-Locations of the COST No. G-1 and G-2 wells in the Georges Bank area. Bathymetric contours in meters.

$(83 \mathrm{~m})$ of water by the semisubmersible rig Ocean Victory at lat $40^{\circ} 50^{\prime} 11.410^{\prime} \mathrm{N}$., long $67^{\circ} 30^{\prime} 29.784^{\prime}$ W. A total section of $21,874 \mathrm{ft}$ $(6,667 \mathrm{~m})$ was drilled.

This circular summarizes data from previously released reports (Amato and Bebout, 1980, for the COST No. G-1 well and Amato and Simonis, 1980 for the COST No. G-2 well) and contains new data on the lithology, stratigraphy, geochemistry, geology, and geophysics of these two wells from studies by the USGS.

The data presented in the nine different papers were obtained from well cuttings, sidewall cores, conventional cores, electric logs, core descriptions, and multichannel seismic profiles. All well depths are relative to the Kelly Pushing (KB), 
which was $98 \mathrm{ft}(30 \mathrm{~m})$ above mean sea level and $255 \mathrm{ft}(78 \mathrm{~m})$ above the sea floor for the COST No. G-1 well; KB was $79 \mathrm{ft}(24 \mathrm{~m})$ above mean sea level and $351 \mathrm{ft}(107 \mathrm{~m})$ above the sea floor for the COST No. G-2 well. Units are reported in the primary system of measurement with English or metric equivalents in parentheses. Thus, for depths in the wells, primary units are in feet (with meters as a secondary conversion); for seismic lines, primary measurements are in kilometers or meters (with miles or feet as a secondary conversion). Only the primary units are reported to a valid number of significant figures.

The COST Nos. G-1 and G-2 wells were drilled intentionally off structure in blocks 79 and 141 respectively of North Atlantic Outer Continental Shelf tracts that were part of Lease Sale No. 42, held December 18, 1979. The public disclosure provision of Federal leasing regulations stipulates that the U.S. Geological Survey release all geologic data from deep stratigraphic test wells 60 days after a lease is granted within 50 nautical miles of such a test site. Blocks adjacent to 79 and 141 were leased on February 1, 1980.

\section{ACKNOWLEDGMENTS}

Piero Ascoli kindly provided samples from the Scotian basin. Raymond Hall and Doris Lcr prepared the foraminifera samples. Invaluable technical assistance was provided by Patty Forrestal, Thomas McClurg, Jane Murphy, Jo Ann Taylor, and Jeffery Zwinakis. The authors benofitted from discussions with F. G. Adinolfi, William Dillon, Jurgen Fritsch, John Grow, Leigh Price, D. R. Shaw, and E. K. Simonis. Elazar Uchupi and J. M. Hunt of Woods Hole Oceanographic Institution and C. Wylie Poag, Kim Klitgord, John Schlee, and Elizabeth Winget read various chapters and provided valuable suggestions. O. W. Girard, Jr., and W. H. Butler review $\supseteq d$ the entire manuscript; their comments and singgestions are much appreciated. 


\title{
Geologic Setting of the Georges Bank Barin
}

\author{
John S. Schlee and Kim D. Klitgord
}

The COST No. G-1 and G-2 wells were drilled on Georges Bank (fig 2), a broad, shallow platform that extends east of New England. The Georges Bank $\left(25,862 \mathrm{mi}^{2} ; 67,000 \mathrm{~km}^{2}\right)$ is part of the U.S. Continental Shelf and is flanked on the north by the Gulf of Maine (Uchupi, 1966). The northern one-third of Georges Bank is covered by shallow, north-trending sand shoals, and the remainder is a flat-floored shelf covered with rippled sand. The southern side is indented by several submarine canyons and numerous smaller gullies and ravines. Two shellow channels separate the bank from the other parts of the shelf. To the west, the Great South Channel separates Georges Bank from Nantucket Shoals, and to the east, the Northeast $\mathrm{C}^{*}$ annel $(722 \mathrm{ft}$; $220 \mathrm{~m}$ deep) provides a deep-water entrance to the Gulf of Maine.

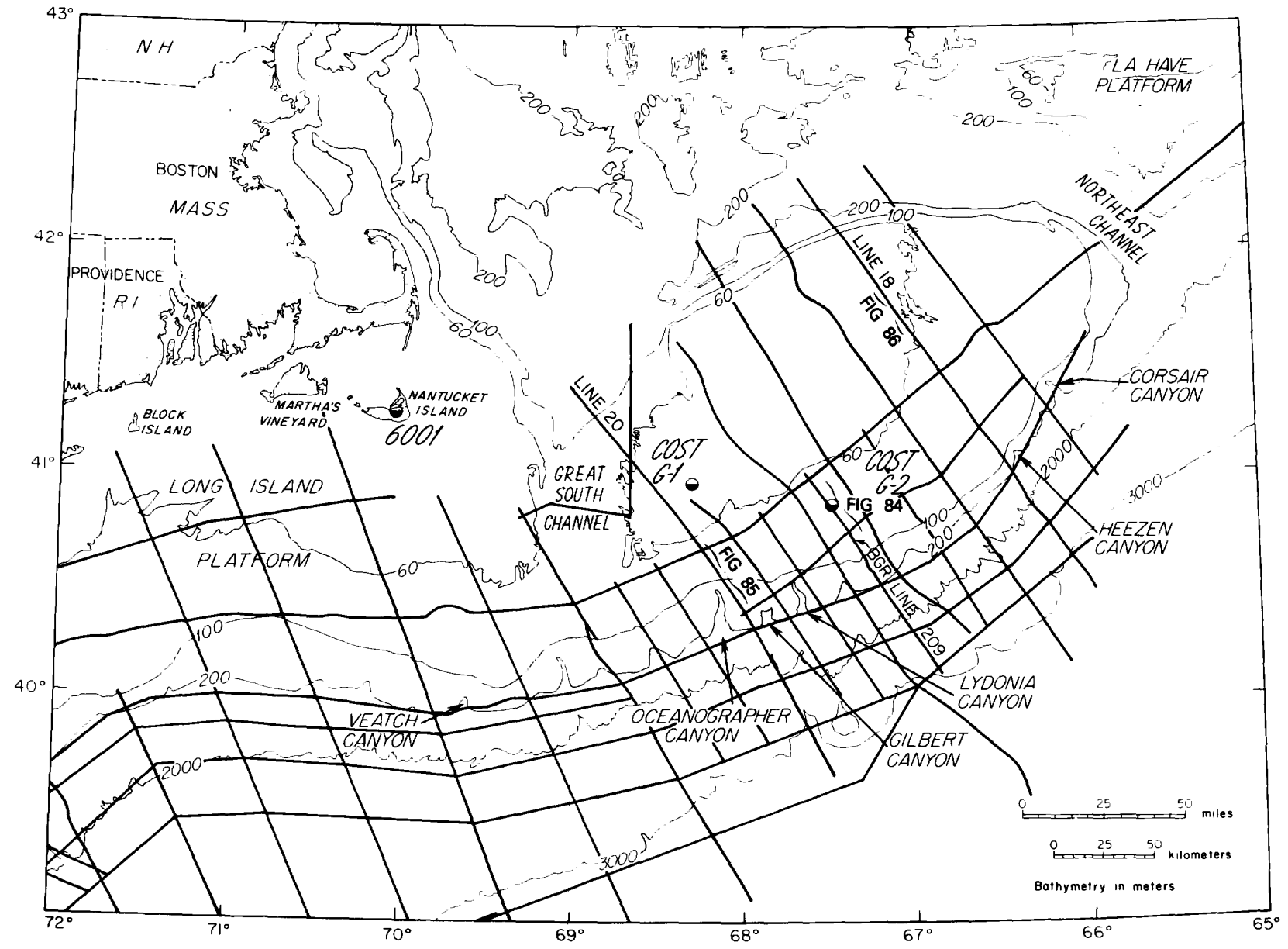

FIgURE 2.-Locations of COST wells Nos. G-1 and G-2, USGS core hole 6001, and the grid of multichannel seismic reflection profiles. Bathymetry is in meters. Bracketed sections of seismic profiles are shown in Klitgord and otr ors (this volume). 


\section{STRUCTURE}

Georges Bank is underlain by a wedge of Triassic and younger sedimentary rock that overlies rifted basement (fig. 3). Tectonically, Georges Bank is a collection of smaller subbasins, some of which are linear grabens that trend northeast (Ballard, 1975; Austin and others, 1980; Mattick and others, 1981; Schlee and Jansa, 1981). Collectively they are termed the Georges Bank basin, and structurally they are situated between the LaHave platform to the northwest, the Gulf of Maine platform to the north, and the Long Island platform to the west.

The basement deepens seaward from the platforms in a series of steps (half-grabens) (fig. 4). A western set of steps seaward of the Long Island platform can be clearly distinguished as small grabens or subbasins, while an eastern set of steps southeast of the Gulf of Maine platform, can be defined as grabens or subbasins on only some of the seismic lines (figs. 3 and 4). Steps \#1 and \#3 (fig. 4), landward of the Yarmouth arch, appear to be grabens or half-grabens. Seismic reflection and magnetic data show that these structures trend N. $30^{\circ} \mathrm{E}$. There is a high magnetic anomaly along the edge of each graben and a low magnetic anomaly over the graben. The most landward of these grabens (step \#1, fig. 4) is a shallow structure that lies along the northern edge of Georges Bank (Ballard and Uchupi, 1972; Oldale and others, 1974). An unconformity over the top of these grabens corresponds approximately to the breakup unconformity of Falvey (1974), and it increases in depth from less than $0.5 \mathrm{~km}(0.3 \mathrm{mi})$ below sea level adjacent to the Gulf of Maine to more than $10 \mathrm{~km}(6.2 \mathrm{mi})$ beneath the center of the bank. Beneath the southeastern part of the bank is a broad subbasin that lies between the Yarmouth arch and the East Coast magnetic anomaly (ECMA) (fig. 4); this subbasin extends to the northeast where it

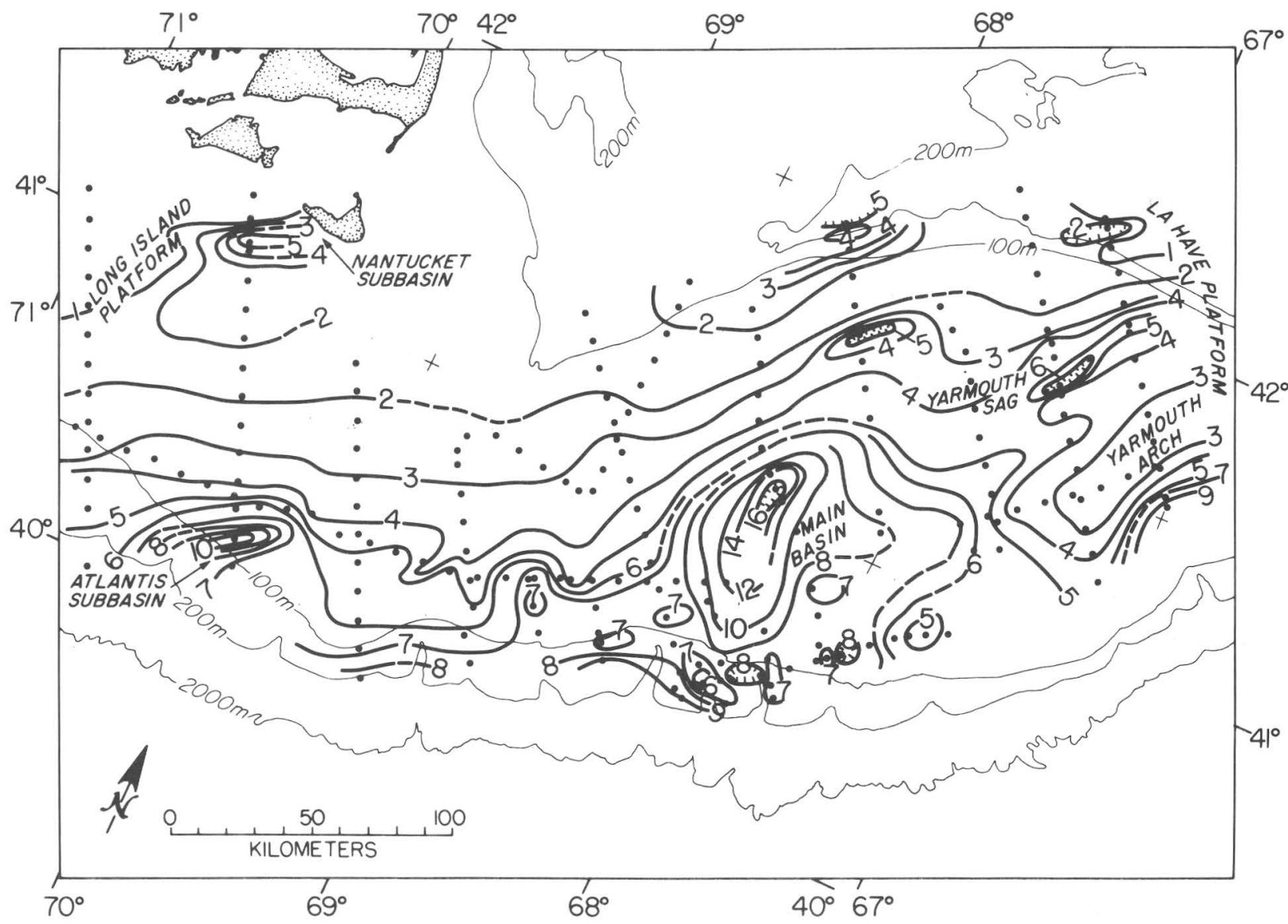

FIGURE 3.-Isopach map of Upper Triassic and younger sedimentary rocks in the Georges Bank basin. Thicknesses in kilometers. Dots show where thickness was measured along the profiles and indicate the control. 


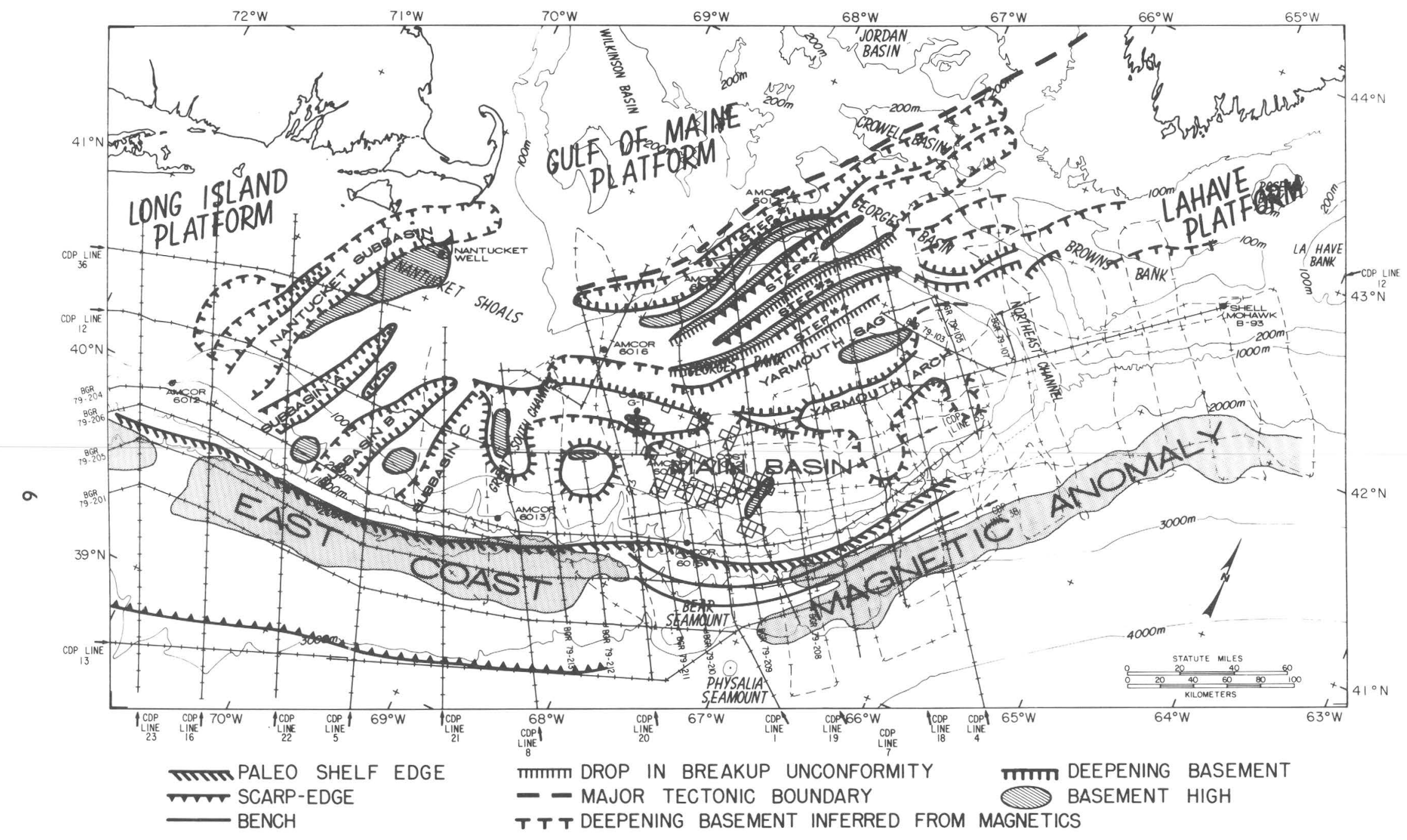

Figure 4.-Tectonic-structural map of the Georges Bank region showing the stable, shallow platforms of Paleozoic continental crust, areas of block- faulted crust (subbasins or grabens), steps (half-grabens) and intervening basement highs, and Jurassic oceanic crust. The East Coast magnetic anomaly and the ancient Jurassic shelf edge are indicated at the boundary between the block-faulted zone and the oceanic crust. The New England Seamounts and possible intrusive volcanic bodies are also shown. The lines indicate locations of multichannel seismic profiles. 
merges with the Scotian Basin beneath the Canadian shelf. This subbasin may be situated on volcanic crust of Early Jurassic age formed in the area of continental separation; the other subbasins or steps are probably underlain by continental crust of Triassic age or older. The COST No. G-1 well was drilled into a small structural high that may be the southwestward extension of the Yarmouth arch and the COST No. G-2 well was drilled into the southeasternmost subbasin, mentioned above.

The New England Seamount chain intersects the Georges Bank region near lat $40^{\circ}$ N., long $68^{\circ} \mathrm{W}$., where there is a major gap in the ECMA. Bear Seamount is located at this intersection and its low magnetic dipole signature may mask the continuity of the ECMA across this gap. Within the Georges Bank basin, three buried seamounts or intrusive bodies are inferred to be present from distinctive magnetic anomaly patterns. All three are just landward of the ECMA and have high oval-shaped magnetic anomalies associated with them. Two of these bodies are located near the shelf edge just west of the Great South Channel (about lat $40^{\circ} \mathrm{N}$., long $70^{\circ} \mathrm{W}$.) within the zone of subbasins formed by grabens. The third and largest body is within the southernmost subbasin about $12.4 \mathrm{mi}(20 \mathrm{~km})$ southeast of the COST No. G-2 well (lat $40^{\circ} 8^{\prime}$ N., long $67^{\circ} 20^{\prime}$ W.).

Acoustic basement has a variable character across the margin and only in certain places does it correspond with the base of the sediment fill. The rugged acoustic basement along the northern edge of Georges Bank probably reflects the Paleozoic metamorphic and igneous rocks along the edges of the grabens. Seismic penetration is variable in this area and also farther south where the grabens are at greater depths. The basement surface on some seismic profiles coincides with inferred Paleozoic rocks, and on other profiles the surface of the dipping rift sediments (post-rift unconformity) forms acoustic basement. Acoustic basement between the Yarmouth arch and the ECMA has a shingled aspect that probably represents the top of a carbonate bank complex near the Jurassic shelf edge. Oceanic crust can be traced landward almost to the ECMA on most of the seismic profiles off Georges Bank (Schlee and others, 1976; Grow and others, 1979; Klitgord and Grow, 1980). In this region acoustic basement is a series of small hyperbolic echoes that are typical of oceanic crust.

\section{STRATIGRAPHY}

Rocks recovered from COST No. G-1 and G-2 wells provide information on the deep stratigraphy of Georges Bank (fig. 5). The G-1 well (Lachance, 1980; Scholle, Krivoy, and Hennessy, 1980) encountered a sequence mostly of sandstone, shale, and siltstone of Late Jurassic to early Tertiary age, that overlies sandstone, anhydrite, and dolomite of Early Jurassic(?) to Middle Jurassic age. The well penetrated Paleozoi? metamorphosed dolomite, quartzite, and phyllite at $15,600 \mathrm{ft}(4,755 \mathrm{~m})$ and reached a total depth of $16,071 \mathrm{ft}(4,898 \mathrm{~m})$. At the COST No. G-2 site, $42 \mathrm{mi}(67 \mathrm{~km})$ to the east, the total section is thicker and contains more carbonate roc's and evaporites. The Upper Jurassic through T rrtiary section contains abundant sandstone and mudstone and also has thick beds of limestone toward the base of the Cretaceous. These limestones are probably equivalent to strata sampled in THeezen Canyon by Ryan and others (1978) in 4,100 to $4,265 \mathrm{ft}(1,250$ to $1,300 \mathrm{~m})$ of water, ar? Neocomian in age, and were deposited in a reefal environment. Oxfordian and older rocks are dominantly limestone, dolomite, and anhydrite in the COST No. G-2 hole; the well bottomed in salt at $21,874 \mathrm{ft}(7,612 \mathrm{~m})$ total depth (Simonis, 1980; Scholle, Schwab, and Krivoy, 1980). The other deep $(1,686 \mathrm{ft} ; 514 \mathrm{~m})$ hole, AMCOR \#6001, was drilled on Nantucket Island (Folger and others, 1978). This well encountered poorly conso'idated nonmarine and marine shelf silts and clay of Late Cretaceous and Tertiary age and bottoned in weathered basalt approximately $183 \pm 8 \mathrm{~m} . \mathrm{y}$. old (Early Jurassic).

Several trends are shown by these three holes. The Cretaceous strata apparently thicken and become finer grained and more calcareous toward the COST No. G-2 well. The Jurassic rocks are present only at the Georges Bank sites, where they thicken and become more carbonate-rich to the southeast over the main part of the basin. Multichannel seismic reflection profiles not only here, but off the mid-Atlantic states as well, support inferences that the rocks become more carbonate- and evaporite-rich with age and toward the southeast (Schlee and others, 1976, 1979; Mattick and others, 1981). The carl onate rocks are inferred to extend beneath the cortinental slope where they form a platform front and interfinger with deep-sea deposits of equivalent age 


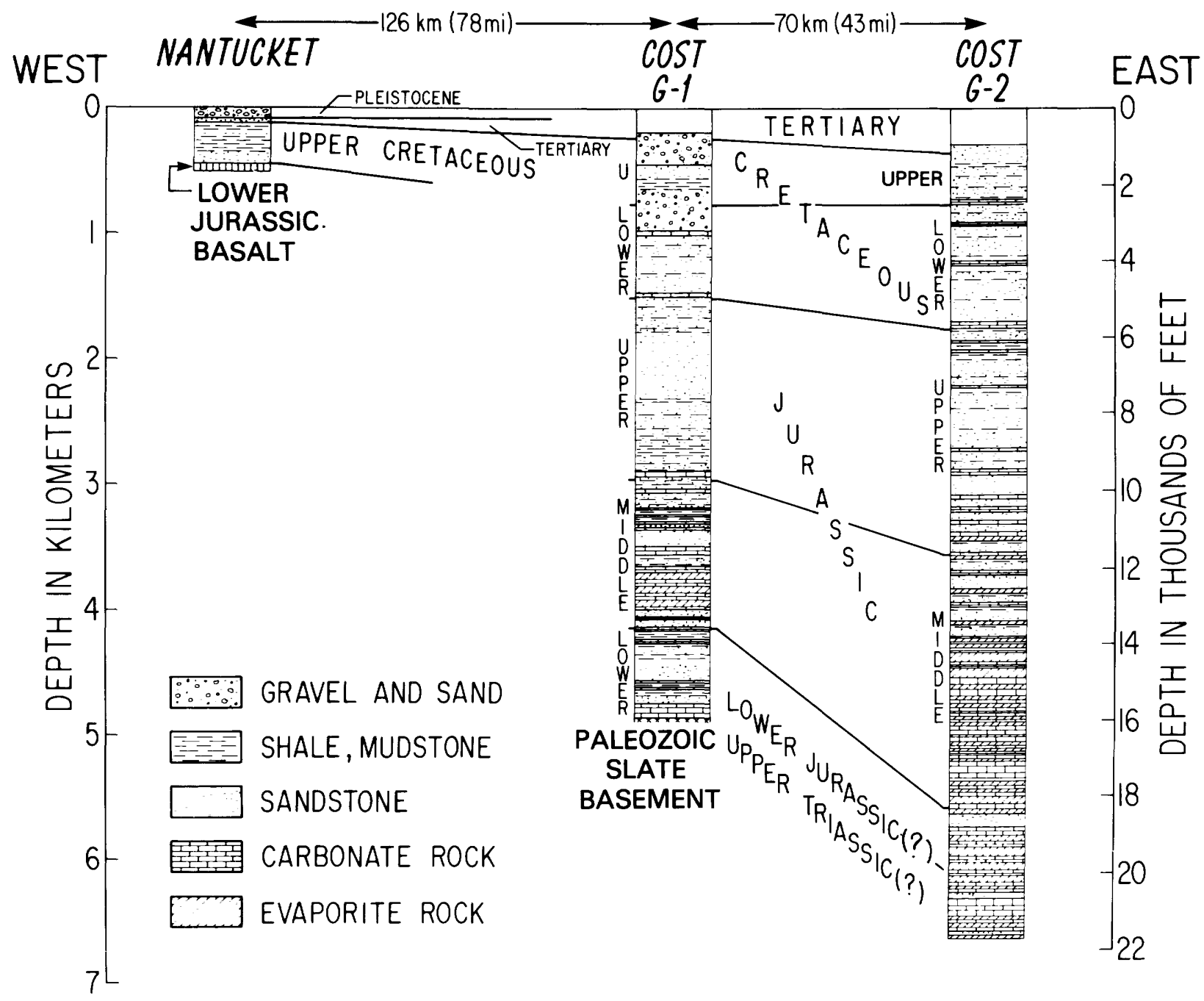

Figure 5.-Lithologic logs of the COST Nos. G-1 and G-2 wells and the Nantucket Island well (6001). Mod: fied from Scholle, Krivoy, and Hennessy (1980); Scholle, Schwab, and Krivoy (1980); Judkins and others (1980); and Folger ard others (1978).

in the North Atlantic oceanic basin (Schlee and others, 1979). Our multichannel seismic profiles reveal that the seaward edge of the carbonate platform may be expressed as a distinct break in slope (Schlee and others, 1979, fig. 6) or as a shingled offlap of reflectors that are presumably part of a seaward prograding platform (Schlee and others, 1979, fig. 7). Most of the profiles show a sharp break in slope, but line 20 (figs. 2 and 4) in the western part of the basin reveals a distinctly prograded arrangement of reflectors that appears to indicate that the shelf was built seaward $12.4 \mathrm{mi}(20 \mathrm{~km})$ over older slope and rise deposits.

These two types of shelf edge are paleoenvironmentally significant because they are related to the amount of deltaic outbuilding that occurs on the shelf. Eliuk (1978, fig. 8) has coscribed these two types of seismic signatures for profiles collected across the Scotian shelf northeast of Georges Bank. He has tied the gepphysical data to the lithologic logs from sever' ${ }^{\prime}$ holes drilled there and found that the prograde $t$ arrangement of reflectors resulted from the formation of a large delta complex nearby that caused the carbonate platform to build seaward of earlier ones. Away from the influence of the delta, a welldefined "platform type" shelf break bounds the seaward side of the Scotian cark nnate buildup (Abenaki Formation). Eliuk drew analogies to the present-day Great Bahama Bank for the platform type of shelf edge and to the Pleistocene deposits of the Florida Bay for the prograding deltaic 
type. The Great Bahama Bank is a sharply defined carbonate platform of bioclastic detritus far from an area of terrigenous input. The Florida Keys deposits show the input of deltaic sand on the ancestral platform near Miami.

The Georges Bank seismic stratigraphy has been tied to Canadian offshore stratigraphy by Wade (1977) and Austin and others (1980) using multichannel seismic reflection profiles. Judkins and others (1980) and Poag (this volume) have tentatively correlated formations and key markers from the stratigraphic section set up for the Scotian margin by McIver (1972), Jansa and Wade (1975a), Gradstein and others (1975), Ascoli (1976), and Given (1977). This correlation was facilitated by presence on Georges Bank of the same major vertical and lateral stratigraphic trends that are seen on the Scotian margin. These trends are an increase in carbonates and evaporites with age in outer shelf holes and an increase in clastic sedimentary rocks, particularly for the Jurassic, at inshore sites.

The oldest rock sequences encountered in the COST Nos. G-1 and G-2 wells are probably equivalent to the Iroquois Formation (dolomite and anhydrite), the Argo Formation (salt at very bottom of the COST No. G-2 well), and the Mohican Formation (sequence of sandstones and shale of early Middle Jurassic to Early Jurassic age present in the COST No. G-1 well). The limestones of Middle Jurassic to earliest Cretaceous age beneath Georges Bank probably correlate with the Abenaki Formation platform limestone and shale sequence on the Scotian shelf: both there and under Georges Bank, the Abenaki Formation or its equivalent changes inshore to the Mic Mac and Mohawk Formations and consists of shelf sandstone, shale and thinbedded limestone.

Utilizing Canadian outer shelf holes, Judkins and others $(1980, \mathrm{pl} .3)$ have also correlated formations of Cretaceous age with the lithologic units of the COST Nos. G-1 and G-2 wells. Their correlations show a major change in the total thickness of the Jurassic and Cretaceous rocks from the central Scotian basin to the area of COST G-wells. The Cretaceous rocks are thinner on Georges Bank $(4,100-4,600 \mathrm{ft} ; 1,250-1,400 \mathrm{~m})$ than in the northern Scotian basin $(9,000-10,000 \mathrm{ft} ; 2,750-3,050 \mathrm{~m})$, but equivalent age units in the Jurassic System (from the top of the Jurassic to the top of the Argo Formation) are thicker beneath the Georges Bank basin: $15,995 \mathrm{ft}$ vs. $5,496 \mathrm{ft}(4,875 \mathrm{~m}$ vs. $1,675 \mathrm{~m})$.

This difference in thickness, which is seen in both G-1 and G-2 holes, is a result of rapid sediment accumulation during the Jurassic and lower rates after that time. At least $15,995 \mathrm{ft}(4,875 \mathrm{~m})$ of rock accumulated during the first $54 \mathrm{~m} . \mathrm{y}$. of basin development at the COST No. G-2 well, whereas only $5,742 \mathrm{ft}(1,750 \mathrm{~m})$ of sediment accumulated in the last $141 \mathrm{~m} . y$., and 79 percent of that accumulated during the Cretaceous (14165 m.y. B.P.). The overall trend is similar to that shown by Poag (1980b, fig. 28) for the CONT No. B-2 and No. B-3 wells in the Baltimore Cinnyon trough on the outer continental shelf.

\section{SUMMARY}

The Georges Bank basin is similar in tretonic setting and sedimentary fill to other basins along eastern North America (Schlee and Jansa, 1981; Grow and Sheridan, 1981). Like the Srotian margin, it was built over a complexly faulted basement whose continued movement during the early stages of basin development probally influenced sedimentary facies and thickness (Klitgord and others, this volume; Eliuk, 1978). The deepest, most restricted part of the basin may contain as much as $26,250 \mathrm{ft}(8.6 \mathrm{rm})$ of Lower Jurassic and older nonmarine clastic rocks and evaporite deposits. Both COST wells anpear to have penetrated a part of this sequence. $M^{\text {Middle }}$ and Upper Jurassic nonmarine clastic rocks and marine carbonate and evaporitic rocks 0 to $13,100 \mathrm{ft}(0$ to $4 \mathrm{~km})$ thick were the initial deposits in the subsidence phase of basin derelopment and signify a transition to an oper -shelf environment. Buildup of the carbonate rocks probably started on elevated basement l'ncks and eventually formed a massive platform that covered much of the southern half of the basin. In the western part of the basin, the platform appears to have prograded seaward $12.4 \mathrm{mi}(20 \mathrm{~km})$, perhaps in response to deltaic sedimentation. During the Cretaceous, transgressive and ragressive marine and nonmarine clastic sedimentary rocks and thin limestone buried the earlier platform as the broad pattern of basin subsidence continued at a diminished rate. The Cenozoin Era was marked by periodic cutback of the continental slope and an even slower rate of sediment accumulation on the bank. As in other eastern 
North American basins, the interval of basin development spans the Late Triassic(?) to the present. The Georges Bank basin like others has accumulated more than $32,800 \mathrm{ft}(10 \mathrm{~km})$ of sediment in several subbasins, and it shows the change from early rift deposits to a complex carbonate buildup during the early subsidence phase, and later burial by sand, silt, and clay as sea level reached its maximum in the Late Cretaceous and early Tertiary. 


\title{
Lithology and Petrography of the COST Nos. G-1 and G-2 Wells
}

\author{
By Michael A. Arthur
}

The following generalized lithologic descriptions for the sedimentary rocks recovered in the COST Nos. G-1 and G-2 wells in the Georges Bank basin are based on initial descriptions of core materials prepared by the Ocean Production Company and on subsequent studies by Lachance (1980) for the G-1 well and Simonis (1980) for the G-2 well. In addition, selected cuttings and thin sections of cuttings from 142 intervals in the G-1 well and 81 intervals in the G-2 well (an average of 10 cuttings per section) have been examined for this study. These observations have been supplemented by descriptions of thin sections of conventional and sidewall cores provided by Core Laboratories, Inc., because the cuttings are inadequate for a complete description of the lithofacies in a well. A total of 190 sections of sidewall cores were described for the G-1 well and 131 sections of sidewall cores were studies for the G-2 well. The boundaries of lithologic units are based on all available lithologic descriptions and data from geophysical logs.

The descriptions of lithology and petrography are given from the bottom of each well to the top in order to facilitate interpretation of the succession of sedimentary environments. All depths are given in feet (meters) below the Kelly Bushing. Ages of lithologic units are based on determinations given in Valentine (this volume) and Poag (this volume).

\section{DESCRIPTION OF COST NO. G-1 SEQUENCE}

The COST No. G-1 (fig. 6) sequence is informally divided in this paper into four major lithologic units (fig. 7), which are further divided on the basis of minor lithologic changes. These lithologies are discussed stratigraphically from bottom to top in the well.

\section{UNIT 4 (16,071-15,650 FT; 4,898-4,770 M) PALEOZIC(?) BASEMENT}

The COST No. G-1 well bottomed in black, fissile, graphitic slate, schist, and phyllite (550-450 m.y. old, on the basis of K/Ar dating techniques; Steinkraus, 1980). The material is highly fractured and the fractures are filled with sparry dolomite or calcite and a fibrous sericitic mica. The rock is carbonaceous and consists of foliated quartz and dolomite (including is lated rhombs), euhedral pyrite, and sericite. Seccndary overgrowths were detected on many nuartz grains. About $20 \mathrm{ft}(6 \mathrm{~m})$ of this low-grade metamorphic basement rock was recovered in a conventional core (Core 6) from the bottom of the hole. The average dip of these strata appears to be about $25^{\circ}$, and the cutting samples in ticate there is another $50 \mathrm{ft}(15 \mathrm{~m})$ of schist anc' slate above this core. An additional $400 \mathrm{ft}(122 \mathrm{~m})$ of dolomite and sandy, argillaceous dolomite that overlies the schistose rocks has also apparently been metamorphosed because much of the dolomitic rock is highly recrystallized and sericitic. The dolomitic rocks are dense, light to dark gray, unfossiliferous, and range from clean to argillaceous, silty, and sandy. Much of the dolonite is micritic and has no discernible original sedimentary structures, but sparry patches and veins are common; some samples exhibit intense recrystallization. Angular quartz and pyrite are common, and some anhydrite-filled voids occur. 


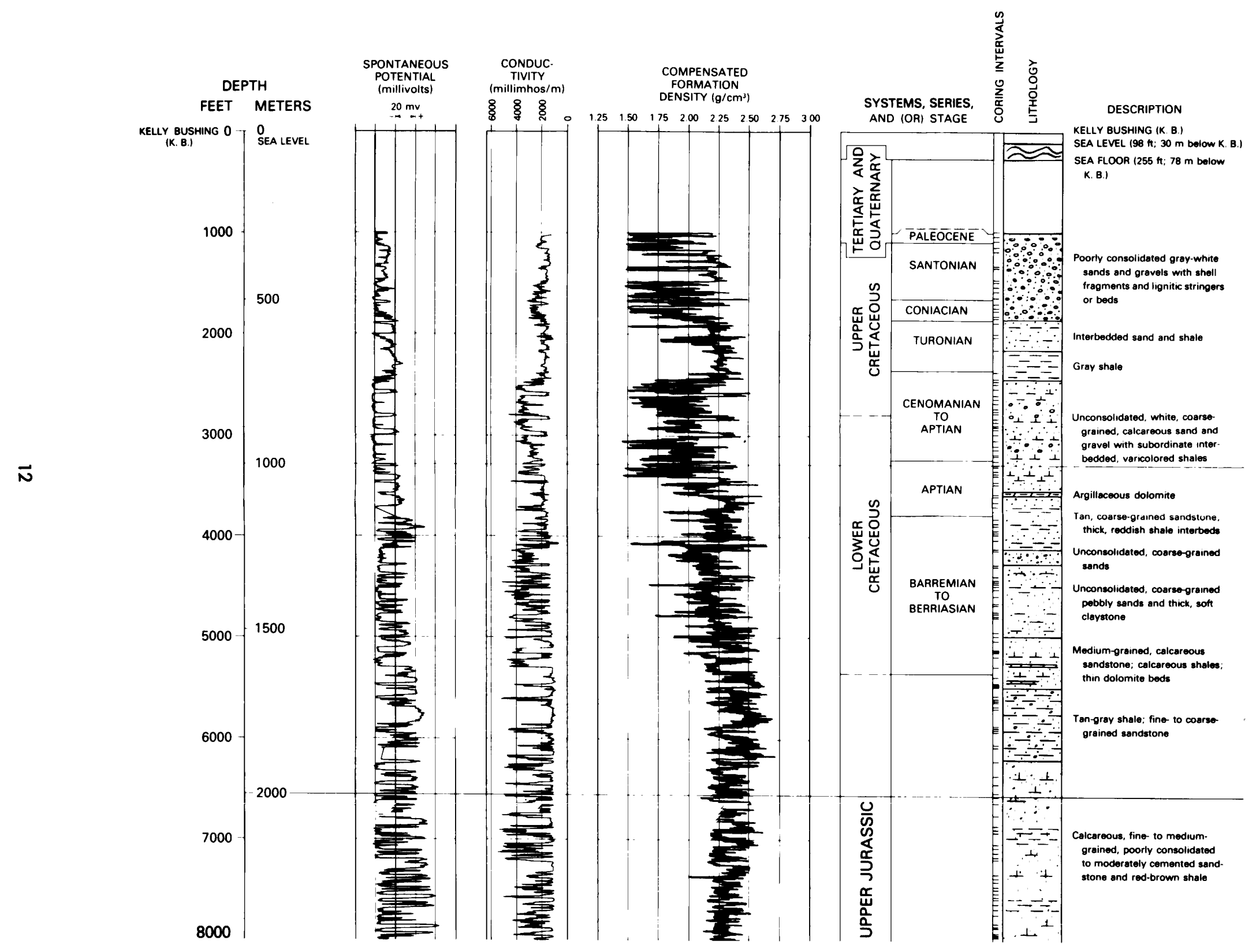




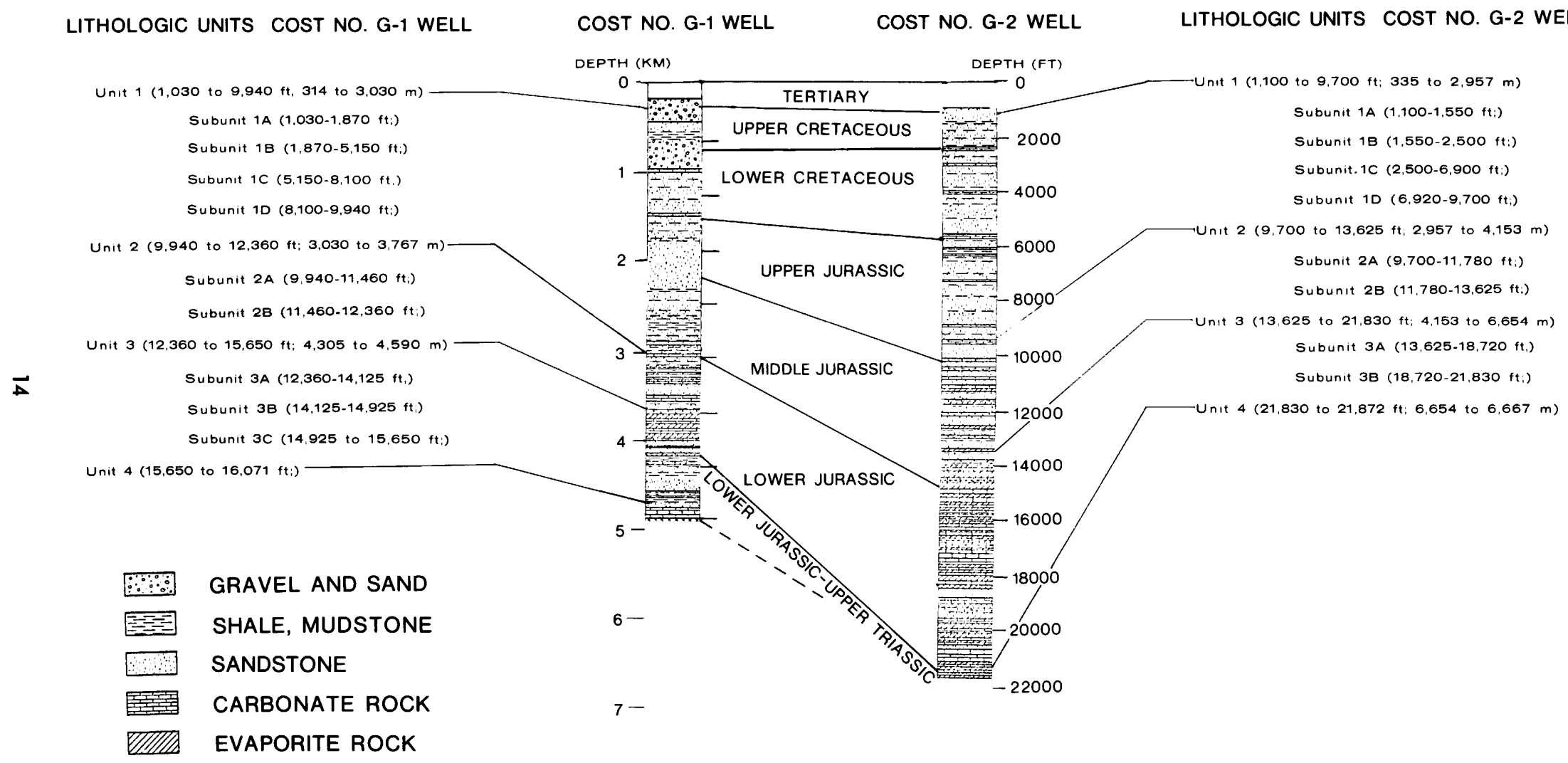

FIGURE 7.-Lithologic correlation between rocks from the COST Nos. G-1 and G-2 wells. 
Unit 3 consists of varying proportions of sandstone, conglomerate, shale, dolomite, and anhydrite with minor amounts of limestone. It has arbitrarily been divided into 3 parts: subunit $3 \mathrm{C}$ consists of sandstone, conglomerate, conglomeratic sandstone, shale, and minor limestone; subunit $3 B$ is composed of shale, sandy shale, sandstone, and thin interbedded dolomite and anhydrite layers; and in subunit $3 \mathrm{~A}$ dolomite and anhydrite prevail and have variable amounts of interbedded sandstone and shale.

SUBUNIT 3C (15,650-14,925 FT; 4,770-4,549 M)

The dolomite of unit 4 is overlain by $150 \mathrm{ft}$ $(46 \mathrm{~m})$ of pink to red, coarse- to very coarsegrained sandstones and interbedded red-brown shales with traces of lignite. Above this interval is about $350 \mathrm{ft}(107 \mathrm{~m})$ of similar rocks containing beds of light- to medium-gray limestone and dolomite. The proportion of conglomerate and conglomeratic sandstone increases upsection, and the uppermost $225 \mathrm{ft}(69 \mathrm{~m})$ consists of red to redpink conglomerate, conglomeratic sandstone, sandstone, and subordinate amounts of shale.

The sandstones range in composition from lithic arenites to quartz wackes and arenites, which range from poorly to well sorted. Subangular to angular quartz predominates in most samples with minor amounts of metamorphic rock fragments $(<15 \%)$, potassium feldspar $(<5 \%)$, and plagioclase $(<1 \%)$. Many of the feldspars are highly altered to clay minerals (sericite and kaolinite). The low porosity of these sandstones is probably due to compaction and formation of carbonate-clay-iron mineral cements. Dolomite is the most common cement and occurs as irregular patches, replacements of framework grains, and as isolated rhombs. Ferruginous clay matrix cements are also common.

Most of these sediments appear to have been deposited in a nonmarine to marginal marine environment. The limestones in the middle of subunit $3 \mathrm{C}$ are medium to light gray and slightly argillaceous, and commonly contain pellets, mollusk fragments, and dolomite as isolated rhombs or patches and as zones of replacement of limestone. The limestones appear to have no primary or secondary porosity. Anhydrite occurs locally as blebs and nodules in shale and in a few beds of chickenwire structure.

SUBUNIT 3B $(14,925-14,125$ FT; 4,549-4,305 M)

This subunit consists largely of interbedded red-brown to dark-gray shale and fine- to me liumgrained sandstone. Some sandstone beds ar? conglomeratic, and dolomite beds and anh.rdrite nodules and beds occur locally. The sandstones have little or no porosity and are similar in composition and texture, but are generally not as coarse grained as those of subunit $3 \mathrm{C}$. Suburit $3 \mathrm{~B}$ appears to have been deposited in a nonmarine to highly restricted marginal marine (sabkah-type) environment.

\section{SUBUNIT 3A $(14,125-12,360 \mathrm{FT} ; 4,305-3,767 \mathrm{M})$}

Subunit 3A is composed largely of dolomite and anhydrite and has lesser amounts of sandstone and shale. The lower $800 \mathrm{ft}(244 \mathrm{~m})$ of subunit $3 \mathrm{~A}$, which is transitional to $3 \mathrm{~B}$, consists largely of pink to red fine- to medium-grained sandstone and dark-gray to red-brown shale interbedded with buff to dark-gray dolomite and anhydrite. The shale and dolomite contain varying amounts of anhydrite as blebs, pore fillings and nodules. Dolomite beds become more abundant towards the top of 3A. The upper $965 \mathrm{ft}(294 \mathrm{~m})$ of subunit $3 \mathrm{~A}$ consists almost entirely of bruff to light- to dark-gray dolomite and interbedded thin, white to gray anhydrite layers.

The sandstones in the lower part of the unit range from feldspathic lithic wacke to lithic arenite and from feldspathic quartzarenite to wacke. Most sandstones are fine to medium grained (grains are angular to subangular', but some coarse-grained sandstone and cong] mematic (mainly granitic, based on descriptions of cores) sandstone is present. Quartz is the dominant mineral, ranging from 5 to 20 percent in the samples examined. Plagioclase and microcline equal about one-half the total feldspar in some samples, but potassium feldspars are the most common. Rock fragments vary in abundancs, and many are difficult to identify because of their similarity to the framework grains. Granitic rock fragments are the most common and usually compose 5 to 10 percent of the framework grains. Fine-grained schistose and slaty fragments and 
reworked carbonate and mudstone rock fragments are also present. Some of the sandstones contain up to 20 percent of clay-hematite matrix. Dolomite, siderite, and anhydrite cements and pore fillings commonly occur in the same sample. Quartz overgrowths are also quite common and result in sandstones with a tight, interlocking, or sutured fabric. Cementation and compaction have reduced porosity to less than 5 percent. Framework feldspars and those in granitic rock fragments are commonly altered to sericitic clay and kaolinite, but dolomite and anhydrite replacements of feldspar have eliminated most of the secondary porosity that may have resulted from the alteration.

The sedimentary sequence in subunit $3 \mathrm{~A}$ records a change in depositional environment from fluctuating restricted marine and nonmarine at the base to largely restricted marine and shallow marine in the upper part. The dolomites in the upper part of the subunit are primarily micritic, but may exhibit patchy recrystallization. Veins or fractures are also filled with sparry dolomite, and anhydrite vein and pore fillings and nodules are also common. In a few samples, micritic dolomite exhibits a relict pelletal texture, and there are ghosts of replaced ostracod and mollusk fragments in other samples. Algal laminations are also present in some dolomite-anhydrite intervals. The dolomites are probably mostly primary, but dolomite replacement of original intertidal to subtidal carbonate mud probably also occurred.

\footnotetext{
UNIT 2 (12,360-9,940 FT; 3,767-3,030 M) LOWER JURASSIC (LOWER PLIENSBACHIAR) TO MIDDLE JURASSIC (BAJOCIAN)
}

The lower boundary of unit 2 represents a sharp lithologic change (also seen in the geophysical logs) from the dolomite-anhydrite interval of subunit $3 \mathrm{~A}$ to predominantly sandstone and shale with some interbedded dolomite and limestone. Two subunits are defined: subunit 2B $(12,360-11,460 \mathrm{ft} ; 3,767-3,493 \mathrm{~m})$ comprises interbedded fine- to medium-grained sandstone and shale with some interbedded dolomite and limestone; subunit 2A (11,460-9,940 ft; 3,493$3,030 \mathrm{~m}$ ) consists of interbedded limestone and dolomitic limestone, shale, and some siltstone to fine-grained sandstone. Predominantly carbonate and predominantly clastic intervals seem to alternate or intertongue on the order of thousands of feet (several hundreds of meters) in both subunits.

SUBUNIT $2 B(12,360-11,460 \mathrm{FT} ; 3,767-3,493 \mathrm{M})$

Subunit 2B contains interbedded thin- to thickbedded, tan to pink or red, very fine- to mediumgrained sandstone and gray to red-brown, somewhat silty or sandy shale. Thin beds of dense, buff to light-gray micritic dolomite and limestone also occur locally, and a relative' $\epsilon^{\prime}$ thick interval of dolomite and limestone occurr between 11,900 and $11,975 \mathrm{ft}(3,627$ and $3,650 \mathrm{~m})$. A few thin lignitic or coaly beds are also prosent.

The carbonate intervals are micritic; limestone and dolomite occur together as interbedded or interlaminated strata and dolomite as a limestone replacement. These carbonate units are argillaceous, silty, or sandy, and are usually closely associated with clastic rocks. All gradations from silty and sandy carbonate rocks to dolomite- and calcite-cemented siltstone and sandstone are present. Anhydrite as rare laminae or blebs was noted in association with the carbonate rocks in subunit 2B. A few slightly fossiliferous (mollusk debris), pelletal carbonate mudstones were noted, but most beds are dense, micritic, and unfossiliferous. Little or no primary or se condary porosity appears to exist at these depths in the well.

Sandstones and siltstones are similar in composition and texture to those ir unit 3 , and are predominantly very fine-grain $? d$ to mediumgrained feldspathic quartz wackes or feldspathic lithic wackes. Clay-hematite cements are very common, and in some samples secondary quartz overgrowths are visible. Most sandstones and siltstones, including the more pc orly sorted ones, are cemented with dolomite, siderite, or calcite. Porosity is usually less than 5 parcent.

\section{SUBUNIT 2A (11,460-9,940 FT; 3,493-3,030 M)}

This subunit consists largely of interbedded buff to gray limestone and dolomite; tan to pink siltstone; fine-grained sandstone; and red-brown, green, and gray shale. It is distinguished from subunit $2 \mathrm{~B}$ by the predominance of carbonate rocks, particularly in the lower $300 \mathrm{ft}(91 \mathrm{~m})$ and 
the uppermost $150 \mathrm{ft}(46 \mathrm{~m})$. Limestone is more abundant than dolomite, and shale and sandy shale are the most common clastic rocks. Beds of lignite or coal occur locally.

The limestones are argillaceous and usually contain less than 10 percent fine sand- or siltsized quartz. Most carbonate intervals are pyritic. Micritic textures are common, particularly in the lower part of this subunit, but pelletal calcareous mudstones also occur. Dolomite is common in the middle part of the unit in association with minor anhydrite pore fillings in the dominantly micritic dolomite. The uppermost limestone strata are much more fossiliferous: they contain fragments of mollusks, ostracods, benthic foraminifers, and echinoderms (crinoids). In addition, pellets and oolites are common constituents. Textures and compositions vary from pelletal calcareous mudstone to pellet-oolite packstone and fossiliferous calcareous packstone. The limestones have little primary or secondary porosity; sparry calcite or dolomite spar fills most void spaces, and micrite has apparently undergone patchy recrystallization to sparry calcite. There is little compaction or breakage evident in the constituents of packstones and grainstones, which suggests that cementation occurred early in the history of the carbonates of this subunit.

The siltstones and sandstones are similar in composition (feldspathic wacke to feldspathic quartz wacke and subordinate arenites) and texture to those of $2 \mathrm{~B}$, and have relatively poor reservoir characteristics.

The lithology of unit 2 records the transition from the prolonged restricted marine sabkah and tidal-flat conditions of subunit $3 \mathrm{~A}$ to more open shallow marine (subtidal-intertidal) conditions in the lowest part, to alternating nonmarine and shallow marine, ard back to shallow marine conditions at the top in lignitic, oolitic, pelletal, and fossiliferous limestone.

UNIT 1 (9,940-1,030 FT; 3,030-314 M) MIDDLE JURASSIC (BAJOCIAN(?)) TO UPPER CRETACEOUS (SANTONIAN)

The base of unit 1 is marked by the sudden disappearance of the fossiliferous limestone of subunit 2A. Lithologic unit 1 contains mostly pebbly sandstone and shale, but has some lignite or coal beds and minor amounts of limestcne and dolomite. The abundance, coarseness, ant composition of the sands change through the rection, and four lithologic subunits are defined on the basis of these changes. Subunit 1D consists of interbedded, thick-bedded, tan to red-browr sandstone and shale and minor thin limestone beds. Subunit 1C contains more tan to red-brorn and gray thin-bedded and pebbly sandstone sandstone with fewer shale interbeds than subunit 1D, and some interbedded coal. Subunit $1 B$ is composed of coarse- to very coarse-grained, commonly pebbly sand and lesser amounts of bedded gray shale, lignite, marlstone, limeston?, and dolomite. Subunit 1A consists almost entirely of pebbly, fossiliferous, glauconitic, poorly consolidated quartz sand.

\section{SUBUNIT ID $(9,940-8,100 \mathrm{FT} ; 3,030-2,469 \mathrm{M})$}

This subunit is made up of light-gray to tan, pink, and light red, fine- to coarse-grained, mostly poorly to moderately sorted sandstone interbedded with red to red-brown and tan to gray micaceous silty shale and shale. Coal is fairly abundant in the sequence, and there are a few thin, light-gray to buff, micritic, argillaceous limestone beds.

The sandstone beds range from lightly cemented to poorly consolidated. The porosity is as high as $\mathbf{2 5}$ percent, but permeabilities (figs. 8 and 9) are low, in part because most of the sandstones are feldspathic quartz wackes, consisting of 60 to 80 percent quartz, 10 to 15 percent fildspar (about equal amounts of K-feldspar and plagioclase), and small percentages of rock fragments. Plant fragments, muscovite, and pyrite an t other heavy minerals are trace constituents. Fe'/spars are commonly altered to clay minerals or replaced by carbonate minerals. The sandston 9 s are cemented by silica-clay mixtures, much of which was probably original matrix material, or by calcite and dolomite. The degree of consol: tation generally decreases upward.

The shale and limestone beds are apparently unfossiliferous and typically silty or sandy. Limestones are buff-tan to light gray, argillaceo'ts, and micritic in texture. Because of the absence of fossils and the association of coal, oxidized sands, and shales, the sedimentary rocks of subrnit 1D are interpreted as having been deposited ir a nonmarine, possibly deltaic, environment. 


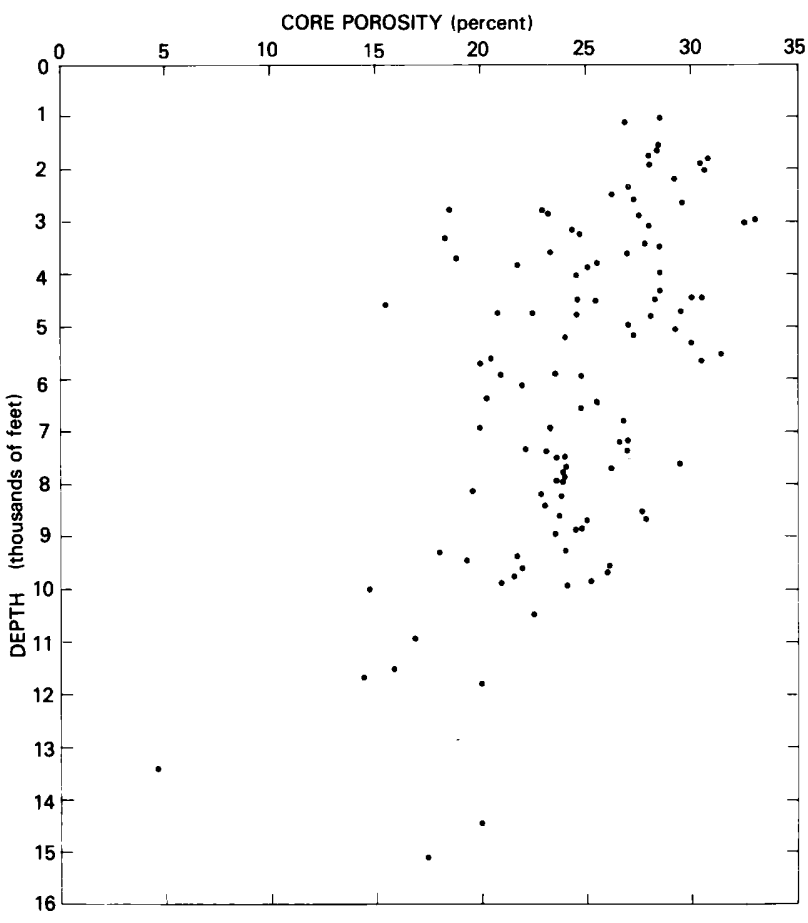

FIgURE 8.-Porosity versus depth for the COST No. G-1 well, from measurements on sidewall cores. After Lachance and Amato (1980); data from Core Laboratories, Inc.

SUBUNIT IC $(8,100-5,150 \mathrm{FT} ; 2,469-1,570 \mathrm{M})$

The sediments of this lithologic subunit differ little from those of subunit $1 D$, except that the sandstone and shale are apparently more thinly bedded and more frequently interbedded in subunit $1 \mathrm{C}$, and that the sandstone beds are medium to very coarse grained and commonly pebbly as well. Coal is present in subunit $1 \mathrm{C}$, but not as abundant as in subunit $1 \mathrm{D}$. Limestone beds are relatively uncommon, but much of the sandstone is calcareous. The interbedded shales are redbrown to about $6,500 \mathrm{ft}(1,983 \mathrm{~m})$, but above that level they are tan to gray and green.

These feldspathic quartz wacke sandstones are similar in composition to those in subunit $1 \mathrm{D}$. The porosity and permeability vary depending on the degree of sorting, but some sandstones with good reservoir potential are present in the interval between 8,000 and $7,000 \mathrm{ft}(2,430$ and $2,134 \mathrm{~m}$ ). Carbonate cements are common in some intervals.

The sedimentary rocks of subunit $1 \mathrm{C}$ record deposition under nonmarine conditions at the base of the unit and shallow marine conditions near the top, possibly in a deltaic environment.

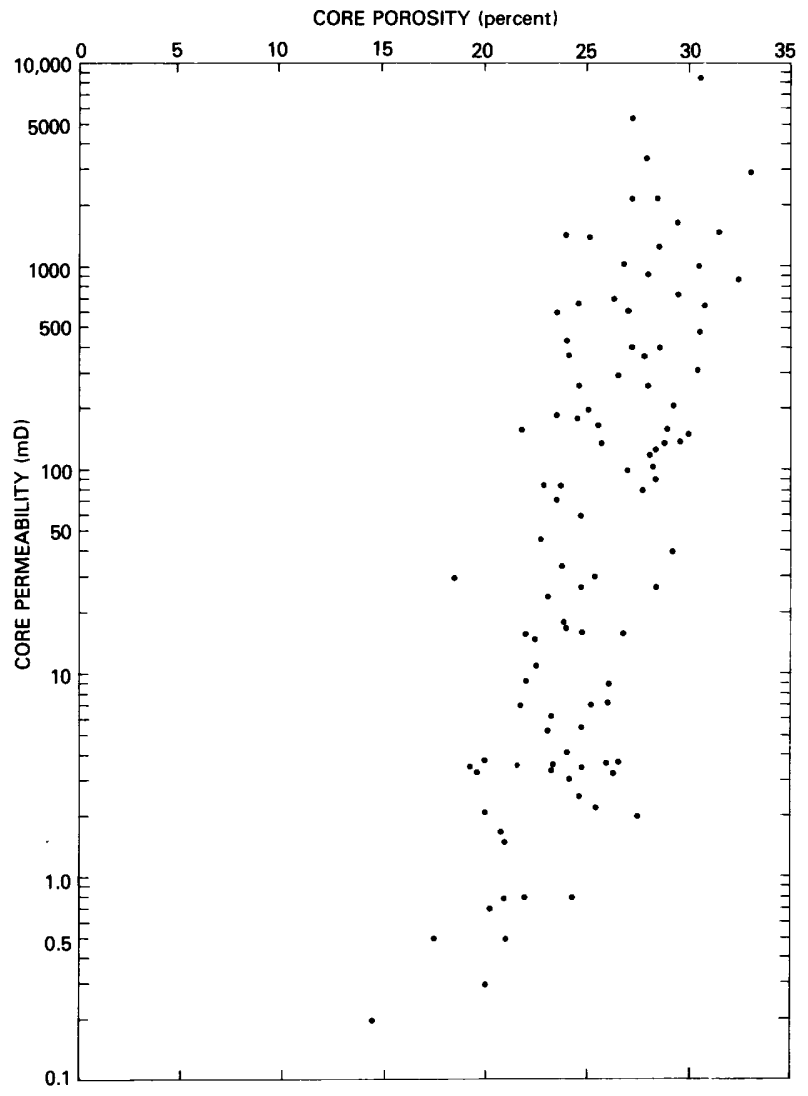

Figure 9.-Porosity versus permeability for the COST No. G-1 well, from measurements on sid swall cores. After Lachance and Amato (1980); data from Core Laboratories, Inc.

SUBUNIT IB $(5,150-1,870 \mathrm{FT} ; 1,57 ?-570 \mathrm{M})$

Thin to thick, tan to buff, mecium- to coarsegrained sands with interbedded gray to reddish shales and marls and some beds of light-gray-buff argillaceous dolomite characterize lithologic subunit 1B. The sands are poor'y consolidated and have porosities up to 35 percent and variable but often high permeabilities (figs. 8 and 9). Sand or sandstone is prevalent from 4,800 to $4,100 \mathrm{ft}$ $(1,463$ to $1,250 \mathrm{~m})$ and from $3,6,00$ to $2,400 \mathrm{ft}$ $(1,097$ to $731 \mathrm{~m})$, whereas shale dominates the remainder of the subunit.

Lignite or coal is common in many parts of the sequence, and there is pyrite in linth shales and sands. Above 3,650 ft $(1,112 \mathrm{~m})$ the sands contain calcareous worm tubes, mollusk fragments, gastropods, foraminifers, bryozoa, ard abundant organic (terrestrial plant?) matter. A thick, fossiliferous, sandy dolomite bed occurs between 3,540 and $3,570 \mathrm{ft}(1,079$ and $1,088 \mathrm{~m})$. 
Sands and sandstones are commonly coarse to very coarse grained and poorly sorted, but some very well-sorted beds are present. Grains are angular to subrounded. Quartz pebbles occur in many intervals. The degree of cementation is variable, and calcite, siderite, and dolomite cements are present. The sands and sandstones range from feldspathic quartz wacke to quartzarenite. The feldspar content seems to generally decline upsection as the degree of sorting increases.

The sediments of subunit $1 \mathrm{~B}$ were deposited primarily under shallow marine conditions, but intervals of nonmarine deposition are possible.

SUBUNIT IA (1,870-1,030 FT; 570-314 M)

This subunit consists almost entirely of pebbly, poorly to well sorted, poorly consolidated quartz sand. Pebbles are usually quartzose and the sand is micaceous, glauconitic, pyritic, and fossiliferous, containing numerous fragments and whole skeletons of bryozoans, planktic and benthic foraminifers, and Inoceramids and other mollusks. Clay and calcite or siderite compose the matrix (or cement, when present). Porosities are commonly greater than 25 to 30 percent and permeability is moderate to high (fig. 8). Some glauconitic and sideritic shale is also present in the section. Lignite beds and pyritic, carbonaceous shale occur between 1,500 and 1,575 ft (457 and $480 \mathrm{~m}$ ). The sequence represents predominantly marine shelf deposition. No cuttings were obtained from above $1,300 \mathrm{ft}(396 \mathrm{~m})$.

\section{DESCRIPTION OF THE COST NO. G-2 WELL SEQUENCE}

The $21,872 \mathrm{ft}(6,667 \mathrm{~m})$ of sedimentary section penetrated in the COST No. G-2 well (fig. 10) in the Georges Bank basin is here divided into four major lithologic units (fig. 7). These are described from the bottom to the top of the well.

\section{UNIT 4 (21,872-21,830 FT; 6,667-6,654 M) UPPER TRIASSIC (RHAETIAN?) OR LOWER JURASSIC}

Unit 4 consists of halite with anhydrite inclusions. No cuttings of salt were recovered, probably because it dissolved during drilling and washing. However, the presence of salt is inferred from a sudden increase in penetration rate during drilling, a large increase in the salinity of drilling mud, and the very clear anhydrite crystals. The salt unit is tentatively correlated to the Argo Formation of Early Jurassic age on the Scotian shelf (Bielak and Simonis, 1980).

\section{UNIT 3 (21,830-13,625 FT; 6,654-4,153 M) LOWER TO MIDDLE JURASSIC (HETTANGIAN(? TO BATHONIAN(?))}

This unit is composed of dolomite and limestone, interbedded with anhydrite, and rav fineto very fine-grained sandstone and shale beds. The sedimentary rocks of unit 3 were deposited in restricted marine and marginal marine environments. Two subunits have been defined: subunit $3 \mathrm{~B}$ of dolomite and anhydrite with some interbedded limestone, siltstone, sandstone, and shale; and subunit $3 \mathrm{~A}$ of limestone and dolomite with interbedded anyhydrite.

The organic carbon contents of rocks in unit 3 (Miller and others, this volume) are low, sveraging about 0.2 to 0.3 weight percent, ard the hydrocarbon source potential of the entire unit appears low. Porosity and permeability (figs. 11 and 12) are also low, suggesting very poor reservoir quality.

\section{SUBUNIT 3B $(21,830-18,720$ FT; 6,654-5,706 M (LOWER JURASSIC(?))}

The lower part of this subunit consists of interbedded anhydrite and dolomite with all intergradations of the two lithologies. The dolomite is light to medium gray and brown and is micritic to sparry. Although some vugs and intercrystalline pores up to $0.5 \mathrm{~mm}$ in diameter were noted. these probably resulted from preparation of the sections; remnants of anhydrite or halite(?) were found in many of the pores. Much of the do'nmite is massive and micritic or exhibits patchy rocrystallization to sparry dolomite (or dolomite pore fillings). In a few zones in the lower part of subunit 3B, dolomite has replaced original oolitic and pelletal limestone. The open and uncompacted structure of the original oolites and pellets suggests early dolomitization.

Limestone is rare in the lower part of subunit $3 \mathrm{~B}$, but becomes more abundant upward. There 


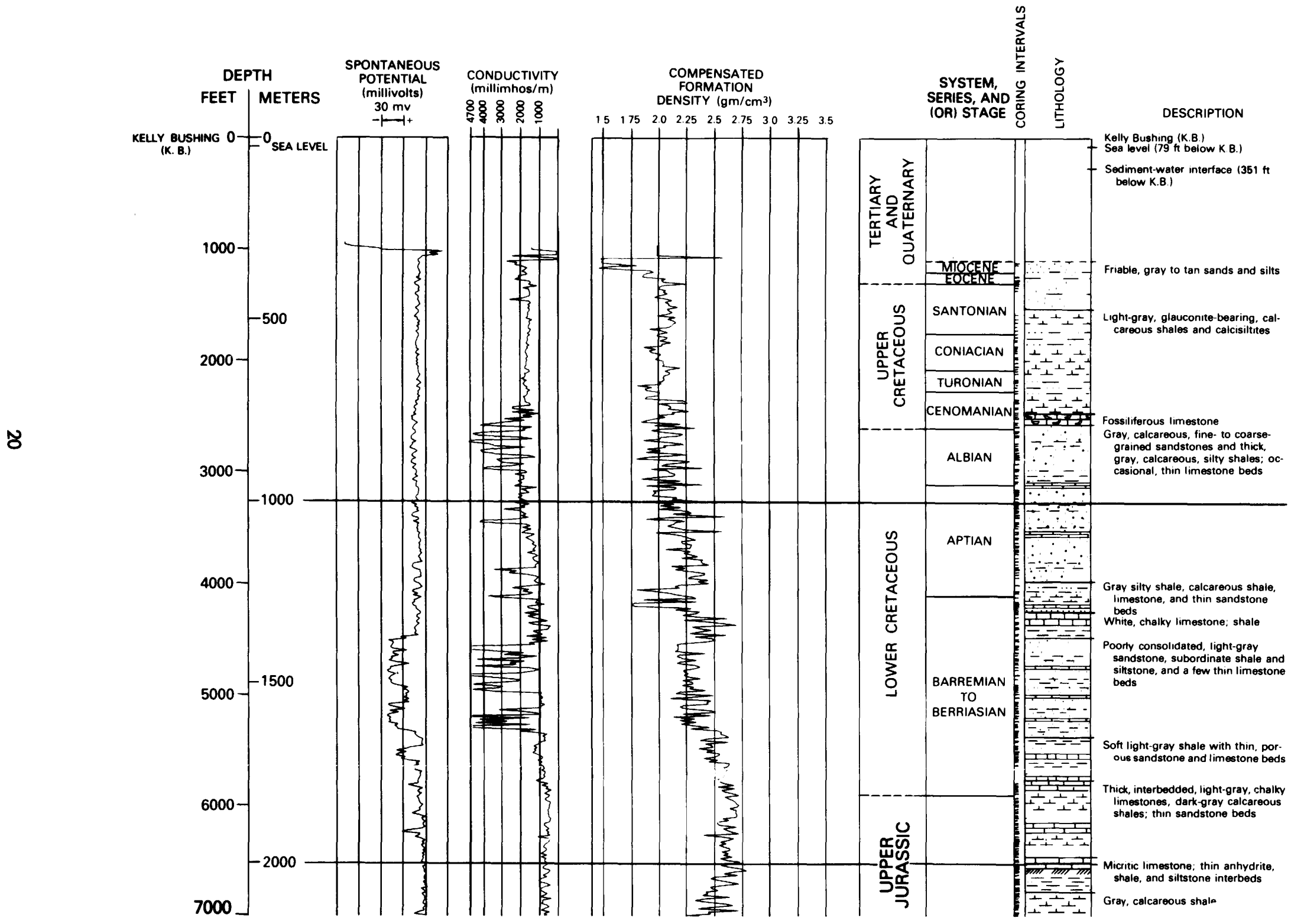




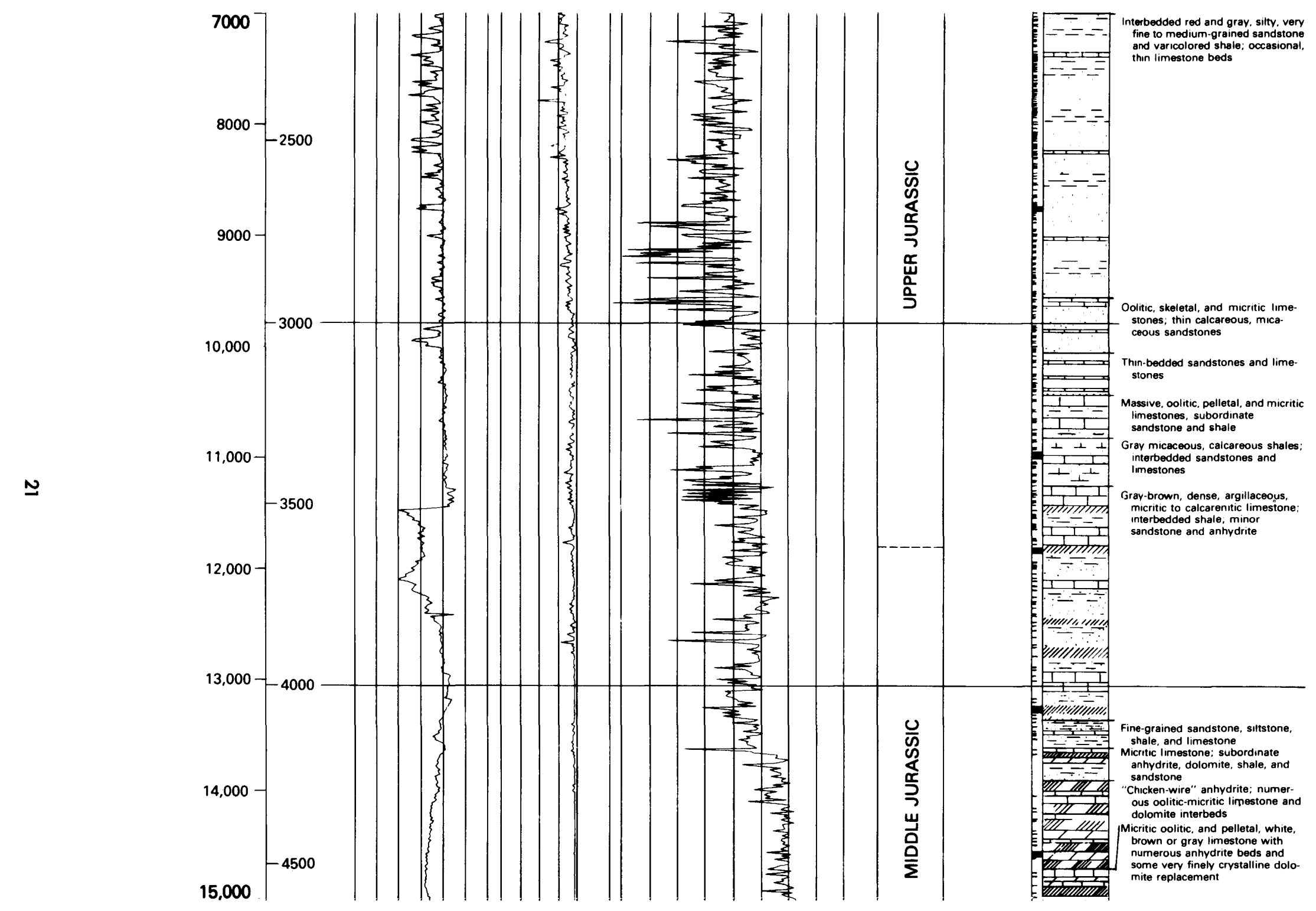

FIGURE 10.-Geophysical logs, lithology, and age for the COST No. G-2 well. Modified from Scholle, Schwab, and Krivoy (1980). Stratigraphic boundaries were based on preliminary data and do not match those shown elsewhere in this volume. 


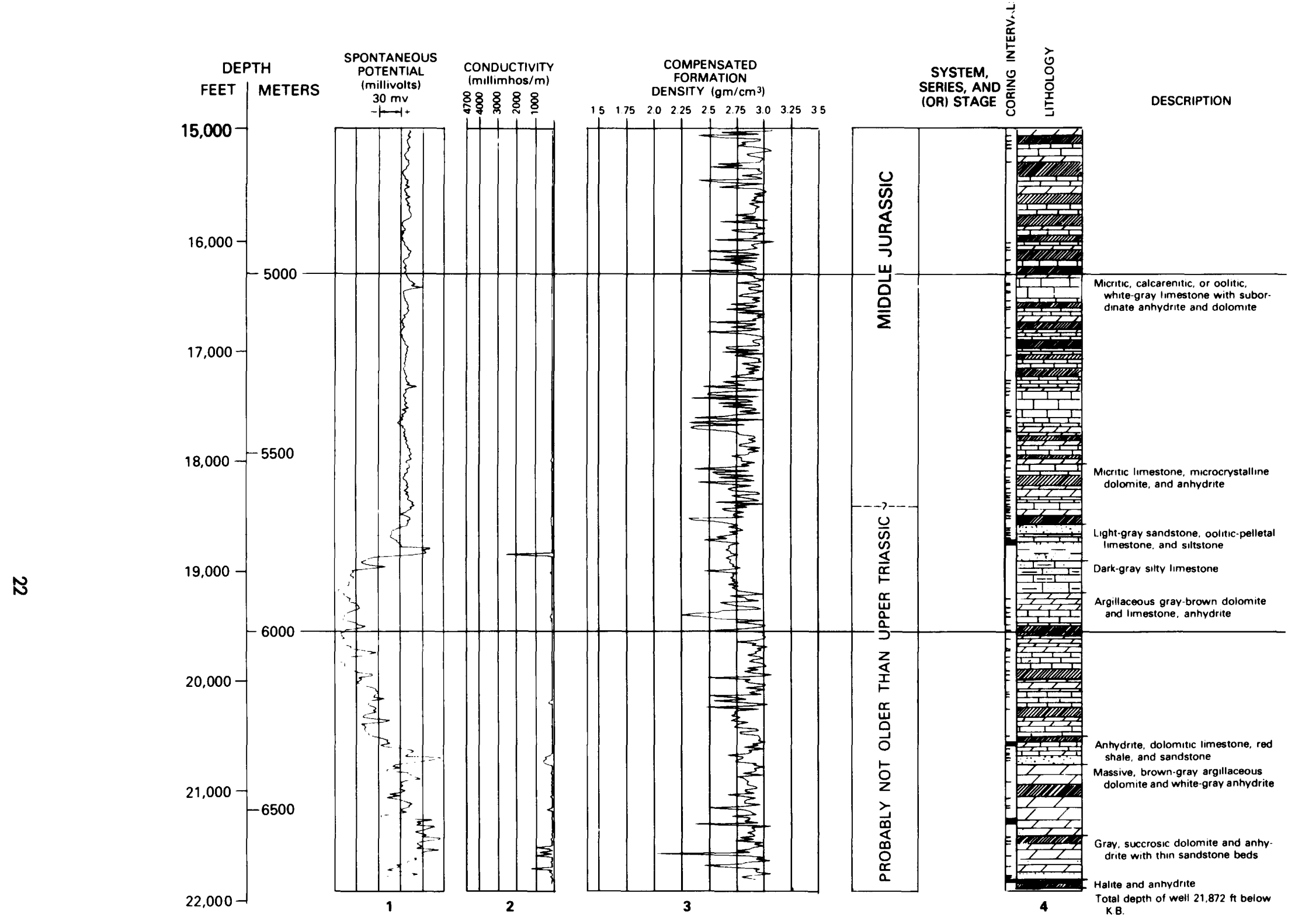

FigURE 10.-Geophysical logs, lithology, and age for the COST No. G-2 well—Continued 
CORE POROSITY (percent)

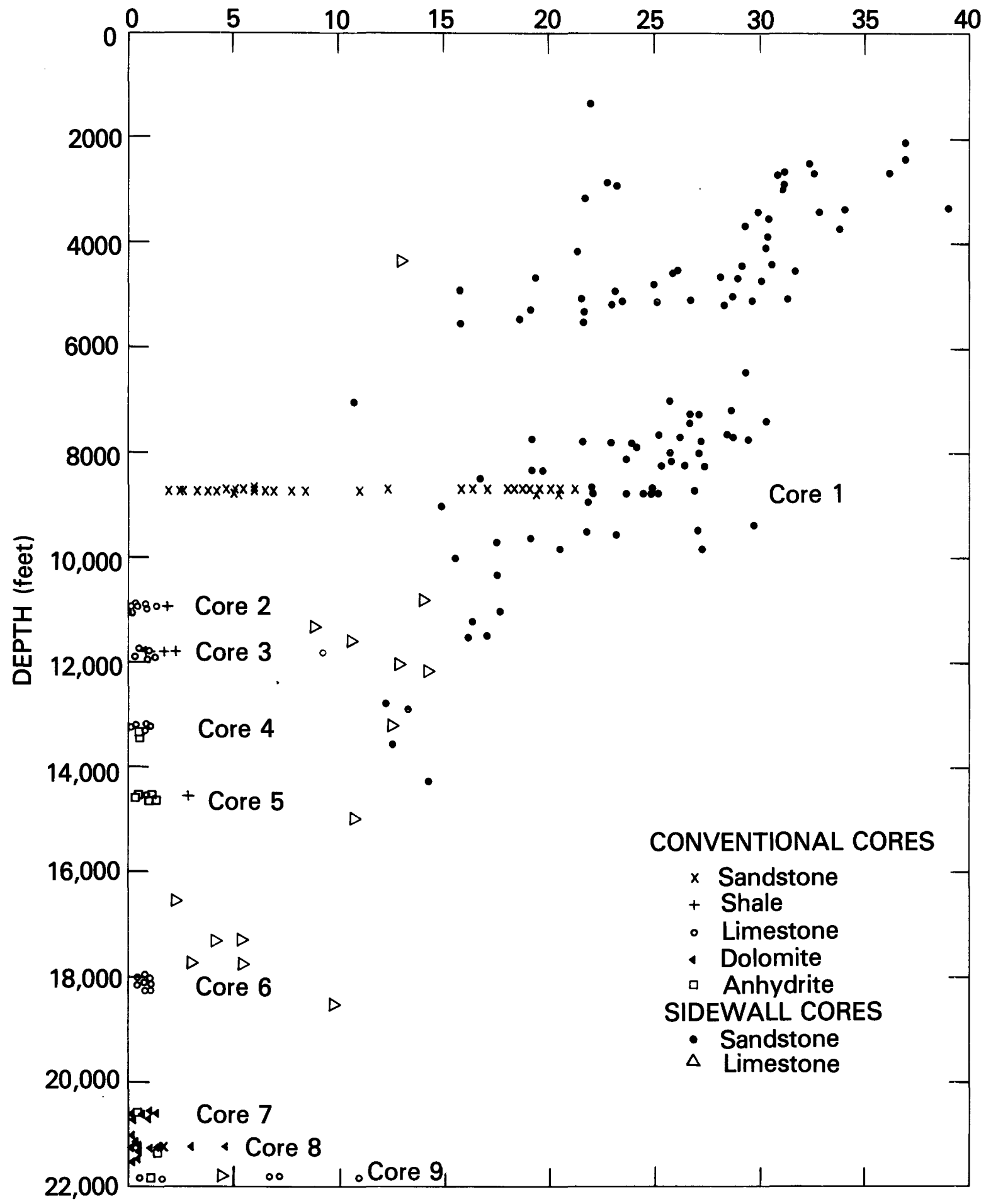

FIgURE 11.-Porosity versus depth for the COST No. G-2 well, from measurements on sidewall cores. After Malinowski (1980); data from Core Laboratories, Inc. 
CORE POROSITY (percent)

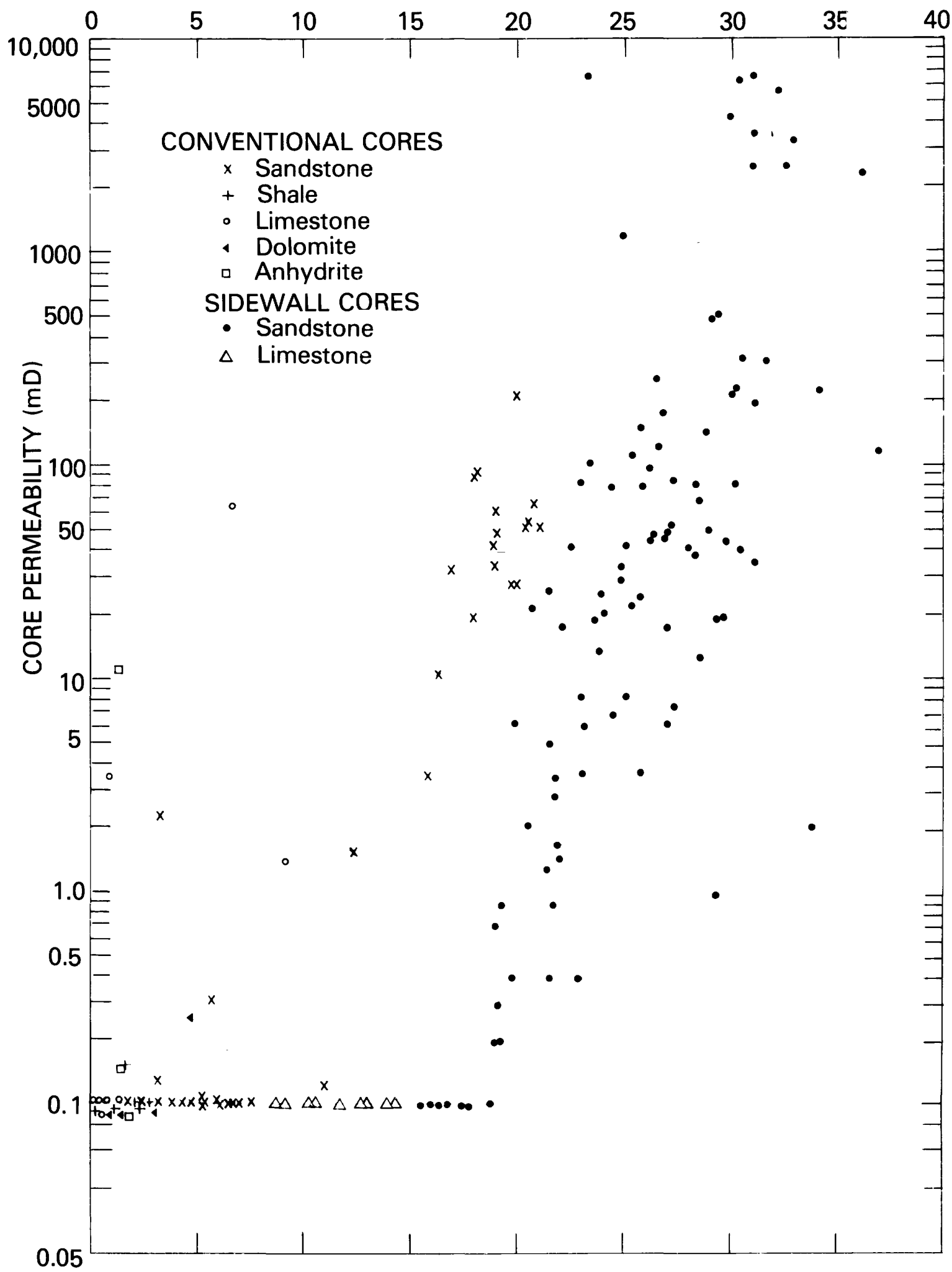

Figure 12.-Porosity versus permeability for the COST No. G-2 well, from measurements on sidewall cores. After Malinowski (1980); data from Core Laboratories, Inc. 
are several layers of oolite or pellet packstones and grainstones, but calcareous mudstones or dolomitized calcareous mudstones are most common. Some samples suggest the presence of interbedded boundstone layers as well. These algal laminates contain silt-sized subangular quartz and appear to be rich in organic matter. Many of the calcareous mudstones contain fractures or vugs filled with anhydrite. A few fossiliferous calcareous wackestones are also present in subunit 3B, containing fragments of ostracods, large benthic foraminifers, echinoderms, and mollusks. Oolites and calcareous fossils are commonly micritic.

The few sandstones in this subunit are highly compacted, well cemented, fine- to very finegrained arkosic wackestones and feldspathic quartz wackestones. Feldspars are commonly chloritized and the framework quartz grains have sutured contacts with one another. Clay, micas, and dolomite usually make up the intergranular matrix. A few thin, brown to gray, calcareous and silty shales also occur interbedded with the sandstones and dolomitic sandstones. The upper $60 \mathrm{ft}$ (18 $\mathrm{m}$ ) of subunit $3 \mathrm{~B}$ consists of dolomitic sandstones and silty to sandy dolomite. Clastic grains are mostly quartz and reworked carbonate particles such as pellets and fossil fragments. Simonis (1980) noted a green tuffaceous shale layer at $18,960 \mathrm{ft}(5,779 \mathrm{~m})$.

SUBUNIT 3A $(18,720-13,625 \mathrm{FT} ; 5,700-4,153 \mathrm{M}$ (LOWER TO MIDDLE JURASSIC)

Subunit 3A comprises tan to medium-gray limestone interbedded and intergradational with dolomite and anhydritic dolomite, and light-gray, white, and translucent, nodular to laminated anhydrite. Sandstone and siltstone beds are rare in the lowermost $50 \mathrm{ft}(15 \mathrm{~m})$ of the subunit, where it is transitional to the sandy dolomites and dolomitic sandstones of upper subunit $3 B$.

The limestone and dolomite are variable in texture. Calcareous mudstones, argillaceous calcareous mudstones, and massive dolomicrites are the most common. There is patchy recrystallization to anhedral sparry calcite or dolomite in some samples. Vugs and other original intercrystalline pore spaces are commonly filled with anhydrite, particularly in the dolomite beds. Small amounts of disseminated silt-sized quartz are common. A second kind of texture is pelletal or oolitic calcareous packstone and wackestone or dolomitized versions of these textures. Some grainstones are also present. Some of these intervals are fossiliferous and contain fragments of ostracods and other mollusks. Many of the calcareous fossil constituents are recrystallized or have micritic envelopes. There is little or no porosity remaining in most intervals. The generall: uncompacted textures suggest early cement tion, dolomitization, and filling of vugs by anhydrite or carbonate spar. Little secondary porosity has been formed.

\section{UNIT 2 (13,625-9,700 FT; 4,153-2,957 M) MIDDLE AND UPPER(?) JURASSIC (BATHONIAN(?)-OXFORDIAN(?) )}

Unit 2 differs from the underlying unit in that it is composed almost entirely of limestone with minor interbedded sandstones and very rare intervals of dolomite and anhydrite. Unit 2 represents a change from carbonate-vaporite depositicn in restricted marginal-marine and highenergy, openmarine shelf conditions to deposition in a more open carbonate shelf setting of variable energy.

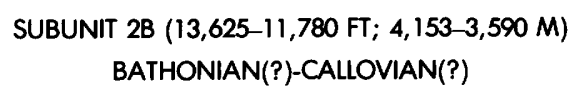

The lower $265 \mathrm{ft}(81 \mathrm{~m})$ of subunit $2 \mathrm{~F}$ are brown-red sandstone and silty hematiticlimonitic mudstone and shale. The sandstones are poorly to moderately sorted, very fine- to medium-grained feldspathic quartz wackes. The sandstones are highly compacted and have sutured grain contacts, some dolomitic cement, and dolomite rhombs replacing feldspar. The mudstone and shale are slightly calcareous and contain disseminated silt-sized quartz. This part of the unit probably represents a tongue of nonmarine clastic sediments deposited after restricted marine deposition of carbonates and evaporites and before the limestones formar in more open marine environments.

Brown to medium-gray micritic limestones predominate in the remainder of subunit $2 B, k$ it a few beds of pellet and oolite calcareous packs ${ }^{\dagger}$ one and grainstone also occur, as do thin laye-s of gray, calcareous, silty mudstone. Many of the calcareous mudstones are burrow-mottled and contain pellets, articulated ostracod fragm?nts, and fine-grained disseminated quartz silt. Fome 
beds may be classified as boundstones on the basis of laminated algal texture. Pyrite and disseminated wisps of organic matter are also common. Original or secondary pores are filled by sparry calcite, and some calcareous mudstones exhibit a dismicritic texture. Stylolitic seams are common, as are spar-filled fractures. Rare dolomite rhombs and anhydrite were noted in some samples.

The pelletal and oolitic packstone beds are also tightly cemented, and original voids are filled with sparry calcite. Ostracod fragments, quartz silt, echinoderm plates, and benthic foraminifers are common to abundant in some of the reworked carbonates, which were deposited in an apparently high-energy environment.

Fragments of altered, green, tuffaceous(?) claystone were also found between 11,720 and $12,100 \mathrm{ft}(3,572$ and $3,688 \mathrm{~m})$. The fragments are vesicular and have a felted, devitrified groundmass surrounding elongate altered feldspar(?) phenocrysts.

\section{SUBUNIT 2A (11,780-9,700 FT; 3,590-2,957 M) \\ CALLOVIAN-OXFORDIAN(?)}

The rocks of this subunit, including the limestones, exhibit a more clastic character, indicated by the prevalent angular to subrounded quartz sand and silt grains in mudstone and limestone, and by the abundance of intraclast and oolitic-pelletal limestones. Moderately sorted, fine- to medium-grained sandstone beds of quartz wacke occur in the lower part of the subunit and are somewhat thicker and more common in the upper part. These sandstones are commonly interbedded with argillaceous calcareous mudstones near the base of the subunit and algal intraclast boundstones, intraclast packstones, and pellet or oolite lime mudstones to packstones in the upper part. Some fossiliferous packstones also occur. Most of the limestones are tightly cemented with calcite spar or silty clay filling the original void space, but some samples have porosities as high as 15 percent. Fragments of ostracods are common throughout $2 \mathrm{~A}$, and echinoderm plates and spines, mollusk and brachiopod fragments, benthic foraminifers, rare coral and bryozoan fragments, and calcareous algae are also present. Individual grains are usually micritized.
Sandstone beds range from poo-ly sorted argillaceous types to moderately sorted calcitecemented varieties in which the coment encloses framework grains, resulting in poikilotopic texture. There is an apparent increase in porosity of the sandstone beds at the top of subunit $2 \mathrm{~A}$.

Shale and silty mudstone occur in some parts of the section. The shale and mudstone range from calcareous, gray to black intervals to hematitic, red, silty, nonfossiliferous zones. The organiccarbon and pyrite content of shales in the upper part of subunit $2 \mathrm{~A}$ is high, commonly greater than 0.6 weight percent.

The depositional environment of subunit $2 \mathrm{~A}$ sediments apparently varied from high-energy shallow marine to nonmarine, and the proportion of terrigenous clastic sediments increases upward in the section.

\section{UNIT 1: (9,700-1,100 FT: 2,95T-335 M) \\ MIDDLE AND UPPER JURASSIC(?) (CALLOVIAN AND OXFORDIAN) TO TERTIARY (MIOCENE AND PLIOCENE)}

The sediments of unit 1 are dominantly marine clastics but have intervals of interbedded limestone and a few nonmarine sandstone-coal-shale sequences. The sedimentation rates decrease upward, and shallow-marine conditions prevailed from the Late Cretaceous through the Cenozoic. The sands of this unit possess good reservoir characteristics.

\section{SUBUNIT ID $(9,700-6,920 \mathrm{FT} ; 2,957-2,109 \mathrm{M})$ CALLOVIAN AND OXFORDIAN TO UPPER KIMMERIDGIAN}

Interbedded white to red santstone, gray to tan oolitic and algal intraclast limestone, and gray to red and maroon shale with thin coal stringers make up most of subunit $1 \mathrm{D}$. The sediments are predominantly rec' to $7,840 \mathrm{ft}$ $(2,390 \mathrm{~m})$. The sandstones are primarily fine to medium grained and moderately to well sorted, and they vary in degree of cementation. Some intervals are more silt- and clav-rich. Porosity ranges from less than 10 percent in fairly tightly calcite-cemented zones to as much as 30 percent in more friable intervals. The sandstones are feldspathic quartz wackes to $\varepsilon$ renites. Framework grains are angular to subangular and consist of 60 to 90 percent quartz, less than 15 
percent feldspar (K-feldspar and plagioclase), and muscovite, chlorite, some carbonate rock fragments, and a variety of heavy minerals. The feldspars are commonly altered to clay minerals. Dispersed organic material is relatively abundant.

The shales or mudstones are calcareous and silty and have high organic carbon contents $\mathbf{0 . 5}$ to 1.2 weight percent), especially in the gray shales within the upper part of the subunit. The more organic-rich intervals, which include thin coal or lignite interbeds, are also pyritic. Darkgray shales are commonly interbedded with the limestone intervals, whereas red shales are interbedded with tan to red sandstones in the lower part of subunit $1 \mathrm{D}$.

Limestone beds are present throughout the section, but their total thickness is less than that of the sandstone. The limestones are oolitic and pellet packstones and grainstones, algal intraclast packstones and boundstones, and some pellet calcareous mudstones to algal lime mudstones. Relatively little primary or secondary porosity was noted in thin sections of the limestones. Nearly all packstones and grainstones have sparry calcite fillings of void spaces. Ostracod and mollusk fragments, echinoderm plates, and benthic foraminifers are the most common faunal constituents. Apparent laminae of blue-green algae bind some intraclast limestones. Many of the limestone beds are silty and contain variable amounts of organic matter and pyrite.

The depositional environment of subunit 1D apparently varied from a nonmarine delta to a shallow marine, high-energy, mixed carbonateclastic shelf.

SUBUNIT IC $(6,900-2,500 \mathrm{FT} ; 2,103-762 \mathrm{M})$

UPPER KIMMERIDGIAN TO APTIAN AND ALBIAN

Subunit $1 \mathrm{C}$ consists of a mixture of lithologies deposited mainly in marginal marine to shallow marine environments. Limestone intervals are sandwiched between sandstone-shale-coal sequences. Porosity reaches as much as $\mathbf{3 5}$ percent, but is quite variable from one interval to another.

The lower $1,200 \mathrm{ft}(366 \mathrm{~m})$ of subunit $1 \mathrm{C}$ consists of fossiliferous calcareous mudstone and chalky mudstone with minor quartz sand and silt and some interbedded gray calcareous shale. Articulated and fragmented ostracods, gastropods, bivalves, echionoderm plates and spines, and benthic foraminifers are common frunal constituents.

Thick-bedded, coarse- to very coarse-grcined, poorly consolidated quartzarenites predominate from about 5,740 to $4,500 \mathrm{ft}(1,750$ to $1,372 \mathrm{~m})$. These are interbedded with dark-gray to browngray, somewhat organic-rich shale or mudstone, coal, and lignite. Fine- to medium-grained, wellsorted sandstone beds also occur, but thes? are usually tightly cemented by calcite or silica. Calcite cements predominate near the bottcm of this interval in transition to the limestone sequence. The proportion of calcareous mudstone beds also increases in the lower part of this interval.

Limestone beds characterize the interval from about 4,500 to $3,950 \mathrm{ft}(1,372$ to $1,204 \mathrm{~m})$. These are primarily argillaceous, glauconitic, cl alky mudstone, but include some fossiliferous onlitic wackestone, packstone, and grainstone beds. Primary or secondary porosity in these bets is fairly high. Glauconitic sandstone and gray calcareous shale is interbedded in the upper part of this interval, and silty calcareous mudstone predominates up to about $300 \mathrm{ft}(91 \mathrm{~m})$ in the section.

Sandstone, interbedded with gray, glauconitic silty mudstone, composes the upper $500 \mathrm{ft}$ $(153 \mathrm{~m})$ of subunit $1 \mathrm{C}$. The sands range from those that are tightly cemented with calcite to friable, fine- to coarse-grained, granular, moderately to well sorted, subangular to subrounded quartz wackes to arenites. Glauconite is common, an are mollusk fragments, lignite, and foraminifers.

\footnotetext{
SUBUNIT IB: $(2,500-1,550$ FT; 762-472 M)

APTIAN AND ALBIAN TO LOWER SANTONIAN
}

Argillaceous to silty calcareous mudstone and chalk compose the bulk of subunit $1 B$. These sediments were deposited in an open marine, possibly outer shelf environment. Glauconite, ostrarods, planktic and benthic foraminifers, Inoceramid fragments, molluscan shell fragments, quartz silt and sand, organic matter, and pyrite are conmon constituents. The degree of induration and cementation by calcite varies, but most coarser grained intervals are fairly tightly cemented. 
SUBUNIT IA: (1,550-1, $100 \mathrm{FT} ; 472-335 \mathrm{M})$

LOWER SANTONIAN TO MIOCENE

This subunit is characterized by unconsolidated marine clastic sediment, predominantly tan to white, fine- to coarse-grained, moderately to well sorted, granular to pebbly quartzarenite interbedded with gray, silty, glauconitic calcareous mudstone and glauconitic siltstone.

\section{SUMMARY}

The COST No. G-1 well was drilled on a basement high to a depth of $16,071 \mathrm{ft}(4,898 \mathrm{~m})$ and is located in shallower water, farther inshore than the COST No. G-2 well, which was drilled to a depth of $21,874 \mathrm{ft}(6,667 \mathrm{~m})$. The G-1 well reached Paleozoic basement, consisting of black slate, phyllite, and metadolomite unconformably overlain by Early Jurassic and younger carbonate and clastic rocks. The G-2 well bottomed in a dolomite-evaporite sequence of possible Late Triassic or Early Jurassic age. The sedimentary rocks in both wells reflect deposition primarily in a shallow marine setting. It appears that the strata at G-1 were deposited in shallower water nearer a source of clastic detritus than the strata at G-2, which contain more carbonate rocks deposited in an inner- to outer-shelf setting. Overall subsidence and sediment accumulation rates during the Jurassic and Early Cretaceous at G-1 were lower than those of the shelf in the vicinity of the G-2 well.

Nearly $3,900 \mathrm{ft}(1,189 \mathrm{~m})$ of Upper Triassic and Lower Jurassic strata were penetrated in the G-2 well. These consisted mainly of interbedded dolomite and anhydrite and subordinate amounts of limestone, shale, and siltstone or sandstone. The lithologies suggest deposition in a restricted marginal marine setting characterized by net evaporation. Environments ranged from supratidal (indicated by nodular anhydrite, dolomite, and sand), to shallow subtidal (indicated by pelletal calcareous mud and oolitic wackestone to packstone). Triassic rocks probably do not exist in the vicinity of the G-1 well, but about $2,100 \mathrm{ft}$ $(640 \mathrm{~m})$ of Lower Jurassic interbedded red shale, sandy-silty shale, red sandstone and conglomerate, sandy dolomite, dolomite, and minor anhydrite were penetrated. These lithologies reflect deposition in nonmarine to restricted marginal-marine environments.
Middle Jurassic strata are pres?nt in both the G-2 (6,500 ft; $1,981 \mathrm{~m}$ thick) and G-1 $(3,900 \mathrm{ft}$; $1,189 \mathrm{~m}$ thick) wells. Interbedded dolomite, anhydrite, and micritic, calcarenitic, and oolitic limestone compose most of the sequence at the G-2 well (plate 1), except for some more sandy, silty and argillaceous beds in the upper part of the Middle Jurassic sequence, agsin suggesting shallow-shelf to restricted margin al-marine depositional environments. The Middle Jurassic at G-1 is characterized by fine-grained dolomite and subordinate anhydrite beds at the base, which give way upward to mainly thin-bedded sandstone, shale, and sandy limestone.

The Upper Jurassic sequence at the G-1 well is about $4,400 \mathrm{ft}(1,341 \mathrm{~m})$ thick and consists largely of medium- to coarse-grained sandstone beds and thick intervals of red to tan shile and silty to sandy shale. Sandstones in the upper part are cemented with calcite or dolomite but are poorly consolidated and more argillaceo'ss in the lower part. The Upper Jurassic at the G-2 well is about $5,800 \mathrm{ft}(1,768 \mathrm{~m})$ thick and much more calcareous than that at the G-1 well. Limestones, including oolitic, calcarenitic, and micritic types, predominate in the lower and upper porticns of this interval, but sandy limestone, calcarrous shale, and fine- to medium-grained calcarenus sandstones also occur, particularly in middle and upper intervals. The contrast between litholc ries at the $\mathrm{G}-1$ and G-2 wells suggests a predominantly nonmarine or marginal marine-deltaic environment in the vicinity of G-1 and shallow-marine deposition at G-2.

About $3,400 \mathrm{ft}(1,036 \mathrm{~m})$ of Lcwer Cretaceous strata were penetrated at the G-2 well. These units consist largely of micritic limestone, chalk, silty and calcareous shale, and sandstone. Glauconite is common in all strata. The G-2 well encountered about 2,500 ft (762 $\mathrm{r}$ ) of Lower Cretaceous coarse-grained pebbly sands, coarsegrained calcareous sands, and trin, interbedded claystone, as well as some argille eous dolomite. Upper Cretaceous strata are 1,400 to $1,600 \mathrm{ft}$ (427 to $488 \mathrm{~m}$ ) thick at both wells. Coarse-grained sands, gravels and shales predominate at the G-1 well, whereas mainly glauconitic chalks, argillaceous chalks, and fine-grained sands and silts occur in the G-2 well. The lithologic trends of Cretaceous sediments reflect a more ne:rshore, clasticdominated depositional envirorment for the vicinity of the G-1 well and onen shelf, even 
pelagic, conditions near the G-2 well. The little sediment of Tertiary age recovered from both wells consists mainly of sand.

Reservoir quality is apparently poor in both wells below about $10,000 \mathrm{ft}(3,048 \mathrm{~m})$. This can be seen both in a sharp decline in porosity and permeability measured on sidewall core samples (figs. 8, 9, 11, and 12) and from petrographic study of sidewall core and cutting samples. Limestone and dolomite beds in both wells are extremely tight (plate 2); no significant secondary porosity was observed in any samples, and much recrystallization is evident. In the G-2 well, many of the sandstones and siltstones inter- bedded with calcareous sequences below $10,000 \mathrm{ft}$ $(3,048 \mathrm{~m})$ are either highly compacted, exhik iting sutured grain contacts, or tightly cemented with dolomite or calcite. Above $10,000 \mathrm{ft}(3,048 \mathrm{~m})$ most samples were calcite cemented; cementation appears to have been relatively early, $k$ ofore significant compaction. Poikilotopic textures are common. Sandstones above $10,000 \mathrm{ft}(3,048 \mathrm{~m})$ in the G-1 well are commonly argillaceous and typically cemented by hematite, ankerite or siderite, or, less commonly, calcite. However, some primary porosity is preserved in many of the better sorted sands. 


\section{PLATE 1}

Thin-section photomicrographs of characteristic carbonate rocks recovered in the COST No. G-2 well (all with crossed nicols; field of view approximately $0.5 \mathrm{~mm}$, except in $\mathrm{D}$, which is $2 \mathrm{~mm}$ ).

Figure A. Pellet packstone containing pyrite, ostracod fragments, echinoderm plates and fragments, angular quartz grains, and sparry calcite void filling. From $12,140 \mathrm{ft}(3,700 \mathrm{~m})$.

B. Dolomitized oolitic grainstone showing relatively loose packing and remanent concentric structure of original oolites; void space filled by dolospar. From $12,770 \mathrm{ft}(3,892 \mathrm{~m})$.

C. Tight anhedral to euhedral mosaic of dolomite crystals containing no recognizable fossil constituents. Abundant wisps of organic matter. From $21,500 \mathrm{ft}(6,553 \mathrm{~m})$.

D. Dark, organic-rich, dolomitic lime mud with void space that had been filled by anhydrite (now dissolved during making of thin section). 

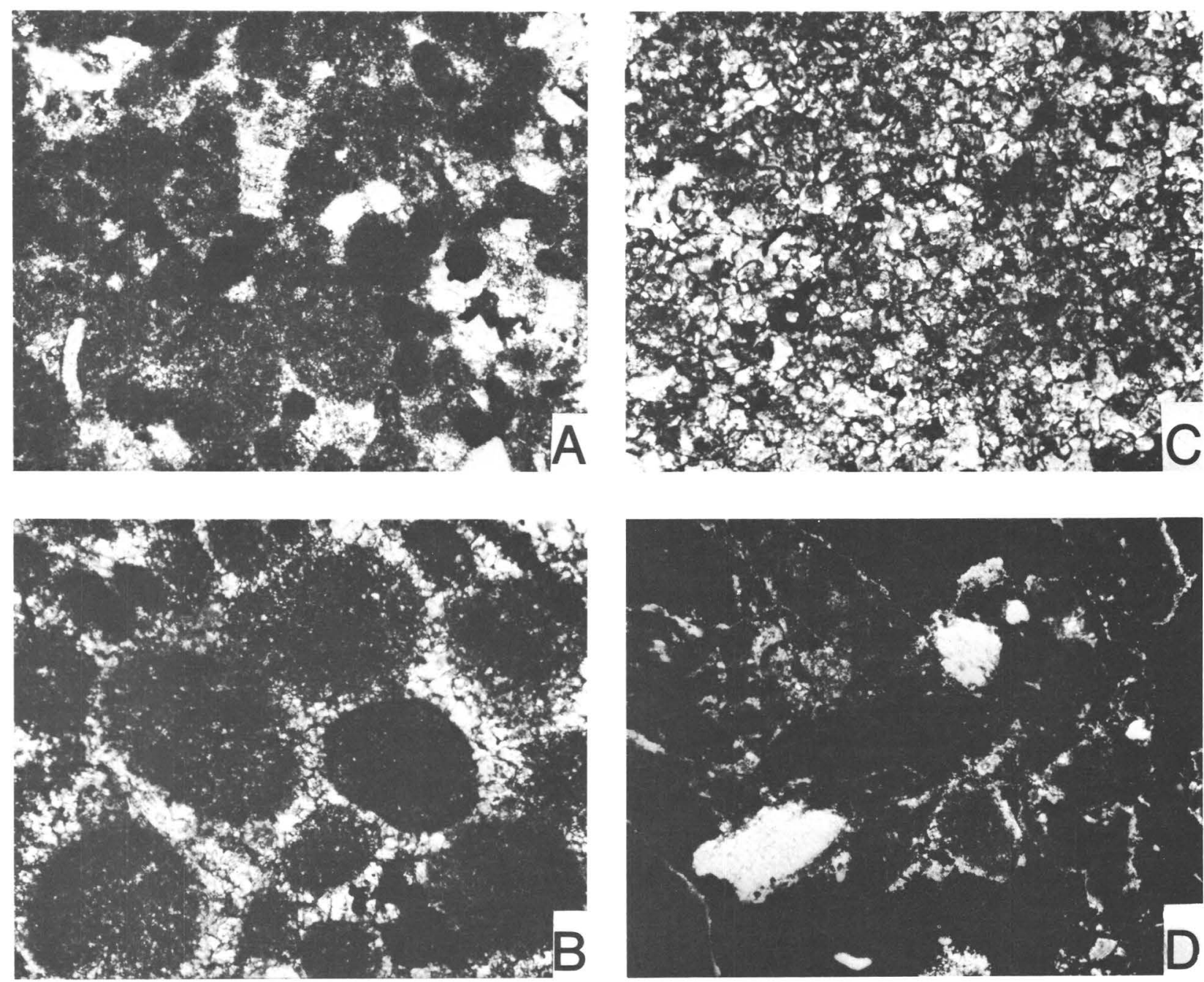


\section{PLATE 2}

Thin-section photomicrographs of representative clastic sedimentary rocks from the COST Nos. G-1 and G-2 wells (all with crossed nicols; field of view in A and D approximately 2mm; all others approximately $0.5 \mathrm{~mm}$ ).

Figure A. Sandy or silty lime mudstone containing angular sand- and silt-sized quartz grains, glauconite, benthic foraminifers, Inoceramid prisms, and echinoderm fragments set in lithified chalk matrix. From 1,320 ft (402 m) in well G-2.

B. Fine-grained quartz sandstone with poikilotopic calcite cement. From $7,570 \mathrm{ft}(2,307 \mathrm{~m})$ in well G-2.

C. Hematite-cemented (dark areas), medium- to fine-grained quartz sandstone. From 9,910 ft $(3,020 \mathrm{~m})$ in well $\mathrm{G}-1$.

D. Slightly argillaceous, fine-grained quartz sandstone; sutured grain contacts, no pore-filling cement (porosity is 5-10 percent), and chloritized feldspars. From $9,190 \mathrm{ft}(2,801 \mathrm{~m})$ in well G-1.

E. Iron-stained quartz siltstone to fine-grained sandstone. Some hematite cement is present, but grains are tightly packed and have sutured contacts; feldspar grains are chloritized. From 13,490 ft $(4,112 \mathrm{~m})$ in well G-2.

F. Fine-grained arkosic sandstone with dolomite and calcite cement in some parts, sutured grain contacts in others; no primary or secondary porosity; feldspar chloritized. 

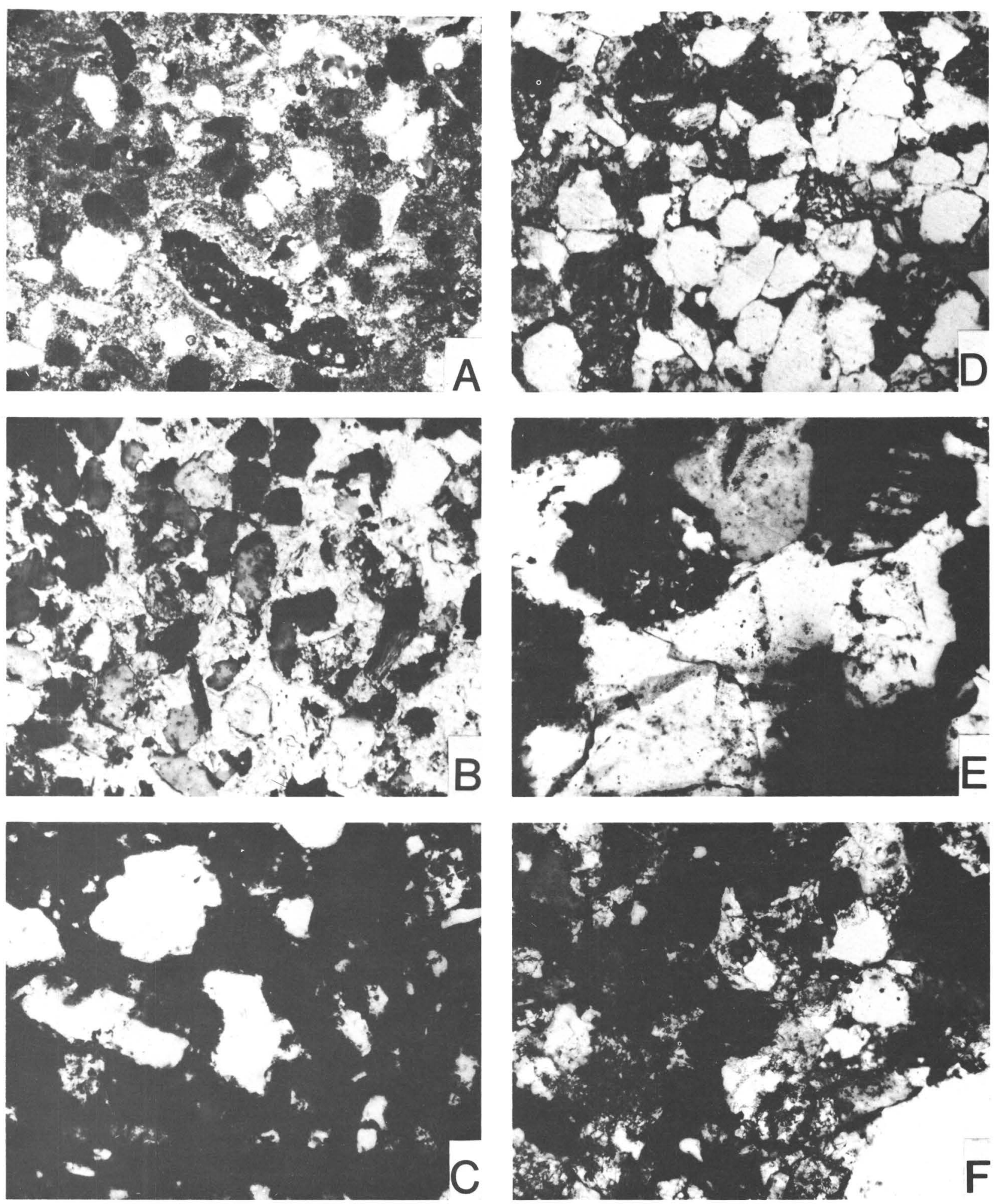


\title{
Calcareous Nannofossil Biostratigraphy and Paleoenvironment of the COST Nos. G-1 and G-2 Wells in the Georges Bank Basin
}

\author{
Page C. Valentine
}

The oldest sedimentary rocks sampled in the COST Nos. G-1 and G-2 wells are not fossiliferous and are of questionable Early Jurassic to Late Triassic age. During Jurassic and Early Cretaceous time, most of the sediments in the Georges Bank basin were deposited in a fluctuating nonmarine to shallow marine environment. Within this sequence, however, there is evidence that deeper marine shelf conditions occurred during the Berriasian at both well sites and also during Valanginian and Hauterivian time at the G-2 site. Marine shelf environments existed during most of the Late Cretaceous, except during the Cenomanian, when there was shallower water over the COST No. G-1 site. There is a hiatus at the Cretaceous-Tertiary boundary, and Campanian and Maestrichtian strata are missing from both sections. There may be other major hiatuses, but the lack of microfossils in some parts of the section makes it difficult to accurately define them. Study of samples of Tertiary strata shows that a marine carbonate shelf province existed in the Georges Bank basin during the Eocene.

\section{BIOSTRATIGRAPHY AND PALEOENVIRONMENT OF THE COST NO. G-1 WELL}

The COST No. G-1 well was drilled to a depth of $16,071 \mathrm{ft}(4,898 \mathrm{~m})$. Calcareous nannofossil biostratigraphy is primarily based on the study of rotary drill cuttings collected over $10-$ to $30-\mathrm{ft}$ (3- to 9-m) intervals. The cutting samples from 1,030 to $2,710 \mathrm{ft}(314$ to $836 \mathrm{~m})$ were studied at intervals of $90 \mathrm{ft}(27 \mathrm{~m})$ or less; from 2,710 to $2,443 \mathrm{ft}$ ( 826 to $745 \mathrm{~m}$ ), samples were studied at 60 - to $120-\mathrm{ft}(18-$ to $37-\mathrm{m})$ intervals, and from 8,010 to $15,310 \mathrm{ft}(2,441$ to $4,666 \mathrm{~m})$ at $290-\mathrm{ft}$ (88-m) intervals or less. Smear slides were made from individual rock fragments representing each of the lithologic units present in a single cutting sample. The oldest assemblage identified in a sample was used to determine the age of the strata at that level. In all, 296 samples from 97 levels in the well were analyzed. Sample depths are relative to the Kelly Bushing, which was $98 \mathrm{ft}$ $(30 \mathrm{~m})$ above sea level and $255 \mathrm{ft}(79 \mathrm{~m})$ above the sea floor. Selected information from the reports on the COST No. G-1 well by International Biostratigraphers, Inc. (1976) and Amato and Bebout (1980) has been incorporated into the present study. The highest and lowest occurrences of stratigraphically important calcareous nannofossil species were determined from this study and from the study by International Biostratigraphers, Inc. (1976) (fig. 13).

\section{EOCENE (972 FT; $296 \mathrm{M})$}

Casing was set at $972 \mathrm{ft}(296 \mathrm{~m})$, apparently in Eocene strata that form a prominent seismic horizon that is widespread beneath Georges Bank (Oldale and others, 1974, figs. 4, 8). This horizon was cored in the Franklin Basin on the northwest flank of Georges Bank and dated as Eocene (Hathaway and others, 1979). In the COST No. G-1 well, sidewall cores and cuttings were collected starting below the casing, and calcareous nannofossils are common and moderately preserved in limestone cuttings from samples from 1,060 and $1,090 \mathrm{ft}(323$ and $332 \mathrm{~m})$ that are probably cavings. The nannofloras are middle to late Eocene in age and contain, among other species, Chiasmolithus grandis, Cyclococcolithina formosa, Dictyococcites scrippsae, Neococcolithes dubius, and Reticulofenestra umbilica. The limestone was deposited on a marine carbonate shelf. 


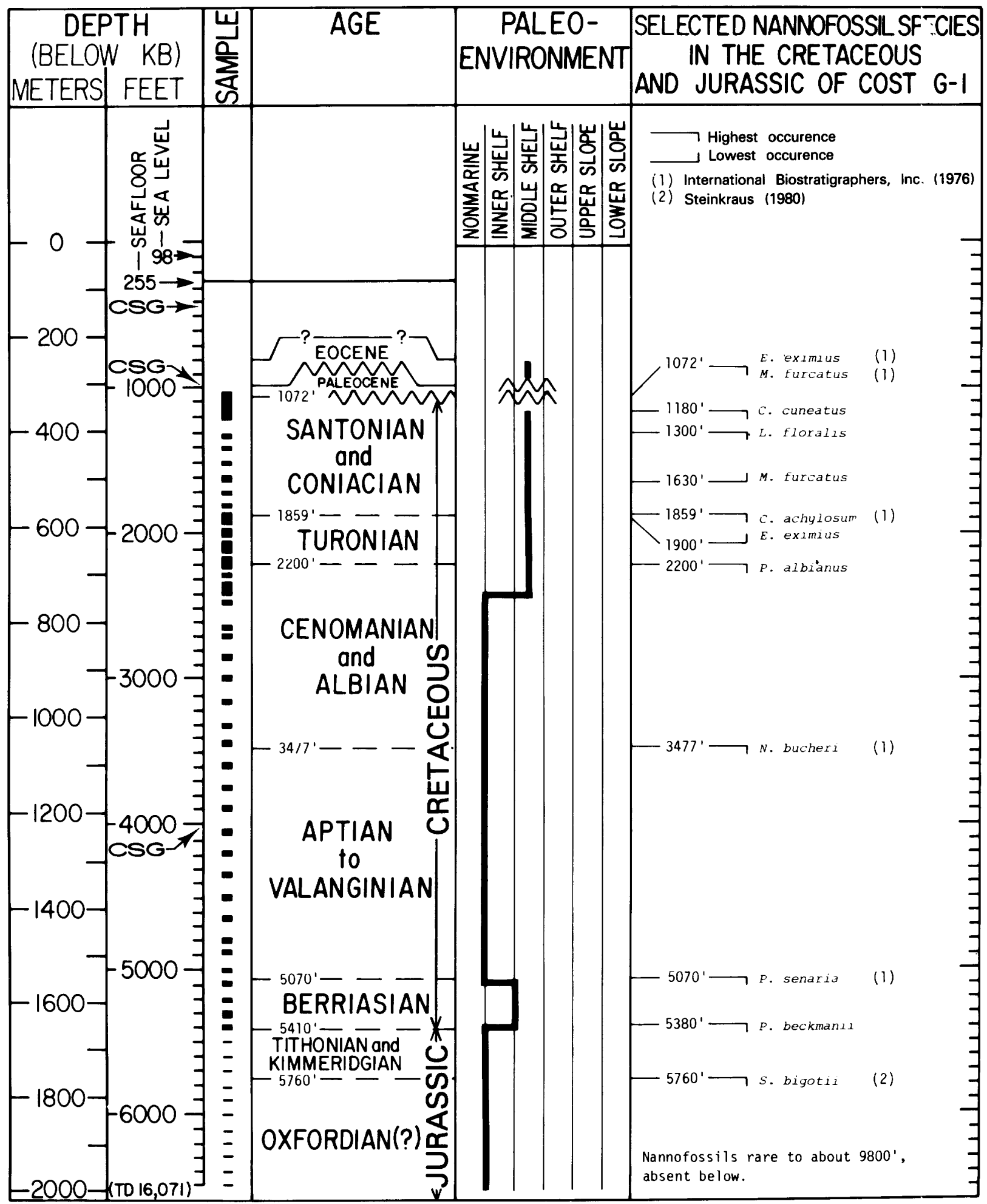

FIgURE 13.-Calcareous nannofossil biostratigraphy and paleoenvironments of the upper 6,500 $\mathrm{ft}(1,981 \mathrm{~m})$ of the COST No. G-1 well. Paleoenvironment curves are qualitative and depict only trends. Depths are relative to the Kelly Rushing (KB), $98 \mathrm{ft}(30 \mathrm{~m})$ above sea level. Water depth is $157 \mathrm{ft}(48 \mathrm{~m})$. CSG indicates a casing point. In sample column, blark areas indicate a complete sequence of samples studied. Ages are based on findings of this study but incorporate some binstratigraphic information from International Biostratigraphers, Inc. (1976). 


\section{SANTONIAN AND CONIACIAN}

(1,072-1,859 FT; 327-567 M).

The 100-ft $(30-\mathrm{m})$ interval between the casing at $972 \mathrm{ft}(296 \mathrm{~m})$ and the top of Santonian and Coniacian strata at $1,072 \mathrm{ft}(327 \mathrm{~m})$ contains few fossils. Paleocene dinoflagellates and a Cretaceous pollen specimen are present in a sidewall core from $1,013 \mathrm{ft}(309 \mathrm{~m})$, but calcareous nannofossils and foraminifers are absent (International Biostratigraphers, Inc., 1976). A cutting sample from 1,030 to $1,060 \mathrm{ft}(314$ to $323 \mathrm{~m})$ contains quartz sand and mollusk shell fragments, as well as cement chips that are contaminated with both Tertiary and Cretaceous nannofossils. The next sample down (1,060-1,090 ft; $323-332 \mathrm{~m})$ is also predominantly quartz sand and cement, but calcareous glauconitic siltstone clasts are also present; some of these clasts contain nannofossils of middle to late Eocene age, and others contain a sparse Late Cretaceous flora. Maestrichtian and Campanian strata were not recovered and are apparently missing at the site. Disconformities probably exist below the Eocene limestone and also between the thin Paleocene strata and the underlying Santonian and Coniacian calcareous siltstone.

Undifferentiated Santonian and Coniacian strata $787 \mathrm{ft}(240 \mathrm{~m})$ thick are present from 1,072 to $1,859 \mathrm{ft}$ ( 327 to $567 \mathrm{~m})$. Fossiliferous calcareous siltstone is interbedded with quartz sand and mollusk shell fragments that were deposited in a marine shelf environment. Marthasterites furcatus, a species that is not known to range above the Santonian, and Eiffellithus eximius are present in sidewall cores at $1,072 \mathrm{ft}(327 \mathrm{~m})$ (International Biostratigraphers, Inc., 1976). Two species that also are not known to range above the Santonian, Chiastozygus cuneatus and Lithastrinus floralis, are found at $1,180 \mathrm{ft}(360 \mathrm{~m})$ and $1,300 \mathrm{ft}$ $(396 \mathrm{~m})$, respectively.

\section{TURONIAN (1,859-2,200 FT; 567-671 M)}

The top of the Turonian is placed at the highest occurrence of Corollithion achylosum, in a sidewall core from 1,859 ft (567 m) (International Biostratigraphers, Inc., 1976). Eiffellithus eximus, a Turonian (and younger) species, is not present below 1,900 ft (579 m). Podorhabdus albianus, a species that ranges from the Albian into the lower Turonian, does not occur above $2,200 \mathrm{ft}(671 \mathrm{~m})$ in the COST No. G-1 well, and its highest occur- rence marks the provisional lower boundary of this interval. The Turonian is $341 \mathrm{ft}(104 \mathrm{~m})$ thick and consists of calcareous siltstone, coarse quartz sand, and mollusk shells that are indicative of a marine-shelf environment.

\section{CENOMANIAN AND ALBIAN (2,200-3,47: FT; 671-1,060 M)}

The 1,277-ft (389-m) section from 2,200 to $3,477 \mathrm{ft}(671$ to $1,060 \mathrm{~m})$ is chiefly quartz sand, except for about $200 \mathrm{ft}(61 \mathrm{~m})$ of calcareous siltstone at the top of the interval. At about $2,400 \mathrm{ft}$ $(732 \mathrm{~m})$, quartz sand and gravel be?ome dominant and are associated with mica, lignite, and mollusk shell fragments, and the few sedimentary clasts that are present do not contain calcareous nannofossils. These strata represent a nonmarine to shallow marine environment. Spcres and pollen are present, and Albian species are reported from the lower part of the interval; foraminifers are absent and dinoflagellates are rare (International Biostratigraphers, Inc., 1976).

\section{APTIAN TO VALANGINIAN (3,477-5,070 FT; 1,060-1,545 M)}

The top of the Aptian to Valanginian section is provisionally placed at $3,477 \mathrm{ft}(1,060 \mathrm{~m})$ based on the highest occurrence of Nannoconus bucheri from a sidewall core (Internaticnal Biostratigraphers, Inc., 1976). This interval is $1,593 \mathrm{ft}$ $(486 \mathrm{~m})$ thick and is characterized by coarse quartz sand and gravel, lignite, mica, and sandstone. Calcareous nannofossils and foraminifers are rare in the sandstone, although several sidewall cores near $3,500 \mathrm{ft}(1,067 \mathrm{~m})$ contain sparse assemblages. Dinoflagellates are present in the upper part of this section; spores and pollen occur throughout (International Biortratigraphers, Inc., 1976). Casing was set at 4,C $23 \mathrm{ft}(1,226 \mathrm{~m})$ and the underlying $700 \mathrm{ft}(213 \mathrm{~m})$ of cuttings are quartz sand devoid of sedimentary rock fragments. Lower Cretaceous stages cannot be differentiated in the Aptian to Valan ginian interval, and hiatuses may be present. These beds were deposited in a nonmarine to shallow marine environment.

BERRIASIAN (5,070-5,410 FT; 1,545-1,649 M)

Berriasian calcareous siltstone $340 \mathrm{ft}(104 \mathrm{~m})$ thick is present from 5,070 to $5,410 \mathrm{ft}(1,545$ to $1,649 \mathrm{~m})$. The top of this interval is placed at the 
highest occurrence of the Berriasian nannofossil species Polycostella senaria in a sidewall core from 5,070 ft (1,545 m) (International Biostratigraphers, Inc., 1976). A small assemblage composed of Cyclagelosphaera margerelii, Micrantholithus obtusus, Polycostella beckmannii, $P$. senaria, Watznaueria barnesae, and $W$. communis that is indicative of Berriasian Age was observed in the sample from 5,380 to $5,410 \mathrm{ft}(1,640$ to $1,649 \mathrm{~m})$. The Jurassic-Cretaceous boundary is drawn here at the lowest occurrence of Polycostella senaria. Polycostella beckmannii is present also somewhat lower in the section, and it has been reported from conventional cores and sidewall cores from $5,478.3 \mathrm{ft}(1,670 \mathrm{~m}), 5,531 \mathrm{ft}$ $(1,686 \mathrm{~m})$, and $5,699 \mathrm{ft}(1,737 \mathrm{~m})$ (International Biostratigraphers, Inc., 1976). Dinoflagellates are rare or absent in overlying strata, but they are more abundant in the Berriasian beds (International Biostratigraphers, Inc., 1976), which were probably deposited in a marine shelf environment.

\section{JURASSIC (5,410-15,310 FT; 1,649-4,666 M)}

The Jurassic-Cretaceous boundary is drawn at the lowest occurrence of Polycostella senaria at $5,410 \mathrm{ft}(1,649 \mathrm{~m})$. International Biostratigraphers, Inc. (1976), reported nannofossil assemblages of Jurassic aspect that included Polycostella beckmannii, Ethmorhabdus gallicus, Cyclagelosphaera margerelii, and Polypodorhabdus escaigii from cores in the interval $5,475.8-5,767 \mathrm{ft}(1,669$ to $1,758 \mathrm{~m})$, but sidewall cores and conventional cores from 5,839 to $15,851 \mathrm{ft}(1,780$ to $4,831 \mathrm{~m})$ contain no nannofossils. The cutting samples from 5,410 to $6,300 \mathrm{ft}(1,649$ to $1,920 \mathrm{~m})$ are barren or contain few nannofossils, and only the species Cyclagelosphaera margerelii is present. However, one sample from 6,400 to $6,410 \mathrm{ft}(1,951$ to $1,954 \mathrm{~m})$ contains rare, moderately preserved specimens of Stephanolithion bigotii, Polypodorhabdus escaigii, Cyclagelosphaera margerelii, and Vagalapilla stradneri and is probably Oxfordian in age. Steinkraus (1980) reported the CallovianOxfordian species Stephanolithion bigotii in cuttings from 5,760 to $5,770 \mathrm{ft}(1,756$ to $1,759 \mathrm{~m})$ and 6,400 to $6,410 \mathrm{ft}(1,951$ to $1,954 \mathrm{~m})$. Oxfordian strata also may exist lower in the section. Four species, Cyclagelosphaera margerelii, Ethmorhabdus gallicus, Polypodorhabdus escaigii, and Watznaueria barnesae, are present sporadically from 6,710 to $7,710 \mathrm{ft}(2,045$ to $2,350 \mathrm{~m})$, and an assemblage containing Cyclagelosphaer. margerelii, Ethmorhabdus gallicus, Watzmaueria barnesae, and $W$. crucicentralis is present at 9,800-9,810 ft $(2,987-2,990 \mathrm{~m})$. All cutting samples below this level contain no calcareous nannofossils. The Jurassic section down to about $10,000 \mathrm{ft}(3,048 \mathrm{~m})$ is interbedded sandstcne and shale that were deposited in a nonmarine environment interrupted by occasional marine incursions. Below about $10,000 \mathrm{ft}(3,048 \mathrm{~m})$. interbedded limestone, dolomite, sandstone, ant shale contain predominantly terrestrial palynomorphs (International Biostratigraphers, Inc., 1976) and are indicative of deposition in nonmarine and shallow marine carbonate bank environments.

\section{BIOSTRATIGRAPHY AND PALEOENVIRON'MENT OF THE COST NO. G-2}

The COST No. G-2 well was drilled to a depth of $21,874 \mathrm{ft}(6.667 \mathrm{~m})$. Rotary cutting s`mples from the COST No. G-2 well were collected and processed for the study of calcareous nannofossils as described for the COST No. G-1 well. From 1,100 to $8,800 \mathrm{ft}(335$ to $2,682 \mathrm{~m})$, the samples studied were generally at intervals of 30 ft $(9 \mathrm{~m})$ or less, but several samples were as much as $60 \mathrm{ft}(18 \mathrm{~m})$ apart. Deeper in the well, down through $21,850 \mathrm{ft}(6,660 \mathrm{~m})$, most samples were studied at $260-\mathrm{ft}(79-\mathrm{m})$ intervals or less, although a few were as much as $360 \mathrm{ft}(110 \mathrm{~m})$ apart. A total of 777 samples from 238 levels in the well were analyzed (fig. 14). Sample depths are relative to the Kelly Bushing, which ws $79 \mathrm{ft}$ $(24 \mathrm{~m})$ above sea level and $351 \mathrm{ft}(107 \mathrm{~m})$ above the sea floor. Selected information from the reports on the COST No. G-2 well by International Biostratigraphers, Inc. (1977) and Amato and Simonis (1980) has been incorporated into the present study. The highest and lowest occurrences of stratigraphically important calcareous nannofossil species were determined from this study and from the study by International Biostratigraphers, Inc. (1977) (fig. 14).

$$
\text { EOCENE ( 1,000-1,310 ft; } \sim 305-399 \mathrm{M})
$$

Casing was set at $505 \mathrm{ft}(154 \mathrm{~m})$ and also at $1,061 \mathrm{ft}(323 \mathrm{~m})$, probably in the Eocene sismic reflector, and samples were collected starting at $1,100 \mathrm{ft}(335 \mathrm{~m})$. Cuttings from 1,100 to $1,460 \mathrm{ft}$ (335 to $445 \mathrm{~m}$ ) are characterized by glauconite, 


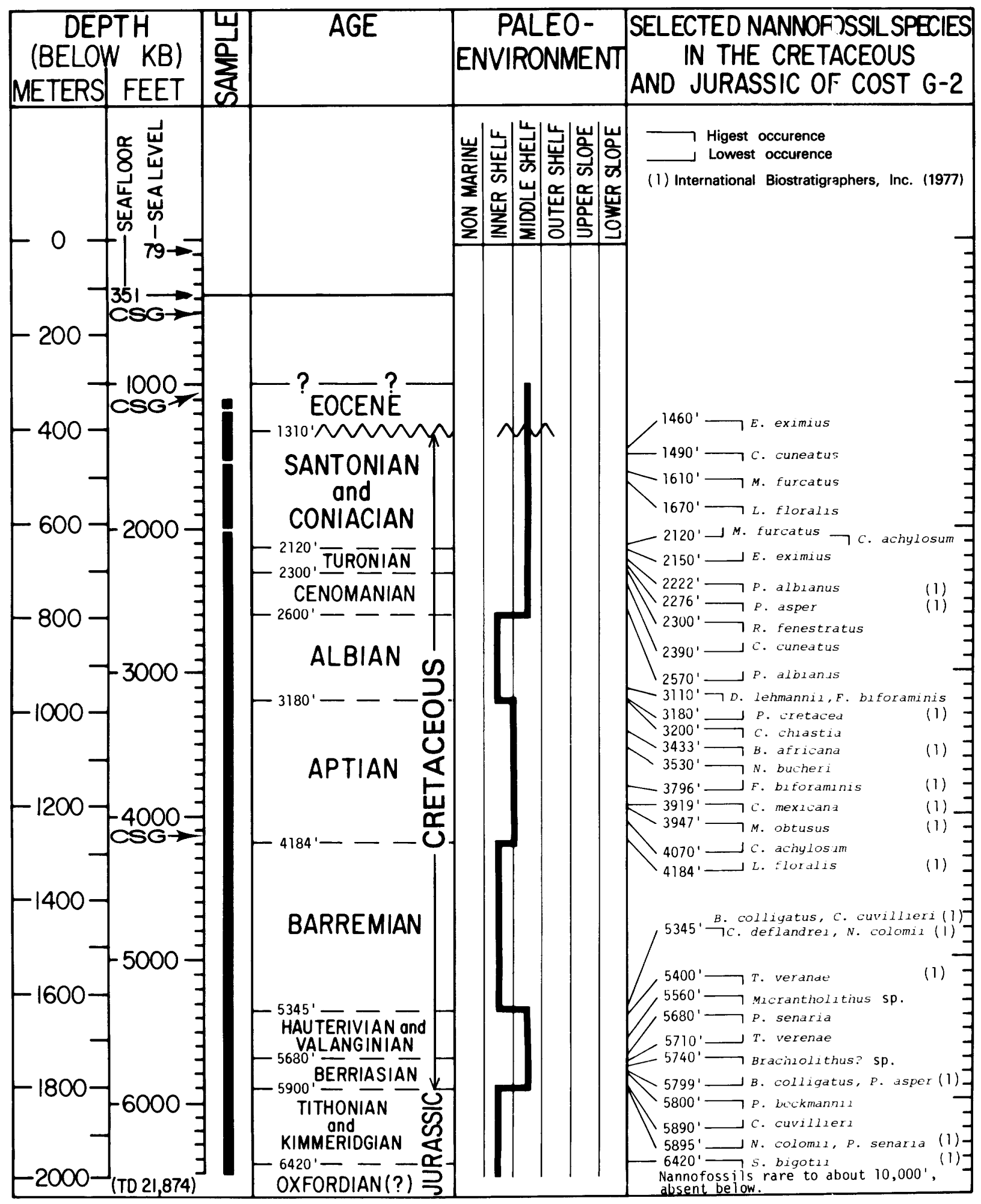

Figure 14.-Calcareous nannofossil biostratigraphy and paleoenvironments of the upper 6,500 $\mathrm{ft}(1,981 \mathrm{~m})$ of the COST No. G-2 well. Paleoenvironment curves are qualitative and depict only trends. Depths are relative to the Kelly Bushing (KB), $79 \mathrm{ft}(24 \mathrm{~m})$ above sea level. Water depth is $272 \mathrm{ft}(83 \mathrm{~m})$. CSG is a casing point. In sample colunn, black areas indicate a complete sequence of samples studied. Ages are based on findings of this study, but incorporate some biostratigraphic information from International Biostratigraphers, Inc. (1977), and Steinkraus (1980). 
quartz sand, fragments of bivalves and bryozoans, and abundant cement. Sedimentary clasts are not common, and most are barren, although glauconitic limestone fragments containing a rich, diverse, well-preserved, calcareous nannofossil assemblage were sampled at $1,310 \mathrm{ft}$ $(399 \mathrm{~m})$. The following species are present, among others, and they are indicative of the upper Eocene Discoaster barbadiensis zone of Bukry (1973, 1975): Chiasmolithus oamaruensis, Cyclococcolithina formosa, Dictyococcites bisectus, Discoaster saipanensis, Reticulofenestra reticulata, and $R$. umbilica. International Biostratigraphers, Inc. (1977), reported a foraminiferal fauna of late middle Eocene age from a sidewall core at 1,289 $\mathrm{ft}(393 \mathrm{~m})$. The Eocene cuttings are indicative of a marine shelf environment. The cuttings may be mostly cavings, but together with the sidewall core they confirm the presence at the COST No. G-2 site of a widespread Eocene limestone unit that has been sampled elsewhere beneath Georges Bank and in submarine canyons on the slope (Weed and others, 1974; Ryan and others, 1978; Hathaway and others, 1979; Valentine, 1981). Upper Eocene limestone cavings are present in samples down to $4,120 \mathrm{ft}(1,256 \mathrm{~m})$.

\section{SANTONIAN AND CONIACIAN (1,310-2,120 FT; 399-646 M)}

Paleocene, Maestrichtian, and Campanian strata were not observed in the COST No. G-2 well, suggesting that there is a major disconformity at the Cretaceous-Tertiary boundary at about $1,300 \mathrm{ft}(396 \mathrm{~m})$. International Biostratigraphers, Inc. (1977), reported Inoceramus shell prisms and Upper Cretaceous foraminifers in cuttings at $1,310 \mathrm{ft}(399 \mathrm{~m})$ and a Santonian foraminiferal assemblage in a sidewall core from $1,324 \mathrm{ft}(404 \mathrm{~m})$. In the present study, a mixed assemblage of rare, poorly preserved Eocene and Upper Cretaceous nannofossils was observed at $1,340 \mathrm{ft}(408 \mathrm{~m})$; and a poorly preserved flora of probable Santonian Age containing Eiffellithus eximius, Tetralithus obscurus, and T. ovalis was found at $1,460 \mathrm{ft}(445 \mathrm{~m})$.

Santonian and Coniacian nannofloras are present in a 796-ft $(243-\mathrm{m})$-thick section of glauconitic, silty limestone and gray calcareous siltstone from 1,460 to $2,120 \mathrm{ft}$ (445 to $646 \mathrm{~m}$ ). The nannofossils are abundant and well-preserved. The highest occurrence of Chiastozygus cuneatus, a species that is not known to range above the Santonian, is at $1,490 \mathrm{ft}(454 \mathrm{~m})$. Mar- thasterites furcatus $(1,610 \mathrm{ft} ; 491 \mathrm{~m})$ and Lithastrinus floralis $(1,670 \mathrm{ft} ; 509 \mathrm{~m})$ are also present lower in this interval. The abundant glauconite and mollusk-shell fragments, particularly Inoceramus prisms, are indicative of deposition in a marine shelf environment.

\section{TURONIAN (2,120-2,270 FT; 646-692 M)}

A relatively thin (150-ft; $46-\mathrm{m})$ section of richly fossiliferous, gray, argillaceous limestone of Turonian Age is present from 2,120 to $2,270 \mathrm{ft}$ $(646$ to $692 \mathrm{~m})$. These beds are litholopically similar to the overlying Santonian and Coniacian strata, and the top of the Turonian is drawn at the highest occurrence of Corollithion achylosum. Podorhabdus albianus, a species that is restricted to Turonian and older rocks, appears in a sidewall core from 2,222 $\mathrm{ft}(667 \mathrm{~m})$ in the COST No. G-2 well (International Biostratigraphers, Inc., 1977). Two species, Marthasterites furcatus and Eiffellithus eximius, which are restricted to Turonian and younger strata, are absent below 2, $120 \mathrm{ft}$ $(646 \mathrm{~m})$ and $2,150 \mathrm{ft}(655 \mathrm{~m})$, respectively. Cuttings from the Turonian interval contain molluskshell fragments that indicate deposition in a marine-shelf environment.

\section{CENOMANIAN (2,270-2,600 FT; 692-792 M)}

Cenomanian gray calcareous siltstone is approximately $330 \mathrm{ft}(101 \mathrm{~m})$ thick and is somewhat more siliceous than the overlying strata. Nannofossils are common and well preserved. The top of the Cenomanian is placed at the highest occurrence of the planktic foraminifer Rotalipora cushmani in a cutting sample from $2,270 \mathrm{ft}(6.2 \mathrm{~m})$ and in a sidewall core from $2,276 \mathrm{ft}(694 \mathrm{~m})$ (International Biostratigraphers, Inc., 1977). Porhabdolithus asper and Reinhardites fenestratus are not present in the COST No. G-2 well above $2,276 \mathrm{ft}(694 \mathrm{~m})$ and $2,300 \mathrm{ft}(701 \mathrm{~m})$, respectively; these nannofossil species become extinct at or near the Cenomanian-Turonian boundary.

The base of the Cenomanian is arbitrarily drawn at 2,600 $\mathrm{ft}(792 \mathrm{~m})$, where the litholo oy of the section changes from a shelly siltstone to a calcareous quartz sandstone containing lignite, mica, and mollusk-shell fragments. Sidewall cores from about 2,600 to $3,100 \mathrm{ft}$ (792 to $945 \mathrm{~m}$ ) contain almost no calcareous nannofossils and foram- 
no younger than Albian age at about $2,650 \mathrm{ft}$ $(808 \mathrm{~m})$ (International Biostratigraphers, Inc., 1977). Cenomanian strata were deposited in a marine-shelf environment, probably shallower than that of Turonian, Coniacian, and Santonian time.

\section{ALBIAN (2,600-3, 180 FT; 792-969 M)}

Albian, Aptian, and Barremian strata approximately $2,745 \mathrm{ft}(837 \mathrm{~m})$ thick are present from 2,600 to $5,345 \mathrm{ft}(792$ to $1,629 \mathrm{~m})$. Most of this section contains few fossils and is difficult to date; therefore, the stratigraphic boundaries are provisional. The upper $580 \mathrm{ft}(177 \mathrm{~m})$, from 2,600 to $3,180 \mathrm{ft}$ (792 to $969 \mathrm{~m}$ ), is gray calcareous sandstone and shale with associated mollusk shells, glauconite, and lignite, and indicates deposition in a marine inner-shelf environment. Sidewall cores contain almost no calcareous nannofossils and foraminifers, and dinoflagellates are less common than in overlying strata (International Biostratigraphers, Inc., 1977). These beds are assigned to the Albian based on the lowest occurrence of Prediscosphaera cretacea in a sidewall core from $3,180 \mathrm{ft}(969 \mathrm{~m})$.

\section{APTIAN $(3,180-4,184$ FT; 969-1,275 M)}

The strata from 3,180 to $4,184 \mathrm{ft}$ (969 to $1,275 \mathrm{~m}$ ) are more fossiliferous than the overlying Albian beds. This $1,004-\mathrm{ft}(306-\mathrm{m})$ interval is provisionally assigned to the Aptian based on the highest occurrences of Nannoconus bucheri, Conusphaera mexicana, and Micrantholithus obtusus, and the lowest occurrences of Flabellites biforaminis, Corollithion achylosum, and Lithraphidites floralis. Nannofossils are not abundant, and preservation is only moderate. The Aptian beds are chiefly sandstone and shale con taining mollusk shell fragments. They are more calcareous and contain less lignite than the overlying Albian strata, and they were laid down in a marine shelf environment.

\section{BARREMIAN (4,184-5,345 FT; 1,275-1,629 M)}

Casing was set at $4,120 \mathrm{ft}(1,256 \mathrm{~m})$, apparently at a lithologic boundary. The 1,161-ft $(354-\mathrm{m})$ section from 4,184 to $5,345 \mathrm{ft}(1,275$ to $1,629 \mathrm{~m})$ is calcareous sandstone containing lignite and mica and a few fossils. It was deposited in an innershelf environment similar to that of the Albian. Sidewall cores from this interval contain almost no calcareous nannofossils and foraminifers, but palynomorphs are present, and the top of the Barremian is based on the highest occurrences of several dinoflagellate species (International Biostratigraphers, Inc., 1977).

\section{HAUTERIVIAN AND VALANGINIAN (5, \$45-5,680 FT; 1,629-1,731 M)}

Hauterivian and Valanginian argillaceous limestone $335 \mathrm{ft}(102 \mathrm{~m})$ thick extends from 5,345 to $5,680 \mathrm{ft}(1,629$ to $1,731 \mathrm{~m})$. Moderately preserved calcareous nannofossils are common. Species indicative of Hauterivian and oldor strata are present at $5,345 \mathrm{ft}(1,629 \mathrm{~m})$. The highest occurrences in sidewall cores of Bipoa'orhabdus colligatus, Cruciellipsis cuvillieri, and Cyclagelosphaera deflandrei are at $5,345 \mathrm{ft}(1,629 \mathrm{~m})$, and Tubodiscus verenae is present at $5,400 \mathrm{ft}$ $(1,646 \mathrm{~m})$. Micrantholithus sp. (Valentine, 1980, pl. 2, fig. 13) is present in two cutting samples from the interval 5,560 to $5,65 \mathrm{C} \mathrm{ft}(1,695$ to $1,722 \mathrm{~m}$ ) in the Hauterivian and Volanginian and in one sample from the underlying Berriasian strata. A single occurrence of this species was reported from the Hauterivian and Valanginian of the COST No. B-3 well on th? continental slope off New Jersey (Valentine, 1980). The Hauterivian-Valanginian argillacenus limestone at the COST No. G-2 site was probably deposited in a marine shelf environment.

\section{BERRIASIAN (5,680-5,900 FT; 1,731-1,798 M)}

The Berriasian is represented $b r$ a short interval $(210 \mathrm{ft} ; 64 \mathrm{~m})$ of light-gray lim?stone that extends from 5,680 to $5,900 \mathrm{ft}(1,7 £ 1$ to $1,798 \mathrm{~m})$. The Berriasian-Valanginian boundary is placed at the highest occurrence of the Berriasian nannofossil Polycostella senaria. The highest occurrence of Polycostella beckmannii, a species that ranges from the Tithonian into the Berriasian, is at $5,800 \mathrm{ft}(1,768 \mathrm{~m})$. Several stratigraphically important species that are restricted to Berriasian and younger rocks and have thei: lowest occurrences in this interval of the well are Bipodorhabdus colligatus and Parhabdolithus asper at $5,799 \mathrm{ft}(1,768 \mathrm{~m})$, Cruciellipsis cuvillieri at 
$5,890 \mathrm{ft}(1,795 \mathrm{~m})$, and Nannoconus colomii and Polycostella senaria at $5,895 \mathrm{ft}(1,797 \mathrm{~m})$. Brachiolithus? sp. (Valentine, 1980, pl. 2, figs. 1, 2) is present at $5,800 \mathrm{ft}(1,768 \mathrm{~m})$ and in several lower samples in the COST No. G-2 well. This species is restricted to the Berriasian of the COST No. B-3 well (Valentine, 1980) and may prove to be a valuable marker for that stage. In addition, the Cretaceous dinoflagellate Pseudoceratium pelliferum is not present in sidewall cores below 5,856 ft $(1,785 \mathrm{~m})$ (International Biostratigraphers, Inc., 1977). The Berriasian limestone probably was deposited in a marine shelf environment similar to that of the overlying Hauterivian and Valanginian beds.

\section{JURASSIC (5,900-21,874? FT; 1,798-6,667? M)}

The Jurassic-Cretaceous boundary is provisionally placed at $5,900 \mathrm{ft}(1,798 \mathrm{~m})$, near the lowest occurrences of the nannofossil species Cruciellipsis cuvillieri, Nannoconus colomii, and Polycostella senaria. Below this depth nannofossil diversity is low and the limestone is partly recrystallized. International Biostratigraphers, Inc. (1977), studied sidewall cores from the boundary interval and observed a Late Jurassic dinoflagellate assemblage at $5,962 \mathrm{ft}(1,817 \mathrm{~m})$; the Jurassic dinoflagellate Meiourogonyaulax staffensis is present from 6,155 to about $7,500 \mathrm{ft}$ (1,876 to about $2,286 \mathrm{~m})$, and the TithonianBerriasian nannofossil species Polycostella beckmannii, is present down to $6,270 \mathrm{ft}(1,911 \mathrm{~m})$. In this study, cuttings that are almost barren of calcareous nannofossils appear at about $5,900 \mathrm{ft}$ $(1,798 \mathrm{~m})$ : Except for Lower Cretaceous cavings, most samples down to about $10,000 \mathrm{ft}(3,048 \mathrm{~m})$ are barren or contain poorly preserved specimens of two long-ranging Jurassic-Cretaceous species, Cyclagelosphaera margerelii and Watznaueria barnesae.

Samples of the present study from below $10,000 \mathrm{ft}(3,048 \mathrm{~m})$ are barren of nannofossils. However, International Biostratigraphers, Inc. (1977), reported the presence of the nannofossil Stephanolithion bigotii, of Callovian-Oxfordian Age, in five sidewall cores from 6,420 to $6,818 \mathrm{ft}$ $(1,957$ to $2,078 \mathrm{~m})$ and in two sidewall cores from 10,135 and $10,247 \mathrm{ft}(3,089$ and $3,123 \mathrm{~m})$; the upper five samples are from a part of the section dated as Kimmeridgian and Tithonian using foraminifers and palynomorphs. At the COST
No. G-1 well, Stephanolithion bigotii was observed in a cutting sample of the present study from 6,400 to $6,410 \mathrm{ft}(1,951$ to $1,954 \mathrm{~m})$; and Steinkraus (1980) reported the species in cuttings from the same level and also from 5,760 to $5,770 \mathrm{ft}(1,756$ to $1,759 \mathrm{~m})$. Thus, in both wells, Stephanolithion bigotii, a species that do s not normally range above the Oxfordian, is present in strata that have been provisionally dated a" Kimmeridgian and Tithonian on the basis of ralynomorphs and foraminifers. Below about $9,500 \mathrm{ft}$ $(2,896 \mathrm{~m})$ in the COST No. G-2 well, ralynomorphs and foraminifers indicate that strrta are Oxfordian, Callovian, and possibly Late T iassic to Early Jurassic in age (International Biostratigraphers, Inc., 1977). The Jurassic section in the COST No. G-2 well is about $16,000 \mathrm{ft}(4,\{77 \mathrm{~m})$ thick. It is predominantly shallow marine limestone, but it also includes dolomite and bars of anhydrite; halite is present at the bottom of the well.

\section{SUMMARY}

The Jurassic stratigraphy of the COST Nos. G-1 and G-2 sites is not well defined. Strata dated as Middle and Late Jurassic age using terrestrial and marine palynomorphs are present in both wells, but the stages are difficult to delineate. The deeper, less fossiliferous beds may be as old as Early Jurassic or late Triassic. The saction in the COST No. G-1 well from the JuassicCretaceous boundary at $5,410 \mathrm{ft}(1,649 \mathrm{~m})$ down to about $10,000 \mathrm{ft}(3,048 \mathrm{~m})$ is composed of calcareous and noncalcareous shale, siltstone, and sandstone, all of which contain dinoflagellates, terrestrial palynomorphs, and sparse calcareous nannofossils. From 10,000 $\mathrm{ft}(3,048 \mathrm{~m})$ dorm to the metasedimentary basement rocks at about $15,600 \mathrm{ft}(4,755 \mathrm{~m})$, shale and sandstone are interbedded with limestone, dolomite, and anhyrdrite; terrestrial palynomorphs are present, but dinoflagellates and calcareous nannofossils are extremely rare. Jurassic strata at the G-1 site were deposited in alternating nonmarine and sl allow marine environments. The COST No. G- $\uparrow$ well was drilled on a basement high (Klitgord and Behrendt, 1979, fig. 7c; Waetjen, 1980, pl. 4), whereas the COST No. G-2 well is in a c'seper part of the Georges Bank basin where the Jurassic section contains more calcareous sediment 
and is representative of a shallow marine environment. At the G-2 site, calcareous shale and sandstone are interbedded with limestone from 5,900 to about $10,000 \mathrm{ft}(1,798$ to about $3,048 \mathrm{~m})$, below which ooltic limestone is the principal rock type down to about $13,500 \mathrm{ft}(4,115 \mathrm{~m})$; below $7,500 \mathrm{ft}$ $(2,286 \mathrm{~m})$, marine and terrestrial palynomorphs are present, but calcareous nannofossils and foraminifers are rare or absent. Limestone, dolomite, and anhydrite dominate the section from about $13,500 \mathrm{ft}(4,115 \mathrm{~m})$ down to the salt encountered near the bottom of the hole; palynomorphs are rare, and calcareous nannofossils and foraminifers are absent in this part of the section.

Lower Cretaceous and Cenomanian rocks at the COST No. G-1 site are present from 2,400 to $5,410 \mathrm{ft}$ (732 to $1,649 \mathrm{~m}$ ). They are chiefly coarsegrained quartz sand and lignitic, micaceous sandstone interbedded with calcareous siltstone representing deposition in nonmarine and shallow marine environments. These strata contain few fossils, and neither the Lower Cretaceous stages nor the Albian-Cenomanian boundary can be delineated accurately. Terrestrial palynomorphs are present throughout the section, whereas dinoflagellates, calcareous nannofossils, and foraminifers are absent except in shallow marine beds near $3,500 \mathrm{ft}(1,067 \mathrm{~m})$ and in the Berriasian strata at the base of the interval.

At the COST No. G-2 site, the upper part of the Lower Cretaceous, from 2,600 to $5,345 \mathrm{ft}$ (792 to $1,629 \mathrm{~m}$ ), is mainly calcareous siltstone and shale containing mollusk shells, glauconite, and lignite. Albian and Barremian strata of this interval are notably less fossiliferous than the intervening
Aptian beds; all were deposited in a marine innershelf environment. At both sites, the Aptian strata show more marine influence than Albian or Barremian strata. The Hauterivian, Valanginian, and Berriasian strata from 5,345 to $5,900 \mathrm{ft}$ $(1,629$ to $1,798 \mathrm{~m})$ are fossiliferous limestone also of marine shelf origin. The Lower Cretaceous at the G-2 site is slightly thicker and generally more fossiliferous than at the G-1 site. The Hauterivian and Valanginian strata in the G-2 well were deposited in a marine shelf environment; strata of the same age in the G-l well represent nonmarine to shallow marine conditions. The Berriasian is marine in both wells

The Upper Cretaceous sections are comparable in thickness at both sites. Cenomanian beds at the COST No. G-2 site are calcareous siltstone of marine shelf origin. At the COS . No. G-1 site, the Cenomanian and Albian quartz sand was deposited in a nonmarine to shallow marine environment. Santonian, Coniacian. and Turonian strata at the two well sites represent different sedimentary facies, but they indicate a marine shelf environment at both sites; at G-1, calcareous siltstone is interbedded with shelly quartz sand, whereas coeval strata at G-2 are glauconitic, argillaceous limestones that represent a facies deposited farther offshore.

Maestrichtian and Campanian beds were not observed in either well; there is a hiatus in the 100 - to $200-\mathrm{ft}(30-$ to $61-\mathrm{m})$ interval of poorly fossiliferous, reworked beds betrreen Santonian and Eocene strata. The Eocene ir both wells is a glauconitic limestone rich in calcareous nannofossils that was deposited on a marine carbonate shelf. 


\section{Foraminiferal and Seismic Stratigraphy, Paleoenvironments and Depositional Cycles in the Georges Bank Basin}

\section{Wylie Poag}

In this paper geologic information from the COST Nos. G-1 and G-2 wells and auxiliary shallow coreholes is combined with interpretations of multichannel seismic reflection profiles to provide a stratigraphy and depositional history of the Georges Bank basin (fig. 15). The biostratigraphic summary is based on the foraminiferal assemblages sampled from rotary cuttings taken at 10- to $90-\mathrm{ft}(3-$ to $29-\mathrm{m})$ intervals, except for wider spacing in the Oxfordian(?) to
Hettangian(?) section of the COST No. G-J well. Sidewall cores provided by International Biostratigraphiers, Inc., were also examined for foraminifers. (See Amato and Bebout, 1980, and Amato and Simonis, 1980, for locations of sidewall cores.) Age sequences are described from the youngest to the oldest. The zonation of the COST Nos. G-1 and G-2 wells is based on the final appearances of diagnostic planktic and benthic foraminifers. Established planktic foraminiferal

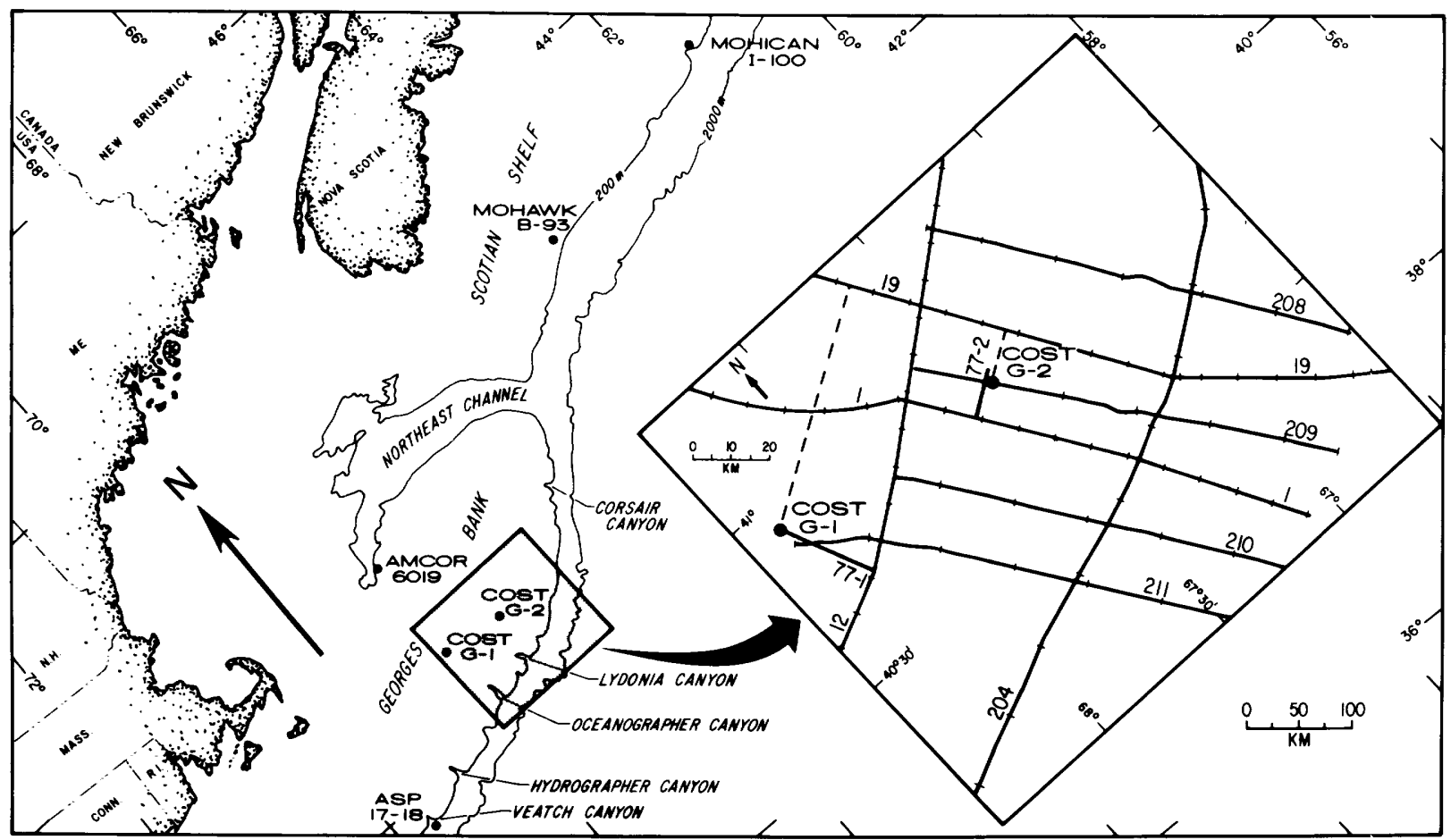

Figure 15.-Locations of well and core sites and seismic reflection profiles on North Atlantic Outer Continental Shelf and slope. 


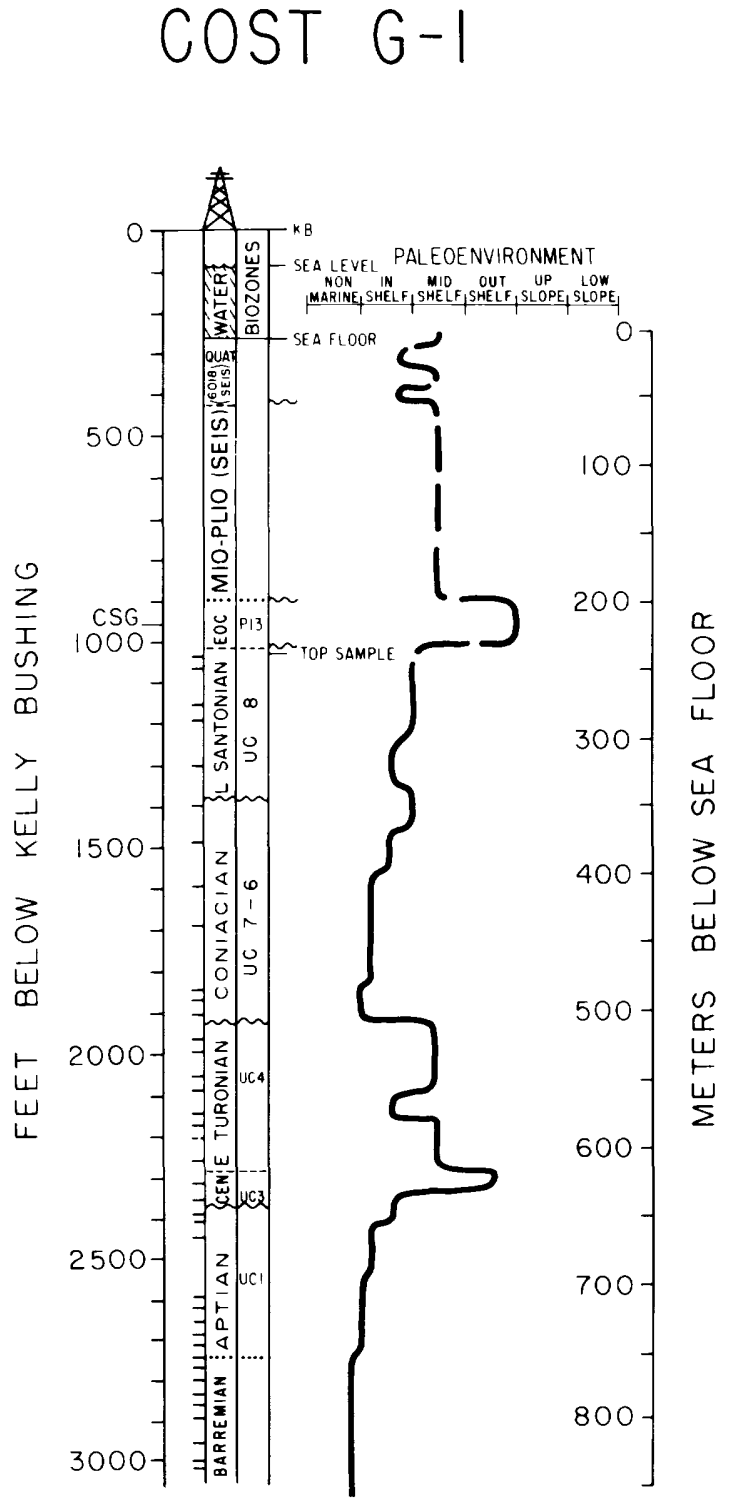

FIGURE 16.-Stratigraphic column of COST No. G-1 well showing chronostratigraphy, biozones, and paleoenvironments. The age terms abbreviated in the left side column are spelled out on figure 17 .

zonations are used where possible (Blow, 1969: Berggren and Van Couvering, 1974; Hardenbol and Berggren, 1978; Pessagno, 1967; Stainforth and others, 1975; van Hinte, 1976a, b). The benthic foraminiferal zonation of Ascoli (1976) was used to date Mesozoic assemblages. The biostratigraphic interpretations presented here are preliminary and later studies may modify and refine them.

The biostratigraphic analyses are used with interpretations of the seismic sequences to deter-

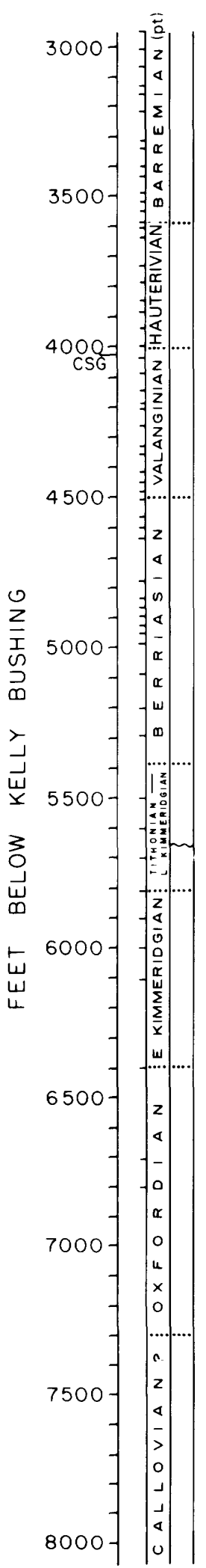
MON IN MID OUT UP LOW

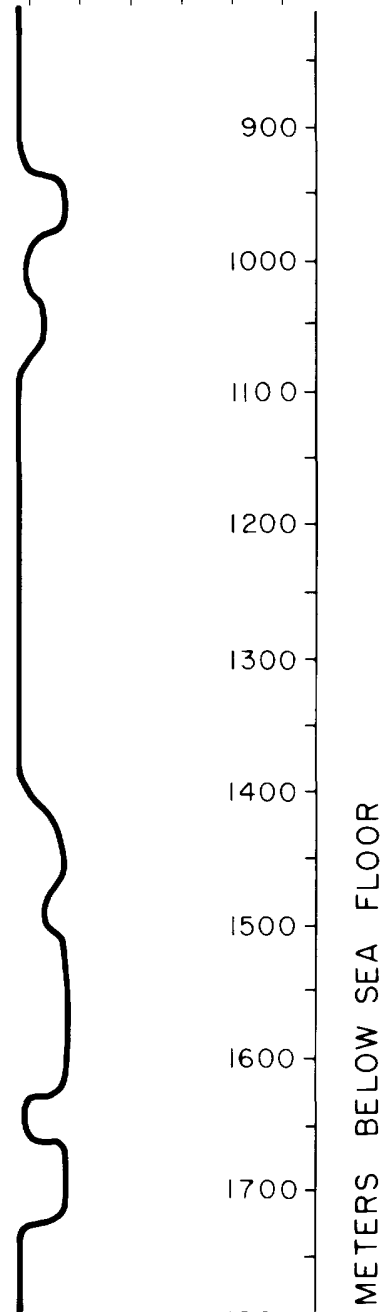

1900

2000 
PALEOENVIRONMENT

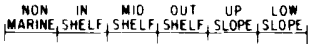

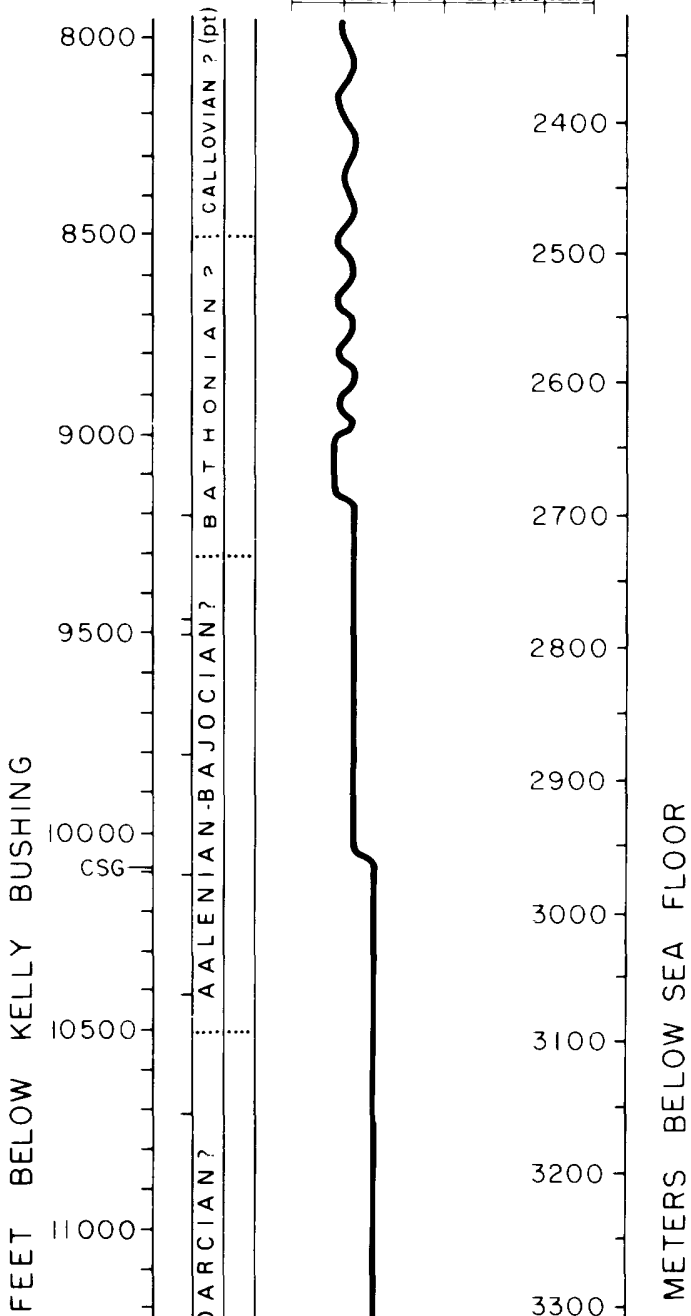

COST G. I

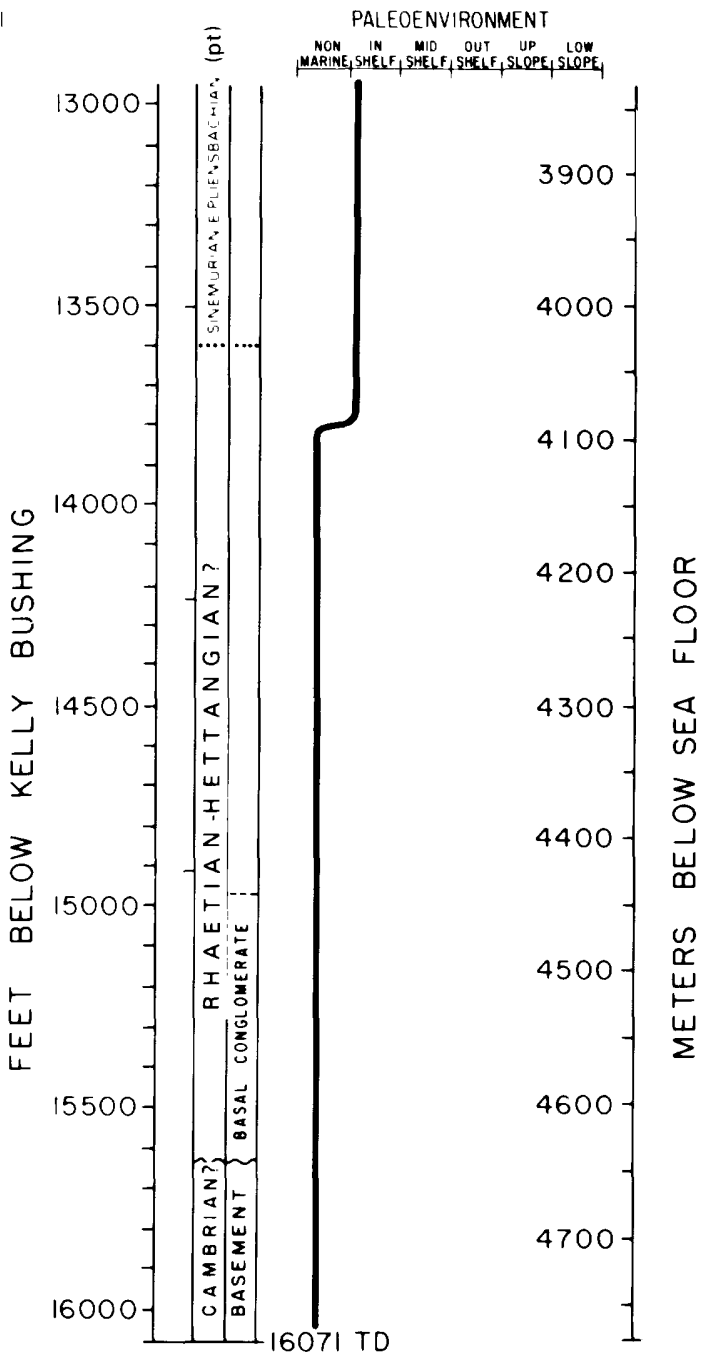

mine the presence of unconformities and to establish a chronostratigraphic framework for each well. The chronostratigraphic sequences are then used to calculate sediment accumuletion rates. The chronostratigraphic and lithost-atigraphic units are compared with those of the Scotian basin of Canada, and correlations are established between the COST No. G-2 and Shell Mohican I-100 wells. The stratigraphic nomenclature used in this basin is extrapolated from that used in wells on the Scotian shelf of Canada.

The paleoenvironmental analysis is based on the microfossil record of the COST Nos. G-1 and G-2 wells and an interpretation of seismic fr mies along USGS multichannel line 19. The biost"atigraphic, paleoenvironmental, and seismic sequence data are combined to determine depositional cycles. The lack of microfossils thrcigh 


\begin{tabular}{|c|c|c|c|c|c|c|c|}
\hline \multicolumn{2}{|r|}{ AGE } & 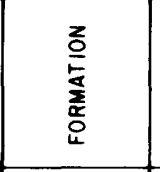 & 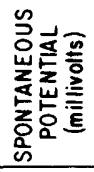 & LITHOLOGY & $\begin{array}{c}\text { RESISTIVITY } \\
\text { (ohms) }\end{array}$ & LITHOLOGY & $\begin{array}{c}\text { DEPTH } \\
\text { feet } \\
\end{array}$ \\
\hline CENOZOIC & PLIOCENE-MIOCENE & BANQUEREAU & & & & & \\
\hline \multirow{2}{*}{ 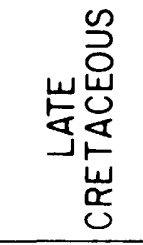 } & SANTONIAN & $\begin{array}{l}1 \\
2 \\
0 \\
2 \\
z \\
z\end{array}$ & & & & $\begin{array}{l}\text { SANDSTONE, and GRAVEL unconsolidoted coarse, ab- } \\
\text { undant shell fragments; glouconite, lignite. }\end{array}$ & $500-$ \\
\hline & E. TURONIAN & 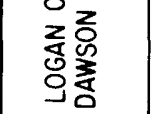 & & & & $\begin{array}{l}\text { SHALE gumbo - like, interbeds of coorse sond, gravel; } \\
\text { gbuconite }\end{array}$ & -2000 \\
\hline \multirow{2}{*}{ 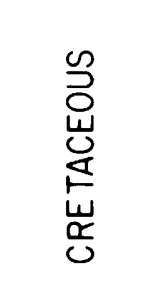 } & \multirow{3}{*}{ BARREMIAN } & 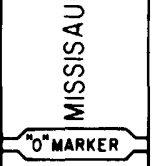 & & & 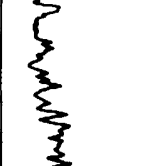 & $\begin{array}{l}\text { SANDSTONE unconsolidated coarse to very coorse, In } \\
\text { port calcoreous interbeds of red and gray gumbo- } \\
\text { like SHALE; ilignite, pyrite; argillocoous DOLOMITE } \\
\text { near bose }\end{array}$ & -3000 \\
\hline & & త్ & & & $\sum_{1}^{\xi}$ & $\begin{array}{l}\text { SHALE: gray (gumbo), few beds of unconsolidated SAND- } \\
\text { STONE; cool near top. }\end{array}$ & -4000 \\
\hline \multirow{3}{*}{$\frac{\partial}{\frac{\partial}{a}}$} & & $\begin{array}{l}\vec{E} \\
\frac{\mathscr{\omega}}{N} \\
心\end{array}$ & & & & $\begin{array}{l}\text { SAND very coorse, scat tered pebbles, thin beds of gray } \\
\text { SHALE (GUMBO); COAL or LIGNITE of bese }\end{array}$ & \multirow[b]{2}{*}{$5_{1500}^{5000}$} \\
\hline & BERRIASIAN & $\Sigma$ & & & & $\begin{array}{l}\text { SHALE and CLAY: light groy; inter beds of coorse SAND; } \\
\text { thin bods of DOLOMITE ond SHALE noor bose. }\end{array}$ & \\
\hline & นחר IITHONIAN- & MISSISAUGA & & & & $\begin{array}{l}\text { SAND and loosely cementod SANOSTONE, medium to } \\
\text { coorse; few COAL and lignite beds; in port shaly, } \\
\text { pyritic, micaceous. }\end{array}$ & \multirow[b]{2}{*}{-6000} \\
\hline \multirow{3}{*}{ 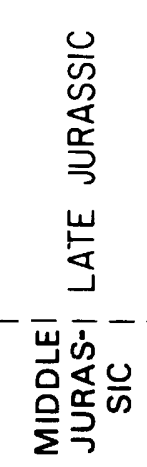 } & $\begin{array}{l}\text { EARLY } \\
\text { KIMERIDGIAN }\end{array}$ & $\stackrel{y}{3}$ & & $\overline{-\overline{-}-\overline{-}}$ & $\frac{\xi}{\xi}$ & $\begin{array}{l}\text { SHALE oronge-brown, dolomitic; abundant lignite, pyrite, } \\
\text { few thin interbeds of fine to coorse SANSSTONE. }\end{array}$ & \\
\hline & OYFORDIAN? & $\sum_{\substack{1 \\
0}}^{1}$ & & 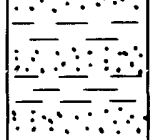 & 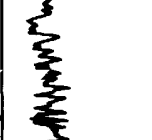 & $\begin{array}{l}\text { SANDSTONE ond SHALE about 60-40 SANDSTONE: } \\
\text { coorse to very coorse, lo vse; ; traces of pyrite, lignite. } \\
\text { SHALE red,yellow, gray, brown in part silty, micace- } \\
\text { ous. }\end{array}$ & -7000 \\
\hline & CALLOVIAN? & $\frac{\mathcal{U}}{\Sigma}$ & & 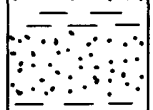 & $\sum_{j}$ & $\begin{array}{l}\text { SANDSTONE unconsolidated, coorse to very coarse, } \\
\text { slightly orkosic, some peo- grovel; thin inter beds of } \\
\text { brown-red ond variegated SHALE. }\end{array}$ & -8000 \\
\hline
\end{tabular}




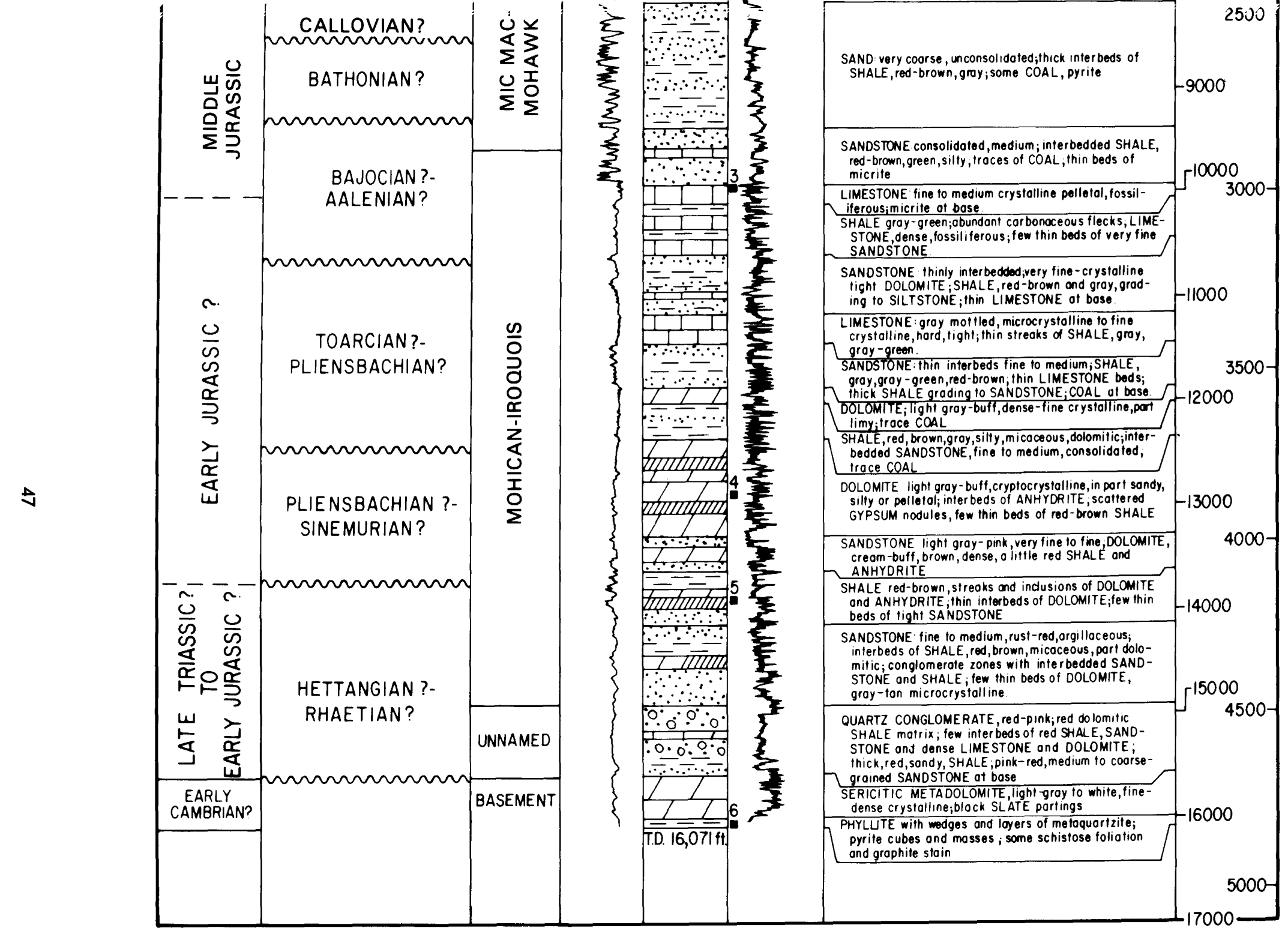

FIGURE 17.-Geologic column of COST No. G-1 well. The formation names in this paper are those of similar rocks on the Scotian shelf of Canada. 
most of the thick Jurassic carbonate sections makes identification of older depositional cycles difficult, but first-order cycles can be easily recognized in the Cretaceous and Cenozoic.

Finally, comparisons of stratigraphic and depositional sequences between the Georges Bank wells, the Scotian basin, and deep-sea sites reveal some marked regional similarities in geologic history.

\section{BIOSTRATIGRAPHY AND CHRONOSTRATIGRAPHY OF \\ THE COST No. G-1 WELL}

CENOZOIC ROCKS (157-1,030 FT; 48-314 M)

The youngest cutting sample from the COST No. G-1 well in this study is from $1,030 \mathrm{ft}(314 \mathrm{~m})$ and is considered to be Santonian in age (figs. 16 and 17). However, it does contain a few middle Eocene foraminifers (Acarinina bulbrooki) and some Paleocene foraminifers (Pseudohastigerina wilcoxensis) which indicate the presence, higher in the well, of unsampled Cenozcic strata.

Seismic correlation with the COST No. G-2 well indicates that the Santonian strata are unconformably overlain by $120 \mathrm{ft}(37 \mathrm{~m})$ of Paleogene rocks (probably mainly middle Eocene), $475 \mathrm{ft}(145 \mathrm{~m}$ ) of Neogene rocks (probably chiefly Miocene), and $170 \mathrm{ft}(57 \mathrm{~m})$ of $P^{\prime}$ istocene rocks. At the G-1 well site, $161 \mathrm{ft}$ (49 m) of Pleistocene rocks was recovered from USGS AMCOR site No. 6018 (Hathaway and others, 1979).

A prominent seismic reflector $650 \mathrm{ft}(198 \mathrm{~m})$ below the sea floor at the G-1 site (Hathaway and others, 1976) apparently marks a middle Eocene limestone unit (fig. 18). This midfle Eocene limestone was penetrated and sampled at AMCOR site No. 6019, $60 \mathrm{mi}(100 \mathrm{~km})$ to the northwest (fig. 15), and at the G-2 well site (figs. 19, 20, 21), and its upper surface can be correlated seismically between the three sites. At AMCOR No. 6019 the middle Eocene limestone is white,

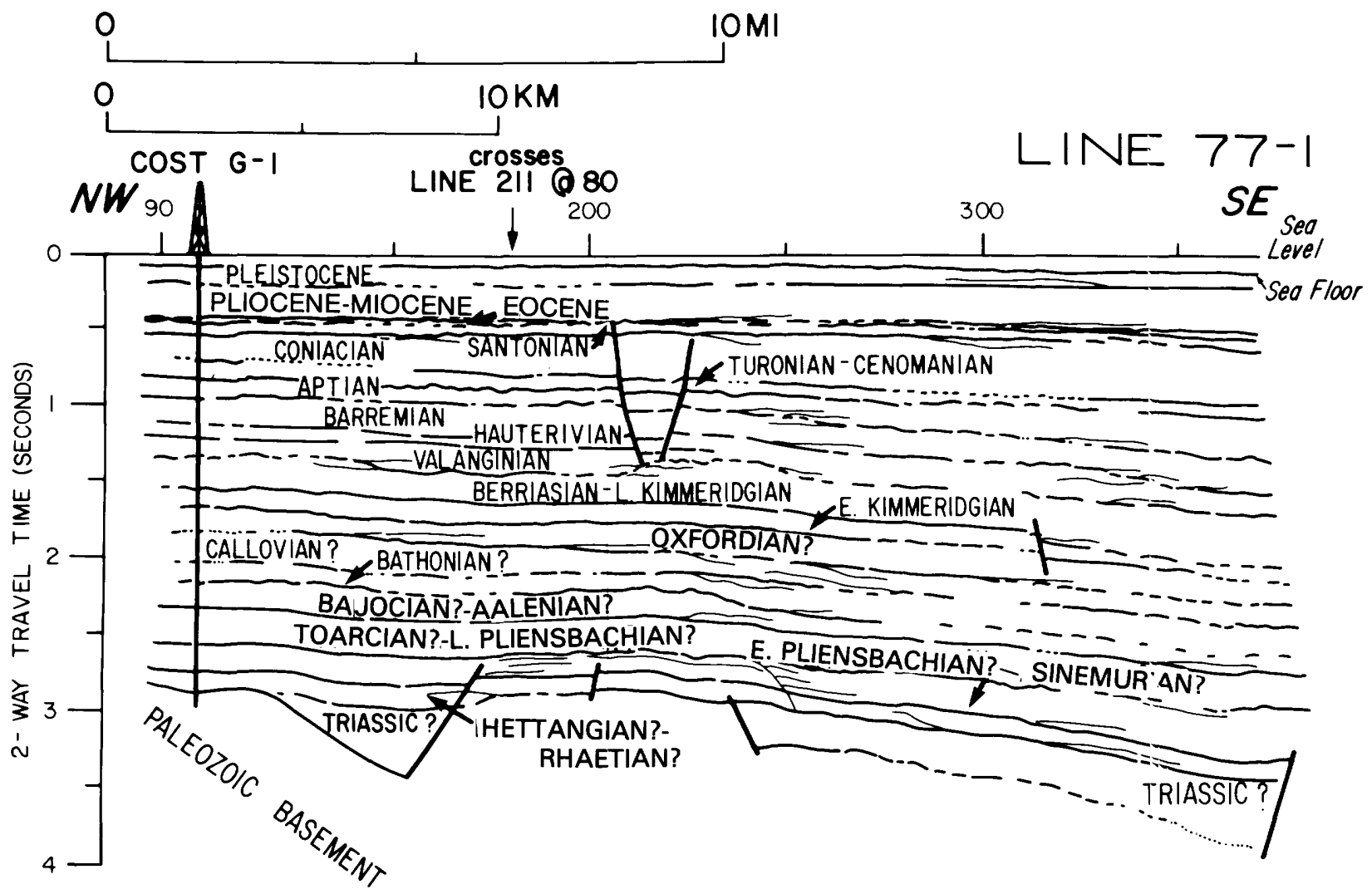

FIGURE 18.-Structural and chronostratigraphic interpretation of seismic reflection profile line $77-1$, which crosses the G-1 well site along dip. 
glauconitic, and bioclastic and contains abundant foraminifers and bryozoan remains. Small to medium fragments of this limestone were present in the uppermost G-1 sample. Some fragments have been altered and have a dense, light-gray, weathered appearance.

\section{CRETACEOUS ROCKS}

\section{SANTONIAN $(1,030-1,390$ FT; 314-424 M)}

The top cutting sample, collected at $1,030 \mathrm{ft}$ $(314 \mathrm{~m})$, contains a predominantly Cretaceous assemblage of Archaeoglobigerina cretacea, Hedbergella delrioensis, Heterohelix sp., Arenobulimina americana, Kyphopyxa christneri, Epistomina supracretacea, Gavelinella sp., Vaginulina wadei, Marginulina silicula, and Bolivinita eleyi. This assemblage could be as young as early Campanian, but seismic correlation with the G-2 well (fig. 21) suggests that the strata are probably Santonian (fig. 16; see below). This is in agreement with palynomorph and nannofossil evidence (Steinkraus, 1980; Valentine, this volume). The lower Santonian indicator foraminifer Marginotruncana sinusoa, appears at $1,150 \mathrm{ft}(351 \mathrm{~m})$ along with Archaeoglobigerina blowi and Globotruncana lapparenti.

CONIACIAN $(1,390-1,940 \mathrm{FT} ; 424-951 \mathrm{M})$

At $1,390 \mathrm{ft}(424 \mathrm{~m})$ there is a slight increase in the number of specimens and an increase in species diversity that coincide with a major unconformable seismic reflector and the appearance of gypsum and siderite nodules (figs. 16, 18, 21). Whiteinella sp. cf. $W$. aprica makes its first appearance $^{1}$ here along with the first specimens of Epistomina spinulifera colomi, and a few redeposited specimens of Rotalipora cushmani and Guembelitria harrisi.

LOWER TURONIAN $(1,940-2,320 \mathrm{FT} ; 591-707 \mathrm{M})$

At $1,941 \mathrm{ft}(593 \mathrm{~m})$ the early Turonian species Marginotruncana helvetica and Praeglobotruncana stephani first appear in a sidewall core (fig. 16). This occurrence coincides with a major un-

\footnotetext{
${ }^{1}$ In this paper, "first appearance" refers to the point at which a species is first encountered in examining the well core from top to bottom. Biostratigraphically, this is the last appearance of the species.
}

conformable seismic reflector (figs. 18, 21). The first occurrence of these species in cuttings is slightly lower at $1,960 \mathrm{ft}(597 \mathrm{~m})$, where th?y are accompanied by Hedbergella amabilis, V'hiteinella archaeocretacea, and abundant Epistomina spinulifera colomi.

UPPER CENOMANIAN $(2,320-2,380 \mathrm{FT} ; 707-725 \mathrm{M})$

The first non-redeposited Rotalipora cushmani occur in abundance at $2,320 \mathrm{ft}(707 \mathrm{~m})$, which coincides with a major seismic unconformity (figs. 16, 18, 21). This species is accompanied by abundant Guembelitria harrisi; however, G. harrisi is abundant without $R$. cushmani sl'ghtly higher in the well at 2,260 $\mathrm{ft}(689 \mathrm{~m})$.

APTIAN $(2,380-2,750 \mathrm{FT} ; 725-838 \mathrm{M})$

At 2,380 $\mathrm{ft}(725 \mathrm{~m})$ a change in the foraminiferal assemblage accompanied by lignite and red shale corresponds to an unconformable seismic reflector that can be correlated with the top of the Aptian interval in the G-2 well (figs. 16, 21); Albian rocks appear to be missing. The Aptian species Lenticulina nodosa and Vaginuliva aptiensis are present in G-1, as is a large number of Epistomina chapmani. The rest of the Aptian rocks at G-1 contain only a sparse, poorly preserved assemblage of foraminifera and occrsional siderite nodules. Steinkraus (1980) reported Aptian dinoflagellates as deep as $3,671 \mathrm{ft}(1,119 \mathrm{~m})$ in a sidewall core.

BARREMIAN $(2,750-3,600 \mathrm{FT} ; 838-1,097 \mathrm{M})$.

The unconformable boundaries of the Barremian Stage at the G-1 site are determined from an analysis of seismic sequences (Vail and others, 1977) on reflection profiles $77-1$ and $19, \varepsilon$ nd by seismic correlation with the G-2 site. The foraminiferal assemblage in this interval is sparise and appears to be chiefly derived from cavings. Steinkraus (1980) reported Aptian dinoflagellates in the lower part of this section.

HAUTERIVIAN $(3,600-4,000 \mathrm{FT} ; 1,097-1,219 \mathrm{M})$

The unconformable boundaries of the Hauterivian Stage at the G-1 site are inferred frcm the 49 


\section{COST $G-2$}
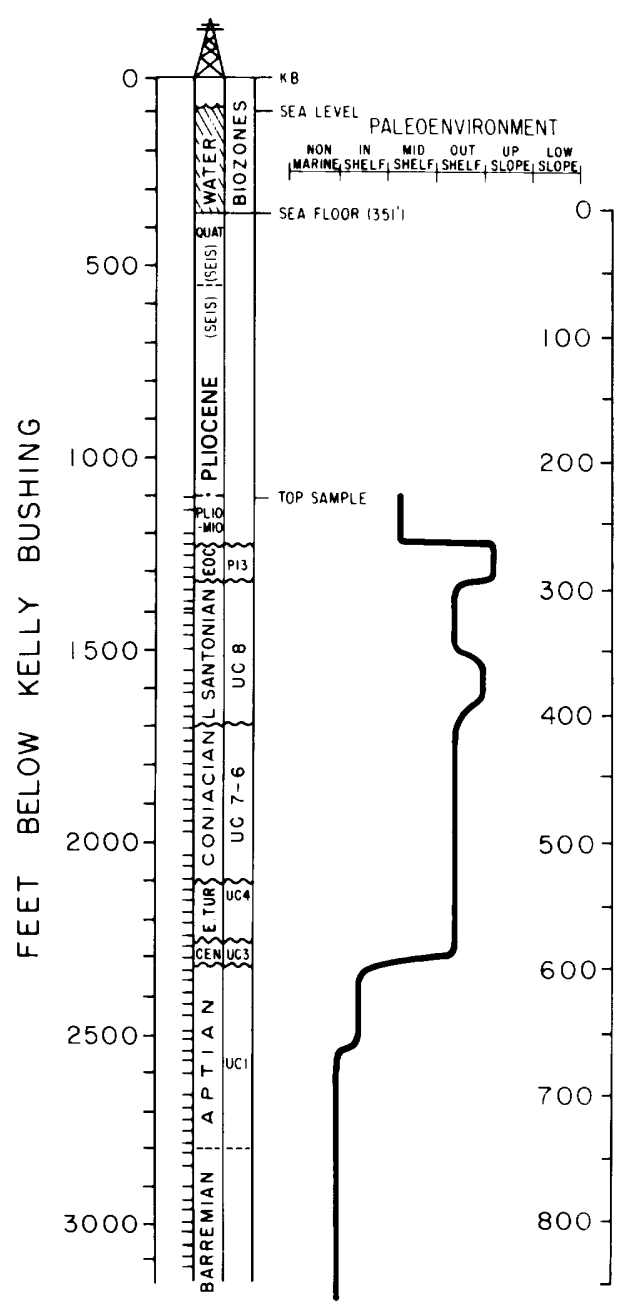

FIGURE 19.-Stratigraphic column of COST No. G-2 well showing chronostratigraphy, biozones, and paleoenvironments. The age terms abbreviated in the left side column are spelled out on figure 22 .

19 , and by seismic correlation with the G-2 well. The foraminiferal assemblages are sparse. The only stratigraphically significant species present are Planularia crepidularis (first appearance at $3,640 \mathrm{ft} ; 1,110 \mathrm{~m}$ ), which does not occur above the Barremian in Scotian shelf wells, and the ostrocod Protocythere triplicata (first appearance at $3,730 \mathrm{ft} ; 1,137 \mathrm{~m}$ ), which is diagnostic of Hauterivian and Barremian rocks in Scotian shelf wells.

$\operatorname{COST} \mathrm{G}-2$

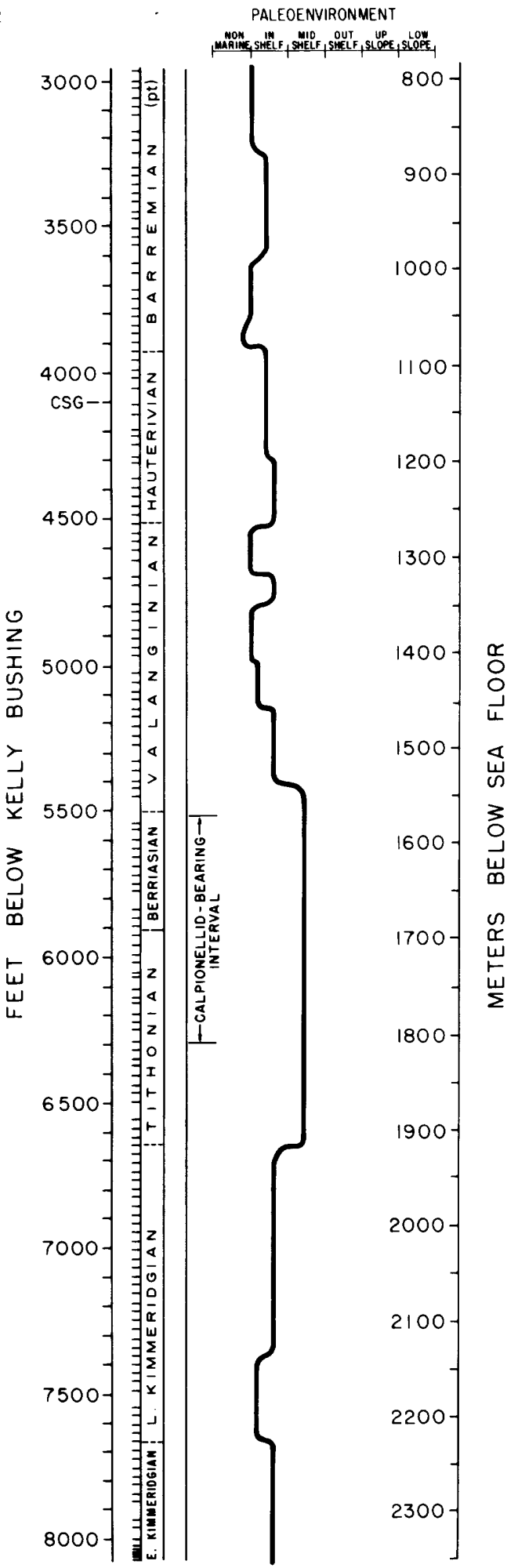


PALEOENVIRONMENT

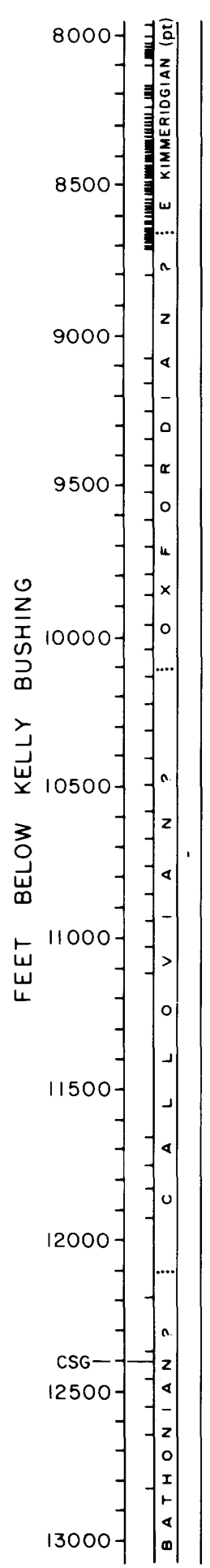

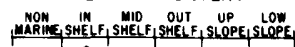

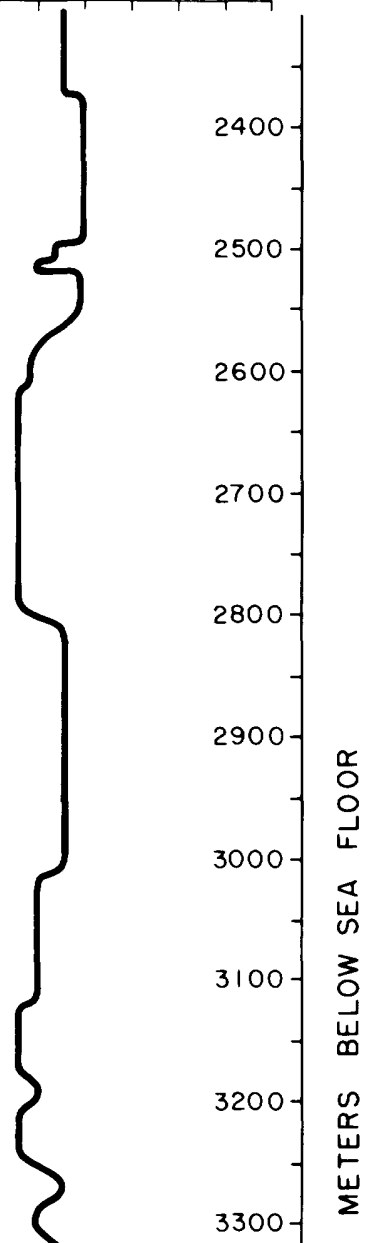

$\operatorname{cosT} \mathrm{G}-2$

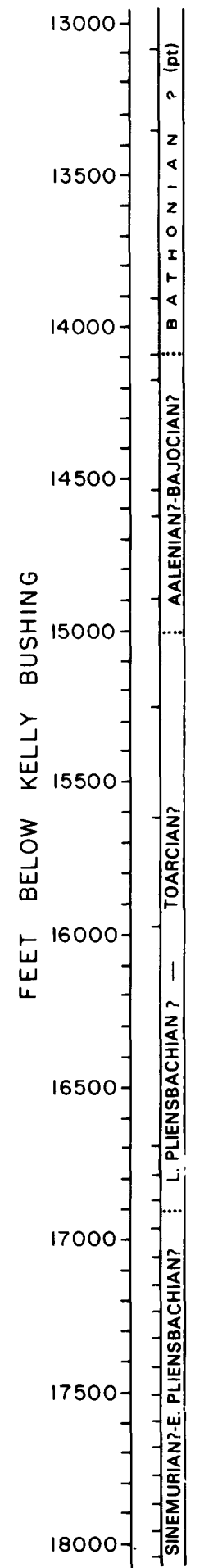

PALEOENVIRONMENT

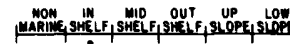

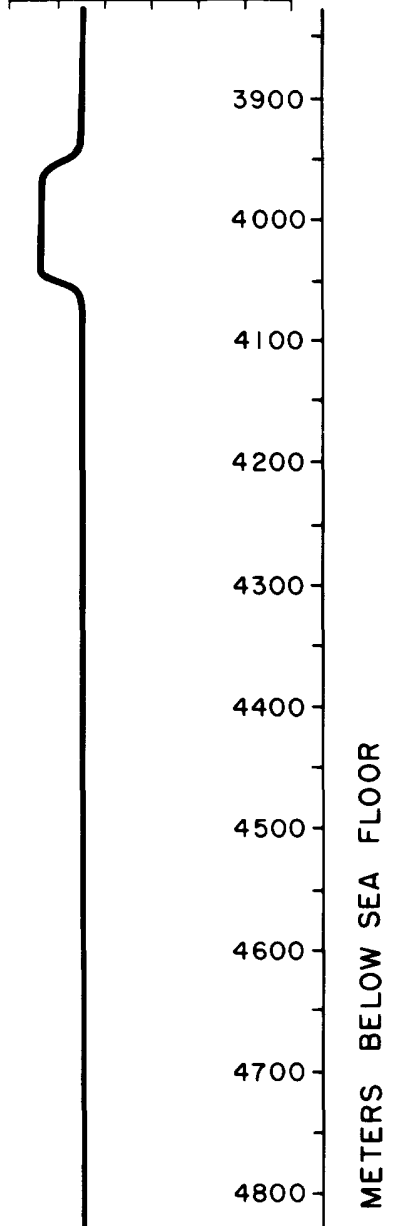

$3500-1$ 


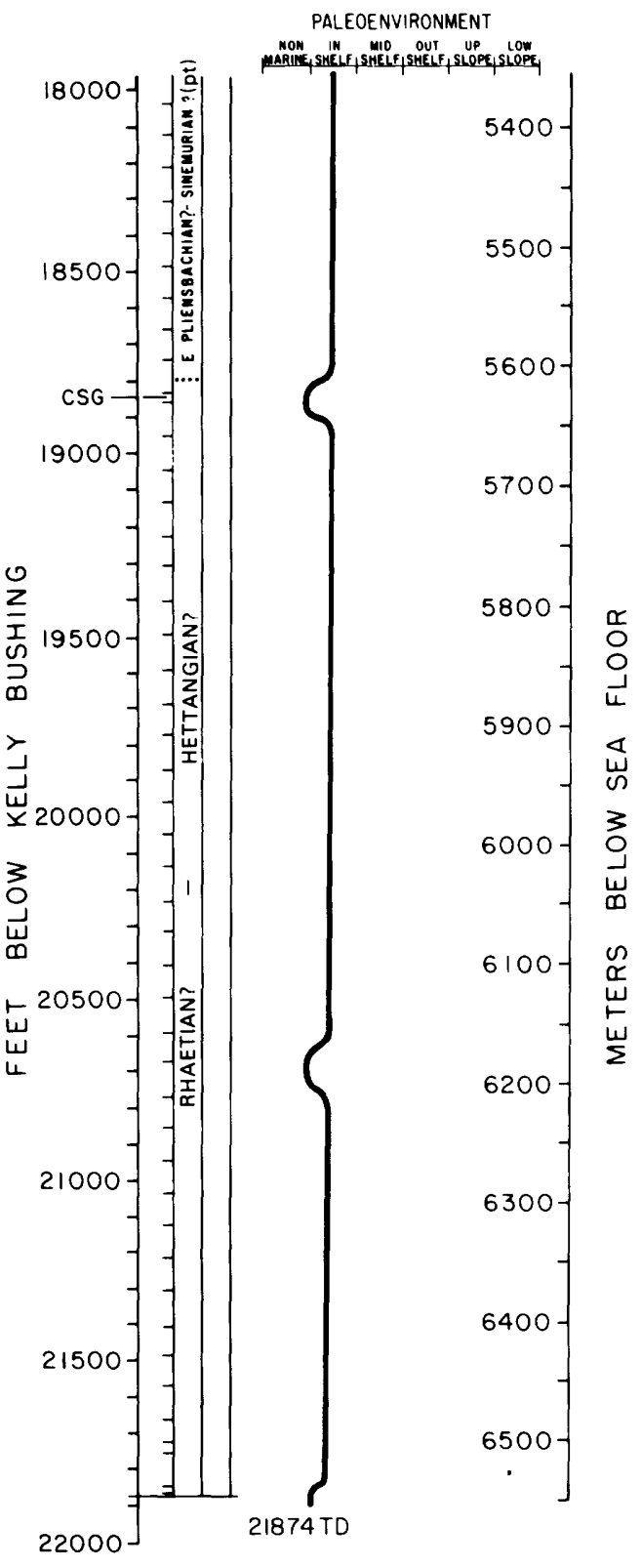

FIgURE 19.-Stratigraphic column of the COST No. G-2 well-Continued.

VALANGINIAN $(4,000-4,500 \mathrm{FT} ; 1,219-1,372 \mathrm{~m})$

The unconformable boundaries of the Valanginian Stage at the G-1 site are estimated from an analysis of seismic sequences on lines 77-1 and 19 , and by seismic correlation with the G-2 site. Microfossils are rare and not diagnostic.
BERRIASIAN $(4,500-5,380 \mathrm{FT} ; 1,372-1,640 \mathrm{M})$

The unconformable upper boundary of the Berriasian Stage at the G-1 site is estimated from an analysis of seismic sequences on lines 77-1 and 19 , and by seismic correlation with the G-2 site. At $5,080 \mathrm{ft}(1,548 \mathrm{~m})$ a major faunal and lithologic change takes place. At the top of a thick sandstone unit, the first specimens of coarse-grained Everticyclammina virguliana app?ar and are accompanied by a small, fragile Haplophragmoides sp., coal fragments, and red shale. Steinkraus (1980) reported Berriasian nannof 'ssils in a sidewall core at $5,070 \mathrm{ft}(1,545 \mathrm{~m})$.

\section{JURASSIC ROCKS \\ TITHONIAN AND UPPER KIMMER'TGIAN \\ $(5,380-5,800 \mathrm{FT} ; 1,640-1,768 \mathrm{M})$}

At 5,380 ft (1,640 m) (fig. 16) Eristomina uhligi first appears in low numbers, Eoguttulina aff. $E$. liassica appears in moderate numbers, a few specimens of Cytherella index apnear, and Everticyclammina virguliana specimons have finer grained tests than younger sperimens of that species. These changes are typical of the top of the Tithonian in other U.S. and Canadian shelf wells, and the Tithonian Age is in agreement with the interpretation of palynomornh and nannofossil assemblages (Steinkraus, 1؟्?)).

\section{LOWER KIMMERIDGIAN $(5,800-6,400 \mathrm{FT} ; 1,768-1,951 \mathrm{M})$}

The unconformable upper and lower boundaries of the lower part of the Kimmeridgian Stage at the G-1 site are estimated from analysis of seismic sequences on lines 77-1 and 19 and seismic correlation with the G-2 well. Tr 9 upper boundary lies within an oxidized zone of foraminifera and siderite nodules $(5,700$ to $6,000 \mathrm{ft} ; 1,737$ to $1,829 \mathrm{~m})$. Steinkraus reported lcwer Kimmeridgian dinoflagellates in a sidewall core at $6,543 \mathrm{ft}$ (1,994 m).

\section{OXFORDIAN(?) TO AALENIAN(?)}

$(6,400-10,500 \mathrm{FT} ; 1,951-3,201 \mathrm{M})$

From 6,400 to $10,000 \mathrm{ft}(1,951 \mathrm{~m}$ to $3,048 \mathrm{~m})$ is a thick sequence of coarse, ligritic sandstones interbedded with brown to red shales, which con- 
tains few calcareous microfossils (fig. 16). Below $10,000 \mathrm{ft}(3,048 \mathrm{~m})$, the carbonate content is much greater (fig. 17). Interbedded pelletal limestones, gray-green shale, finely crystalline dolomite, and fine-grained sandstones and siltstones are found down to $10,500 \mathrm{ft}(3,201 \mathrm{~m})$, but free tests of foraminifera are absent. The unconformable boundaries of stages and groups of stages within this interval are estimated from analysis of seismic sequences on USGS multichannel lines 77-1 and 19 (figs. 18, 21) as follows:

Oxfordian(?), 6,400-7,400 ft (1,951-2,256 m;

Callovian(?), 7,400-8,500 ft (2,256-2,591 m);

Bathonian(?), 8,500-9,300 ft (2,591-2,835 m);

Bajocian(?) to Aalenian(?), 9,300-10,500 ft $(2,835-3,201 \mathrm{~m})$.

TOARCIAN(?) TO SINEMURIAN(?)

$(10,500-13,600 \mathrm{FT} ; 3,201-4,145 \mathrm{M})$

The rocks from 10,500 to $13,600 \mathrm{ft}(3,201$ to $4,145 \mathrm{~m}$ ) are chiefly carbonates (gray, microcrystalline to finely crystalline limestones, gray to buff, finely crystalline to cryptocrystalline dolomite, and anhydrite) with thin interbeds of sandstone and shale, occasional coal beds, and scattered gypsum nodules (fig. 17). No foraminifera were recovered in this interval, but it can be divided into two parts through analysis of seismic sequences on lines $77-1$ and 19, (figs. 16, 18, 21) as follows: Toarcian(?) to upper Pliensbachian(?), 10,500-12,300 ft (3,201-3,749 m), and Lower Pliensbachian(?) to Sinemurian(?), $12,300-13,600 \mathrm{ft}$ $(3,749-4,145 \mathrm{~m})$.

HETTANGIAN(?) TO RHAETIAN(?)

$(13,600-15,630 \mathrm{FT} ; 4,145-4,764 \mathrm{M})$

The age of these sedimentary rocks is estimated from analysis of seismic sequences as interpreted from USGS lines 77-1 and 19. The upper rocks are chiefly sandstones and shales with thin intervals of dolomite and anhydrite (13,600-14,970 ft; 4,145-4,563 m). Late Triassic dinoflagellates have been recovered from the lower part of this unit (anonymous oral commun., 1980 ). From 14,970 to $15,630 \mathrm{ft}(4,563$ to $4,764 \mathrm{~m})$ is a quartz conglomerate with a matrix of red dolomitic shale and interbeds of red shale, sandstone, and dense limestone and dolomite (fig. 17). The conglomerate lies unconformably upon a metamorphic basement composed of sericitic metadolomite and black slate $(15,630-16,000 \mathrm{ft}$; 4,764-4,877 m), which overlies graphitic phyllite, metaquartzite and gneiss (16,000-16,071 ft; $4,877-4,899 \mathrm{~m})$. Radiometric dates of 450 to 550 m.y. (K/Ar) indicate that the metamorphism took place in the Cambrian or Ordovician (Steinkraus, 1980).

\section{BIOSTRATIGRAPHY AND CHRONOSTRATIGRAPHY OF THE COST NO. G-2 WELL}

\section{CENOZOIC ROCKS (351-1,324 FT; 107-404 M)}

The first cutting sample in the COST No. G-2 well was collected at $1,100 \mathrm{ft}(335 \mathrm{~m})$ (fig. 19). From there to $1,250 \mathrm{ft}(381 \mathrm{~m})$ a sparse benthic fauna consisting chiefly of Brizalina bradyi, Globobulimina auriculata, Bulimina elongata, Lentliculina spinosa, L. americana, Cassidulina "carinata", Florilus pizzarensis, and Cibicidoides aff. C. floridanus indicates rocks of Pliocene to Miocene age. A few radiolarians and reworked Cretaceous planktic foraminifers also are present in this interval. Seismic sequence analysis and results from AMCOR drilling (Hathaway and others, 1979) indicate that Pliocene to Miocene rocks are present up to $550 \mathrm{ft}(168 \mathrm{~m})$ in the section, and are overlain unconformably by $260 \mathrm{ft}$ $(61 \mathrm{~m})$ of Quaternary rocks (figs. 19, 21, 22).

Below $1,250 \mathrm{ft}(381 \mathrm{~m})$ the number of foraminiferal specimens and the diversity of species increases dramatically, and there is an abundance of large fragments of cheilostome bryozoans. Among the many planktic species present, Truncorotaloides rohri and Acarinina bullbrooki indicate that this rich assemblage is of middle Eocene age. These same planktic species are present in a sidewall core from $1,289 \mathrm{ft}$ $(393 \mathrm{~m})$, along with Morozovella spinulosa, Truncorotaloides topilensis, Eoglobigerina senni, and Globigerinatheka subconglobata. This middle Eocene assemblage continues to $1,324 \mathrm{ft}$ $(404 \mathrm{~m})$; and additional middle Eocene species, such as Acarinina pentacamerata, appear within this interval. The presence of a few specimens of Globigerina opima opima at 1,289 ft (393 m) suggest that a thin interval of late Oligocene strata may lie unconformably above the middle Eocene rocks. 

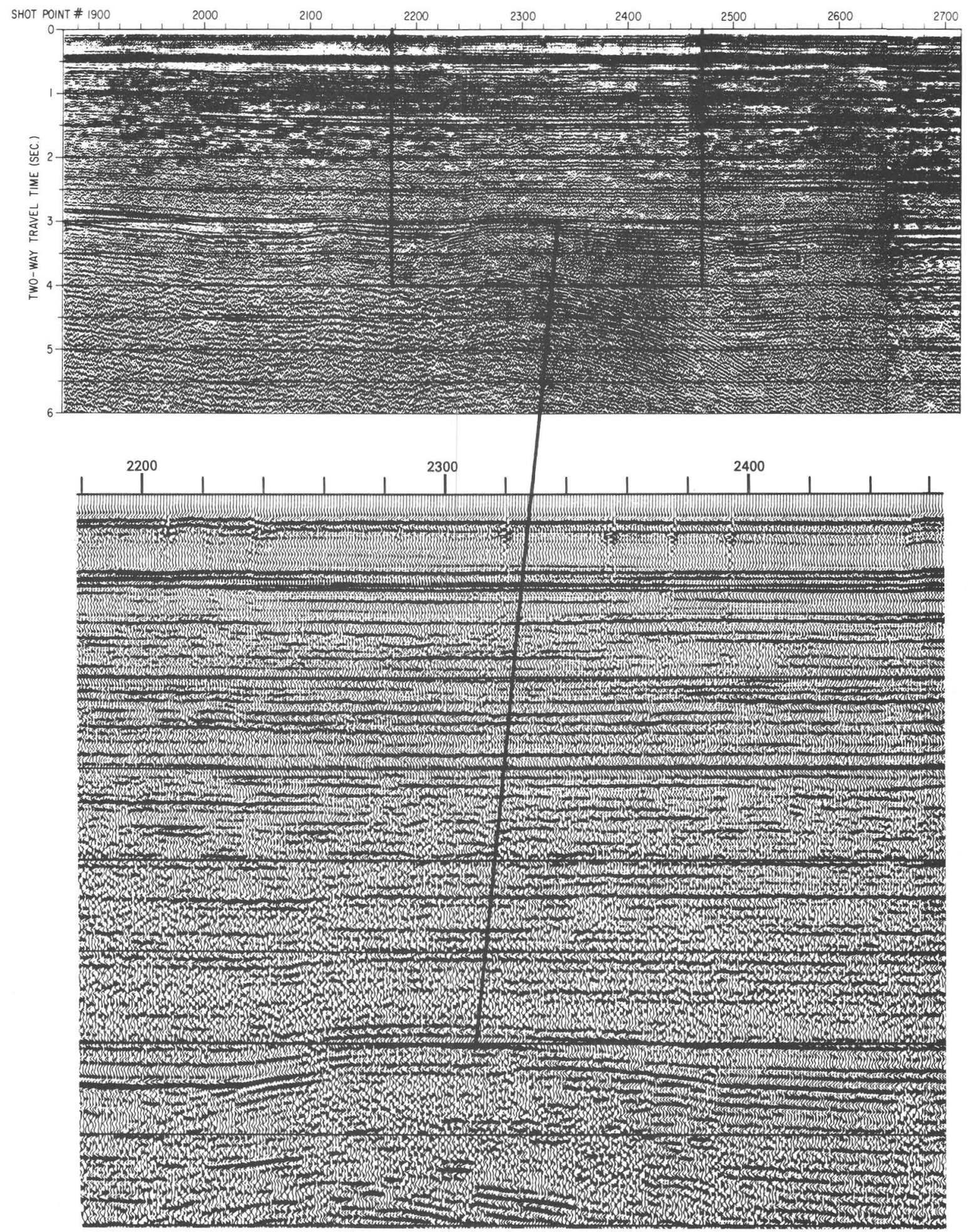

Figure 20.-Uninterpreted portion of seismic reflection profile line 19, which traverses the Georges Bank basin along dip approximately $15 \mathrm{~km}(9.3 \mathrm{mi})$ northeast of the COST No. G-2 well. 


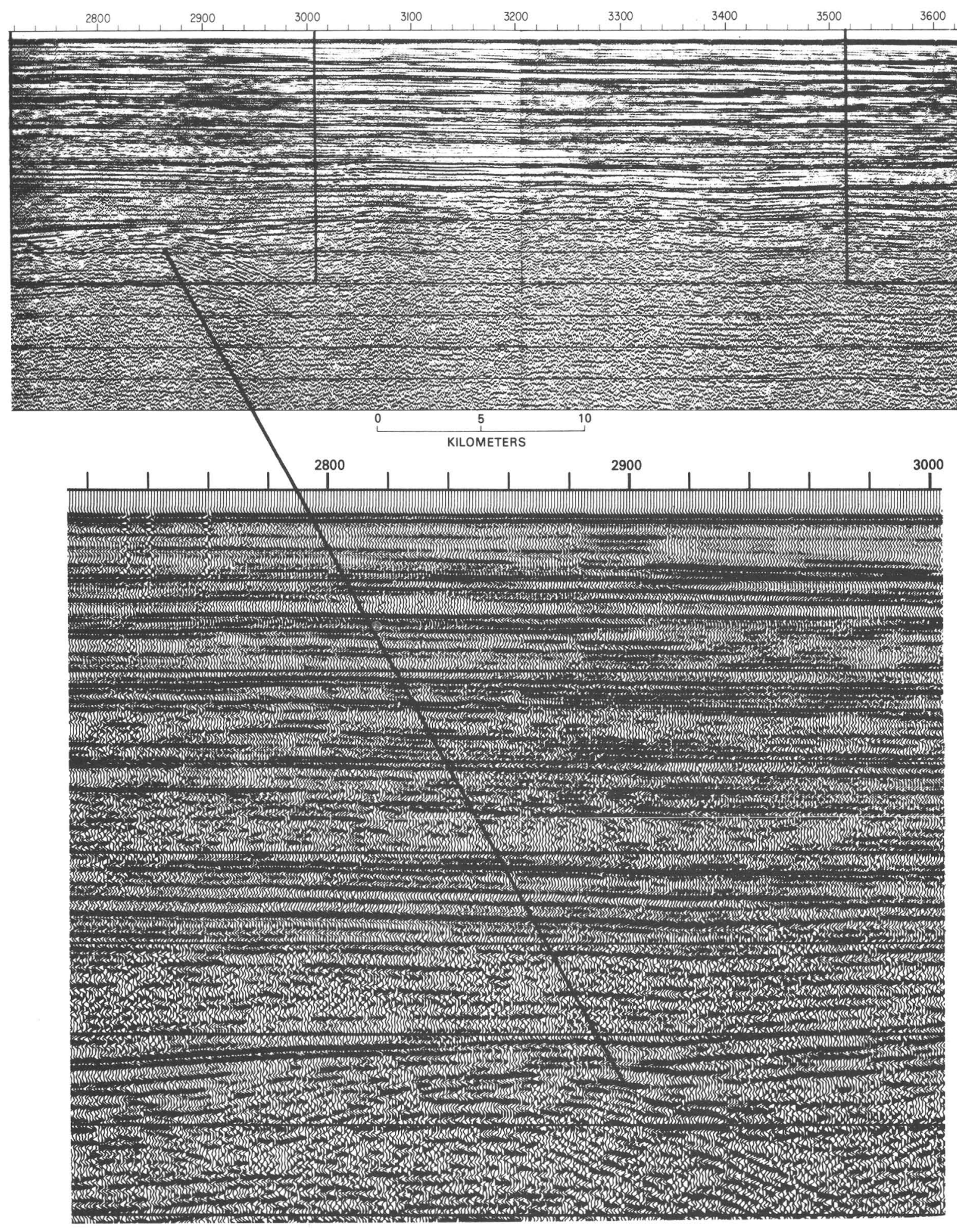

FIGURE 20.-Uninterpreted portion of seismic reflection profile line 19-Continued. 


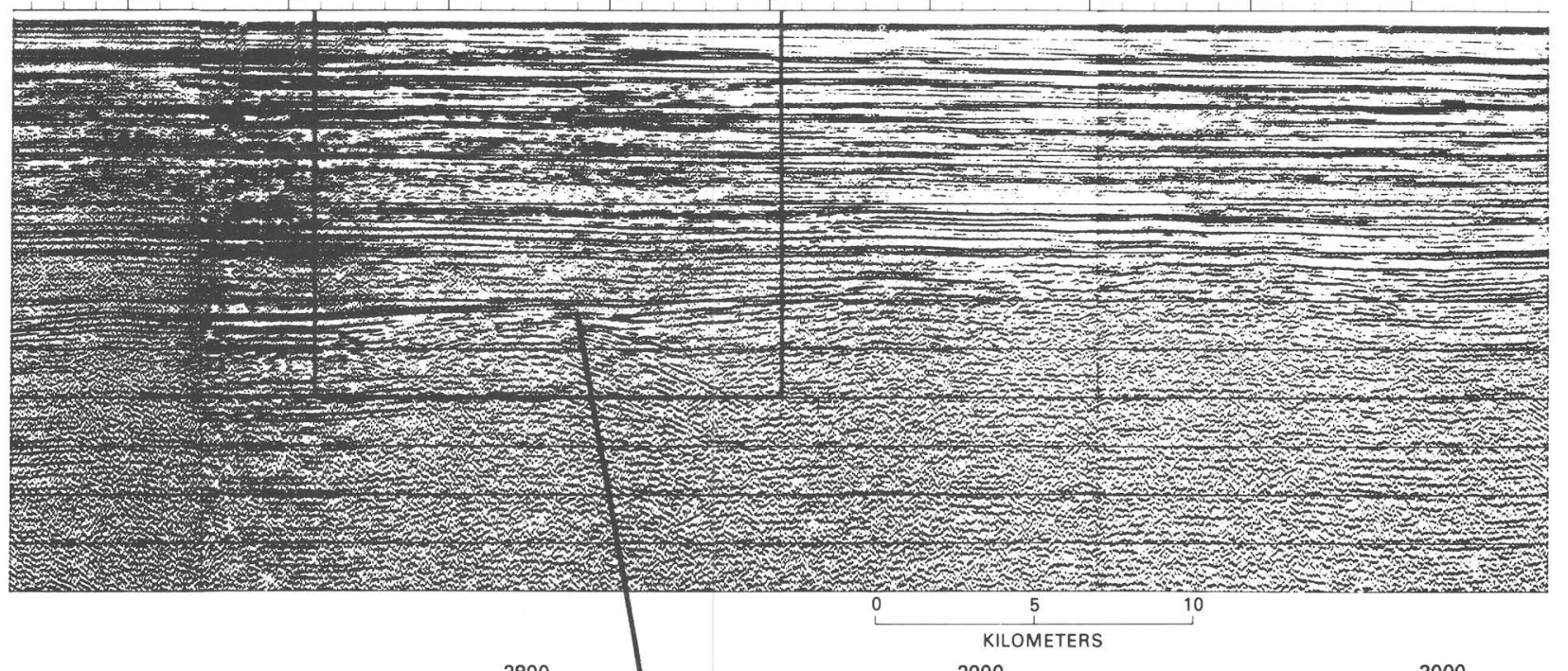

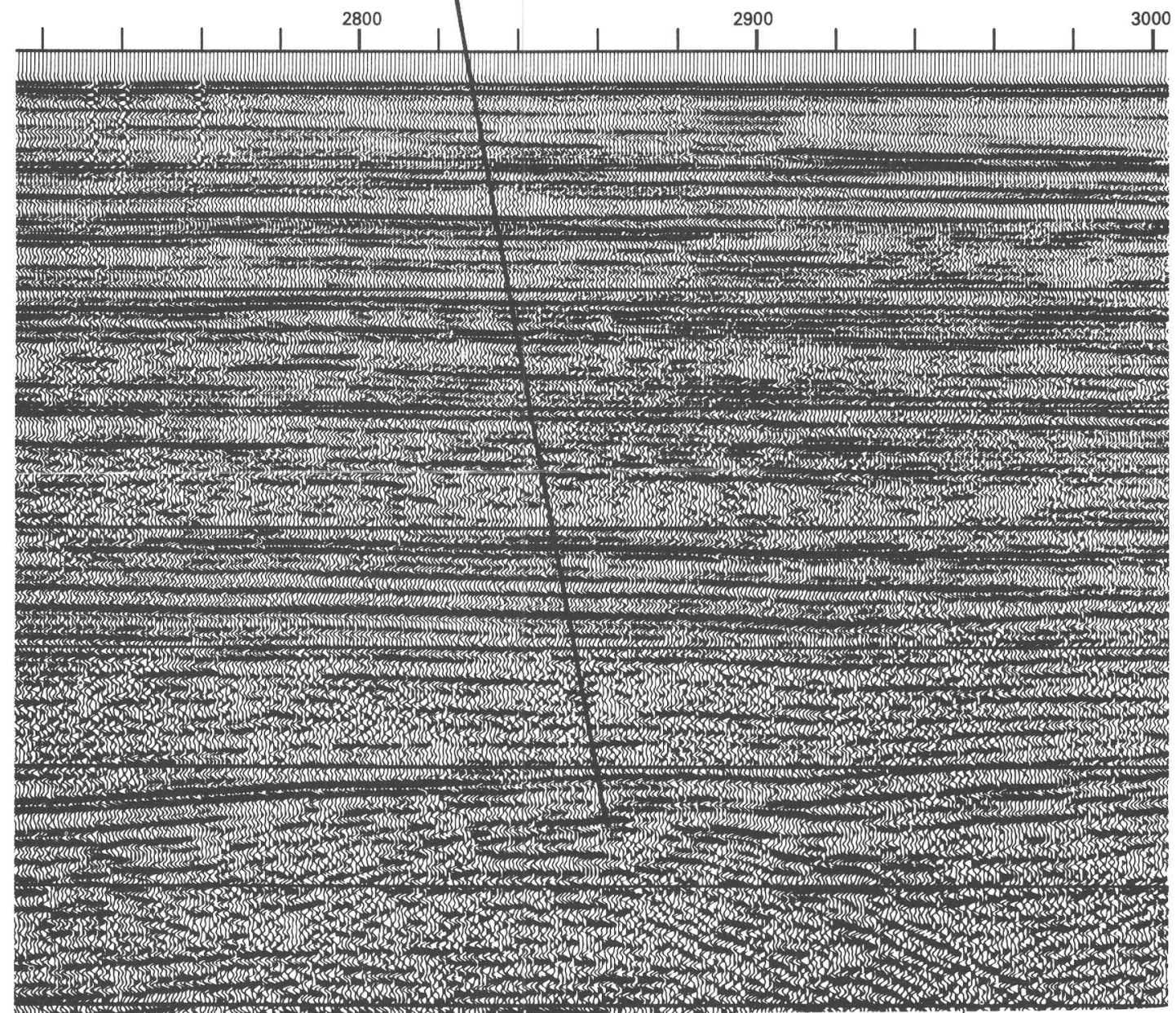

FIGURE 20.-Uninterpreted portion of seismic reflection profile line 19-Continued. 

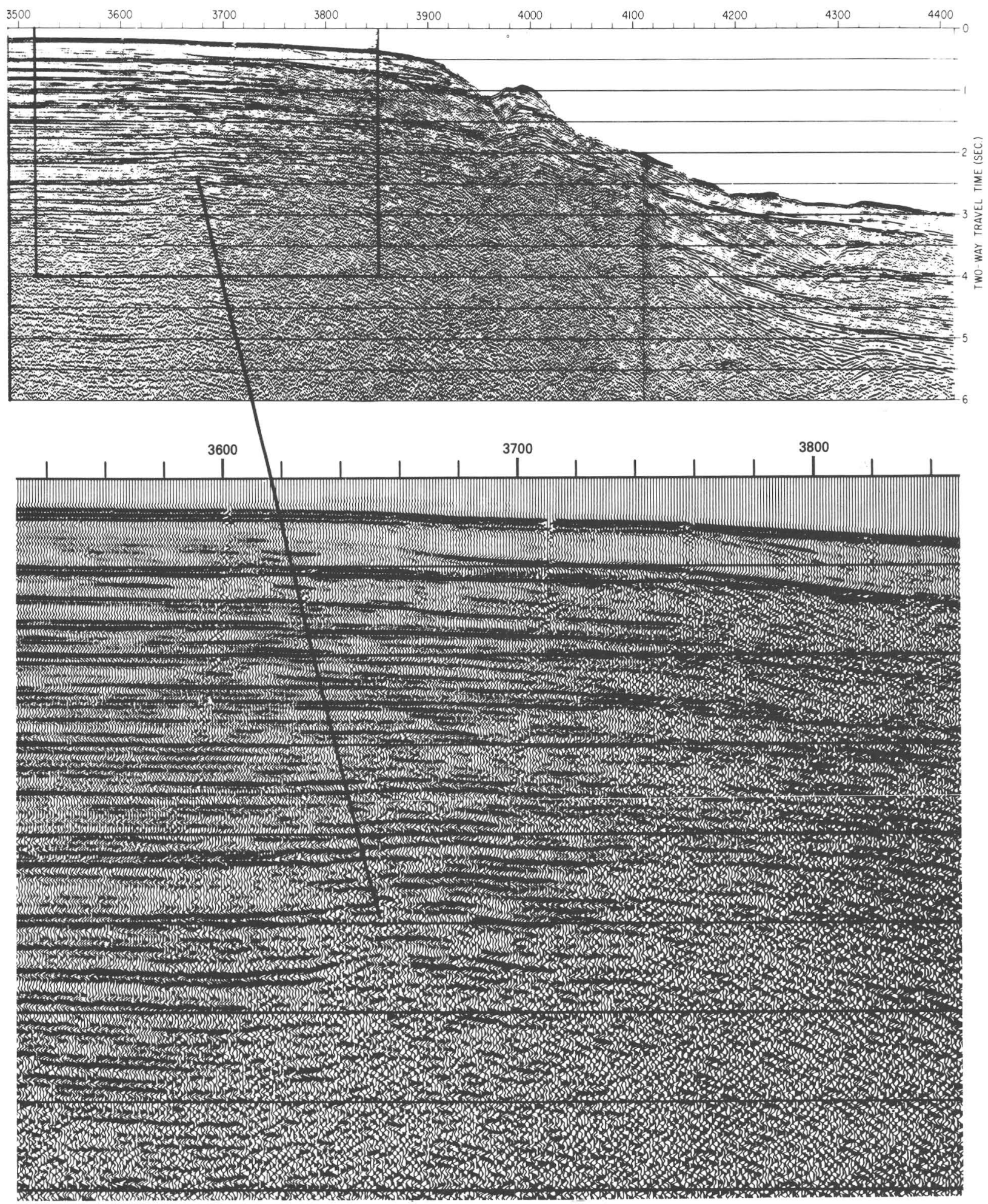

FIGURE 20.-Uninterpreted portion of seismic reflection profile line 19-Continued. 

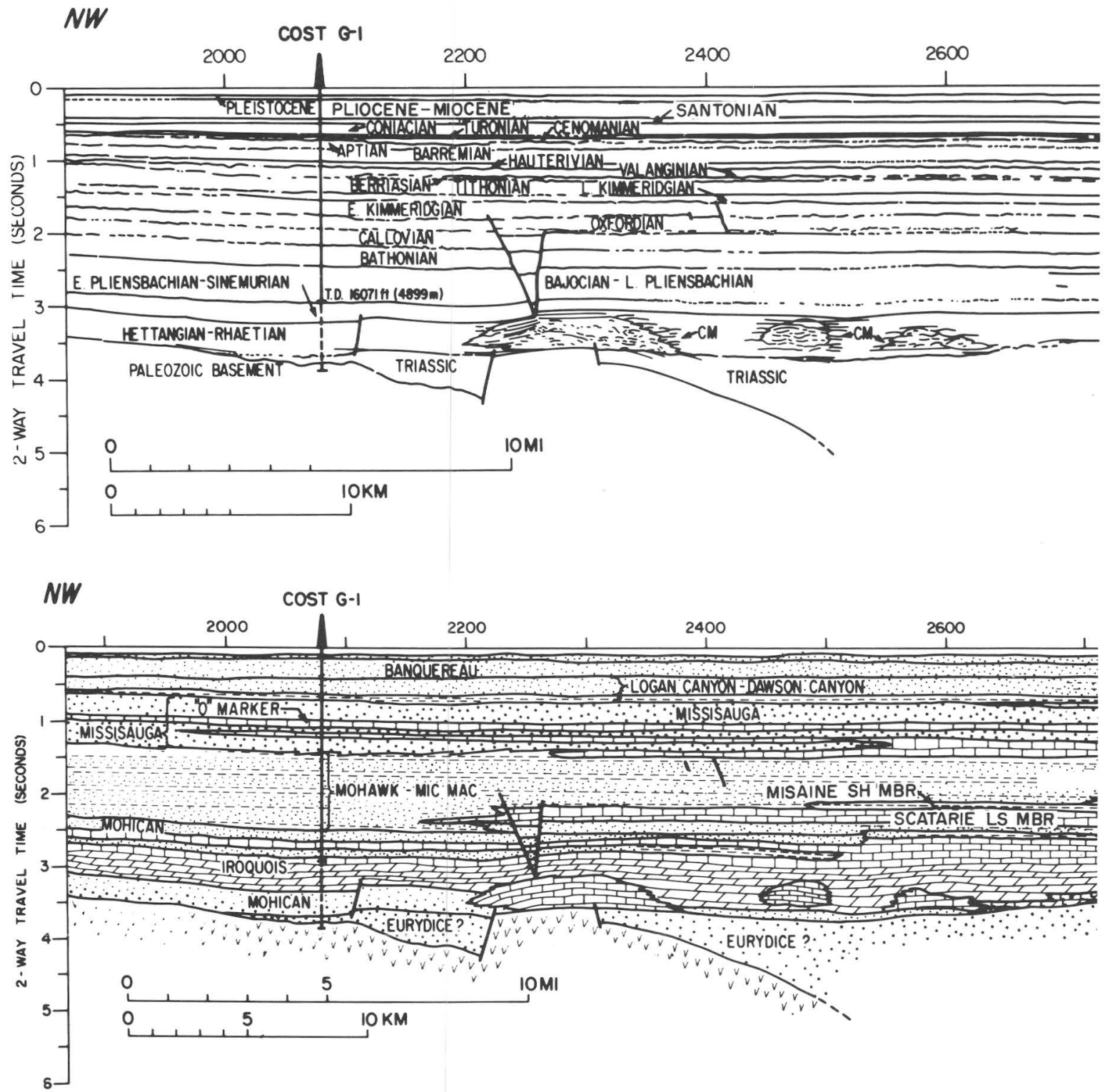

FIGURE 21.-Interpretations of structure, chronostratigraphy, and lithostratigraphy of the portion of seismic line 19 shown in figure 20. COST well locations are projected northeastward along strike to line 19. Section at G-1 projection is thicker than at the actual well site; chronostratigraphic boundaries are adjusted to accomodate this difference. CM, carbonate mound. Many of the age terms shown are uncertain. The formation names in this paper are those of similar rocks on the Scotian shelf of Canada.

\section{CRETACEOUS ROCKS}

LOWER SANTONIAN (1,324-1,700 FT; 404-518 M)

The first non-redeposited Cretaceous assemblage occurs in cuttings at 1,400 ft (427 m) and is characterized by Marginotruncana sinuosa, Globotruncana lapparenti, Heterohelix striata and Archaeoglobigerina cretacea, an early Santonian association. A sidewall core at $1,324 \mathrm{ft}$
$(404 \mathrm{~m})$ contains a similar association. The presence of well preserved Globorotalites pseudomenardii in the $1,400-\mathrm{ft}(427-\mathrm{m})$ sample indicates that a thin interval of Paleocene rock is present above the Santonian. No evidence of Maestrichtian or Campanian strata was observed. Santonian rocks are present down to $1,700 \mathrm{ft}(518 \mathrm{~m})$ and Sigalia ornatissima, Globigerinelloides prairiehillensis, Hedbergella planispira, Archaeoglobigerina blowi, and Mar- 

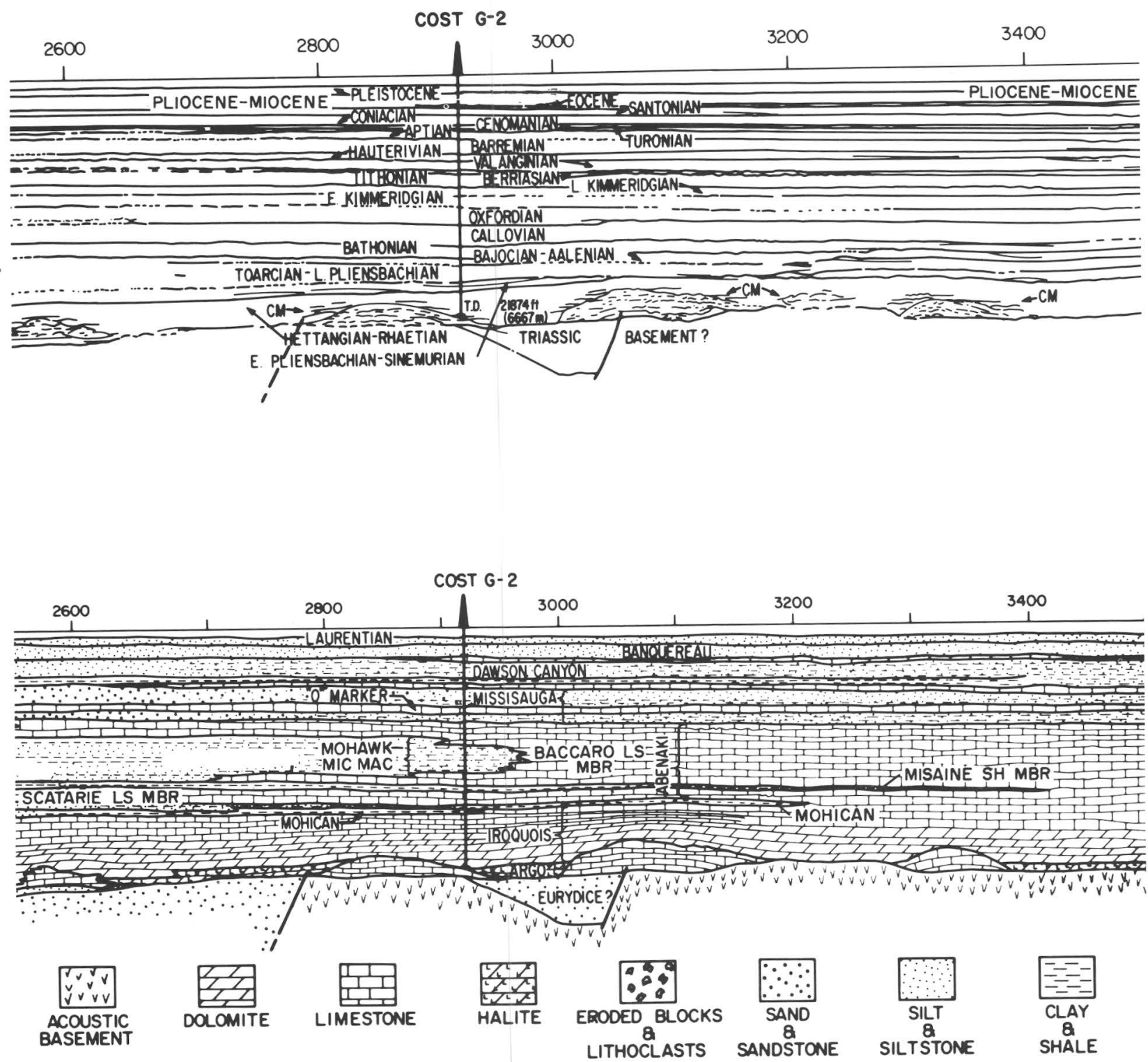

Figure 21.-Interpretations of a portion of seismic line 19-Continued.

UPPER TO MIDDLE CENOMANIAN

(2,270-2,330 FT; 692-710 M)

At $2,270 \mathrm{ft}(692 \mathrm{~m})$, the appearance of Rotalipora cushmani marks the Cenomanian. (Guembelitria harrisi appears $30 \mathrm{ft}(9 \mathrm{~m})$ above this in the Turonian interval.) Rotalipora cushmani is accompanied at $2,270 \mathrm{ft}(692 \mathrm{~m})$ by
R. greenhornesis, which indicates that the top part of zone UC3 is missing or very thin. This rotaliporid association is also found in a sidewall core at 2,276 ft (694 m). Whiteinella aprica, Epistomina chapmani, and Gavelinopsis cenomanica also first appear at $2,270 \mathrm{ft}(692 \mathrm{~m})$, as do numerous specimens (presumably redeposited) of Lenticulina nodosa, an Aptian marker (Ascoli, 1976). 


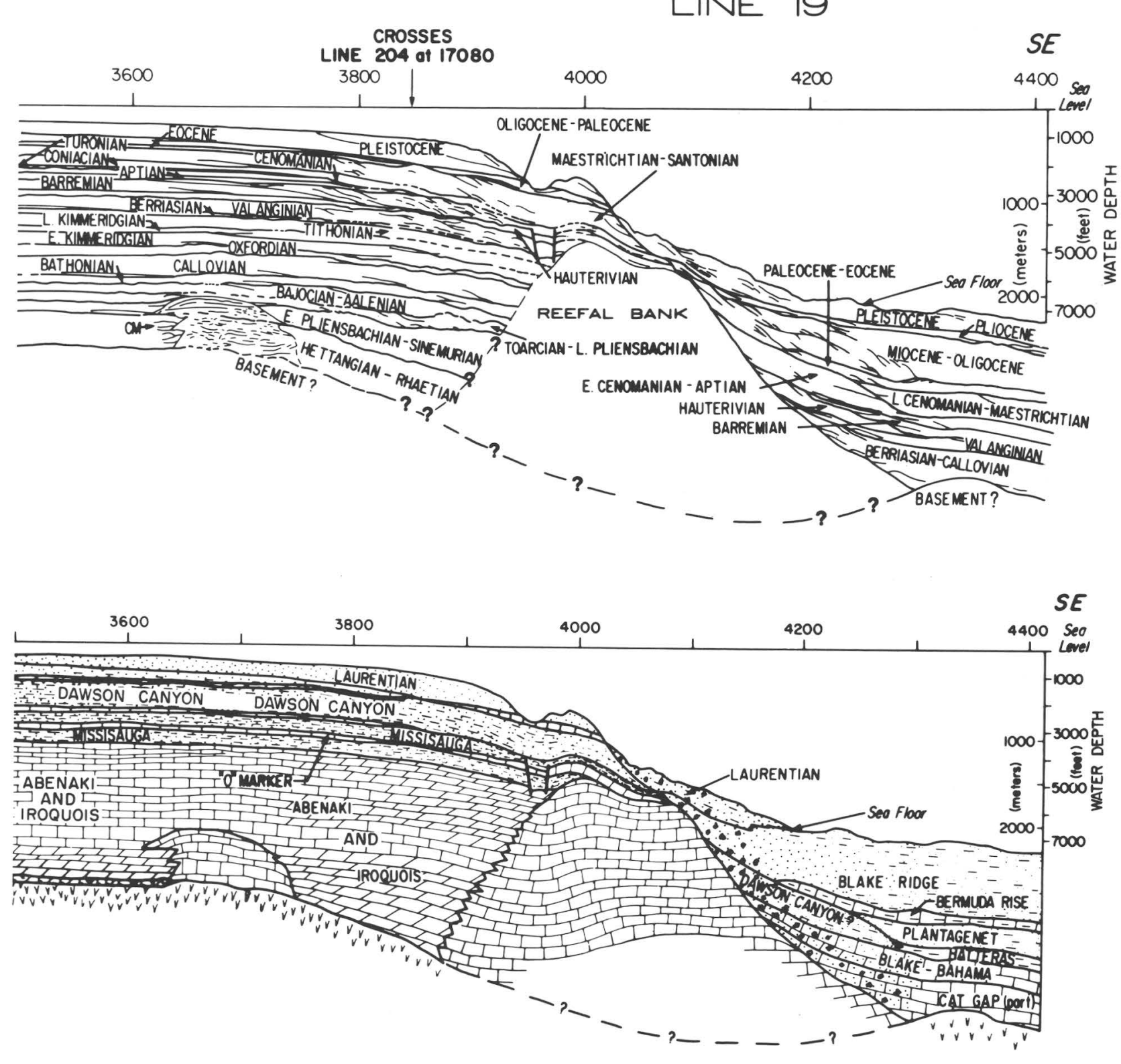

FigURE 21.-Interpretations of a portion of seismic line 19-Continued.

APTIAN (2,330-2,810 FT; 710-857 M)

At $2,330 \mathrm{ft}(710 \mathrm{~m})$ seismic, faunal, and sedimentological data indicate that a major unconformity separates the very thin middle to upper Cenomanian strata from the Aptian. Here, the lithofacies changes, the fauna is somewhat diminished and more poorly preserved, and the number of rotaliporids decreases, but the number of Lenticulina nodosa remains high. At 2,360 ft $(719 \mathrm{~m})$ the foraminifer Lenticulina aff. $L$. gaultina and the ostracod Hechticythere derooi appear. Lenticulina nodosa is an amphiatlantic marker for Aptian rocks (Bartenstein, 1974), and Lenticulina aff. L. gaultina ranges no higher than the Aptian on the Scotian shelf (Ascoli, 1976). At $2,360 \mathrm{ft}(719 \mathrm{~m})$ the sample contains abundant oxidized, calcareous sandstone and lignite. Below this depth the species diversity is further reduced. Similar lithologic and faunal changes mark the unconformable Cenomanian-Aptian contact in the Shell Mohawk B-93 well, the 


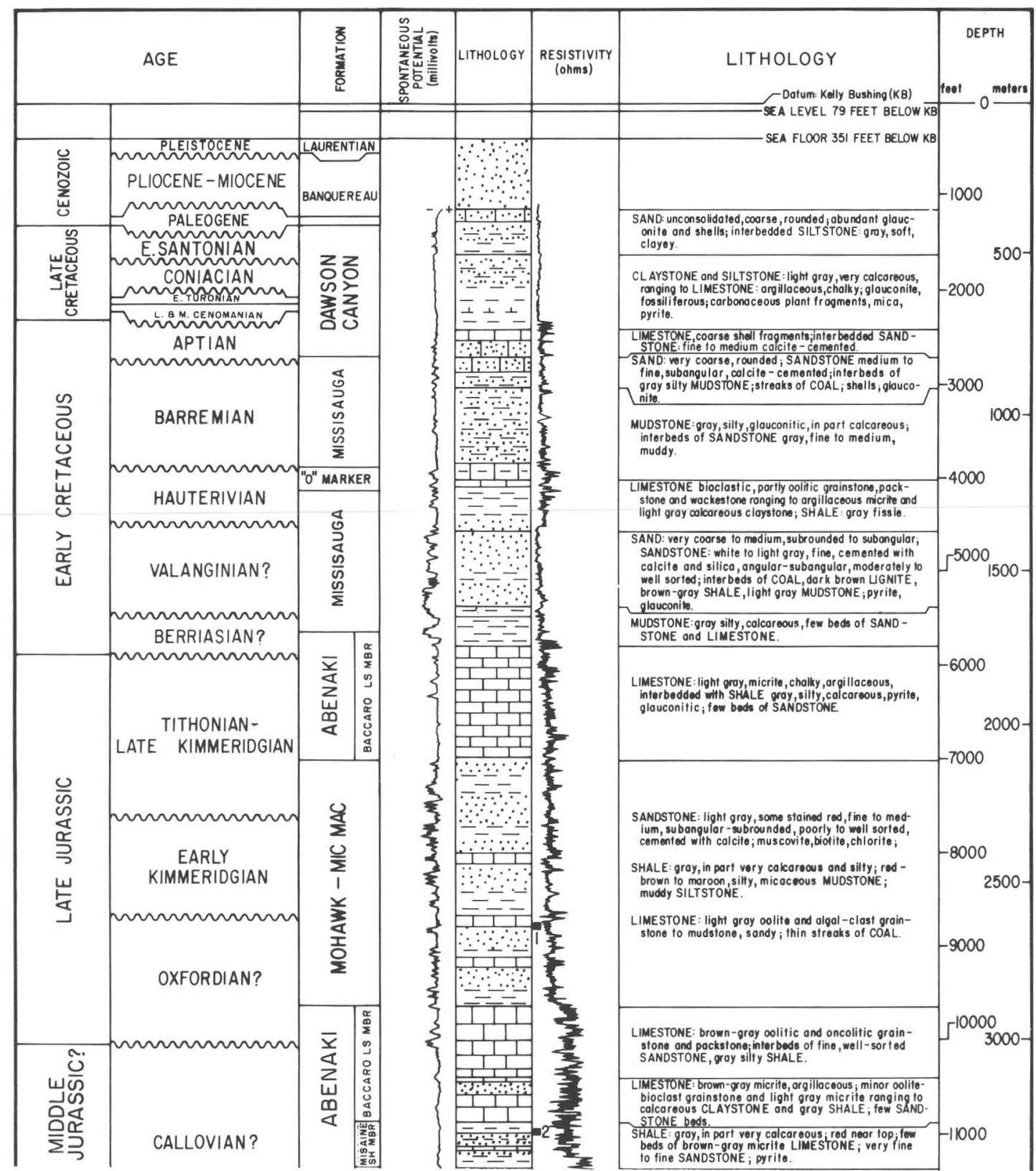




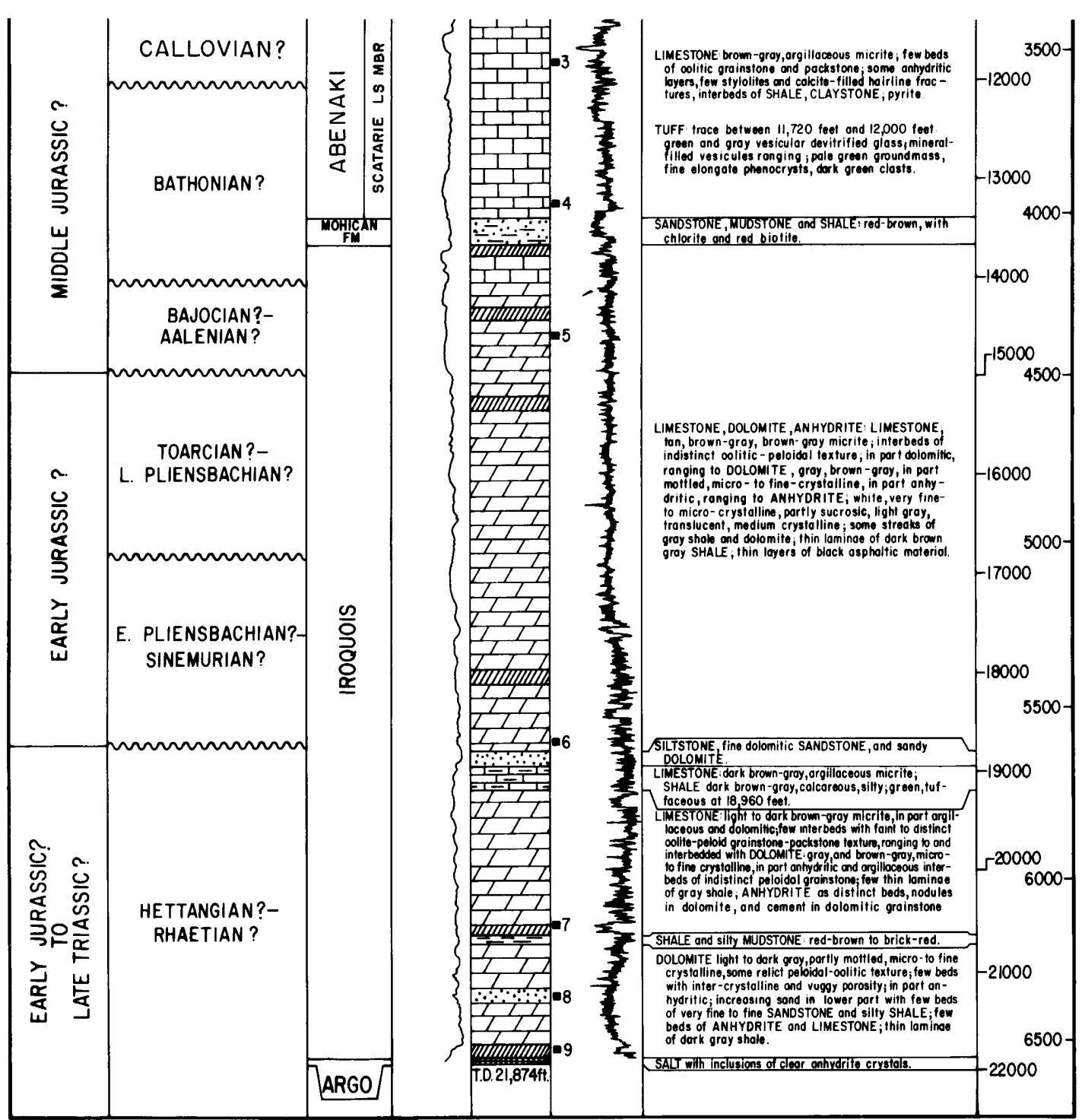

FIGURE 22.-Geologic column of COST No. G-2 well. The formation names in this paper are those of similar rocks on the Scotian shelf of Canada. 
closest drill hole on the Scotian shelf. Analysis of seismic sequences shows that this unconformity is a strong reflector (figs. 20, 21) that displays irregular physiographic relief and terminates underlying reflectors, indicating that it is an erosional surface. Single specimens of Ticinella roberti, T. breggiensis, and T. primula between 2,300 and 2,390 $\mathrm{ft}(701$ and $728 \mathrm{~m}$ ) suggest that a thin remnant of Albian strata may have been penetrated at this site, but no other firm evidence of Albian rocks in the COST No. G-2 well has been observed. (See also Bebout, 1980.)

BARREMIAN $(2,810-3,920 \mathrm{FT} ; 857-1,195 \mathrm{M})$

The next significant faunal change occurs at $2,810 \mathrm{ft}(857 \mathrm{~m})$, where Conorboides bulgaricus becomes a persistent part of the sparse foraminiferal assemblage. This form is diagnostic of Barremian rocks in the Scotian basin (P. Ascoli, written commun., April 1980) and in Europe (Bartenstein and others, 1971). Other benthic foraminifers and ostracods diagnostic of Barremian strata in the Scotian basin occur just below this: Conorotalites bartensteini at $2,960 \mathrm{ft}(902 \mathrm{~m})$; Schuleridea sp. 9 of Ascoli (1976) at $2,990 \mathrm{ft}$ $(911 \mathrm{~m}) ;$ Epistomina ornata at $3,260 \mathrm{ft}(994 \mathrm{~m})$; Neocythere aff. $N$. mertensi at $3,260 \mathrm{ft}(994 \mathrm{~m})$ and Conorboides hofkeri at 3,290 $\mathrm{ft}(1,003 \mathrm{~m})$. Bebout (1980) placed this interval in the Aptian Stage on the basis of a single dinoflagellate species believed to be restricted to the Aptian.

HAUTERIVIAN $(3,920-4,510 \mathrm{FT} ; 1,195-1,375 \mathrm{M})$

At $3,920 \mathrm{ft}(1,195 \mathrm{~m})$, there is a increase in foraminifers and the species Haplophragmoides concavus, Planularia crepidularis, Lenticulina saxonica and Lamarckina lamplughi appear, which are typical of Hauterivian intervals in the Scotian basin (Ascoli, 1976). The Hauterivian species Marssonella kummi, Hechticythere hechti, and Hutsonia sp. 3 of Ascoli (1976) are found at 4,010 ft (1,222 m); Dolocytheridea sp. 1 and Macrodentina sp. 1 of Ascoli (1976) at $4,130 \mathrm{ft}(1,259 \mathrm{~m}) ;$ Eoguttulina spp. and the ostracod Rehacythereis senckenbergi group at $4,300 \mathrm{ft}$ $(1,311 \mathrm{~m})$. The highest occurrence of Choffatella decipiens is at $3,950 \mathrm{ft}(1,204 \mathrm{~m})$, but I interpret this level to be older than its known time of extention. Bebout (1980) used C. decipiens and several dinoflagellates to assign most of this interval to the Barremian.

VALANGINIAN(?) $(4,510-5,440 \mathrm{FT} ; 1,375-1,658 \mathrm{M})$

A major lithological and faunel change occurs at $4,510 \mathrm{ft}(1,375 \mathrm{~m})$, where thore is coarse to medium sandstone which contain " an assemblage of small, fragile, loosely cemented specimens of Ammobaculites and Haplophrcgmoides along with gypsum crystals. Although this fauna is not age-diagnostic, the sedimentological and faunal changes appear to coincide with a strong, unconformable seismic reflector near this depth (figs. $20,21)$. The underlying reflectors that terminate against it indicate an erosional s'rface, which is in accordance with the low sea level postulated for Valanginian time by Vail ant others (1977). Bebout (1980) reported one pre-Hauterivian dinoflagellate species from $4,450 \mathrm{ft}(1,356 \mathrm{~m})$.

BERRIASIAN(?) $(5,440-5,920 \mathrm{FT} ; 1,658-1,804 \mathrm{M})$

At $5,440 \mathrm{ft}(1,658 \mathrm{~m})$ there is ar increase in the diversity and number of specimens and a change from sandstone to mudstone (fig:s, 19, 22). This level is marked by a strong unconformable seismic reflector which terminates underlying reflectors, indicating erosion (figs. 20, 21). These events correlate well with the ser-level changes postulated for the Berriasian by Vail and others (1977). The foraminiferal fauna cannot be assigned a Berriasian Age, but Bebout (1980) identified Berriasian spores in his samples of the COST No. G-2 well at 5,020 (?) to $5,920 \mathrm{ft}$ $(1,530(?)$ to $1,804 \mathrm{~m})$. Everticyclammina virguliana, a distinctive agglutin $\varepsilon^{+}$ed benthic forminifer, first appears at $5,530 \mathrm{ft}(1,686 \mathrm{~m})$, but this is older than its known Valanginian range. At $5,650 \mathrm{ft}(1,722 \mathrm{~m})$ a tubericulate form of Epistomina appears, and it is quite abundant in deeper samples. P. Ascoli (written commun., April 1980) has noted this same form in the Scotian basin where it ranges from the late Kimmeridgian to the early Valanginian. It may prove to be useful for approximating the top of the Berriasian.

P. Ascoli has examined thin sections of cutting samples from the COST No. G-2 well for of calpionellids. Calpionellids are planktic microfossils that occupy a narrow biostratigraphic zone of 
Valanginian to Tithonian Age in Europe (Alleman and others, 1971) and in Canadian offshore wells (Jansa and others, 1980). Jansa (written commun., 1980) reports that they are absent above $5,530 \mathrm{ft}(1,686 \mathrm{~m})$, but appear in low numbers down to $5,710 \mathrm{ft}(1,740)$ and are abundant from 5,710 to $5,950 \mathrm{ft}(1,740$ to $1,808 \mathrm{~m}$; fig. 19).

\section{JURASSIC ROCKS}

TITHONIAN $(5,920-6,700 \mathrm{FT} ; 1,804-2,042 \mathrm{M})$

The first rare Epistomina uhligi appears in cuttings at 5,920 ft (1,804 m) (fig. 19). It occurs in a sidewall core at $5,962 \mathrm{ft}(1,817 \mathrm{~m})$ and becomes more abundant below $6,040 \mathrm{ft}(1,841 \mathrm{~m})$. This form is a consistent Tithonian marker in the Baltimore Canyon trough and the Scotian basin (Poag, 1980b; Ascoli, 1976). Rocks in this depth interval also were assigned a Tithonian age on the basis of nannofossils and palynomorphs (Bebout, 1980). Epistomina stellicostata, another Tithonian form in the Scotian basin (Ascoli, 1976), appears at 6,610 ft $(2,015 \mathrm{~m})$. Calpionellids are absent below $6,300 \mathrm{ft}(1,920 \mathrm{~m})$.

UPPER KIMMERIDGIAN (6,700-7,660 FT; 2,042-2,335 M)

At 6,700 $\mathrm{ft}(2,042 \mathrm{~m})$ the fauna is sparse and Cytherella index, a species that last appears in upper Kimmeridgian strata in the Scotian basin (P. Ascoli, oral commun., April 1980) is present. At $6,910 \mathrm{ft}(2,106 \mathrm{~m})$ in cuttings and at $7,148 \mathrm{ft}$ $(2,179 \mathrm{~m})$ in a sidewall core, Eoguttulina liassica occurs in great abundance at a lithologic change from limestone above to dark shale below (fig. 22). In abundance this species is typical of Kimmeridgian strata elsewhere (Lloyd, 1962). Other species present in the G-2 well that range no higher than Kimmeridgian in the Scotian basin are Lenticulina bruckmanni at $6,970 \mathrm{ft}(2,125 \mathrm{~m})$ and $L$. varians at $7,060 \mathrm{ft}(2,152 \mathrm{~m})$. A strong seismic reflector at $6,700 \mathrm{ft}(2,040 \mathrm{~m})$ is interpreted as an erosional unconformity because underlying reflectors terminate against it (figs. 20, 21).

LOWER KIMMERIDGIAN $(7,660-8,660 \mathrm{FT} ; 2,335-2,640 \mathrm{M})$

Alveosepta jaccardi, which marks the top of the lower Kimmeridgian in the Scotian basin, ap- pears and is abundant at $7,660 \mathrm{ft}(2,335 \mathrm{~m})$ (fig. 19). Another Kimmeridgian marker found in the Scotian basin, Schuleridea triebeli, occurs at $7,690 \mathrm{ft}(2,344 \mathrm{~m})$. The Kimmeridgian specie: $C y$ therelloides weberi occurs at $8,530 \mathrm{ft}(2,600 \mathrm{~m})$, and Galliaecytheridea sp. 2 of Ascoli (197f' occurs at $8,610 \mathrm{ft}(2,624 \mathrm{~m})$.

OXFORDIAN(?) $(8,660-10,100 \mathrm{FT} ; 2,640-3,079 \mathrm{M})$

The large numbers of Alveosepta jaccardi that occur at $8,660 \mathrm{ft}(2,640 \mathrm{~m})$ are typical of $C$. fordian assemblages of the Scotian basin (P. Ascoli, written commun., April, 1980; fig. 19). This faunal increase coincides with a strong unconformable reflector on seismic profiles 19 and 209 (figs. 20, 21). Oxidized sediments are also associated with the upper boundary.

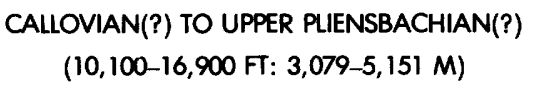

The boundaries of the stages in this interval are estimated from the presence of prominent, unconformable reflectors on seismic lines 77-2, 1? and 209. The tentative stage determinations and depth intervals are as follows:

Callovian(?), 10,100-12,100 ft (3,079-3,689 m); Bathonian(?), $12,100-14,100 \mathrm{ft} \quad(3,688-$ $4,298 \mathrm{~m}$ );

Bajocian(?) and Aalenian(?), 14,100-15,000 ft $(4,298-4,572 \mathrm{~m})$;

Toarcian(?) and upper Pliensbachian(?), $15,000-16,900 \mathrm{ft}(4,572-5,151 \mathrm{~m})$.

LOWER PLIENSBACHIAN(?) AND SINEMURIAN(?)

$(16,900-18,800 \mathrm{FT} ; 5,151-5,730 \mathrm{M})$

The boundary between the upper and lower parts of the Pliensbachian(?) Stage and the lower boundary of the Sinemurian(?) Stage are estimated from an analysis of seismic sequences on lines 77-2, 19, and 209, where they apprar as prominent unconformable reflectors (figs. 27, 21). A calcareous quartzose sandstone is assoniated with the lower Sinemurian(?) boundary (fig. 19). Bebout (1980) tentatively assigned this interval to the Middle Jurassic on the basis of a few palynomorphs. 
HETTANGIAN(?) AND RHAETIAN(?)

$(18,800-21,874 \mathrm{ft} ; 5,730-6,667 \mathrm{M})$

The upper boundary of the Hettangian(?) Stage is estimated from seismic sequence analysis of lines 77-2, 19, and 209 to be the prominent reflector at $18,800 \mathrm{ft}(5,730 \mathrm{~m})$ at the G-2 site (figs. 19 , $20,21,22)$. The halite-bearing strata at $21,874 \mathrm{ft}$ $(6,667 \mathrm{~m})$ appear to be of Rhaetian Age (Late Triassic), on the basis of seismic sequence analysis, correlation with the Rhaetian section in the COST No. G-1 well, and the presence of Triassic dinoflagellates in rocks overlying it (Anonymous, oral commun., 1980). If this interpretation is correct, this evaporitic section is equivalent to the Argo Formation of the Scotian basin (Eliuk, 1978; Barss and others, 1979). Seismic lines 77-2 and 209 indicate that basement lies $1,000 \mathrm{ft}$ $(305 \mathrm{~m})$ below the bottom of the COST No. G-2 well. A prominent unconformable reflector just below the bottom of the well on line 209 may mark the Rhaetian-Norian boundary, and if so, the oldest rocks above basement at this site are probably of Norian (Late Triassic) age. However, Bebout (1980) identified no fossils definitely older than Middle Jurassic.

\section{SEDIMENT ACCUMULATION RATES}

Knowing the detailed chronostratigraphy of the COST Nos. G-1 and G-2 wells allows the calculation of sediment accumulation rates at these sites. These rates can be extrapolated to other parts of the Georges Bank basin using seismic data.

Figure 23 shows the rates of sediment accumulation the G-1 and G-2 sites and compares them with rates at the three other Atlantic COST wells. During the Jurassic and Early Cretaceous the rates at G-2 exceeded those at G-1, but this pattern was reversed during the Late Cretaceous, and rates were nearly equal during the Cenozoic. The general trend from high to low rates with decreasing age can be seen in all the wells, but there are some exceptions, such as the high middle Miocene rates in the COST No. B-3 well (Poag, 1980b). The accumulation rates calculated for the Callovian and older rocks in the COST Nos. G-1 and G-2 wells are minimum rates, because there is no way to estimate from the seismic stratigraphy how much time each uncon- formity represents. The stage thinknesses determined from seismic stratigraphy have been divided by the duration of the stage, a given by Vail and Mitchum (1979).

During deposition of the olde rocks penetrated (Hettangian?-Rhaetian?), the accumulation rates at $\mathrm{G}-1$ and $\mathrm{G}-2$ were $6.8 \mathrm{~cm} / \mathrm{kyr}$ $(2.7 \mathrm{in} / \mathrm{kyr}) \quad(\mathrm{kyr}=1,000$ years) and $(10.0 \mathrm{~cm} / \mathrm{kyr})$ $(4 \mathrm{in} / \mathrm{kyr})$ respectively. The rates decreased at each location in the early Pliensbachian(?)Sinemurian(?) and remained near'y the same or decreased slightly through the Toarcian(?). In the Bajocian(?)-Aalenian(?) the rates dropped to half or less than half of what they were in the Toarcian(?): at G-1 the rate was $3.5 \mathrm{~cm} / \mathrm{kyr}$ (1.4 in/kyr), and at G-2 the rate was $2.7 \mathrm{~cm} / \mathrm{kyr}$ (1.1 in/kyr). These lower rates cortinued at $\mathrm{G}-1$ through the Bathonian(?), but not at G-2. In the Callovian(?) at G-1 and in the Pathonian(?) at G-2, the rates resumed approximately their preBajocian(?)-Aalenian(?) values. Maximum rates in both wells occurred during the Kimmeridgian. At G-1 the rate was $8.9 \mathrm{~cm} / \mathrm{kyr}(£ .6 \mathrm{in} / \mathrm{kyr})$ and at G-2 the early Kimmeridgian rate was $15.0 \mathrm{~cm} / \mathrm{kyr}(6 \mathrm{in} / \mathrm{kyr})$. The rate dropped to $7.5 \mathrm{~cm} / \mathrm{kyr}$ ( $3 \mathrm{in} / \mathrm{kyr}$ ) in the late Kimmeridgian to Tithonian at G-2, but fell even mowe dramatically at G-1 to $2.2 \mathrm{~cm} / \mathrm{kyr}(0.9 \mathrm{in} / \mathrm{kyr})$. From the Berriasian to the Barremian the rates varied from 2.2 to $4.5 \mathrm{~cm} / \mathrm{kyr}(0.9$ to $1.8 \mathrm{in} / \mathrm{kyr})$ at G-1 and from 2.0 to $6.0 \mathrm{~cm} / \mathrm{kyr}(0.8$ to $2.4 \mathrm{in} / \mathrm{kyr})$ at $\mathrm{G}-2$. A significant drop occurred at each well site in the Aptian: at G-1 the rate was $1.5 \mathrm{~cm} / \mathrm{kyr}(0.6 \mathrm{in} / \mathrm{kyr})$, and at G-2 the rate was $2.1 \mathrm{~cm} / \mathrm{kyr}(0.8 \mathrm{in} / \mathrm{kyr})$. During the Cenomanian to Santonian interval, rates ranged from 2.8 to $6.0 \mathrm{~cm} / \mathrm{kyr}$ (1.1 to $2.4 \mathrm{in} / \mathrm{kyr}$ ) at $\mathrm{G}-1$, but only from 2.0 to $3.0 \mathrm{~cm} / \mathrm{kyr}(0.8$ to $1.2 \mathrm{in} / \mathrm{kyr}$ ) at G-2.

Cenozoic rates ranged from 0.6 to $3.3 \mathrm{~cm} / \mathrm{kyr}$ (0.2 to $1.3 \mathrm{in} / \mathrm{kyr}$ ) at $\mathrm{G}-1$ and from 0.5 to $3.8 \mathrm{~cm} / \mathrm{kyr}(0.2$ to $1.5 \mathrm{in} / \mathrm{kyr})$ at G-2. The highest Cenozoic rates prevailed during the Pleistocene.

\section{CORRELATION WITH SCOTIAN BASIN WELLS}

The offshore Canadian well nearest the Georges Bank wells is the Shell Mohawk B-93, drilled 195 statute miles $(310 \mathrm{~km})$ northeast of the COST No. G-2 well on a small basement ligh (Mohawk ridge) on the southwestern margin (western shelf) of the broad Lahave platform (fig. 15). Because of 
INTERVAL

DEPTH BELO SEA FLOOR IN AETERTO

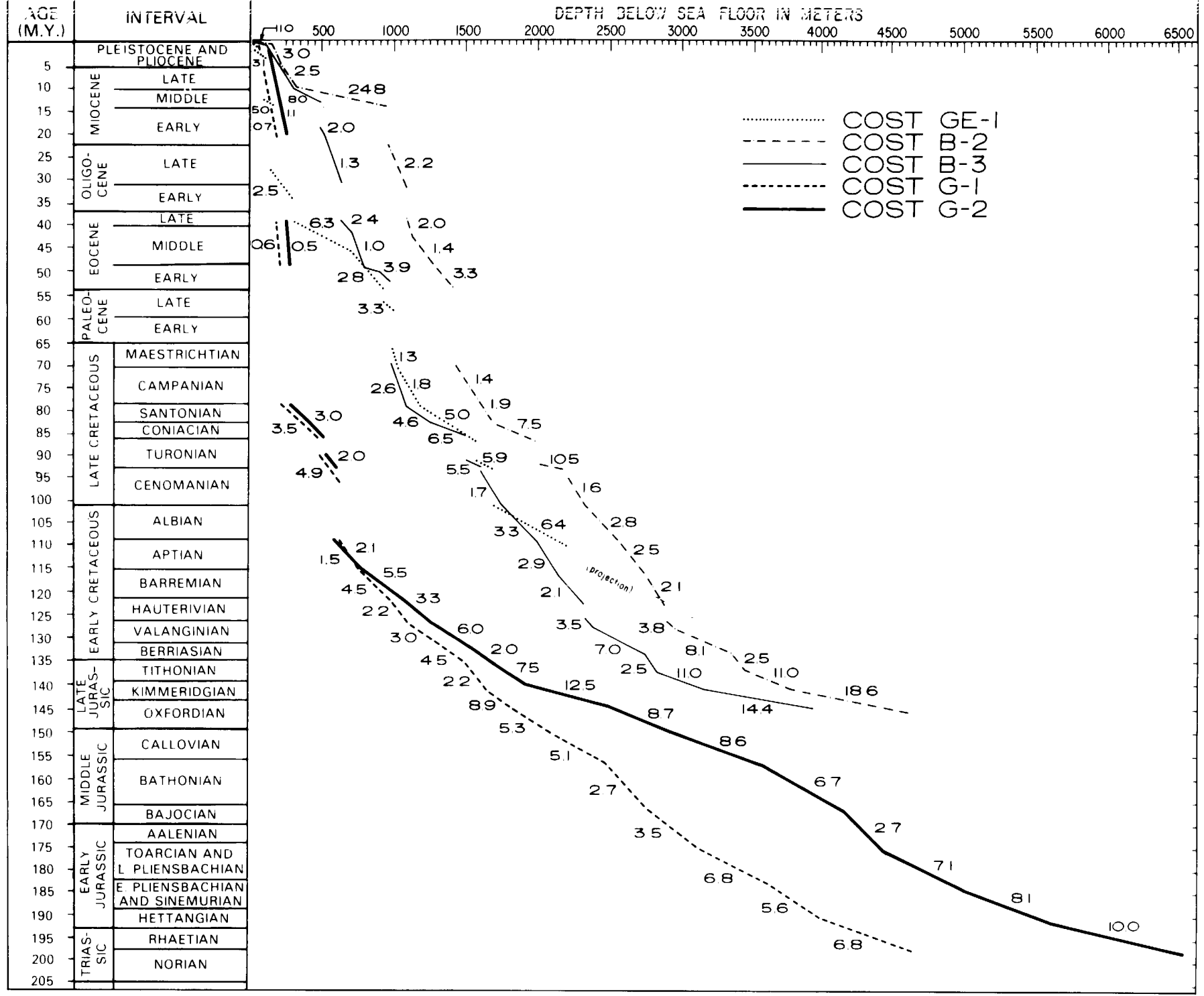

FIGURE 23.-Sediment accumulation rate curves for the COST Nos. G-1 and G-2 wells compared with those for the COST Nos. GE-1, B-2 and B-3 wells. Values are sentimeters per thousand years. Gaps in curyes are hiatuses, detected by faunal nnd lithic analyses. Unconformities inferred entirely from the seismic profiles are not shown because the magnitudes of time gaps are not known. As a result, the accumulation rates in the Triassic, Jurassic, and earliest Cretaceous are minimum rates. The formation names in this paper are those of similar rocks on the Scotian shelf of Canada. 
its high structural position, the Mohawk B-93 well reached granitic basement at $6,930 \mathrm{ft}$ $(2,112 \mathrm{~m})$ and penetrated sedimentary rocks as old as Bathonian (Barss and others, 1979). The nearest well in the Scotian basin (Mohican subbasin) is the Shell Mohican I-100 (313 mi (504 km) NE. of COST No. G-2; fig. 15). This well is more like the COST G wells (especially G-2) in structural setting than the Mohawk B-93, and reached salt at $14,322 \mathrm{ft}(4,365 \mathrm{~m})$ after penetrating rocks of Early Jurassic age (early Sinemurian?-late Hettangian?) (fig. 24; Barrs and others, 1979). Both Canadian wells are located 18 mi $(29 \mathrm{~km})$ landward of the Upper Jurassic shelfedge bank, a paleogeographic position similar to that of the COST No. G-2 well (Eliuk, 1978). The sequence of rocks, paleoenvironments, and faunal assemblages in the COST G wells is similar to that of the Canadian wells and allows correlation of the Scotian shelf formations (McIver, 1972; Given, 1977) with the rocks beneath Georges Bank (figs. 17, 21, 22, 24).

In general, the updip Jurassic formations of the Scotian basin and the LaHave platform are chiefly nonmarine sandstones and shales; these grade diachronously downdip into the marine shales, mudstones, limestones, dolomites, and evaporites found in wells nearer the basin. The lateral relationships among these formations are extremely complex (Given, 1977, Eliuk, 1978) and the lithostratigraphic terminology presently employed is not entirely satisfactory, but it simplifies the discussion of the depositional facies involved.

\section{ARGO FORMATION}

The name Argo Formation has been given to salt deposits at or near the base of the Jurassic section beneath the Scotian shelf (McIver, 1972). At least $2,500 \mathrm{ft}(762 \mathrm{~m})$ of relatively pure, white, coarsely crystalline halite with a few shale and anhydrite interbeds have been penetrated, and seismic evidence indicates that several thousand feet of salt occupies the Orpheus, Abenaki, and Sable basins. At the Mohican I-100 well, $92 \mathrm{ft}$ (28 $\mathrm{m}$ ) of Argo Formation was penetrated directly under rocks of Sinemurian to Hettangian Age (Barss and others, 1979). In the COST No. G-2 well, the $41 \mathrm{ft}(12 \mathrm{~m})$ of halite and anhydrite that lies below rocks of inferred Hettangian to Rhaetian Age (figs. 21, 24) is thought to represent the Argo Formation.
Overlying the Argo Formation in the Scotian basin is a sequence of dominantly brown, anhydritic dolomite, red to brown shale interbeds, and some limestones in the upper part. Given (1977) reported that two types of dolomite have been recognized in the Iroquois Formation: a microcrystalline dolomitic (commonly anhydritic) mudstone indicating shallow, rertricted marine, often supratidal, deposition; anc a dolomitized oolitic and pelletal grainstone that represents higher energy marine deposition.

In the Mohican I-100 well, $1,970 \mathrm{ft}(579 \mathrm{~m})$ of dolomitic Iroquois Formation was penetrated (fig. 24). It ranges in age from E ajocian to Hettangian (Barss and others, 1979'. In the COST No. G-2 well an $8,200-\mathrm{ft}(2,49 £ \mathrm{~m})$ section of dolomite, limestone, and anhydrite equivalent to the Iroquois constitutes the lower Bathonian(?) to Rhaetian(?) interval immediately above inferred Argo Formation (figs. 21, 24). This section is more than four times thicker than that penetrated in the Scotian basin. This sequence in the COST No. G-2 well is also sandy near its base as in the Mohican I-100 well.

\section{MOHICAN FORMATIOI}

The carbonate regime of the Scotian shelf was interrupted in the early Middle Jurassic by deposition of the widespread siliciclastic Mohican Formation. Given (1977) described the Mohican as chiefly sandstones, generally immature texturally, poorly sorted, dolomitic, sil $^{+} y$, argillaceous, kaolinitic, and locally interbed ted with varicolored shale. Given (1977) further suggested that the Mohican sands may refresent the first depositional phase of onlapping sands after the breakup of North America and Furo-Africa, but in the Georges Bank basin available seismic data suggest the continental breakup occurred earlier.

In the Mohican I-100 well $55 \mathrm{f}:(17 \mathrm{~m})$ of argillaceous sandstone and shale constitutes the type section of the Mohican Formatior. It is chiefly of Bathonian Age, but the base is upper Bajocian (Barss and others, 1979). In the COST No. G-2 well, a 30-ft (9-m) interval of sandstone, mudstone, and shale separates the Irxquois from the Abenaki Formation and is of early Bathonian(?) age; these terrigenous rocks aro presumed to 
NE SCOTIAN BASIN

SHELL MOHICAN I-10O

BASIN

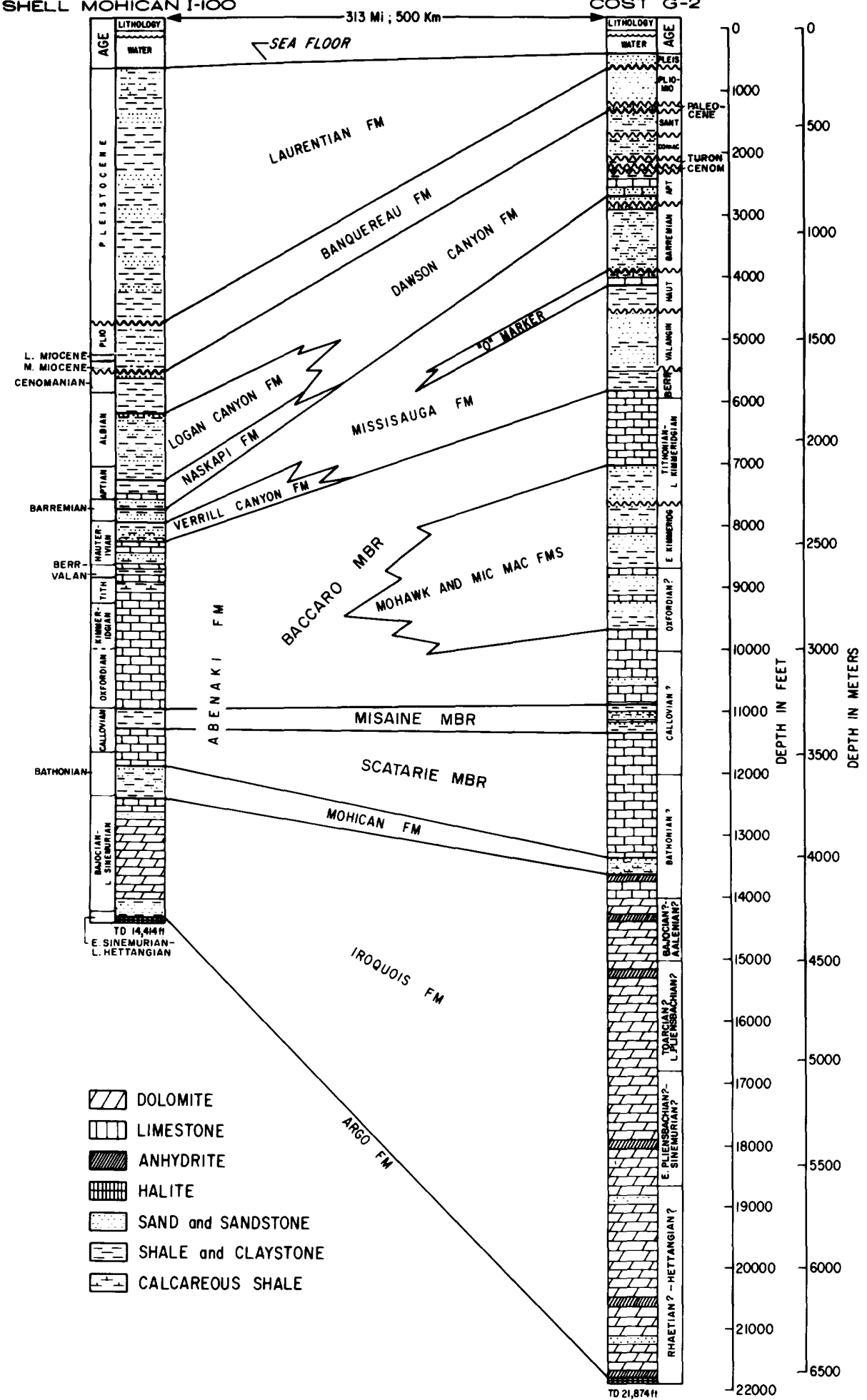

FIGURE 24.-Lithologic correlations between the Shell Mohican I-100 and COST No. G-2 wells. The formation names given are those that have been applied to similar rocks on the Scotian shelf of Canada. The age terms abbreviated in the left and right side columns are spelled out on figure 22. 
represent the equivalent of the Mohican Formation (figs. 21, 24).

At the G-1 site, the lower $6,000 \mathrm{ft}(1,829 \mathrm{~m})$ of sedimentary rocks appears to be a repetitious interfingering of Iroquois dolomite and limestone with sandstone, shale, and siltstone of the Mohican Formation (figs. 17, 24). The age of the interval is Bajocian(?) to Rhaetian(?). The lower third is quartz conglomerates, fine to mediumgrained sandstones, and red-brown shale; the middle third is dolomite and anhydrite; the upper third is limestone and sandstone; a thick Mohican sandstone tongue constitutes the top of the sequence.

\section{ABENAKI FORMATION}

On the Scotian shelf the Mohican Formation is overlain by dominantly oolitic, reef-bearing limestones of the Abenaki Formation. The lowest or Scatarie Limestone Member of the Abenaki is oolitic lime packstone to grainstone; it accumulated in warm, agitated, shallow marine waters. The Scatarie reaches a maximum thickness of $600 \mathrm{ft}(183 \mathrm{~m})$ in the Mohican I-100 well and is of Bathonian and Callovian Age. In the COST No. G-2 well, a 2,000-ft (610-m) section of argillaceous micrite and oolitic grainstone and packstone of Bathonian(?) and Callovian(?) age constitutes the Scatarie Limestone Member equivalent (figs. 21, 24).

The middle member is the Misaine Shale Member, a dark-olive-gray to gray-brown, somewhat calcareous, sparsely fossiliferous shale, which has a maximum thickness of $560 \mathrm{ft}(171 \mathrm{~m})$ on the Scotian shelf. In the Mohican I-100 well, the Misaine Shale Member is $330 \mathrm{ft}(101 \mathrm{~m})$ thick and is late Callovian in age. In the COST No. G-2 well, the Misaine Shale Member equivalent is $475 \mathrm{ft}$ $(145 \mathrm{~m})$ thick and is of middle Callovian(?) age.

The thickest member of the Abenaki Formation on the Scotian shelf is the Baccaro Limestone Member. The limestone comprises pelletal, oolitic fossiliferous, and "reefal" facies, and the member includes shale, sandstone, and dolomite. All the dolomites analyzed have been diagenetically altered limestones (Eliuk, 1978). The Baccaro is as much as $3,680 \mathrm{ft}(1,122 \mathrm{~m})$ thick and was deposited during Middle and Late Jurassic and Early Cretaceous time.

In the Mohican I-100 well the Baccaro Limestone Member is a 2,700-ft $(823-\mathrm{m})$-thick limestone (micritic to oolitic and oncolitic) with sandstone, claystone, and shale interbeds of late Callovian(?) and early Oxfordian ag: (figs. 21, 24). The upper part of $1,360 \mathrm{ft}$ (396 m) cf micritic limestone of Tithonian or late Kimmer dgian to early Berriasian age.

\section{MOHAWK AND MIC MAC FORMATIONS}

Updip equivalents of the Baccaro Limestone Member of the Abenaki Formation are the sandy Mohawk Formation and the shaley Mic Mac Formation. The sandstones of the Mohawk are distinguished from the Mohican sandstones by their more mature texture, better sorting, and locally calcareous nature.

The Mic Mac shales are medium to dark brown to olive gray and have fine-grained sandstone and limestone interbeds. These finer lithologies are not developed at the Mohican I-100 or Mohawk B-93 locations (Eliuk, 1978). At the COST No. G-2 well, a 2,500-ft (762-m) sequence of coaly sandstone, shale, and limestone intertongues with the Baccaro equivalent and ar nears to represent both Mohawk and Mic Mac lithologies (figs. $21,24)$. The age of the sequence is Oxfordian to late Kimmeridgian or Tithonian. Updip in the G-1 well, the Abenaki carbonates are not present, but the equivalent of the Mohawk and Mic Mac Formations is a $3,900-\mathrm{ft}(1,189-\mathrm{m})$ sequence of coarse- to very coarse-grained coaly sandstones, and red, yellow, gray, brown, and variegated shales (figs. 17, 21). The age range of this unit is Bajocian(?) to Tithonian.

\section{MISSISAUGA AND VERRILL CANYON FORMATIONS}

Above the Abenaki and its upcip equivalents on the Scotian shelf are the santy Missisauga Formation and its downdip shalely equivalent, the Verrill Canyon Formation. Massive sandstones (maximum thickness $3,800 \mathrm{ft} ; 1,158 \mathrm{~m}$ ) grade downdip to thinner sand units. A persistent calcareous seismic marker near the base of the Barremian, named the " 0 " ma"ker, is present over most of the Scotian shelf about $1,000 \mathrm{ft}$ (305 $\mathrm{m}$ ) below the top of the Missisauga. It consists of about $150 \mathrm{ft}(46 \mathrm{~m})$ of thin limestone beds and calcareous shales that contair a characteristic foraminiferal fauna dominated by Choffatella decipiens. Downdip, the Missisauga interfingers 
with medium-gray to brown carbonaceous shale of the Verrill Canyon Formation, whose maximum thickness is around $1,200 \mathrm{ft}(366 \mathrm{~m})$. The Missisauga and Verrill Canyon Formations range in age from Tithonian to Barremian. The " 0 " marker persists near the base of the Barremian Stage.

In the Mohican I-100 well, the Missisauga and Verrill Canyon Formations overlap, constituting a $500-\mathrm{ft}(152-\mathrm{m})$ unit of shale, sandy shale, and sandstone of Hauterivan to Barremian Age (fig. 24). The " 0 " marker is not developed there.

At the COST No. G-2 site, massive, lignitic, coarse-grained sandstones and mudstones assignable to the Missisauga Formation are $1,100 \mathrm{ft}$ $(335 \mathrm{~m})$ thick; their age is Berriasian to Hauterivian. These are overlain by a $550-\mathrm{ft}(168-\mathrm{m})$ section of calcareous claystones and gray fissile shales, topped by a $225-\mathrm{ft}(69-\mathrm{m})$ interval of bioclastic limestone and calcareous shale. These upper carbonates are of late Hauterivian age and contain the characteristic Choffatella descipiens fauna of the " 0 " marker.

Updip at G-1, four massive, coaly, medium- to very coarse-grained sandstone units and two thick, gray shale units (total 3,200 ft $(975 \mathrm{~m}$ ) thick) constitute the Missisauga Formation equivalent of late Kimmeridgian or Tithonian to early Aptian age; figs. 17, 21). A thin argillaceous dolomite at the top of the Hauterivian Stage (1,000 ft (305 m) below top of Missisauga) may be the equivalent of the " 0 " marker, but Choffatella decipiens was not observed in the sparse faunas of this well.

Commonly overlying the Missisauga Formation on the Scotian shelf is the Naskapi Formation, 500 to $600 \mathrm{ft}(152$ to $183 \mathrm{~m})$ thick, which is gray and olive-gray to dusky-red, fissile, carbonaceous shale of early Aptian age. In the Mohican I-100, the Naskapi Formation is $500 \mathrm{ft}(152 \mathrm{~m})$ thick and represents late Barremian through early Aptian deposition. The middle part is sandy and calcareous. In the COST Nos. G-1 and G-2 wells, the Naskapi Formation is not recognized.

\section{LOGAN CANYON AND DAWSON CANYON FORMATIONS}

On the Scotian shelf these lateral equivalents overlie the Naskapi and Missisauga Formations. The Logan Canyon Formation is the sandier updip unit, consisting of $3,000 \mathrm{ft}(914 \mathrm{~m})$ of alternating sandstone, mudstone, and shale, sepa- rated into two parts by an olive-green midc"e unit (Sable shale) 200 to $300 \mathrm{ft}$ (61 to $91 \mathrm{~m}$ ) thick. The Dawson Canyon Formation is the shalier downdip unit consisting of $900 \mathrm{ft}(274 \mathrm{~m})$ or more of calcareous, marly to glauconitic shale, becoming siltier at the base. The Logan Canyon is lete Aptian to late Cenomanian in age, whereas the Dawson Canyon Formation can be as young as late Maestrichtian. The thin Petrel Limsstone Member is a widespread marker in the Turonian part of the Dawson Canyon. The Logan Canyon Formation underlies the Dawson Canyon Tormation in the Mohican I-100 well; the two formations have a total thickness of $1,700 \mathrm{ft}(\mathrm{s} 18 \mathrm{~m})$. and represent the late Aptian and Cenomanian (fig. 24).

At the COST No. G-2 well the mudstones and sandstones equivalent to the Logan Canyon Formation also underlie the claystone and sil'stone of the Dawson Canyon equivalent, and tre two are separated by a 200-ft (61-m) thick shelly limestone of Aptian Age that may represent the Petrel Limestone Member, although it is older here than on the Canadian shelf (figs. 21, 22). The Logan Canyon equivalent is $1,200 \mathrm{ft}(3: 6 \mathrm{~m})$ thick, and is of Barremian through early Aptian age; the Dawson Canyon equivalent is $1,000 \mathrm{ft}$ $(305 \mathrm{~m})$ thick and represents the late Aptian to Santonian interval. At the COST No. G-1 well, $1,450 \mathrm{ft}(442 \mathrm{~m})$ of unconsolidated, messive, coarse-grained, glaucontic, lignitic sandstore and gravel, and gray, glaucontic shale beds represent both the Logan Canyon and Dawson Canyon Formations and are Cenomanian to Santonian in age (figs. 17, 21).

\section{BANQUEREAU FORMATION}

The Tertiary strata of the Scotian shelf have not yet been subdivided into formations: the varied siliciclastic sandstones, mudstones, shales, siltstones, and claystones are lumped together into the Banquereau Formation. In the Mohican I-100 well, the Banquereau Formation is $750 \mathrm{ft}(229 \mathrm{~m})$ thick and includes middle Miocene, upper Miocene, and Pliocene siltstones.

In contrast to the siliciclastic Tertiary strata of the Scotian shelf, the Tertiary of the Genrges Bank basin contains carbonates of Palencene, Eocene, and possibly Oligocene age, which should eventually be designated as a separate form ation or formations from the terrigenous Miocen? and 
Pliocene strata. Therefore, Banquereau is not a satisfactory term to use for the Paleogene units of Georges Bank. White bioclastic limestone mostly of Eocene age similar to that found further offshore is present throughout the Coastal Plain province of North America and crops out as the Ocala, Cooper, Castle Hayne, and other formations. One of these Coastal Plain names could probably be appropriately applied to the offshore Eocene strata, including those of the Georges Bank basin.

\section{LAURENTIAN FORMATION}

The Laurentian Formation of the Scotian shelf consists of Quaternary glacial drift and stratified proglacial sediments ranging in thickness from $100 \mathrm{ft}(30 \mathrm{~m})$ to $4,000 \mathrm{ft}(1,220 \mathrm{~m})$ (Jansa and Wade, 1975a). The rocks are even thicker near the shelf edge. The Mohican I-100 well penetrated more than $4,200 \mathrm{ft}(1,280 \mathrm{~m})$ of Laurentian sands, silts, and clays that represent several glacial cycles (fig. 24; G. L. Williams, written commun., 1974). The thickness of the Laurentian Formation is variable on the upper continental slope as a result of submarine slumping and erosion, but Jansa and Wade (1975a) estimated a maximum thickness of more than $6,000 \mathrm{ft}(>1,800 \mathrm{~m})$ on the lower slope and rise.

The Laurentian Formation equivalent appears to be no more than $200 \mathrm{ft}(61 \mathrm{~m})$ thick in the COST Nos. G-1 and G-2 wells and consists of glacially derived sands (figs. 17, 22). It thickens toward the shelf edge, reaching $800 \mathrm{ft}(244 \mathrm{~m})$ on line 19 (fig. 21). (See also Lewis and Sylvester, 1977; Hathaway and others, 1979.) It may be somewhat thicker on the lower slope and rise, where it constitutes a chaotic olisthostrome. (See Comparison with Deep-Sea Sedimentary Sequences, this chapter).

\section{LITHOLOGIC FACIES AND PALEOENVIRONMENTS AT THE}

\section{COST G WELL SITES AND ALONG SEISMIC LINE 19}

The analyses of lithologic facies and paleoenvironments of the COST Nos. G-1 and G-2 wells and vicinity are based on foraminiferal and lithologic interpretations of well samples and on seismic facies analysis of nearby seismic lines
(Vail and others, 1977). The discus rion herein proceeds from oldest to youngest ronks. Line 19 is the closest long profile to which bcth the G-1 and G-2 wells can be projected along strike (figs. 15, $20,21)$. This line is augmented br dip line 77-1 (fig. 18), which nearly crosses the G-1 site, and strike line 204 (collected by the Bundesanstalt fuir Geowissenschaften und Rohstoffe; BGR), which crosses line 19 near the shelf edg! (fig. 25). BGR line 209 crosses the G-2 well site but is not discussed here because the G-1 well cannot be projected to it along strike (fig. 15). However, my analysis of line 209 and that of Klitgord and others (this volume) confirm the fiatures inferred from line 19.

\section{HETIANGIAN(?) AND RHAETIAN'?) ROCKS}

Hettangian(?) or Rhaetian(?) rocks lie on a block-faulted basement which is believed to be Paleozoic metasedimentary strata. Thick accumulations of Triassic arkosic sandstones and marine interbeds (indicated by the dinoflagellates in the $\mathrm{G}$ wells) fill the basement grabens (figs. 18 , 21). At G-1 the basal $1,600 \mathrm{ft}(48 \Omega \mathrm{m})$ of sedimentary rocks are sandstones, shales, and conglomerates. Pink, red, and red-brown colors (fig. 17) suggest oxidizing, high-energy environments in an alluvial or fluvial depositional ragime. Thin interbeds of anhydrite and dolomite indicate occasional flooding by shallow marine. waters.

Seismic lines 77-1 (fig. 18) and 19 (figs. 20, 21) show that the coarse siliciclastic part of the Hettangian(?)-Rhaetian(?) sequence f:ls a basement low that extends southeastward from the G-1 well site. The discontinuous, subparallel, slightly chaotic reflectors in these updip siliciclastics are characteristic of accumulation un ter rapidly fluctuating environments in a higl onergy regime (Vail and others, 1977). Downdip the beds onlap and interfinger with a sequence of somewhat chaotic reflectors near shotpoint 2300 that are interpreted to come from an elongate carbonate mound, which overlies a basement high. This high may be the southern end of the Yarmouth arch (see Klitgord and others, this vol ime). Two more small carbonate mounds occur between s.p. 2400 and 2600.

The uppermost $300 \mathrm{ft}(91 \mathrm{~m})$ of Hettangian(?)Rhaetian(?) rocks in the G-1 well comprises redbrown shale with dolomite and anhydrite inclusions, some thin interbeds of dolomite, and a few 


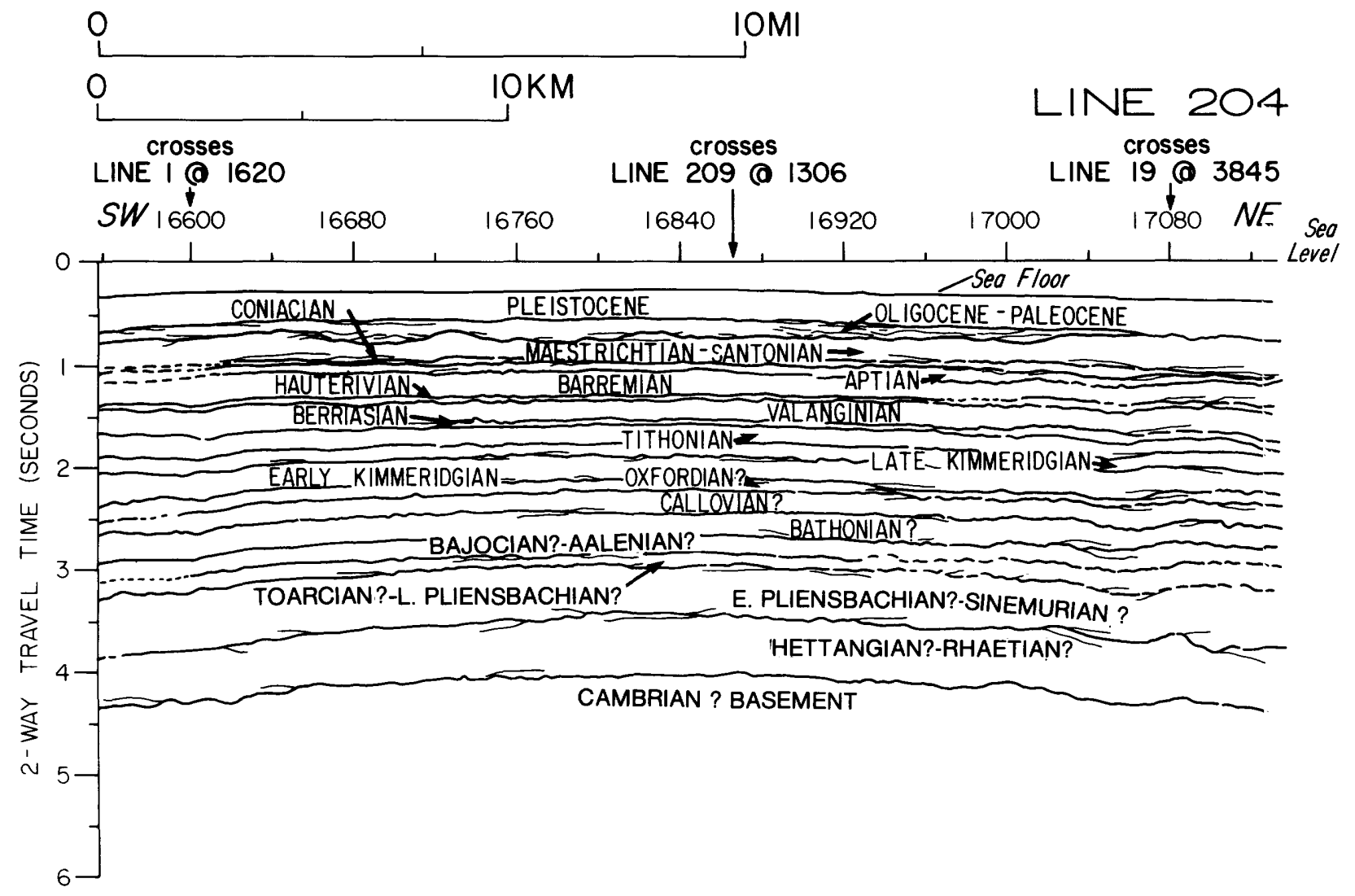

FIGURE 25.-Structural and chronostratigraphic interpretation of seismic reflection profile line 204 (collected kv the

Bundesanstalt fuir Geowissenschaften und Rohstoffe, Hanover, West Germany), which traverses the outer part of the

Georges Bank basin along strike.

beds of well cemented sandstone (fig. 17). The seismic profiles show few reflectors in this interval, indicating either lithologic homogeneity or bedding too thin to detect with the seismic frequencies used (figs. 18, 20, 21). Nearshore marine to nonmarine paleoenvironments are inferred for this interval. The reflection-free interval extends from the updip end of line 19 to approximately s.p. 2200. At this position a series of highamplitude reflectors appear and lap onto the carbonate mound.

Downdip from s.p. 2200, a series of continuous, parallel, high-amplitude reflectors extend to about s.p. 2760. These continuous reflectors are typical of uniform, low-energy environments, and their high amplitudes, interpreted along with rocks recovered from the well, suggest discrete strata within carbonate rock sequences (Vail and others, 1977). The continuity of these reflectors is interrupted at s.p. 2480 and 2580 by the more chaotic high-amplitude reflectors of the carbonate mounds. Farther downdip the continuous reflectors become intermittent and onlap both flanks of a large carbonate mound just updip from the projected G-2 well site (figs. 20, 21). This carbonate mound (or perhaps another) is also visible at a similar paleogeographic position on line 209, but is much smaller there. Th? G-2 well penetrated mostly carbonates in the Hettangian(?)-Rhaetian(?) interval (fig. 22). A 3,000-ft (914-m) sequence of light- and dark-brown-gray, micritic and oolitic, pelloidal limestone, gray and brown-gray, fine to crystalline dolomite, b idded anhydrite, and interbeds of fine- to very finegrained sandstone and dark-brown-gray, calcareous, silty shale overlies $40 \mathrm{ft}(12 \mathrm{~m})$ of halite. (Acoustic basement appears to be about 1,500 ft $(457 \mathrm{~m})$ below the top of the halite.) Presur ably, the salt accumulated in restricted shallow marine waters in an arid climate. The overlying rocks probably accumulated chiefly in quiet, nearshore marine waters and in supratidal sabkhas, $k$ " $t$ intervals of higher energy marine conditions are indicated by the oolitic strata. 
On line 19, downdip from the G-2 projection, high-amplitude, intermittent, subparallel carbonate reflectors persist to about s.p. 3340 , but are interrupted by three zones of more chaotic, arched reflectors interpreted here as carbonate mounds (figs. 20, 21). Between s.p. 3340 and s.p. 3680 the reflectors regain some of their updip continuity and parallelism, suggesting quieter, more uniform deposition than that near the mounds. The somewhat chaotic bedding of another large mound is present, however, between s.p. 3680 and 3750. Downdip from this mound the reflectors become indistinct as the strata intersect the shelf-edge reefal bank.

\section{LOWER PLIENSBACHIAN(?) AND SINEMURIAN(?) ROCKS}

At G-1, the early Pliensbachian(?) and Sinemurian(?) are represented by $1,200 \mathrm{ft}(366 \mathrm{~m})$ of light-gray to buff, crypotocrystalline to pelletal dolomite with interbeds of anhydrite, thin beds of red-brown shale, fine- to very fine-grained sandstone, and gypsum nodules (fig. 17). The seismic character on line 77-1, which crosses near the G-1 well site, shows nearly reflector-free intervals above and below a single, high-amplitude, continuous reflector that occupies the middle of the sequence (fig. 18). At the G-1 projection on line 19 , a zone of faint subparallel reflectors crosses the well site and extends updip to the end of the profile (figs. 20, 21). These characteristics suggest rather uniform shallow marine paleoenvironments much like those of the Hettangian(?)Rhaetian(?) interval.

On line 19, at about s.p. 2120, the parallel reflectors become more continuous and their amplitude increases as the section thins and drapes over the underlying carbonate mound (figs. 20, 21). These reflector characteristics suggest more strongly defined bedding and less uniform, shallow-water carbonate environments than observed updip. Downdip from the carbonate mound, the lower Pliensbachian(?) and Sinemurian(?) rocks thicken somewhat, reaching a maximum thickness of 0.2 seconds (two-way traveltime) in a small trough near s.p. 2520. In this interval, the low-amplitude, discontinuous reflectors suggest more uniform depositional conditions. From near s.p. 2520 to the G-2 projection the lower Pliensbachian(?)-Sinemurian(?) interval is nearly reflector-free, suggesting lithologic homogeneity or very thin bedding.
At the G-2 well site the lower Pliensbachian(?) and Sinemurian(?) section is tan to brown-gray to dark-brown-gray micritic limestone with oolitic and pelloidal interbeds, gray to light-gray to brown-gray, fine-grained to microcrystalline dolomite and white, very fine-grained to microcrystalline anhydrite (fig. 22). All these characteristics suggest shallow nearshowe marine and sabkha-like environments (fig. 19). Alternating zones of low- to high-amplitude, continuous reflectors (shallow-water carbonates) extend downdip from the G-2 projection and onlap the arched reflectors of a low carbonate mound between s.p. 3620 and s.p. 3720 (figs. 20, 21). Downdip from this mound, the lower Pleinsbachian(?)-Sinemurian(?) rocks appear to thicken considerably as the reflectors lo $^{-}$, definition in the shelf-edge reefal bank.

\section{BAJOCIAN(?) TO UPPER PLIENSBACHAN(?) ROCKS}

In the G-1 well, the Briocian(?)-upper Pliensbachian(?) rocks are a $4,00 \mathrm{C}-\mathrm{ft}(1,219-\mathrm{m})$ sequence of generally thin-bedded, alternating units of limestone, sandstone, and shale, with some dolomite near the base (fig. 22). The evaporitic rocks common in the underlring section are not present. The limestones include microcrystalline to medium crystalline, pelletal, and micritic textures; sandstones are medium to very fine grained; shales are red-brown, gryy-green, green, and gray. Thin coal beds are scattered throughout the sequence.

On profile 77-1 the Bajocian(?)-upper Pliensbachian(?) interval displays continuous highamplitude reflectors in the lower two-thirds, but the reflectors are discontinuous and of lower amplitude in the upper one-third (fig. 18). At the G-1 projection on line 19 , similar reflector characteristics with lower amplitudes mark the Bajocian(?)-upper Pliensbachian(?' section (figs. $20,21)$. These lithologic and seismic characteristics suggest high-energy regimes in fluctuating shallow marine and nonmarine coastal environments (fig. 16). The seismic characteristics and thickness of the interval are constant on line 19 from the updip limit to s.p. 274C. At this point the unit begins to thin markedly and the reflectors became intermittent, more widely separated vertically, and of higher amolitude. These changes persist downdip to the G-2 projection.

In the G-2 well, the $2,800-\mathrm{ft}(853 \mathrm{~m})$ section of 
Bajocian(?)-upper Pliensbachian(?) rocks is a continuation of the thick sequence of shallow marine limestones, dolomites, and anhydrites that make up the underlying lower Pliensbachian(?) and Sinemurian(?) rocks. This unit continues downdip from the G-2 projection with approximately the same thickness and seismic characteristics to near s.p. 3040, where it lies unconformably above Hettangian(?)-Rhaetian(?) rocks. Where the Bajocian(?)-upper Pliensbachian(?) rocks resume contact with the lower Pleinsbachian(?)-Sinemurian(?) rocks (near s.p. 3180), their seismic character changes to include wide nonreflective intervals between high-amplitude, moderately continuous reflectors, and the unit thins even more. The section becomes even thinner where the Bajocian(?)-upper Pleinsbachian(?) rocks onlap the carbonate mound near s.p. 3600 . The unit thickens again downdip from the carbonate mound, becoming indistinguishable in the shelfedge reefal bank. Rocks as old as Pliensbachian may be present in the basal sedimentary sequences on the oceanic side of the reefal bank. (See Comparison with Deep Sea Sedimentary Sequences, this chapter.)

\section{BATHONIAN(?) ROCKS}

At the G-1 well site Bathonian(?) rocks are very coarse-grained, unconsolidated sandstones with thick interbeds of red-brown and gray shale and scattered coal seams and pyrite (fig. 22). The seismic reflectors on lines 77-1 and 19 are discontinuous, subparallel, and of moderate to low amplitude (figs. 20, 21). These characteristics are typical of nonmarine fluvial and shallow-marine environments (fig. 16). These discontinuous reflectors extend downdip to near s.p. 2230 where the lower reflectors become more continuous and increase in amplitude, which is indicative of carbonate facies. Near s.p. 2460 the seismic characteristics of carbonates appear throughout the entire Bathonian(?) section. They persist to the G-2 well, which penetrated brown- gray micritic limestones, a few oolitic beds, and layers of anhydrite. Interbeds consist of shale, claystone, and sandstone; traces of tuff occur between 11,720 and $12,000 \mathrm{ft}(3,572$ to $3,658 \mathrm{~m})$. Alternating shallow-marine and nonmarine environments are inferred for most of the time interval represented by this section (fig. 19).

Downdip, near s.p. 3280, the thickness of the
Bathonian(?) unit is half its thickness updip at s.p. 2230; the amplitude and continuity of reflectors increase, suggesting perhaps the absence of the nonmarine facies at the downdip site. The Bathonian(?) rocks drape over the carb onate mound near s.p. 3680 and can be traced as indistinct reflectors to about s.p. 3940 where they abut the shelf-edge reefal bank. Bathonian rocks may be present on the oceanic side of the reefal bank.

\section{CALLOVIAN(?) ROCKS}

At the G-1 well site the Callovian(?) rocks comprise $1,200 \mathrm{ft}(366 \mathrm{~m})$ of very coarse-grainet, unconsolidated, slightly arkosic sandstones, some pea gravel, and red, yellow, gray, brown. and variegated shales with a few coal and pyritic beds (fig. 17). The seismic reflectors on lines 77-1 and 19 are discontinuous, parallel, and of variable amplitude (figs. 20, 21). These characteristics sugest deposition in fluctuating nonmarine fluvial and shallow-marine coastal environments (fig. 16). Near s.p. 2480 on line 19 the reflnctors become more continuous and increase in amplitude, suggesting more uniform marine condtions and carbonate deposition. The high-amplitude, continuous reflectors extend downdip and cross the $\mathrm{G}-2$ projection.

At G-2 the inferred Callovian unit comprises $2,000 \mathrm{ft}(610 \mathrm{~m})$ of chiefly brown-gray, oolitir. oncolitic, bioclastic limestones with interbers of well-sorted, fine-grained sandstones, and gray to red silty and partly calcareous shales (fig. 22). The reflections nearly disappear downdip at s.p. 3400 , which suggests very thin bedding or more homogeneous lithology. The continuous, highamplitude reflectors reappear near s.p. 3680 where they drape over the buried carbonate mound. The reflectors are indistinguishable downdip from s.p. 3940 as they enter the shelfedge reefal bank. A series of intermittent highamplitude reflectors above basement on the oceanic side of the shelf-edge reefal bank may include Callovian rocks.

\section{OXFORDIAN(?) ROCKS}

At the G-1 well site the Oxfordian(?) rocks comprise $900 \mathrm{ft}(274 \mathrm{~m})$ of alternating coarse- to very coarse-grained, loosely consolidated, lignitic and pyritic sandstone and red, yellow, gray, 
brown, silty, micaceous shale (fig. 17). The intermittent, variable-amplitude seismic reflectors on lines 77-1 and 19 (figs. 20, 21) are typical of nonmarine fluvial and shallow-marine coastal deposits (fig. 16). The sparse benthic assemblages of this section appear to be entirely cavings and the lack of indigenous fauna could indicate nonmarine deposition or diagenetic destruction of the original assemblages. Steinkraus (1980) reports dinoflagellates in a core at $6,543 \mathrm{ft}(1,994 \mathrm{~m})$, indicating that some marine beds are present in the upper part of the Oxfordian section.

Downdip between s.p. 2500 and 2700 are bursts of discontinuous, parallel, very high amplitude reflectors, which indicate high-energy nonmarine deposition. Between s.p. 2700 and the G-2 projection the loss of internal reflectors suggests either uniform lithology or very thin bedding. The G-2 well encountered $1,400 \mathrm{ft}(427 \mathrm{~m})$ of alternating sandstone, shale, mudstone, and limestone (fig. 22). The sandstone is white, gray, and red, fine to medium grained, poorly to well sorted, coaly, and micaceous; the shales and mudstones are gray, dark gray, red brown, and maroon; limestones, which are concentrated in the lower part of the section, are tan to light gray, oolitic, and oncolitic. These characteristics indicate fluctuating, mostly nonmarine fluvial environments for the upper parts of the unit and chiefly shallow-marine conditions for the lower part (fig. 19). The foraminiferal assemblages are typical of shallow marine Tethyan faunas of western Europe and the Scotian basin. Agglutinated species predominate, chiefly Alveosepta jaccardi, accompanied by Everticyclammina virguliana, Epistomina spp., and Trocholina spp. High-spired microgastropods, ostracods, fish teeth, and charophytes are also present.

Just downdip from the G-2 projection, the greater continuiuty and higher amplitude of the reflectors suggests a change to widespread shallow-water carbonate deposition (figs. 20, 21). The Oxfordian rocks drape over the buried carbonate mound at s.p. 3680 and become indistinguishable downdip in the shelf-edge reefal bank. A series of intermittent high-amplitude reflectors above basement on the oceanic side of the reefal bank may include Oxfordian rocks.

\section{LOWER KIMMERIDGIAN ROCKS}

The lower Kimmeridgian rocks at G-1 are chiefly sandstones and shales similar to the underlying Oxfordian rocks, ercept for some oolitic limestones in the upper part of the interval. Siderite nodules are scattered throughout the section (fig. 17). The faunas consist mainly of sparse, poorly preserved, and often oxidized foraminifers and ostracods. Everticyclammina virguliana is the predominant foraminifer, accompanied by a few lenticulinids. Sfismic reflectors on lines 77-1 and 19 are discontinuous, parallel, and of variable amplitude (figs. 21, 21). All these characteristics indicate deposition in alternating nonmarine fluvial and shallow marine coastal environments, perhaps including some "middle shelf" deposits (fig. 16).

On line 19, the intermittent sfismic reflectors persist downdip to the G-2 projection. The G-2 well penetrated sandstones and shales (comparable to the Oxfordian(?) sandstones and shales) in the lower part of the lower Kimm?ridgian section (fig. 22). Gray oolitic limestones are present near the middle and at the top of the rection.

The foraminiferal assemblages at G-2 are somewhat more abundant and more diverse than at G-1. Tethyan shallow-mariro agglutinated forms still predominate, chiefly Everticyclammina virguliana and various sp?cies of Haplophragmoides and Ammobaculites. Among the calcareous forms Eoguttulina is prominent. Ostracods and high-spired micrngastropods are sparse. Oolites, lignite, and oxidized shale and sandstone fragments are common in the washed rotary cuttings.

These characteristics suggest greater marine influence at G-2 than at G-1 (fig. 19). The continuity and amplitude of seismic reflectors increase downdip from the G-2 projection, with the exception of a nearly reflector-f:ee interval between s.p. 3100 and 3560 (figs. 20, 21). The highamplitude reflectors are especially prominent downdip from s.p. 3680 but becon 9 indistinguishable in the shelf-edge reefal bank. A series of intermittent high-amplitude reflectors on the oceanic side of the reefal bank mcy include lower Kimmeridgian rocks.

\section{UPPER KIMMERIDGIAN TO BERRIASIAN ROCKS}

In the G-1 well, the $1,300-\mathrm{ft}(396-\mathrm{m})$ upper Kimmeridgian-Berriasian interval is divided into two sandstone sections separated by interbedded shale and dolomite (fig. 17). The sandstones are chiefly medium to very coarse grained, lignitic, 
micaceous, and pebbly; the shale and dolomite are light gray. In the shales and lower sandstones foraminifers are common and ostracods and highspired microgastropods are present. Dominant foraminifers are Everticyclammina virguliana, small, fragile Haplophragmoides, Eoguttulina sp., Trocholina sp., Epistomina spp. and Lenticulina spp. The seismic reflectors at the G-1 projection on lines 77-1 and 19 are parallel and of variable continuity and amplitude (figs. 23,24$)$. A single high-amplitude reflector appears to represent the dolomitic zone.

All these characteristics suggest deposition in fluctuating nonmarine fluvial to shallow marine inner-shelf environments (figs. 16). The intermittent variable-amplitude reflectors and the dolomite reflector can be traced downdip on line 19 to near s.p. 2520, where the strata just above the inferred dolomite begin to display closely spaced, continuous, parallel, high-amplitude reflectors (figs. 20, 21). This pattern suggests a basinward change to more carbonate-rich facies. The inferred carbonate interval thickens toward the basin from s.p. 2520 until it makes up the entire Berriasian to upper Kimmeridgian interval at the G-2 projection. The G-2 well encountered a 1,300-ft (417-m) interval of light-gray to tan, micritic to chalky limestone bounded above by $200 \mathrm{ft}(61 \mathrm{~m})$ of mudstone and below by $600 \mathrm{ft}(183 \mathrm{~m})$ of sandstone (fig. 22).

Rich, diversified foraminiferal assemblages occur throughout this section. Everticyclammina virguliana, Choffatella decipiens, Lenticulina spp., and Epistomina spp. predominate, accompanied by Trocholina, Conorboides, Ophthalmidium, and Eoguttulina. Ostracods and highspired microgastropods also are abundant in some intervals. The presence of common to abundant calpionellids in the upper, more calcareous part of this unit suggests moderately deep, open marine conditions (300 ft; $100 \mathrm{~m}$ ) (fig. 19). Intervals containing well-developed assemblages alternate with more sparsely populated intervals in which leached specimens, lignite, gypsum, and oxidized clays all suggest shoaling and perhaps subaerial exposure.

Downdip from the G-2 projection (figs. 20, 21) the vertical spacing of reflectors is variable, few reflectors are continuous, and many have high amplitudes and are parallel. These characteristics suggest continued carbonate deposition in a variable shallow-marine environment. Upper Kimmeridgian and Tithonian reflectors can be traced to the shelf-edge reefal bank near s.p. $395 \mathrm{C}$. but the thin Berriasian unit can be traced no f $\varepsilon$ ther than s.p. 3930.

Reefal rocks of Berriasian and Neocomian (Hauterivian to Barremian) Age have beer collected from Heezen Canyon, northeast of line 19 (fig. 15; Ryan and others, 1978). The Berriasian limestone sample was identified on the baris of pelagic calpionellids, and it also containet remains of the pelagic crinoid Saccocoma, abur tant corals, hydrozoa, calcareous algae, and large foraminifers. This unit is interpreted to have accumulated in an ocean-facing reef environment. Neocomian samples contained rudistids, echinoids, bivalves, bryozoans, ostracods, benthic foraminifera, and calcareous algae, but lacket the corals and other colonial organisms. These associations probably accumulated in non-reefal parts of the carbonate platform. Equivalent facins on line 19 would be expected between s.p. $400 C$ and 4100 (figs. 20, 21).

A series of high-amplitude, discontinuous reflectors on the seaward side of the shelfedge reefal bank may include upper Kimmeridgian to Berriasian carbonate rocks of hemipelagic and pelagic origin.

\section{VALANGINIAN ROCKS}

In the G-1 well, Valanginian rocks consint of very coarse-grained pebbly sandstones, inter'beds of gray shale, and coal and lignite at the base. (fig. 17). These sandstones may be a continuation of the sandstones of the underlying Berriasian section. The Valanginian microfossils are sparse and may be entirely cavings.

On seismic line 77-1 the reflectors in the Valanginian interval are intermittent and of low amplitude. At the G-1 projection on line 19, a single intermittent reflector with variable amplitude occupies the middle of an other -ise reflector-free Valanginian section (figs. 20, 21).

These characteristics indicate dominantly nonmarine fluvial deposits that accumulated under uniform conditions (fig. 16). The same seirmic characteristics extend downdip on line 19 to the G-2 projection (figs. 23, 24). The G-2 well als? encountered a thick sandstone unit of Valanginian Age. The sandstone is very coarse to fine gre ined and white to gray and has interbeds of coal, lignite, dark-gray shale, light-gray mudstone, pyrite, and glauconite (fig. 22). 
A sparse to moderately well developed microfauna is scattered throughout the Valanginian rocks at G-2. The large shallow-marine Tethyan agglutinated foraminifer Choffatella decipiens is prominent, as are large Ammobaculites sp., small fragile Ammobaculites sp., and Trochammina sp. In the lower $350 \mathrm{ft}(107 \mathrm{~m})$ of the Valanginian section, calcareous microfossils are more abundant and include Epistomina spp., Lenticuluina spp., Planularia sp., and Conorboides sp. These lithologic, seismic, and faunal characteristics are typical of deposits that accumulated in fluctuating nonmarine fluvial and shallow-marine coastal environments (fig. 19).

Downdip from the G-2 projection the Valanginian section nearly doubles in thickness, reaching a maximum near s.p. 3860 . As the section thickens, more reflectors are present, but they are intermittent and of variable amplitude (figs. 20, 21). Near s.p. 3860, a delta-like wedge of intermittent, variable-amplitude, sigmoid clinoform reflectors fills a faulted depression landward of the shelf-edge reefal bank. Oceanward of the reefal bank, Valanginian rocks may be present as a thin, rather reflector-free unit lying above the high-amplitude Berriasian(?) to Callovian(?) reflectors.

\section{HAUTERIVIAN ROCKS}

At G-1 the upper part of the $400-\mathrm{ft}(122-\mathrm{m})$ Hauterivian section is a thin argillaceous dolomite. A thin, unconsolidated, very coarse-grained sandstone separates the dolomite from a thick, gray shale unit that contains a coal bed near the top. The microfossil assemblages in the Hauterivian rocks are sparse and are probably all cavings from overlying fossiliferous beds. On seismic line 77-1 the Hauterivian interval contains characteristic discontinuous reflectors of variable amplitude. On seismic line 19 at the G-1 projection, a single, central, nearly continuous reflector of variable amplitude characterizes the Hauterivian interval; the reflector can be traced downdip to near s.p. 2580 (figs. 20, 21). These characteristics indicate early deposition in chiefly nonmarine fluvial environments followed by a shallow marine incursion in the late Hauterivian (fig. 16).

On line 19 from s.p. 2580 to near s.p. 2880 the central Hauterivian reflector becomes more intermittent than at updip positions. At s.p. 2880 a second low-amplitude reflector appears and both reflectors cross the $\mathrm{G}-2$ projection site. The $\mathrm{G}-2$ well penetrated $600 \mathrm{ft}(183 \mathrm{~m})$ of bioclastic, partly oolitic limestone, argillaceous micrite, light-gray calcareous claystone, and gray, fissile, silty shale in the Hauterivian interval (fig. 22).

A moderately rich foraminiferal assemblage is present in the G-2 Hauterivian rocks. Choffatella decipiens is prominent, along with Lenticulina spp., Planularia sp., Marssonelia sp., and occasional floods of Eoguttulina sp., and Trocholina sp. High-spired microgastropods, ostracods, echinoid spines, free ooids, and crcasional charophytes also are typical. These $\epsilon$ lements suggest that here Hauterivian rocks accumulated in shallow marine to coastal normarine environments (fig. 19).

Downdip from the G-2 projection the seismic reflectors are widely separated, intermittent, and of variable amplitude, sugge ting continued shallow-marine and coastal normarine environments. Hauterivian rocks appe $\varepsilon^{*}$ to be severely eroded near s.p. 3860 , but the section thickens again in the structural low behind the shelf-edge reefal bank. This unit is the first that can be traced with some confidence across the top of the reefal bank. The crossing reflectors are discontinuous, have variable amplitudes, and appear to pinch out or to be truncated near s.p. 4100 . Hauterivian rocks are inferred to reappear near s.p. 4140 on the seaward flank of the shelf-edge reefal bank.

\section{BARREMIAN ROCKS}

At $\mathrm{G}-1$ the Barremian rocks are $825 \mathrm{ft}(251 \mathrm{~m})$ of unconsolidated, coarse- to verr coarse-grained partly calcareous sandstones with interbeds of red and gray sticky shale, lignits, and pyrite (fig. 17). The microfauna are sparse and are probably cavings from overlying fossiliferous beds. However, a sidewall core from 3,274 ft $(998 \mathrm{~m})$ contained Trochammina sp. and Lenticulina spp., and $a$ few of the lenticulinids and epistominids in the cuttings may be indigenous. On lines 77-1 and 19 the Barremian interval contains parallel, discontinuous, variable-amplitude reflectors at the $\mathrm{G}-1$ location and its project in (figs. 20, 21). These characteristics suggest deposition in nonmarine fluvial and shallow-marine environments with variable energy regimes (fig. 16).

On seismic line 19 , the Barremian reflectors maintain constant characteristics downdip to the 
G-2 projection, although the unit thickens. At $\mathrm{G}-2$, the top one-quarter of the $1,100-\mathrm{ft}(335-\mathrm{m})$ section is very coarse, rounded sand and mediumto fine-grained, subangular, calcareous sandstone with interbeds of gray silty mudstone and some coal and glauconite (fig. 22). The lower threequarters are gray, silty, glauconitic, partly calcareous mudstone with interbeds of mediumto fine-grained sandstone.

Microfossils at G-2 are not abundant in the Barremian interval. The fauna consists of the foraminifers Epistomina spp., Lenticulina spp., Gavelinopsis sp., Trochammina sp., and highspired microgastropods and ostracods. These characteristics indicate greater marine influence than at G-1, but nearshore marine environments may have been replaced occasionally at G-2 by nonmarine fluvial environments (fig. 19).

On line 1 downdip from the G-2 projection, the seismic characteristics of the Barremian section hange very little (figs. 23, 24). Between s.p. 3620 and 3940 , a series of low- to high-angle, sigmoid linoform reflectors indicate progradation of finerrained hemipelagic deposits as low-energy turbidites. This unit thins in front of and across the "uried shelf-edge reefal bank and pinches out or is runcated near s.p. 4080. A slope-front fill facies of Barremian Age appears to lie above the infer-od Hauterivian and Valanginian units seaward of the shelf-edge reefal bank.

\section{APTIAN ROCKS}

In the G-1 well the Aptian rocks are $400 \mathrm{ft}$ $(122 \mathrm{~m})$ thick and are similar in lithology to the underlying Barremian sandstones and mudstones (fig. 18). Fossils are rare or absent except in the upper samples where there are abundant Epistomina chapmani. Lenticulina nodosa and Vaginulina aptiensis are also probably indigenous. There are also abundant specimens from cavings of the overlying, richly fossiliferous Cenomanian and Turonian strata.

On seismic lines 77-1 and 19, the G-1 location and its projection are characterized by intermittent, parallel to subparallel, variable-amplitude reflectors indicative of nonmarine fluvial to shallow marine deposits (figs. 16, 20, 21). The fauna at the top of the section indicates a shallow narine origin. The subparallel reflectors may indicate somewhat higher energy regimes during the Aptian than during deposition of older rocks at this site.

Near s.p. 2380 (line 19) the reflectors are more continuous and parallel, suggesting lower erorgy regimes and more uniform environmental conditions; these persist to the G-2 projectior. At G-2, the upper part of the 475-ft (145-m) Aptian sequence comprises coarse, shelly limestones interbedded with fine- to medium-grained, ca'citecemented quartz sandstones. Sandstone is more abundant in the lower part of the section.

Microfossils are rare in the sandy lower pert of the Aptian sequence, but in the calcareous upper part, abundant Epistomina chapmani and Lenticulina nodosa, plus a few Lenticulina sp., Vaginulina procera, Gavelinella sp. and ostrocods appear to be indigenous.

All these characteristics suggest that the lower part of the Aptian section at G-2 is of nonmarine fluvial origin, but the upper part accumulated in shallow marine shelf environments (fig. 19).

Downdip from the G-2 projection, intermittent, parallel, variable-amplitude reflectors extend to near s.p. 3700 . The distal portion of the Aptian section is completely truncated by an erosional unconformity and can be traced no farther than s.p. 3850. Aptian rocks appear to be part of a slightly chaotic, slope-front fill sequence that onlaps the seaward side of the shelf-edge roefal bank.

\section{CENOMANIAN ROCKS}

Erosion during the mid-Cenomanian low sealevel stand has eliminated most or all of the Albian rocks from both $\mathrm{G}$ wells, and the seismic interpretations of lines 19 and 209 suggest that Albian rocks are missing over most of the Georges Bank basin (figs. 20, 21). At G-1, Artian rocks are overlain by a thin, glauconitic, gray shale and claystone unit of Cenomanian Age (fig. 19). The microfauna at G-1 is moderately rich and diverse and contains an abundance of planktic foraminifers. The predominant benthic genera are Lingulogavelinella, Vaginulina, Bolivinita, Lenticulina, Gavelinopsis, and Epistomina. The Cenomanian interval is so thin $(75 \mathrm{ft} ; 23 \mathrm{~m})$ that it cannot be distinguished on seismic line 77-1, but on line 19, it appears as a narrow reflectorfree zone at the G-1 projection. Downdip the Cenomanian interval thins and thickens over the eroded Aptian surface (fig. 24). All these seismic, 
lithologic and faunal characteristics suggest that deposition took place in a moderately deep middle to outer shelf marine environment under a lowenergy regime (fig. 16).

At the G-2 projection on line 19, the Cenomanian interval is still thin (60 ft; $18 \mathrm{~m}$ ) and reflector-free. The claystones here contain a very rich and diverse microfauna, including abundant planktic foraminifers. The predominant benthic genera are Epistomina, Gavelinopsis, Lingulogavelinella, Lenticulina, Vaginulina, Bolivinita, Praebulimina, and Frondicularia. Pyritized microgastropods are also common. The faunal, lithologic, and seismic characteristics suggest that deposition took place in an outer shelf marine environment under a low-energy regime (fig. 19). The seismic character and thickness change little downdip from the G-2 projection. The Cenomanian section may be entirely truncated by erosion near s.p. 3800 , or it may be too thin to identify on line 19. A prominent slope-front fill sequence, which onlaps the seaward edge of the shelf-edge reefal bank, appears to include Cenomanian rocks.

\section{LOWER TURONIAN ROCKS}

At $\mathrm{G}-1$, the lower Turonian rocks are $350 \mathrm{ft}$ $(107 \mathrm{~m})$ of gray, sticky, glauconitic shales bounded by coarse-grained sand and gravel with lignite at the top and base (fig. 17). Pyrite is common throughout the section. On seismic line 77-1, the entire interval contains parallel, intermittent, variable-amplitude reflectors. The lower Turonian interval is very thin on line 19 and shows up as a reflectorless zone bounded by strong unconformable reflectors (figs. 20, 21). The microfauna at the COST No. G-1 well is abundant and diverse and includes abundant planktic foraminifers in most samples. The predominant benthic genera are Epistomina, Lingulogavelinella, Gavelinella, Lenticulina, and Marssonella. High-spired microgastropods are common.

These faunal, lithologic, and seismic characteristics suggest that most lower Turonian deposition occurred in low energy middle shelf marine environments (fig. 16). Shallower marine conditions and perhaps nonmarine fluvial conditions prevailed during the two sandy intervals.

Seismic characteristics on line 19 do not change downdip to the G-2 projection (figs. 20, 21). At G-2 the lower Turonian rocks are $150 \mathrm{ft}(46 \mathrm{~m})$ of calcareous, glauconitic claystone (fig. 22). The abundant, diverse microfauna contains abundant planktic foraminifers. Predominant benthic genera include Epistomina, Gavslinella, Lingulogavelinella, Lenticulina, Neofirbellina, Gaudryina, Bolivinita, and Praebulimina. These characteristics suggest that depositior took place in a low-energy regime on an open marine outer shelf (fig. 19). On line 19 the lower Turmian rocks are uniform in thickness and seismic character from the G-2 projection downdip to an apparent pinchout or erosional truncation near s.p. 3740. Turonian rocks may be included in a sequence of horizontal basin-fill reflectors that onlap the inferred early Cenomanian to Aptian sequence on the seaward side of the shelf-edge reefal bank.

\section{CONIACIAN ROCKS}

At the COST G-1 well the lower part of the $550-\mathrm{ft}(168-\mathrm{m})$ section of Coniacian rocks consists of unconsolidated coarse-grained sandstone and gravel overlain by a thin shale unit (fig. 17). On seismic line 77-1, the Coniacian roflectors at G-1 are intermittent, subparallel, and of variable amplitude. At the G-1 projection on line 19, the reflectors are discontinuous, of low amplitude, and parallel (figs. 20, 21). A single, more continuous, higher amplitude reflector can be seen near the top of the interval. The microfauna in the sandy lower part of the Coniacian interval is sparse. Benthic forms include a f $? w$ Epistomina, Ceratobulimina, and Neobulimina. A slightly richer fauna occurs in the shale $a^{+}$the top of the section, including a moderate assemblage of planktic foraminifera. Predominant benthic forms are Epistomina, Vaginulina, and Gavelinella.

These faunal, lithologic, and seismic characteristics suggest that deposition at G-1 during the early part of the Coniacian occurrnd in nonmarine fluvial to shallow marine coastal environments in a relatively high-energy regime (fig. 16). Water depth increased and the energy level dropped during deposition of the shale layer.

Downdip from the G-1 projection on line 19 high-amplitude reflectors several miles long appear (fig. 20, 21). At the G-2 projection a single high-amplitude reflector occupies the middle of the Coniacian interval. In the G-2 well the Coniacian rocks are $425 \mathrm{ft}(130 \mathrm{~m})$ of ch iefly light-gray calcareous claystones and siltstones with one 
thin argillaceous limestone in the middle of the interval (fig. 22).

The microfauna in the G-2 well is abundant and includes a varied planktic foraminiferal assemblage. Benthic forms include Gavelinella spp., Stensioina, Allomorphina, Valvulineria, Nodosaria, Lingulina, Eouvigerina, Epistomina, and Neoflabellina. These faunal characteristics suggest that deposition took place in a lowenergy, open marine, outer shelf environment (fig. 19).

Downdip from the G-2 projection the central high-amplitude reflector disappears near s.p. 3460 (fig. 23, 24). The Coniacian interval may be truncated near s.p. 3900, beyond which it cannot be indentified. Coniacian rocks may be included in the sequence of horizontal basin-fill reflectors that onlap the early Cenomanian(?)-Aptian(?) sequence seaward of the shelf-edge reefal bank.

\section{SANTONIAN ROCKS}

At the COST No. G-1 site Santonian rocks consist of $380 \mathrm{ft}(116 \mathrm{~m})$ of unconsolidated coarsegrained sandstone and gravel containing some glauconite and lignite (fig. 17). The microfaunas are moderately rich and planktic foraminifers are common. The predominant benthic forms are Epistomina, Gavelinella, Lenticulina, Frondicularia, and Vaginulinopsis. On seismic line 77-1 the Santonian interval at the $\mathrm{G}-1$ projection is reflector-free, but at the $\mathrm{G}-1$ projection on seismic line 19 , a very high amplitude, continuous reflector occurs in the middle of the Santonian interval; this appears to be a "follow" cycle beneath the principal unconformable reflector that separates the Santonian rocks from overlying Tertiary strata (figs. 23, 24). These lithologic, faunal, and seismic characteristics indicate that Santonian rocks accumulated under uniform highenergy conditions in near-shore, inner to middle shelf marine environments (fig. 16).

The seismic character of the Santonian interval does not change appreciably on line 19 between the G-1 and G-2 projections. At G-2 the rocks are $420 \mathrm{ft}(128 \mathrm{~m})$ of unconsolidated, coarsegrained sand and gray, soft, clayey siltstone (fig. 22). The Santonian microfossil assemblage in the G-2 well is diverse and contains an abundance of planktic foraminifers. The predominant benthic forms are Eouvigerina, Epistomina, Planulina, Gavelinella, Nodosaria, Marginulina, Stensioina, and Gaudryina. Caved Eocene specimens are abundant in these samples. These faunal, lithologic, and seismic characteristics suggest that Santonian deposits at G-2 accumulated in open marine, middle to outer shelf depths in a moderate- to low-energy regime (fig. 19).

The high-amplitude central reflector in the Santonian interval continues downdip from the G-2 projection, and as the section thickens, the reflector moves closer to the top of the section (figs. 20, 21). Occasional downlapping high-amp'itude reflectors appear at the base of the otherwise reflector-free Santonian sequence. The section becomes thicker near s.p. 3640, and prograding, chaotic reflectors are present from s.p. 3740 to 3960 , where the sequence is nearly four timos as thick as it was at the G-2 well. This thicken ad sequence may also include Campanian and Maestrichtian rocks. Maestrichtian rocks have been collected from Veatch, Oceanographer, and Heezen Canyons, which border Georges Bank (fig. 15); Campanian rocks have been cor?d in Veatch Canyon (Ryan and others, 1979; Valentine and others, 1980). Santonian rocks crop c'it in Veatch and Oceanographer Canyons and have been cored at Atlantic Slope Project (ASP) s te 18 in Veatch Canyon (figs. 15, 26). At these locetions the rocks are chiefly indurated mudstones and siltstones at least $400 \mathrm{ft}(128 \mathrm{~m})$ thick. Moderately well developed planktic and benthic fc-aminiferal assemblages include Bolivinoides, Epistomina, Stensionina, Lenticulina, Gavelinella, Globorotalites, Gaudryina, Brizalina, Nodcsaria, Gyroidina, and miliolids. All these faunal, lithologic, and seismic characteristics suggest that deposition took place in outer shelf to upper slope environments.

Santonian rocks may be part of a sequerce of horizontal basin-fill reflectors that onlap the early Cenomanian to Aptian sequences seaward of the shelf-edge reefal bank.

\section{CAMPANIAN ROCKS}

Though Campanian rocks have not been identified in either of the COST G wells, ther are known from one corehole drilled for the At antic Slope Project (ASP 18) in the lower part of Veatch Canyon (figs. 15, 26). Dark-olive-gray to brownish-gray laminated and massive siltstone with minor amounts of dark-olive-gray sand and medium-gray clay was penetrated between 
$3,975 \mathrm{ft}$ and $4,095 \mathrm{ft}(1,212$ to $1,248 \mathrm{~m})$ below sea level. The abundance of Bolivinoides, Gavelinella, Lenticulina, Gaudryina, Marssonella, Praebulimina, and Arenobulimina and the presence of fewer Nodosaria, Pleurostomella, and Valvulineria suggest outer shelf to upper slope deposition.

Campanian rocks also may be part of the basinfill sequence indicated by horizontal, variableamplitude, intermittent reflectors that onlap the inferred early Cenomanian to Aptian reflectors seaward of the shelf-edge reefal bank.

\section{MAESTRICHTIAN ROCKS}

Maestrichtian rocks have also not been identified in the two $G$ wells, but they have been sampled in ASP corehole 18 (figs. 15, 26). There, $190 \mathrm{ft}(58 \mathrm{~m})$ of early Maestrichtian, dark-olivegray to brownish-gray, laminated and massive siltstone with minor amounts of dark-olive-gray sand and medium-gray clay are present between 3,785 and $3,975 \mathrm{ft}(1,154$ to $1,212 \mathrm{~m})$ below sea level. The abundance of Osangularia, Eouvigerina, Bolivinoides, Brizalina, Nodosaria, Praebulimina, Gyroidina, Robertina, and Pseudouvigerina suggests an upper slope paleoenvironment. In addition, lower Maestrichtian hemipelagic deposits have been collected from outcrops at depths of 4,659 to $5,134 \mathrm{ft}(1,452$ to $1,565 \mathrm{~m}$ ) in Oceanographer and Corsair Canyons (fig. 15; Ryan and others, 1978; Gibson and others, 1968; Valentine and others, 1980).

Maestrichtian rocks may be included in the basin-fill facies represented by the horizontal, variable-amplitude, intermittent reflectors that onlap the inferred early Cenomanian to Aptian reflectors seaward of the shelf-edge reefal bank.

\section{PALEOCENE ROCKS}

A few specimens of Paleocene planktic foraminifers were found in the uppermost samples of both the G-1 and G-2 wells, indicating the presence of some Paleocene strata above the Santonian section. Steinkraus (1980) also reported Paleocene dinoflagellates in the G-1 well. These samples, along with planktic Paleocene assemblages recovered from silty claystones in Oceanographer Canyon and Veatch Canyon (fig. 15, ASP 17; Poag, 1978) indicate open marine conditions as far updip as G-1 during the Paleocene and bathyal conditions at the canyon localities. The Paleocene interval is either missing or too thin to be observed on mos $^{\dagger}$ of the seismic profiles over the shelf. However, a thickened wedge of inferred Paleogene ag? between s.p. 3860 and 4020 on line 19 may include Paleocene strata (figs. 20, 21). Paleocene strata also may be present in a thin zone of very high-amplitude, nearly continuous reflectors that form a basin-fill facies overlying the inferred Maestrichtian to late Cenomanian basin fill between S.F. 4200 and the seaward end of line 19 . The high-amplitude reflectors and lithologic extrapolation from DSDP coreholes (such as site 108) suggisst these rocks may be cherty carbonates.

\section{EOCENE ROCKS}

The bulk of Paleogene strata in both the G-1 and G-2 wells appears to be of middle Eocene age. Even so, the middle Eocene interval is thin and cannot be recognized with cor fidence on seismic line 19 between the $G-1$ and $G-2$ well projections (figs. 23, 24). At $\mathrm{G}-1$ the few planktic specimens of middle Eocene age indicate open marine conditions (fig. 16). Farther updip, at AMCOR $6019,49 \mathrm{ft}(15 \mathrm{~m})$ of light- to dark-green, glauconitic clay and hard, gray to white bioclastic limestone contains outer shelf to upper slope middle Eocene foraminiferal faunas (fig. 15; Poag, 1978; Hathaway and others, 1979). Chunks of this white bioclastic limestone are present in the upper cutting samples at G-1.

At G-2, where a strong reflector is inferred to mark the top of the middle Eocene (figs. 20, 21), the dominant benthic forms are Gyroidina, Nodosaria, Dentalina, Bulimina. Cibicidoides, Globocassidulina, Anomalinoides, Brizalina, Turrilina, Uvigerina, and Siphonina. Large fragments of cheilostome bryozoans and echinoid spines are common. The lithology is dark-green, coarse-grained, glauconitic sand and leached, white, glauconitic, quartzose, linclastic limestone. These fauna and lithologies indicate outer shelf to upper slope environments in a low-energy regime. On the shelf, downdip frcm s.p. 3000 on line 19, the Eocene is very thin and may be missing in places. Eocene strata frcm outcrops in Oceanographer and Corsair Canyons (fig. 15; Gibson and others, 1968; Ryan and $0^{+}$hers, 1978) are brown, silty mudstones, glauconitic calcarenites, 


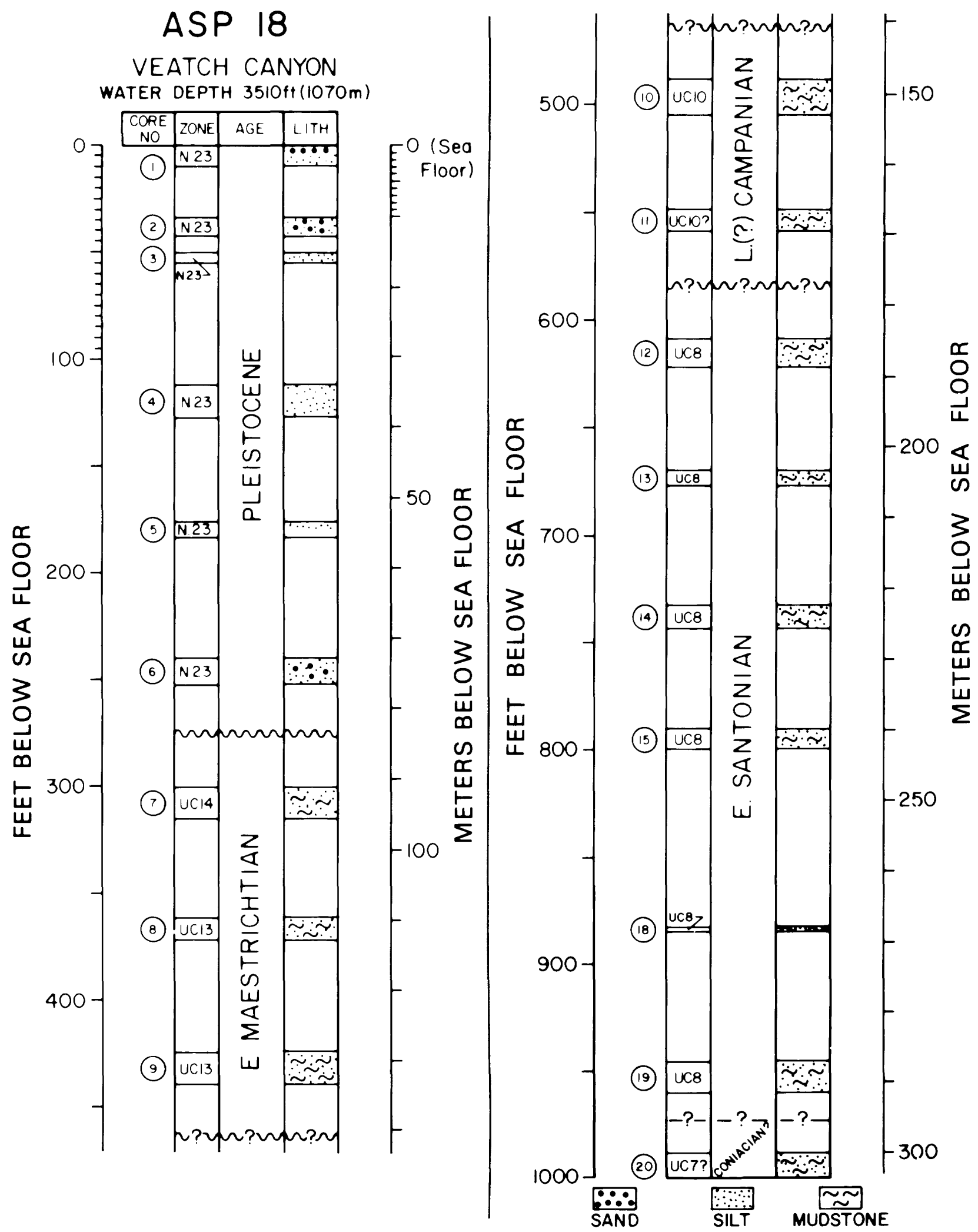

FIGURE 26.-Geologic column of Atlantic Slope Project (ASP) core 18 (taken in 1967 by Exxon, Chevron, Gulf, and Mobil oil companies as part of their Atlantic Slope Project), near the mouth of Veatch Canyon. See figure 15 for location. 
and white pelagic chalks, representing hemipelagic channel deposition to pelagic basin deposition. A few early Eocene planktic specimens are also present in ASP 17 in Veatch Canyon (Poag, 1978).

Similar Eocene strata may be present beneath the upper slope as seen on line 19 (figs. 20, 21). A discrete wedge of high-amplitude, nearly continuous reflectors between s.p. 3860 and 4020 is interpreted to be chiefly Eocene limestones and mudstones of presumably bathyal origin. Between s.p. 4200 and the seaward end of line 19, a series of high-amplitude, intermittent, basin-fill reflectors is interpreted to include calcareous, cherty strata of Eocene age.

\section{OLIGOCENE ROCKS}

Oligocene strata have not been identified in the $G$ wells, but a few Oligocene planktic specimens in G-2 suggest that a thin Oligocene unit may lie above the highest sampled interval. The only other Oligocene strata known from the Georges Bank basin were dredged from Oceanographer Canyon (Gibson and others, 1968). The rocks are buff, calcareous clay and brown, glauconitic, sandy clay, both containing abundant planktic foraminifers indicating open marine depositional environments in low-energy regimes. The wedge of high-amplitude reflectors between s.p. 3860 and 4020 on line 19 may also include bathyal Oligocene strata (figs. 20, 21).

Beneath the lower continental slope and rise, between s.p. 4100 and the seaward end of line 19, is a thick sequence of chaotic, steeply dipping to subhorizontal, discontinuous reflectors of variable amplitude representing slope-front and basin-fill facies presumably deposited by highenergy debris flows and turbidity currents (Vail and others, 1977). Oligocene strata may be included in this sequence.

\section{PLIOCENE-MIOCENE ROCKS}

The only Neogene strata recovered on Georges Bank occur at the G-2 well site. Here, $\tan$ to yellow-brown, micaceous, clayey siltstone contains a sparse Miocene to Pliocene benthic fauna. The dominant benthic forms are Bulimina elongata, Lenticulina spinosa, Florilus pizzarensis, and Cassidulina sp. A series of continuous, parallel, variable-amplitude reflectors are present at the G-2 projection on seismic lin? 77-2. On line 19 the reflectors are less continuous across the G-2 projection, but become more continuous downdip. The thick sequence of ch aotic reflectors overlying presumed Paleocene and Eocene strata between s.p. 4140 and the seaward end of line 19 probably contains Pliocene and Miocene sediments.

Updip from the B-2 projection the parallel reflectors can be traced to about s.p. 2480 , but most of them are faint between there and the G-1 projection. Discontinuous, parallel reflectors with highly variable amplitudes develc? in the upper part of the Pliocene-Miocene section at the G-1 projection and extend updip from it to the end of line 19.

These characteristics suggest tl at at G-2 and downdip from the site, shallow inner to middle shelf marine environments were present during the Pliocene-Miocene deposition (fig. 19). Updip, shallow marine to nonmarine f ivial environments prevailed (fig. 16).

\section{PLIESTOCENE ROCKS}

Pleistocene strata were sampled at the $\mathrm{G}-1$ well site by AMCOR corehole 6018. A 161-ft (49-m) section of coarse, shelly sand that was recovered contained a few organic-rich layer and scattered specimens of benthic foraminifers, such as $E l$ phidium spp. and Buccella sp. (Pong, 1978; Hathaway and others, 1979). At least one interval contains Epistominella and Buliminella with pyritized diatoms and radiolarians. These characteristics indicate that shallow-water, inner shelf to coastal lagoon and perhaps nonmarine fluvial environments prevailed during the Pleistocene at this site when it was not covered with ice (fig. 16).

The Pleistocene unit can be tra?ed downdip as it thickens to $200 \mathrm{ft}(61 \mathrm{~m})$ at the $\mathrm{G}-2$ projection (figs. 20, 21). The unit is nearly reflector-free between the two G-well projectior a except for a strong "follow cycle" beneath the sediment-water interface. Downdip from the G-2 projection, the Pleistocene unit becomes thicker, until it is approximately 0.27 seconds (two-vray traveltime) thick at s.p. 3760 , where it develops into two separate prograding wedges and continues to thicken downdip. An erosional channel cuts 
through the Pleistocene strata into presumed Paleocene to Oligocene strata between s.p. 3940 and 3965, but from s.p. 3965 to 4015 the Pleistocene cover forms a topographic mound. On the middle and lower continental slope, a thick unit of divergent, discontinuous, variable-amplitude reflectors make up a slope-front fill deposit that is probably a Pleistocene submarine fan. This unit also undoubtedly includes talus from eroded Tertiary and Cretaceous strata that crop out along the bank margin and in submarine canyons. (See Ryan and others, 1978.) On the continental rise (s.p. 4200 to the end of line 19), the Pleistocene sequence contains a few scattered high-amplitude reflectors. This sequence presumably represents homogeneous, silty, hemipelagic, distal turbidite deposits.

\section{COMPARATIVE GEOLOGIC HISTORY OF THE GEORGES BANK AND SCOTIAN BASINS}

During the block faulting phase of early rifting, coarse continental and evaporitic rocks accumulated in the Scotian shelf area in narrow basement grabens under arid climatic conditions (McIver, 1972; Given, 1977). After these rift valleys were filled by the terrigenous and evaporitic Eurydice, Argo, Iroquois, and Mohican Formations, the resulting broad basin floor became the site of restricted marine deposition during late Iroquois time. A similar history has been inferred for the Georges Bank basin (Schlee and others, 1976) and is confirmed by the record in the COST Nos. G-1 and G-2 wells, although the Eurydice Formation equivalent was not recovered. There are differences in detail between the two regions, however. The Georges Bank basin grabens in the area of the COST Nos. G-1 and G-2 wells seem to have been filled by the end of Hettangian(?)-Rhaetian(?) time (figs. 20, 21), and the presence of Triassic dinoflagellates at G-1 and G-2 is a sign of occasional marine incursions. These characteristics, the persistent influx of micritic and oolitic normal marine limestones throughout the 8,200-ft $(2,499-\mathrm{m})$ Iroquois sequence at G-2 (fig. 22), and the widespread development of carbonate mounds (figs. 20, 21), are evidence of more frequent and earlier connection to open marine Tethyan waters at Georges Bank than on the Scotian shelf.

Given (1977) has postulated that continental drift began near the end of Iroquois depc sition (end of Aalenian Stage) and that the upper Mohican (Bajocian) detrital rocks represert the first deposits above a breakup unconformity. On the Scotian shelf, widespread marine depc sition began with the Scatarie Limestone Member of the Abenaki Formation, and the maximum Jurassic marine transgression took place curing depositon of the Misaine Shale Member (Callovian; Given, 1977). But in the part of the Grorges Bank basin considered here, the Misaine equivalent is not traceable seismically very far up lip or downdip from the G-2 well (figs. 20, 21). Major Late Jurassic transgressions may have occurred here during deposition of the lower and upper parts of the Baccaro Limestone Member (Callovian(?) to Bathonian(?) and Tithonian to Kimmeridgian, respectively), but marine cond tions were even more widespread earlier (Aalenian(?) to Sinemurian(?)), during deposition of the Irc ruois Formation.

During the Late Jurassic on the Scotian shelf, carbonate deposition was concentrated alor $r$ the stable shelf edge in a discontinuous series of banks of the Baccaro Limestone Member. The shelf-edge facies is a skeletal-reef association, while the bank interior is a nonskeletal, righly terrigenous, oolitic, muddy limestone assoc'ation (Eliuk, 1978). A broad "moat" of calcsreous shales developed in a depression behind the shelfedge banks, and farther updip the siliciclastic Mohawk sands and Mic Mac shales were deposited as fluvial and nearshore facies (Pliuk, 1978). Periodic subaerial exposure and de-velopment of a freshwater lens on the emergent $T$-anks altered much of the Baccaro from limestone to dolomite.

The same general facies patterns develorid in the Georges Bank basin. The equivalent of the Baccaro Limestone Member accumulated in shelf-edge banks (presumably including reef facies), and a broad back-bank platform of onlitic, pelletal, and micritic limestones extended to the G-2 well site (figs. 20, 21). From there, the Baccaro was split into two parts by a thick siliciclastic tongue of Mohawk-Mic Mac facies. The lower Baccaro unit extended only a few tens of kilometers updip from G-2, but the upper Baccaro unit extended shoreward of the strike position of the G-1.

On the Scotian shelf, the widespread Late Jurassic carbonate deposition ended abruptly 
during the Hauterivian, and the sediments were buried under the siliciclastic deltaic deposits of the Missisauga Formation near the Sable Island delta. A rapid sea-level rise influenced deposition of the marine shales of the Verrill Canyon Formation in locations away from the Sable Island delta, such as at the Mohican I-100 site (Eliuk, 1978).

Slightly earlier in the Georges Bank basin, during the Berriasian, the coarse siliciclastics of the Missisauga Formation began to cover the Baccaro shelf carbonates at G-2 (figs. 20, 21). During the early Valanginian to early Hauterivian, siliciclastic deposition progressed seaward to the shelf-edge reefs and began to spill onto the ancient slope.

The Missisauga siliciclastic deposition was interrupted briefly in both regions by carbonate deposition of the " 0 " limestone marker. The interruption occurred in the early Barremian on the Scotian shelf, and in the late Hauterivian to early Barremian in the Georges Bank basin; however, the resolution of faunal zones and stage boundaries in this time interval is not precise, and deposition of the " 0 " marker may have been essentially isochronous over the entire region.

Progressively deeper marine paleoenvironments encroached upon both the Nova Scotian and New England shelves during the Late Cretaceous, depositing sandstones, shales, and mudstones (figs. 20, 21). On the Scotian shelf, the Upper Cretaceous deep-water deposits culminated in the chalks of the Wyandot Formation, but contemporaneous deposits appear to have been eroded from the old shelf of the Georges Bank basin. However, a thick, slope-fill unit of Wyandot age (Campanian-Maestrichtian) appears to be present on the continental slope.

Deep-water carbonate deposition continued into the Paleogene in both regions as bioclastic, middle Eocene chalky limestones accumulated in the Georges Bank basin. The Neogene sedimentation returned to a shallower water siliciclastic depositional mode, which continued into and through the Pleistocene.

\section{SEA-LEVEL FLUCTUATIONS AND DEPOSITIONAL CYCLES}

Relative changes in sea level have a direct effect on the lithology and fauna and flora of rock sequences and on their vertical and lateral facies relationships. Conversely, the interpretations of microfaunas and seismic facies leads to the recognition of ancient sea-level fluctuations.

A curve illustrating changing paleobathymetry in the G-1 and G-2 wells is shown in figure 27 . In both wells the Lower to Middle Jurassic carbonate rocks are highly indurated, and microfossils were rare or absent in the cuttings. Several shale samples from conventional cores were also processed, but they yielded no calcareo's microfossils or palynomorphs. Only broad depositional cycles could be inferred from lithologic an 1 seismic data. These suggest nonmarine fluvial to shallow, nearshore marine conditions in the Early to Middle Jurassic.

Inner shelf marine foraminiferal faunas begin to appear in the upper Callovian-lcwer Oxfordian rocks. The first sustained Jurassic middle shelf faunas occur in the Tithonian.

The early parts of supercycle Ka (Valanginian through Albian) are represented by inner shelf to nonmarine paleoenvironments, but the Albian is poorly represented in the two $G$ wells. The earliest part of cycle $\mathrm{Kb}$ is not represented, but deep waters (outer shelf conditions) were present throughout the late Cenomanian to Santonian interval at G-2. G-1 shows a peak transgression during the late Cenomanian, a regression during the Coniacian, and a minor transgression during the Santonian. The peak of cycle $\mathrm{Y}^{\prime} \mathrm{b}$ (Campanian and Maestrichtian) is not represented in either well.

Tertiary supercycles are poorly represented. However, the outer shelf and slope environments of the late middle Eocene reflect tr 9 major transgression postulated by Vail and otl ors (1977) and shown in the other Atlantic COST wells (GE-1, Poag and Hall, 1979; B-2 and B-3. Poag, 1980b). Miocene, Pliocene, and Pleistocene intervals contain outer, middle, and inner shelf deposits.

In general, the pattern of transgression and regression coincides with the patter's seen in the other Atlantic COST wells and tr ose published by Vail and others (1977; fig. 27).

\section{COMPARISON WITH DEET.SEA SEDIMENTARY SEQUEN TES}

The western part of the North American Basin, which borders the Georges Bank basin to the 
south and east, has now been penetrated by 25 Deep Sea Drilling Project (DSDP) coreholes from Legs $1,2,11,43$, and 44 and has been crisscrossed with thousands of kilometers of seismic reflection profiles. Tucholke (1979), Tucholke and Vogt (1979), Tucholke and Mountain (1979) and Jansa and others (1979) have summarized the sedimentary evolution and stratigraphy of this vast deep-sea region. Six widespread formations of Mesozoic and Cenozoic age have been formally recognized at the core sites, and a series of eight major seismic reflectors have made possible extrapolation of the core data across the abyssal plain and under the lower continental rise of North America (fig. 28). Some of these reflectors have been traced beneath the continental rise adjoining Georges Bank (see Schlee and others, 1979; Klitgord and Grow, 1980) and provide a few tie points through which slope and upper rise sequences can be correlated with those of the deep sea.

The seismic sequences and inferred lithologic facies are more complex beneath the slope and upper rise than at those deep-sea basin localities that serve as stratotypes for the oceanic formations. For this reason, and because we have very little direct evidence of their composition, the slope and rise strata are referred to as "updip equivalents" of the oceanic formations.

Line 19 provides a typical example of the seismic sequences beneath the slope and upper rise off Georges Bank. Six high-amplitude, unconformable reflectors or series of reflectors and several of lesser amplitude permit tentative subdivision of the slope-rise wedge into the chronostratigraphic section shown in figure 21 . The oldest seismic sequence overlying the oceanic basement comprises a series of steeply dipping, nonparallel, discontinuous, variable-amplitude reflectors that form a slope-front fill facies and onlap the seaward base of the shelf-edge reefal bank between s.p. 4140 and 4280 . At s.p. 4280 , the reflectors become flatter, parallel, and continuous and remain so to the end of line 19. The very high amplitudes of these reflections suggest that they represent carbonate strata. The slopefront fill facies can probably be classified as an olistostrome, formed by debris flows that incorporated eroded fragments of the shelf-edge reefal bank, whereas the more flat-lying, basin-fill facies probably contains finer-grained strata deposited by turbidity currents. Some terrigenous detritus may have reached the reef front as well, through breaks in the barrier (indicated by the lack of a reefal bank on some dip lines). These strata constitute the second major seismic sequence below the $\beta$ horizon (fig. 28), and as such are believed to represent Middle and Upper Jurassic and lowest Cretaceous rocks. The presence of carbonate strata of this age behind the reefal bank and in the DSDP sites (site 105, for example) supports the conclusion that carbonate rocks should be abundant on the ancient slope too. Lithostratigraphically, this unit appears to inclute an equivalent of the Cat Gap Formation (fig. 28); its equivalents farther updip beneath the sholf are the Abenaki, Mohawk, and Mic Mac Formetions. The old slope sequence may, however, include older formations not yet sampled in the North Atlantic Basin, because Tucholke and Mountain (1979) have recognized a thick $(10,469-\mathrm{ft} ; 3,200-\mathrm{m})$ series of reflectors older than the $\beta$ sec"rence, which they estimated may be as old as Pliensbachian. They interpreted these strata to be coarse terrigenous and calcareous debris.

The next seismic sequence is bounded at the top by what is believed to be reflector $\beta$ (figs. 20 , 21,28 ). At least two facies (slope-front fill and basin fill) can be recognized in this unit, and they appear to be similar in origin and composition to the underlying sequence. However, the amplitudes of the reflectors are not as high as tlinse of the underlying unit suggesting, perhans, a greater proportion of siliciclastic turbidites and fewer carbonates. These strata appear to be of Valanginian to Barremian Age and are updip equivalents of the Blake-Bahama Format:ons, a pelagic limestone known from the basin. Shelf equivalents are the upper part of the Abenaki Formation, the " 0 " marker limestone, and the Missisauga Formation.

The seismic sequence immediately above $\beta$ also consists of a slope-front fill facies and a be sin-fill facies (figs. 20, 21). The slope-front fill facies has the same intermittent, variable-amplitude, divergent reflectors as the underlying slope-front fill facies, but the amplitudes are not as high, which suggests a change to predominantly siliciclastic debris flows. The basin-fill facies also ccntains lower amplitude reflectors than the underlying facies, and its reflectors are fairly continuous. These basin-fill rocks are interpreted to 1 ? siltstones and clays that are updip equivalents of the organic-rich black clays of the Hatteras Forma- 


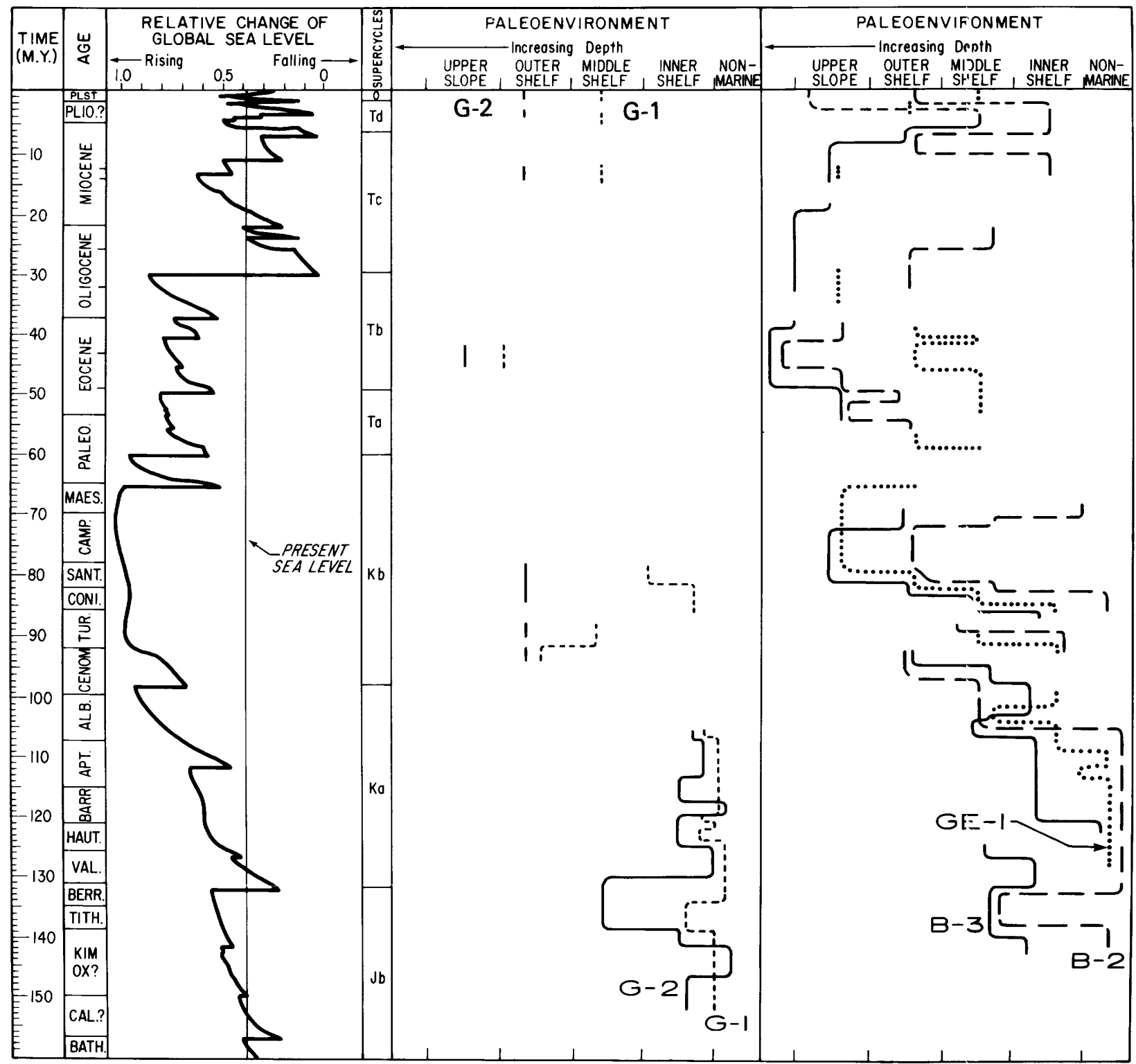

FIGURE 27.-Paleoenvironments of the COST Nos. G-1 and G-2 wells, compared with those of previou COST wells, the relative sea-level curve of Vail and others (1977), and global supercycles. Gaps in paleoenvironmental crrves are hiatuses. The age terms abbreviated in the left side column are spelled out on figures 17 and 22.

tion. The inferred coarseness of the slope-front fill facies, however, probably makes it similar to the equivalent lower siltstones of the Dawson Canyon Formation.

The next seismic sequence is a basin-fill facies bounded above by high-amplitude reflectors that are believed to represent reflector $A^{*}$ of the deep sea (approximately the Cretaceous-Tertiary contact) (figs. 20, 21, 28). The reflectors are subparallel in the upper and outer parts of the se- quence, but divergent and intermittent in the basal part beneath s.p. 4300 . This sequence is interpreted to be terrigenous turlidites of Late Cretaceous age. It is the updip ec uivalent of the Plantagenet Formation, and its sl alf equivalents are the upper parts of the Dawson Canyon and Logan Canyon Formations.

Above the Plantagenet Formation equivalent and onlapping the Dawson Canycr(?) equivalent are a series of intermittent, very high amplitude 


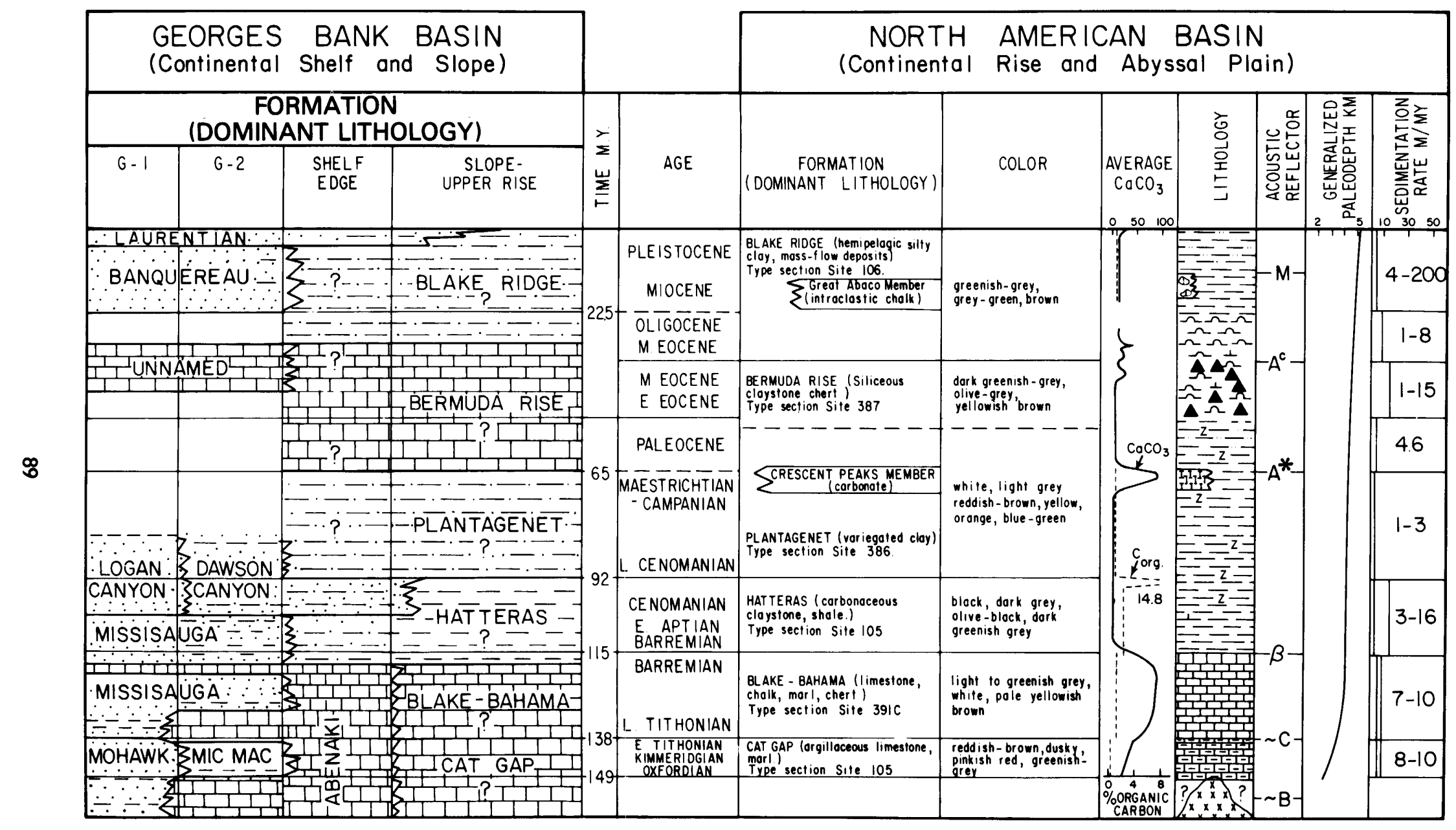

FigURE 28.-Comparison of stratigraphy of Georges Bank basin with that of the adjacent North American Basin. Data for North American Basin after Jansa and others (1979). 
reflectors thought to represent the cherty Paleocene and Eocene carbonate strata equivalent to the Bermuda Rise Formation (figs. 20, 21). The shelf equivalents are unnamed Paleocene and Eocene limestones. Some of the high amplitudes may be caused by cherty horizons known from deep-sea sites to cause the well-known reflector $A^{\text {c }}$ (fig. 28).

Above the Bermuda Rise equivalent is a thick sequence of slope-front fill and basin-fill facies. The slope-front fill extends from s.p. 4080 to 4300 and contains steeply dipping, divergent, variableamplitude, intermittent reflectors, indicative of an olistostrome. The basin-fill facies contains horizontal, chaotic reflectors with some arcuate, high-amplitude reflectors in the middle of the sequence. These probably represent siliciclastic turbidites deposited during the Miocene and Oligocene and constitute part of the updip equivalent of the Blake Ridge Formation. Under the shelf, equivalent beds belong to the Banquereau Formation.

The next younger sequence is a narrow band of faint reflectors below a moderately highamplitude, discontinuous reflector, believed to be a turbidite sequence of Pliocene age (figs. 20, 21). Above the Pliocene is another seismic facies representing slope-front fill and basin fill. The dipping, divergent, high-amplitude, slope-front facies is believed to be an olistostrome of Pleistocene age that includes older clastic fragments and blocks derived from outcropping Tertiary and Upper Cretaceous beds, such as were observed by Ryan and others (1978) in Heezen Canyon. The basin-fill facies probably is composed of finer grained Pleistocene turbidite sequences, but older (Eocene, Cretaceous) debris is also present much farther seaward (for example DSDP Site 107; Hollister, Ewing and others, 1972). The slopefront fill facies can be correlated with the Laurentian Formation of the shelf, and the basin-fill facies and the underlying Pliocene beds form the upper part of the updip equivalent of the Blake Ridge Formation (figs. 20, 21, 28).

These sequences show that depositional cycles on the shelf have been coupled with and have affected depositional cycles in the deep sea. Carbonate deposition was predominant on the shelf and in the deep sea in the Jurassic and Early Cretaceous. The shelf-edge reefal bank and the broad carbonate platform behind it served as barriers that prevented terrigenous sediments from reach- ing the deep basin in significant quantities, except in a few areas where the reefal bank system was breached or absent. Carbonate olistostromes and turbidites buried the basinward flank of the reefal bank and built the protocontinental slope and rise, while pelagic limestones accumulated on the oceanic basement.

Sometime during Hauterivian to Barremian time the terrigenous constituents of the Missisauga Formation began to cover the reefal bank, spilling down the seaward flank and extending the terrigenous depositional regime to the deep sea. At the same time the rising carbonate compensation depth (CTD) and widespread oxygen-deficient conditions over the abyssal plain allowed preservation of layers enriched in terrestrial organic matter, which became the distinctive black clicys of the Hatteras Formation (Tucholke and Mountain, 1979; Tissot and others, 1979, 1980).

Hemipelagic deposition prevailed until the Paleocene and Eocene, when crmbonates again dominated both the shelf and perts of the deep sea. Then the rapidly deposited siliciclastics of the Oligocene and Miocene began to build a thick slope-rise wedge that included eroded blocks and fragments of the Upper Cretacenus to Eocene beds that cropped out along the edge of Georges Bank.

During the Pleistocene, gleciofluvial and glaciomarine deposition took place on the bank, and during glacial intervals the Laurentian ice sheets scoured large volumes of sediment off the bank, forming a thick slope-front fill and basin fill beneath the upper continental rise. Even now, bankedge erosion continues to contribute Cretaceous and lower Tertiary debris to the slope-rise wedge.

\section{SUMMARY}

The COST Nos. G-1 and G-2 wells in the Georges Bank basin penetrated $15,257 \mathrm{ft}$ $(4,650 \mathrm{~m})$ and $21,490 \mathrm{ft}(6,550 \mathrm{~m})$, respectively, of marine and nonmarine sedimentary rocks ranging in age from Late Triassic to Pleistocene and Holocene(?). The lithologic, faunal, and floral records from these wells and from auxiliary short cores and dredgings, and the ana'yses of seismic sequences and facies show that the geologic development of the Georges Bank basin generally 
paralleled that of the neighboring Scotian basin.

The initial rifting of the Triassic was characterized by terrigenous graben-fill deposits (Eurydice(?) Formation) interspersed with occasional marine beds and followed by accumulation of thick evaporitic strata (Argo Formation). In the Late Triassic and Early Jurassic, as much as $8,200 \mathrm{ft}(2,500 \mathrm{~m})$ of shallow-marine limestones, dolomites and evaporites (Iroquois Formation) accumulated in the outer part of the basin as elongate carbonate mounds and widespread platform facies behind a bordering shelf-edge complex of reefal banks. Concurrently, the inner part of the basin was the site of coarse terrigenous deposition (Mohican Formation). The Mohican sandstones and mudstones prograded far out onto the carbonate platform during the early Middle Jurassic(?) (early Bathonian(?)), but did not reach the shelf edge.

A major marine transgression during the late Bathonian(?) reestablished a carbonate regime nearly as far updip as the G-1 well site, depositing the oolitic and pelletal strata of the Abenaki Formation. Another pulse of terrigenous deposition spread thick sandstones and shales of the Mohawk and Mic Mac Formations as far downdip as the G-2 well site during the Oxfordian(?) to late Kimmeridgian interval. Carbonates were dominant for the last time in the late Kimmeridgian to early Berriasian as Abenaki facies once more nearly reached as far updip as the G-1 well site.

During the Early Cretaceous (Berriasian and Valanginian) a sustained influx of coarse-grained, lignitic terrestrial sediments (Missisauga Formation) replaced the carbonate regime over the entire shelf, and during the early Hauterivian the terrigenous sediment spilled over the shelf edge into the North American Basin. A short-lived but widespread interruption of this influx by the thin, calcareous " 0 " marker took place in the late Hauterivian.

During the rest of the Cretaceous, sandstones, claystones, and mudstones of the Missisauge and Dawson Canyon Formations spread across the shelf and down onto the shelf and rise.

The sparsely sampled record of Tertiary deposition shows that during the Paleogene, ar unnamed, white chalk, carbonate unit, prominent as far south as the southeast Georgia embaynent, extended across the Georges Bank basin as well. Terrigenous marine deposition resumed during the Neogene (Banquereau Formation) and wes replaced by glaciofluvial and glaciomarine denosition in the Pleistocene (Laurentian Formation).

The depositional sequences, hiatuses, sediment accumulation rates, and paleoenvironmental changes at the COST Nos. G-1 and G-2 well sites suggest that the continental shelf of the Georges Bank area was created by changing sea level, changing volumes of terrigenous and carbonate sediments, and episodic subsidence of the basin.

Deposition on the adjacent slope and rise was affected by sedimentation on the shelf, and throughout the Jurassic and Early Cretaceor's by the intervening shelf-edge reefal banks. Sholf, slope, and rise deposition was significantly altered in the middle Cretaceous (HauterivianBarremian), when the carbonate platform and its bordering reefal bank were buried, allowing: terrestrial debris to reach the deep sea.

Terrestrial organic matter was preserved in the black shales of the Hatteras Formation or the oxygen-deficient, carbonate-free abyssal plain. 



\title{
Significance of the Mesozoic Carbonate Bank-Reef Sequence for the Petroleum Geology of the Georges Bank Basin
}

\author{
Robert E. Mattick
}

Analyses of rock cuttings and cores from the Jurassic section in the COST No. G-2 well indicate the following: above $10,500 \mathrm{ft}(3,200 \mathrm{~m})$ the predominantly clastic rocks have high porosities and permeabilities and are too thermally immature for the generation of liquid petroleum (Smith, 1980, p. 98). Between $10,500 \mathrm{ft}(3,200 \mathrm{~m})$ and $14,000 \mathrm{ft}(4,300 \mathrm{~m})$ there are moderately porous (10-15 percent) limestones which contain little organic material. Below 14,000 ft $(4,300 \mathrm{~m})$, the carbonate rocks show minimal to moderate amounts of organic matter, and many rock samples near the bottom of the well contain "amorphous-sapropelic" organic matter (Smith, 1980 , p. 98). These deeper rocks, however, have porosities below 10 percent and permeabilities of about 0.1 millidarcy (Malinowski, 1980, figs. 12 and 13).

These results suggest that on the North Atlantic Outer Continental Shelf potential source rocks are generally not in close contact with potential -eservoir rocks. High-porosity sandstones occur at shallow depths where the potential source ocks are immature; at greater depths where nature potential source rocks occur, porosities and permeabilities of potential reservoir beds are "ow. Without proximity of source and reservoir eds, petroleum can accumulate in significant pmounts only through long distance lateral nigration or through vertical migration along aults. There is little possibility that significant -mounts of petroleum have accumulated on the 'J.S. Atlantic shelf by long distance migration, ecause of the probable absence of laterally coninuous, porous Jurassic sandstone beds and the absence of major post-Triassic tectonic events "hat might have provided major fluid migration aths along fault and fracture systems. However, there may have been some migration at the shelf margin along faults related to mass movement of sediment rather than tectonic events (Mrttick and others, 1981).

Preliminary analyses of seismic data recorded farther seaward on the continental slope than the COST No. G-2 well suggest that potential source rocks may be in close contact with potential reservoir rocks. According to Mattick and $0^{+}$hers (1978), Jurassic forereef and reef facies could interfinger with basinal facies on the contin nntal slope. Although the seismic evidence for tr 9 interfingering of these facies is strong, neither the source-rock potential of the basinal facies no* the porosity and permeability potential of the possible reef and associated facies has been ertablished. Evidence from the COST No. G-2 wall in the Georges Bank basin indicates that the sedimentary rocks of Jurassic age at this site were deposited at or near sea level; thus, reef and associated carbonate facies deposited at the edge of the ancient shelf margin possibly were inte"mittently exposed to subaerial weathering and, as a result of leaching by freshwater and perhaps dolomitization, secondary porosity may have developed. The basinal facies of the ancient slope environment may have been deposited in a zone of low oxygen concentration (comparable to the ox:'gen minimum zone that intersects the present continental slope), enhancing the preservation of organic matter and making these sedimertary rocks a potential source for petroleum if subjected to deep burial. Under these conditions the organic content of the basinal shales is like'y to contain a higher percentage of marine-derivet organic matter than shales formed on the shelf and hence should have a greater capacity for ginerating liquid instead of gaseous hydrocarbons. 
The purpose of this paper is to analyze the development of the shelf margin during Jurassic time and to show the relationship between carbonate facies, which may or may not be significantly porous, and basinal facies, which may contain large amounts of marine-derived organic carbon. Areas in which these facies are in proximity may prove to be areas where significant amounts of petroleum have accumulated in stratigraphic traps. Although this work is based chiefly on the interpretation of seismic data and is therefore speculative, a proposed well to test these interpretations (COST No. B-4) may be drilled in about $4,300 \mathrm{ft}(1,300 \mathrm{~m})$ of water in the Baltimore Canyon trough area. It should penetrate an area where, based on the interpretation of seismic data, Jurassic forereef facies interfinger with basinal facies of the same age.

\section{SEISMIC DATA}

Figure 29 shows the U.S. Geological Survey common depth point (CDP) seismic profiles re- corded on the northern and central U.S. Atlantic margin. The parts of the record discussed in this paper are marked, and each is abnut $30 \mathrm{mi}(50 \mathrm{~km})$ long.

In order to correlate reflection events with stratigraphy and lithology, the seismic grid was tied to the COST No. G-2 well. In figure 30 the data from the well (Judkins and others, 1980) is plotted alongside a segment of saismic profile 15 that crosses over the well site. TI $?$ well bottomed in salt at 21,851 ft $(6,660 \mathrm{~m})$. Between $13,571 \mathrm{ft}$ $(4,136 \mathrm{~m})$ and the top of the $\mathrm{sa}^{1} \mathrm{t}$, the dominant lithology is dolomite, anhydrite, and limestone of Early and Middle Jurassic(?) age. Because of the similarity in age and litholog.', Judkins and others (1980) correlated this part. of the Jurassic section with the upper part of the Iroquois Formation of the Scotian shelf. If the correlation is correct, these rocks represent derosition during a rift valley stage in the development of the Atlantic Ocean basin (Given, 1977). From 13,306 ft $(4,056 \mathrm{~m})$ to the top of the Jura'sic section, the rocks are chiefly limestone and sandstone. Judkins and others (1980) correlated the thick

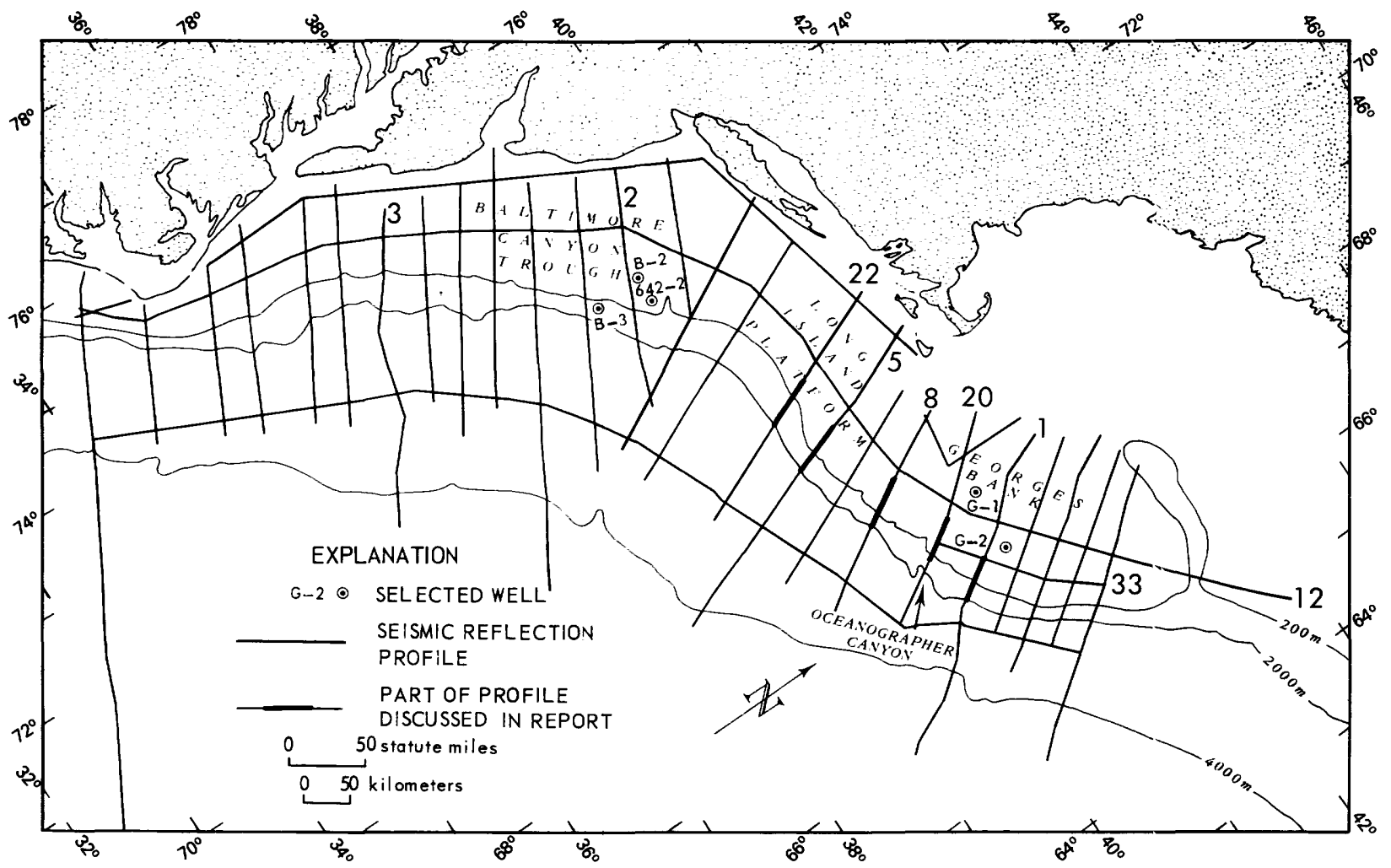

FIgURE 29.-U.S. Geological Survey common depth point (CDP) seismic reflection profiles recorded on the northern and central U.S. Atlantic margin. The parts of the profiles displayed in other figures are shown by heavy lines and those discussed in the text are numbered. 


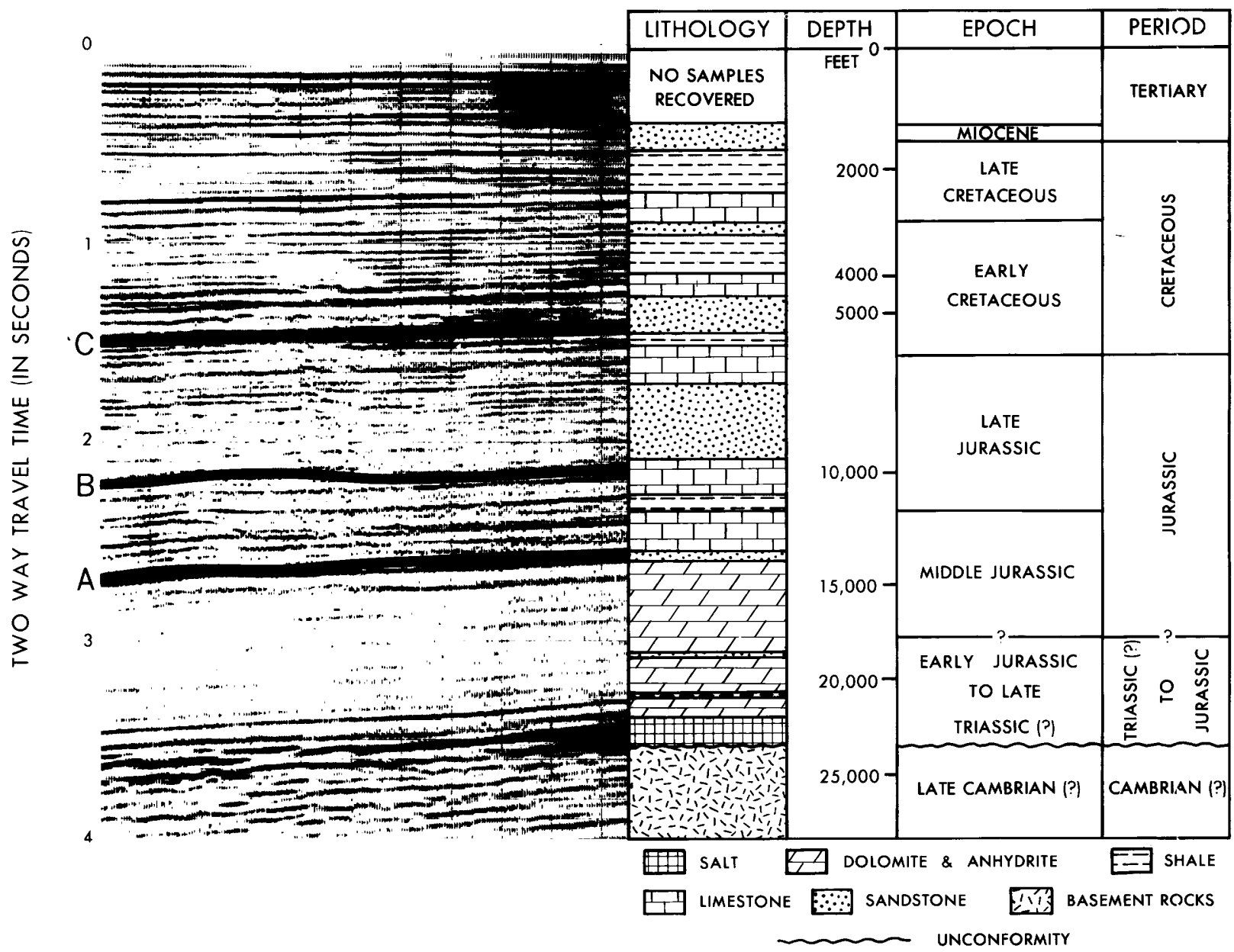

FIGURE 30.-Data from the COST No. G-2 well plotted alongside a part of seismic reflection profile 15 that crosses th? well site. The vertical scale is two-way reflection time, and depths (not to scale) are annotated on the right. Three prominent reflectors (A, B, and C) can be mapped throughout much of the Georges Bank basin. The top of basement rorks is estimated from interpretation of seismic data. Evidence from the COST No. G-1 well indicates that the basement consists of highly metamorphosed rocks of Cambrian(?) age.

limestone unit with the Abenaki Formation of the Scotian Shelf and the thick sandstone unit with a tongue of the Mohawk and Mic Mac Formations. On the Scotian shelf these formations represent deposition during the post-breakup transgression of the early Atlantic (Given, 1977).

Three prominent reflectors were noted and labeled from deep to shallow as A, B, and C. The deepest reflector (A) can be correlated with the contact between the dolomite-anhydrite unit of Early-Middle Jurassic(?) age and the overlying limestone unit, and marks the continental breakup. Reflector A can be mapped throughout the Georges Bank basin except in areas where it terminates against basement in a shoreward direction and in the vicinity of the Long Island platform. Reflector $B$ was picked at a depth of about $10,000 \mathrm{ft}(3,000 \mathrm{~m})$, near the contact between a thick Upper Jurassic sandstone unit and an underlying Upper Jurassic limestone unit. Reflector C, at a depth of about $5,300 \mathrm{ft}(1,601 \mathrm{~m})$, correlates with Lower Cretaceous strata lorated near the top of the Jurassic section. Through hout this paper, these reflectors are assumed to be time correlative rather than lithologic markers. This assumption, although probably not completely valid, results in good correlation betreen seismic events recorded on the shelf margir and slope.

Reflector A at the G-2 site is correlated with 
the "breakup unconformity," which refers to the erosional surface developed between the rift valley stage of development and the onset of seafloor spreading. According to Falvey (1974), the rift valley stage of development is a protracted event that involves hogback uplift due to extensive thermal expansion and later, as a result of block collapse, results in the accumulation of considerable volumes of clastic sediments in the rift valley. However, the process of continental breakup and the onset of seafloor spreading was not instantaneous. Following block collapse and accumulation of clastic rocks in grabens, a shallow sea apparently occupied the site of the present Atlantic Continental Shelf. This event is reflected by the salt layer and the dolomiteanhydrite sequence penetrated in the bottom of the COST No. G-2 well. Klitgord and others (this volume) seem to suggest, by their placement of the breakup unconformity between the salt interval and the dolomite-anhydrite sequence, that the onset of seafloor spreading immediately followed deposition of the salt unit. This author infers that seafloor spreading coincided with a deepening of the early Atlantic and places the breakup unconformity between the dolomite-anhydrite sequence and the overlying limestone unit. According to Falvey (1974), the onset of seafloor spreading should involve a secondary heating event that leads to a short period of emergence just prior to breakup. This short period of uplift, resulting in a regression of the sea, may be reflected by the thin sandstone interval that separates the dolomiteanhydrite sequence from the overlying limestone unit at a depth of about $13,450 \mathrm{ft}(4,100 \mathrm{~m})$ in the COST No. G-2 well. Accurate placement of the breakup unconformity requires better time correlation between the Jurassic sedimentary rock units deposited on the continental rise and those deposited on the continental shelf.

Figure 31 shows the part of seismic profile 1 that crosses the shelf margin in the central Georges Bank area. The profile is typical of those recorded across the northeastern end of the Georges Bank basin. Reflectors can be traced from the central basinal area to the outer part of the shelf, where they become faint and disappear in a poorly defined structureless mass, which Mattick and others (1978) and Schlee and others (1979) have interpreted to be a Jurassic-Lower Cretaceous limestone platform. On seismic lines to the southwest, details of the platform complex become distinguishable.
Figure 32 shows part of seismic reflection profile 20 located about $25 \mathrm{mi}(40 \mathrm{~km})$ southwest of the previously discussed seismin section. On a shelf margin of Late Jurassic age, represented by reflections between reflectors B and C, Mattick and others (1978) and Schlee ard others (1979) mapped a possible reef sequence. The sequence is not well developed on this profile, and it appears on other sections as a loss of reflections. Two distinct facies can be mapped: an obliqueprogradational seismic facies be $^{+}$ween reflectors as $A$ and $B$, and a sigmoid-progratational seismic facies between reflectors $B$ and $C$. According to Vail and others (1977) the distinction between the two facies is as follows: in the obliqueprogradational seismic facies, reflections terminate by toplap truncation at o- near the upper surface and by downlap at the ba`e. The sigmoidprogradational seismic units are characterized by gentle S-shaped reflections along depositional dip. On seismic lines parallel to depositional strike, the sigmoid-progradation $\varepsilon^{\prime}$ reflections are usually parallel and concordant vith unit boundaries. In figure 32 only the upfor parts of the sigmoid reflections are seen: the lower parts of the reflections are lost under the slope where reflections become faint and chaotic.

As can be seen on figure 32 , the obliqueprogradational seismic facies app ?ar to be associated primarily with shelf outbuilding; the sigmoid-progradational seismic f cies appear to be associated primarily with upbuilding of the shelf and a lesser amount of secward progradation. These two types of progradational seismic facies can be mapped throughont much of the Georges Bank basin.

Oblique-progradational seismic facies on shelf margins are characteristic of fluvial deltas and associated coastal-plain sediments and contain high-energy deposits (Vail and others, 1977). The undaform zone, corresponding to a delta-plain environment, and the upper part $c^{f}$ the clinoform zone, corresponding to a delta-front environment, are likely to contain sand. The lower clinoform and fondoform zones, corresponding to a prodelta environment, are typically shale prone. In addition, the fondoform part of the oblique seismic facies may contain turbidite deposits of sands interbedded with marine shales.

In their discussion of sigmoid.progradational facies, Vail and others (1977) suggest that the corresponding sedimentary rocks are usually deposited on the slope along continental margins 

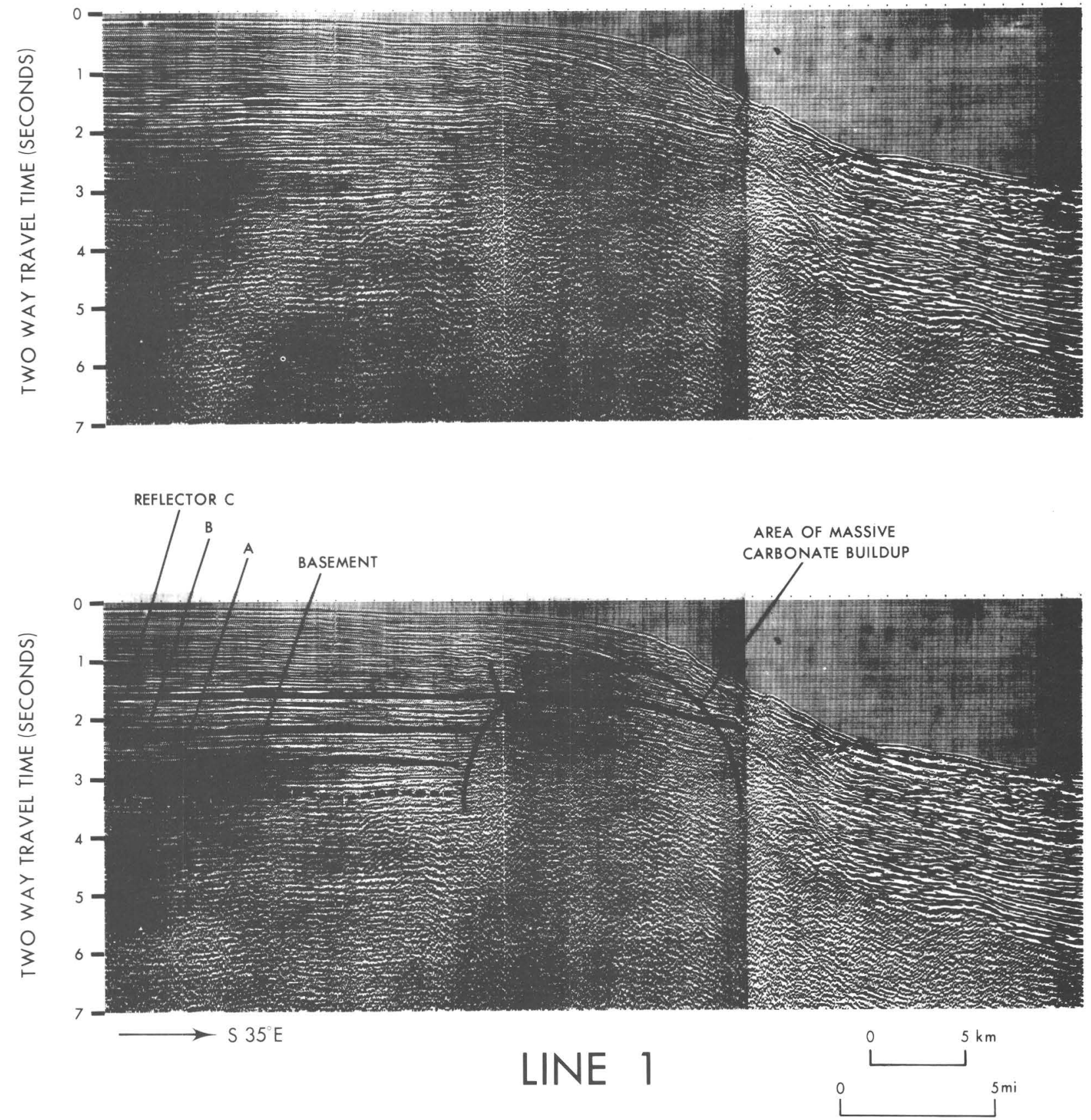

FIGURE 31.-Part of seismic reflection profile 1 recorded across the outer shelf and slope in the central part of the Georges Bank basin. Location of profile is shown in figure 29. Uninterpreted section is shown above and interpretive lines have been added below.

and that the undaform part of the reflection event extends into shelf margin facies. Shelf upbuilding produces thick deposits corresponding to the undaform parts of the reflections. Clinoform facies represent dominantly fine-grained clastics that were most likely deposited from low-energy turbidity currents and from low-velocity currents as hemipelagic deposits. Sedimentary rocks represented by the undaform facies may result from wave or fluvial transport, hence there is some possibility of coarse reservoir clastics in the undaform environment.

These interpretations suggest that the oblique facies between reflectors $A$ and $B$ represent more sand-prone sedimentary rocks than do the sigmoid facies between reflectors $B$ and $C$. At the COST No. G-2 well there are predominantly limestone facies below reflector $\mathrm{B}$ and predominantly 

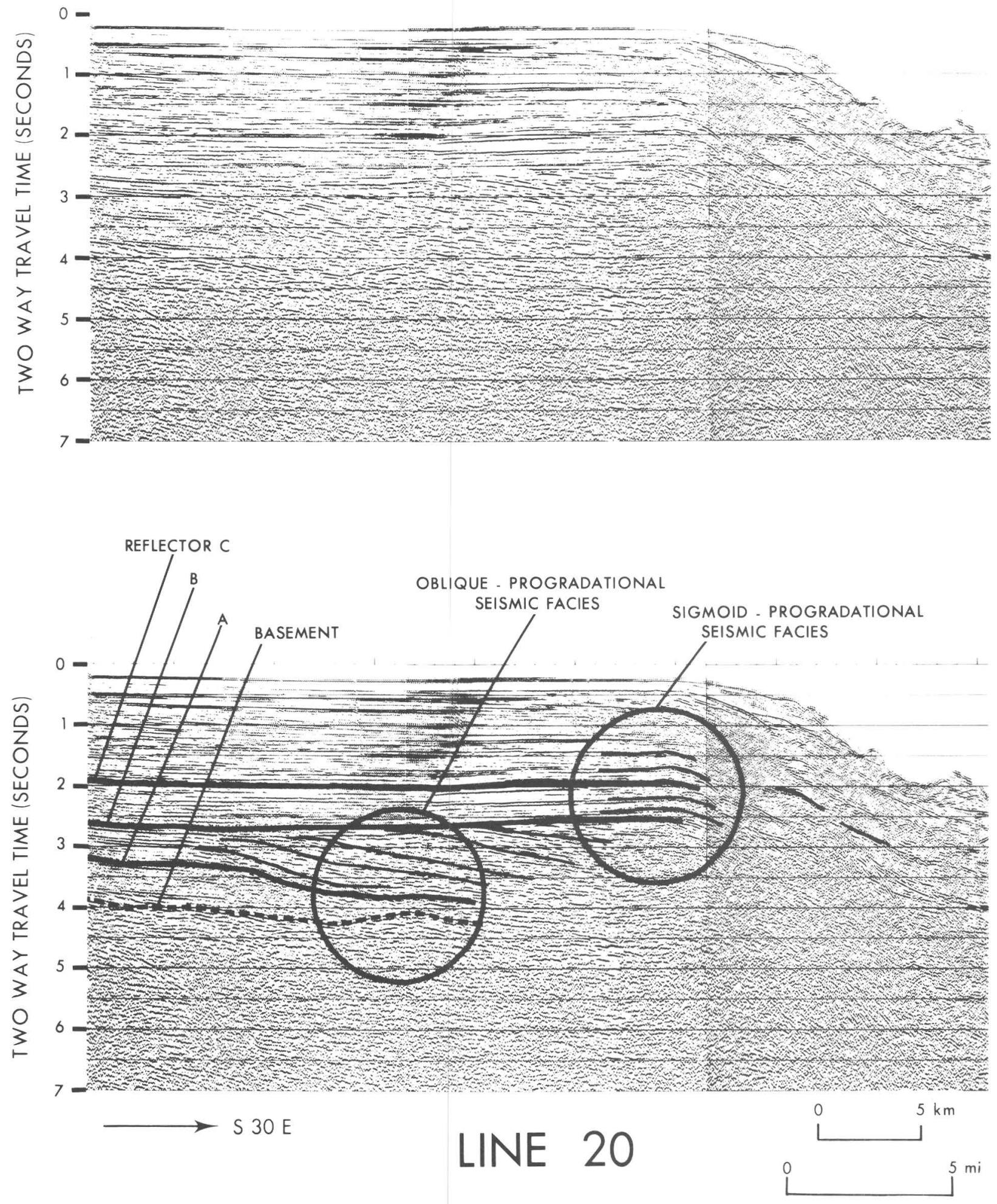

FIGURE 32.-Part of seismic reflection profile 20 recorded across the outer shelf and slope in the central part of the Georges Bank basin. Location of profile is shown in figure 29. Uninterpreted section is shown above and interpretive lines have been added below. The reflections between reflectors A and B are classified as oblique-progradational seismic facies and those between reflectors $\mathrm{B}$ and $\mathrm{C}$ are classified as sigmoid-progradational seismic facies. 
sandstone facies above. This pattern suggests that the oblique seismic facies represent limestone beds deposited in a high-energy environment, perhaps an oolitic limestone. In this case, termination of reflections by toplap near the upper surface suggests that the limestone was derived at or near a shelf edge and deposited on the slope by wave action. Upbuilding of the shelf did not occur during this time because there was little influx of clastics to the shelf. As the influx of clastic material increased after the time represented by reflector $B$, the shelf began to build upwards.

Seismic profiles 8, 5, and 22 are shown in figures 33,34 , and 35 respectively. The reflecting horizons noted in these figures were carried from profile to profile by additional mapping on seismic profile 12 (fig. 29), which intersected all of the seismic lines discussed in this paper. Although they differ in detail, all of the profiles reveal the same overall structure of the shelf margin during the Jurassic: oblique-progradational seismic
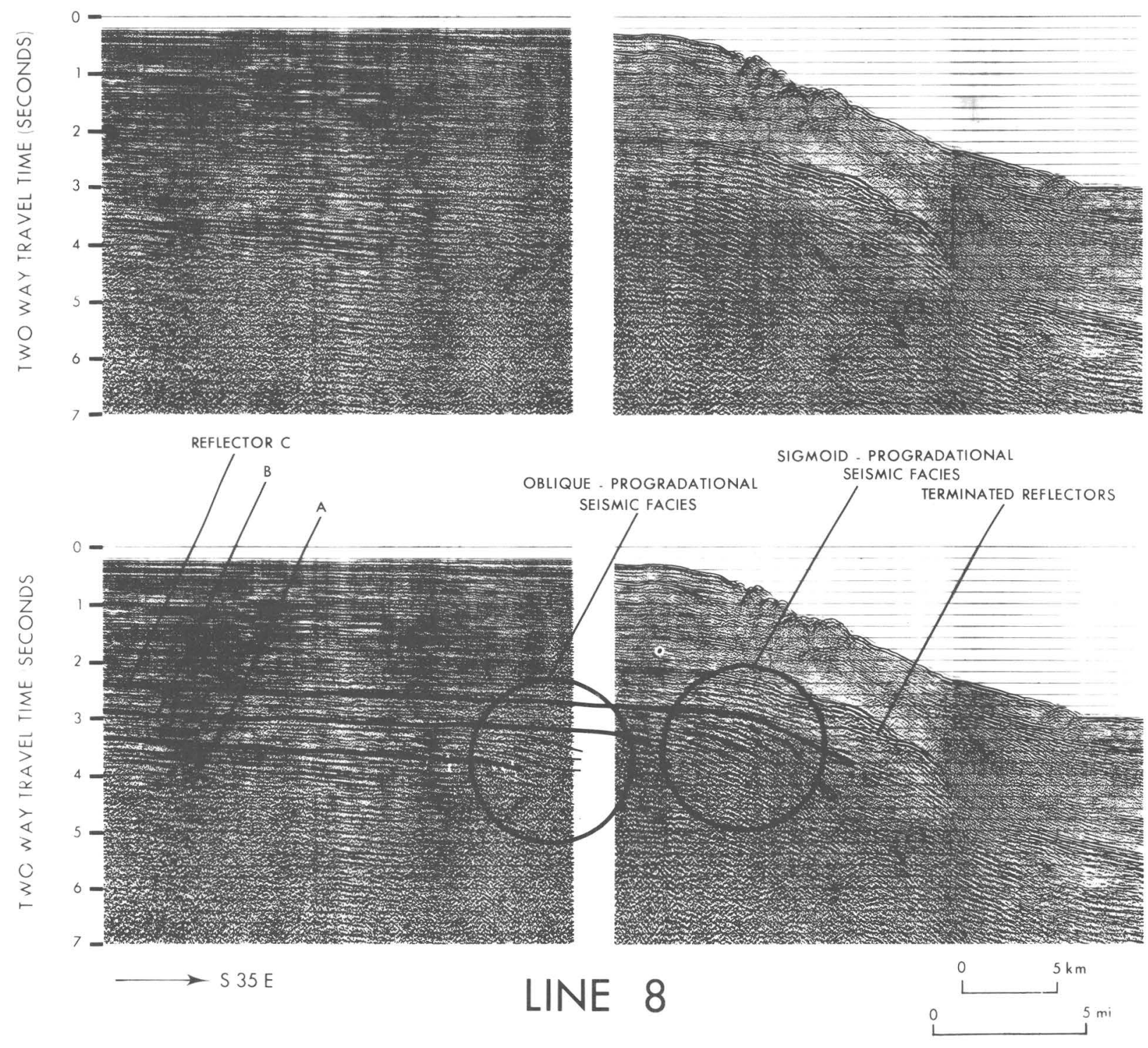

Figure 33.-Part of seismic reflection profile 8 recorded across the outer shelf and slope in the southwestern part of the Georges Bank basin. Location of profile is shown in figure 29. Uninterpreted section is shown above and interpretive lines have been added below. 

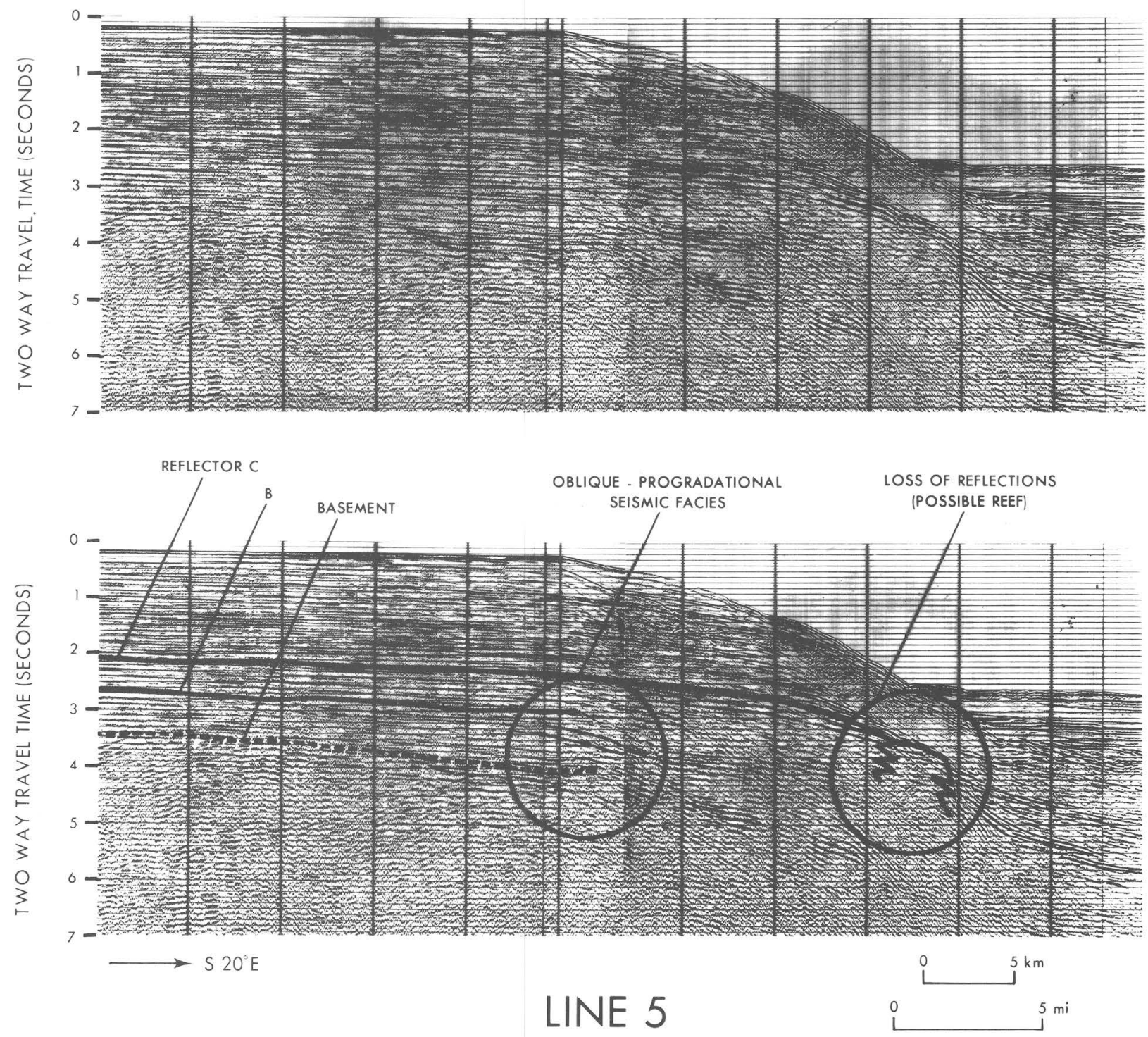

Figure 34.-Part of seismic reflection profile 5 recorded across the outer shelf and slope in the southwestern part of the Georges Bank basin. Location of profile is shown in figure 29. Uninterpreted section is shown above and interpretive lines have been added below.

facies, which represent outbuilding of the shelf margin during Middle and Late Jurassic time, and sigmoid-progradational seismic facies, which represent upbuilding of shelf margin during Late Jurassic time. On profile 8 (fig. 33) the reflectors immediately above reflector A suggest that a carbonate ramp began to build seaward following continental breakup. Later, during the Cretaceous, the shelf margin apparently prograded seaward over the Upper Jurassic shelf edge for some undetermined distance. The truncation of reflectors that represent Cretaceous strata suggests that the Cretaceous shelf edge has retreated shoreward because of erosion.

Profile 5 (fig. 34) is located just northeast of the Long Island platform and profile 22 (fig. 35) crosses the platform. On the shoreward ends of these profiles reflector $\mathrm{A}$, which terminates against the basement surface in the shallower parts of Georges Bank basin, was absent. Oblique seismic facies can be seen at a depth of about 3.4 seconds (two-way traveltime) on profile 5; the base of this seismic facies probably correlates with reflector A. Near the southeast end of profile 

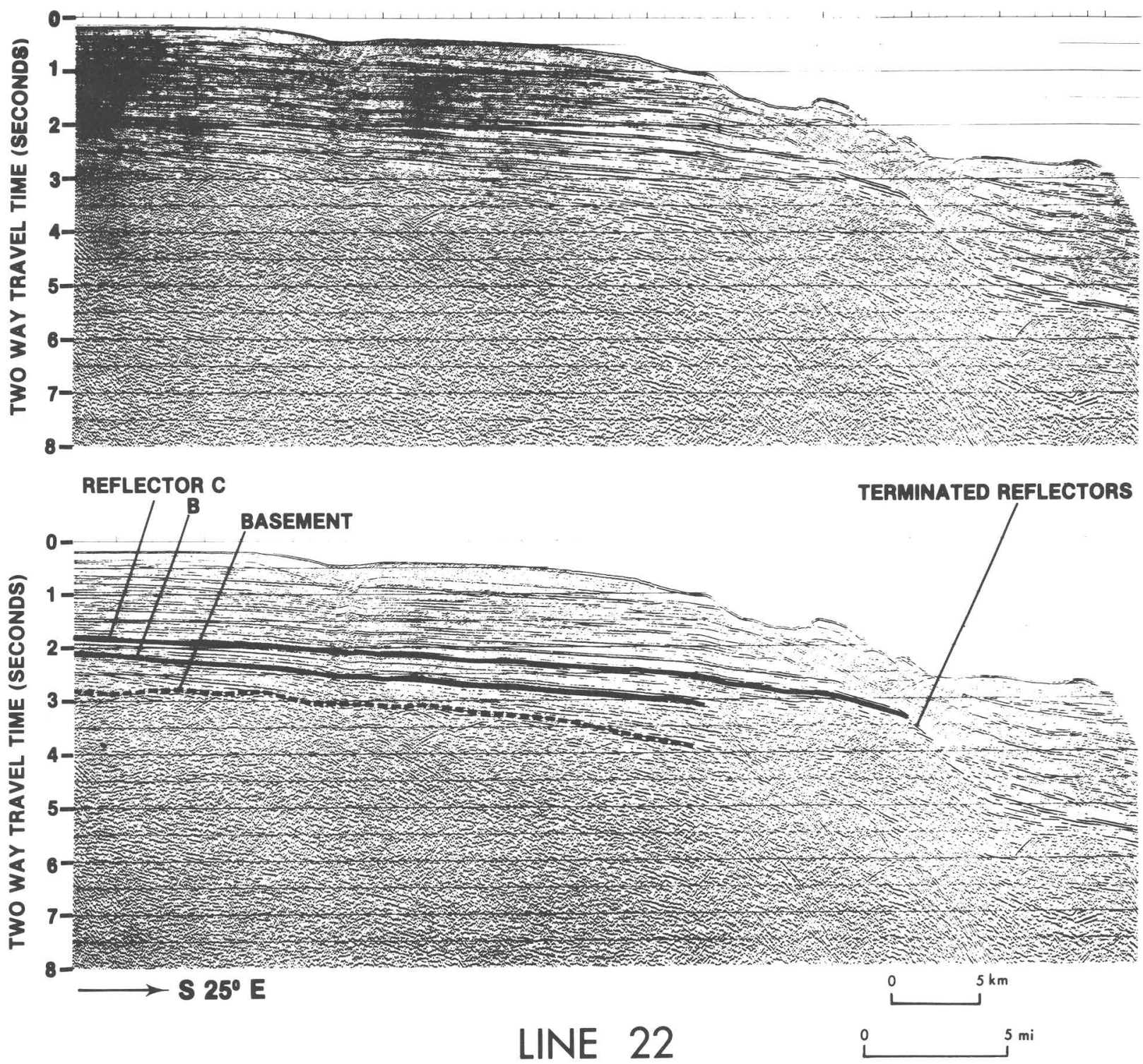

FIGURE 35.-Part of seismic reflection profile 22 recorded across the Long Island platform immediately south of the Georges Bank basin. The location of profile is shown in figure 29. Uninterpreted section is shown above and interpretive lines have been added below.

5 , a zone of weak reflections is interpreted as a reef facies of Late Jurassic to Early Cretaceous age that grew along the shelf margin during that time. Along profile 22 (fig. 35), the sedimentary section is substantially thinner than that shown on previous profiles. On the Long Island platform this thinness results from the absence of the rocks correlating to the basal part of the obliqueprogradational seismic facies below reflector $\mathrm{B}$. In this area the location of the Middle Jurassic shelf edge probably coincides with that of the
Upper Jurassic-Lower Cretaceous shelf edge. Terminated reflectors appear to mark that location.

\section{GEOLOGIC IMPLICATIONS}

The interpretation of seismic data recorded along the central and northern part of the U.S. Atlantic margin indicates two styles of shelf construction during the Jurassic and Early Cretaceous (fig. 36). Middle Jurassic time, following 


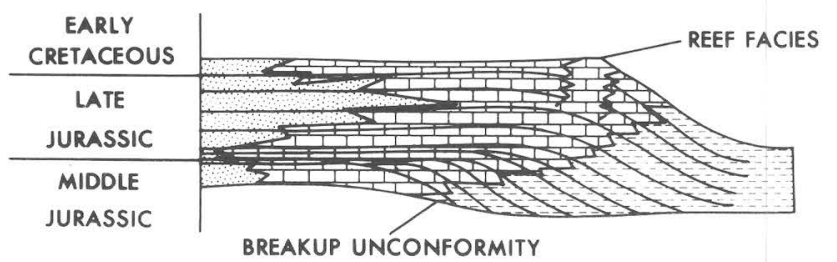

MOSTLY MOSTLY
SANDSTONE

Figure 36.-Construction of continental shelf during Jurassic time. In this period, the shelf margin was marked by two primary styles of shelf construction-outbuilding during Middle Jurassic time and upbuilding during Late Jurassic-Early Cretacous time.

continental breakup, was marked primarily by out-building of the shelf. Late Jurassic-Early Cretaceous time was a period of shelf upbuilding with reef growth along the shelf margin. Correlation with the COST No. G-2 well on Georges Bank suggests that the change from outbuilding to upbuilding correlates with a Late Jurassic influx of clastic material.

The locations of the Middle Jurassic and Late Jurassic-Early Cretaceous shelf margins can be mapped using differing seismic facies. These locations and the location of the present shelf margin are shown in figure 37 . The present shelf margin follows the $600-\mathrm{ft}(200-\mathrm{m})$ bathymetric contour. The Late Jurassic-Early Cretaceous shelf margin was mapped by following the main mass of suspected reef trend on seismic records. The Middle Jurassic shelf margin was delineated by following the onset of oblique seismic facies nearest the shore.

In the Baltimore Canyon trough area southeast of line 2, the age correlations of the shelf margin are tentative because the oldest strata penetrated in that area is of Late Jurassic age (Poag, 1980b). It was assumed, for purposes of interpretation in the Baltimore Canyon trough area, that the change from oblique to sigmoid seismic facies is

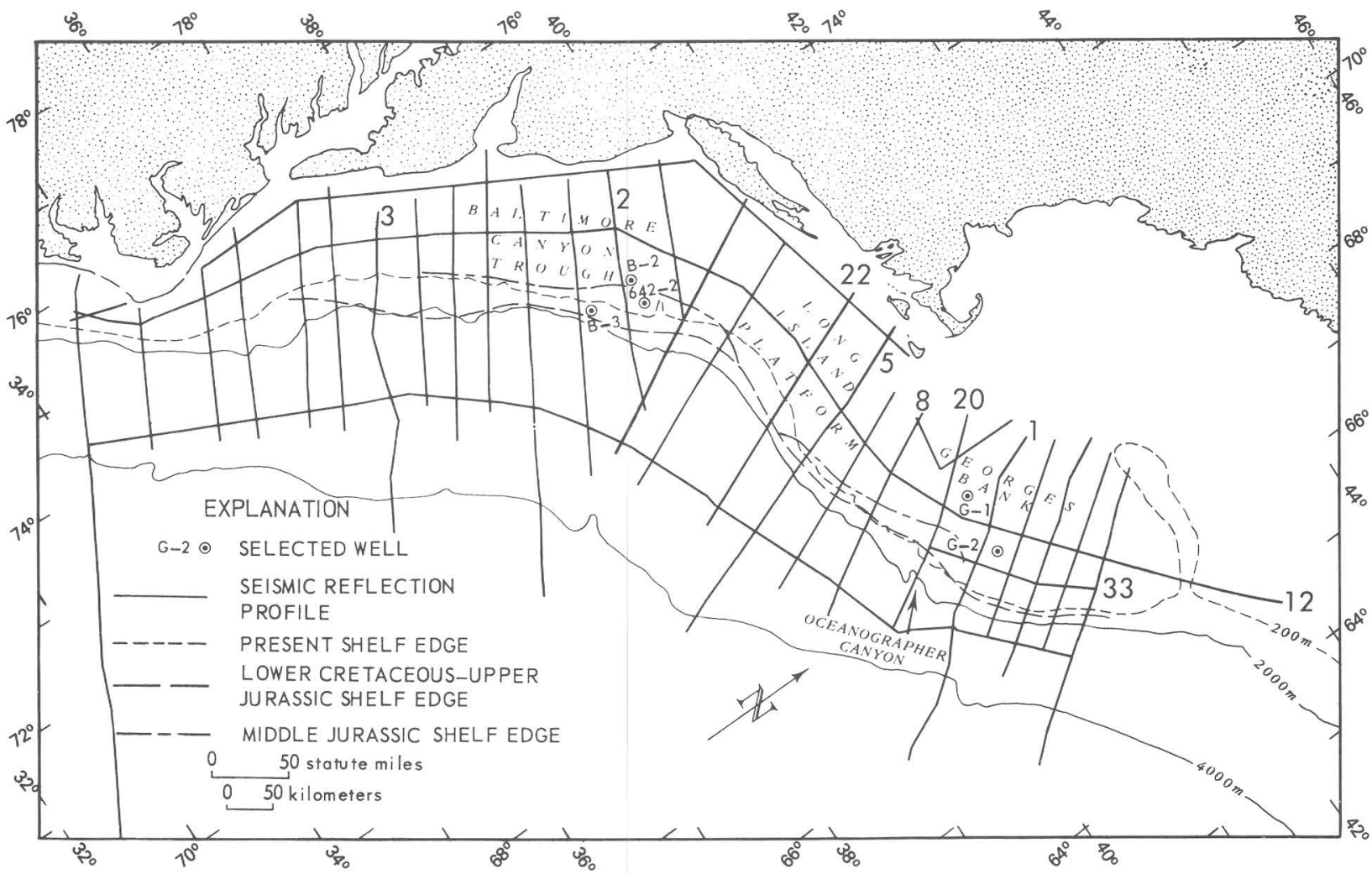

Figure 37.-Locations of the continental shelf margin during Middle Jurassic, Late Jurassic-Early Cretaceous, and present times. This mapping suggests that basinal shales (possibly containing oil-prone source rocks) underlie the present continental shelf in two areas-one in the vicinity of the Tenneco 642-2 well (the only well on the U.S. Atlantic margin reported to have flowed significant amounts of oil) and the other in the vicinity of Oceanographer Canyon on Georges Bank. The numbered seismic profiles are those that are discussed in the report. 
the same age as Reflector B mapped in the Georges Bank area. As in the Georges Bank area, the top of the Jurassic section occurs slightly below the top of the sigmoid facies representing the Upper Jurassic-Lower Cretaceous shelf edge.

In the Georges Bank basin, the Late JurassicEarly Cretaceous shelf margin lies just seaward of the present shelf margin except in vicinity of line 20 (fig. 37). In the Baltimore Canyon trough area, the Late Jurassic-Early Cretaceous shelf margin lies almost $30 \mathrm{mi}(50 \mathrm{~km})$ seaward of the present shelf-slope break. At the southern end of the Baltimore Canyon trough, along line 3, deepwater multiple reflections obscured most of the seismic data and prevented interpretation. The Middle Jurassic shelf margin lies shoreward of the present shelf-slope break except in the vicinity of the Long Island platform, where it is assumed to coincide with the Late Jurassic margin.

\section{SUMMARY}

Several generalizations about the petroleum geology of the shelf margin can be made from the foregoing discussion. Promising areas for petroleum accumulation occur on the continental shelf and especially on the continental slope. On the present continental shelf, petroleum may have accumulated in porous limestone or sandstone beds of Late Jurassic and Early Cretaceous age by upward migration along faults from possible organic-rich sinal shales of Middle Jurassic age. The most likely areas for such accumulations would be where Jurassic shales extend under the present shelf. As shown in figure 36, the maximum shoreward deposition of basinal shales occurred in Middle Jurassic time after continental breakup. The shoreward extent of these shales is represented by the Middle Jurassic shelf edge shown in figure 37 . The maximum displacements between the Middle Jurassic and present shelf margins occur in the vicinity of line 2 in the Baltimore Canyon trough and in the vicinity of line 20 in the Georges Bank basin (fig. 37). These two areas are especially attractive for petroleum exploration because the only wildcat well on the U.S. Atlantic margin reported to date to have flowed significant amounts of oil is Tenneco $642-2$, located at the shelf margin in the vicinity of line 2.

The oil (48.4 API gravity) from the Tenneco
642-2 well flowed at a rate of 630 barrels por day from a thin Lower Cretaceous sandstone bed at a depth of $8,315 \mathrm{ft}(2,535 \mathrm{~m})$ (Mattick and Bayer, 1980). According to these authors, the shallow depth of the discovery, together with geochemical and temperature data from the COST Nos. B-2 and B-3 wells (Scholle, 1977a, 1980), preclute the possibility that the oil was generated in proximate strata. Whether the 642-2 reservoir was charged with liquid hydrocarbons genera ${ }^{+}$ed in more deeply buried basin facies is not known, but normal faults mapped in the vicinity of the Tenneco 642-2 well (Mattick and others, 1981) could have provided the necessary avenues for upward migration to Lower Cretaceous beds.

On the Atlantic continental slope of the United States, a primary task of petroleum exploration will be to locate possible hydrocarbon traps in forereef, reef, and backreef facies (fig. 38). Although not yet tested, the basinal shales that interfinger with carbonate rocks of the forereef facies may be some of the best potential source rocks on the continental slope in this area. Data from the COST wells drilled on the continental shelf (Scholle, 1977b, 1979, 1980; Amato and Bebout, 1980; Amato and Simonis, 1980) indicate that rocks deposited in the backreef environment have poor potential to generate liquid hydrocarbons.

If these basinal shales prove to have had the capacity to generate large amounts of petroleum, the key to hydrocarbon production will be locating strata with high porosity and permeability,

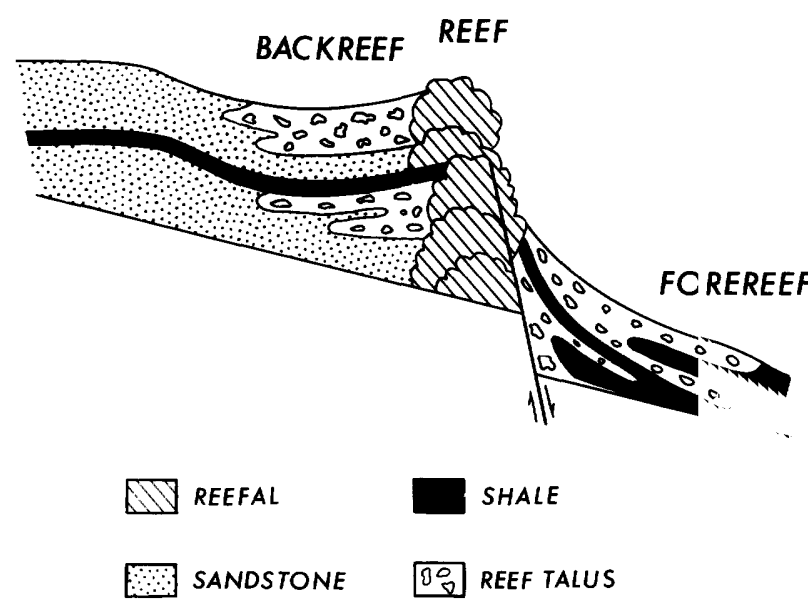

FIGURE 38.-Forereef, reef, and backreef facies of a crrbonate bank. Basinal shales deposited in the forereef area could prove to be good source rocks for the generation of liquid hydrocarbons. 
which formed as a result of subaerial exposure during periods of relatively low sea level. According to Benson and others (1976), Lower Cretaceous reef, bank, and backreef facies in DSDP holes 390,392 , and $392 \mathrm{~A}$ all showed "evidence of subaerial weathering and leaching by fresh water." Although Mattick and others (1978) considered the Mesozoic shelf margin complex of the U.S. Atlantic comparable to the reef and forereef trend of the El Abra-Tamaulipas Formation of the Golden Lane and Poza Rica trends of Mexico, Simonis $(1979$, p. 105) points out that there have been no discoveries of hydrocarbons in the Upper and Middle Jurassic Abenaki Formation (carbonate unit) of the Scotian shelf, offshore eastern Canada, and that oolitic limestone penetrated in the COST No. B-3 well had porosities of less than 8 percent and permeabilities of less than $0.1 \mathrm{mD}$. Although comparison with the Abenaki Formation (Middle to Late Jurassic age) of the Scotian shelf would suggest that carbonate units of the same age on the U.S. Atlantic margin are usually tight, the Shell Demascota G-32 well, drilled as a shelf edge test on the Scotian shelf, penetrated
$551 \mathrm{ft}(168 \mathrm{~m})$ of porous dolomite and limestone (including reef carbonates) that have porosities as high as 14 percent in the limestone and fracture porosities of unknown magnitude in the dolomite (Given, 1977, p. 74). The dolomite in the Iroquois Formation (Upper Triassic, Ea-ly to Middle Jurassic) on the Scotian shelf hes porosities as high as 15 percent and oil staining has been reported in several wells (Given, 1977, p. 71). It is not known whether such potentidl reservoirs exist on the old shelf margin (the prosent continental slope) in the Georges Bank area, or whether these reservoirs have been charired with sufficient amounts of liquid hydrocarhons generated in the nearby basin facies.

As can be seen from figure 37, in the Georges Bank area the Upper Jurassic-Lo'ver Cretaceous reef trend underlies relatively shallow waters of the upper slope. In other areas of the U.S. Atlantic margin, this feature is under d'eeper water on the lower slope. Therefore, the Georges Bank should be one of the first areas targeted for the exploration of potential reservoirs in Mesozoic reef trends on the Atlantic margir. 


\title{
Organic Geochemistry of the Georges Bank Basir- COST Nos. G-1 and G-2 Wells
}

\author{
R. E. Miller, H. E. Lerch, G. E. Claypool, M. A. Smith, \\ D. K. Owings, D. T. Ligon, and S. B. Eisner
}

\section{PURPOSE AND SCOPE}

The objectives of this petroleum geochemistry study were to (1) compare the source-rock characteristics of the stratigraphic intervals that may be considered prospects for the generation of oil or natural gas in the COST Nos. G-1 and G-2 wells from the Georges Bank basin; (2) assess the depth of burial required for the onset of thermal maturation processes; and (3) evaluate the geochemical effects that mud additives may have on the source-rock interpretations.

\section{CONCEPTS AND TERMS}

The basic concepts of petroleum generation and source rock geochemistry used in this study are those established by Vassoyevich and others (1970), Dow (1977), Tissot and Welte (1978), and Hunt $(1974,1978,1979)$. The terms used to describe source-rock richness, maturity, and potential are consistent with the definitions and concepts reported by Claypool and others (1977) and Miller and others $(1979,1980)$.

The quality or organic richness of a source shale and the source potential of such a bed to provide petroleum hydrocarbons may be indicated by (1) a minimum amount of total organic carbon $(0.7$ to 1.0 weight percent for argillaceous rocks); (2) pyrolytic oil yields greater than 0.2 to 0.3 percent, and (3) solvent extractable hydrocarbon concentrations in excess of 100 to $500 \mathrm{ppm}$. It is important to note that the weight percent of total organic carbon necessary to constitute an excellent, good, or poor source rock is not as well defined for fine-grained, medium- to dark-gray limestones and dolomites. Hunt (1979) points out that because of the amorphous nature of the organic matter derived from hydrogen-rich marine algae, dark-gray carbonates may have the potential to generate more hydrocarbons than shales with equivalent amounts of total o-ganic matter. Thus, medium- to fine-grained, dar'-gray to dull-brown limestones and dolomites with a total organic carbon content as low as 0.3 reight percent may have sufficient richness to be classified as source rocks (Hunt, 1967).

The definitions of the terms thermally immature and thermally mature are those established by Claypool and others (1977) and Miller and others $(1979,1980)$. If sedimentary rocks that contain an abundance of organic matter are subjected to thermal pyrolysis and are shown to be capable of generating petroleum hydroca-bons, and yet these organic-rich sedimentary rocks have not been altered by thermochrmical petroleum-generating reactions to the degrne that a minimum amount of petroleum has been generated and physically expelled, then the sourco rock is defined as "immature." A source rock is "mature" when thermochemical processer have converted the indigenous extractable hydrocarbons to a molecular composition and concentration that is identical to that of petroleum, and the extractable hydrocarbons are present in quantities of about 1 to 2 percent of the total organic carbon.

"Possible" or "potential" source rock refers to the degree of thermal maturity of the organic-rich rock. An immature organic-rich rock is defined as a "potential source rock," whereas a thermally mature organic-rich rock is designated a "possible source rock" (Claypool and others, 1977; Miller and others, 1979, 1980). 


\section{ANALYTICAL METHODS AND PROCEDURES}

The USGS analyzed 23 well-cutting samples from the COST No. G-1 well from 1,090 to $16,070 \mathrm{ft}$ ( 332 to $4,898 \mathrm{~m}$ ) and 26 well-cutting samples from the COST No. G-2 (1,190 to $21,540 \mathrm{ft} ; 363$ to $6,565 \mathrm{~m}$ ). The unwashed well cuttings were removed from their plastic storage bags, and the drilling mud was carefully removed from each rock chip by thoroughly washing each chip under running water on a Tyler 100-mesh $(150-\mu \mathrm{m})$ screen. The washed rock chips were oven dried at $95^{\circ}$ to $104^{\circ} \mathrm{F}\left(35^{\circ}\right.$ to $\left.40^{\circ} \mathrm{C}\right)$. Each sample was examined under a binocular microscope, the lithology was described, and all of the foreign substances were removed, including string, plastic, rubber, and mica. The lithologic descriptions of the samples analyzed for the COST Nos. G-1 and G-2 wells are shown in tables 1 and 2, respectively. Only those rock chips larger than 10 to 20 mesh $(2.0$ to $0.85 \mathrm{~mm}$ ) were used for the $\mathrm{C}_{15+}$ hydrocarbon analyses. Each sample was ground, using mortar and pestle, to smaller than 60 mesh $(250 \mu \mathrm{m})$ and weighed. Aliquots of the ground sample were taken for totalorganic-carbon determinations. Thermal pyrolysis analyses were determined on a separate set of washed and ground samples from depths of burial that were similar to those used for the extractable $\mathrm{C}_{15+}$ hydrocarbon studies.

The details of the solvent-extraction methods, liquid-column chromatography, and gas chromatography procedures employed for the $\mathrm{C}_{15+}$ liquid-hydrocarbon analyses have been described previously (Miller and others, 1979, 1980). The major steps involved are Soxhlet-solvent extraction in chloroform, followed by removal of sulfur by passing the sample over activated copper, then elution-column chromatography (gravimetrics) on silica gel. The saturated paraffinnaphthene fractions were analyzed both qualitatively and quantitatively on Perkin-Elmer Sigma 2-B and 3920 gas chromatographs, respectively. Both systems were supported by Sigma 10 data microprocessors. The qualitative gas chromatographic analyses were performed on $8 \mathrm{ft}$ $\times 0.125$ in. $(2.4 \mathrm{~m} \times 0.318 \mathrm{~cm})$ stainless steel columns packed with 3 percent OV-101, 100- to 200-mesh (150- to 75- $\mu \mathrm{m}) \mathrm{GCQ}$. The column temperature was $176^{\circ} \mathrm{F}\left(80^{\circ} \mathrm{C}\right)$ at injection and was programmed to increase initially at a rate of $29^{\circ} \mathrm{F} / \mathrm{min}\left(16^{\circ} \mathrm{C} / \mathrm{min}\right)$ for 8 minut $\mathrm{s}$ and then at a rate of $14^{\circ} \mathrm{F} / \mathrm{min}\left(8^{\circ} \mathrm{C} / \mathrm{min}\right)$ to a final temperature of $572^{\circ} \mathrm{F}\left(300^{\circ} \mathrm{C}\right)$. Quantitative analyses were performed on an OV-1 50-ft (15-m) SCOT column. The column was held for one minute at an injection temperature of $212^{\mathrm{c}} \mathrm{F}\left(100^{\circ} \mathrm{C}\right)$; it was then programmed to increase at $7^{\circ} \mathrm{F} / \mathrm{min}$ $\left(4^{\circ} \mathrm{C} / \mathrm{min}\right)$ to a final temperature of $473^{\circ} \mathrm{F}$ $\left(245^{\circ} \mathrm{C}\right)$ and held at the final termperature until n- $\mathrm{C}_{32}$ eluted. The following expression, modified from Hunt (1974), was used to ca'culate the Carbon Preference Index (CPI):

$\mathrm{CPI}=\frac{\frac{\left(\% \mathrm{nC}_{25}+\% \mathrm{nC}_{27}+\% \mathrm{nC}_{29}+\% \mathrm{nC}_{31}\right)}{\left(\% \mathrm{nC}_{24}+\% \mathrm{nC}_{26}+\% \mathrm{nC}_{28}+\% \mathrm{nC}_{30}\right)}+\frac{\left(\% \mathrm{nC}_{25}+\% \mathrm{nC}_{27}+\% \mathrm{nC}_{29}+\% \mathrm{nC}_{31}\right)}{\left(\% \mathrm{nC}_{26}+\% \mathrm{nC}_{28}+\% \mathrm{nC}_{30}+\% \mathrm{nC}_{32}\right)}}{2}$

Total organic carbon is a mea ure of the organic richness of a source rock. Triplicate total organic carbon analyses were performed by the USGS on dried, weighed alinuots of the carbonate-free residue produced by leaching with hot, 6-normal hydrochloric acid of approximately $0.07 \mathrm{oz}$ avdp $(0.2 \mathrm{~g})$ of ground sample smaller than 60 mesh $(250 \mu \mathrm{m})$. The samples were combusted in a Perkin-Elmer model 240 Carbon, Hydrogen, Nitrogen Analyzer. T organic carbon analyses for the thermal pyrolysis studies were performed by Rhinehart Laboratories, Arvada, Colo., on sample aliquots using the chromic oxidation method outlined by Bush (1970).

The thermal pyrolysis analyse: performed in this study were carried out by the USGS on a Rock-Eval system following the basic principles of source-ock characterization of Espitalie and others (1977). The terms used to describe the thermal pyrolysis measurements are those of Claypool and Reed (1976), Claypool ant others (1977), Tissot and Welte (1978), and Miller and others $(1979,1980)$. The free or indigeno's hydrocarbon component (expressed as $\mathrm{mg} \mathrm{HC} / \mathrm{gC}$ (ppt)) already present in the rock and volatilized when the rock is heated at $481^{\circ} \mathrm{F}\left(250^{\circ} \mathrm{C}\right)$ for five minutes is the original generation potential of the source rock, $S_{1}$. Those hydrocarbons ard related compounds generated by pyrolysis $\varepsilon^{t}$, temperatures from about $480^{\circ}$ to $1,020^{\circ} \mathrm{F}\left(250^{\circ}\right.$ to $\left.550^{\circ} \mathrm{C}\right)$ from the nonvolatile organic matter are referred to as the residual generation potentia'. expressed by 
the term $S_{2} . S_{1}$ and $S_{2}$ are expressed in units of $\mathrm{mgHC} / \mathrm{gC}$ (ppt). The sum $\left(S_{1}+S_{2}\right)$ is expressed on a weight percent basis and is a measure of the generation potential of the rock when expressed in $\mathrm{kgHC} /$ ton rock (Tissot and Welte, 1978). The carbon dioxide generated from the kerogen, $S_{3}$, was not determined for the kerogens in this study.

The ratio of pyrolytic hydrocarbon yield $\left(S_{1}\right.$ $+S_{2}$ ) to percent total organic carbon is a measure of the thermal maturation of the organic matter. The maximum temperature at which the yield of volatile organic components is produced by pyrolysis of the solid organic matter $\left(T_{S_{2}}{ }^{\circ} \mathrm{C}\right)$ is also used as an indicator of thermal maturation (Tissot and Welte, 1978). The ratio $S_{2} /$ Org. C is the hydrogen index, whereas $S_{3} /$ Org. C (not determined) is a measure of the oxygen content of a kerogen (Tissot and Welte, 1978). Atomic (hydrogen/carbon) ratios, carbon isotopic compositions $\left(\delta^{13} \mathrm{C} \mathrm{PDB}\right)$, and classes of relative percent of kerogen are also used to evaluate the kerogen types.

\section{RESULTS AND DISCUSSION}

This study compares the source-rock potential of the sedimentary rocks in the Georges Bank COST wells No. 1 and No. 2. The interpretations of source-rock richness, maturity, and type based on the results of different geochemical techniques have been assessed and evaluated.

The amount and molecular composition of the solvent-extractable organic matter in shales is considered to be indicative of the quality (richness), degree of thermal maturation, and type of original organic matter, assuming that the extractable organic matter is indigenous to the sedimentary rocks (Tissot and Welte, 1978; Miller and others, 1979, 1980). Lithologic descriptions, extractable organic matter data, and paraffin-naphthene hydrocarbon gas chromatograms for the Georges Bank COST Nos. 1 and 2 wells are given in tables 1-4 and figures 39-51. Thermal pyrolysis-FID analyses of selected well cuttings for determination of the original genetic $\left(S_{1}\right)$ and residual $\left(S_{2}\right)$ source-rock potential were carried out on sample suites different from those used for the extractable-organic-matter analyses. The whole-rock thermal evolution (pyrolysis) data are reported in tables 5 and 6.

Geochemical analyses on different sampls sets collected from the COST Nos. G-1 and G-2 wells were performed for the drilling participants by several commercial laboratories. These dat $\varepsilon$ have been summarized by Smith (1980) and Smith and Shaw (1980). Measurements of relative kerogen types and abundances (percent) and thrormal alteration indices (TAI) determined by optical methods were made by GeoChem Laboratories, Inc., for both wells; vitrinite reflectance measurements were conducted by Superior Oil Company for the COST No. G-1 well and by Core Laboratories, Inc., for the G-2 well; hydrogencarbon ratios were provided by Amoco Production Company for the COST No. G-1 and by Core Laboratories, Inc., for the COST No. G-2; stable carbon isotope ratios of the saturated paraffinnaphthene and aromatic hydrocarbons, as woll as the total extractables and kerogens were determined by Phillips Petroleum Company for both COST wells (J. G. Erdman, written commun., 1978). The concentrations and distributions of the light hydrocarbons $\left(C_{1}\right.$ to $\left.C_{4}\right)$ and gasolinerange hydrocarbons $\left(C_{5}\right.$ to $\left.C_{7}\right)$ were determin $\cong$ by GeoChem Laboratories, Inc., for both wells. These data are shown in summary depth profiles in figures 53-56.

Drilling mud additives may influence th? molecular composition and distribution of the $\mathrm{C}_{15+}$ saturated paraffin-naphthene hydrocarbons and as a consequence can affect interpretations of the maturity and type of the indigenous, extrartable organic matter (K. F. Thompson, Atlantic Richfield, written commun., 1977; Miller and $0^{+}$hers, 1979, 1980). Mud additive effects are believed to be of particular importance in limestones that have less than 0.3 percent organic matter, especially if the organic matter is not all liptinitic (J. M. Hunt, written commun., 1981). Aliquots of the major mud additive components used in drilling the COST G-1 and G-2 wells were not made available to the USGS for direct comparative analysis. However, previously analyzed mud additives similar in type and composition to those used in drilling both wells were compared to make a first-order assessment of the possible influence such additives may have had on the distrib ition and composition of the extractable hydroca-bons (Miller and others, 1979, 1980). The cutting samples used in this study were thoroughly washed, 
TABLE 1.-Lithologic descriptions of COST No. G-1 well cuttings used for organic geochemical analyses

[Lithologic descriptions by F. Adinolfi and D. Shaw]

\begin{tabular}{cll}
\hline \multicolumn{2}{c}{ Depth } & Lithology \\
\hline Feet & Meters & \\
\hline
\end{tabular}

$1,090-1,130 \quad 332-344$

$2,080-2,110 \quad 634-643$

$3,190-3,220 \quad 972-981$

$4,000-4,030 \quad 1,219-1,228$

$5,140-5,170 \quad 1,567-1,576$

$5,940-5,950 \quad 1,811-1,814$

$7,020-7,060 \quad 2,140-2,152$

$8,040-8,080 \quad 2,451-2,463$

$9,030-9,070 \quad 2,752-2,765$

$\mathbf{9 , 5 4 0}-\mathbf{9 , 5 8 0} 2,908-2,920$

$10,020-10,060 \quad 3,054-3,066$

$10,440-10,480 \quad 3,182-3,194$

$10,950-10,970 \quad 3,338-3,344$
95\% coarse- to very coarse-grained quartz sand; $3 \%$ coarse, goliten-brown feldspar fragments; $1 \%$ fossil fragments, mostly pelecypods; $1 \%$ coarse muscovite flakes, green chlorite, traces of medium- to fine-grained glauconite pellets, lignite, chert, igneous rock fragments, coarse-grained feldspathic sandstone, brown glauconitic siltstone, hematite, phosphate, mica schist, fine-grained quartz fragments and quartz pebbles, and aragonite.

$80 \%$ white, very coarse- to coarse-grained quartz sand; $10 \%$ gray to buff quartz and feldspar gravel, subrounded to well rounded; $6 \%$ light-gray, sandy, silty, micacenus, and calcareous mudstone; $3 \%$ tan mud and claystone; $1 \%$ mica flakes, lignite, pyrite, cl $7 y$, and fine-grained quartz sand and sandstone.

$97 \%$ white to clear, very coarse- to medium-grained quartz sand with minor pebbles; $3 \% \tan$ to brownish-red sandy mudstone; traces of lignite, chert, large feldspa- fragments, pyrite, muscovite, hematite, and glauconite.

$95 \%$ coarse- to very coarse-grained quartz sand; $2 \%$ white to buff feldspar sand and gravel; $2 \%$ gray coarse-grained quartz sandstone with buff mud matrix; $1 \%$ tan, hard mudstone; traces of lignite, glauconite, calcite, pyrite, and very fine-grained silica-cemented qu rtz sandstone.

$96 \%$ white, coarse- to medium-grained quartz sand; $3 \%$ black to dark-gray lignite; $1 \%$ lightbrown mudstone; traces of feldspar, hematite, muscovite, pyrite, calca-oous siltstone, and peat.

$30 \%$ white medium- to very fine-grained calcite-cemented sandstone; $30 \%$ medium-gray, calcareous fissile shale; $25 \%$ hard tan mudstone with minor sandy mudstone; $5 \%$ mediumto fine- grained angular quartz fragments; $5 \%$ light-gray siltstone; $1 \%$ black to dark-gray lignite; traces of calcite, aragonite, pyrite, and muscovite.

$60 \%$ very coarse- to medium-grained sub-arkosic sand ( $15 \%$ feldspar); $10 \%$ red calcareous mudstone; $5 \%$ feldspar gravels; $5 \%$ white calcite-cemented sandstone; $5 \%$ red siltstone; $5 \%$ green siltstone; $4 \%$ quartz gravel; $3 \%$ medium-grained arkosic sandston? with red hematite cement; $3 \%$ light- to medium-gray, slightly calcareous siltstone; traces of calcite, chalk, black coal, and mica.

$45 \%$ very coarse- to medium-grained feldspathic sand; $30 \%$ reddish-brown sandstone; $10 \%$ red calcareous siltstone; $5 \%$ feldspar gravel; $4 \%$ quartz gravel; $2 \%$ whi ${ }^{+o}$ calcite-cemented, medium-grained quartz sandstone; $2 \%$ light-gray calcareous shale; $2 \%$ modium- to very finegrained, green, purple, and red arkosic sandstone; traces of coal, calcite, and mica.

$35 \%$ reddish-brown mudstone; $30 \%$ medium- to dark-gray shale; $20 \%$ white, calcitecemented sandstone; $5 \%$ brown siltstone; $5 \%$ light-brown, very fine-gr ?ined arkosic sandstone; $5 \%$ medium- to coarse-grained quartz sand; traces of coal, feldspar, buff mudstone, and mica.

$40 \%$ white, coarse- to fine-grained quartzarenite; $40 \%$ red to reddish-brown mudstone; $8 \%$ coarse- to medium-grained quartz sand having angular grains, generally white; $5 \%$ arkosic, red, very fine grained sandstone and siltstone; $5 \%$ gray siltstone; $2 \%$ ccorse to very coarse feldspar fragments; traces of feldspar and quartz pebbles.

25\% oolitic quartz sandstone (medium-gray oolites in a very fine-grainet quartz sandstone matrix); $25 \%$ dark-brown to reddish-brown mudstone; $25 \%$ gray, soft, fiøsile, somewhat silty shale; $10 \%$ slightly oolitic quartzarenite, oolitic sandstone, sandy oolite, and oolitic limestone; $10 \%$ white, calcite-cemented, very fine-grained sandstone; $5 \%$ brown dolomitic limestone; traces of coal, mica, medium- to fine-grained quartz fragment 3 and feldspar pebbles.

$40 \%$ buff limestone with micritic matrix; $20 \%$ medium-gray shale; $10 \%$ oolitic limestone; $10 \%$ brownish-gray, slightly dolomitic limestone; $10 \%$ light-gray ca'careous shale; $5 \%$ white, medium- to fine-grained, calcite-cemented sandstone (quartzarenit); $2 \%$ white to tan, slightly calcareous anhydrite; $1 \%$ brownish-red mudstone; $1 \%$ red shale; $1 \%$ brown, arkosic, medium-grained sandstone; traces of sandy anhydrite, quartz grains, pyrite, and green shale.

$38 \%$ buff to white anhydritic sandstone, very fine-grained to fine-grained; $30 \%$ greenishgray to medium-gray fissile shale; $10 \%$ brown to buff limestone; $10 \%$ light to reddish-brown shale; $5 \%$ white to buff anhydrite; $5 \%$ buff siltstone and sandy anhydrite; $2 \%$ very finegrained quartzarenite; traces of calcite, coarse quartz grains, and oolitic limestone. 


\begin{tabular}{ccc}
\hline Depth & Lithology
\end{tabular}

$11,220-11,260 \quad 3,420-3,432$

$11,850-11,890 \quad 3,612-3,624$

$12,360-12,400 \quad 3,767-3,780$

$12,960-13,000 \quad 3,950-3,962$

$13,530-13,570 \quad 4,124-4,136$

$14,040-14,080 \quad 4,279-4,292$

$14,550-14,590 \quad 4,435-4,446$

$15,040-15,080 \quad 4,584-4,596$

$15,640-15,670 \quad 4,767-4,776$

$16,030-16,070 \quad 4,886-4,898$
$45 \%$ brown micritic limestone; $30 \%$ slightly siliceous, light- to medium-gray hard shale; $10 \%$ buff, slightly sandy siltstone; $5 \%$ white to buff, finely crystalline limestone; $5 \%$ reddishbrown shale; $2 \%$ green shale; $2 \%$ dark-gray laminated micaceous shale; $1 \%$ red siltstone and fine-grained white slightly micaceous sandstone with subangular to angular grains; traces of orange hematite staining, anhydrite, and coal.

$40 \%$ medium- to very fine-grained, white to light-pink quartz sandstone; $20 \%$ medium- to dark-gray shale, somewhat fissile; $15 \%$ reddish-brown shale with minor silty shale; $10 \%$ medium-grained, tan arkosic sandstone, tightly cemented; $5 \%$ medium to coarse quartz fragments; $5 \%$ red and gray siltstone; $5 \%$ brown micritic limestone; traces of blacl coal, biotite, and white anhydrite.

$25 \%$ white, pink, and light-gray, fine-grained feldspathic sandstone, silica-cemented: $18 \%$ red silty mudstone; $18 \%$ gray and buff dolomite, some coated with white anhydrite; $15 \%$ pink to white, transparent anhydrite, some sucrosic; $7 \%$ medium- to dark-gray, fissie and carbonaceous shale; $5 \%$ hard, red shale; $5 \%$ brown, micritic, dolomitic limestone; $5 \%$ white to buff sparry limestone; $2 \%$ red, micaceous siltstone; traces of coal, biotite, calcite, hematite, purple sandstone, green siltstone, and laminated gray siltstone.

$55 \%$ anhydrite; $25 \%$ reddish-brown mudstone (coated with yellow anhydrite); $10 \%$ derk- to medium-gray, slightly carbonaceous shale (coated with anhydrite) and minor light-green shale; $10 \%$ medium- and light-gray dolomite; trace of very fine-grained sandstone.

$40 \%$ light- to medium-gray and brown, micritic to vuggy dolomite, some porous: $17 \%$ anhydrite, some yellowish brown and microcrystalline, some white, sucrosic, and cryptocrystalline; $15 \%$ sandstone, some quartzitic (white with anhydrite and silica cement. very fine-grained to fine-grained); $10 \%$ medium- to dark-gray shale, $8 \%$ reddish-brown mud stone and minor muddy siltstone; $5 \%$ light-gray dolomite with clear anhydrite nodules; $3 \%$ white crystalline limestone with sparry calcite cement; $2 \%$ pelletal dolomite; traces of coal, rvrite, hematite, and large quartz grains.

$30 \%$ light-gray to buff micritic dolomite; $20 \%$ tan, white, buff and light-gray anhydrite; $15 \%$ red mudstone; $10 \%$ buff to white anhydritic dolomite; $10 \%$ red micaceous siltstone: $10 \%$ dark-gray carbonaceous shale and medium-gray, slightly micaceous shale; $5 \%$ very finegrained, pink and reddish-brown sandstone; traces of coal, and calcite.

$35 \%$ red medium- to very fine-grained sandstone, some with anhydrite cement; $20 \%$ medium-hard, red shale, some with anhydrite streaks; $20 \%$ white, tan, pink, and buff anhydrite; $5 \%$ white anhydritic sandstone with red hematite cement; $5 \%$ large crartz fragments; $5 \%$ sandy anhydrite; $5 \%$ very fine- grained white and gray sandstone; $4 \%$ micaceous dark- and medium-gray shale; $1 \%$ angular feldspar fragments; traces of mici, and hematite.

$35 \%$ white, coarse - to very coarse-grained quartz sandstone, some coated with red hematite; $25 \%$ white anhydrite coated with red hematite; $25 \%$ red, slightly micaceous mudston ; $8 \%$ red to tan dolomite; $5 \%$ very fine-grained to medium-grained red quartzitic sandston $; ; 2 \%$ light-gray to buff feldspar pebbles; traces of gray shale and hematite.

$65 \%$ red, tan, white, and light-gray anhydrite, some sucrosic, some transparent, some slightly dolomitic; $23 \%$ tan, light-gray, and buff dolomite; $7 \%$ brownish-red mudston?; $5 \%$ angular, white, coarse quartz grains; traces of gray shale, coal, brown and green pabbly mudstone (green feldspar in brown clay matrix), light-green feldspar pebbles, fine-grained anhydrite, and light-green lithic sandstone.

$69 \%$ dark-gray to black, schistose, slaty, shiny', micaceous shale; $12 \%$ red to brownish-red silty mudstone; $8 \%$ brown to light-gray, very fine-grained sandstone; $7 \%$ brow 7 to brownish-gray micritic dolomite; $2 \%$ buff to light-gray anhydrite; $2 \%$ brown and buff siltstone; traces of angular quartz pebbles, microbreccia of green sanidine in red mud matrix, coal, and white calcareous mudstone. sieved, and picked to eliminate the effects of mud additives, but very low levels of drilling mud contamination may have occurred in several intervals in the Jurassic section. Results for those intervals that are thought to be influenced by mud additives have been marked on tak'e 4 . Figure 39 is the saturated paraffin-naphthene hydrocarbon gas chromatogram of leonerdite 
TABLE 2.-Lithologic descriptions of COST No. G-2 well cuttings used for organic geochemical analyses [Descriptions by F. Adinolfi and D. Shaw]

\begin{tabular}{ccc}
\hline \multicolumn{2}{c}{ Depth } & Lithology \\
\hline Feet & Meters & \\
\hline
\end{tabular}

$\begin{array}{rr}1,190-12,220 & 363-372 \\ 2,180-2,210 & 664-674 \\ 3,020-3,050 & 920-930 \\ 4,130-4,160 & 1,259-1,268\end{array}$

$6,070-6,100 \quad 1,850-1,859$

$7,000-7,030 \quad 2,134-2,143$

$7,990-8,020 \quad 2,435-2,444$

$9,010-9,040 \quad 2,746-2,755$

$10,490-10,510 \quad 3,197-3,203$

$11,500-11,510 \quad 3,505-3,508$

$12,520-12,540 \quad 3,816-3,822$

$13,500-13,520 \quad 4,115-4,121$

$14,480-14,500 \quad 4,414-4,420$

$15,490-15,510 \quad 4,721-4,727$

$15,900-15,920 \quad 4,846-4,852$

$16,450-16,470 \quad 5,014-5,020$

$17,020-17,540 \quad 5,188-5,346$
$90 \%$ buff to light-yellow calcareous mud, slightly micaceous, with about $1 \%$ limonitic siltstone; $9 \%$ white to buff mud; traces of hematite and calcite.

95\% light-gray mud, slightly micaceous, moderately calcareous; $5 \%$ white mud; trace white calcite, angular to round quartz grains, glauconite, chert, and hematite.

$\mathbf{9 0 \%}$ grayish-brown calcareous mud; $4 \%$ fossil fragments; $5 \%$ white, roinded, coarse quartz grains; $1 \%$ drilling mud (buff); trace hematite, mica, calcite, coal, and possible pipe dope.

$90 \%$ gray, soft to firm, partly silty and sandy mudstone, contains spots of white, chalky limestone, abundant fossils, and shell fragments; $10 \%$ loose, very coarse quartz sand grains and tan, medium-grained, medium to well sorted sandstone with calcite cement and subangular glauconite.

$80 \%$ tan to tan-gray, argillaceous, firm (some hard) micrite limestone; $20 \%$ gray, partly fissile, calcareous, silty shale.

$70 \%$ medium-gray shaley limestone; $25 \%$ gray to buff limestone; $2 \%$ tan, silty mudstone, $1 \%$ quartz grains, $2 \%$ gray shale; trace pipe dope, drilling mud, threads, gastropod fragments, and mica.

$80 \%$ white, very fine-grained, calcite-cemented quartz sandstone; $14 \%$ medium-gray, slightly calcareous shale; $4 \%$ red mudstone; $1 \%$ muscovite flakes; $1 \%$ oolit: $:$ limestone (brown pellets in gray matrix); trace brown lignite, and asphalt.

$40 \%$ silty, reddish-brown, micaceous shale with streaks of yellow-brown and gray mottling; $\mathbf{2 5} \%$ micaceous quartz sandstone with detrital coal and calcite cement; $20 \%$ dark-brown, fissile, waxy, noncalcareous shale; $10 \%$ dark-gray, micaceous, noncalcareous shale; $2 \%$ light-pink to reddish sandstone and buff-white and brown pelletal limestone; $1 \%$ rounded coal grains; trace glauconite and foraminifers.

$30 \%$ microcrystalline, tan to light-brownish-gray limestone; $20 \%$ oolitic, buff-white, $\tan$, and dark-brown limestone; $30 \%$ gray, silty shale with detrital coal; $15 \%$ yellow-brown to dark-reddish-brown micaceous, silty, shale; $5 \%$ fine-grained, sub-rounted white to light reddish-brown sandstone, well-cemented with calcite cements and containing detrital coal; traces of coal and yellow mudstone.

$90 \%$ microcrystalline, brown, gray, and buff-tan pelletal limestone; $8 \%$ dark-gray shale with traces of coal; $2 \%$ very fine-grained, green and white glauconitic quartzite sandstone.

$\mathbf{7 5 \%}$ microcrystalline, blocky, light grayish-brown and buff-white limestone; $15 \%$ white and grayish-brown pelletal limestone; 3-5\% light-gray, slightly micaceous, noncalcareous shale with disseminated organic material; $2 \%$ very fine-grained, light- to dark-green, hard glauconitic sandstone; $3 \%$ silty, micaceous, reddish-brown shale; $2 \%$ fine-grained, calcitecemented, glauconitic, light-green, clear, and white sandstone; trace quartz grains, coarsegrained pyrite, coal, and orange rust staining.

$80 \%$ fine-grained to medium-grained, well-sorted, subrounded, pink to rad, clear, and white sandstone containing quartz, feldspar, biotite, and glauconite; $15 \%$ grev to grayish-brown limestone; $3 \%$ dark-gray, fissile, carbonaceous shale; $2 \%$ silty, micacenus, reddish-brown shale; trace pelletal limestone, green, hard shale, and coal.

$40 \%$ yellow-brown, translucent dolomite; $40 \%$ white, light-gray and grayish-brown limestone with larger grains than the dolomite; $20 \%$ conglomeratic, well-cemented rock fragments of grayish-brown limestone and dark-brown, medium-crystalline dolomite in a matrix of yellow-brown, clear, to white anhydrite and calcite cement; trace gray shale, reddish-brown silty shale, and coal.

45\% light-gray, tan to brownish-gray micritic, partly dolomitized limestone; $45 \%$ browngray, dark-brownish-gray, and gray, very finely crystalline, partly ar; $10 \%$ dark-reddish hard shale and coal.

$40 \%$ buff micritic limestone; $29 \%$ medium-gray micrite limestone; $20 \%$ dark-gray, slightly shaley limestone; $9 \%$ sparry white limestone; $2 \%$ buff mudstone and gray-white mud; trace pyrite, red mudstone, and hematite staining.

$40 \%$ light-gray to brownish-gray, partly pelletal, partly recrystallized micrite limestone; $30 \%$ soft, white, chalky, limestone with sugary texture; $30 \%$ dark gray, argillaceous, dolomitic limestone.

Composite. ${ }^{1}$ 
TABLE 2.-Lithologic descriptions of COST No. G-2 well cuttings used for organic geochemical analyses-Continued [Descriptions by F. Adinolfi and D. Shaw]

\begin{tabular}{llc}
\hline \multicolumn{2}{c}{ Depth } & Lithology \\
\hline Feet & Meters & \\
\hline
\end{tabular}
$17,020-17,040 \quad 5,188-5,194$
$70 \%$ buff to cream, loosely consolidated limestone, mostly sparry calcite, sugary textured; $25 \%$ medium- to dark-gray limey dolomite; $5 \%$ buff, crystalline, sparry limestone; trare tan mudstone, black bituminous limestone, and coal.
17,520-17,540 5,340-5,346 $40 \%$ buff limestone, micritic; $30 \%$ medium-gray shaley limestone; $10 \%$ light-gray calcreous mudstone; $10 \%$ limey, dark dolomite, slightly shaley; $5 \%$ black, fibrous soft coal, $\mathrm{m}$ st in fine fragments; $5 \%$ white, sparry limestone, sugary textured; traces of hematite and asphaltite.

$17,470-17,520 \quad 5,325-5,340$

$60 \%$ tan, grayish-brown, and brown, micritic, blocky, dense, slightly dolomitic limestone; $10 \%$ white, chalky micrite limestone; $20 \%$ white, clear, coarsely crystalline anhydrite. with layers of dark-brown dolomite; $10 \%$ dark-gray and black, carbonaceous, slightly calcrreous shale; trace of a white, soft substance.

17,980-18,000 5,480-5,486 55\% buff micritic limestone; $15 \%$ white sucrosic, crystalline, sparry limestone; $30 \%$ shaley, dark- to medium-gray micritic limestone; trace dolomite, coal, hematite, limonite, and oolitic limestone.

$18,470-18,500 \quad 5,630-5,639$

$35 \%$ brownish-gray, micritic, sparry limestone; $35 \%$ buff sparry limestone, slightly anhydritic; $15 \%$ medium-gray micritic, argillaceous limestone; $12 \%$ dark-gray, shale ${ }^{\prime}$ and calcareous dolomite; $3 \%$ buff anhydrite; trace coal, tan limonite, bituminous limestone. and oolitic limestone.

$18,980-19,030 \quad 5,785-5,800$

$95 \%$ dark-gray to black bituminous limestone, micritic; $2 \%$ white to buff pordery anhydrite; $2 \%$ dark-gray calcareous sandstone containing fine-grained angular fragnents; $1 \%$ medium- to light-gray limestone (micrite with sparry calcite cement).

$19,500-19,530 \quad 5,944-5,953$

$65 \%$ brownish-gray to medium-gray micrite limestone with minor sparry calcite cement; $10 \%$ buff to light-gray anhydritic dolomite with sucrosic texture; $15 \%$ buff to white calcareous anhydrite, some chalky, some clear and microcrystalline; $10 \%$ dark-gray, micritic, bituminous limestone.

$19,950-20,010 \quad 6,081-6,099$

25\% light-gray micritic dolomite; $25 \%$ brownish-gray micritic dolomite; $25 \%$ darl-gray shaley dolomite; $8 \%$ brown micritic limestone; $8 \%$ dark-gray dolomitic shale; $8 \%$ whit : and buff anhydrite, some powdery and cryptocrystalline, some sucrosic and microcrystalline; $1 \%$ brownish-gray calcareous dolomite; trace quartz grains and gypsum.

$20,480-20,520 \quad 6,242-6,254$

$75 \%$ brownish-gray to medium-gray micritic limestone; $10 \%$ dark-gray, shaly bituminous limestone; $10 \%$ powdery white anhydrite; $5 \%$ light-gray, sucrosic, calcareous dolomite with sparry calcite cement; trace white microcrystalline anhydrite and quartz fragments.

20,970-21,030 6,392-6,410 50\% brownish-gray to medium-gray anhydritic micrite dolomite with sucrosic dol $\backslash$ mite rhombs; $10 \%$ buff to white, anhydritic, powdery, chalky limestone; $40 \%$ tan, light- to medium-brown clear, and white anhydrite with greasy luster; trace dark-gray shale, cruartz sandstone, red mudstone, hematite, and calcite.

21,460-21,540 6,541-6,565 35\% light brown to brownish-gray dolomite, micritic greasy texture; $20 \%$ dark- to me diumgray dolomitic shale; $20 \%$ buff to light-brown micritic limestone; $20 \%$ buff, tan, and white anhydrite; 5\% light- to medium-gray anhydritic dolomite; trace coal, red mudstone, micaceous siltstone, and white sandstone.
'The 17,020- to 17,540-ft sample is a composite of two samples from 17,020-17,040 and 17,520-17,540 ft.
used in the commercial preparation of the mud additive lignosulfonate. Except for the specific in- tervals designated, the influence of this compo- nent on the saturated hydrocarbon fraction ap- pears to be minimal because of the dissimilarity in the molecular distribution and concentration. The effects of drilling mud additives on the deeper stratigraphic samples are believed to be restricted to specific zones, because there is no constant, pervasive mud-additive fingerprint on the entire suite of $\mathrm{C}_{15+}$ extractable hydrocarbons. In USGS samples from the COST No. G-2 well,
from 17,500 to $18,000 \mathrm{ft}(5,330$ to $5,480 \mathrm{~m})$, traces of an asphalt-like substance were found. Th? gas chromatogram revealed only an unresolved enve- lope and had no resolved normal aliphatics. GeoChem Laboratories, Inc., observed a similar substance below $14,000 \mathrm{ft}(4,267 \mathrm{~m})$, and a gas chromatogram of their paraffin- naphthene frac- tion is shown in figure 39 . This asphal-like substance was not found in the matrix of the rock fragments but appeared to be coating only $\varepsilon$ part of the individual rock chips and thus acted as a cement to hold several rock fragments together. 
TABLE 3.-Organic carbon and extractable organic matter, COST No. G-1 well

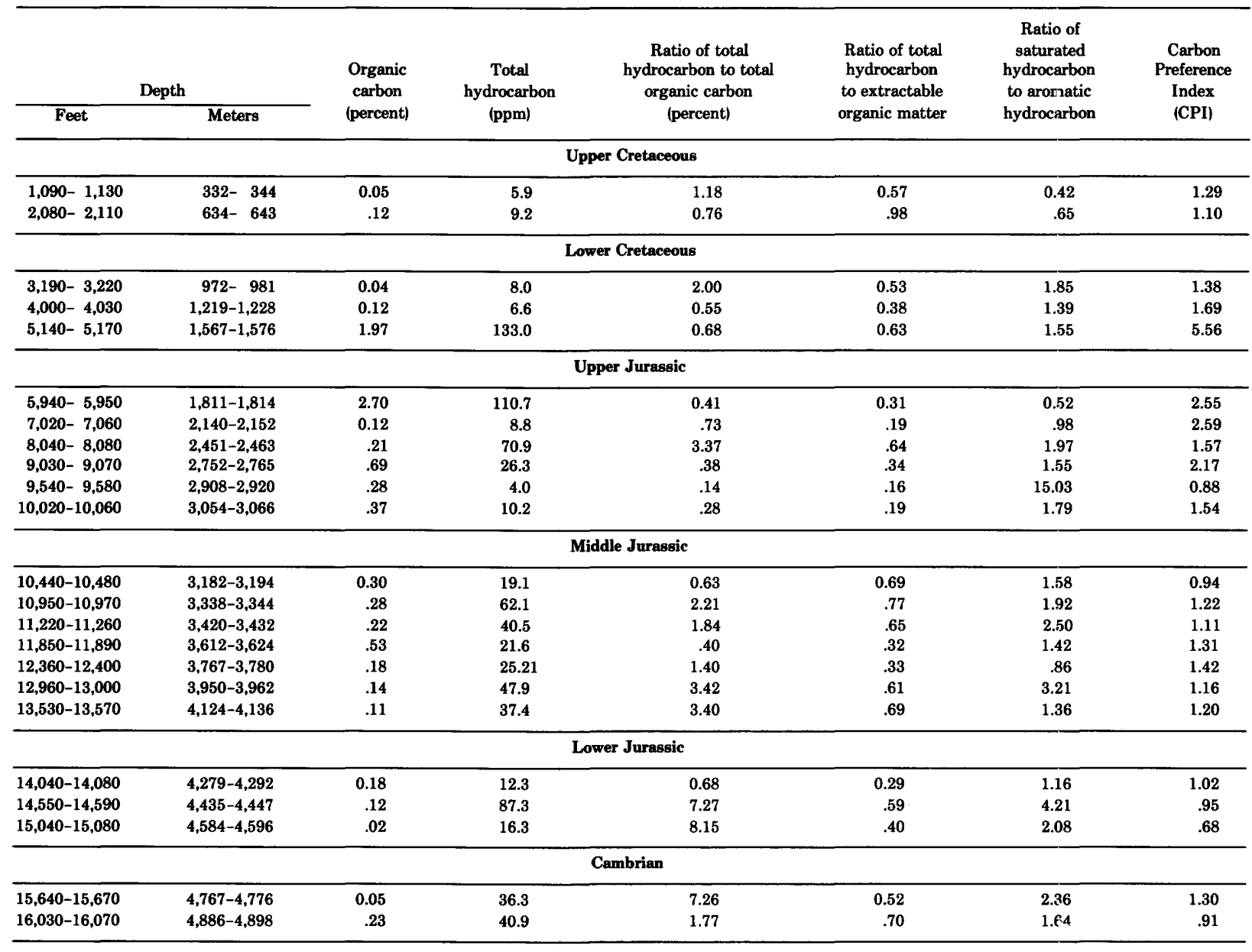

The origin of this heavy hydrocarbon substance is unknown; it may be a well-cutting contaminant, but an indigenous source cannot be discounted.

\section{COMPARISON AND EVALUATION OF SOURCE-ROCK RICHNESS AND OF THE TYPE AND MATURITY CHARACTERISTICS OF THE ORGANIC MATTER IN THE cost NOS. G-1 AND G-2 WELLS}

\section{TERTIARY}

The thin Tertiary strata recovered in the G-1 and G-2 wells ranged in depth from 1,013 to $1,030 \mathrm{ft}$ ( 309 to $314 \mathrm{~m}$ ) and from 1,100 to $1,310 \mathrm{ft}$ $(335$ to $399 \mathrm{~m})$, respectively. The Tertiary sediments in G-1 consisted of unconsolidated, coarseto very coarse-grained quartz sand with traces of glauconite, lignite, chert, mica schists, and phosphate. The G-2 Tertiary sediments are calcareous muds with subordinate limonitic silt- stone. Because of the lack of available Tertiary cuttings, only one interval represonting the Tertiary in the COST G-2 $(1,190$ to $1,220 \mathrm{ft} ; 363$ to $372 \mathrm{~m}$ ) underwent solvent extrantion for determination of the total extractabl? hydrocarbons (153 ppm) and analysis for total organic carbon (0.95 percent by weight) (tables 3 and 4). The saturated paraffin-naphthene hydrocarbon gas chromatogram (fig. 43) shows an unresolved, bimodal complex mixture that is equal to or that predominates over the resolved aliphatics, a characteristic signature that suggests thermal immaturity.

\section{UPPER CRETACEOUS}

The Upper Cretaceous strata r $\varepsilon$ nge from 1,030 to $2,680 \mathrm{ft}(314$ to $817 \mathrm{~m})$ and 1,310 to $2,600 \mathrm{ft}$ (399 to $792 \mathrm{~m}$ ) in the COST Nos. G-1 and G-2 wells, respectively. The G-1 Upper Cretaceous 
TABLE 4.-Organic carbon and extractable organic matter, COST No. G-2 well

\begin{tabular}{|c|c|c|c|c|c|c|c|}
\hline \multicolumn{2}{|c|}{ Depth } & \multirow{2}{*}{$\begin{array}{l}\text { Organic } \\
\text { carbon } \\
\text { (percent) }\end{array}$} & \multirow{2}{*}{$\begin{array}{c}\text { Total } \\
\text { hydrocarbon } \\
\text { (ppm) }\end{array}$} & \multirow{2}{*}{$\begin{array}{l}\text { Ratio of total } \\
\text { hydrocarbon to total } \\
\text { organic carbon } \\
\text { (percent) }\end{array}$} & \multirow{2}{*}{$\begin{array}{l}\text { Ratio of total } \\
\text { hydrocarbon } \\
\text { to extractable } \\
\text { organic matter }\end{array}$} & \multirow[t]{2}{*}{$\begin{array}{c}\text { Ratio of } \\
\text { saturated } \\
\text { hydrocarbon } \\
\text { to aromatic } \\
\text { hydrocarbon }\end{array}$} & \multirow{2}{*}{$\begin{array}{l}\text { Cathon } \\
\text { Prefinence } \\
\text { Intex } \\
\text { (CPI) }\end{array}$} \\
\hline Feet & Meters & & & & & & \\
\hline \multicolumn{8}{|c|}{ Tertiary } \\
\hline $1,190-1,220$ & $363-372$ & 0.95 & 153.1 & 16.61 & 0.51 & 4.01 & 1.75 \\
\hline \multicolumn{8}{|c|}{ Upper Cretaceous } \\
\hline $2,180-2,210$ & $664-674$ & 1.06 & 74.0 & 0.69 & 0.34 & 2.94 & 2.36 \\
\hline \multicolumn{8}{|c|}{ Lower Cretaceous } \\
\hline $3,020-3,050$ & $920-930$ & 1.06 & 162.7 & 1.53 & 0.69 & 4.10 & 2.17 \\
\hline $4,130-4,160$ & $1,259-1,268$ & 0.42 & 42.9 & 1.02 & 0.42 & 2.09 & 1.79 \\
\hline \multicolumn{8}{|c|}{ Upper Jurassic } \\
\hline $6,070-6,100$ & $1,850-1,859$ & 0.55 & 154.3 & 2.80 & 0.54 & 4.35 & 1.73 \\
\hline $7,000-7,030$ & $2,134-2,143$ & 0.86 & 74.5 & .87 & .58 & 1.73 & 1.23 \\
\hline $\begin{array}{l}7,990-8,020 \\
9,010-9,040\end{array}$ & $\begin{array}{l}2,435-2,444 \\
2,746-2,755\end{array}$ & $\begin{array}{l}.66 \\
.72\end{array}$ & $\begin{array}{r}60.2 \\
344.7\end{array}$ & $\begin{array}{r}.91 \\
4.65\end{array}$ & $\begin{array}{l}.43 \\
.67\end{array}$ & $\begin{array}{l}2.73 \\
2.91\end{array}$ & $\begin{array}{l}1.32 \\
1.76\end{array}$ \\
\hline $10,490-10,510$ & $3,197-3,203$ & .62 & 186.8 & 3.01 & .83 & 3.44 & 1.44 \\
\hline $11,500-11,510$ & $3,505-3,508$ & .31 & 109.4 & $\mathbf{3 . 5 1}$ & .55 & 2.29 & 1.81 \\
\hline \multicolumn{8}{|c|}{ Middle Jurassic } \\
\hline $12,520-12,540$ & $3,816-3,822$ & 0.33 & 74.6 & 2.27 & 0.58 & 1.71 & 1.44 \\
\hline $13,500-13,520$ & $4,115-4,121$ & .05 & 31.5 & 6.30 & .58 & 1.84 & 1.27 \\
\hline $14,480-14,500$ & $4,414-4,420$ & .19 & 225.6 & 11.89 & .43 & 3.52 & 1.07 \\
\hline${ }^{1} 15,490-15,510$ & $4,721-4,727$ & .29 & 792.3 & 27.31 & .44 & 2.18 & 1.41 \\
\hline $15,900-15,920$ & $4,846-4,852$ & .14 & 65.2 & 4.65 & .68 & 2.01 & 1.13 \\
\hline${ }^{1} 16,450-16,470$ & $5,014-5,020$ & .15 & 363.8 & 24.26 & .51 & 3.92 & 2.26 \\
\hline${ }^{2} 17,020-17,540$ & $5,188-5,346$ & .24 & 179.0 & 7.45 & .50 & 2.07 & 1.38 \\
\hline $17,470-17,520$ & $5,325-5,340$ & 0.14 & 131.9 & 9.42 & 0.41 & 3.07 & 1.15 \\
\hline${ }^{1} 17,980-18,000$ & $5,480-5,486$ & .17 & 93.9 & 5.52 & .42 & 2.67 & 1.53 \\
\hline $18,470-18,500$ & $5,630-5,639$ & .12 & 32.0 & 2.66 & .47 & 1.91 & 1.07 \\
\hline $18,980-19,030$ & $5,785-5,800$ & 0.29 & 117.9 & 4.06 & 0.62 & 1.85 & 1.14 \\
\hline $19,500-19,530$ & $5,944-5,953$ & .18 & 125.4 & 6.96 & .52 & 1.67 & 1.01 \\
\hline $19,950-20,010$ & $6,081-6,099$ & .15 & 75.8 & 5.05 & .80 & 2.07 & 1.02 \\
\hline $20,480-20,520$ & $6,242-6,254$ & .10 & 42.0 & 4.20 & 1.41 & 1.58 & 1.77 \\
\hline '20,970-21,030 & $6,392-6,410$ & .18 & 152.4 & 8.46 & .52 & 1.26 & .75 \\
\hline $21,460-21,540$ & $6,541-6,565$ & .42 & 210.0 & 5.00 & .42 & 1.58 & 1.01 \\
\hline
\end{tabular}

${ }^{1}$ Possible mud additive contamination.

${ }^{2} 17,020-17,540$ is a composite interval of $17,020-17,040$ and $17,520-17,540$.

strata are characterized by calcareous shales, coarse quartz sands, and gray sticky shales that contain trace amounts of glauconite, biotite, pyrite, lignite, feldspar, and calcite. In comparison, the Upper Cretaceous rocks of the G-2 well are represented by light-gray calcareous shales, claystones, and chalky limestones with varying quantities of glauconite, fossil fragments, plant fragments, ostracods, foraminifers, mica, and pyrite (Lachance, 1980; Simonis, 1980).

The Upper Cretaceous strata of the COST No. G-1 well contain significantly less total organic carbon than the Upper Cretaceous calcareous shales and fine to medium sands present in G-2. The total extractable hydrocarbons in the Upper Cretaceous of the G-1 are very low, averaging $8.0 \mathrm{ppm}$, whereas the single Upper Cretaceous sample analyzed from G-2 contains $74.0 \mathrm{ppm}$ of total extractable hydrocarbons. The nitrogen, sulfur, and oxygen contents of the Upper Crotaceous interval in the COST No. G-1 well are about five times greater than in the Upper Cretareous of the COST No. G-2 well (tables 1-4, figs. 49 and 41).

The gas chromatograms of the saturated paraffin-naphthene hydrocarbons of the Upper Cretaceous from the two wells are shov'n in figures 42 and 43. The resolved alkanes in tho Upper Cretaceous strata from the G-1 (1,090-1,130 and 2,080-2,110 ft; 332-344 and 634-643 $\mathrm{m}$ ! have a molecular composition and boiling-point range that extends from about $n-C_{15}$ to $n-C_{32}$ and a CPI ratio that averages 1.20. The resolved alirhatic components are dominated by a broad, bimodal, 


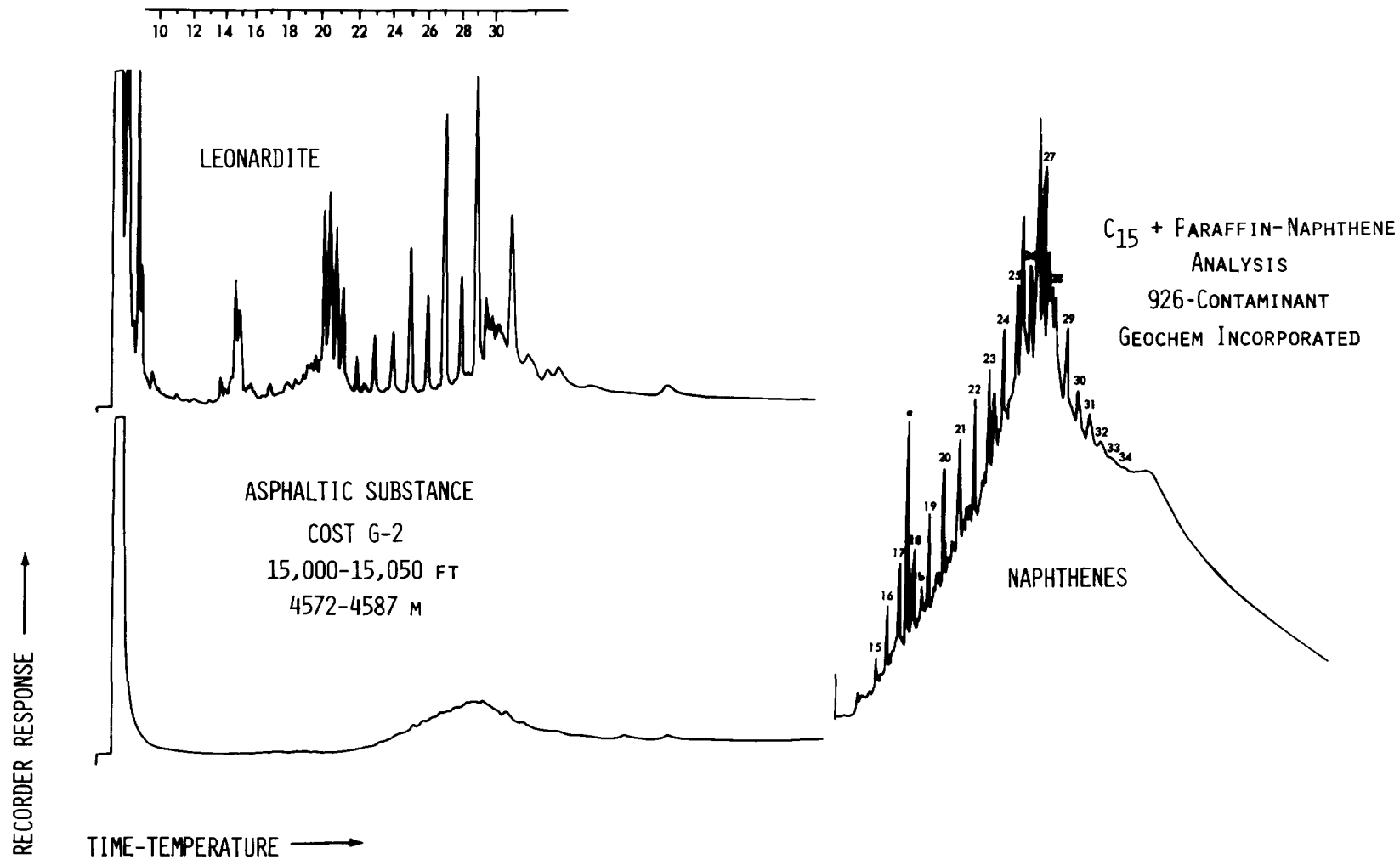

FIGURE 39.-Gas chromatographic analyses of (upper left) saturated paraffin-naphthene hydrocarbons in lignosulfonate (leonardite), (lower left) an asphalt-like substance isolated from the 15,000- to 15,050 -ft $(4,572-$ to $4,587-\mathrm{m})$ interval of the COST No. G-2 well by the USGS, and (at right) a solid black hydrocarbon substance isolated by GeoC' 1em Laboratories, Inc., from the COST No. G-2 well at about $14,000 \mathrm{ft}(4,267 \mathrm{~m})$.

unresolved complex mixture. In contrast, the extractable paraffin-naphthene hydrocarbons from the Upper Cretaceous rocks of G-2 (2,180$2,210 \mathrm{ft} ; 664-674 \mathrm{~m}$ ) are characterized by highly resolved alkanes that range from $n-C_{15}$ to $n-C_{28}$ and dominate over the much less pronounced bimodal, unresolved complex mixture. The predominant normal aliphatic species occur in the $n-C_{15}$ to $\mathrm{n}-\mathrm{C}_{2} \mathrm{O}$ range and have a CPI ratio of 2.36 (tables 3 and 4; figs. 42 and 43). The narrow range of the resolved alkanes $\left(n-C_{15}\right.$ to $\left.n-C_{2} 0\right)$ is consistent with a thermally mature hydrocarbon assemblage and is similar to molecular distribution of diesel fuel. The pristane and phytane isoprenoid hydrocarbons are dominated by the resolved normal alkanes, a signature that is usually associated with mature saturated hydrocarbons. However, the shallow burial depth and the thermalpyrolysis maximum yield temperatures that range from $837^{\circ}$ to $860^{\circ} \mathrm{F}\left(447^{\circ}\right.$ to $460^{\circ} \mathrm{C}$ ) (tables 3-6) are inconsistent with the extractable hydro- carbon chemical maturity signatures. The degree of convertibility of the sedimentary organic matter to petroleum hydrocarbons may be expressed by the ratio of the total pyrolytic hydrocarbons $\left(S_{1}+S_{2}\right)$ to total organic carbon (Claypool and others, 1977; Miller and others, 1979, 1980). This convertibility ratio for the Upror Cretaceous strata averages 8.9 percent for G-1 and 7.6 percent for G-2. Such values imply a strong influence of hydrogen-poor kerogens. The thermal pyrolytic measurements and geocl ?mical sourcerock parameters indicate that the organic matter in the Upper Cretaceous strata is thermally immature and would be a poor sorrece for liquid petroleum hydrocarbons in both wells of the Georges Bank basin.

\section{LOWER CRETACEOUS}

The Lower Cretaceous strata in the COST Nos. G-1 and G-2 wells range from 2,680 to $5,290 \mathrm{ft}$ 
(817 to $1,612 \mathrm{~m}$ ) and from 2,600 to $5,960 \mathrm{ft}$ (792 to $1,817 \mathrm{~m})$, respectively. Alternating units of glauconitic, unfossiliferous sandstones and shales containing trace amounts of coal, pyrite, and plant fragments (with small amounts of silty dolomite near the base of the interval) characterize the Lower Cretaceous of the G-1. In contrast, the Albian sandstones of G-2 (2,500 to $3,950 \mathrm{ft}$; 762 to $1,204 \mathrm{~m})$ contain glauconitic pellets and shell fragments, plant debris, thin coal streaks, and carbonaceous dark-gray shales. Underlying these units is a bioclastic limestone intercalated with argillaceous micrites, calcareous claystones, and silty mudstones $(3,950$ to $4,500 \mathrm{ft} ; 1,204$ to $1,372 \mathrm{~m})$. From $4,500 \mathrm{ft}$ to $5,320 \mathrm{ft}(1,372 \mathrm{~m}$ to $1,622 \mathrm{~m})$ are thickly bedded, poorly consolidated sandstones with thin beds of coal and lignitic shales (tables 1 and 2) (Lachance, 1980; Simonis, 1980).

Based on the combustion oxidation method, the Lower Cretaceous strata of the G-1 well contain very low amounts of total organic carbon: 0.04 weight percent between 3,190 and $3,220 \mathrm{ft}(972$ and $981 \mathrm{~m})$, and 0.12 weight percent between 4,000 and $4,030 \mathrm{ft}(1,219$ and $1,228 \mathrm{~m})$. The exception is the interval from 5,140 to $5,170 \mathrm{ft}(1,567$ to $1,576 \mathrm{~m}$ ), which contains 1.97 weight percent total organic carbon. In comparison, the Lower Cretaceous strata from the COST No. G-2 well contain total organic carbon ranging from 0.42 to 1.06 weight percent (tables 3 and 4). The total extractable hydrocarbon content for the Lower Cretaceous in the $\mathrm{G}-1$ and $\mathrm{G}-2$ averages 49 and $103 \mathrm{ppm}$, respectively. The total organic carbon and total extractable hydrocarbon values indicate that the Lower Cretaceous strata of the Georges Bank basin have comparatively low source-rock quality and richness. The average total hydrocarbon to total organic carbon values are 1.07 percent for $\mathrm{G}-1$ and 1.3 percent for $\mathrm{G}-2$; total hydrocarbon to extractable organic matter ratios average 0.51 and 0.56 for $\mathrm{G}-1$ and $\mathrm{G}-2$ respectively; and saturated paraffin-naphthene to aromatic hydrocarbon ratios average 1.60 and 3.10 , respectively, for the Lower Cretaceous of G-1 and G-2 (tables 3 and 4). The saturated paraffin-naphthene to aromatic hydrocarbon ratio is unusually high, but may reflect the thermal history of the rocks as well as the type and amount of the organic matter and the preferential destruction of aromatic hydrocarbons (Baker, 1972; Baker and Claypool, 1970; Louis and
Tissot, 1967). The low hydrocarbon to total organic carbon and total hydrocarbon to ex tractable organic matter ratios, and the averag? CPI values of 2.88 for the G-1 and 1.98 for th? G-2 well suggest that the organic matter in the Lower Cretaceous strata is thermally immature with regard to liquid hydrocarbon generation (tables 3 and 4).

The saturated paraffin-naphthene hydrocarbon gas chromatograms for the Lower Cretc ceous from the No. COST G-1 well are characterized by a moderately strong bimodal, unresolved complex mixture (fig. 42). The resolved alijhatic hydrocarbons have a molecular composition and distribution that ranges from $n-C_{15}$ to $n-C_{30}$. With the exception of those in the 4,000- to 4,030-ft (1,219- to $1,228-\mathrm{m})$ interval, the resolved normal alkanes are equal to or dominant ov?r the unresolved branched and cyclic paraffin envolope. The resolved aliphatics also show significant concentrations of the $n-C_{22}$ to $n-C_{30}$ plant-wax hydrocarbons probably associated with ter:estrially derived organic matter. In comparison, saturated paraffin-naphthene hydrocarbon gas chromatograms for Lower Cretaceous strata from the COST No. G-2 well show a well resolved, strong predominance of the normal aliphatics over the unimodal unresolved complex envelope (fig: 43). The narrow range of molecular composition and distribution of the normal alkanes $\left(n-C_{15}\right.$ to $n-C_{22}$ ) in these Lower Cretaceous strata tend to resemble those of thermally mature hydrocirbon assemblages, whose presence may also be indicated by the predominance of the normal al anes over the isoprenoid hydrocarbons pristane and phytane. Inconsistent with an interpretation of maturity, however, is the odd-carbon pretominance indicated by an average CPI ratio of 1.98 ,

which suggests thermal immaturity (table 4). However, because of the restricted range of the resolved normal alkanes the CPI ratio of 1.98 is considered to be of limited use as an indicator of thermal maturity (Swetland and others, 1978; Miller and others, 1979, 1980; figs. 42 and 43; tables 3 and 4). Although the influence of diesel fuel cannot be totally disregarded, the narrow molecular range and distribution of the resolved aliphatics probably reflects a marine algal source of the aliphatics (Hunt, 1979).

The thermal pyrolysis convertibility parameter $\left(S_{1}+S_{2}\right) /$ Org. C of the Lower Cretaceous rocks 


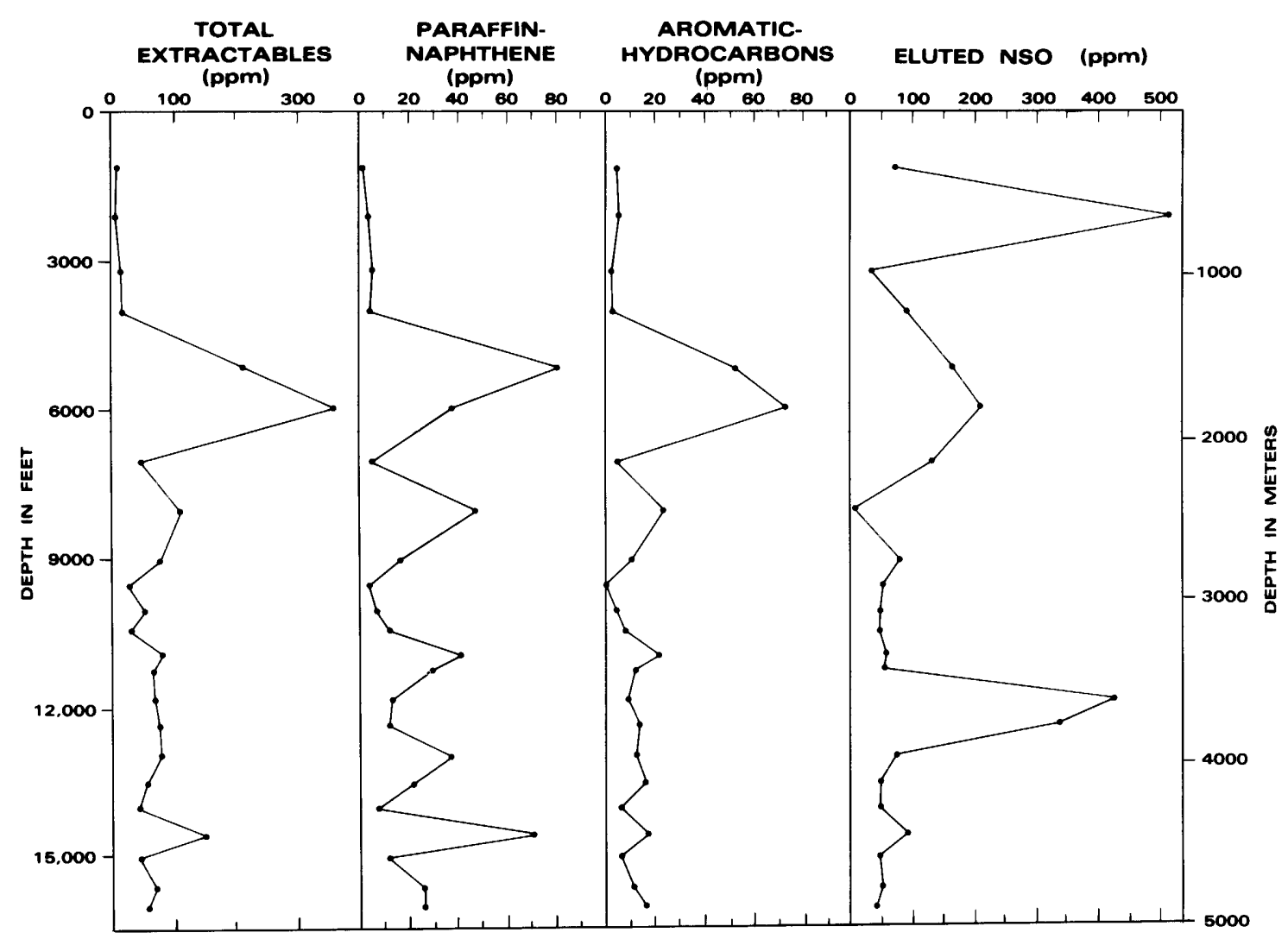




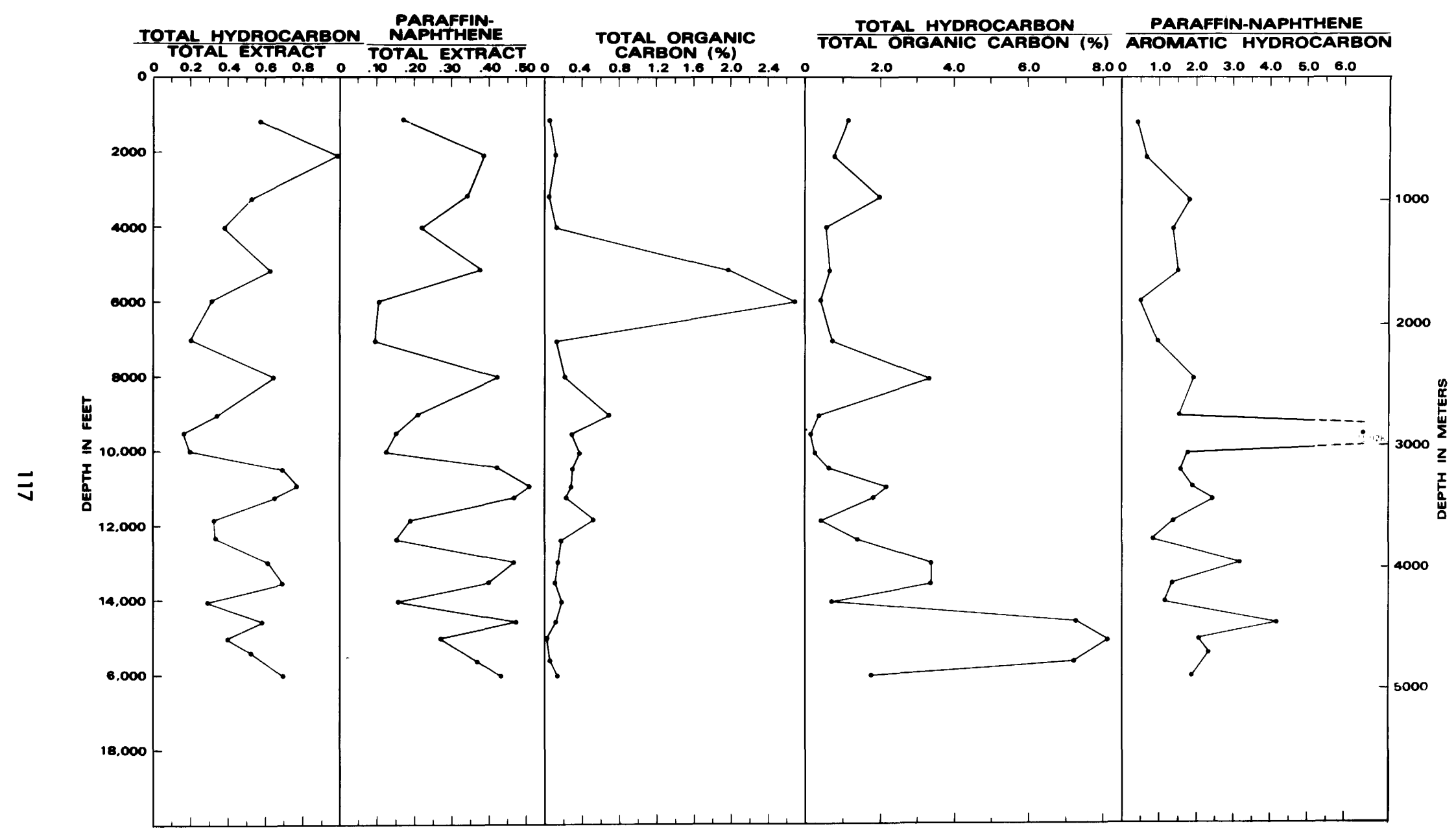

FIGURE 40.-Summary of organic-richness analyses on $\mathrm{C}_{15+}$ hydrocarbon extractables of samples from the COST No. G-1 well. 


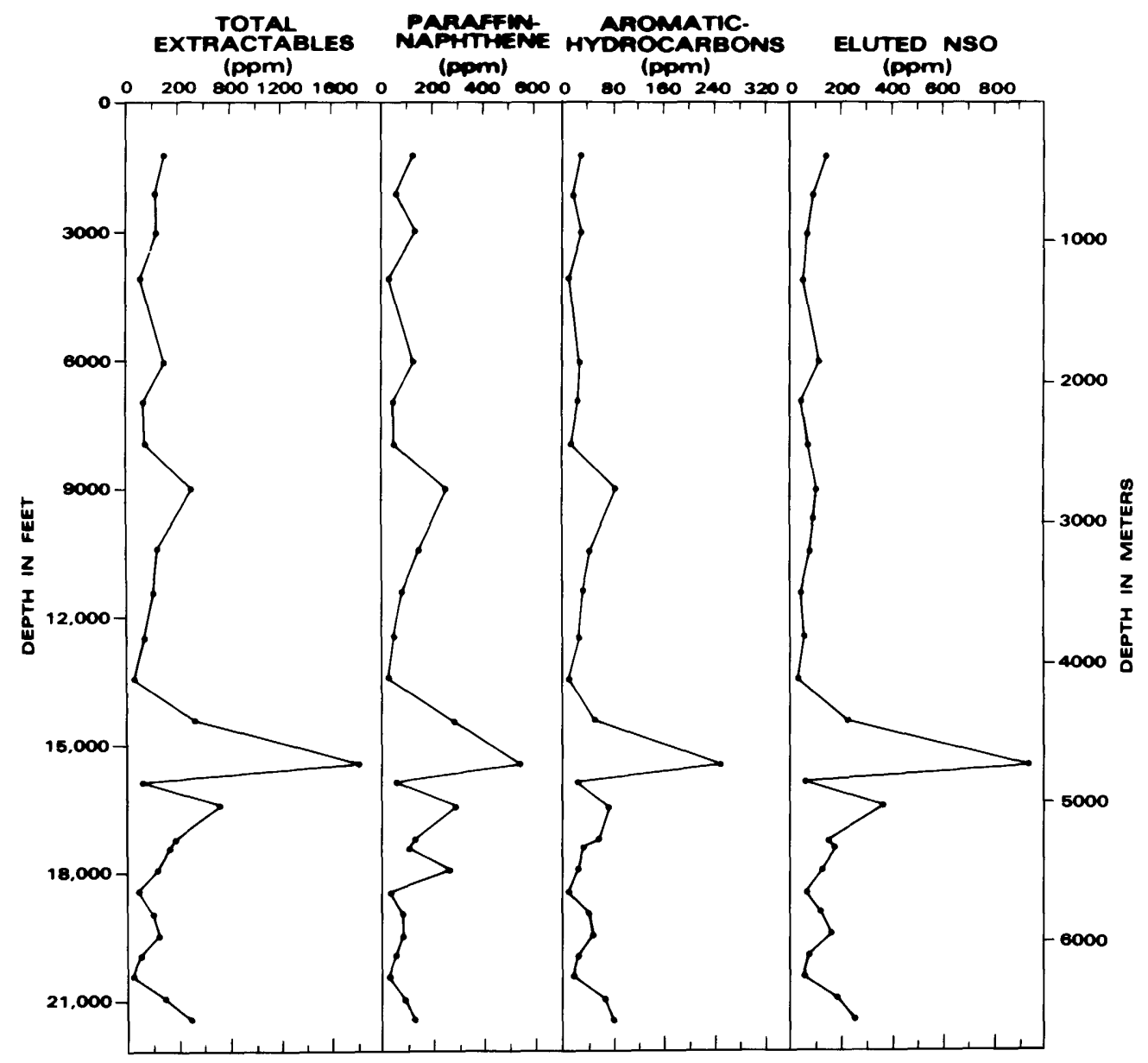




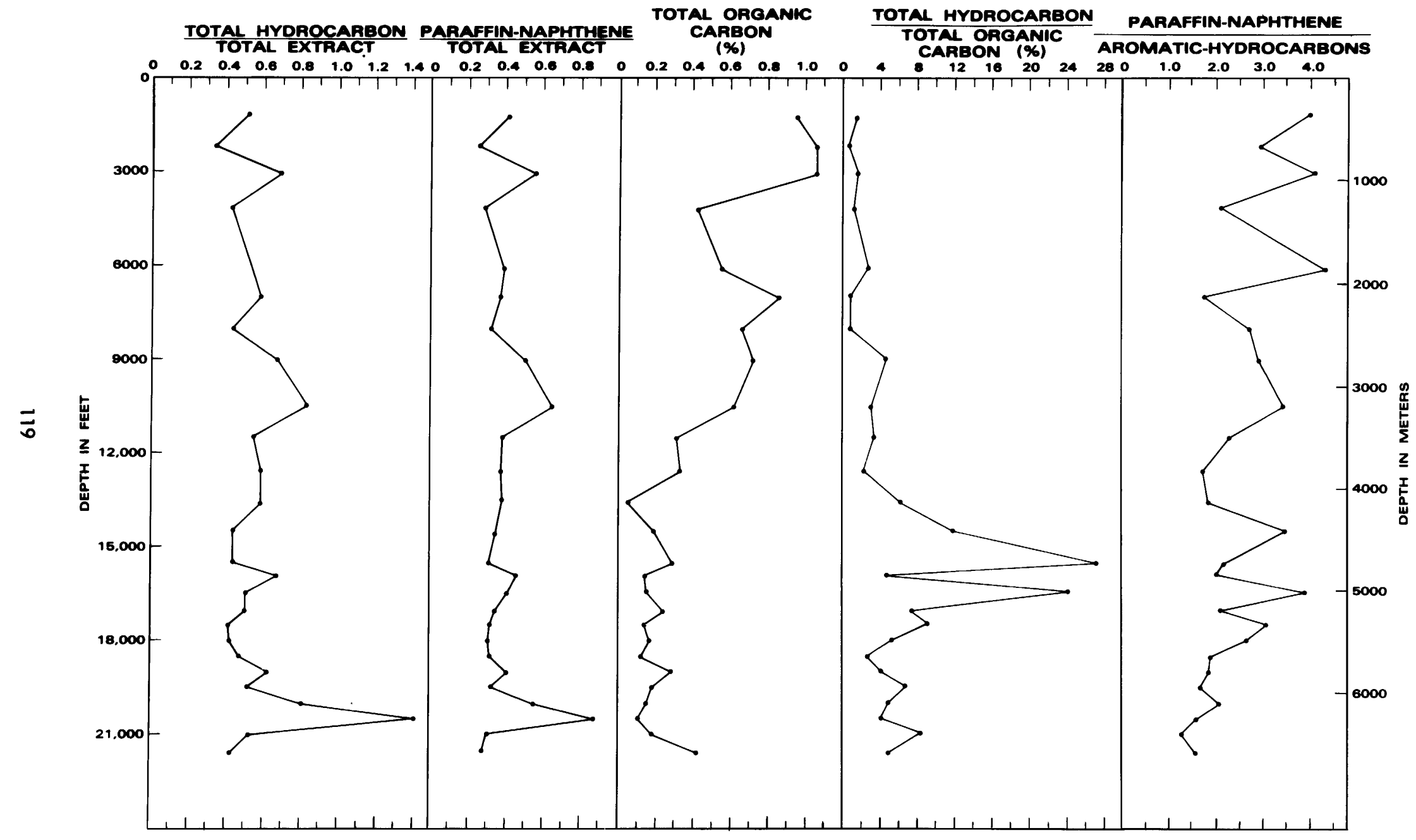

FIGURE 41.--Summary of organic-richness analyses on $\mathrm{C}_{15+}$ hydrocarbon extractables oî samples from the COST No. G-2 well. 

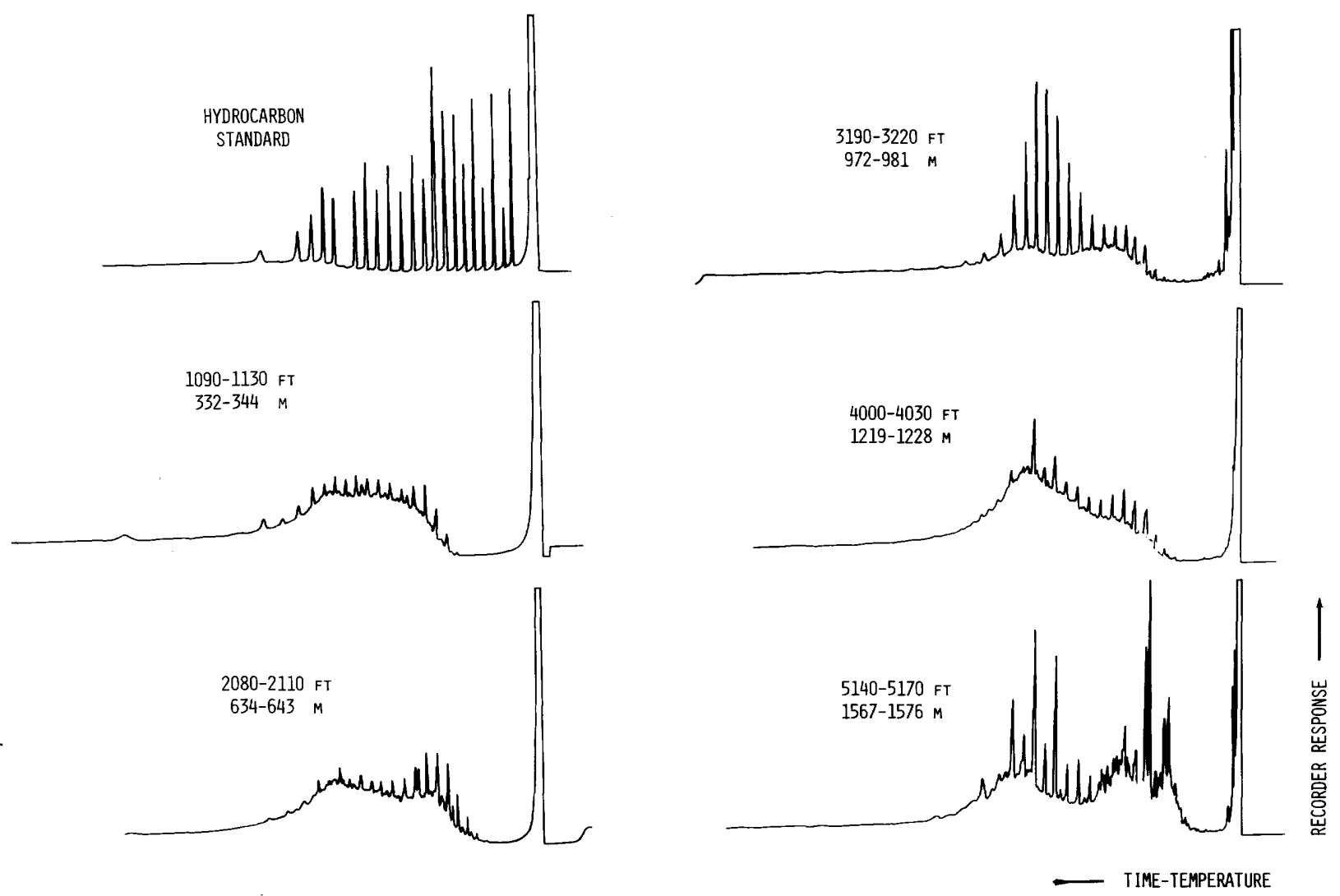

FIGURE 42.-Gas chromatographic analyses of saturated paraffin-naphthene hydrocarbons of Upper to Low?r Cretaceous rock above $5,290 \mathrm{ft}(1,612 \mathrm{~m})$, COST No. G-1 well.

from the COST No. G-1 well averages 11.7 percent, indicating that the most common type of kerogens present are predominantly of the hydrogen-poor variety, with a temperature of maximum pyrolysis $\left(T_{S_{2}}\right)$ ranging from $828^{\circ}$ to $878^{\circ} \mathrm{F}\left(442^{\circ}\right.$ to $\left.470^{\circ} \mathrm{C}\right)$. In comparison, the Lower Cretaceous rocks of the COST No. G-2 well have thermal pyrolytic convertibility ratios that average 7.4 percent. From 4,510 to $4,600 \mathrm{ft}$ $(1,375$ to $1,402 \mathrm{~m})$ and 5,050 to $5,080 \mathrm{ft}(1,539$ to $1,548 \mathrm{~m}$ ) the convertibility ratios average 90.5 percent, suggesting the presence of a zone of hydrogen-rich kerogens. The temperature of maximum pyrolysis $\left(T_{S_{2}}\right)$ for the solid organic matter ranges from $851^{\circ}$ to $869^{\circ} \mathrm{F}\left(455^{\circ}\right.$ to $\left.465^{\circ} \mathrm{C}\right)$ and is in the submature to immature temperature range (tables 5 and 6). The richness, type, and maturity characteristics of the extractable organic matter and the thermal pyrolysis measurements of the solid orgaric matter suggest that the potential for generation of liquid or gaseous hydrocarbons in the Lower Cretaceous strata is very poor.

UPPER JURASSIC

The Upper Jurassic stata of the COST No. G-1 well are characterized by alternating very fine- to coarse-grained sandstone, sligh tly calcareous shales with thin beds of silty dol mmite, traces of coal, pyrite, muscovite, shell fragments, and rare glauconite. The carbonate contert, of the Upper Jurassic section increases towards the UpperMiddle Jurassic boundary. The Upper Jurassic lithologies of the COST No. G-2 well are, in general, similar to those of the G-1. The G-2, however, contains a larger percentage of brown oolitic and algal carbonate rocks from 6,000 to 

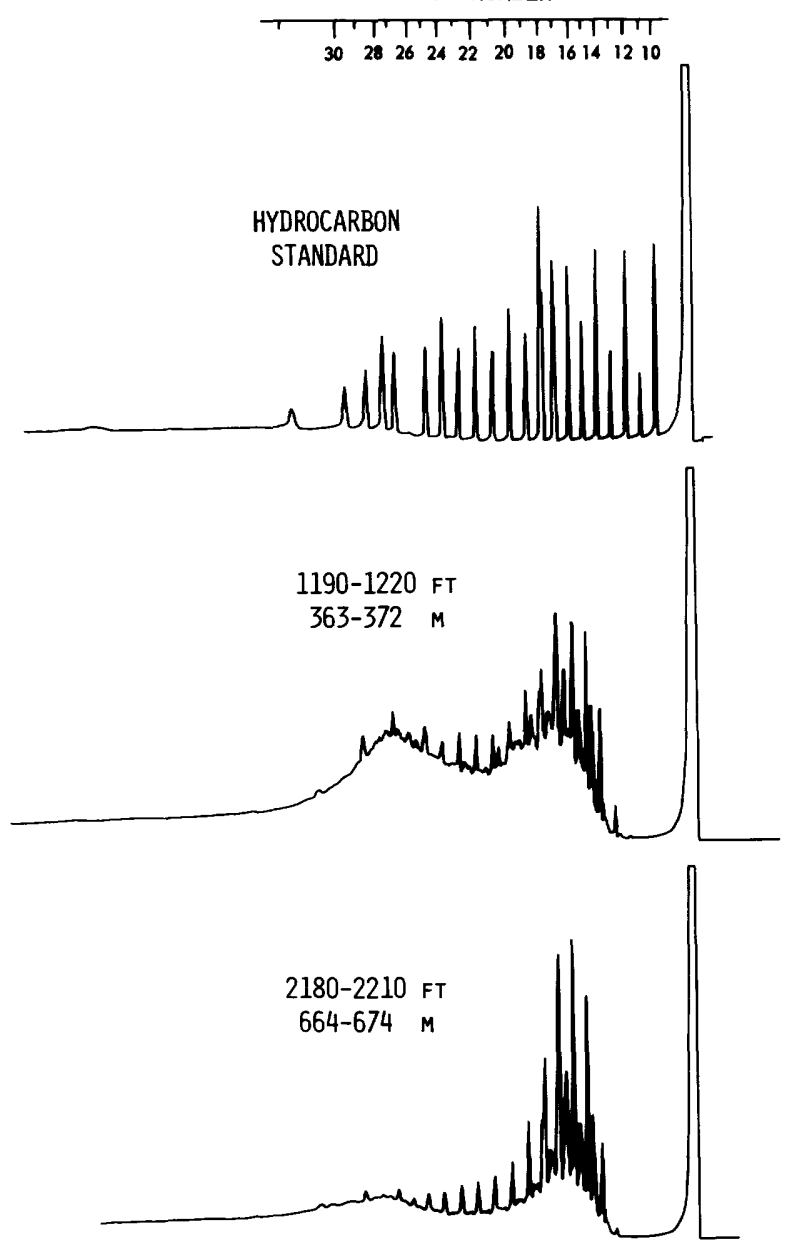

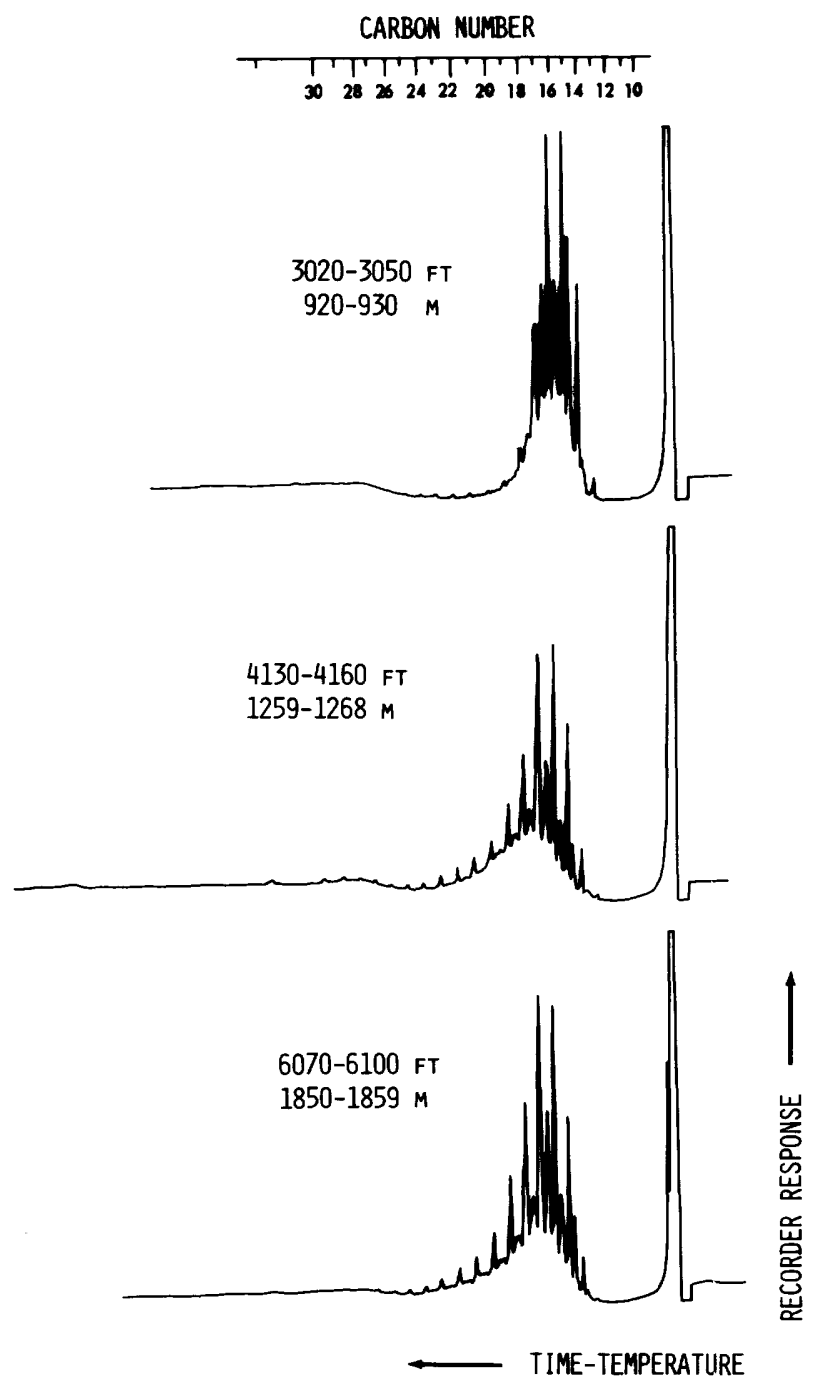

Figure 43.-Gas chromatographic analyses of saturated paraffin-naphthene hydrocarbons of Tertiary $(1,190$ to $1,220 \mathrm{ft} ; 363$ to $372 \mathrm{~m}$ ), Upper Cretaceous (2,180 to 2,210 ft; 664 to $674 \mathrm{~m}$ ), Lower Cretaceous (3,020 to 4,160 ft; 920 to 1,268 m), and Upper Jurassic $(6,070$ to $6,100 \mathrm{ft} ; 1,850$ to $1,859 \mathrm{~m})$ samples, COST No. G-2 well.

$7,000 \mathrm{ft}(1,829$ to $2,134 \mathrm{~m})$ (tables 1 and 2$)$ (Lachance, 1980; Simonis, 1980).

The Upper Jurassic strata in the two wells have similar average total organic carbon values of 0.73 percent $(G-1)$ and 0.62 percent $(G-2)$. The average hydrocarbon to total organic carbon ratios of 0.88 percent $(G-1)$ and 2.62 percent (G-2) suggest that the extractable organic matter of the Upper Jurassic units is approaching thermal maturity in the G-2. However, because of the effect that small absolute concentrations may have on a specific geochemical ratio, the interpretation of maturity must be viewed with caution (Claypool and others, 1978; Swetland and others, 1978; Miller and others, 1979, 1980. The Upper Jurassic rocks of the COST No. G-2 well have an average total extractable hydrocarbon content of $155 \mathrm{ppm}$ and a total hydrocarbon to extractable organic matter ratio of 0.60 . These values are higher than those for equivalent COST No. G-1 well strata, which average $39.0 \mathrm{ppm}$ total extractable hydrocarbons and 0.31 total hydrocarbon to extractable organic matter (tables 3 and 4). The polar nitrogen, sulfur, and oxygen concentrations range from 10 to $20 \mathrm{Cpm}$ for Upper Jurassic units in the COST No G-1 well and are usually less than $150 \mathrm{ppm}$ in the COST No. G-2 well. Although G-2 contains more 
TABLE 5.-Organic carbon and thermal analysis (Rock-Eval pyrolysis) data for samples from the COST No. G-1 well [Organic carbon analyses, wet oxidation method by Rhinehart Laboratories, Inc., Arvada, Colo. Rock-Eval pyrolysis by Jeff Baysinger, U.S. Geological Survey. The parameter $\mathrm{S}_{3}\left(\mathrm{CO}_{2}\right.$ derived from kerogen) was not determined in this study]

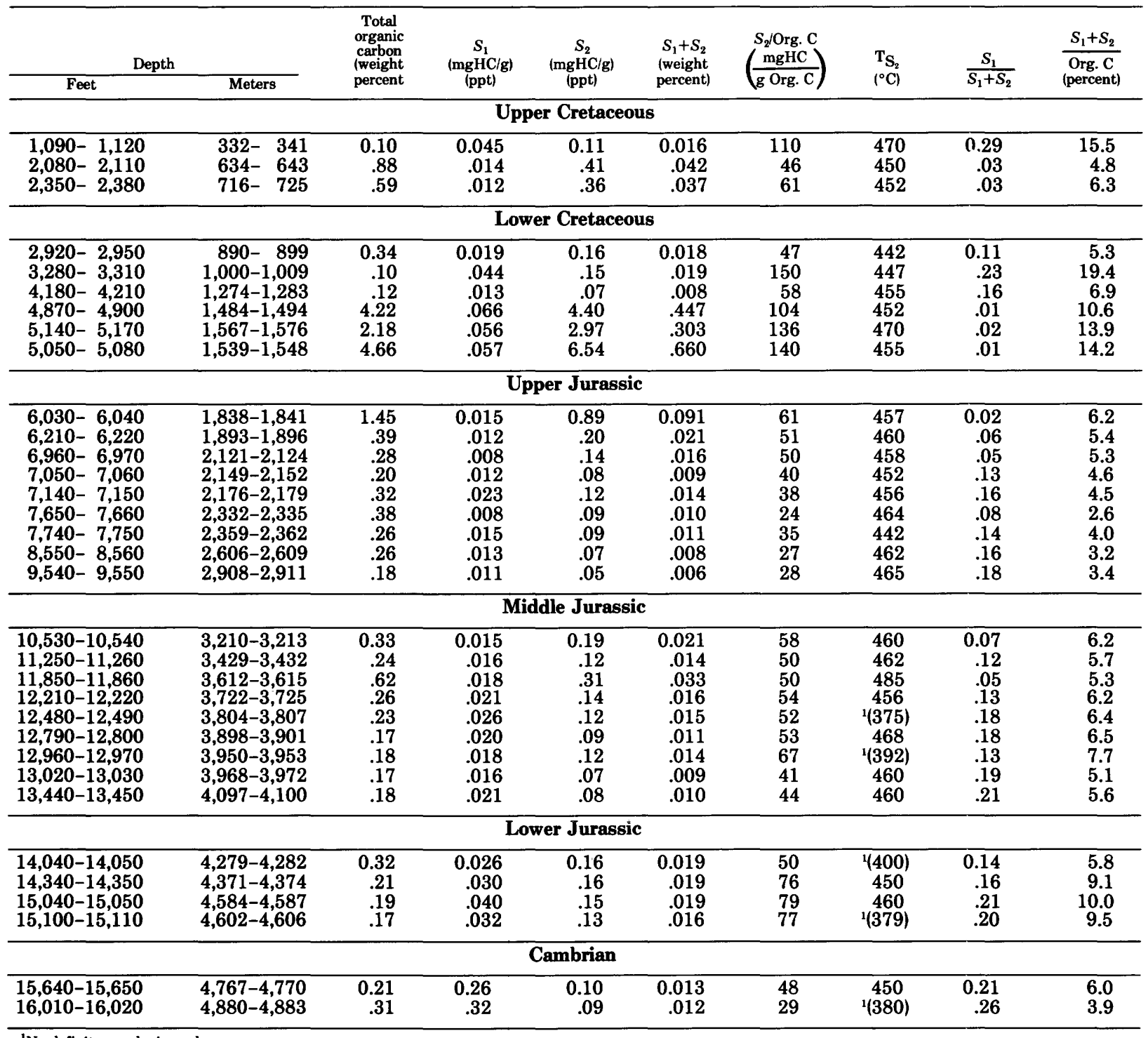

${ }^{1}$ No definite pyrolysis peak.

organic-rich sediment than G-1, the organicrichness properties of total organic carbon and total extractable hydrocarbons suggest that the Upper Jurassic rocks of the Georges Bank basin area have very poor source-rock quality (tables 3 and 4; figs. 40 and 41).

The saturated paraffin-naphthene hydrocarbon gas chromatograms for the Upper Jurassic rocks in the COST No. G-1 well, with the exception of the 9,030- to 9,070-ft (2,752- to 2,765-m) interval, show a strong unresolved bimodal envelope of branched and cyclic paraffins. The resolved aliphatics range from $n-C_{15}$ to $n-C_{30}$ and have an average CPI of 1.88 . The isoprennid pristane continues to predominate over both the isoprenoid phytane and $\mathrm{n}-\mathrm{C}_{17}$. There is no consistent change in the molecular composition and distribution of the resolved aliphatics or in the character of the unresolved complex envelope with increasing depth of burial in the Upper Jurassic strata of the COST No. G-1 well (fig. 44). In comparison, the resolved aliphatics of the Upper Jurassic strata from the COST No. G-2 well continue to dominate the unresolved envelope and are character- 
TABLE 6.-Organic carbon and thermal analysis (Rock-Eval pyrolysis) data for samples from the COST No. G-2 we" [Organic carbon analyses, wet oxidation method by Rhinehart Laboratories, Inc., Arvada, Colo. Rock-Eval pyrolysis by Jeff Baysinger, U.S. Geological Surrey. The parameter $\mathrm{S}_{\mathbf{3}}\left(\mathrm{CO}_{2}\right.$ derived from kerogen) was not determined in this study]

\begin{tabular}{|c|c|c|c|c|c|c|c|c|c|}
\hline \multicolumn{2}{|c|}{ Denth } & $\begin{array}{c}\text { Total } \\
\text { organic } \\
\text { carbon } \\
\text { (weight } \\
\text { percent }\end{array}$ & $\underset{\text { (mgHC) }}{S_{1}}$ & $\underset{(\mathrm{mghHC})}{S_{2}}$ & $\begin{array}{l}S_{1}+S_{2} \\
\text { (weight } \\
\text { percent) }\end{array}$ & $\left(\frac{S_{2} / \text { Org. C }}{\text { mgHC }}\right)$ & $\begin{array}{l}\mathbf{T}_{\mathbf{S}_{2}} \\
{ }^{\left({ }^{\circ} \mathrm{C}\right)}\end{array}$ & $\frac{S_{1}}{S_{1}+S_{2}}$ & $\frac{S_{1}+S_{2}}{\begin{array}{c}\text { Or.?. C } \\
\text { (percent }\end{array}}$ \\
\hline \multicolumn{10}{|c|}{ Tertiary } \\
\hline $1,130-1,160$ & $344-354$ & 0.65 & 0.310 & 1.20 & 0.151 & 185 & 460 & 0.205 & 23.2 \\
\hline \multicolumn{10}{|c|}{ Upper Cretaceous } \\
\hline $\begin{array}{l}1,550-1,580 \\
2,150-2,180 \\
2,510-2,540\end{array}$ & $\begin{array}{ll}472- & 482 \\
655- & 664 \\
765- & 774\end{array}$ & $\begin{array}{r}1.04 \\
.83 \\
.65\end{array}$ & $\begin{array}{r}0.090 \\
.100 \\
.045\end{array}$ & $\begin{array}{r}0.42 \\
.81 \\
.41\end{array}$ & $\begin{array}{r}0.051 \\
.091 \\
.046\end{array}$ & $\begin{array}{l}40 \\
98 \\
63\end{array}$ & $\begin{array}{c}447 \\
\text { ND } \\
451\end{array}$ & $\begin{array}{r}0.176 \\
.110 \\
.099\end{array}$ & $\begin{array}{r}4.9 \\
11.0 \\
7.0\end{array}$ \\
\hline \multicolumn{10}{|c|}{ Lower Cretaceous } \\
\hline $\begin{array}{l}3,110-3,140 \\
3,530-3,560 \\
4,130-4,160 \\
4,510-4,600 \\
5,050-5,080 \\
5,560-5,590\end{array}$ & $\begin{array}{r}948-957 \\
1,076-1,085 \\
1,259-1,268 \\
1,375-1,402 \\
1,539-1,548 \\
1,695-1,704\end{array}$ & $\begin{array}{r}0.83 \\
.74 \\
.54 \\
.37 \\
3.09 \\
1.73\end{array}$ & $\begin{array}{r}0.045 \\
.045 \\
.090 \\
2.000 \\
8.000 \\
6.600\end{array}$ & $\begin{array}{r}0.33 \\
.43 \\
.47 \\
2.10 \\
13.70 \\
8.00\end{array}$ & $\begin{array}{r}0.038 \\
.048 \\
.056 \\
.410 \\
2.170 \\
1.460\end{array}$ & $\begin{array}{r}40 \\
58 \\
87 \\
568 \\
443 \\
462\end{array}$ & $\begin{array}{l}465 \\
460 \\
456 \\
455 \\
465 \\
460\end{array}$ & $\begin{array}{l}0.120 \\
.095 \\
.161 \\
.488 \\
.369 \\
.452\end{array}$ & $\begin{array}{r}4.5 \\
6.4 \\
10.4 \\
110.8 \\
77.2 \\
8.4\end{array}$ \\
\hline \multicolumn{10}{|c|}{ Upper Jurassic } \\
\hline $\begin{array}{r}6,010-6,040 \\
6,550-6,580 \\
9,730-9,740 \\
10,230-10,240 \\
10,730-10,740 \\
11,230-11,240 \\
11,730-11,740\end{array}$ & $\begin{array}{l}1,832-1,841 \\
1,996-2,006 \\
2,966-2,969 \\
3,118-3,121 \\
3,271-3,274 \\
3,423-3,426 \\
3,575-3,578\end{array}$ & $\begin{array}{l}0.84 \\
.71 \\
.48 \\
.72 \\
.42 \\
.53 \\
.33\end{array}$ & $\begin{array}{l}1.000 \\
.660 \\
.630 \\
.550 \\
.390 \\
.340 \\
.290\end{array}$ & $\begin{array}{r}1.80 \\
1.00 \\
.87 \\
1.02 \\
.64 \\
.68 \\
.56\end{array}$ & $\begin{array}{l}0.280 \\
.166 \\
.150 \\
.157 \\
.103 \\
.102 \\
.085\end{array}$ & $\begin{array}{l}214 \\
141 \\
181 \\
142 \\
152 \\
128 \\
170\end{array}$ & $\begin{array}{l}482 \\
457 \\
470 \\
452 \\
472 \\
462 \\
464\end{array}$ & $\begin{array}{l}\mathbf{0 . 3 5 7} \\
.398 \\
.420 \\
.350 \\
.379 \\
.333 \\
.341\end{array}$ & $\begin{array}{l}3 \cap 3 \\
2.4 \\
31.3 \\
21.8 \\
24.5 \\
19.2 \\
2 \div .8\end{array}$ \\
\hline \multicolumn{10}{|c|}{ Middle Jurassic } \\
\hline $\begin{array}{l}12,230-12,240 \\
12,740-12,750 \\
13,230-13,240 \\
13,250-13,260 \\
13,750-13,760\end{array}$ & $\begin{array}{l}3,728-3,731 \\
3,883-3,886 \\
4,033-4,036 \\
4,039-4,042 \\
4,191-4,194\end{array}$ & $\begin{array}{l}0.38 \\
.267 \\
.33 \\
.29 \\
.20\end{array}$ & $\begin{array}{r}0.320 \\
.170 \\
.530 \\
.240 \\
.160\end{array}$ & $\begin{array}{r}0.49 \\
.31 \\
1.01 \\
.61 \\
.30\end{array}$ & $\begin{array}{l}0.081 \\
.048 \\
.154 \\
.085 \\
.046\end{array}$ & $\begin{array}{l}129 \\
119 \\
306 \\
210 \\
150\end{array}$ & $\begin{array}{l}462 \\
446 \\
448 \\
454 \\
\text { ND }\end{array}$ & $\begin{array}{r}0.395 \\
.354 \\
.344 \\
.282 \\
.348\end{array}$ & $\begin{array}{l}21.3 \\
18.5 \\
4 \times .7 \\
23.3 \\
23.0\end{array}$ \\
\hline $\begin{array}{l}14,250-14,260 \\
14,740-14,750 \\
15,250-15,260 \\
15,750-15,760 \\
16,240-16,250\end{array}$ & $\begin{array}{l}4,343-4,346 \\
4,493-4,496 \\
4,648-4,651 \\
4,801-4,804 \\
4,950-4,953\end{array}$ & $\begin{array}{l}.50 \\
.43 \\
.51 \\
.46 \\
.27\end{array}$ & $\begin{array}{l}.310 \\
.230 \\
.200 \\
.460 \\
.151\end{array}$ & $\begin{array}{r}1.66 \\
.58 \\
.66 \\
1.22 \\
.38\end{array}$ & $\begin{array}{l}.197 \\
.081 \\
.086 \\
.168 \\
.053\end{array}$ & $\begin{array}{l}332 \\
135 \\
129 \\
256 \\
141\end{array}$ & $\begin{array}{l}464 \\
468 \\
456 \\
460 \\
448\end{array}$ & $\begin{array}{l}.157 \\
.284 \\
.233 \\
.274 \\
.284\end{array}$ & $\begin{array}{l}37.4 \\
18.8 \\
16.9 \\
36.5 \\
20.0\end{array}$ \\
\hline $\begin{array}{l}16,740-16,750 \\
17,250-17,260 \\
17,750-17,760 \\
18,250-18,260 \\
18,750-18,760\end{array}$ & 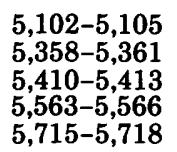 & $\begin{array}{r}.22 \\
.41 \\
.29 \\
.53 \\
1.10\end{array}$ & $\begin{array}{r}.110 \\
.150 \\
.074 \\
.175 \\
1.700\end{array}$ & $\begin{array}{r}.29 \\
.51 \\
.27 \\
.85 \\
5.24\end{array}$ & $\begin{array}{l}.040 \\
.066 \\
.034 \\
.103 \\
.694\end{array}$ & $\begin{array}{r}132 \\
124 \\
93 \\
160 \\
476\end{array}$ & $\begin{array}{l}446 \\
456 \\
436 \\
450 \\
460\end{array}$ & $\begin{array}{l}.275 \\
.227 \\
.215 \\
.171 \\
.245\end{array}$ & $\begin{array}{l}18.2 \\
16.1 \\
11.9 \\
19.3 \\
63.1\end{array}$ \\
\hline
\end{tabular}

ized by a rather narrow range of normal alkanes with an average CPI of 1.54 extending from $n-C_{15}$ to $\mathrm{n}-\mathrm{C}_{22}$, which are probably of a marine algal origin (figs. 43 and 45 ).

The average thermal pyrolysis convertibility of the Upper Jurassic strata from the COST No. G-2 well is 25.6 percent, which is significantly higher than the 4.4 percent of the COST No. G-1 well. This difference is thought to reflect the hydrogen-rich nature of the Upper Jurassic kerogens in the G-2, associated with shallow-water marine algal carbonates, as opposed to the predominance of hydrogen-poor humic-type kero- gens present in the $G-1$. The transformation ratios $\left(S_{1} /\left(S_{1}+S_{2}\right)\right)$ for the Upper Jurassic strata can be grouped into two distinct populations with the higher ratios predominating in the $\operatorname{COS}^{m}$ No. G-2 well samples. This difference may incicate greater thermal evolution of the more hydrnoenrich Upper Jurassic kerogens in the COST No. G-2 well. The temperature of maximum pyrclysis yield $\left(T_{S_{2}}\right)$ for the solid organic matter in the Upper Jurassic rocks ranges from $828^{\circ}$ to $86^{\circ}{ }^{\circ} \mathrm{F}$ $\left(442^{\circ}\right.$ to $\left.465^{\circ} \mathrm{C}\right)$ for the COST No. G-1 well. With the exception of the 6,010 - to $6,040-\mathrm{ft}(1,832-$ to $1,841-\mathrm{m})$ interval, which is $900^{\circ} \mathrm{F}\left(482^{\circ} \mathrm{C}\right)$, the 

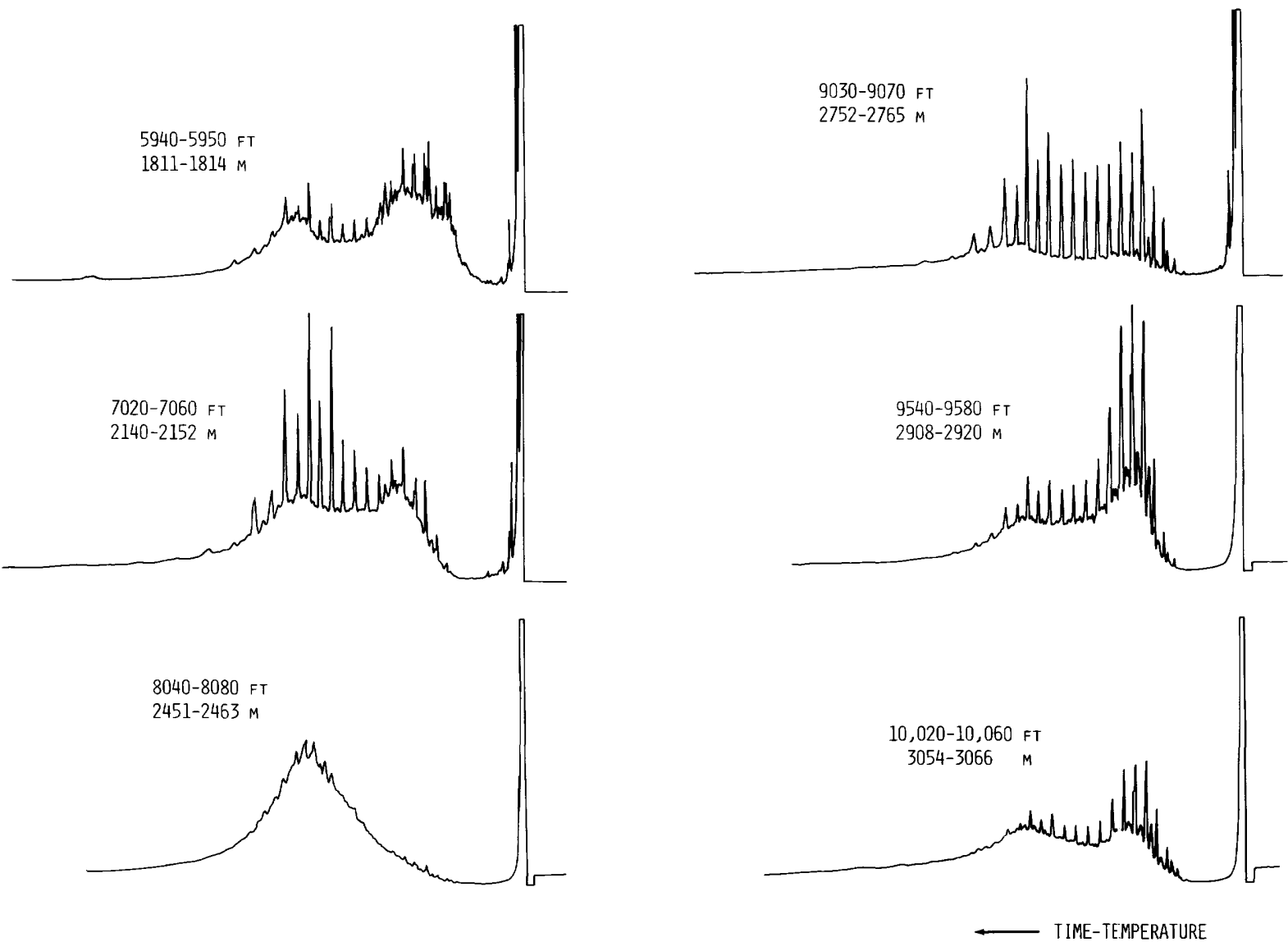

FIGURE 44.-Gas chromatographic analyses of saturated paraffin-naphthene hydrocarbons of Upper Jurissic rocks between $5,290 \mathrm{ft}(1,612 \mathrm{~m})$ and $10,100 \mathrm{ft}(3,078 \mathrm{~m})$, COST No. G-1 well.

temperature of maximum pyrolysis yield ranges from $846^{\circ}$ to $882^{\circ} \mathrm{F}\left(452^{\circ}\right.$ to $\left.472^{\circ} \mathrm{C}\right)$ for the Upper Jurassic strata of the COST No. G-2 well (tables 5 and 6). A maximum pyrolysis temperature of $878^{\circ} \mathrm{F}\left(470^{\circ} \mathrm{C}\right)$ is believed to be the critical temperature required to indicate the onset of maturation (Claypool and Baysinger, 1978). This temperature is also influenced by kerogen type, lithology, and design of the pyrolysis system (Hunt, 1979). For the COST No. G-2 well, the Upper Jurassic rocks appear to be slightly below the critical temperature threshold.

\section{MIDDLE JURASSIC}

The Middle Jurassic strata of the COST No. G-1 well occur from 10,100 to $14,000 \mathrm{ft}(3,078$ to $4,267 \mathrm{~m}$ ) and are characterized by interbedded pelletal carbonates, siltstones, sandstones, and gray shales that grade downward into dolomites, anhydrites, and thin shales. Traces of coal and pyrite occur from about 10,000 to $13,000 \mathrm{ft}(3,048$ to $3,962 \mathrm{~m}$ ). The Middle Jurassic strata from the COST No. G-2 well range from $11,800 \mathrm{ft}$ $(3,597 \mathrm{~m})$ down to at least $18,070 \mathrm{ft}(5,486 \mathrm{~m})$. Below $18,000 \mathrm{ft}(5,486 \mathrm{~m})$ and to the total well depth of $21,874 \mathrm{ft}(6,667 \mathrm{~m})$ it is possible that Lower Jurassic or Triassic strata may be present; however, because of the lack of micropaleontological control, the exact age of these older rock units cannot be determined (Behout, 1980). The Middle Jurassic interval in the G-2 well contains a much thicker section of brown to gray micritic and oolitic limestones, microcr.rstalline to fine crystalline dolomites, and anhydrites with considerably less shale and sandstor 9 than occurs in 

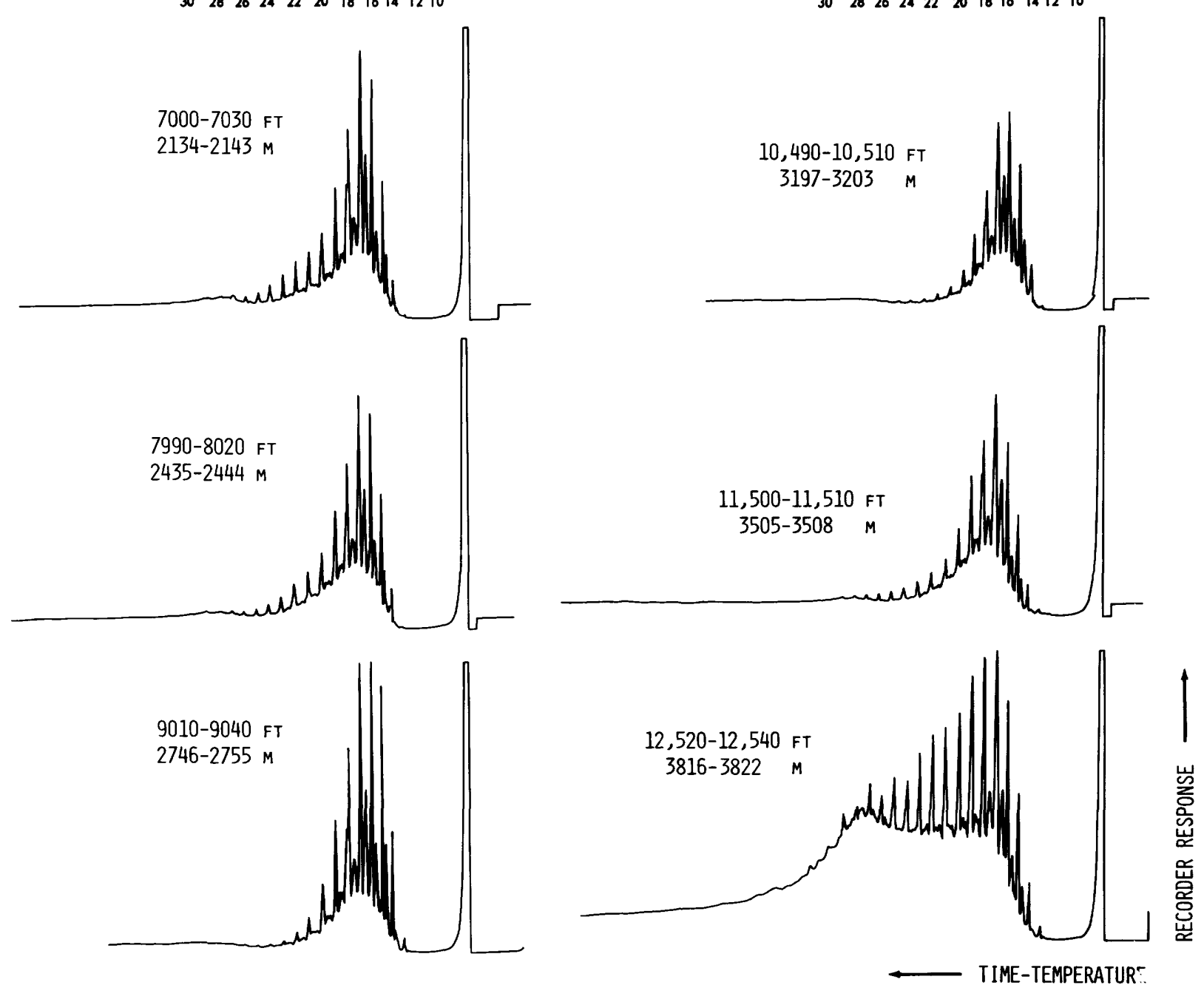

FIGURE 45.-Gas chromatographic analyses of saturated paraffin-naphthene hydrocarbons of Upper Jurassic 17,000 to $9,040 \mathrm{ft} ; 2,134$ to $2,755 \mathrm{~m})$, and Middle Jurassic rocks down to $12,540 \mathrm{ft}$ (3,822 m), COST No. G-2 well.

the G-1 well (tables 1 and 2). The Middle Jurassic strata probably were deposited in a shallowwater, restricted (supratidal to subtidal) environment (Lachance, 1980; Simonis, 1980).

The total organic carbon contents of the Middle Jurassic rocks from the COST Nos. G-1 and G-2 wells average 0.25 and 0.20 weight percent, respectively (tables 3 and 4). These values are slightly below the 0.3 percent considered adequate for some carbonate strata to be termed source rocks (Hunt, 1967). However, fine-grained, dark-colored carbonate rocks may be capable of generating more hydrocarbons than some shales that contain the same amount of total organic matter. Carbonate rocks commonly contain only amorphous organic matter derived from algae. This kind of organic matter has the highest yield of petroleum among the kerogen types, which may explain why dark-gray to medium-gray carbonate rocks commonly yield more oil than shales that have the same total organic-carbon content (Hunt, 1979). The question of how much organic carbon is needed to make an excellent, goxd, or poor carbonate source rock is highly cont oversial. From a qualitative point of view, horever, limestones and dolomites that are predominantly gray to dull brown or black commonly have an extractable hydrocarbon content equivalent t - that 

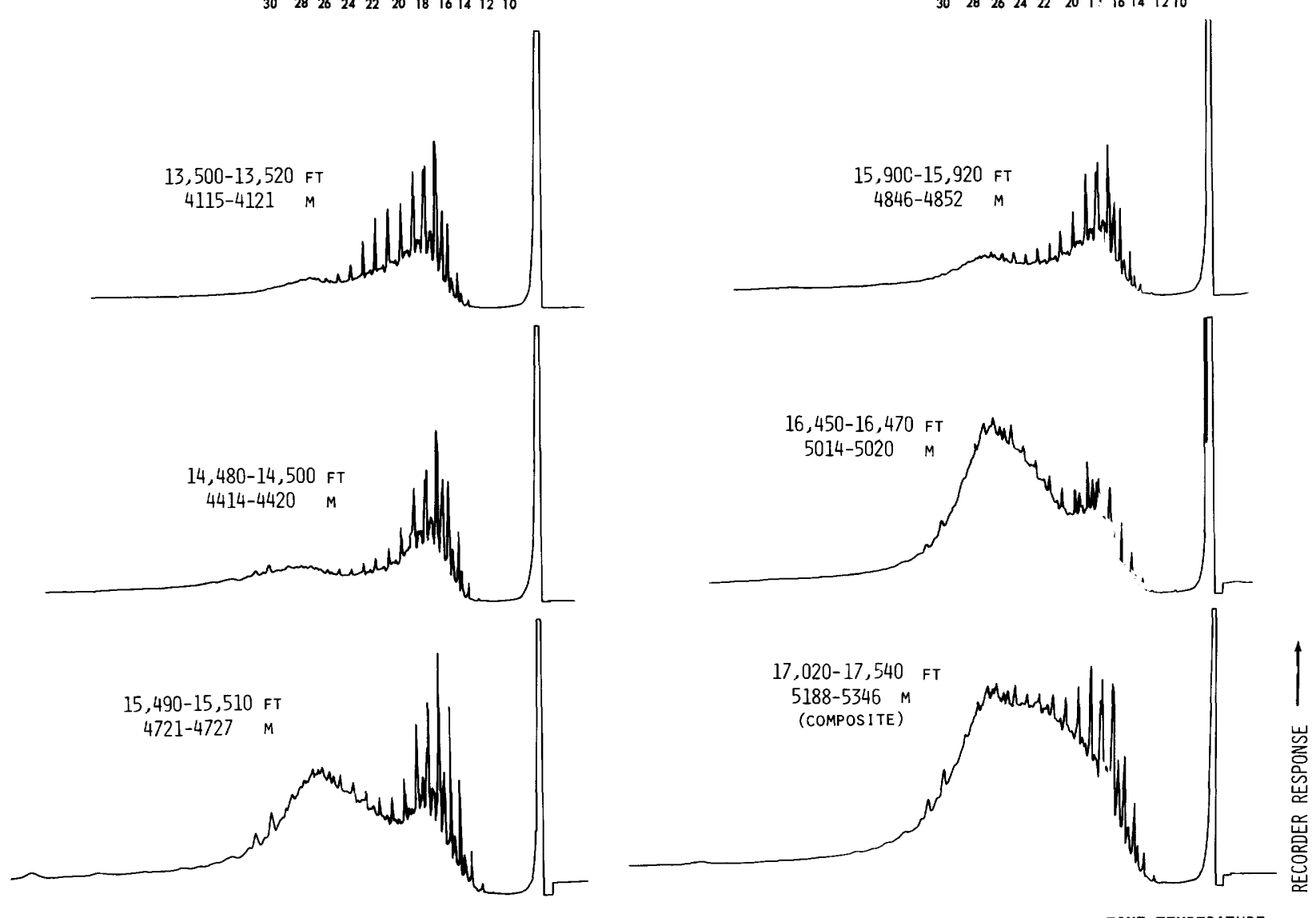

FIGURE 46.-Gas chromatographic analyses of saturated paraffin-naphthene hydrocarbons of Middle Jurassic rocks from 13,500 to $17,540 \mathrm{ft}(4,115$ to $5,346 \mathrm{~m})$, COST No. G-2 well. The 17,020 - to 17,540 -ft sample is a composite of two samples from $17,020-17,040$ and $17,520-17,540 \mathrm{ft}(5,188-5,194$ and $5,340-5,346 \mathrm{~m})$.

associated with good source rocks, whereas lightcolored, recrystallized carbonate rocks generally have very few, if any, indigenous hydrocarbons (Hunt, 1979). In addition, it has been demonstrated that organic matter and bitumen content increases with an increase in the clay content of carbonate strata (Hunt, 1967). Thus, the lightgray to black, argillaceous, fine-grained carbonate rocks of the Middle Jurassic section could be considered as potential source rocks.

A major difference exists between the average total extractable hydrocarbons of the Middle Jurassic sediments from the COST Nos. G-1 and G-2 wells. The G-1 rocks contain an average of $36 \mathrm{ppm}$, whereas the G-2 strata average $170 \mathrm{ppm}$. Although these values are both low in terms of source-rock richness, the difference in quality may be related to the nearshore character of the Middle Jurassic in the COrT No. G-1 well. The Middle Jurassic section of th: G-2 contains a much larger percentage of marine carbonate rocks and anhydrites. The average total hydrocarbon to total organic carbon ritios may signal the begining of the intense oil generation process below $10,000 \mathrm{ft}(3,050 \mathrm{~m})$ in the Middle Jurassic (table 3 and 4). Between 15,000 and 18,000 ft $(4,572$ and $5,486 \mathrm{~m})$ in the COST $\Gamma^{\top} \mathrm{o}$. G-2 well, the Middle Jurassic rocks contain a higher concentration of nitrogen, sulfur, and oxygen compounds than occurs in the Upper Jurassic or Cretaceous rocks (fig. 41). This higher concontration of the polar compounds is believed to reflect the nature and type of organic matter present in this interval. Traces of a black, asphalt-like substance, soluble in carbon disulfide, was presint in several of the cutting samples between 15,500 and $18,000 \mathrm{ft}$ 
$\begin{array}{llllllllllll}30 & 28 & 26 & 24 & 22 & 20 & 18 & 16 & 14 & 12 & 10\end{array}$
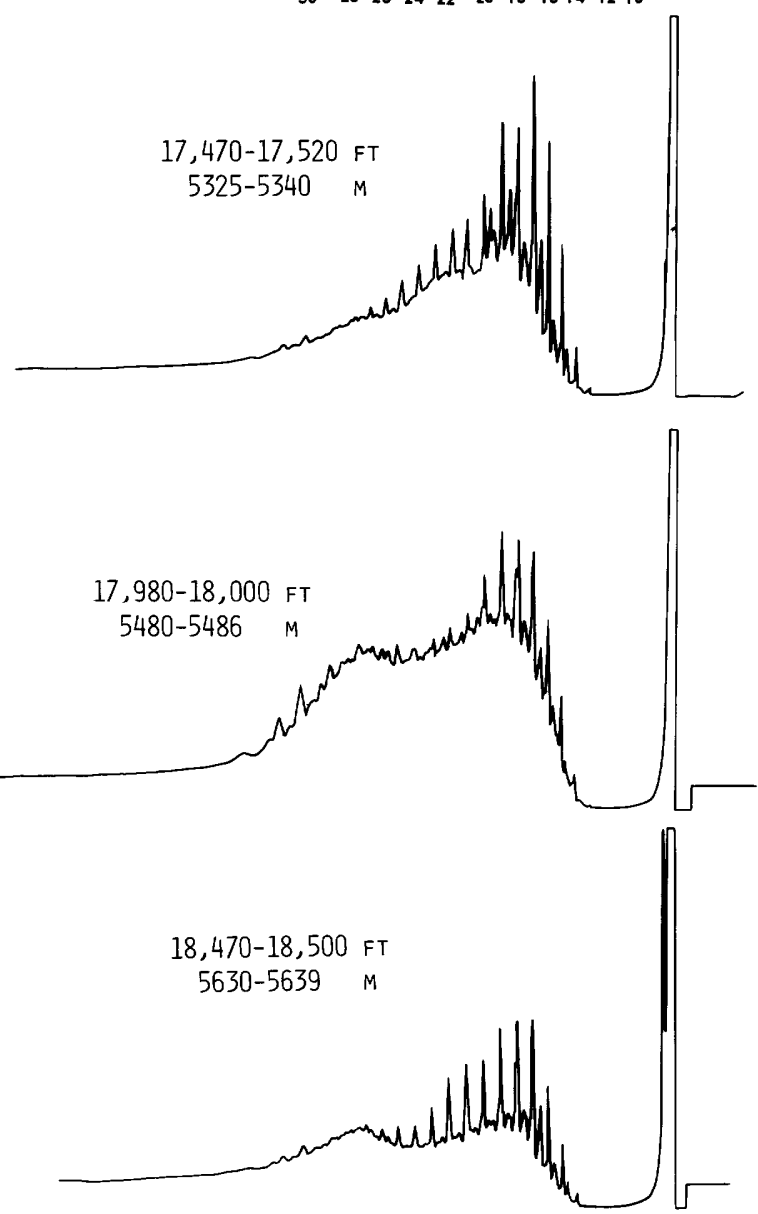

$\begin{array}{lllllllllll}30 & 28 & 26 & 24 & 22 & 20 & 18 & 16 & 14 & 12 & 10\end{array}$
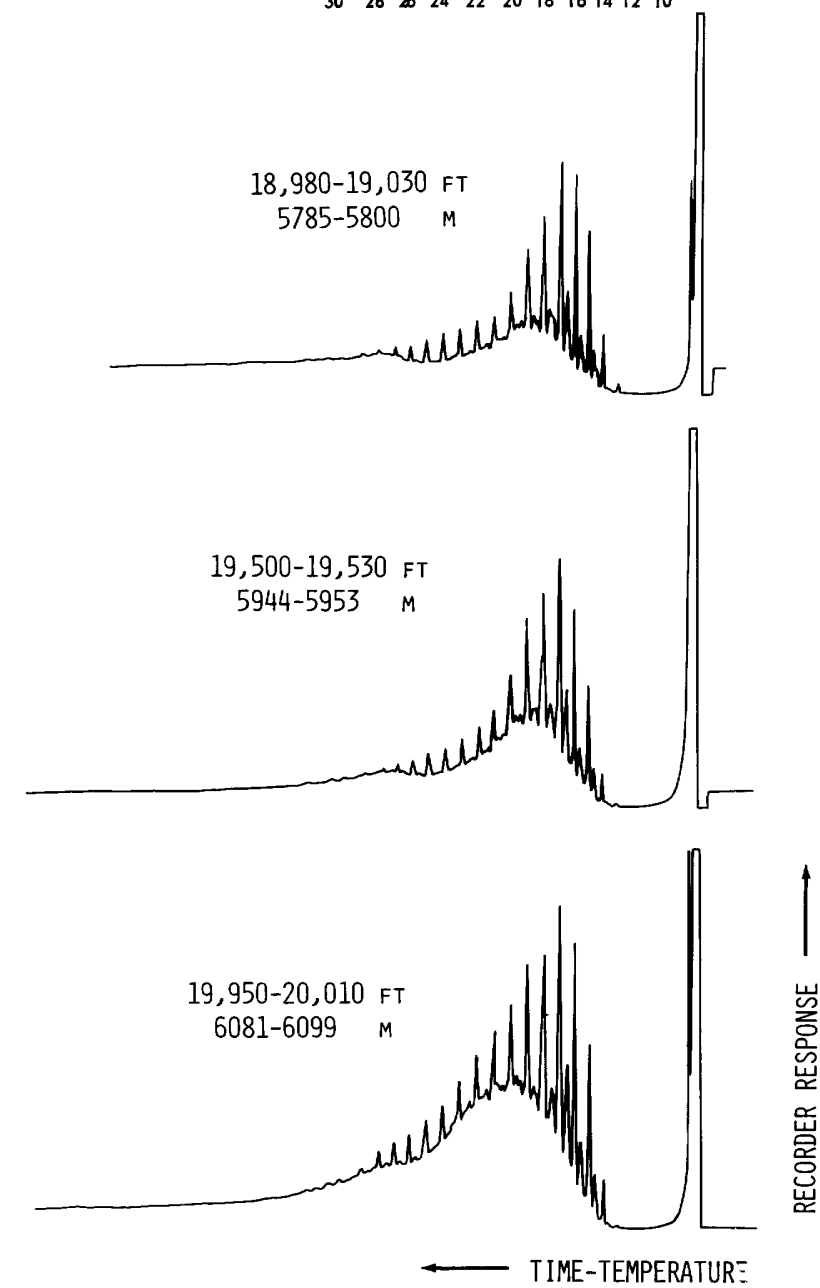

FIGURE 47.-Gas chromatographic analyses of saturated paraffin-naphthene hydrocarbons of Middle Jurassic rocks from 17,470 to $20,010 \mathrm{ft}(5,325$ to $6,099 \mathrm{~m})$, COST No. G-2 well.

$(4,724$ and $5,486 \mathrm{~m})$. A gas chromatogram of the saturated paraffin-naphthene hydrocarbons from a similar substance isolated by GeoChem Laboratories, Inc., in samples from below $14,000 \mathrm{ft}$ $(4,267 \mathrm{~m})$ is shown in figure 39 . If this substance is indigenous, it supports the interpretation of low thermal maturity; however, the possibility is equally good that the substance may be a mud contaminant. Because this substance was present only in a few samples from a limited interval, its interference with the paraffin-naphthene signatures of this interval is believed to be minimal except where noted.

The saturated paraffin-naphthene hydrocarbon gas chromatograms for the Middle Jurassic strata from 12,520 to $21,540 \mathrm{ft}(3,816$ to $6,565 \mathrm{~m})$ in the COST No. G-2 well show an irregula: and inconsistent change in the magnitude of the unresolved bimodal branched and cyclic paraffins relative to the resolved aliphatics (figs. 4f, 47, 48). This inconsistent change may be due in part to possible background interference by mut additives. Except in the 12,520- to $12,10-\mathrm{ft}$ $(3,816$-to $3,822-\mathrm{m})$ interval, the major portion of the resolved aliphatic hydrocarbons are the $n-C_{15}$ to $\mathrm{n}-\mathrm{C}_{22}$ molecular species, which predominate over the isoprenoid hydrocarbons pristane and phytane. Although not completely source-sp?cific because of the masking effects of catagensis, the pristane/phytane ratio varies throughout the Middle Jurassic between 1.1 and 2.0, prol ably indicating the influence of mixed marine-glgal, 
CARBON NUMBER

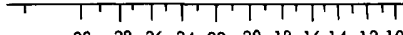

$\begin{array}{lllllllllll}30 & 28 & 26 & 24 & 22 & 20 & 18 & 16 & 14 & 12 & 10\end{array}$

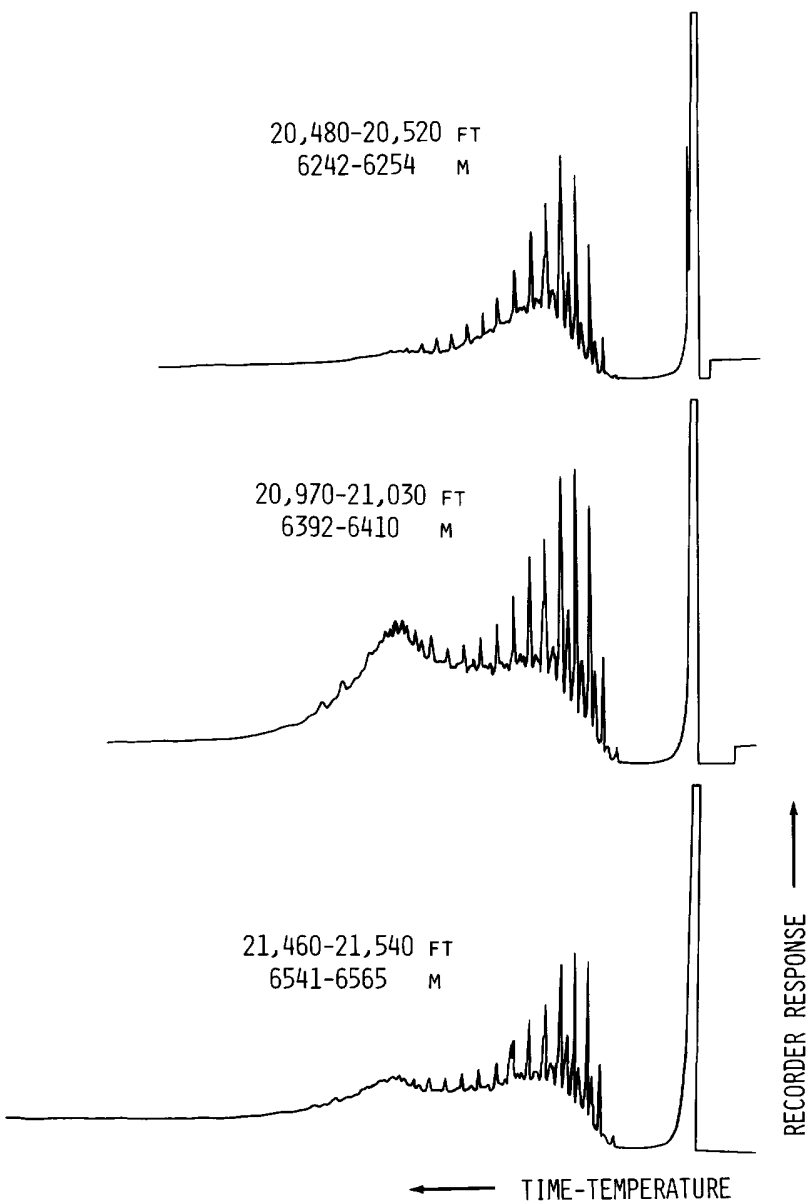

FIGURE 48.-Gas chromatographic analyses of saturated paraffin-naphthene hydrocarbons of Middle Jurassic rocks from 20,480 to $21,540 \mathrm{ft}(6,242$ to $6,565 \mathrm{~m})$, COST No. G-2 well.

herbaceous, and woody organic matter. At about $18,500 \mathrm{ft}(5,639 \mathrm{~m})$, the resolved normal alkanes begin to predominate over the unresolved complex envelope and shift toward the lower molecular weight ranges, and the CPI ratio approaches unity (figs. 47 and 48). Such characteristics indicate that thermal maturation processes have been active. However, at a depth of 21,460 to $21,540 \mathrm{ft}(6,541$ to $6,565 \mathrm{~m})$, the resolved normal aliphatics, the molecular distribution and composition, and the unresolved napthenic envelope still do not resemble those of thermally mature petroleum hydrocarbons and may be influenced by mud additives (fig. 48).
In the COST No. G-1 well, the Middle Jurassic section is much thinner than in the COST No. G-2 well, extending from $10,1 \mathrm{C}$ ? $14,000 \mathrm{ft}$ $(3,078$ to $4,267 \mathrm{~m})$. The resolved normal aliphatics occur predominantly in the $\mathrm{n}-\mathrm{C}_{14}$ to $\mathrm{n}-\mathrm{C}_{22}$ range, except for the 12,360 - to $12,400-\mathrm{ft}(3,767-$ to $3,780-\mathrm{m}$ ) sample, and generally aro dominated by a strongly bimodal, unresolved, complex mixture, a signature that usually indicates a lowtemperature thermal history for the liquid $\mathrm{C}_{15+}$ hydrocarbons (figs. 49 and 50). Throughout the Middle Jurassic section, the risolved normal aliphatic hydrocarbons dominat? over the isoprenoids pristane and phytane. The generally low concentration of the aliphatics in the $n-C_{27}$ to $n-C_{35}$ range, the predominance of the resolved normal aliphatics from $n-C_{14}$ tc $n-C_{22}$, and an average CPI ratio of 1.2 are cl aracteristics of hydrocarbons that are considered to have a marine origin.

The temperatures of maximum thermal pyrolysis yield for the Middle Jurassic strata in the COST Nos. G-1 and G-2 wells average $867^{\circ} \mathrm{F}$ $\left(464^{\circ} \mathrm{C}\right)$ and $849^{\circ} \mathrm{F}\left(454^{\circ} \mathrm{C}\right)$, respectively. These temperatures are consistent with the interpretation of a relatively low degree of thermal maturation, which is in general agreement with the lowthermal-maturity signatures of the saturated paraffin-naphthene hydrocarbon gas chromatograms (tables 5 and 6; figs. 45-5C!

\section{LOWER JURASSIC AND CAME PIAN}

Lower Jurassic and Cambrian rocks were penetrated in the COST No. G-1 well. The Lower Jurassic rocks extend from $14, \mathrm{C} 20$ to $15,630 \mathrm{ft}$ $(4,267$ to $4,764 \mathrm{~m})$, and the Cambrian from 15,630 to $16,061 \mathrm{ft}(4,764$ to $4,895 \mathrm{~m})$. The Lower Jurassic is characterized by light-gray to buff dolomites, anhydrites, and mica?eous siltstones that grade downward into coarse-grained sandstones and red hematitic mudstones (table 1). Only traces of dolomite are present below a depth of about $15,000 \mathrm{ft}(4,572 \mathrm{~m})$. Chips of black, graphitic schist, present from 16,056 to $16,061 \mathrm{ft}$ $(4,894$ to $4,895 \mathrm{~m})$, yielded $\mathrm{K}-\mathrm{Ar}$ ages of 450 to 550 million years (Steinkraus, 1980).

The total extractable hydrocarbons for the Lower Jurassic and Cambrian rocks averaged $39 \mathrm{ppm}$, and these intervals hav'e average total organic carbon values of 0.11 and 0.14 weight percent, respectively. The ratio of total hydrocarbon 

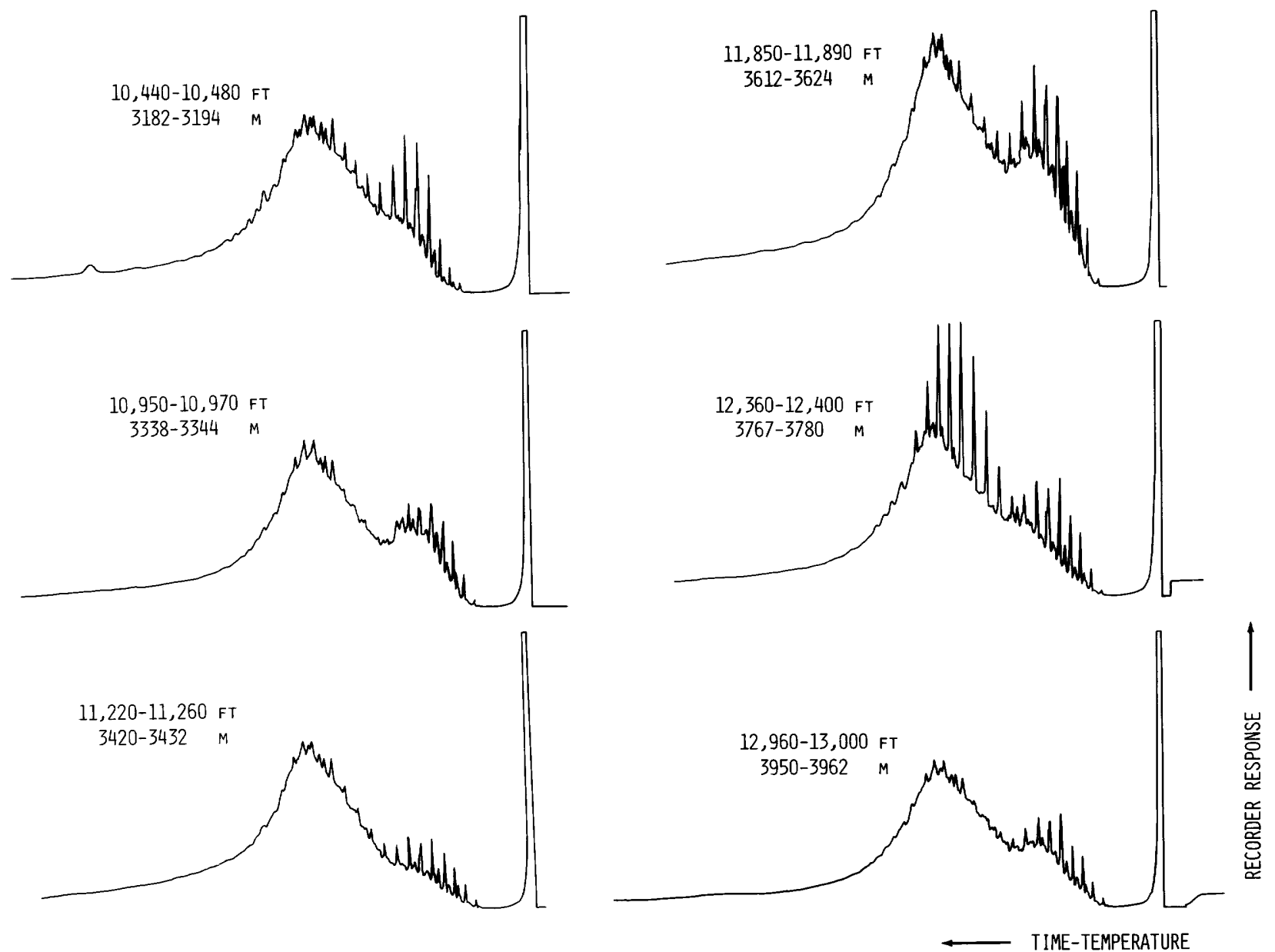

FIGURE 49.-Gas chromatographic analyses of saturated paraffin-naphthene hydrocarbons of Middle Jurassic rocks above $13,000 \mathrm{ft}(3,962 \mathrm{~m})$, COST No. G-1 well.

to total organic carbon averages 5.37 percent for the Lower Jurassic and 4.52 percent for the Cambrian rocks. The average ratios of total hydrocarbon to extractable organic matter are 0.43 and 0.61 , saturated hydrocarbon to aromatic hydrocarbon ratios are 2.48 and 2.00 , and Carbon Preference Indices (CPI) are 0.88 and 1.10 for the G-1 Lower Jurassic and Cambrian, respectively (table 3). The progressive increase in the average values from the Upper through Lower Jurassic strata indicates progressively increasing thermal maturation. The saturated paraffin-napthene hydrocarbon gas chromatograms, however, continue to show a strong bimodal distribution of the unresolved complex mixture with a predominance of the naphthenes over the resolved n-alkanes, a signature that may indicate mud additive effects (fig. 50). These gas chromatographic chararteristics of thermal immaturity are inconsistent with the extractable hydrocarbon ratios that indicate a time-temperature history characterist: $\mathrm{c}$ of mature sources. The low average convertibility $\left(\left(S_{1}+S_{2}\right) / O r g\right.$. C) of 8.6 indicates the predominance of hydrogen-poor organic matter. The average thermal-pyrolysis maximum-yield temperature for the Lower Jurassic and Cambrian rock: was calculated to be $847^{\circ} \mathrm{F}\left(453^{\circ} \mathrm{C}\right)$ where definite thermal peaks were present (table 5). This temperature of maximum yield indicates that the solid organic matter in the Lower Jurassi: and 

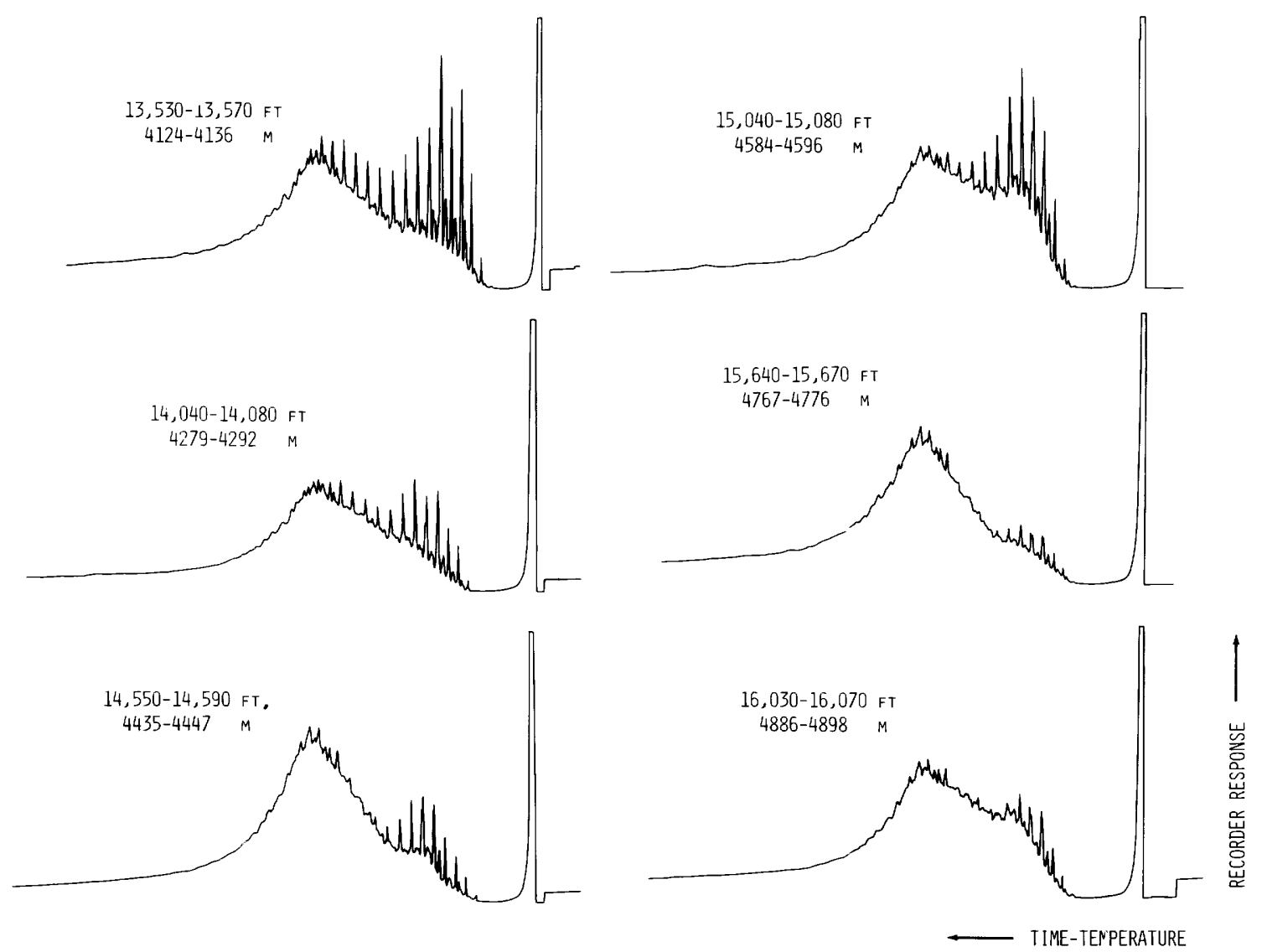

Figure 50.-Gas chromatographic analyses of saturated paraffin-naphthene hydrocarbons of Middle J:rrassic (13,530 to $13,570 \mathrm{ft} ; 4,124$ to $4,136 \mathrm{~m})$, Lower Jurassic $(14,040$ to $15,080 \mathrm{ft} ; 4,279$ to $4,596 \mathrm{~m})$, and Cambrian $(15,640$ to $16,070 \mathrm{ft} ; 4,767$ to $4,898 \mathrm{~m}$ ) rocks, COST No. G-1 well.

Cambrian rocks are apparently still thermally immature with respect to the generation of liquid hydrocarbons. This temperature of maximum yield may be influenced by the low total organic matter content of the rocks. The $S_{1} /\left(S_{1}+S_{2}\right)$ production index ratio, which is a measure of maturation, does however, show a consistent increase from 0.14 at 14,040 to $14,050 \mathrm{ft}(4,279$ to $4,282 \mathrm{~m})$ to 0.26 at 16,010 to $16,020 \mathrm{ft}(4,880$ to $4,883 \mathrm{~m})$ and indicates significant thermal maturity.

The low total organic carbon (average 0.12 weight percent) and the thermal-pyrolysis and gas chromatographic maturity characteristics of the organic matter in the Lower Jurassic and Cambrian rocks suggest that this interval in the COST No. G-1 has a very poor oil and gas sourcerock potential.

\section{KEROGEN TYPES AND THERMAL MATUF A TION FOR THE COST NO. G-1 WELL}

The geochemical parameters used to classify the kerogens in the COST No. G-1 well are relative type and abundance, hydrogen to carbon ratios, stable carbon isotope comnositions $\left(\delta^{13} \mathrm{C}\right)$, and thermal pyrolysis hydrogen ir tex $\left(S_{2} / \mathrm{Org}\right.$. C $)$, (fig. 51). The sediments of the COST No. G-1 down to a burial depth of about $6,000 \mathrm{ft}(1,820 \mathrm{~m})$ contain mainly amorphous and herbaceous, hydrogen-rich kerogens (fig. 51). Below 6,0.00 ft $(1,829 \mathrm{~m})$, there is a considerable decrease in the abundance of amorphous keroger and a significant increase in the herbaceous, wrody, and coaly types. This predominance of hydrogen-poor kerogen extends into the Lower Jurrssic and Cambrian rocks below $14,000 \mathrm{ft}(4,267 \mathrm{~m})$ and is be- 


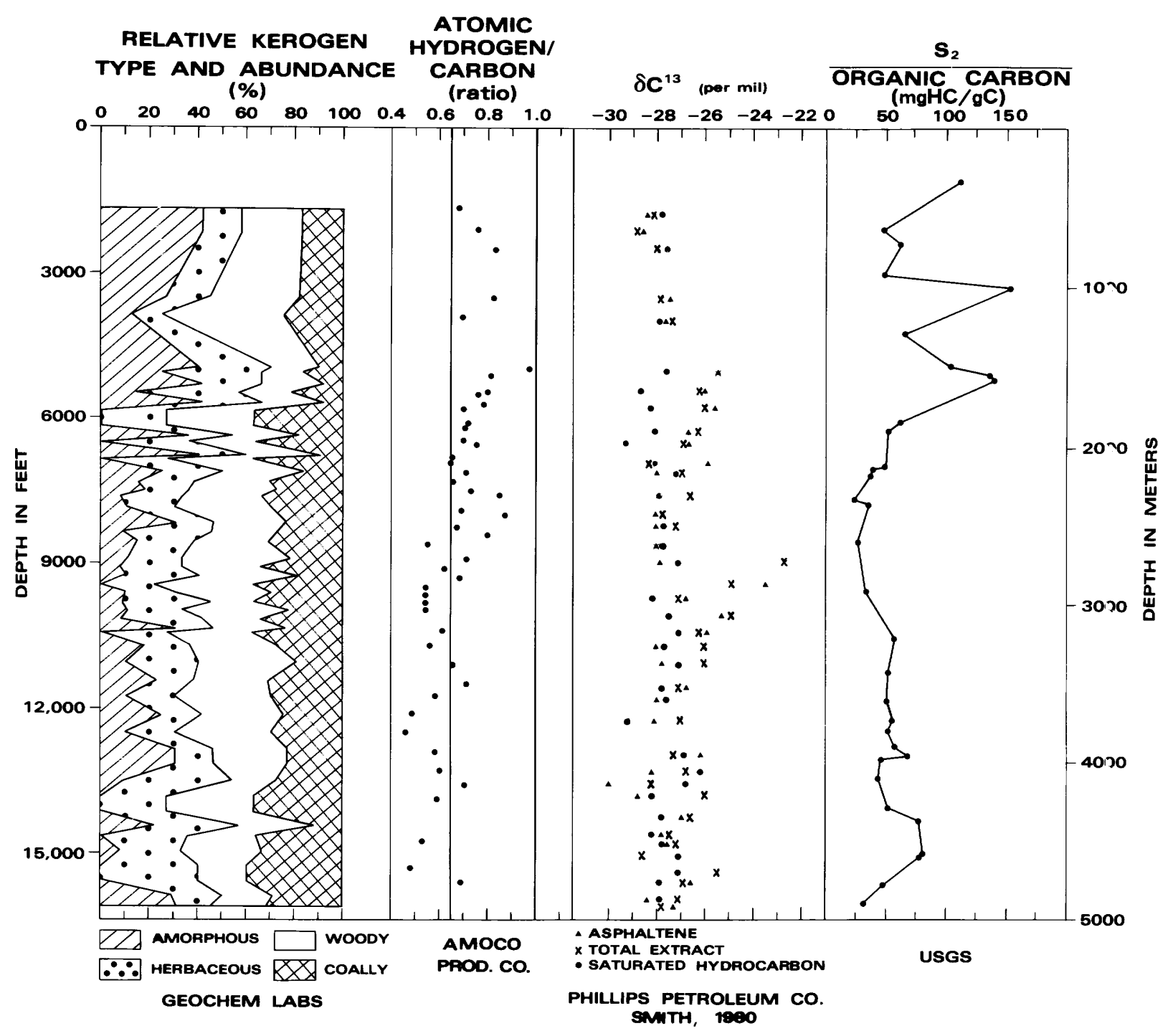

FIGURE 51.-Summary profile of indicators of types of organic matter present in the COST No. G-1 well as a function of depth of burial.

lieved to reflect the influence of the terrestrially derived organic matter associated with nearshore sedimentary facies.

In the COST No. G-1 well, the hydrogen to carbon ratios of the kerogens range from 0.5 to 0.9 . The hydrogen-poor character of these kerogens is also indicated by their average thermal pyrolysis hydrogen indices $\left(S_{2} / \mathrm{Org}\right.$. C), which range from 38 in the Cambrian to 118 in the Lower Cretaceous (table 5). Such values are generally consistent with poor-quality source rocks that contain predominantly hydrogen-lean, type III, gasprone kerogens. The stable carbon isotopic compositions of the asphaltene, total extracts, and saturated paraffin-naphthene fractions are shown in figure 51. Yen (1972) has reported thet the asphaltene fraction of an oil should have a $\delta^{13} \mathrm{C}$ value similar to that of the kerogen from wl ich it was derived. This isotopic relationship is due to the structural and chemical similarities be ${ }^{+}$ween the asphaltene and kerogen. Stahl (1978' confirmed the isotopic similarity between genetically associated kerogens and asphaltenes from crude oils. In the COST No. G- well, no $\delta^{13} \mathrm{C}$ values of the kerogens were available for comparisor with those of the asphaltenes. However, if it is assumed that a genetic asphaltene-kerogen chemical structure relationship does exist (Yen, 1972; 
Stahl, 1978) and that this relationship can be extended to include the asphaltene fractions associated with the total bitumen extractables of the source shales (believed to represent that portion of the generated hydrocarbons remaining at the place of origin), then the $\delta^{13} \mathrm{C}$ values of the asphaltene fraction of the source shales may be interpreted as being representative of the $\delta^{13} \mathrm{C}$ ratio of the source kerogens. The $\delta^{13} \mathrm{C}$ values for the asphaltene fractions of the COST No. G-1 well are predominatly between -26 and -28 permil. Such $\delta^{13} \mathrm{C}$ values are, however, inconsistent with the $\delta^{13} \mathrm{C}$ values of the predominantly terrestrial kerogen types described from well cuttings. With the exception of those from the Cretaceous strata, the kerogens of $\mathrm{G}-1$ are considered to have a predominantly terrestrial source, as indicated by their relative abundances determined by optical microscopy methods (fig. 51).

The distribution and concentration of the $C_{1}$ to $\mathrm{C}_{7}$ hydrocarbons, the percent gas wetness, and the $\mathrm{n}-\mathrm{C}_{4}$ to $\mathrm{n}-\mathrm{C}_{7}$ ratios for the COST No. G-1 well are shown in figure 52, and the thermal maturation geochemical characteristics for G-1 are shown in figure 53. The maximum $C_{1}$ to $C_{4}$ light hydrocarbon concentrations range from 15,000 to $27,000 \mathrm{ppm}$ in the $4,500-$ to $6,500-\mathrm{ft}(1,372-$ to 1,981-m) Cretaceous-Jurassic interval, and generally the strata have less than 10 percent gas wetness. These Cretaceous-Jurassic rocks contain lignitic and peaty types of organic matter. The extractable organic matter from this interval is characterized by the highest total organic carbon, total extractable saturated paraffin-naphthene, and aromatic hydrocarbons. The nitrogen, sulfur, and oxygen compound concentrations in this interval range from 50 to $200 \mathrm{ppm}$. The apparently low thermal maturity of the extractable organic matter, and low gas wetness, as well as the presence of terrestrial organic matter associated with these Cretaceous-Jurassic sandstones and shales, suggest that the light hydrocarbons in this interval are probably unrelated to indigenous, thermally produced, mature liquid petroleum hydrocarbons. This interpretation is consistent with the bimodal distributions of the saturated paraffin-naphthene hydrocarbon gas chromatograms, the CPI ratios that show a predominance of odd-carbon chain hydrocarbons, the moderately low temperatures of maximum thermal pyrolysis yield $\left(846^{\circ}\right.$ to $878^{\circ} \mathrm{F} ; 452^{\circ}$ to $470^{\circ} \mathrm{C}$ ), and TAI values that range from 1.5 to 1.8 (figs. 41, 43, 44, and 49-53).

Where the $n-C_{4} / n-C_{7}$ profile shows values that are less than unity, the possibility exists that diesel fuel contamination may be present $(7,000-$ $10,000 \mathrm{ft}, \quad 2,134-3,048 \mathrm{~m} ; 12,000-13,000 \mathrm{ft}$, $3,658-3,962 \mathrm{~m}$; and $14,000-15,000 \mathrm{ft}$; 4,267-4,572 m) (fig. 52). However, the $n-C_{4} / n-C_{7}$ ratio compares molecular speciss that are in gaseous and liquid physical states. Because of the possibility of preferential loss of the lower molecular weight species due to the difference in vapor pressures, this ratio may be misleading and should be used with caution; the presence of diesel fuel should not be inferred on the basis of this ratio alone. The molecular distribution and concentrations of the saturated paraffinnaphthene hydrocarbons do not reflect the presence of diesel fuel in the litholo ric units below $6,500 \mathrm{ft}(1,981 \mathrm{~m})$. Although an ir consistency exists with the $n-C_{4} / n-C_{7}$ ratio . the normal saturated paraffin-naphthene hydrocarbon distributions and the thermal-maturation interpretations are not believed to be influmnced by diesel fuel effects.

If vitrinite reflectance $\left(R_{o}\right)$ values are determined on primary (first-cycle) vitrinite macerals and the geothermal gradient is assumed to be constant, then for a sedimentar. ${ }^{r}$ basin with a simple burial history involving $r$ ? loss of overburden by erosion, vitrinite reflectance is the only thermal maturation parameter that is believed to increase exponentially with thermal maturity and to be unaffected by kerogen composition (Dow, 1977). The slope of the vitrinite reflectance profile is a function of the maximum $\varepsilon$ othermal gradient and the age of the lithologic units or, more specifically, the length of the time of heating. In those instances where sedimentary units have experienced varying geothermal gradients, segmented maturation gradients may occur. If the $R_{o}$ values are plotted on a log scale and depth on a linear scale, the relationship between the two parameters for each segment will usually be a straight line (Dow, 1977). Vitririte reflectance values determined on well cuttings, however, may give anomalous results. Sucl factors as the presence of oxidized vitrinite or recycled material, natural variations, and statistical and technical errors in not selecting first-cycle vitrinite, can produce abnormally high $R_{o}$ values, 


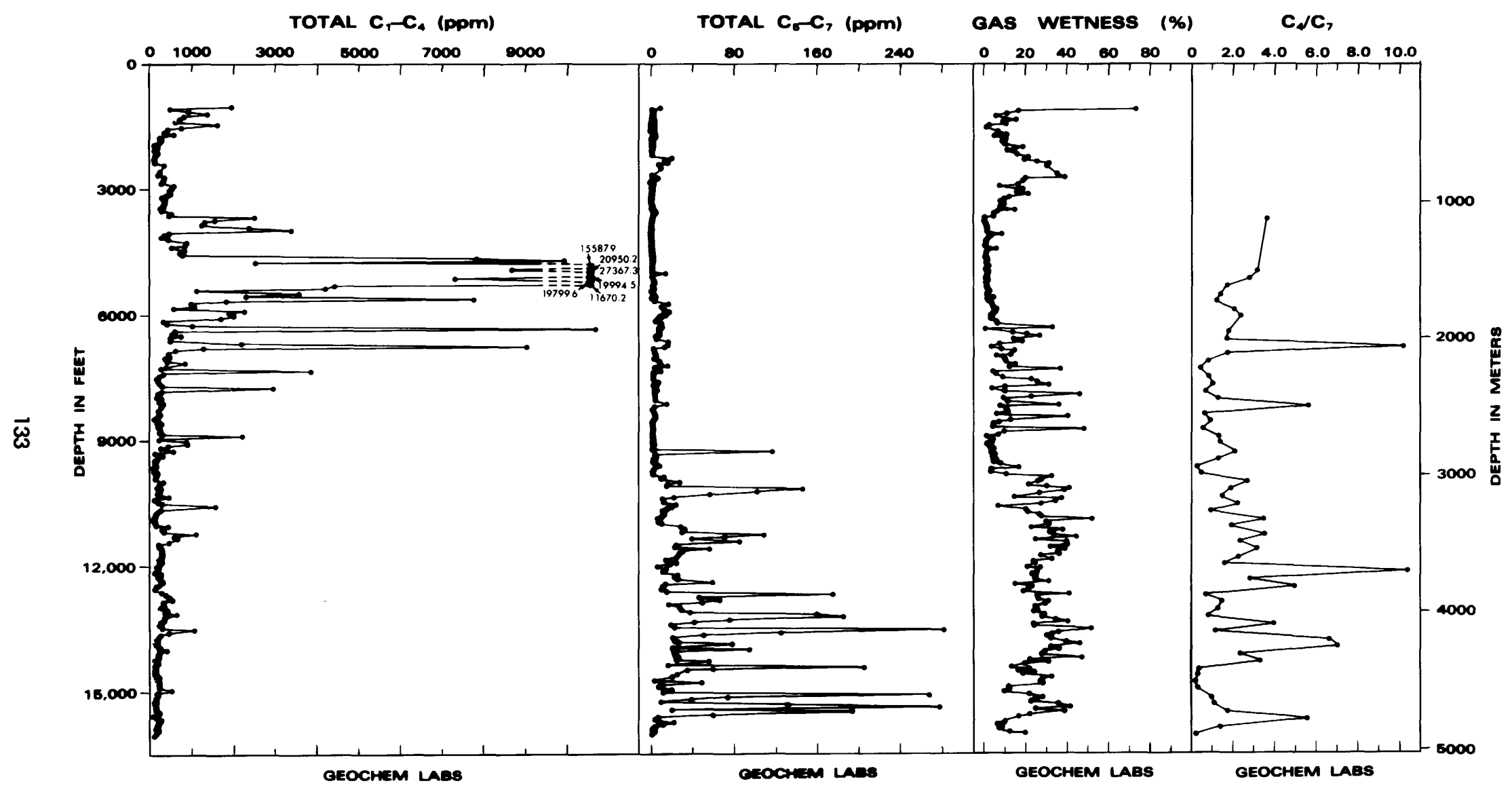

FIGURE 52.-Summary of $C_{1}$ to $C_{7}$ hydrocarbon analyses of samples from the COST No. G-1 well. 


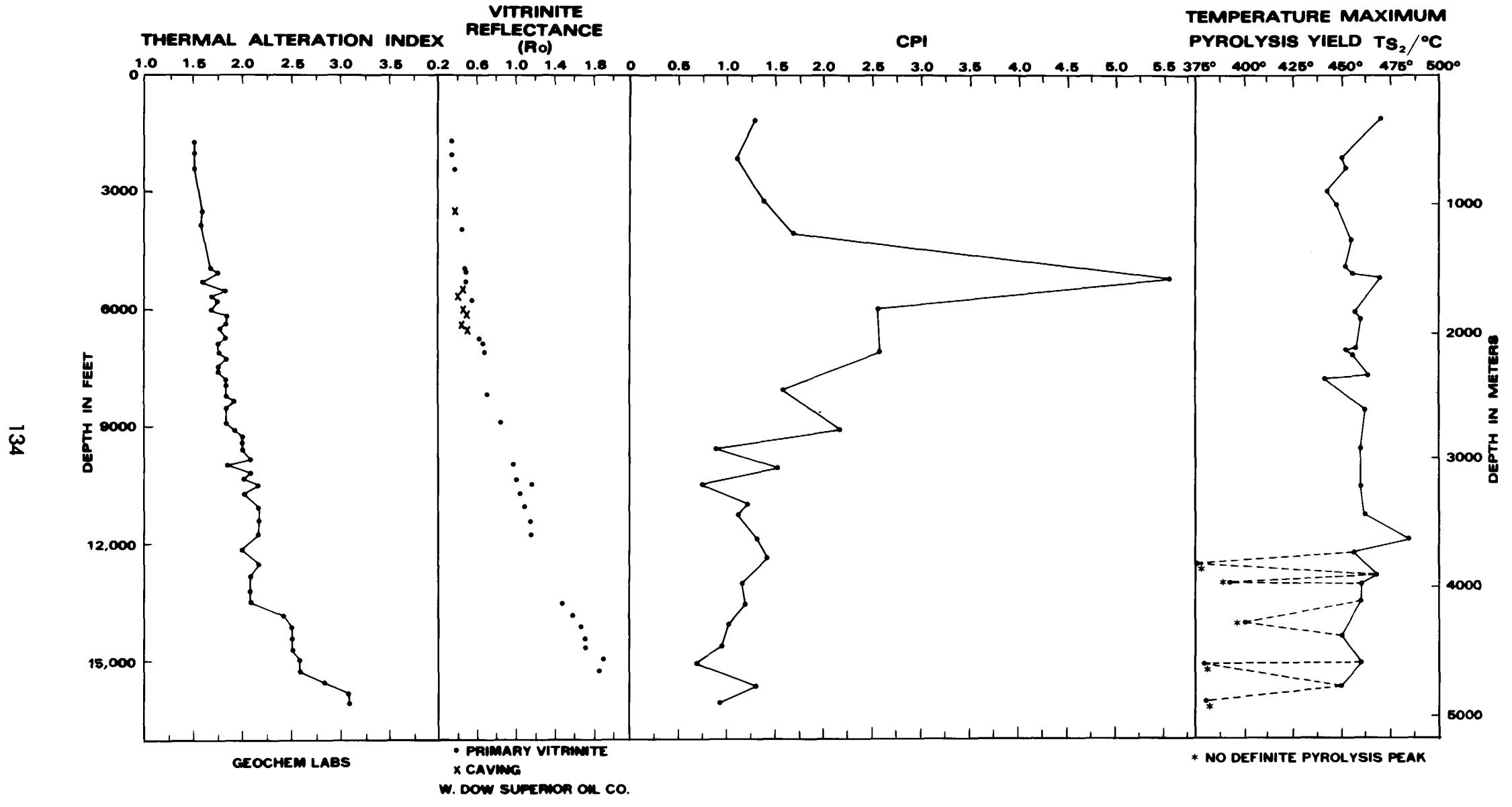

FIGURE 53.-Maturity profiles of organic matter as a function of depth of burial for samples from the COST No. G-1 well. 
whereas cavings, rough vitrinite, and mud contamination can result in abnormally low $R_{o}$ values (Dow, 1977; Bostick and others, 1978).

The $R_{o}$ values from the COST No. G-1 well were reported as having been determined on primary vitrinite except in the 5,500- to $6,500-\mathrm{ft}$ (1,676- to $1,981-\mathrm{m})$ interval, where cavings from overlying coals may have given abnormally low $R_{o}$ values (Smith and Shaw, 1980). The slope of the $R_{o}$ profile for the sedimentary section from about $6,500 \mathrm{ft}(1,981 \mathrm{~m})$ to the bottom of the well $(16,071 \mathrm{ft} ; 4,898 \mathrm{~m})$ is less steep than the profile from $2,000 \mathrm{ft}(610 \mathrm{~m})$ down to $6,500 \mathrm{ft}(1,981 \mathrm{~m})$ (fig. 53). The change in slope of the $R_{o}$ profile at about $6,500 \mathrm{ft}(1,981 \mathrm{~m})$ suggests a cooler thermal history for the overlying Cretaceous-Jurassic rocks and a higher geothermal gradient for the older Jurassic rocks below this depth. These vitrinite data suggest that a complex thermal and burial history may have existed for the Cretaceous and Jurassic. The effect of possible removal of overburden on the vitrinite profile is open to question. The degree of thermal maturity indicated by the vitrinite reflectance values below $6,500 \mathrm{ft}(1,981 \mathrm{~m})$ is also not consistent with the TAI values, oddeven carbon preference indices (CPI), or temperature of maximum pyrolysis yield $\left(T_{S_{2}}\right)$. If the range of $R_{o}$ values (0.62 to 1.8$)$ below $6,500 \mathrm{ft}(1,981 \mathrm{~m})$ is representative of indigenous, first-cycle vitrinite, then the existence of a higher thermal gradient is suggested for the more deeply buried Jurassic rocks.

This history of higher temperatures is not totally corroborated, however, by the other comparative thermal maturation parameters. The vitrinite reflectance data suggest paleotemperatures have already exceeded those needed for the first-order chemical reactions that are responsible for the formation of petroleum and have passed into the temperature range where dry gas may be formed. However, because of the inconsistencies between the level of thermal maturation indicated by the vitrinite-reflectance $\left(R_{o}\right)$ values and the other geochemical maturation parameters, the paleotemperatures are believed to have been lower than those required for peak gas generation. The threshold for intense oil generation as defined by Hunt (1979) is placed at $10,500 \mathrm{ft}(3,202 \mathrm{~m})$ and is based on the significant increase in the concentration of the $\mathrm{C}_{4}$ to $\mathrm{C}_{7}$ gasoline-range hydrocarbons (fig. 52). Peak oil generation appears to have occurred between
13,000 and $15,000 \mathrm{ft}(3,965$ to $4,575 \mathrm{~m})$. The change in the slope of the $R_{o}$ profile below $6,500 \mathrm{ft}(1,981 \mathrm{~m})$ may have been influenc?d by oxidized vitrinite or recycled organic matter, which would yield an anomalously high palentemperature history for the strata down to at least $15,630 \mathrm{ft}(4,764 \mathrm{~m})$. Below this depth, the degree of influence that Cambrian metamorphism may have had on the strata is unknown. Similarly, there is no clear evidence for a massive Jurassic thermal event associated with plate breakup in the COST No. G-1 well.

\section{KEROGEN TYPES AND THERMAL MATURATION FOP THE COST NO. G-2 WELL}

The data on the relative kerogen types and abundance in the COST No. G-2 well are inconsistent (fig. 54). The analyses reported by Core Laboratories, Inc., show a relatively large percentage of inertinite and exinite along with a comparatively small contribution of amorphou s-algal kerogen. The relative percentages of kerogen types and abundances determined by GenChem Laboratories, Inc., show a significant amo'int of marine, amorphous-herbaceous organic matter (fig. 54). Whether this inconsistency in the kerogen characterization is due to sampl? contamination, analytical procedure, or inhcmogenous sample suites is not known. Smith (1980) has suggested that the Core Laboratories procedure may have inadvertently regarded the amorphous, sapropelic type of organic matter as a mud contaminant and that the GeoChem Laboratories, Inc., estimates of amorphous kirogen may have been slightly high.

The stable carbon isotope ratios for the Tertiary and Cretaceous kerogen and solvent-soluble fractions (paraffin-naphthenes, aromatics, total extractable hydrocarbons) range from -24 to -28 permil. With the exception of one sam nle interval $(16,200 \mathrm{ft} ; 4,938 \mathrm{~m})$, the stable-carbonisotope ratios range from -22 to -29 permil for organic matter from the Upper Jurassic $(5,960$ to $11,800 \mathrm{ft} ; 1,817$ to $3,597 \mathrm{~m}$ ) and Middle Jurassic strata $(11,800$ to $18,000 \mathrm{ft} ; 3,597$ to $4,586 \mathrm{~m})$. The Middle Jurassic rocks below $18,000 \mathrm{ft}(5,486 \mathrm{~m})$ have $\delta^{13} \mathrm{C}$ values that range from -24 to -28 permil (fig. 54). The $\delta^{13} \mathrm{C}$ composition of a number of Cretaceous and Jurassic kerogens were reported to range from -22 to -28 permil 


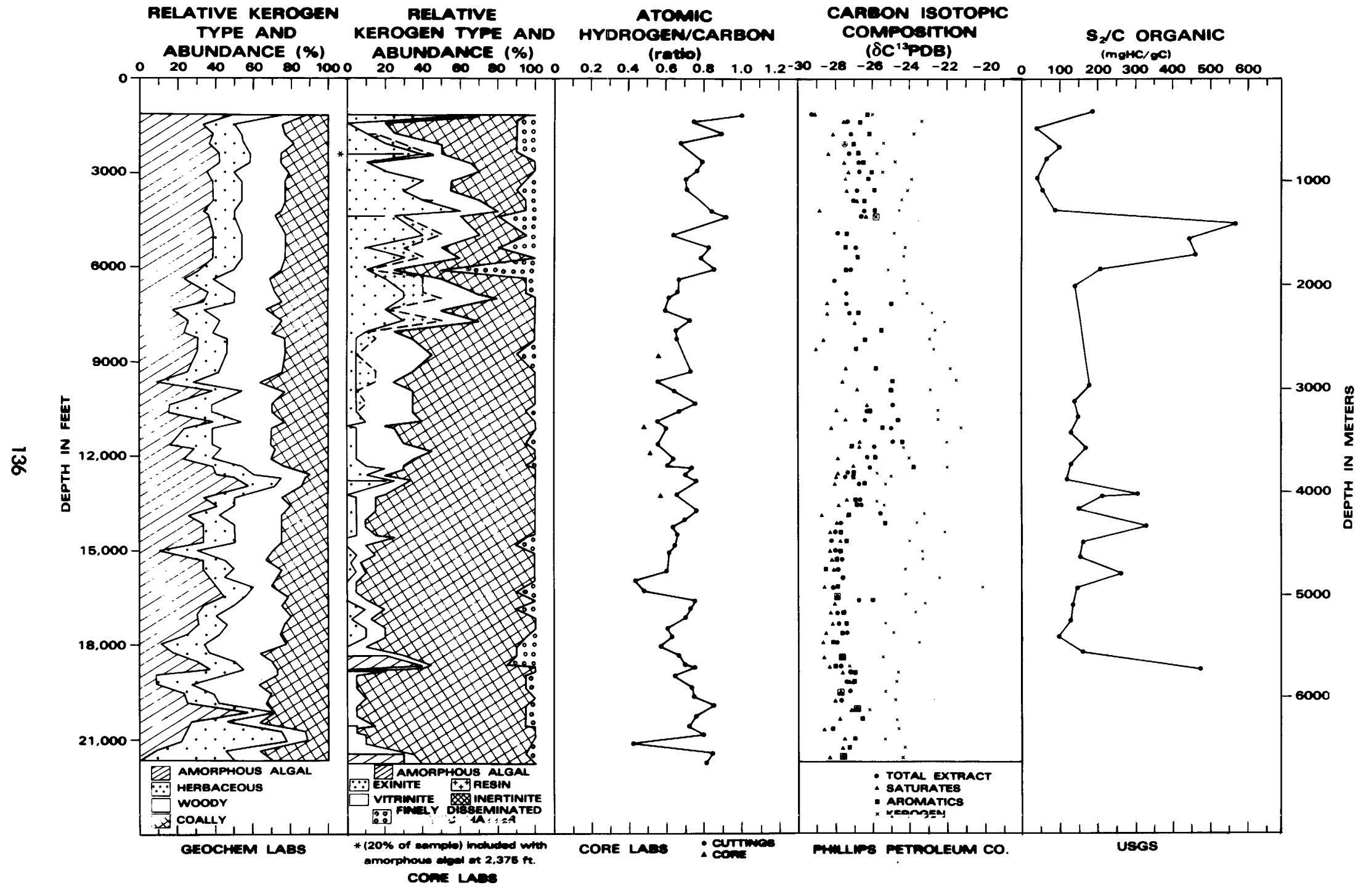

FIGURE 54.-Summary profiles of indicators of types of organic matter present in the COST No. G-2 well as a function of depth of burial. 
(Degens, 1969). Such an isotopic spread is believed to be characteristic of organic matter derived from predominantly open-marine sources and is consistent with the stable carbon isotope ratios in almost all of the Cretaceous and Jurassic kerogens in the COST No. G-2 well.

There is a difference of 4 permil between the $\delta^{13} \mathrm{C}$ values of saturated paraffins-naphthenes, aromatic hydrocarbons, and total extractable hydrocarbons, and those of the kerogens from the COST No. G-2 well (fig. 54). This spread of values suggests that a genetic relationship probably does not exist between the extractable bitumens and the kerogens. However, it is possible that thermal-maturation processes can induce carbon isotopic fractionation and exchange during catagenesis and metagenesis (Galimov, 1973; Tissot and Welte, 1978) and that the $\delta^{13} \mathrm{C}$ balance in kerogen is generated at an early stage of diagenesis when all the humic acid enters the kerogen structure (Galimov, 1980).

The kerogen types and abundances reported by Core Laboratories, Inc., show major amounts of woody to coaly (type III) kerogen and a very small amount of the amorphous algal (type I) variety in the COST No. G-2 well (fig. 54). In contrast, the kerogen types and abundances as determined by GeoChem Laboratories, Inc., show that the amorphous and herbaceous (type I and II) varieties compose 40 to 50 percent of the solid organic matter present in the Cretaceous and Jurassic strata (fig. 54). The stable carbon isotope ratios reported in this study were determined on the kerogen and bitumen extracts prepared by GeoChem Laboratories, Inc. (fig. 54), but other stable carbon isotope ratios reported by Phillips Petroleum Co. are consistent with the type and abundance of kerogens reported by GeoChem Laboratories, Inc. If, however, the woody and coaly-humic (type III) kerogens were the most abundant species in the GeoChem Laboratories, Inc., samples, then the $\delta^{13} \mathrm{C}$ ratios determined on the bitumen extracts and kerogen isolates should have been isotopically lighter, trending toward the -30 to -31 permil range characteristic of more terrigenous kerogen.

For that part of the Lower Cretaceous section between 4,510 and $6,000 \mathrm{ft}(1,375$ and $1,829 \mathrm{~m})$, the thermal pyrolysis hydrogen index $\left(S_{2} / \mathrm{Org}\right.$. C) averages $491 \mathrm{mg} \mathrm{HC} / \mathrm{g}$ Org. $\mathrm{C}$ and suggests the presence of a more hydrogen-rich type of kerogen that is suitable for the generation of liquid petroleum hydrocarbons (fig. 54; table 6). For the underlying Upper and Middle Jurassic rocks below $6,000 \mathrm{ft}(1,829 \mathrm{~m})$, the more hydrogen-poor, gas-prone kerogens have thermal-py:olysis hydrogen indices $\left(S_{2} / \mathrm{Org}\right.$. $\left.C\right)$ that average 161 and $193 \mathrm{mg} \mathrm{HC} / \mathrm{g} \mathrm{Org.} \mathrm{C,} \mathrm{respectively} \mathrm{(fig.} \mathrm{54).} \mathrm{Hunt}$ (1979) has shown that the hydrogen to carbon ratios for the inertinite type of kerogen fall within the 0.3 to 0.45 range, whereas the woody type of humic kerogen has hydrogen to carbon ratios from 0.3 to 1.0 . The hydrogen to carbon ratios for these Cretaceous and Jurassic sediments are in the 0.5 to 0.8 range and are more consistert. with a woody humic type rather than a coaly (inertinite) type of kerogen (fig. 54).

Below about $9,600 \mathrm{ft}(2,926 \mathrm{~m})$ the Upp $\mathrm{r}$ and Middle Jurassic strata of the COST No. G--2 well are predominantly calcareous shales, limertones, dolomites, and anhydrites. The carbonate and evaporite strata are believed to have been deposited in shallow-water, restricted marine environments, and contain only small amounts of terrestrially derived (type III) kerogens (fir. 54). The terrestrial (type III) kerogens present in these carbonate strata are believed to be largely recycled. Highly carbonized organic matte- such as inertinite is fairly resistant to weatheriro and may be transported without significant f urther loss of hydrogen to new depositional basire and mixed with young, thermally immature organic matter (Tissot and Welte, 1978). If the organic matter that has been identified as inertirite or coal in the COST No. G-2 well is truly as abundant as indicated by Core Laboratories, Inc., then the potential for generation of gas is very poor (fig. 54). On the other hand, if the woody-humic type III kerogens are more abundant, $\varepsilon$ ? the hydrogen to carbon ratios seem to suggest, then the potential for gas generation may be significant, depending upon the abundance of primary solid organic matter and the time and intensity of thermal maturation.

The possibility of mud additive contamination or coaly cavings cannot be discounted as a cause of the inconsistent kerogen-type determinations. Moreover, the probability of two laboretories receiving totally and consistently dissimilar sample suites seems rather remote. Therefore, the reported differences in the kerogen type and their relative abundances may be related to the analytical techniques and methods employed in 
the preparation and identification of the kerogen types.

The TAI, vitrinite reflectance $\left(R_{o}\right), \mathrm{CPI}$, and temperature of maximum pyrolysis yield $\left(T_{S_{2}}\right)$ maturation parameters for the G-2 well samples are shown in figure 55. During the thermal maturation process (as the burial depth and temperature increase), the breaking of carboncarbon bonds occurs more and more frequently, and, depending upon the predominant type of organic matter, varying proportions of light $\left(\mathrm{C}_{1}\right.$ to $\mathrm{C}_{4}$ ) hydrocarbons and gasoline range $\left(\mathrm{C}_{4}\right.$ to $\left.\mathrm{C}_{7}\right)$ hydrocarbons are produced (Tissot and Welte, 1978). The profiles of the concentrations of the $C_{1}$ to $\mathrm{C}_{4}$ and $\mathrm{C}_{5}$ to $\mathrm{C}_{7}$ hydrocarbons, the percent gas wetness, and the $n-C_{4} / n-C_{7}$ molecular ratio are shown in figure 56 . Although the $n-C_{4} / n-C_{7}$ ratio is less than unity in several isolated intervals of the COST No. G-2 well, the effect of diesel fuel on the thermal maturation characteristics of the $\mathrm{C}_{15+}$ liquid hydrocarbons below $12,000 \mathrm{ft}$ $(3,660 \mathrm{~m})$ is believed to be minimal. The total concentration of $\mathrm{C}_{1}$ to $\mathrm{C}_{7}$ hydrocarbons in the Cretaceous and Jurassic strata is low, usually less than $1500 \mathrm{ppm}$, which may be related to the poor source-rock quality.

The two sets of TAI data are inconsistent in their description of the levels of thermal maturity for similar burial depths (fig. 55). Because the TAI profile established by Core Laboratories, Inc., includes samples down to a burial depth of only $12,000 \mathrm{ft}(3,658 \mathrm{~m})$, their data do not permit the development of a complete, comparative thermal maturation interpretation of the COST No. G-2 well and will not be discussed further. The TAI values reported by GeoChem Laboratories, Inc., include samples from the entire well and are discussed below. The level of thermal maturation indicated by Core Laboratories, Inc., vitrinite reflectance $\left(R_{o}\right)$ measurements is inconsistent with and abnormally high when compared with the level of thermal maturation indicated by the liquid $\mathrm{C}_{15}+$ hydrocarbon $\mathrm{CPI}$ ratios and the thermal pyrolysis yield $\left(T_{S_{2}}\right)$ values, and by the TAI values reported by GeoChem Laboratories, Inc.

Below $3,500 \mathrm{ft}(1,067 \mathrm{~m})$ the vitrinite reflectance values appear to be grouped into several families of straight-line relationships, each with a slightly different slope, that may suggest the presence of different past geothermal gradients. Any offset at the breakpoint of the straight-line relationship has been interpreted by Dow (1977) to signify a possible unconformity (fig. 55). The possibility of recycled organic metter as a factor in the unusually high vitrinite reflectance measurements must not be discounted. If the level of thermal maturation were as adv $n$ nced, for such shallow burial depths, as the vitrinite reflectance values suggest, then the concent-ations of $C_{1}$ to $\mathrm{C}_{4}$ light hydrocarbons and $\mathrm{C}_{4}$ to $\mathrm{C}_{7}$ gasoline-range hydrocarbons generated would be expected to be much greater. Furthermore, the saturated paraffin-naphthene hydrocarbon molecular distribution and composition would be expected to show a more mature character. Bocause the TAI values determined by GeoChem Laboratories, Inc., and the CPI values and thermal pyrolysis measurements made by the USGS are in agreement, it is believed that the threrhold of intense oil generation begins between 9,000 and $10,000 \mathrm{ft}$ $(2,743$ and $3,048 \mathrm{~m})$ in the COST No. G-2 well, and peak generation and maturation processes occur between about 14,000 and $18,000 \mathrm{ft}(4,267$ and $5,486 \mathrm{~m}$ ). It is important tc note that the threshold or transition temperature of intense oil generation tends to be higher or to occur at greater burial depths in carbonates than in shales. This tendency is consistert with the idea that the activation energy for kerogen decomposition in limestones and dolomites rould be higher than in clays because of the catalytic effect of the clays (Hunt, 1979). Localized zones of high heat flow may play a significant role in thermal maturation within the Georges Bank basin and the possibility may exist for dry gas generation in the Jurassic of the COST G-2 area below $18,000 \mathrm{ft}(5,486 \mathrm{~m})$. Howe the poor-to-fair quality of the source rocks, the potential for significant resources may be reduced.

\section{SUMMARY AND IMPLICATIONS FOR OIL AND GAS GENERATION}

The Tertiary strata of the COST No. G-1 well $(1,013$ to $1,030 \mathrm{ft} ; 309$ to $314 \mathrm{~m})$ and the COST No. G-2 well $(1,100$ to $1,310 \mathrm{ft}$; 355 to $399 \mathrm{~m})$ are characterized by thin layers of unconsolidated, coarse quartz sands and light-yrellow to buff calcareous muds and siltstones, respectively. Because of the extremely shallow burial depths, the thermally immature nature of the lignitic to 


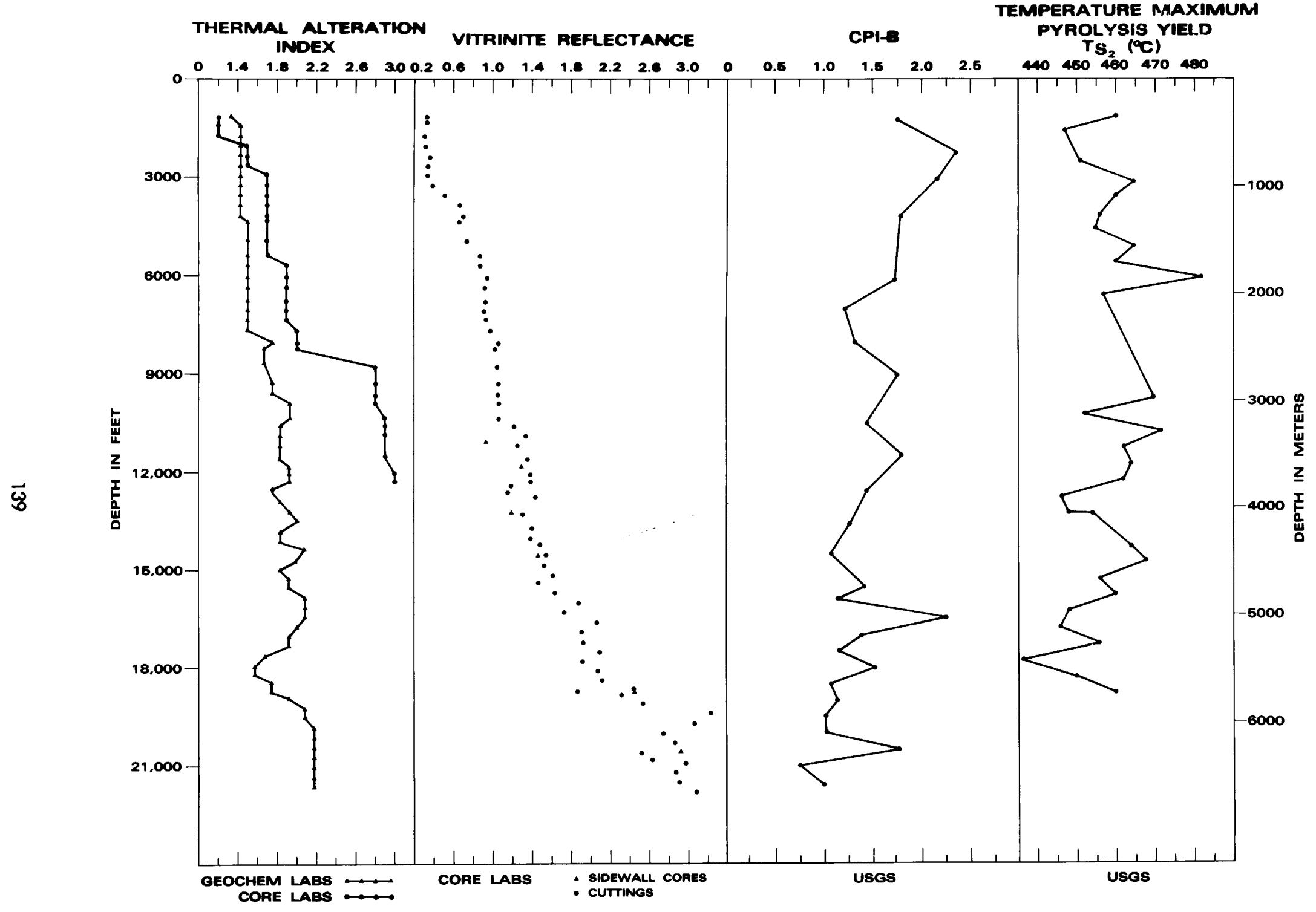

FIGURE 55.-Maturity profiles of organic matter as a function of depth of burial for samples irom the COST iło. G-2 well. 


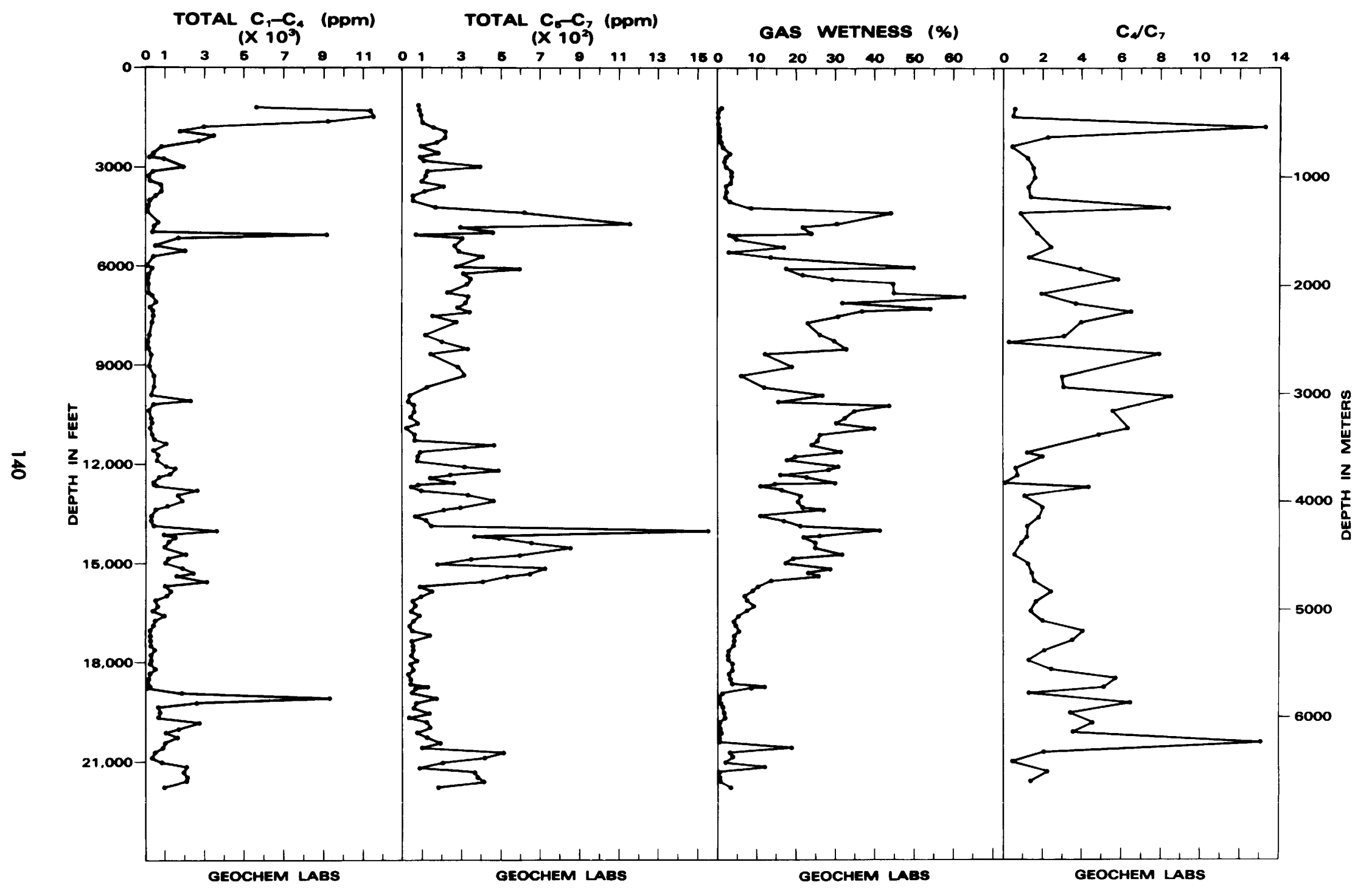

FiguRE 56.-Summary of $C_{1}$ to $C_{7}$ hydrocarbon analyses of samples from the COST No. G-2 well. 
woody kerogens, and the character of the extractable organic matter, the Tertiary is not considered a target for oil or natural gas exploration in the Georges Bank region.

Cretaceous strata were penetrated in the COST No. G-1 well from 1,030 to $5,290 \mathrm{ft}$ (314 to $1,612 \mathrm{~m}$ ) and in the COST No. G-2 well from 1,310 to $5,960 \mathrm{ft}$ (399 to $1,817 \mathrm{~m}$ ). Source-rock richness characteristics for the Cretaceous in these two wells are in the poor-to-fair quality range. This interpretation is based on the average total organic carbon values of 0.46 to 0.85 (weight percent), and average total extractable hydrocarbons of 33 and 93 ppm for the G-1 and G-2 wells, respectively. The Cretaceous kerogens have hydrogen to carbon ratios that range from 0.63 to 0.97 . Such ratios are comparable with type II and III terrestrially derived, hydrogen-poor, humic, gas-prone kerogens. The molecular distribution and concentration of the $\mathrm{C}_{15}+$ saturated paraffinnaphthene hydrocarbons, the low temperature of maximum pyrolysis yield $\left(T_{S_{2}}\right)$, and TAI levels of 1.4 to 1.6 suggest that the Cretaceous extractable organic matter and kerogens have not yet experienced a sufficient time and temperature history to allow the generation of petroleum hydrocarbons and gas.

The vitrinite reflectance values suggest that a much higher degree of thermal maturity may have existed during the Cretaceous of the Georges Bank basin than is suggested by the other light optical, pyrolysis, and geochemical maturation parameters. This inferred higher level of thermal maturation may be the result of prior thermal histories imprinted on recycled organic matter. The indigenous extractable hydrocarbons present in the Cretaceous sediments down to $6,000 \mathrm{ft}(1,829 \mathrm{~m})$ in the COST Nos. G-1 and G-2 wells are believed to be thermally immature and have not been produced by petroleum-generating processes.

The potential for mud-additive influence from diesel fuel or other additives such as barite, spersene, bentonite, carboxymethylcellulose, pipe dope, and lignosulfonate (leonardite) cannot be disregarded. The mud-additive effects are not believed to have been pervasive but rather are restricted to certain zones, influencing the character of the indigenous $\mathrm{C}_{15}+$ hydrocarbons at specific intervals in the Jurassic below $12,000 \mathrm{ft}$ $(3,660 \mathrm{~m})$. The mud-additive effect on the extractable organic matter is believed to be localized and restricted because of the consistently low total organic carbon values and the lack of a uniform mud-additive fingerprint on the hydrocarbon molecular composition and distribution of the entire suite of samples.

The Middle Jurassic strata of the COST No. G-2 well below $13,650 \mathrm{ft}(4,161 \mathrm{~m})$ are chararterized by abundant shallow-water dolomite, limestone, and anhydrite-evaporite facies. The Jurassic section of the G-1 $(5,290$ to $15,630 \mathrm{ft} ; 1,612$ to $4,764 \mathrm{~m}$ ) has a higher percentage of sand and silt, and less carbonate and argillaceous sediment than the G-2. This difference is also reflected in the distribution and type of the solid organic matter in the samples. The Jurassic kerogens in the G-1 are predominantly terrigenous, humic, and gas-prone (type III), with little of the hydrogenrich, oil-prone (type I) variety. The Jurnssic strata of the G-2 $(5,960$ to $21,874 \mathrm{ft} ; 1,817$ to $6,667 \mathrm{~m}$ ) contain amorphous and algal (tyme I) gas-prone and herbaceous (type II) and wrody (type III) kerogens. In the COST No. G-1 well, the average total organic carbon values for the Upper, Middle, and Lower Jurassic samples are $0.73,0.25$, and 0.11 weight percent, respectirely, and the values for total extractable hydrocarhons in these strata are 38,36 and $39 \mathrm{ppm}$, respectively. These source-rock organic-richness value are considered to be very poor to poor. For the U Jper and Middle Jurassic shales of the COST No. G-2 well, the average total organic carbon value are 0.62 and 0.23 weight percent, and the average total-extractable-hydrocarbon concentrations are 155 and $170 \mathrm{ppm}$, respectively. Although the source-rock organic-richness characteristic of the G-2 Jurassic strata appear to be better than those of the Jurassic in the G-1, such values only indicate a poor-to-fair oil and gas source rock potential.

The possibility exists that oxidized vitrinite or recycled organic matter in the Jurassic of the COST Nos. G-1 and G-2 wells may have influenced the vitrinite reflectance values by imnarting abnormally high thermal-maturity level acquired from earlier thermal histories. Because of the consistent agreement between the temnerature of maximum pyrolysis yield $\left(T_{S_{2}}\right)$, the thermal alteration index, and the molecular distribution and concentration of the $\mathrm{C}_{15}+$ hydrocarhons, the peak of liquid hydrocarbon generation is placed at burial depths of about 13,00 ) to $15,000 \mathrm{ft}(3,962$ to $4,572 \mathrm{~m})$ in the COST G-1. The 
depth of peak petroleum generation is believed to occur in the COST G-2 between 14,000 and $18,000 \mathrm{ft}(4,267$ and $5,486 \mathrm{~m})$.

In the COST No. G-1 well, the thermalchemical maturation processes may be influenced by the presence of localized metamorphism. How representative the thermal maturity data from the COST Nos. G-1 and G-2 wells may be for a regional view of the Georges Bank basin is open to question, because the basin appears to be characterized by a complex thermal and burial history, and the effects of possible overburden loss in the Tertiary and Cretaceous have not yet been evaluated. Localized zoner of abnormally high heat flow may have exicted along with patches of organic-rich Jurassic evaporite-reefal carbonate rocks. Such factors ar? believed to be critical in controlling the maturation processes and occurrence of possible deen Jurassic gas. Because of the predominance of the hydrogenpoor kerogens, the potential for generation may exist at greater depths in the vicinity of the COST No. G-2 well. However, because of the poor to fair source-rock quality, the commercial attractiveness may be significantly diminished. 


\title{
Thermal History of the Georges Bank Basin
}

\author{
Michael A. Arthur
}

A study of the thermal history of the Atlantic continental margin basins is necessary for an evaluation of the possibility of generating hydrocarbons from potential source rocks. The depths at which petroleum and thermogenic gas may have been generated can be estimated from present-day thermal gradients taken from well temperature logs (Tissot and others, 1974), but this approach is more useful for near-surface, younger sedimentary horizons (100-120 m.y. old), which probably have not been affected by burial temperatures higher than those existing today. However, the older, more deeply buried strata, particularly those deposited within 50-70 m.y. after the initiation of rifting along the Atlantic continental margin, may have been initially subjected to higher temperatures and may have generated hydrocarbons early in their evolution. The thermal gradient probably decreases both through time and with depth in sedimentary basins along rifted passive margins (Royden and others, 1980). Also, older strata such as those in thinner sedimentary sequences on the continental rise may have been heated sufficiently to produce significant amounts of petroleum or gas early in the history of sedimentation without deep burial. Therefore it is important to know the thermal history of a sedimentary basin as well as its modern thermal gradient, because generation and preservation of petroleum hydrocarbons is a function of both time and temperature (Waples, 1980).

The purpose of this paper is to discuss aspects of the present-day thermal gradient and the thermal history of the Georges Bank basin based on data from the COST Nos. G-1 and G-2 wells. Aspects of basin subsidence, sedimentation, and continental margin evolution are discussed with regard to the indications of thermal maturity in sedimentary organic matter and possible hydrocarbon generation in the Georges Bank basin. The discussion of thermal history is based largely on recent models of the thermal evolutic $n$ of passive margins (Steckler and Watts, 1978; Royden and others, 1980; Angevine and Turcotte, 1981) and is intended only to place some limits on estimates of the petroleum potential of the landward part of the Georges Bank basin.

\section{PRESENT-DAY THERMAL GRADIENT}

Figure 57 illustrates the downhole temperture profiles for the COST Nos. G-1 and G-2 wells based on Schlumberger temperature logs (Scholle and others, 1980). The geothermal gradient? calculated by applying linear regression analyris to these data (Jackson and Heise, 1980; Heise and Jackson, 1980) are $1.26^{\circ} \mathrm{F}$ per $100 \mathrm{ft}\left(23.0^{\circ} \mathrm{C} / \mathrm{km}\right)$ for the G-1 well and $1.34^{\circ} \mathrm{F}$ per 10 ? $\mathrm{ft}$. $(24.4 \mathrm{C} / \mathrm{km})$ for the $\mathrm{G}-2$ well. Jackson and J'eise (1980) and Heise and Jackson (1980) have "corrected" the temperature log data at sereral depths to remove the effects of drilling (no"malized to a 25-hr post-drilling period) and cotermined revised gradients of $1.17^{\circ} \mathrm{F}$ per $100 \mathrm{ft}$ $\left(21.3^{\circ} \mathrm{C} / \mathrm{km}\right)$ and $1.46^{\circ} \mathrm{F}$ per $100 \mathrm{ft}\left(26.6^{\circ} \mathrm{C} / \mathrm{km}\right)$ for the G-1 and G-2 wells respectively. Corrieted bottom-hole or near-bottom-hole temperatures were $247^{\circ} \mathrm{F}\left(119^{\circ} \mathrm{C}\right)$ at $16,400 \mathrm{ft}(5,000 \mathrm{~m})$ in the $\mathrm{G}-1$ and $360^{\circ} \mathrm{F}\left(182^{\circ} \mathrm{C}\right)$ at $21,790 \mathrm{ft}(6,640 \mathrm{~m})$ in the G-2 well.

The present-day temperature gradients from the Georges Bank COST wells are comparid to those of other Atlantic margin COST wells and several other localities in table 7. The gradient at the G-2 well is the highest measured along the Atlantic margin, while that at the G-1 woll is close to the average for wells on other parts of the margin. However, it is likely that absolute temperatures and thermal gradients in the lower part of G-1 were once higher because of higher heat flow associated with the extensional thinning of the crust during the rifting in latest 
DOWN HOLE

TEMPERATURE $\left({ }^{\circ} \mathrm{F}\right)$

$100 \quad 300$

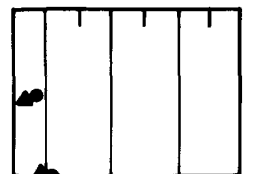

$0.0 \quad 0.6 \quad 1.4 \quad 2.2 \quad 3.0$

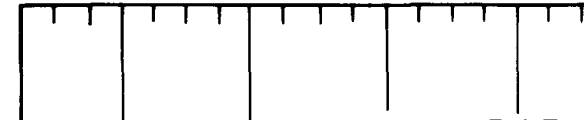

- G-1 WELL DATA
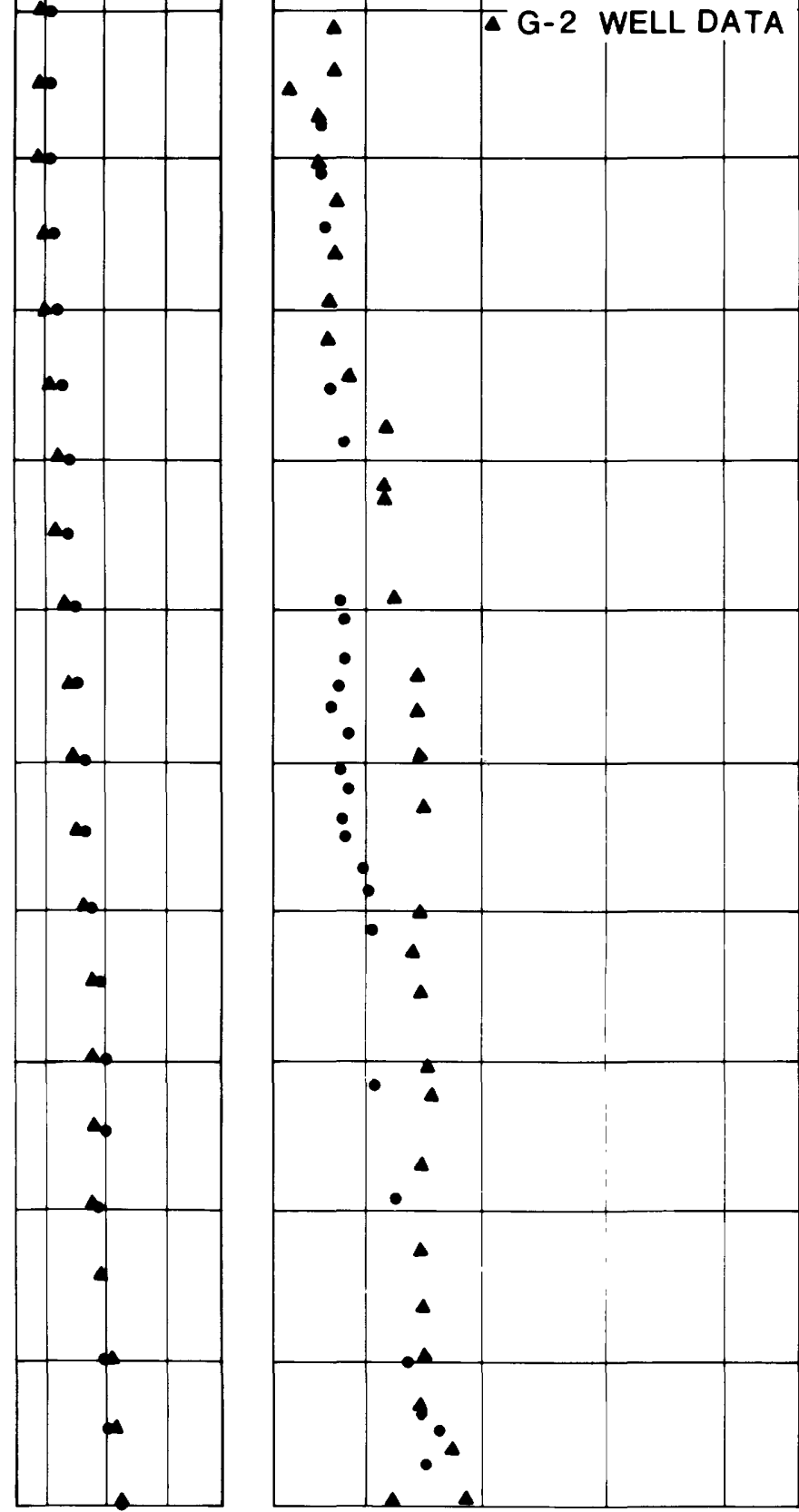

$\Delta$

$\triangle$

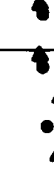

$\mathbf{1}$

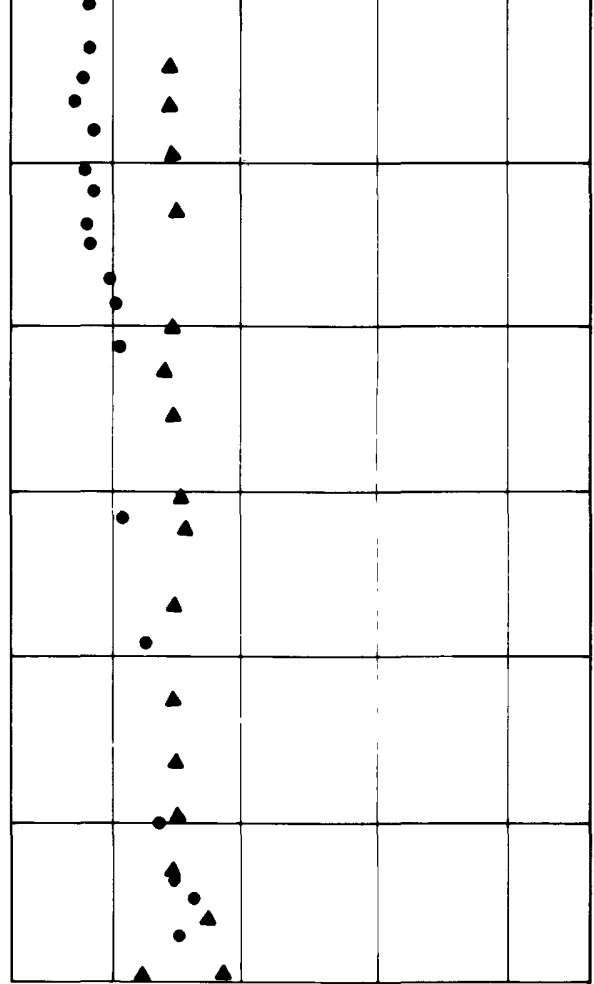

Ro

THERMAL

ALTERATION INDEX

$\begin{array}{llll}1 & 2 & 3 & 4\end{array}$

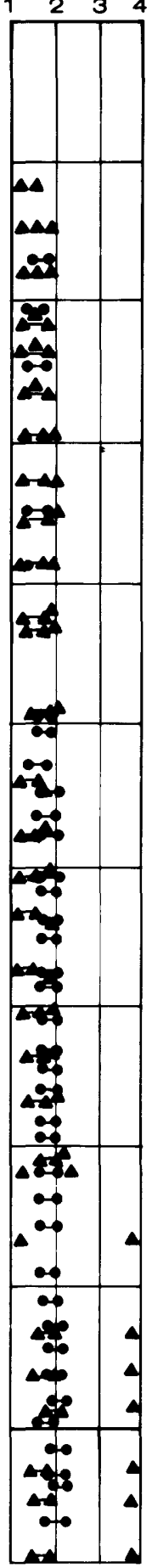

CEPTH

FEET METERS

$$
\begin{aligned}
& \text { OT } \\
& \text { SEA } \\
& \text { LEVEL }
\end{aligned}
$$

$1000-$
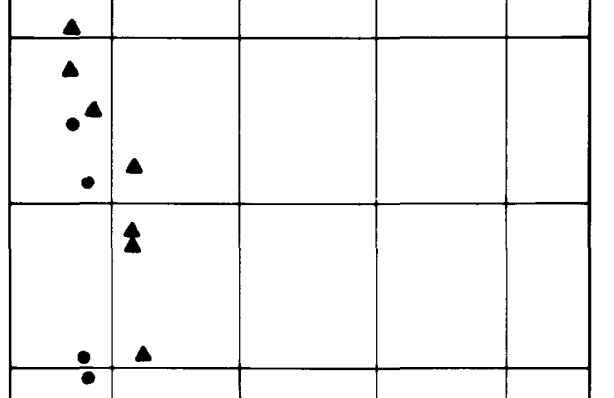
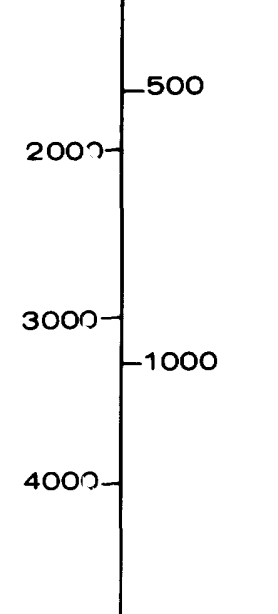

500ว- -1500

$600 ?$

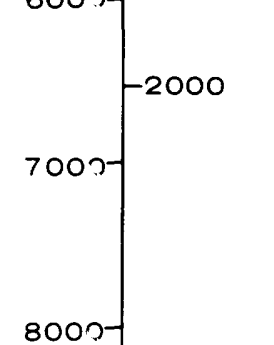

$9000-$

10.000

$-3000$
$-2500$

FIGURE 57.-Downhole temperature profiles from temperature logs (Scholle, Krivoy, and Hennes y, 1980; Scholle, Schwab, and Krivoy, 1980), mean vitrinite reflectance values (Superior Oil Co. and Core Laboratories, Inc.), and thermal alteration indices (TAI; GeoChem Laboratories, Inc.) for the COST Nos. G-1 and G-2 wells. 
DOWN HOLE

TEMPERATURE

$\left({ }^{\circ} \mathrm{F}\right)$

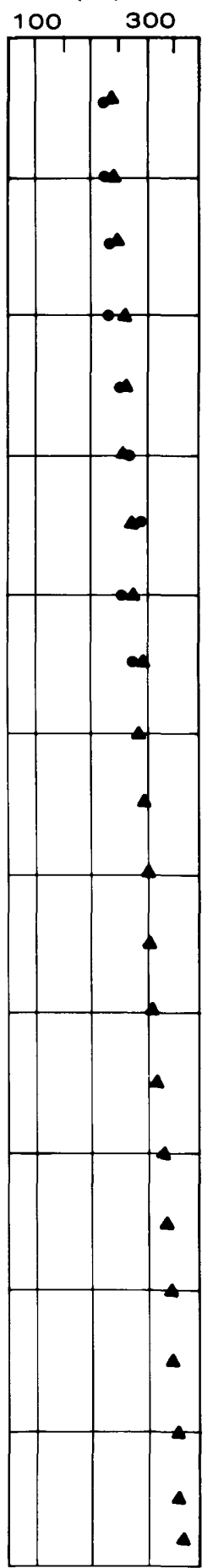

Ro

(MEAN VITRINITE REFLECTANCE)
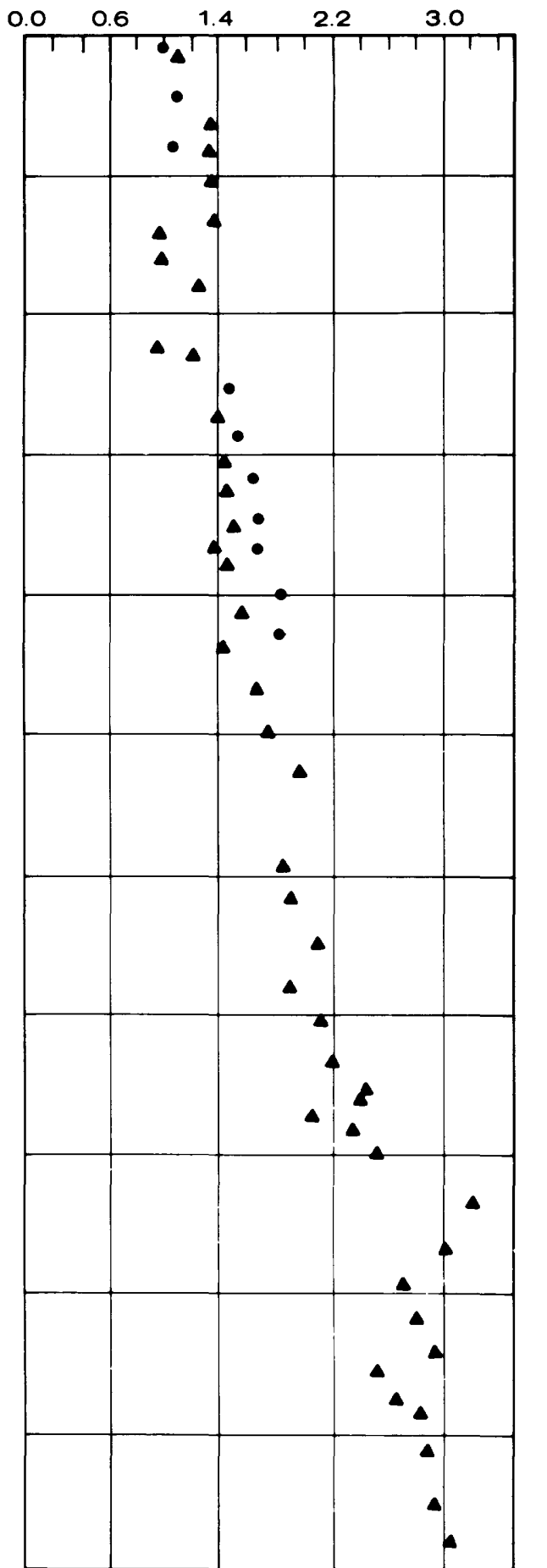

THERMAL

ALTERATION INDEX

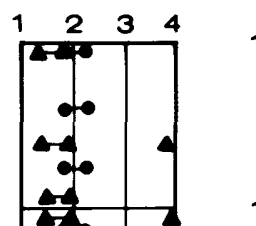

FEET METERS

11.000

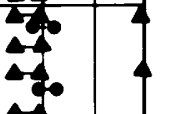

4

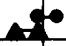

-

\&o

4 승

Arac

슨

$\rightarrow$

$\rightarrow$

nee

-100

4
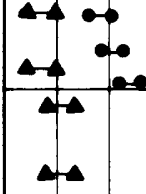

4

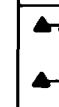

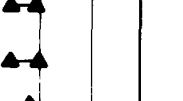

.

$\rightarrow$

2

4

4

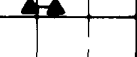

4

4

2

at

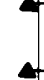
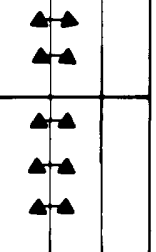

12,000

17.000

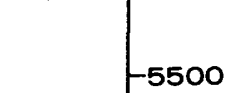

$-3500$

14,000

$-4500$

15,000

$16.000-5000$

18.000

$19.000-6000$

0.000

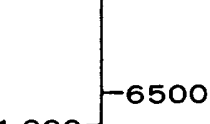

$21,000-$

22.000

Figure 57.-Downhole temperature profiles from temperature logs (Scholle, Krivoy, and Hennessy, 1980; Scholle, Schwab, and Krivoy, 1980), mean vitrinite reflectance values (Superior Oil Co. and Core Laboratories, Inc.), and thermal alteration indices (TAI; GeoChem Laboratories, Inc.) for the COST Nos. G-1 and G-2 wells.-Continued 
TABLE 7.-Geothermal gradients on passive continental margins

[Data from Jackson and Heise (1980) and Robbins and Rhodehamel (1976)]

\begin{tabular}{|c|c|c|c|}
\hline \multirow[b]{2}{*}{ Area } & \multirow[b]{2}{*}{ Well } & \multicolumn{2}{|c|}{ Gradient } \\
\hline & & ${ }^{\circ} \mathrm{F} / 100 \mathrm{ft}$ & ${ }^{\circ} \mathrm{C} / \mathrm{km}$ \\
\hline $\begin{array}{l}\text { Georges Bank } \ldots \ldots \ldots \ldots \ldots \\
\text { Do } \ldots \ldots \ldots \\
\text { Baltimore Canyon } \ldots \ldots \ldots \ldots \ldots \\
\text { Do } \ldots \ldots \ldots \ldots \ldots \ldots \ldots\end{array}$ & $\begin{array}{l}\text { G-1 } \\
\mathrm{G}-2 \\
\mathrm{~B}-2 \\
\mathrm{~B}-3\end{array}$ & $\begin{array}{l}1.2 \\
1.5 \\
1.3 \\
1.2\end{array}$ & $\begin{array}{l}22 \\
27 \\
24 \\
22\end{array}$ \\
\hline $\begin{array}{l}\text { Southeast Georgia } \\
\text { embayment } \ldots \ldots \ldots \ldots \ldots \ldots \\
\text { Scotian shelf } \ldots \ldots \ldots \ldots \ldots \ldots \\
\text { Texas Gulf Coast } \ldots \ldots \ldots \ldots \ldots \\
\text { North Sea basin } \ldots \ldots \ldots \ldots \ldots\end{array}$ & 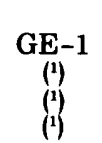 & $\begin{array}{r}.9 \\
1.2 \\
1.6 \\
1.7\end{array}$ & $\begin{array}{l}16 \\
22 \\
29 \\
32\end{array}$ \\
\hline
\end{tabular}

${ }^{1}$ Average from several wells.

Triassic-Early Jurassic time. The present-day gradients suggest that there has been no significant hydrocarbon generation above $8,000 \mathrm{ft}$ $(2,440 \mathrm{~m})$ in the G-1 well and above $6,700 \mathrm{ft}$ $(2,040 \mathrm{~m})$ in the G-2 well, based on the generalizations offered by Pusey (1973) for the "oil window" $\left(150^{\circ}-300^{\circ} \mathrm{F} ; 66^{\circ}-149^{\circ} \mathrm{C}\right)$. Dry gas may be expected below about $18,000 \mathrm{ft}(5,490 \mathrm{~m})$ in the G-2 well and below about $16,000 \mathrm{ft}$ $(4,870 \mathrm{~m})$ in the vicinity of the G-1 well. Generation of hydrocarbons is a function of time as well as temperature (Lopatin, 1976), and the organic geochemical and thermal maturation data (Miller and others, this volume) generally agree with the estimates given above.

\section{SUBSIDENCE AND THERMAL HISTORY}

The subsidence history of the Cost Nos. G-1 and G-2 wells was examined using the method of Steckler and Watts (1978). In this method the sedimentary section recovered in the well is "backstripped" in order to examine the sequential subsidence history of a given part of the continental margin. Sediments of each defined time interval are restored to their former thickness by correcting for compaction, and the amount of subsidence induced by sediment loading is calculated incrementally using the Airy isostatic model and assuming local loading of the crust. The depth to basement after removal of the effects of local sediment (and water) loading are obtained by using the following equation:

$$
Y=S^{*} \frac{(\rho m-\rho s)}{(\rho m-\rho w)}+W_{d}-\Delta S L \frac{\rho m}{(\rho m-\rho w)}
$$

where

$Y=$ depth to basement with no loading ("tectonic component of subsidence")

$S^{*}=$ interval sediment thiclness corrected for compaction

$\rho m=$ density of the upper mantle (assumed $\left.3.3 \mathrm{~g} / \mathrm{cm}^{3}\right)$

$\rho s=$ initial density of a given sediment package (calculated)

$\rho w=$ density of seawater (assumed $1.03 \mathrm{~g} / \mathrm{cm}^{3}$ ) $W_{d}=$ average water depth during a given time interval

$\Delta S L=$ eustatic sea level chan $\xi^{\circ}$ (relative to today).

The value of $S^{*}$ was calculated for a given thickness of sediment by determining the change in porosity during compaction. The lithology of much of the COST Nos. G-1 ard G-2 wells is variable, so the assumption of constant grain density does not hold and the single porosity reduction curve with compaction used by Steckler and Watts (1978) and Watts and Strokler (1979) in "backstripping" the COST No. B-2 well is not applicable. Therefore, in this study the sedimentary sequence was subdivided into time intervals using the biostratigraphic age assignments of Poag (this volume). These age as rignments may be in error, particularly for the Iurassic part of the sequence in which fossils wisre sparse. The ratios of sand and shale to carbonate and to evaporite sediments was calculated for each sediment interval using lithologic descriptions (Arthur, this volume; Scholle, Krivoy, and Hennessy, 1980; Scholle, Schwab, and Krivorr, 1980). Clastic sediments were assigned an initial porosity of 52 percent, carbonate sediments a porosity of 30 percent, and evaporites a porosity of 10 percent. The precision of this method is inherently low in such generalized calculations.

Estimates of water depth at the time of deposition are based on those of Poag (th is volume), and the sea level curve derived by Wat.ts and Steckler (1979) was used to make the eustatic correction. The data and calculations for the COST No. G-2 well are shown in table 8 , and this subsidence history is illustrated in figure 58 .

Assuming that the amount of "tectonic" subsidence is related to the amount of crustal thinning during initial rifting, Royden and others (1980) 
TABLE 8.-Data used and results of calculations of basin subsidence at the COST No. G-2 well [Depth figures are feet below Kelly Bushing $(1 \mathrm{ft}=0.3048 \mathrm{~m}$ ). -, not applicable; (?), uncertain]

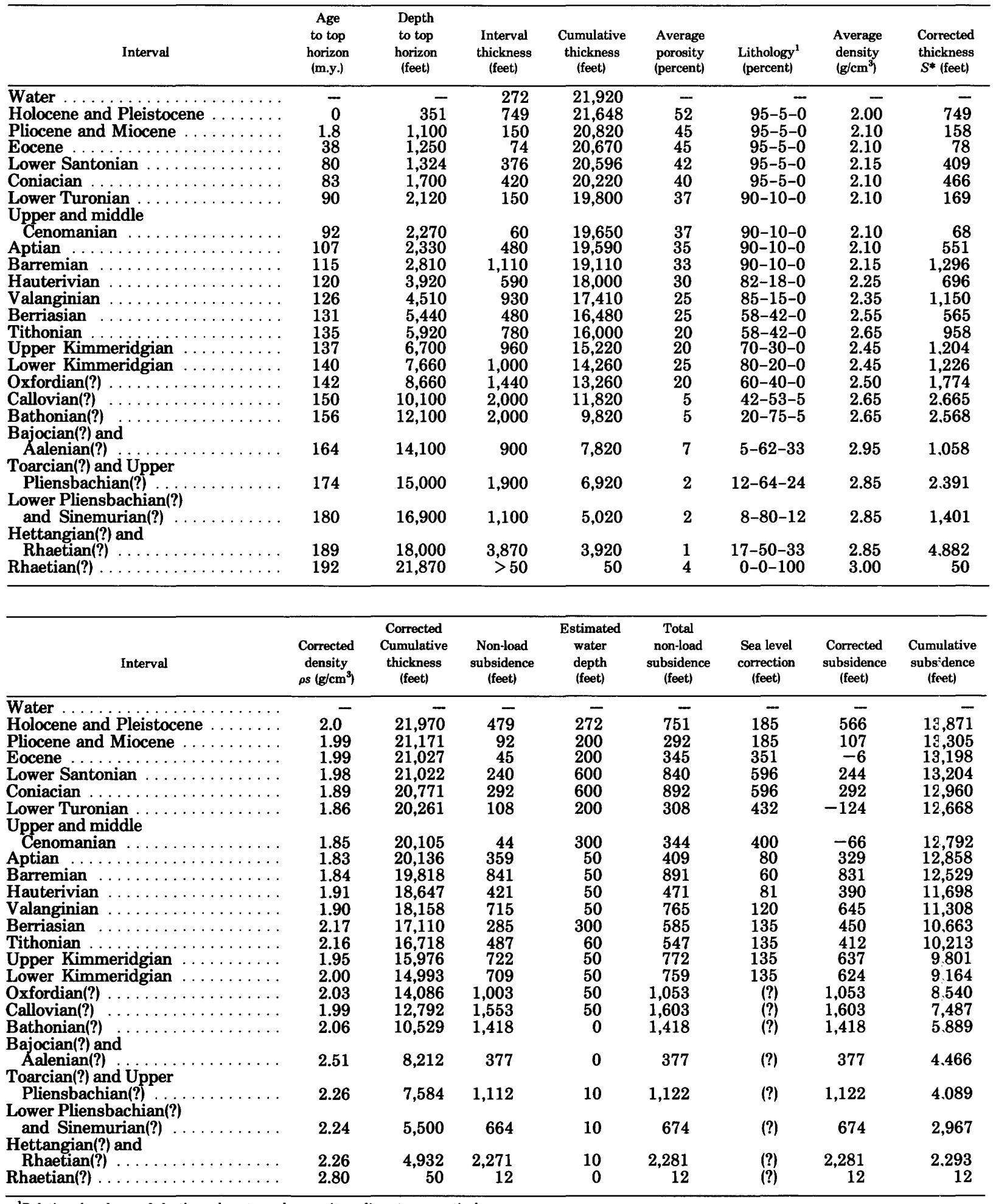

\footnotetext{
${ }^{1}$ Relative abundance of clastic, carbonate, and evaporite sediments, respectively.
} 


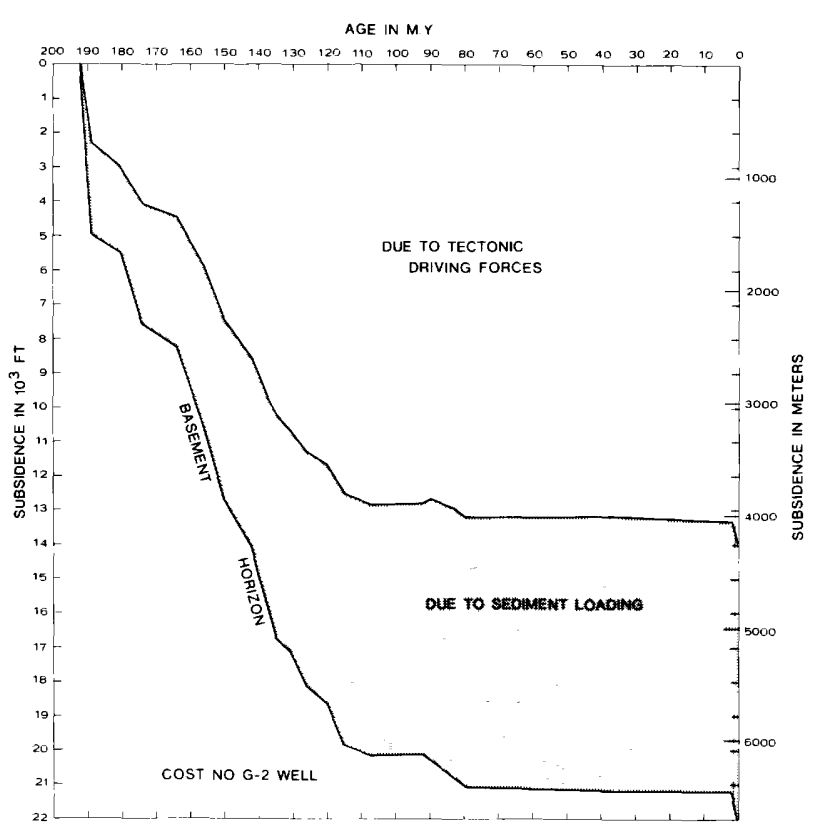

Figure 58.-Subsidence history of the basement (194 m.y. B.P.) and sedimentation at the COST G-2 well. Stippled area shows subsidence due to sediment loading assuming local loading and Airy isostasy. The clear portion is that part of the subsidence due to cooling after crustal thinning or dike intrusion following rifting. See text and table 8 for details of reconstruction.

and Angevine and Turcotte (1981) have demonstrated that the history of heat flow in continental margins can be modeled. The heat flow models allow reconstruction of the general thermal history of sedimentary horizons of different ages, assuming decay of the initial heat flux without addition of heat from other sources, an average thermal conductivity for the basin sediment sequence, and continuous thermal equilibrium within the sequence. These are all reasonable assumptions for the Georges Bank basin.

Royden and others (1980) have constructed thermal models for crust of various thicknesses. They defined a factor, $\gamma$, which equals 0 for normal continental crust and 1 for oceanic crust. The crust at the COST No. G-2 well was thinned to a $\gamma$ value of 0.6 on the basis of the calculated amount of "tectonic" subsidence (Sawyer and others, in press), while the crust at the COST No. G-1 well was thinned to a $\gamma$ value of 0.4 . Sawyer and others (in press) arrived at these values using modeling techniques more sophisticated than those used in this study. The total tectonic subsidence derived here (fig. 58) is about 1,640 to $1,969 \mathrm{ft} \mathrm{(500-600}$ $\mathrm{m})$ greater than in the Sawyer and others model.
Figure 59 shows the model of Royden and others (1980) for the evolution of geotherms in a basin in which the initial thinning occurred at about 200 m.y. B.P. and had a $\gamma$ value of 0.6 (the COST No. G-2 estimate). Estimates of the burial history of several sedimentary hrizons are also illustrated. From these data, time-temperature profiles can be constructed (Waples, 1980). These are shown in table 9.

\section{TIME-TEMPERATURE INDICES AND HYDROCARBON MATUR ATION}

On the basis of temperatures of maximum pyrolysis, thermal alteration indires, and the concentrations of $\mathrm{C}_{15+}$ hydrocarbons, Miller and others (this volume) have inferred that peak thermal maturation of hydrocarbons occurs between 13,000 and $16,000 \mathrm{ft}(3,960$ and $4,570 \mathrm{~m})$ in the COST No. G-1 well and between 14,000 and $18,000 \mathrm{ft}(4,270$ and $5,490 \mathrm{~m})$ in the COST No. G-2 well. Miller and others (this volume) place the "threshold of intense oil generation" at about 9,000 to $10,000 \mathrm{ft}(2,750$ to $3,050 \mathrm{~m})$ in the COST Nos. G-1 and G-2 wells. The estimated "oil window" occurs between about 8,000 and $16,000 \mathrm{ft}$ $(2,440$ and $4,570 \mathrm{~m})$ in the $G-1$ vrell and between 6,700 and $17,000 \mathrm{ft}(2,040$ and $5,180 \mathrm{~m})$ in the $\mathrm{G}-2$ well. There is a general agreemont between the very general estimates of the "oil window" and organic geochemical indicators of thermal maturity of organic matter.

Vitrinite reflectance values, commonly used indicators of thermal maturity, are shown in figures 60,61 , and 62, (analysis by Superior Oil Company for the COST No. G-1 well and by Core Laboratories, Inc., for the COST No. G--2 well). Thermal alteration indices (TAI, figs. 57 and 60) were determined by GeoChem Laboratories, Inc. A vitrinite reflectance $\left(R_{o}\right)$ value of 0.6 is believed to represent the onset of thermal maturation and hydrocarbon generation (Dow, 1؟77; Hunt, 1979). This value occurs at an anoralously shallow depth of about $3,800 \mathrm{ft}(1,160 \mathrm{~m})$ in the G-2 well in Cretaceous sediments and at about $7,000 \mathrm{ft}$ $(2,130 \mathrm{~m})$ in the G-1 well in Upper Jurassic sedimentary rocks. The "oil florr" $\left(R_{o}=1.35\right)$ should occur at about $13,500 \mathrm{ft}(4,120 \mathrm{~m})$ in the G-1 well and $11,500 \mathrm{ft}(3,510 \mathrm{~m})$ in the G-2 well. However, Miller and others (this volume) have discussed the other indications of organic 
TIME IN M.Y B. P.

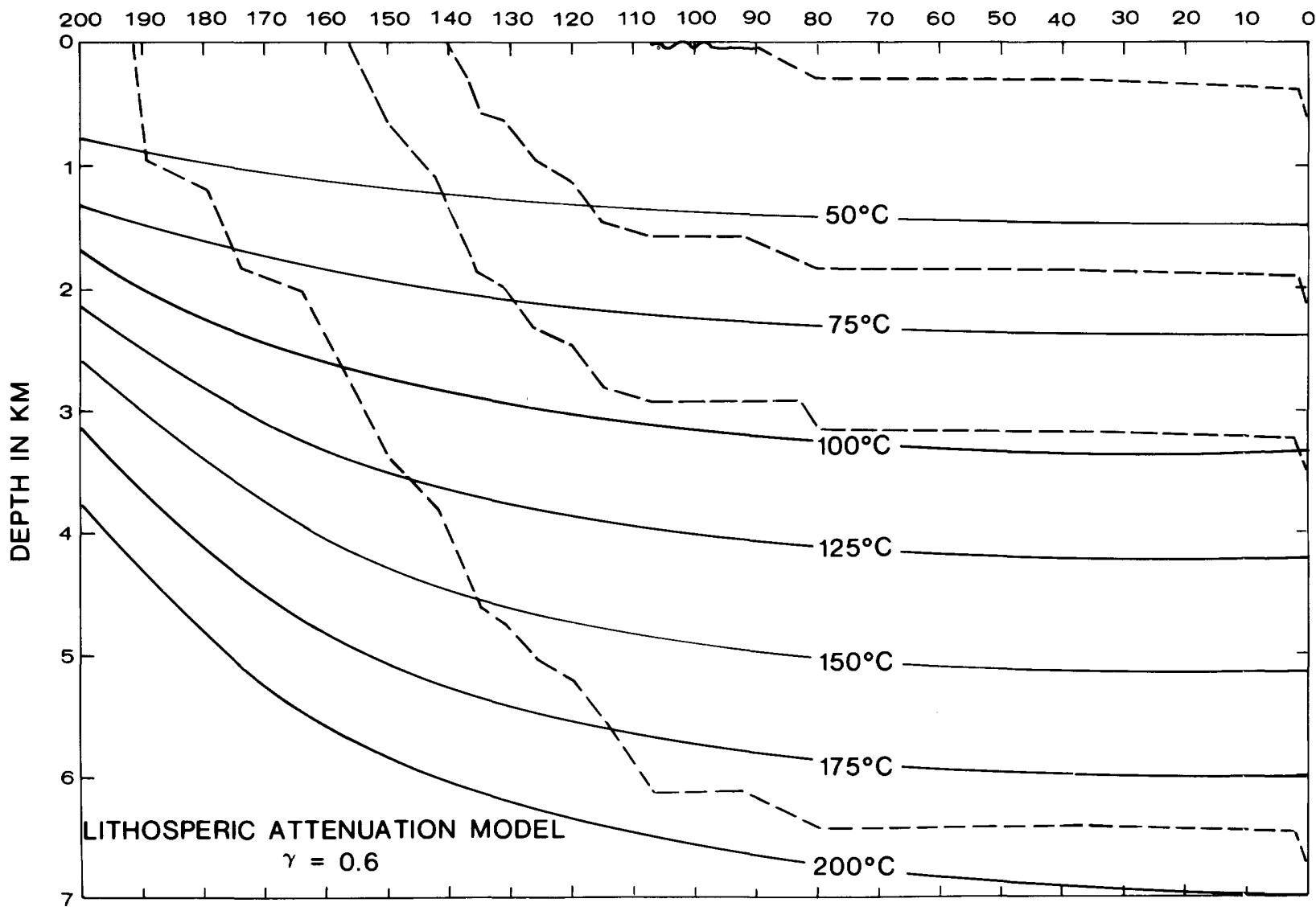

FigURE 59.-Thermal model based on the amount of crustal thinning $(\gamma=0.6)$ at the COST No. G-2 well (after Roydin and others, 1980). The burial histories of sediments approximately 191, 156, 140, and $107 \mathrm{~m} . y$. old (dashed lines) are shown relative to the time-temperature field. These traces were used to calculate the time-temperature indices in table 9.

maturation, which conflict with the vitrinite reflectance data in the COST No. G-2 well. Figure 60 suggests that vitrinite reflectance values are generally too high when compared with TAI in the same samples.

It is possible that the anomalous reflectance values are from reworked or highly oxidized vitrinite derived from a previous sedimentary cycle, or that there is some nonsystematic error in the reflectance determinations. The first possibility is geologically reasonable, but the COST Nos. G-1 and G-2 wells do not exhibit the same pattern of reflectance values with depth, as would be expected if the sediment at both wells was derived from the same source. The reflectance values increase normally and systematically downhole in the G-1 well (figs. 6l, 62), and $R_{o}$ values of equivalent strata in the G-2 well are considerably higher, which suggests errors in the measurements for the G-2 well or bias towards the higher rank vitrinite in each sample.

Figure 62 is a semilog plot of vitrinite reflectance and downhole temperature. The G-1 data plot on a straight line segment with reletively little scatter, suggesting that the values are reasonable and that they increase in a predintable fashion with increasing temperature. The G-2 data define several line segments having dif ${ }^{f}$ erent slopes. The values from about $12,750 \mathrm{ft}(3,890 \mathrm{~m})$ to the bottom of the hole define a line raving about the same slope as the G-1 data. This pattern suggests that the G-2 data from the Jurassic and older section may be accurate. In fact, they reflect a somewhat lower reflertance value for a given temperature than do th? $\mathrm{G}-1$ data. The problem occurs in the reflertance values from 914 to $12,750 \mathrm{ft}$ (278 to $3,890 \mathrm{~m}$ ) in the G-2 well. These data suggest an anonalous 
TABLE 9.-Time-temperature indices for representative horizons in the COST No. G-2 wel:

[TTI, time-temperature index; $r^{n}$, assumed increase in rate of maturation relative to the $100^{\circ}-110^{\circ} \mathrm{C}$ interval, as described in Waples (1980) ]

\begin{tabular}{|c|c|c|c|c|c|c|}
\hline $\begin{array}{l}\text { Temp. } \\
\text { interval } \\
\left({ }^{\circ} \mathrm{C}\right)\end{array}$ & $\mathbf{r}^{\mathbf{n}}$ & $\begin{array}{c}\Delta \text { Time } \\
\text { (m.y.) }\end{array}$ & $\begin{array}{l}\text { Interval } \\
\text { TTI }\end{array}$ & $\begin{array}{l}\text { Total } \\
\text { TTI }\end{array}$ & m.y. B.P. & $\begin{array}{c}\text { Equivalent } \\
\boldsymbol{R}_{\boldsymbol{O}}\end{array}$ \\
\hline \multicolumn{7}{|c|}{ 191-m.y.-old sediment (now at $20,000 \mathrm{ft}(6,096 \mathrm{~m}))$} \\
\hline $\begin{array}{l}100-110 \\
110-120 \\
120-130 \\
130-140 \\
140-150 \\
150-160 \\
160-170 \\
170-180 \\
180-190\end{array}$ & $\begin{array}{l}1 \\
2 \\
2^{2} \\
2^{3} \\
2^{4} \\
2^{5} \\
2^{8} \\
2^{7} \\
2^{8}\end{array}$ & $\begin{array}{c}3.5 \\
4 \\
9 \\
4 \\
2.5 \\
8.5 \\
11 \\
6 \\
110\end{array}$ & $\begin{array}{r}3.5 \\
8 \\
36 \\
32 \\
40 \\
272 \\
704 \\
768 \\
28,160\end{array}$ & $\begin{array}{r}9.84 \\
17.8 \\
53.8 \\
85.8 \\
125.8 \\
397.8 \\
1,108.8 \\
1,869.8 \\
30,029.8\end{array}$ & $\begin{array}{c}151.5 \\
147.5 \\
138.5 \\
134.5 \\
132 \\
123.5 \\
112.5 \\
106.5 \\
-\end{array}$ & $\begin{array}{l}{ }^{10} 0.6 \\
1.65 \\
1.9 \\
11.05 \\
{ }^{1} 1.2 \\
1.7 \\
2.1 \\
3.8 \\
4.2\end{array}$ \\
\hline \multicolumn{7}{|c|}{ 156-m.y.-old sediment (now at $12,100 \mathrm{ft}(3,688 \mathrm{~m})$ ) } \\
\hline $\begin{array}{l}20-30 \\
30-40 \\
40-50 \\
50-60 \\
60-70 \\
70-80 \\
80-90 \\
90-100\end{array}$ & $\begin{array}{l}2^{-8} \\
2^{-7} \\
2^{-6} \\
2^{-5} \\
2^{-4} \\
2^{-3} \\
2^{-2} \\
2^{-1}\end{array}$ & $\begin{array}{c}6 \\
3 \\
3.5 \\
3.5 \\
6 \\
9 \\
7 \\
118\end{array}$ & $\begin{array}{c}.024 \\
.024 \\
.056 \\
.112 \\
.384 \\
1.13 \\
1.75 \\
59\end{array}$ & $\begin{array}{c}.024 \\
.048 \\
.114 \\
.226 \\
.610 \\
1.73 \\
3.48 \\
62.48\end{array}$ & $\begin{array}{l}150 \\
147 \\
143.5 \\
140 \\
134 \\
125 \\
\overline{1}\end{array}$ & $\begin{array}{c}<0.3 \\
<.3 \\
<.3 \\
<.3 \\
<.3 \\
<.3 \\
.45 \\
.5 \\
2 . .95\end{array}$ \\
\hline \multicolumn{7}{|c|}{140 -m.y.-old sediment (now at $7,680 \mathrm{ft}(2,340 \mathrm{~m})$ ) } \\
\hline $\begin{array}{l}20-30 \\
30-40 \\
40-50 \\
50-60 \\
60-70\end{array}$ & $\begin{array}{l}2^{-8} \\
2^{-7} \\
2^{-6} \\
2^{-5} \\
2^{-4}\end{array}$ & $\begin{array}{r}9 \\
6 \\
4 \\
32 \\
89\end{array}$ & $\begin{array}{l}.036 \\
.048 \\
.064 \\
1.02 \\
5.70\end{array}$ & $\begin{array}{l}.036 \\
.084 \\
.148 \\
1.17 \\
6.87\end{array}$ & $\begin{array}{r}131 \\
125 \\
121 \\
89 \\
-\end{array}$ & $\begin{array}{c}<0.3 \\
<.3 \\
<.3 \\
\\
\quad .4 \\
\quad .55\end{array}$ \\
\hline
\end{tabular}

\footnotetext{
${ }^{1}$ In empirical oil-generation window between 11,480 and $15,580 \mathrm{ft}(3,500$ and 4,750 m) burial depth (only $50 \mathrm{~m} . \mathrm{y}$. after deposition).

${ }^{2}$ In oil-generation window at approximately 95 m.y. B.P. at burial depth of $9,500 \mathrm{ft}(2,900 \mathrm{~m})$.

${ }^{3}$ Immature.
}

thermal event that affected only the Upper Jurassic through Upper Cretaceous section of the COST No. G-2 well. Although such a thermal event would not be impossible, it is unlikely that the heating would have increased vitrinite rank without altering TAI values or other indicators of thermal maturity. Therefore the anomalously high average $R_{o}$ values probably do not reflect such an event.

Despite the problem with the vitrinite reflectance values in the G-2 well, the estimates of thermal maturity by Miller and others (this volume) are in general agreement with the thermal model approach. Different estimates are obtained from models of the thermal history of the sediments. The thermal model constructed in figure 59 was used to calculate time-temperature indices (TTI shown in table 9; method outlined by
Waples, 1980) for the following 1 rizons at the COST No. G-2 site: 191 m.y. $(20,000 \mathrm{ft} ; 6,100 \mathrm{~m}$ present depth); 156 m.y. (12,000 ft: 3,690 m present depth); 140 m.y. $(7,680 \mathrm{ft} ; 2,340 \mathrm{~m}$ present depth); and 107 m.y. (2,330 ft; $710 \mathrm{~m}$ present depth). The burial history of each of these sedimentary layers is shown super:mposed on the theoretical depth distribution of temperature through time in the Georges Bank basin. The calculation of TTI for each hc rizon gives a general indication of the thermal maturity of each horizon, based on the data of Wap'os (1980).

The organic matter in the strate near the base of the G-2 well is overly mature on the basis of the calculated TTI; that is, bolow the "oil window" but still within the dry gas stability field. The TTI history indicates that these strata reached the oil window within 50 m.y. after their 


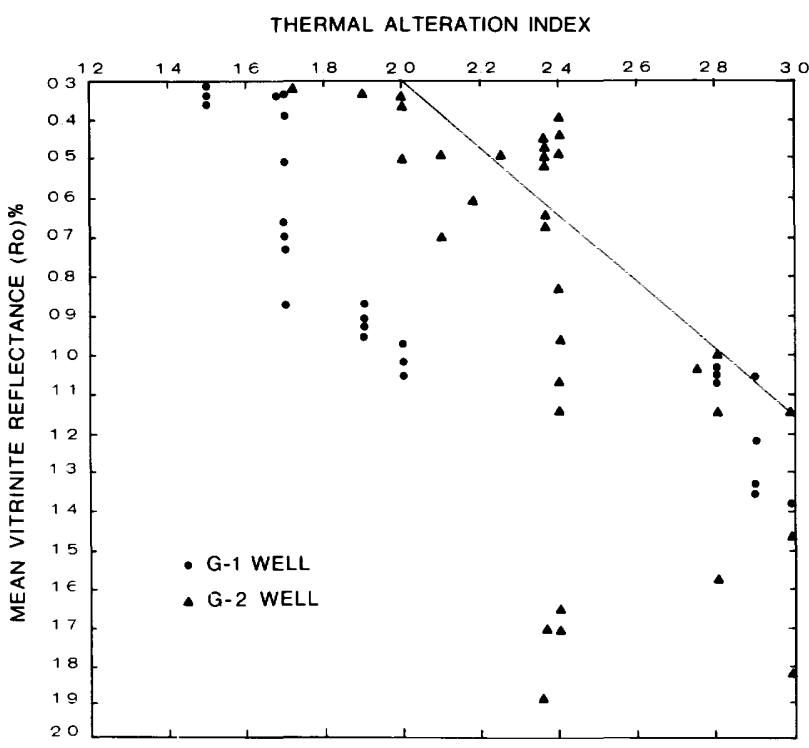

Figure 60.-Mean vitrinite reflectance values versus thermal alteration indices (TAI) for samples from COST wells G-1 and G-2. Line indicates optimum relationship between the two values.

deposition (at a burial depth of about $11,500 \mathrm{ft}$ $(3,500 \mathrm{~m}))$. The TTI values also indicate that these strata remained within the "oil window" for only $15 \mathrm{~m} . \mathrm{y}$. TTI estimates suggest that those units presently buried deeper than $18,000 \mathrm{ft}$ $(5,490 \mathrm{~m})$ are overly mature.

The onset of thermal maturation of the organic matter in the sediments deposited about $156 \mathrm{~m} . \mathrm{y}$. B.P. is estimated to have occurred about $95 \mathrm{~m} . \mathrm{y}$. B.P. at a depth of about $9,514 \mathrm{ft}(2,900 \mathrm{~m})$. The stratum is still within the zone of hydrocarbon generation based on calculated TTI values.

The organic matter laid down at 140 m.y. B.P. is still immature on the basis of TTI values. Sediments near the G-2 well above about $8,500 \mathrm{ft}$ $(2,600 \mathrm{~m})$ have TTI values that apparently indicate thermal immaturity, which is consistent with the organic geochemical data.

The models suggest that the thermal history of the area surrounding the COST No. G-1 well was similar to that at the G-2 well except for somewhat lower temperatures at given depths in G-1. Therefore the maturation horizons should be lower in the G-1 well, which is in agreement with the present-day difference in thermal gradient at the two wells, but not with the organic maturation indicators.

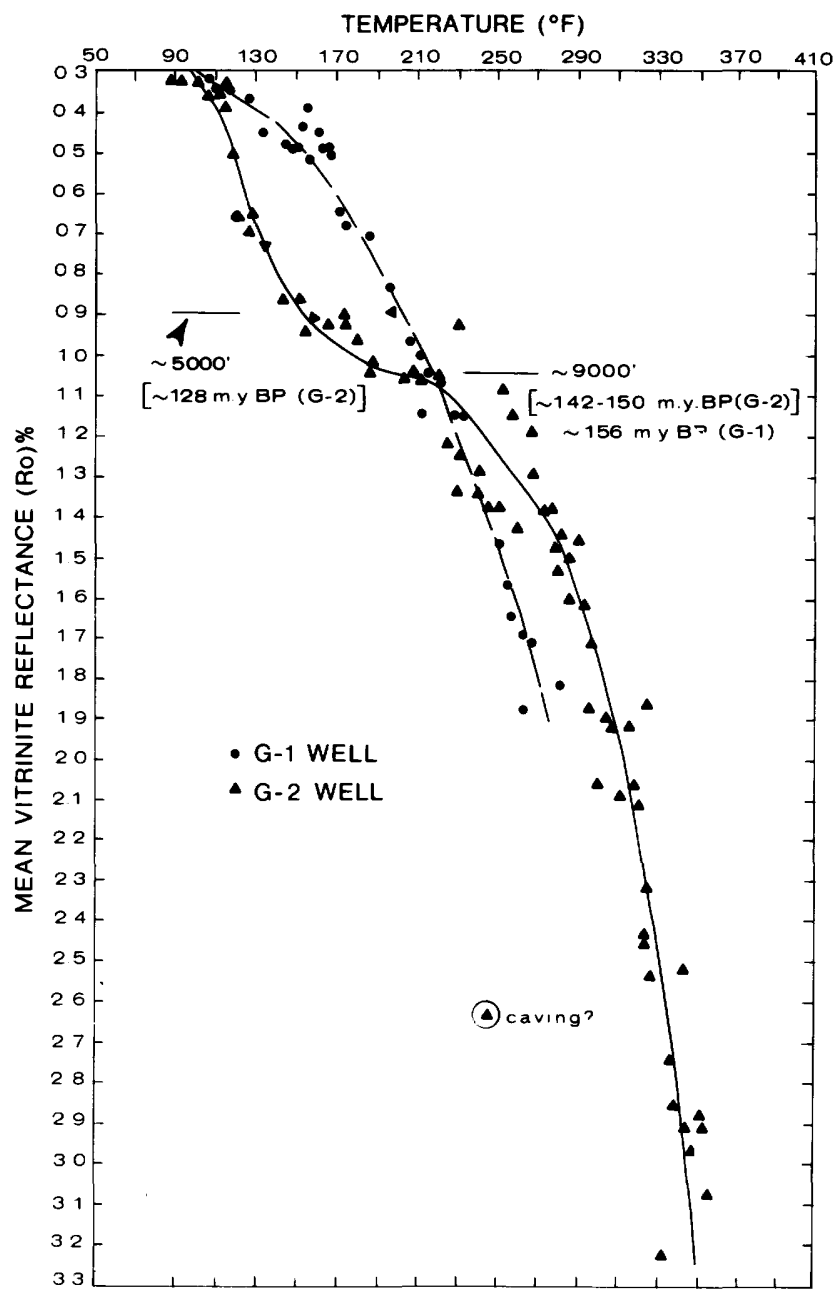

FIgURE 61.-Mean vitrinite reflectance $\left(R_{o}\right)$ versus present in situ temperature (linear plot) for samples from COST wells Nos. G-1 and G-2. Note differences between the tw? wells.

\section{CONCLUSIONS}

There is conflicting evidence of the degree of thermal maturation of organic matter in the COST Nos. G-1 and G-2 wells. The estimates of Miller and others (this volume) are that peak thermal maturation occurs between 13,000 and $15,000 \mathrm{ft}(3,960$ to $4,570 \mathrm{~m})$ in the COST No. G-1 well and at 14,000 to $18,000 \mathrm{ft}(4,270$ to $5,490 \mathrm{~m})$ in the COST No. G-2 well, with the "threst old of intense oil generation" occurring in both walls at about 9,000 to $10,000 \mathrm{ft}(2,750$ to $3,050 \mathrm{~m})$. These estimates are based mainly on the concent"-ation of $\mathrm{C}_{15}+$ hydrocarbons, the temperatures of maximum pyrolysis, and thermal alteration index (TAI) values. The modern thermal gradient at the two wells, the vitrinite reflectance values, and 


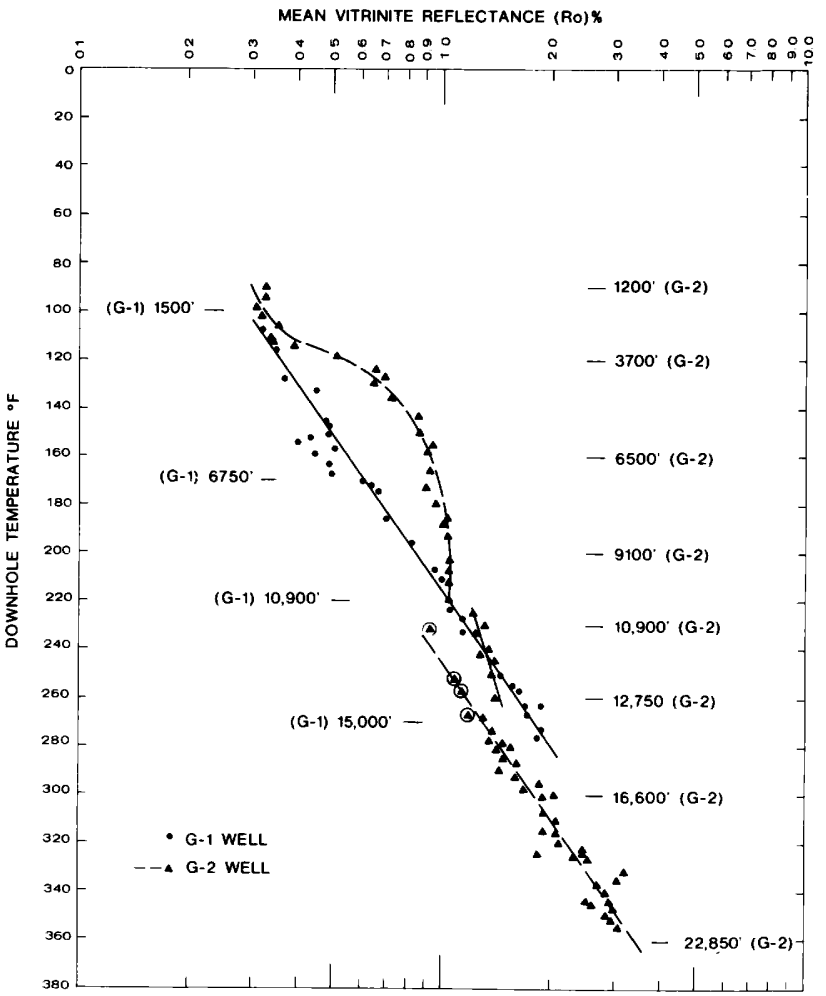

FIGURE 62.-Semilog plot of mean vitrinite reflectance $\left(R_{o}\right)$ versus present in situ temperature for samples from COST wells Nos. G-1 and G-2. thermal models and calculated time-temperature indices (TTI) suggest that the cnset of thermal maturation should occur at slimhtly shallower depths in the two wells; a dejth of $8,500 \mathrm{ft}$ $(2,590 \mathrm{~m})$ in the G-2 well seems re asonable for the beginning of thermal maturity. TAI values below this depth are around 2 and the carbon preference index (CPI) is about 1.5 and decrases downhole. These values are taken as an indication of the onset of thermal maturity.

Previous estimates of the depth of the beginning of maturation in other Atlantic area COST wells are about $9,000 \mathrm{ft}(2,750 \mathrm{~m})$ in the GE-1 well, $11,300 \mathrm{ft}(3,450 \mathrm{~m})$ in the B-2 well, and $14,300 \mathrm{ft}(4,350 \mathrm{~m})$ in the B-3 well. The COST No. G-2 well does have the highest present-day geothermal gradient of these wells; however, thermal maturation is affected by the richness and type of organic matter in the sediment. Therefore the prospects for significant generation and accumulation of oil and gas from in situ sources in the Georges Bank basin near the COST No. G-1 or G-2 well are not good, regardless of the thermal history of the basin. (See Miller and others, this volume.) 


\title{
Geophysical Studies of the COST Nos. G-1 and G-2 Wells
}

\author{
David J. Taylor and R. C. Anderson
}

Digital well log data from the COST Nos. G-1 and G-2 wells were used to compute subsurface velocities and synthetic seismograms. The interval-traveltime log from each well was integrated over each respective depth range, producing a relationship between depth and two-way traveltime for a seismic wave propagating through the subsurface. This relationship was used to convert the suite of well logs recorded as a function of linear depth to linear functions of time. The interval-traveltime log also provided other velocity information relevant to seismic reflection processing and interpretation. Synthetic seismograms were also computed using the velocity and density logs from the wells. The synthetic seismograms were bandpass filtered to match the seismic field data for correlation, and then spliced into the seismic line at the appropriate location.

\section{VELOCITY INFORMATION}

The average velocity function, shown in figure 63 for the COST No. G-1 well and figure 64 for

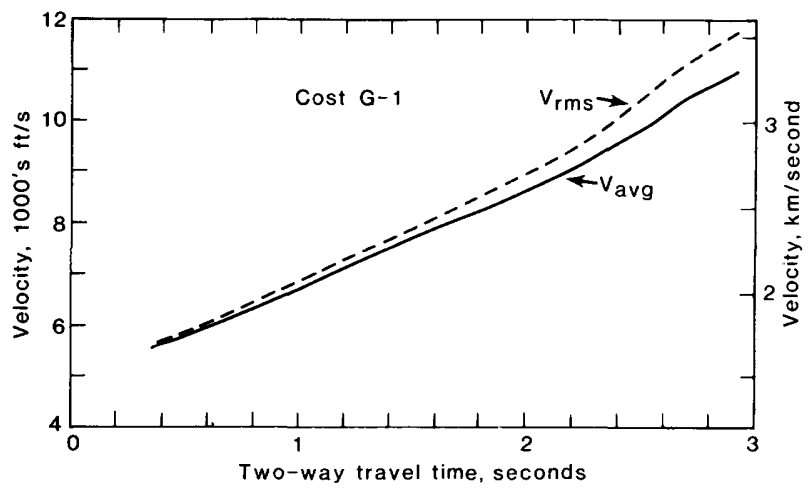

Figure 63.-Average velocity $\left(\mathrm{V}_{\text {avg }}\right)$ and root-mean-square velocity $\left(V_{r m s}\right)$ as a function of two-way traveltime from sea-level datum for the COST No. G-1 well. the COST No. G-2 well, can be used to compute the depth of a seismic reflection given its or ?-way time position. Average velocities are also ured in the migration processing of seismic data in areas of geologic structure. The root-mean-square velocity shown on the same plots can be used for computing normal-moveout times, an imprrtant step to perform prior to the stacking proc?ss of multifold seismic reflection data. These velocities are only applicable in areas where the subs urface layers are relatively flat.

The curve that relates depth to two-way traveltime below the sea floor is shown in figure 65 for both wells. Because the wells are fairly close to each other, the curves nearly overlap throughout the extent of the logs. This crossplot can be used directly to determine the depth of a reflector given its two-way time position on the seismic line.

\section{SEISMIC DATA}

Two multichannel seismic reflection line were recorded for the USGS in 1977 by Digicon, Inc. of

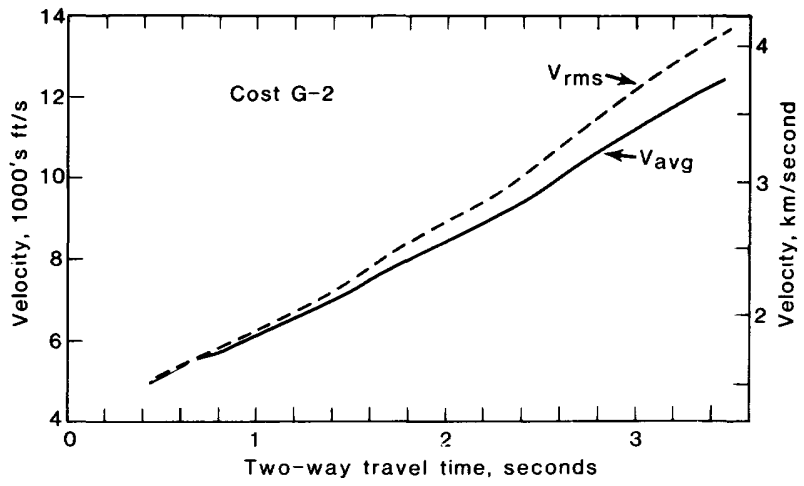

FIGURE 64.-Average velocity $\left(V_{\text {avg }}\right)$ and root-mear-square velocity $\left(\mathrm{V}_{\mathrm{rms}}\right)$ as a function of two-way traveltine from sea-level datum for the COST No. G-2 well. 


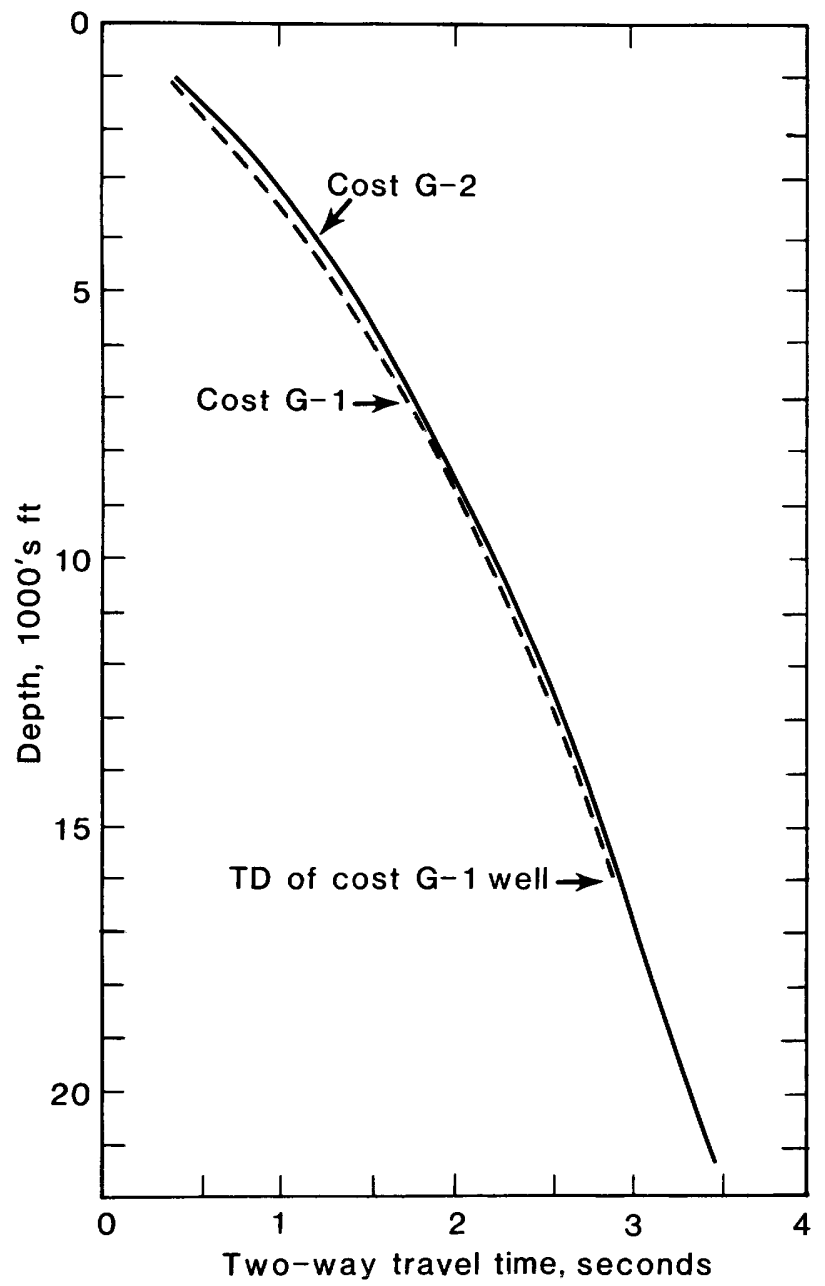

FIgURE 65.-Two-way traveltime below sea-level datum as a function of depth for the COST No. G-1 and COST No. G-2 wells.

Houston, Tex., to tie the COST Nos. G-1 and G-2 wells into the regional network of USGS multichannel seismic reflection lines on the Atlantic Outer Continental Shelf (AOCS). The orientations of these seismic lines with respect to regional USGS seismic reflection lines and the Cost Nos. G-1 and G-2 well locations are shown in figure 66. Line 77-1 crosses the COST No. G-1 well at shotpoint 95, and line 77-2 crosses the COST No. G-2 well at shotpoint 96 . Both lines were recorded for 36-fold common-depth-point (CDP) multiplicity with a record length of 7 seconds two-way time. Shotpoint 350 on line 77-1 intersects USGS line 12 at shotpoint 10,800 . Shotpoint 205 on line 77-2 intersects USGS line 1 at shotpoint 1,200 .
Both seismic lines 77-1 and 77-2 were recorded on a 48-channel streamer at a 4-millisecond sampling interval. The data proressing of each line consisted of the following procedures. After demultiplexing and applying exponential gain to the field tapes, velocity analyses were performed on both seismic lines at $1-\mathrm{mi}(1.6-\mathrm{km})$ intervals for normal-moveout correction and stacking. To attenuate multiple reflections and reverberations, two deconvolution filters were applied to the stacked data. After deconvolutior a set of bandpass filters of 10 to $35 \mathrm{~Hz}$ from 0 to 1.6 seconds, and 5 to $25 \mathrm{~Hz}$ from 1.6 to 4.0 seconds were applied to remove extraneous noise left on the data. A final gain process (AGC) bas $¥ d$ on 1-second sliding windows was applied to ba'ance the amplitudes on the section.

\section{SYNTHETIC SEISMOGRAMS}

Using the digitized interval-traveltime and density logs from the two COST wells, zero-offset synthetic seismograms were computer generated and correlated to the multichannel reflection seismic lines described in the previous section. A reflection coefficient series was fir.t generated by converting the log data from depth to time, and computing the change of acoustic impedance (product of density and velocity) anross each time layer. These reflection coefficients were then filtered with a bandpass filter $n$ hose passband was chosen to match that of seismic reflection lines 77-1 and 77-2.

The generation and utilization of synthetic seismograms is well described by Sengbush and others (1961) and Peterson and ot' ors (1955). The shortcomings of the methods use $d$ in constructing accurate synthetic seismograms are that plane waves are assumed, the source wavelet is usually not known, interbed multiples are not properly modeled, absorption and attenuation are not computed, and the effects of noise are not added. The effects of these problems are not corrected and degrade the comparison of synthetic seismograms to field data, although correlations are still worth making.

The seismic lines were deliberately recorded close to the two COST wells to allow a reliable correlation of well data with seisnic data. Based on the results in figures 67 and 68 , there are certain areas of the log where the correlations to the 


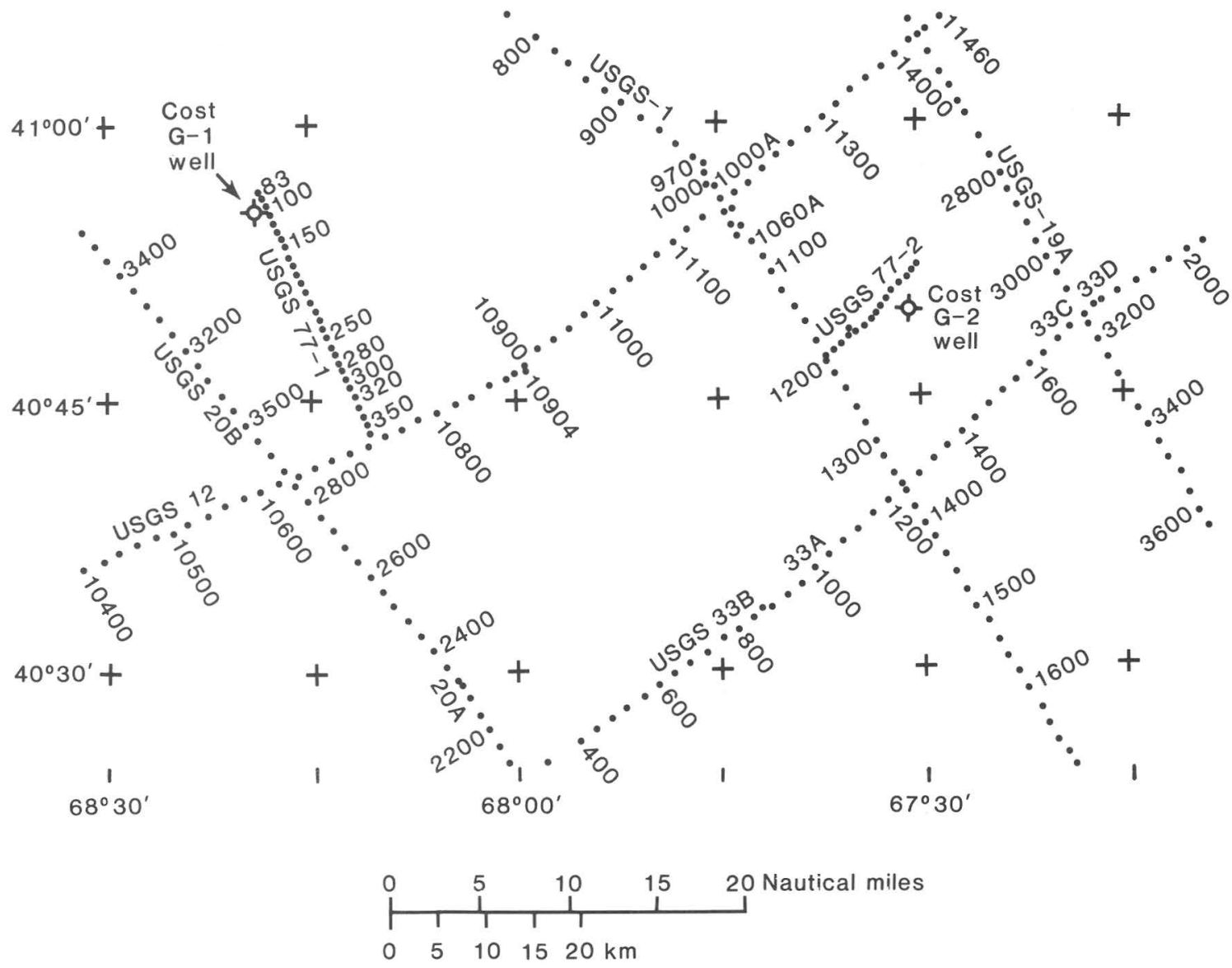

FIGURE 66.-Locations of seismic lines 77-1 and 77-2 with respect to the COST wells and other regional USGS seismic reflection lines.

seismic data are very good, while at other locations there are reflection amplitudes on the synthetic seismogram that are not as prevalent on the seismic data. We suspect that the seismic data provide the more accurate description of the subsurface geology, and it is the well log data that is in error, mainly because of the inaccurate measurement of the true formation velocities by the interval-traveltime log. The log data were not edited prior to the generation of the synthetic seismograms, although the data were smoothed to reduce noise.

Selected data-versus-depth curves from both wells were converted to two-way traveltime and plotted with the synthetic seismograms for G-1 (fig. 69) and for G-2 (fig. 70). These curves include caliper, gamma ray, conductivity, neutron porosity, and interval velocity derived from the interval-traveltime curve. Age boundaries and a condensed description of lithology are also included in these figures. The figures show the correlation of lithology and porosity with seismic reflection expression, and demonstrate (under ideal conditions) the "detectability" of particular geologic horizons. Obtaining a reasonably good correlation of the synthetic seismogram data to the seismic reflection field data is desirable, so that major geologic boundaries can accurately be defined and carried away from the well to other regional seismic lines. 


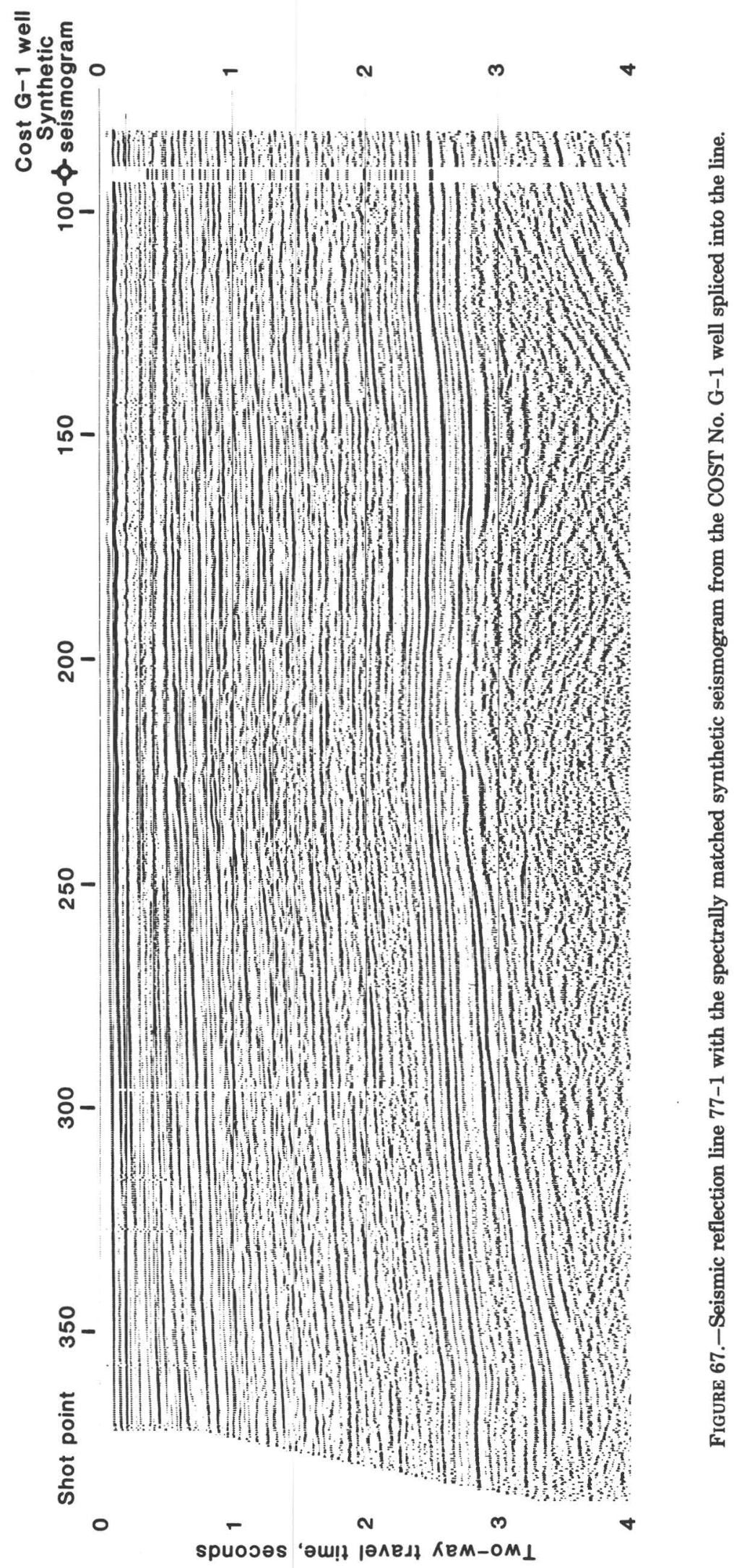




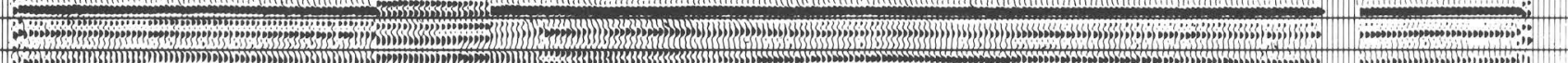

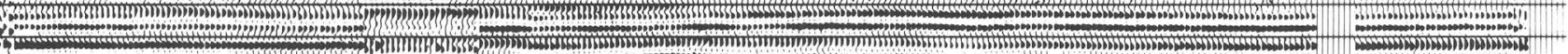

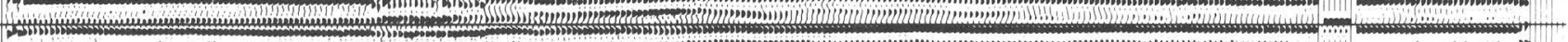

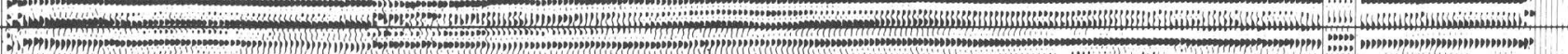
2.

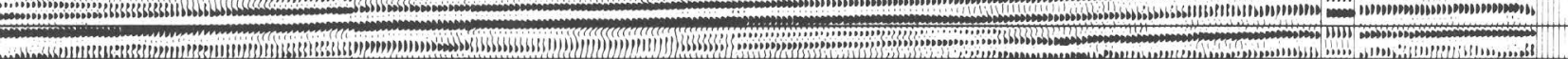

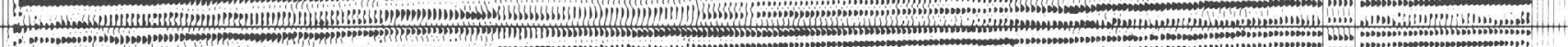
1.

1

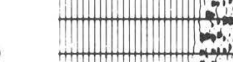
3. 7. - 2.

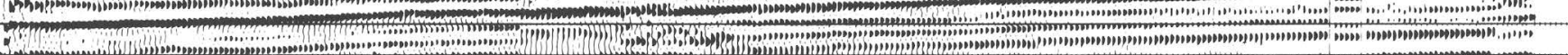

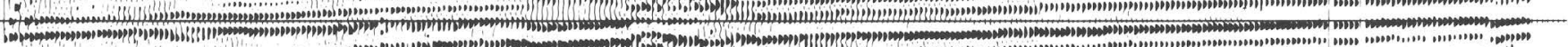
1. 1

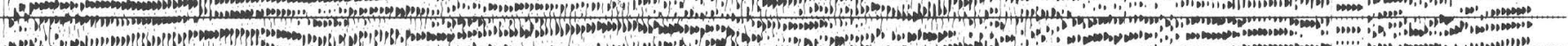

Hon D.

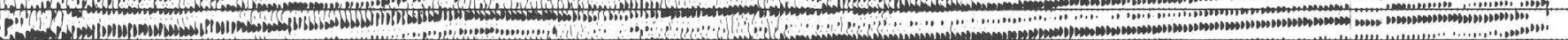
G 17. 2. 冉

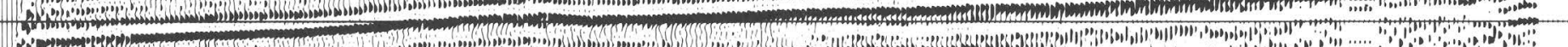
(3) ding 3 W (2) C. 24. 2.SS MTIU⿴囗十) (2) 4 -

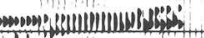
(n)

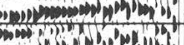

FIGURE 68.-Seismic reflection line 77-2 with the spectrally matched synthetic seismogram from the COST No. G-2 well spliced into the line. 


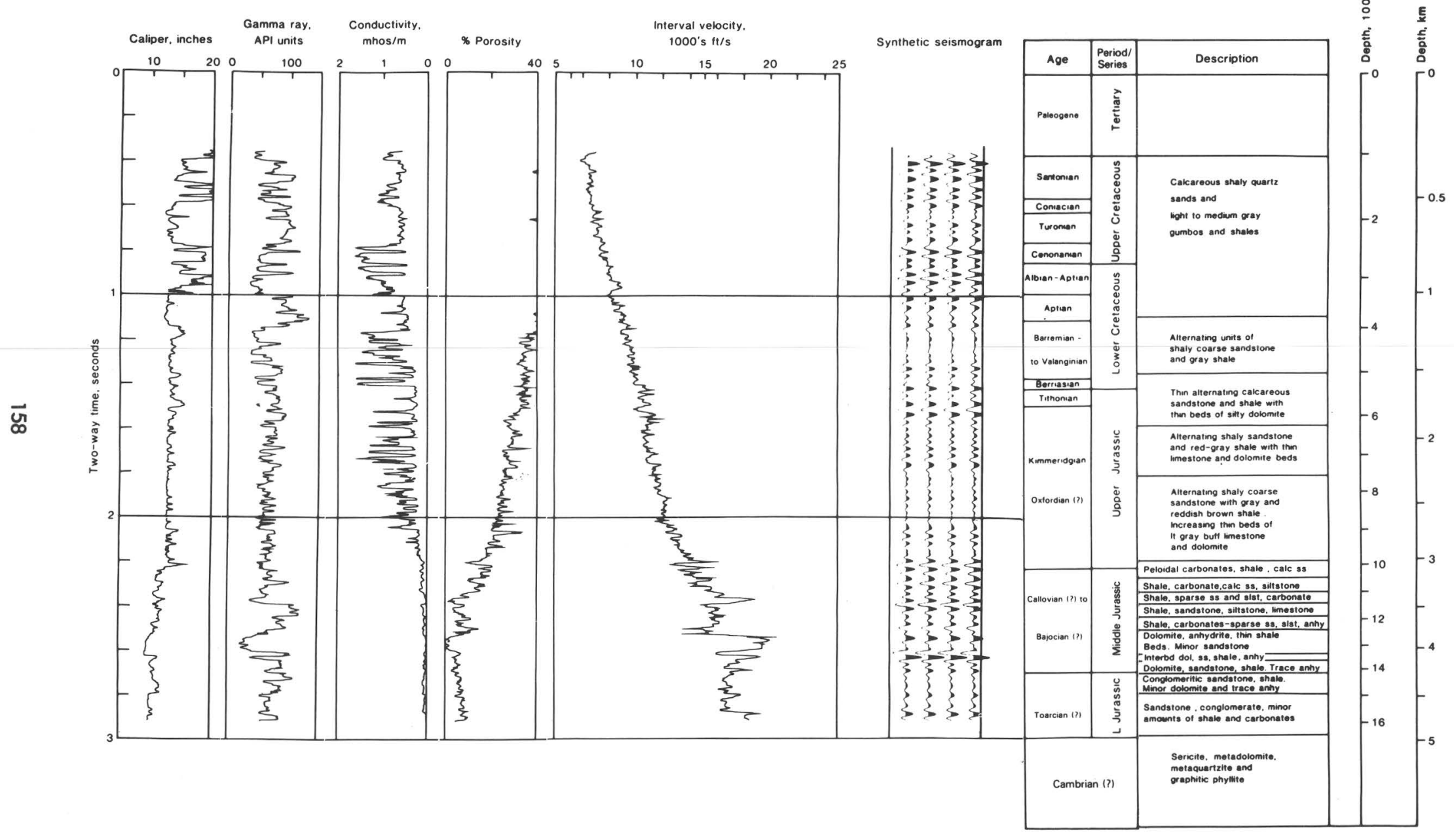

FigURE 69.-Selected log curves and the synthetic seismogram from the COST No. G-1 well plotted as a linear function of time. Age boundaries and lithologic descriptions from Amato and Simonis (1980). 


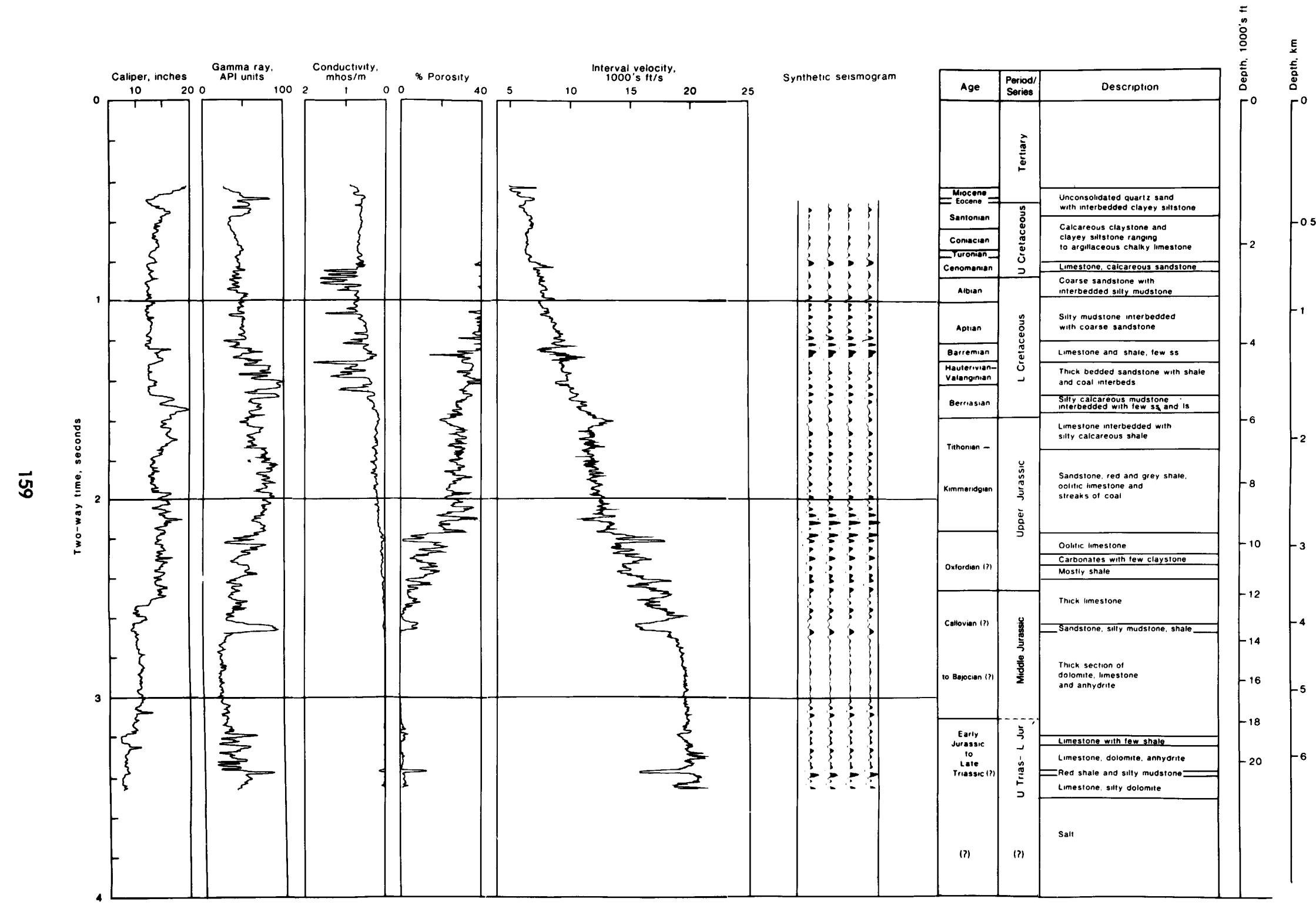

FIGURE 70.-Selected log curves and the synthetic seismogram from the COST No. G-2 well plotted as a linear function of time. Age boundaries and lithologic descriptions from Amato and Simonis (1980). 


\title{
Basement Structure, Sedimentation, and Tertonic History of the Georges Bank Basin
}

\author{
Kim D. Klitgord, John S. Schlee, and Karl Hinz
}

\section{INTRODUCTION}

The sediment-filled basins beneath Georges Bank formed as the continental margin subsided during and following the rifting of Africa from North America. We shall develop a tectonic history for this region by examining the crustal foundation beneath these basins and by outlining the stages in sedimentary buildup. The analysis of magnetic and gravity data integrated with seismic reflection profiles provides clues as to the nature of basement rocks, their depth of burial, composition, and tectonic setting. The interpretation of seismic reflection profiles and the correlation of seismic stratigraphic units with lithostratigraphic units at the COST Nos. G-1 and G-2 wells gives a history of basin filling over the past $200 \mathrm{~m} . y$., including major trends in rock types and their thicknesses, relative ages of interregional unconformities, and the relationship of the basin sedimentation to the construction of the adjacent continental slope and rise.

Before the G-1 and G-2 wells were drilled, most of the information concerning the subsurface of Georges Bank was derived from a combination of geophysical data and the extrapolation of stratigraphy from the Shell Mohawk well on the Scotian shelf. (See, for instance, Ballard and Uchupi, 1972; Mattick and others, 1974; Schlee and others, 1976, 1979; Klitgord and Behrendt, 1979; Austin and others, 1980.) In this report, magnetic and gravity data are used in conjunction with multichannel seismic reflection data (fig. 71) to outline the basement structures, to interpolate seismic basement features between seismic lines, and to provide depth estimates for basement in regions of limited acoustic penetration.

The seismic stratigraphy for the Georges Bank shelf, slope, and rise was determined from correla- tion with the lithostratigraphy at the Shell Mohawk well (Schlee and other. 1976), at the COST Nos. G-1 and G-2 wells (Amato and Bebout, 1980; Amato and Simonis, 1980; Poag, this volume), at the Nantucket rell (Folger and others, 1978), and at Deep Sea Drilling Project (DSDP) sites (Klitgord and Grow, 1980). Additional information concerning the shallow stratigraphy was provided by the 1976 Atlantic Margin Coring Project (AMCOR) (Hathaway and others, 1976, 1979) and other multichannel seismic data (Austin and others, 1980). The correlation of deep-sea and shelf seisric stratigraphy is tenuous, because a buried shelf edge of Lower Cretaceous and older carbonate rocks (Schlee and others, 1979) obscures the acoustic record of the transition across the shelf and slope.

Interval velocities determined from the USGS multichannel seismic data have $\mathrm{b}$ œen used to correlate the seismic stratigraphy on the seismic lines with the lithostratigraphy in the various drill holes (Schlee and others, 1976; Ditty, 1980; Waetjan, 1980; Poag, this volume). This same velocity information has also be? $n$ used to produce depth sections (fig. 72), iso nach maps, and structure contour maps (fig. 3 in Schlee and Klitgord, this volume). The interval velocities were determined from the multinhannel profile velocity scans using the method of Taner and Koehler (1969).

\section{BASEMENT STRUCTURE}

\section{MAGNETIC ANOMALY DATA}

Magnetic surveys of the Georfes Bank region were conducted in 1965-196 $\epsilon^{\circ}$ by Project MAGNET (U.S. Naval Oceancoraphic Office, 1966; Taylor and others, 1968; K ane and others, 


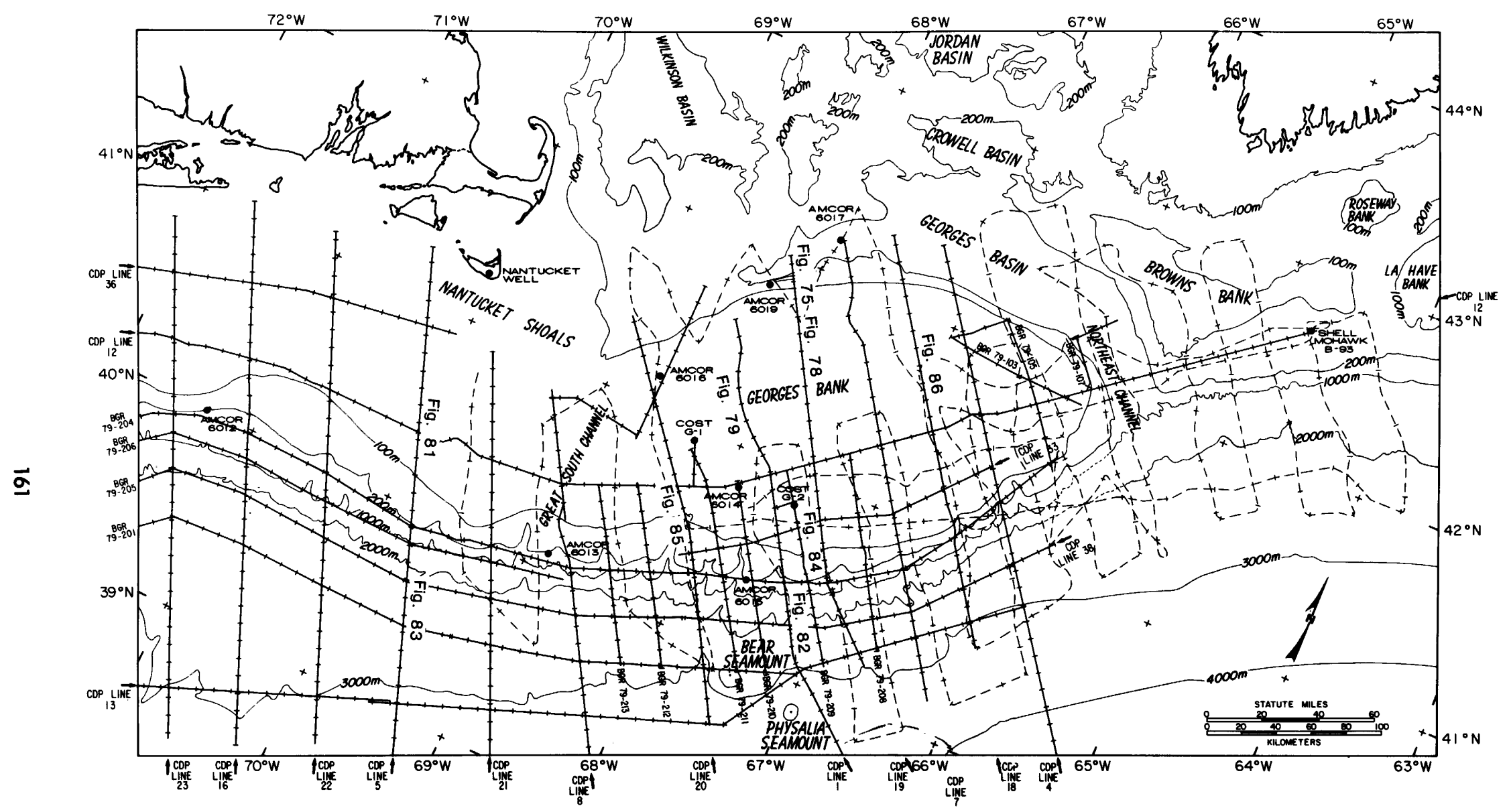

FIGURE 71.-Multichannel seismic reflection profiles in the Georges Bank region. U.S. Geological Survey common depth point (CDP) profiles (24- or 48-channel stacks) and Bundesanstalt fuir Geowissenschaften und Rohstoffe (BGR) profiles (48-channel stacks) are shown as solid lines with crossticks at 10-km intervals. Woods Hole Oceanographic Institution (WHOI) CDP profiles (6-channel stacks) are indicated by dashed lines. Bathymetric contours, in meters, are from Uchupi (1966). Continental Offshore Stratigraphic Test (COST) drill sites and Atlantic Margin Coring Program (AMCOR) drill sites are shown by circles. 

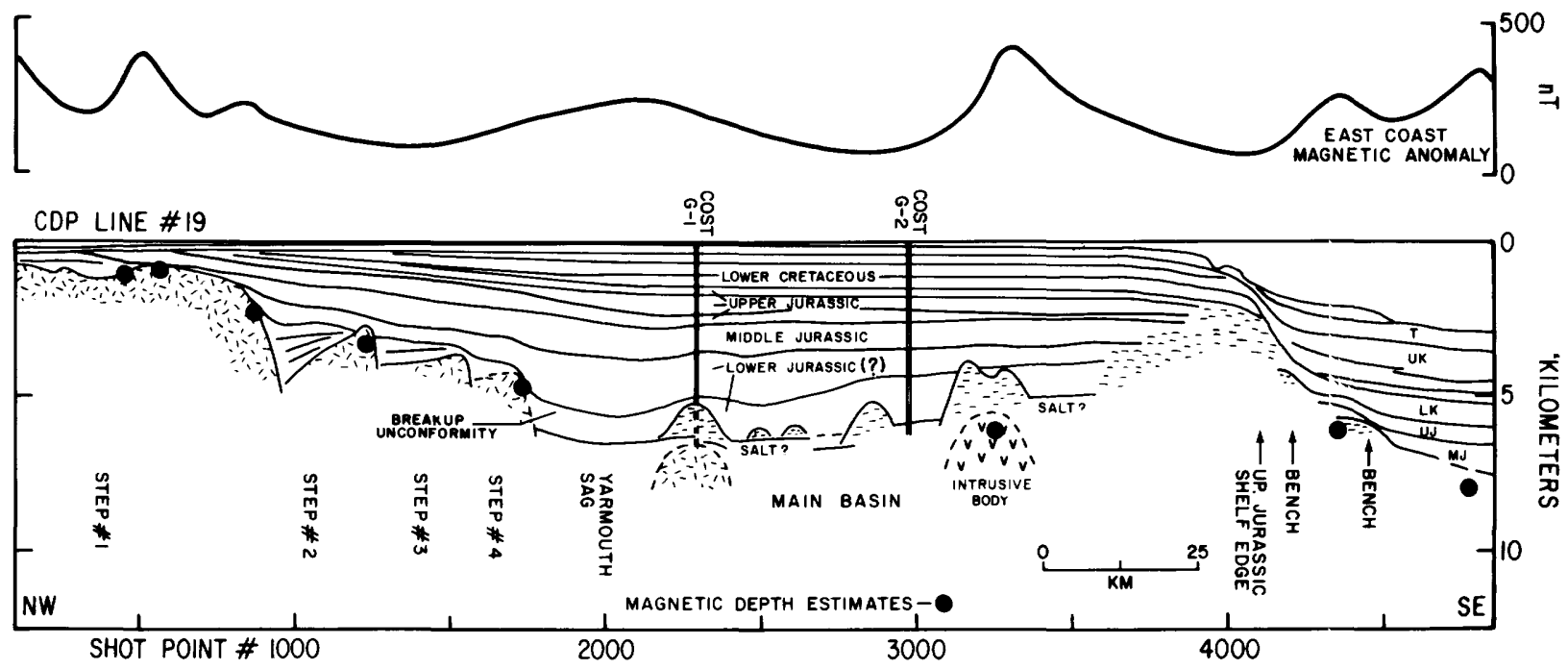

FIGURE 72.-Typical cross section and magnetic anomaly profile for the Georges Bank basin based on CDP line 19. The dashed basement beneath the breakup unconformity is inferred from adjacent seismic profiles and magnetic drta. The locations of the COST Nos. G-1 and G-2 wells are projected onto the cross section. Ages of seismic stratigraphic units are from Poag (this volume). Solid dots show locations of depth-to-magnetic-basement estimates from Klitgord and Behrendt (1979).

1972) and again in 1975 by LKB Resources, Inc., for the USGS (Klitgord and Behrendt, 1977, 1979). The magnetic anomaly contour map (fig. 73) is a composite of these two surveys plus some data published by the Geological Survey of Canada (Haworth and MacIntyre, 1975). A 50-nanotesla (1 nT=1 gamma) contour interval was used for the entire map ( $2 \mathrm{nT}$ and $10-\mathrm{nT}$ contours are 'also available for the LKB/USGS survey; Behrendt and Klitgord, 1979). Flight lines for the LKB/USGS survey have a spacing of $2.5 \mathrm{~km}(1.5 \mathrm{mi})$ at an elevation of $300 \mathrm{~m}(984 \mathrm{ft})$ over eastern Georges Bank and $3.2 \mathrm{~km}(2.0 \mathrm{mi})$ at an elevation of $450 \mathrm{~m}(1,475 \mathrm{ft})$ over western Georges Bank. The Project MAGNET survey (U.S. Naval Oceanographic Office, 1966) was flown at an elevation of $750 \mathrm{~m}(2,46 \mathrm{ft})$, and flight line spacing was about $8 \mathrm{~km}(5 \mathrm{mi})$. For a more complete discussion of these two surveys, see Taylor and others (1968) and Klitgord and Behrendt (1979).

Basement structures were mapped using inferred magnetic source depths to interpolate seismic basement structures between seismic lines. Depth-to-magnetic basement estimates were determined for the entire LKB/USGS survey (fig. 74) (Klitgord and Behrendt, 1979). A comparison between these depth-to-magnetic basement estimates and a seismic depth section (fig. 72) demonstrates the close correlation between magnetic and seismic basement. Also, low magnetic anomalies correlate well with shallow grabens (fig. 75); narrow magnetic highs k order the edges of the grabens and may be caused by intrusive igneous features along the edges of the grabens.

\section{GRAVITY ANOMALY DATA}

The gravity anomaly map (fig. 76 ) is a composite of several maps (Kane ard others, 1972; Haworth and MacIntyre, 1975; Grow and others, 1976 ; 1979) that were based on marine profiles and measurements from a few httom stations. Free-air gravity anomalies with a 10-mGal contour interval were used offshore south of lat $42^{\circ} \mathrm{N}$. and simple Bouguer gravity anomalies with a 10-mGal contour interva' were used onshore and offshore north of lat $42^{\circ} \mathrm{N}$. The most prominent gravity feature in this area is the large peak and trough at the shelf breat. This anomaly is produced by the horizontal consity contrast between sediment and water in the vicinity of the shelf break and slope (Worzel and Shurbet, 1955). The calculation of Bouguer anomalies or isostatic anomalies (Talwani and Eldholm, 1973; Rabinowitz, 1974; Rabinowitz and LøBrecque, 1977; Grow and others, 1979) removes most of this edge effect anomaly. An example of this can be seen in the Bouguer anomaly contours north of lat $42^{\circ} \mathrm{N}$. and in the isostatic anc naly calculated along CDP line 5 (fig. 77). 
Gravity anomalies over the shelf reflect the same general basement structure indicated by the magnetic and seismic data. The northeasttrending gravity highs over Martha's Vineyard and Nantucket, and between Step \#1 and Step \#2 (lat $42^{\circ} \mathrm{N}$., long $68^{\circ} \mathrm{W}$.), are located above basement highs. The northeast-trending gravity low around lat $41^{\circ} \mathrm{N}$., long $69^{\circ} \mathrm{W}$., coincides with the deepest part of the Georges Bank basin (Schlee and others, 1976) and extends to the northeast over the broad basement sag just north of the Yarmouth arch. The gravity field over the main basin seaward of the Yarmouth arch is dominated by the edge-effect anomaly at the shelf break.

\section{SEISMIC BASEMENT}

Seismic reflection profiles across the Georges Bank region (fig. 71) show great variability in depth and character of seismic (acoustic) basement. Except in the vicinity of the carbonate buildup associated with the ancient shelf edges (Schlee and others, 1976, 1979) there is a general seaward deepening of seismic basement. We use the term crystalline basement to refer to the surface that is the bottom of the sedimentary fill and the top of metamorphic or igneous rocks. Seismic basement is the surface of maximum interpretable acoustic penetration, and the depth to that surface can vary between seismic lines, depending upon data quality. We have attempted to interpret those regions where seismic basement does not coincide with crystalline basement.

The deep structure for Georges Bank can be divided into four characteristic zones: (1) a lowrelief zone of Paleozoic or older metamorphic and igneous rocks that is present on the shallow stable platforms; (2) a block-faulted zone of Paleozoic or older metamorphic or igneous rocks that deepens seawards in distinct steps; (3) a zone of very thick sediments with prograding carbonate deposits at its seaward edge; and (4) a zone of oceanic basement that was generated by sea-floor spreading. Crystalline basement and seismic basement usually coincide in zone 1 (continental crust) and zone 4 (oceanic crust). The seismic basement in zone 1 is characterized by a very strong reflector associated with shortwavelength undulating relief in some areas, sets of diffraction patterns in other areas, and negligible relief in still other areas. The seismic basement in zone 4 is characterized by closely space hyperbolic echoes and generally low relief.

The most complex area of basin development is in zones 2 and 3 , where seismic basement rarely coincides with crystalline basement. On many of the seismic profiles the breakup unconformity (Falvey, 1974) coincides with seismic basement, and the nature of crystalline basement somewhere beneath it can be inferred only from the character and shape of this unconformity surface. Across the block-faulted zone 3, a number of halfgrabens that form subbasins lie beneath the breakup unconformity. Sediments within these grabens appear as zones of seaward- or landwarddipping reflectors truncated by the breakup unconformity (fig. 78). The unconformity deepens abruptly over the downthrown side of the graben (shotpoint 900, fig. 78) and then levels off until encountering the next graben (shotpoint 1220, fig. 78). The diffraction pattern and rough seismic basement on the upthrown side of the half-graben (shotpoint 1200, fig. 78) may indicate crystalline basement; on some profiles, this rough basement can be traced beneath the dipping reflectors. On profiles where the breakup unconformity coincides with seismic basement (fig. 79), these same narrow zones of steep dips (separated by more gently dipping segments) give the seismic basement a steplike appearance. We infer that crystalline basement, as illustrated in figure 78 , is probably a series of half-grabens beneath these steps. Seaward of this block-faulted zone, seismic basement is usually an interval of chaotic reflectors, either directly beneath or at the breakup unconformity. The recovery of halite at the bottom of the COST No. G-2 well (Amato and Simonis, 1980 ), from the stratigraphic unit that we would place directly below the breakup unconformity suggests that salt forms seismic basement. The patches of chaotic reflectors directly below the unconformity have been interpreted by Poag (this volume) as carbonate mounds. Seaward of the COST No. G-2 well, seismic basement becomes shallower because of a prograding carbonate buildup near the Jurassic and Lower Cretaceous shelf edge. We cannot identify crystalline basement in this region.

\section{DISCUSSION}

The basement structure map for the Georges Bank region (fig. 73) combines magnetic basement (fig. 74) and seismic basement information. 


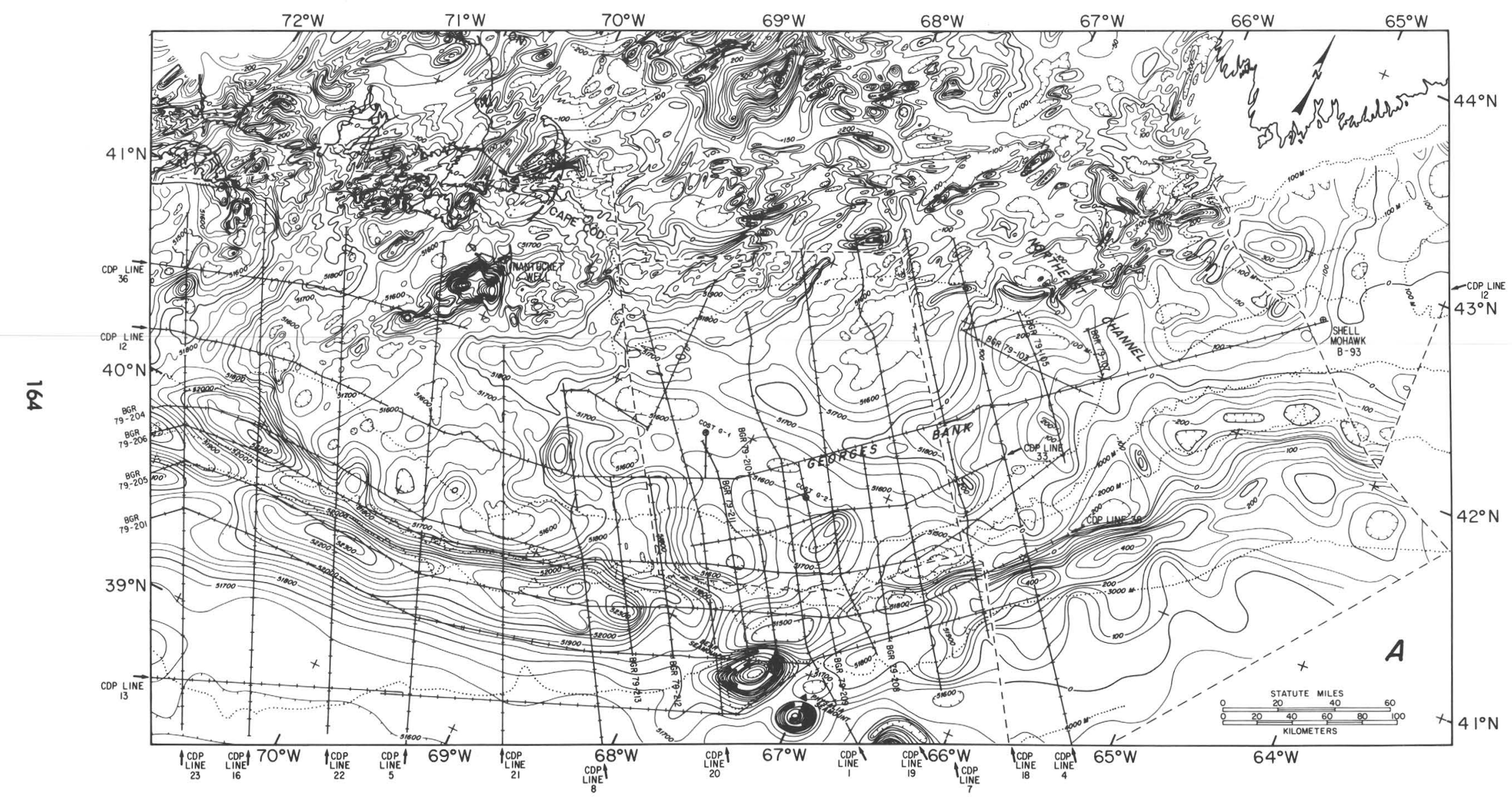




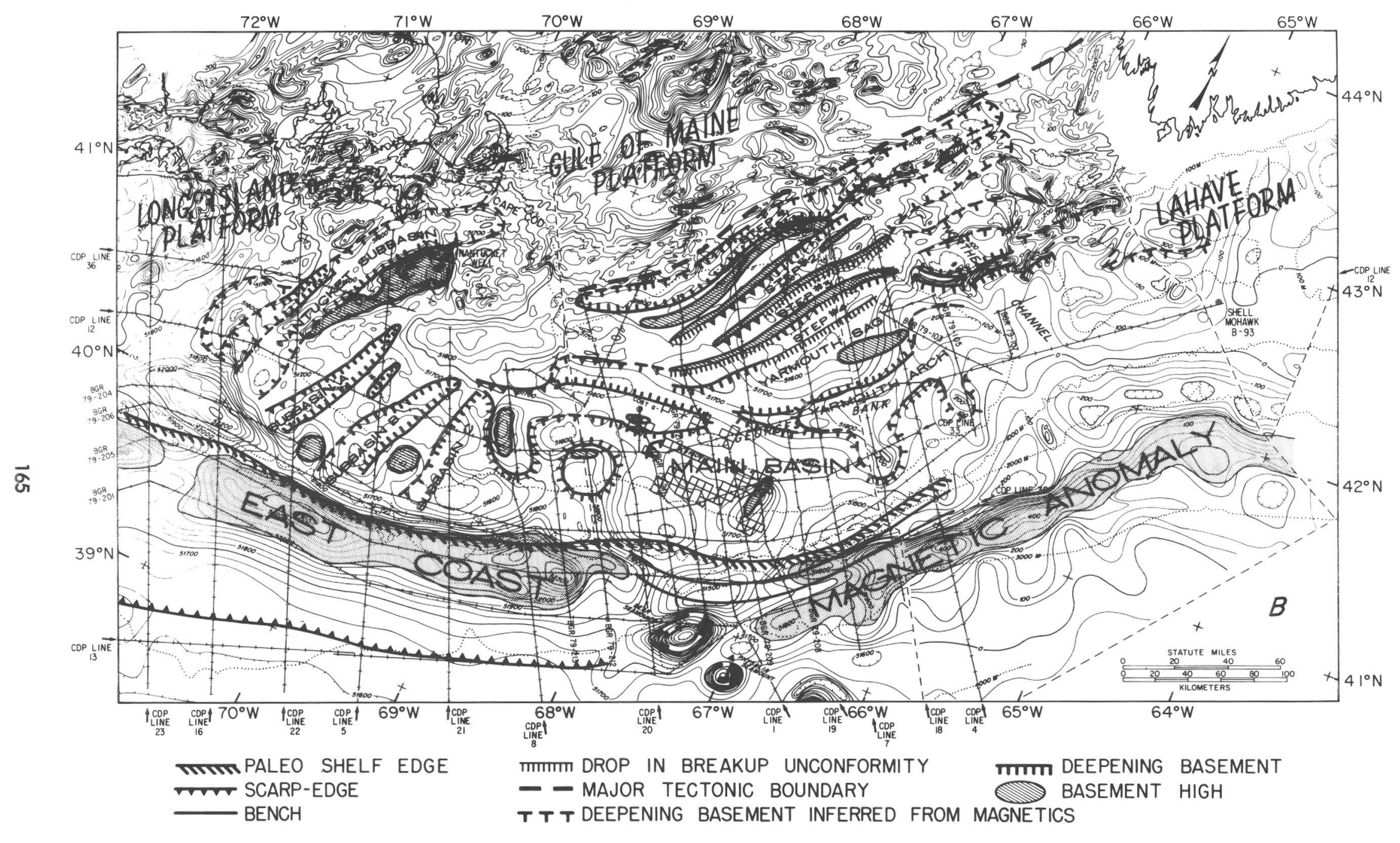

FIGURE 73.-Magnetic anomaly maps of the Georges Bank area, composited from the maps of Klitgord and Behrendt (1977) and Haworth and MacIntyre (1975). Contour interval $50 \mathrm{nT}$; Universal Transverse Mercator projection. $A$, USGS and BGR multichannel seismic line locations superimposed. $B$, Tectonic structure (Schlee and Klitgord, this volume, fig. 4) superimposed. 


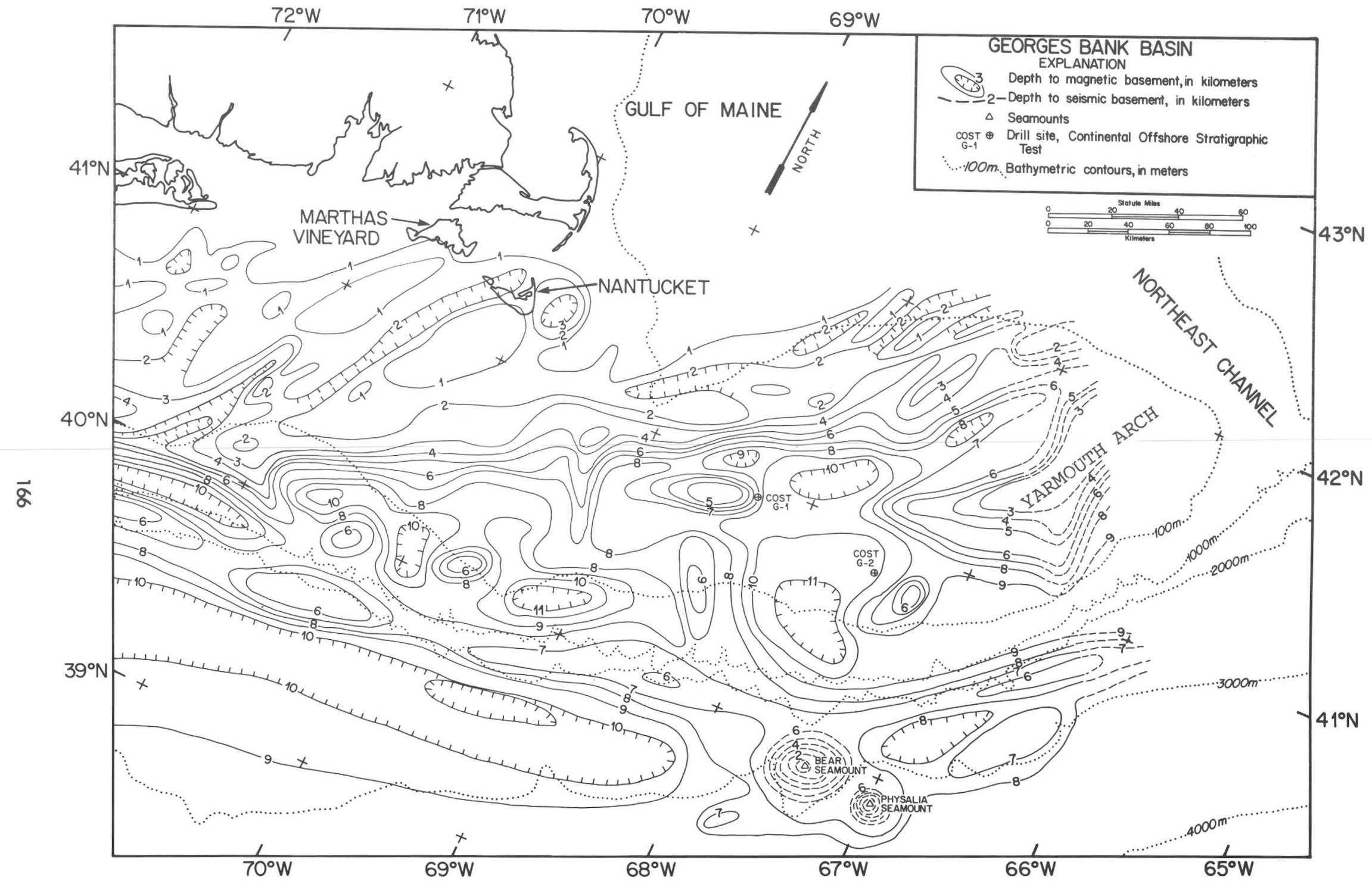

FIGURE 74.-Depth to magnetic basement in the Georges Bank area. Contour interval $1 \mathrm{~km}(0.62 \mathrm{mi}) ;$ Universal Transverse Mercator projection. Depths were determined using magnetic depth estimates to interpolate between CDP lines 1, 4, 5, 7, 8, 12, and 13. From Klitgord and Behrendt (1979, fig. 7C). 


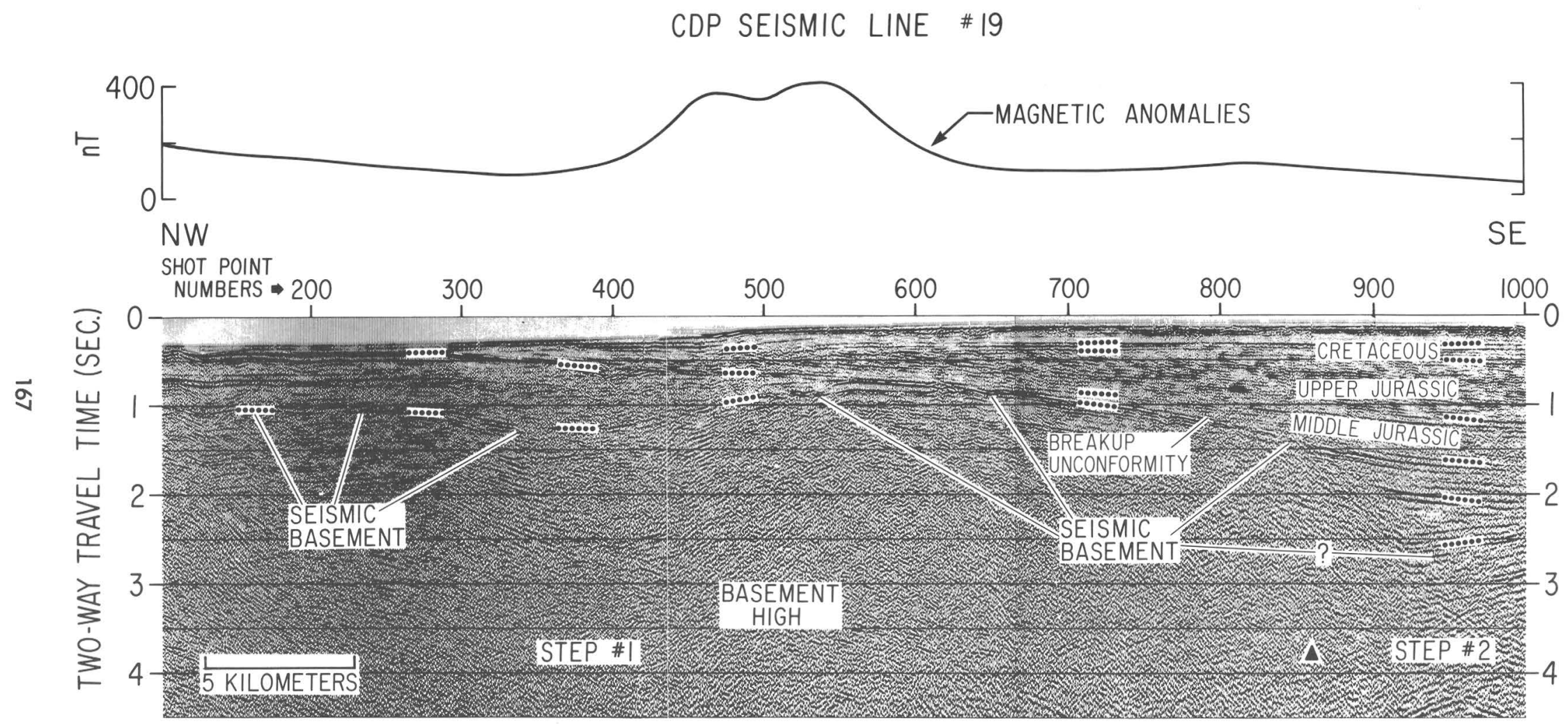

Figure 75.-Magnetic anomaly and seismic reflection profiles for a portion of CDP line 19 across Step \#1. Note the correspondence between the magnetic high and the basement high, and between the magnetic low and the basement trough. See figure 71 for location. 


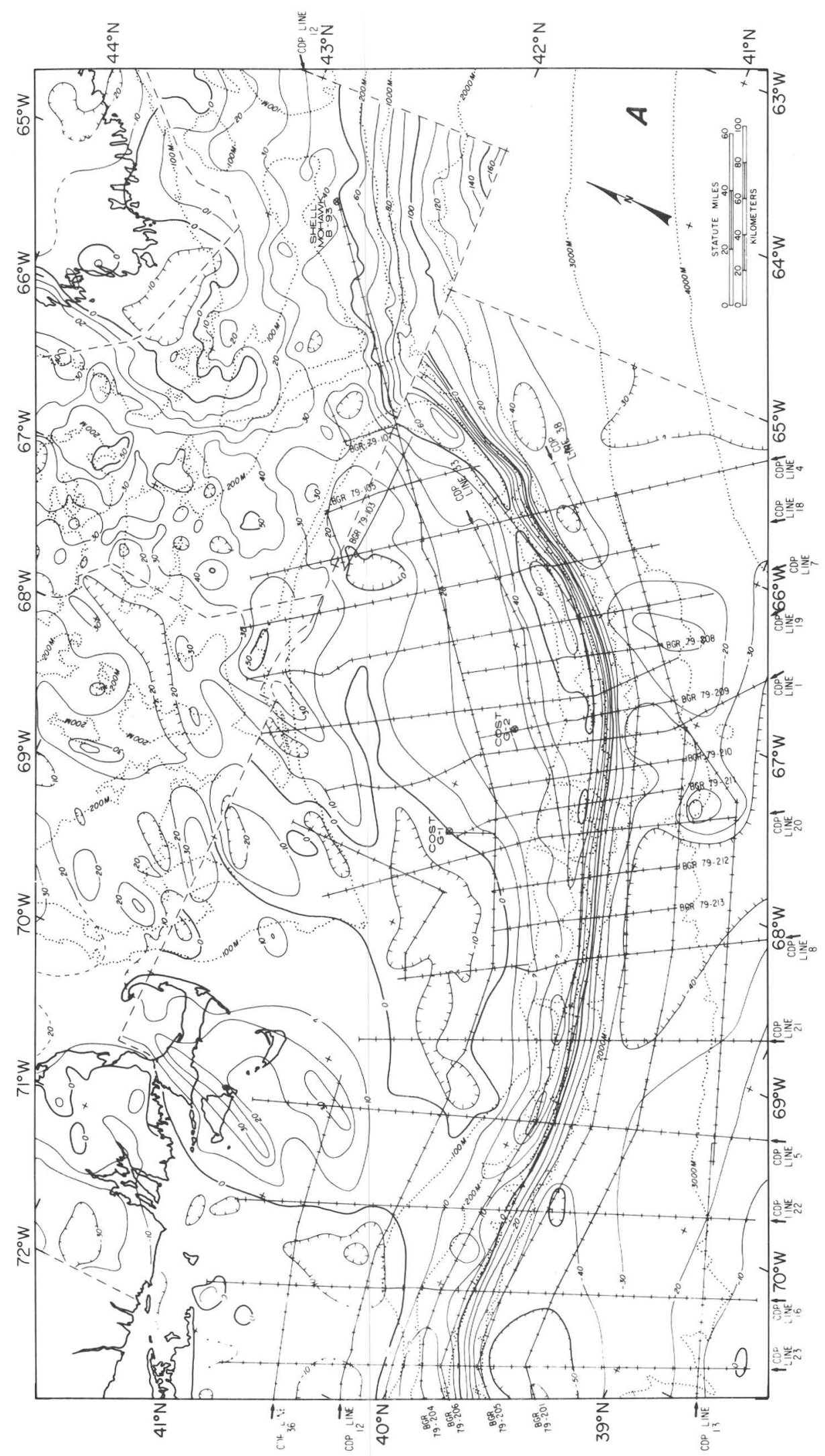




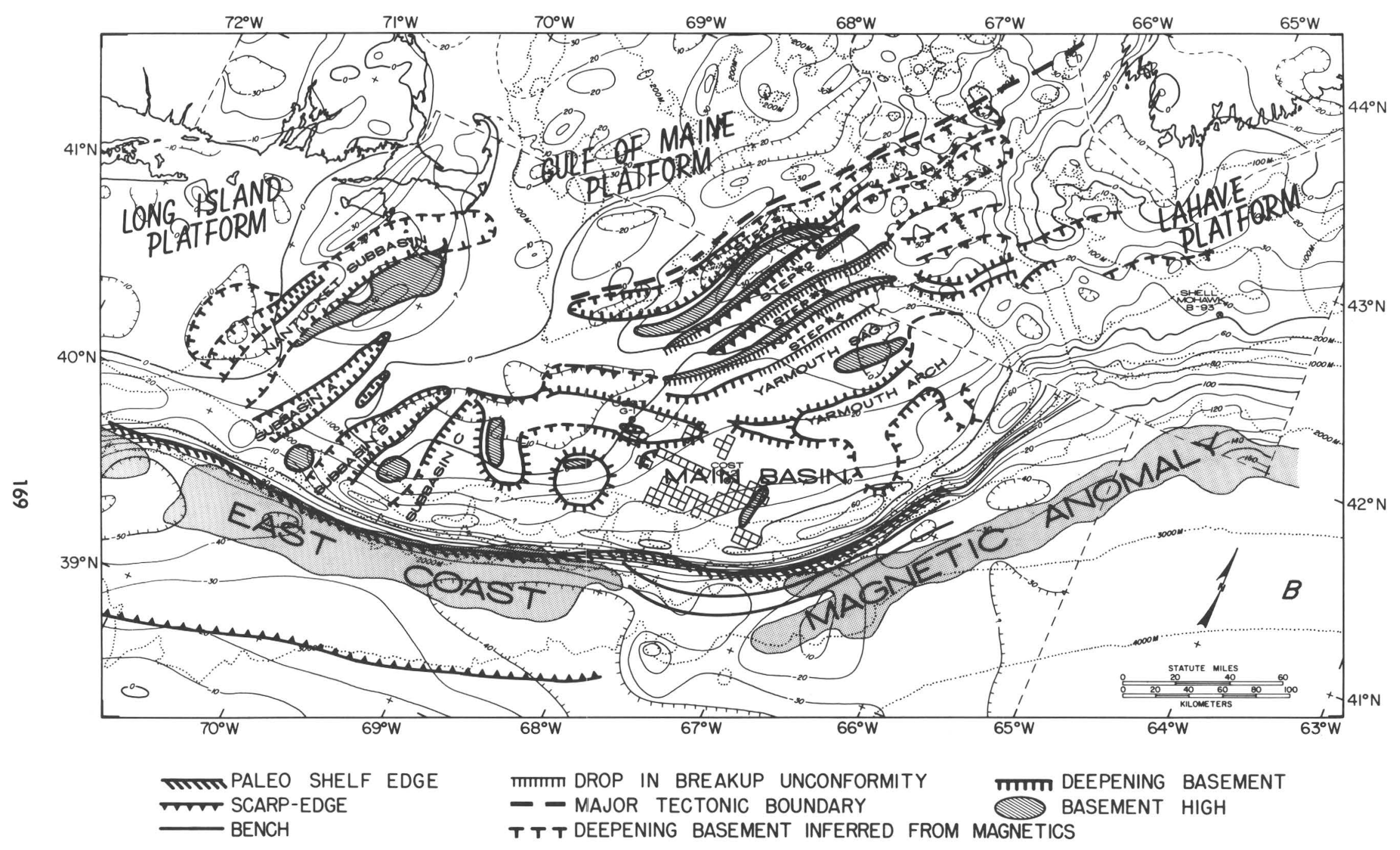

FigURE 76.-Gravity anomaly maps of the Georges Bank area, composited from the free-air gravity anomaly map of Grow and others (1976) and the Bouguer gravity anomaly maps of Kane and others (1972) and Haworth and MacIntyre (1975). Contour interval 10 mGal; Universal Transverse Mercator projection. A, USGS and BGR multichannel seismic line locations superimposed. B, Tectonic structure (Schlee and Klitgord, this volume, fig. 4) superimposed. 
USGS LINE 5-CAPE COD

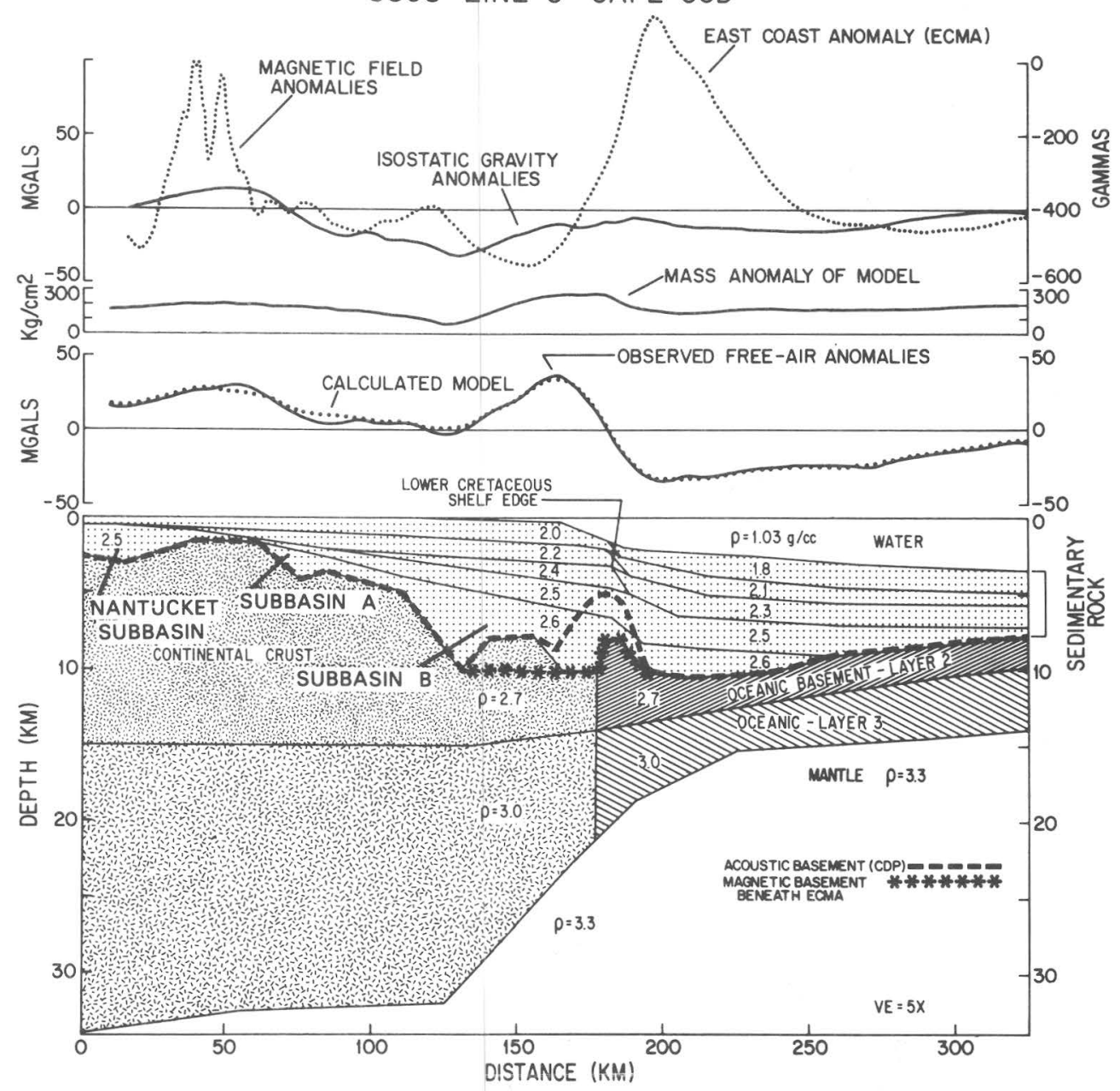

FIGURE 77.-Two-dimensional gravity model for CDP line 5. Sediment thickness and densities are inferred from the multichannel velocities. Magnetic basement from Klitgord and Behrendt (1979) was used for the base of the sediments in the vicinity of the East Coast magnetic anomaly, where seismic basement is the top of the Jurassic shelf-edge bank. The upper and lower crust were assumed to have densities of 2.7 and $3.0 \mathrm{~g} / \mathrm{cm}^{3}$ respectively, although no refraction data are available. The relative shape of the crust-mantle boundary was modified to fit the gravity data, but the absolute depth-to-Moho could be in error by several kilometers. This line typifies the narrow zone of progressively deepening small subbasins between stable platforms of continental crust (just to the left of the profile) and oceanic crust (to the right of the 200-km mark) and demonstrates a rapid crustal thinning over a distance of only $100 \mathrm{~km}(62 \mathrm{mi})$. From Grow, Bowin, and Hutchinson (1979, fig. 5).

Shallow, stable platforms lie northeast, north, and northwest of Georges Bank, where seismic basement is less than $2 \mathrm{~km}(6,600 \mathrm{ft})$ deep. The block-faulted zone seaward of the platforms is divided into two segments, one southeast of the Long Island platform and the other southeast of the Gulf of Maine platform. These two segments are separated by a set of east-west structures near lat $41^{\circ} \mathrm{N}$. Seismic basement depths at the top edges of the grabens and basins range from less than $2 \mathrm{~km}(6,600 \mathrm{ft})$ to more than $6 \mathrm{~km}$ $(19,700 \mathrm{ft})$; several thousand meters of sediments fill isolated basins beneath the breakup unconformity. Seaward of the block-faulted zone, the main basin lies beneath the outer Georges Bank and contains more than $6.5 \mathrm{~km}(21,500 \mathrm{ft})$ of sediments. The Jurassic-Lower Cretaceous shelf edge forms the seaward border of both the main basin and the small subbasins to the west. Oceanic basement can be traced landward to within $50 \mathrm{~km}$ 


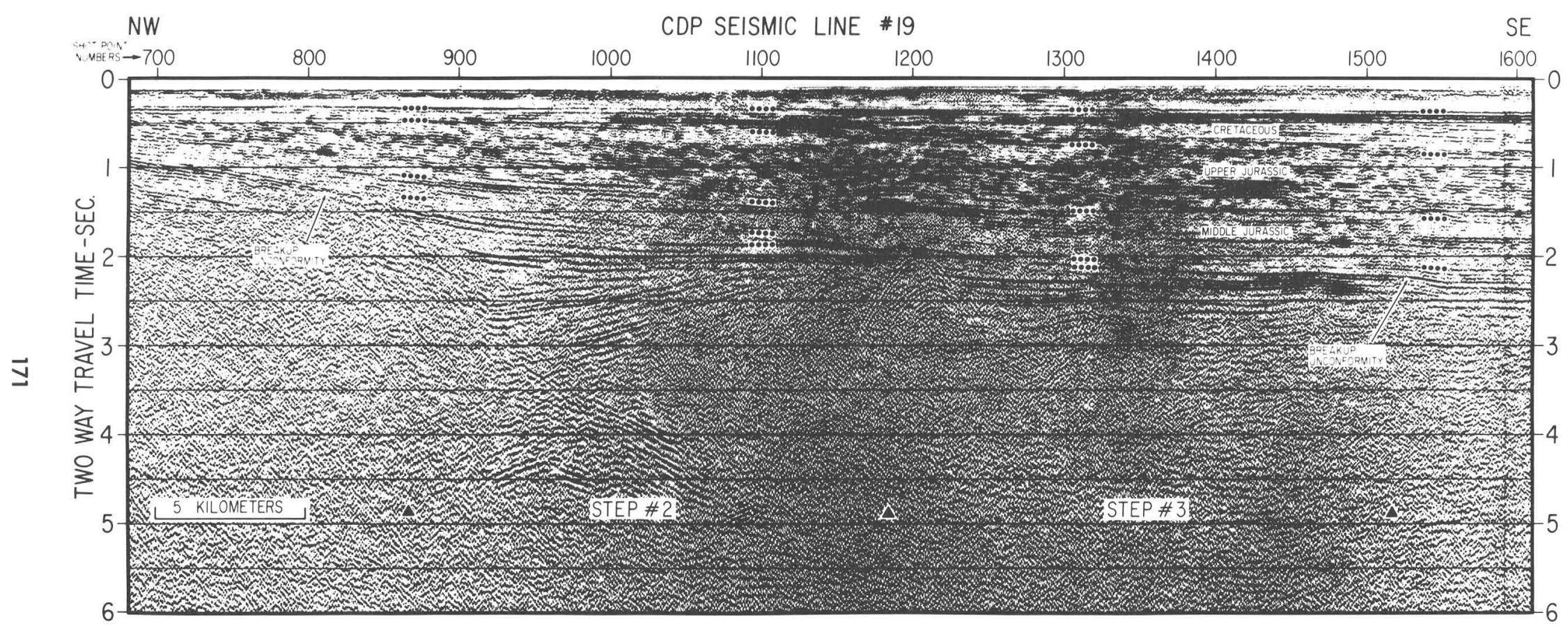

FIGURE 78-A portion of CDP line 19 showing the landward-dipping reflectors beneath the breakup unconformity for the half-grabens that form Steps \#2 and \#3. The basement hinge for Step \#2 is at shotpoint 1200; the hinge for Step \#3 is at shotpoint 1500. Drops in the breakup unconformity area indicated by triangles. See figure 71 for location. 


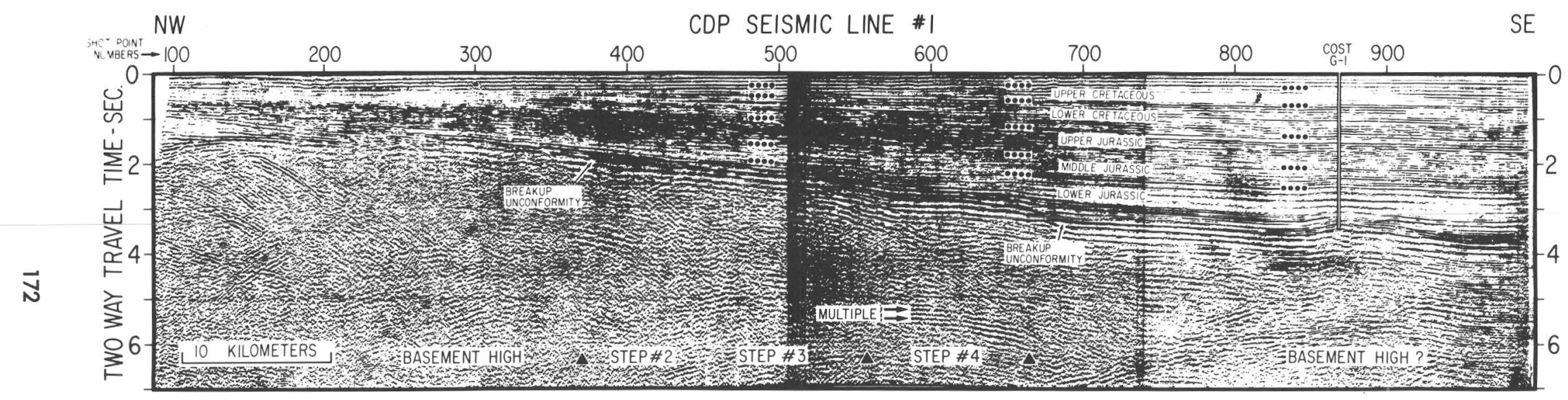

FIGURE 79.-A portion of CDP line 1 over the buried steps. See figure 71 for location. Notice the drops in the breakup unconformity (triangles) to the left of Steps \#2, between Steps \#3 and \#4, and to the right of Step \#4. Steps \#2 and \#3 have merged on this line. The small basement high that the COST No. G-1 well penetrated is seen as a small rise in the breakup unconformity. The deep reflectors at 6 sec to the right of Step \#4 may be real (Schlee and others, 1976), indicating a thick sequence of prerift and synrift sediment in this region. Also, these deep reflectors possibly are pegleg multiples off landward-dipping synrift sediments obscured by the acoustic reflectors associated with the breakup unconformity ( 3 to 4 sec depth) but similar to those shown in figure 78 . 
(31 mi) of the axis of the East Coast magnetic anomaly (ECMA) on most of the seismic profiles and to within $20 \mathrm{~km}$ (12.4 mi) of it on some lines. The depths of these structures are shown in the series of cross sections in figure 80 .
The block-faulted zone southeast of the Gulf of Maine platform deepens in a series of steps into a broad sag (the Yarmouth sag) before abutting against the Yarmouth arch. There may be a small subbasin beneath the breakup unconformity at
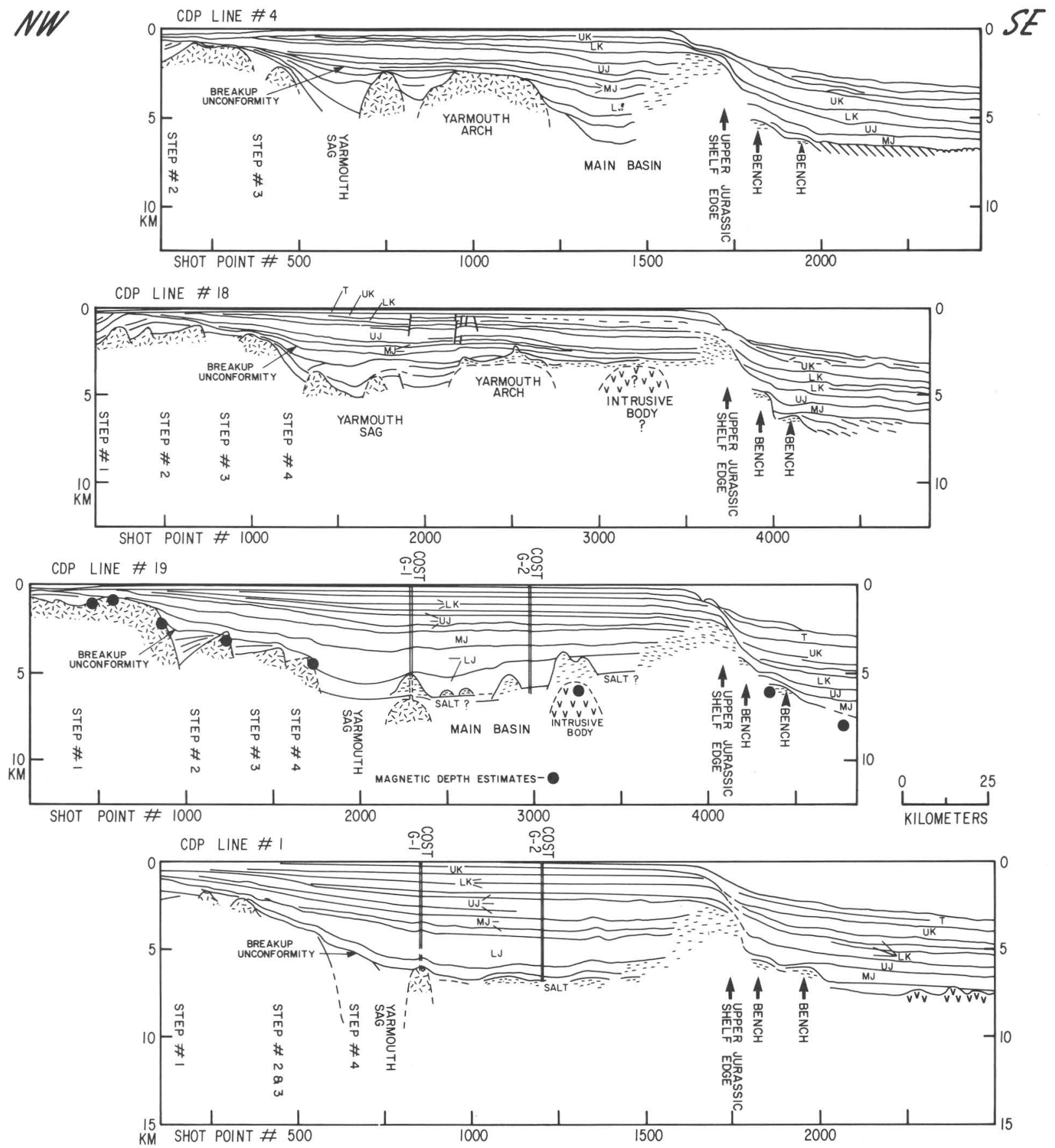

FIGURE 80.-Interpretive cross sections of the Georges Bank basin seaward of the Gulf of Maine platform along CDP lines 4, 18, 19, and 1. See figure 71 for locations. UK, Upper Cretaceous; LK, Lower Cretaceous; UJ, Upper Jurassic; MJ, Middle Jurassic; LJ, Lower Jurassic(?). 
each of these steps but these subbasins can be seen on only some of the seismic profiles. Step \#1 is a linear trough that is well defined on most multichannel seismic profiles (fig. 75; basin at $0000 \mathrm{~h}$ on line 17-19, fig. 5 of Austin and others, 1980) and even on some single-channel profiles (such as fig. 3B of Ballard and Uchupi, 1972, and fig. 4 of Oldale and others, 1974). Step \#1 lies at the hinge zone between the Gulf of Maine platform (which contains a number of the other Triassic grabens; Ballard and Uchupi, 1972) and the deepening basement to seaward. Steps \#1 and \#2 are separated by a broad basement high (fig. 75) that is associated with a large positive magnetic anomaly and a high gravity anomaly. These two potential field highs suggest that a mafic intrusive body separates the two basins. Step \#2 is a half-graben that is well defined on common-depth-point (CDP) line 4 (Grow and Schlee, 1976) and line 19 (fig. 78). On CDP lines 1, 7 , and 18 , the breakup unconformity dips steeply along the landward edge of the step. This graben can also be seen on some single-channel seismic profiles (such as fig. 3C of Ballard and Uchupi, 1972). Step \#3 also clearly appears as a halfgraben on line 19 (fig. 78), but the other seismic lines show only a small basement high on each side of the step. Between Step \#3 and the Yarmouth arch, the broad Yarmouth sag (including Step \#4) overlies a major gravity low. The Yarmouth sag deepens to the southwest and includes a small basement high on CDP line 4 (Grow and Schlee, 1976) and line 18 (fig. 78). The basin becomes very deep where it is crossed by CDP lines 7,19 and 1. Only the steeply dipping sides of the Yarmouth sag can be seen on lines 7 and 19 but suggestions of a deep crystalline basement can be seen on CDP line 1 (shotpoints 550 to 850 , fig. 79). On line 1 the drop in the breakup unconformity is visible at both edges of Step \#4, but the drop is negligible on lines 18 and 7. We consider the Yarmouth arch the seaward end of this blockfaulted zone. The arch deepens to the southwest until on line 19 (shot point 2250 , fig. 80 ) it is only a small basement high with a possible carbonate mound on top (Poag, this volume). The small basement high on CDP line 1 (shotpoint 880, fig. 79 ) is interpreted, using the magnetic data, to be a continuation of the small east-west basement high encountered on CDP lines 8 and 20, which was drilled into at the COST No. G-1 well (fig. 73). It may be connected to the Yarmouth arch.
The small east-west basin just north of this high is either a continuation of the Yarmouth sag or a separate subbasin.

The basement of the block-faulted zone to the southeast of the Long Island platform does not deepen in a steplike fashion, but it does contain four small, elongate subbasins (fig. 73). The depth to the tops of these subbasins increases gradually to the southeast, as shown in figure 81. All of these basins deepen to the south, where their seaward margins are obscured by the carbonate buildup near the Jurassic-Lower Cretaceous shelf edge. The Nantucket subbasin is well defined on CDP lines 5 (Grow and Schlee, 1976) and 36, and the northwestern part of the basin can be seen on line 22. The rest of the outline of the subbasin was determined from the magnetic data (fig. 74) and the gravity data. Nowhere do the margins of the Nantucket subbasin exceed $4 \mathrm{~km}(13,000 \mathrm{ft})$. There is a seismic basement high (fig. 81) associated with a large magnetic high and gravity high between the Nantucket subbasin and subbasin $\mathrm{A}$. We interpret this basement high to be the upper surface of a mafic body similar to that noted previously between Steps \#1 and \#2. Subbasin A (fig. 81) gradually deepens to the south, but its margins do not exceed $5 \mathrm{~km}(16,400 \mathrm{ft})$ depth; it appears as a half-graben on CDP line 22. Subbasin B also appears on CDP line 5 (fig. 81) where it is deeper and broader than Subbasin A. The deepest of this western set of subbasins, Subbasin $\mathrm{C}$, broadens to the east and may merge with the main basin (fig. 73). Subbasin $C$ is bounded on the west by a small basement high that may represent an intrusive igneous feature; to the northeast is a larger basement high. As with the other three subbasins, the seaward edge of Subbasin $\mathrm{C}$ is obscured by the carbonate buildup near the Jurassic-Lower Cretaceous shelf edge.

The main basin of the Georges Bank lies between the Yarmouth arch and the ECMA. The region of greatest sediment accumulation (Schlee and Klitgord, this volume, fig. 3) encompasses this main basin and the Yarmouth sag. The COST No. G-2 well was drilled into the main basin and encountered salt at a depth of about $21,300 \mathrm{ft}$ $(6.5 \mathrm{~km})$ (Amato and Simonis, 1980). This salt unit forms seismic basement beneath most of the main basin, but there are deeper reflectors beneath the salt layer towards the edges of the main basin. There may be an additional 3 to $4 \mathrm{~km}$ $(9,800$ to $13,100 \mathrm{ft})$ of Mesozoic sediments 


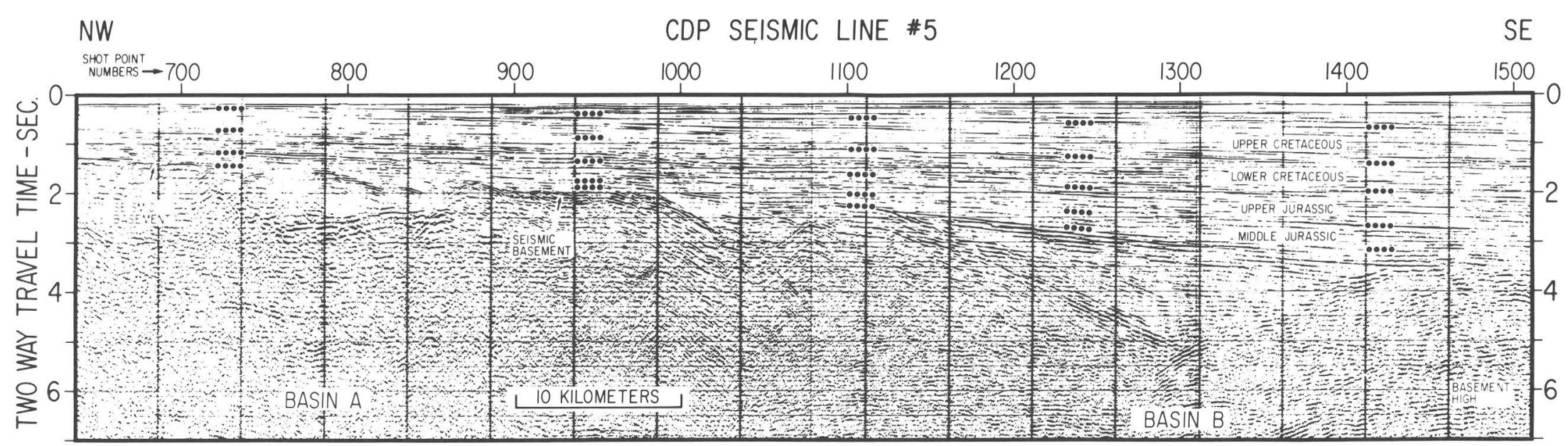

FIgURE 81.-A portion of CDP line 5 across the prerift or synrift basins. See figure 71 for location. Note the changes in slope in the breakup unconformity and the basins beneath the unconformity.

$\vec{G}$

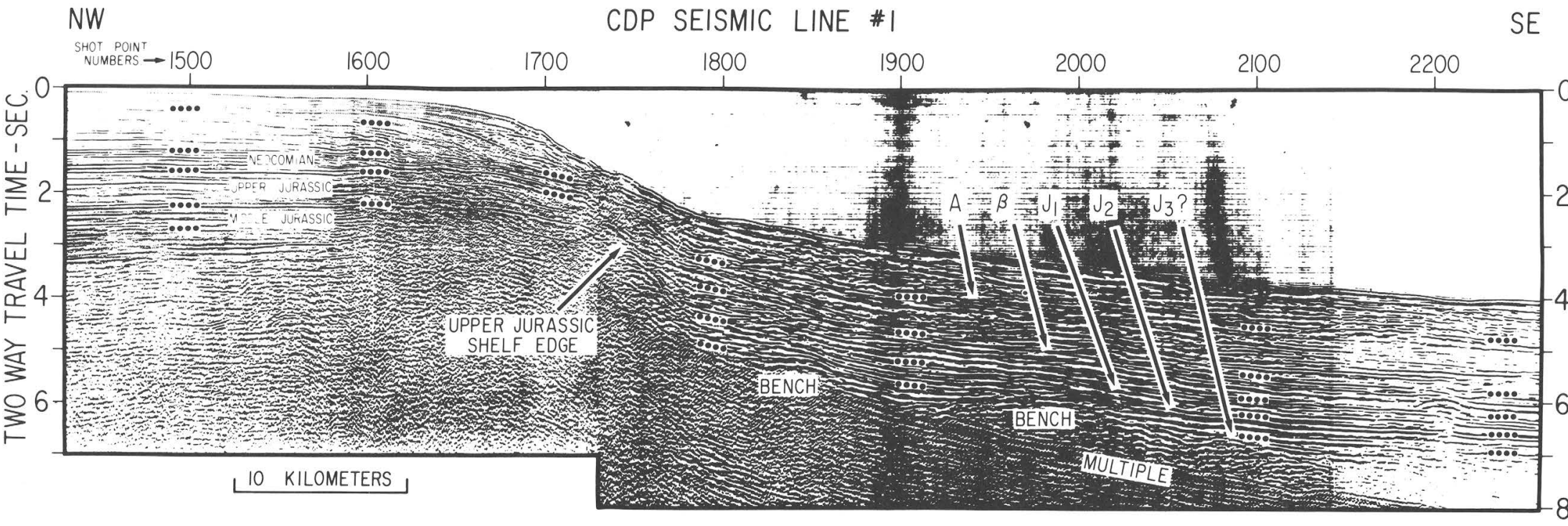

FIGURE 82.-Portion of CDP line 1 across the Jurassic shelf edge. See figure 71 for location. The identification of the deep sea Jurassic units are from Klitgord and Grow (1980). The age identification of the shelf seismic units are from Poag (this volume). Note how the deep reflectors $J_{3}$, $J_{2}$, and $J_{1}$, onlap the buried benches and the Upper Jurassic shelf edge, respectively. 
beneath this seismic basement. A buried igneous body is located just east of the COST No. G-2 well in the main basin and it may protrude more than $3,300 \mathrm{ft}(1 \mathrm{~km})$ above the salt layer (line 19 , shotpoint 3300 , fig. 80 ). The seaward edge of the main basin is formed by a series of three benches (figs. 72, 80, and 82) that form descending steps seaward. The most landward bench is the same Upper Jurassic-Lower Cretaceous shelf edge that has been identified along the entire margin (Schlee and others, 1979). The two most seaward benches may be the erosional relics of Middle and Lower Jurassic shelf edges or elevated blocks of crystalline basement. The seismic reflectors $J_{1}, J_{2}$, and $J_{3}$, which onlap these three benches, have been identified as the tops of Upper, Middle, and Lower(?) Jurassic units respectively (Klitgord and Grow, 1980). The seismic basement just landward of the Upper Jurassic shelf edge is the top of the prograding carbonate buildup. The magnetic basement (fig. 74) reflects the deep main basin, the Yarmouth sag, the small high between them, and the buried intrusive feature in the main basin. The shallow ridge in the magnetic basement beneath the landward edge of the ECMA coincides with the most seaward bench. Although the estimated depth of magnetic basement is slightly shallower than the depth of seismic basement, the error associated with such estimates (Klitgord and Behrendt, 1979) would permit the two basement depths to be about the same.

The crystalline basement seaward of the ECMA is primarily igneous rock that forms the top of oceanic crust. Seismic basement to within $50 \mathrm{~km}(31 \mathrm{mi})$ of the ECMA is marked by hyperbolic echoes, a signature typical of oceanic basement (Grow, Mattick, and Schlee, 1979; Klitgord and Grow, 1980). Seismic basement and crystalline basement coincide to the east of a basement scarp $50 \mathrm{~km}$ (31 mi) east of the ECMA (fig. $73 B$ ). The acoustic horizon $J_{3}$ terminates at this scarp and forms seismic basement on most of the multichannel seismic profiles southwest of the New England Seamounts. The irregular, hyperbolic echo type seismic basement beneath the $J_{3}$ reflector can be traced landward of this scarp on CDP lines 5 (fig. 83) and 22 to within $20 \mathrm{~km}(12.4 \mathrm{mi}$ ) of the ECMA. This suggests that oceanic basement (and the underlying oceanic crust) may continue landward to the ECMA (Grow, Mattick, and Schlee, 1979). Crustal velocity information for the area off the New Jersey coast within $50 \mathrm{~km}$
(31 mi) of the ECMA indicates that crustal structure is similar to that normally found for oceanic crust (Sheridan and others, 1979). In the vicinity of the New England Seamounts, the seismic basement has a shingled character (fig. 5 of Schlee and others, 1976) that can be traced landward to the axis of the ECMA. This acoustic characteristic of shingle-like reflections is common for a carbonate buildup, but it also could result from volcanic debris from the New England Seamounts or an overlapping of sedimentary and volcanic layers near a spreading center.

The New England Seamount chain intersects the margin of the Georges Bank at the southwestern edge of the main basin and the three benches described above. This point of intersection, where Bear Seamount lies within the gap in the ECMA, coincides with the zone of east-west structures that separates the block-faulted zone seaward of the Long Island platform from the block-faulted zone seaward of the Gulf of Maine platform. The most likely igneous intrusive features landward of Bear Seamount are the body within the main basin, one feature between subbasins $A$ and $B$, and one feature between subbasins $B$ and $C$. The seismic data from the two highs between subbasin $\mathrm{C}$ and the main basin suggest that these are more likely structural basement highs.

\section{BASIN FILL}

The 6,350 km (3,943 $\mathrm{mi})$ of multichannel CDP seismic reflection profiles collected for the USGS over the Georges Bank area (fig. 71) have allowed a clear look at deeper basement structures and the mapping of key reflectors within the sedimentary section. Analysis of the sedimentary sequences interpreted from these profiles indicates the existence of rift and postrift basin fill above an extensively block-faulted basement. The geometry of the several subbasins (fig. 3, Schlee and Klitgord, this volume) determined from the reflection profiles is similar to the pattern obtained using the depth-to-basement estimates inferred from the magnetic data (fig. 74).

Two profiles (figs. 84 and 85 ) demonstrate the arrangement and character of reflectors in the Georges Bank basin. Bundesanstalt für Geowissenschaften und Rohstoffe (BGR) line 209 (fig. $84)$ crosses the site of the COST No. G-2 well, and the $60-\mathrm{km}(37-\mathrm{mi})$ section of line 20 shown in 


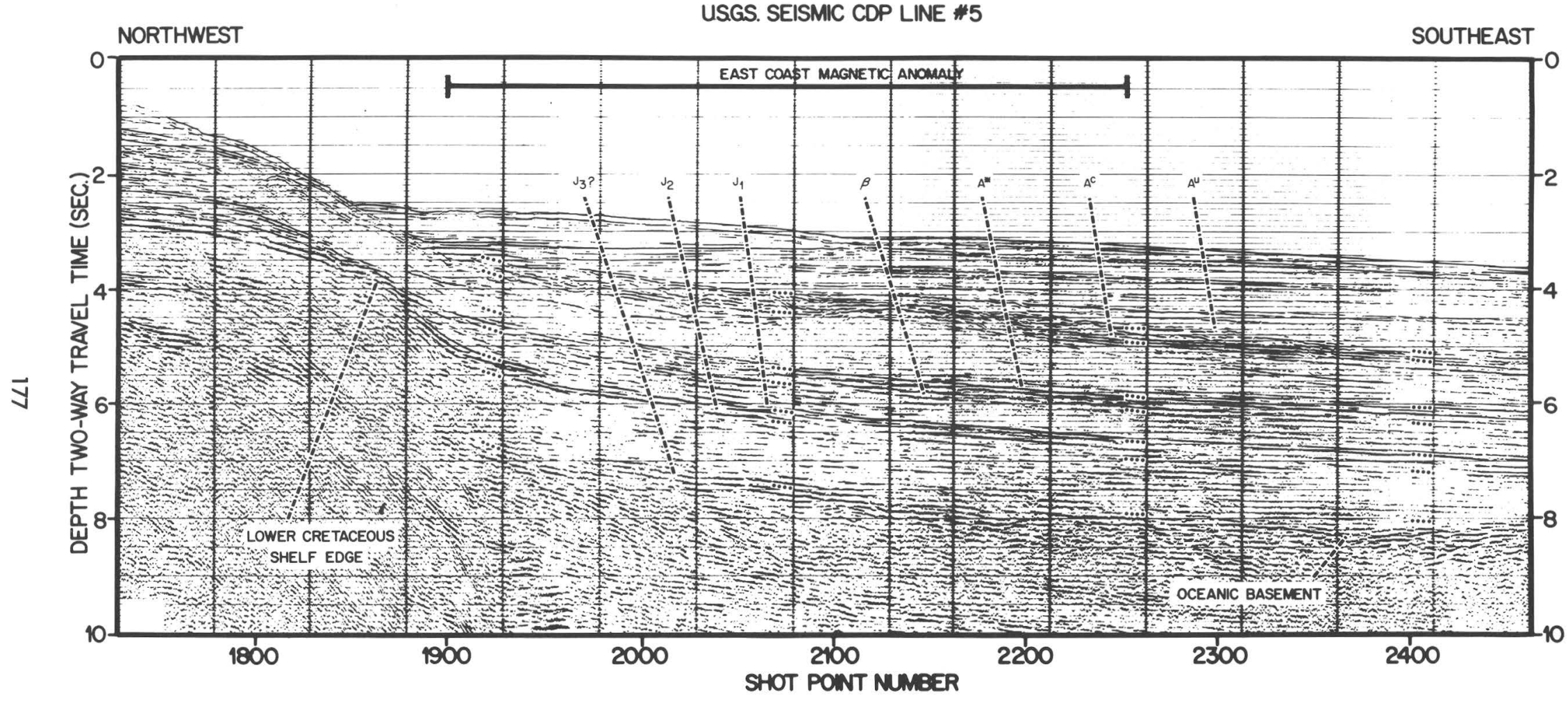

FIGURE 83.-Portion of CDP line 5 across the Jurassic shelf edge. See figure 71 for location. Note the deep reflector $J_{3}$ that onlaps basement near shotpoint 2300 and the lack of the benches seen on CDP line 1 (fig. 82). 


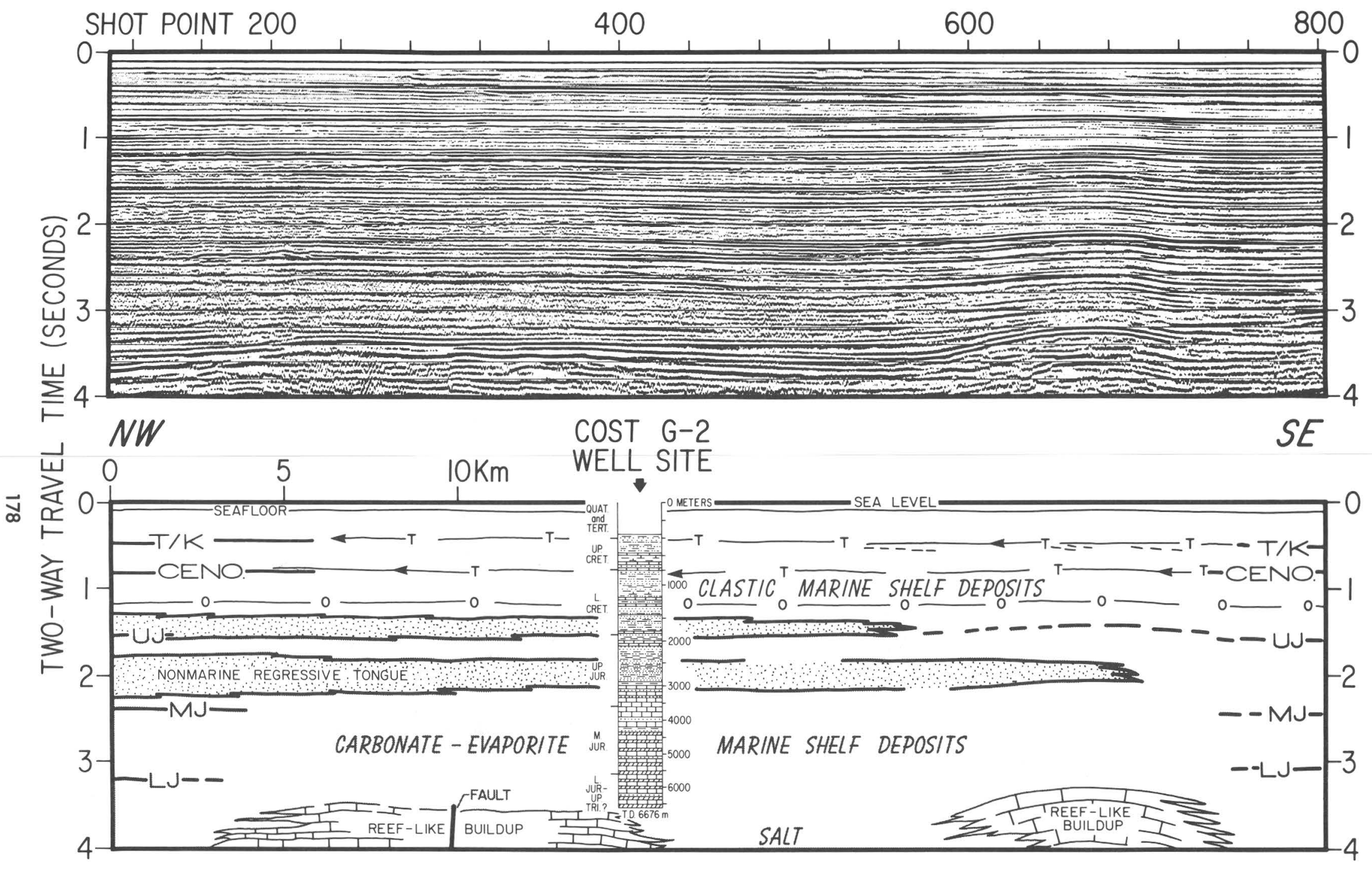
$\because:$ GRAVEL AND SAND
SHALE, MUDSTONE
$\square$ SANDSTONE
臣 CARBONATE ROCK
VIIID EVAPORITE ROCK

FIGURE 84.-A part of BGR line 209 across central Georges Bank basin. The actual time-scaled profile is shown and an interpretation of the stratigraphy is given below it. Also superimposed on the interpretation section is the lithology of the COST No. G-2 well at the approximate position where the profile crossed the drill site. T/K, Tertiary/Cretaceous boundary; CENO., Cenomanian; UJ, near the top of the Upper Jurassic section; MJ, within the Middle Jurassic section; LJ, near the base of the Lower Jurassic(?) section. T marks a thin transgressive unit. $\mathrm{O}$ marks the correlation with the "O marker"-a zone of limestone within the Missisauga Formation beneath the Scotian margin (Jansa and 


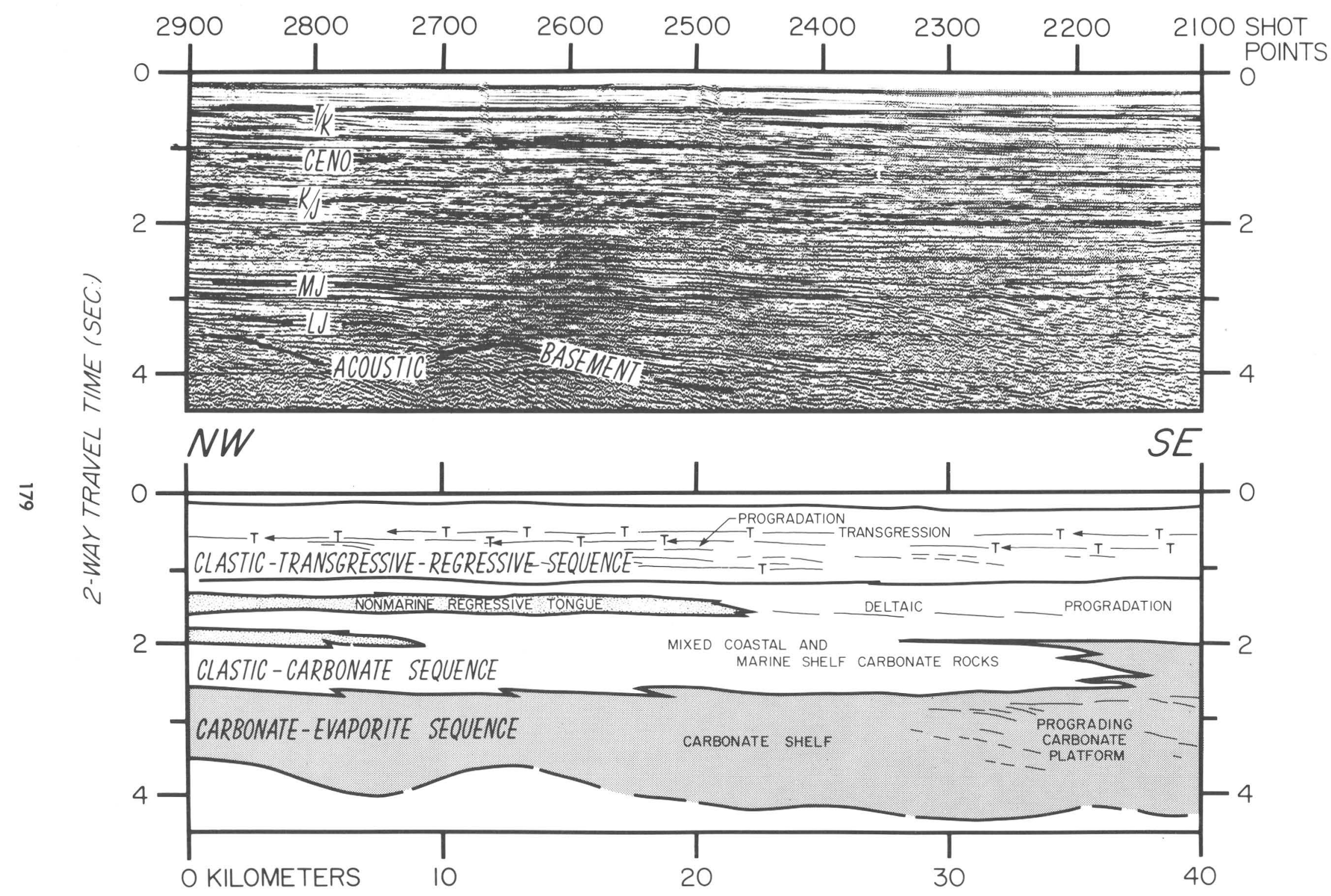

FIGURE 85.-A part of line 20 across the west-central part of Georges Bank basin. Below, the interpretation of the profile gives main stratigraphic sequences thought to compose the sedimentary section, and inferred environments of deposition. T/K, Tertiary/Cretaceous boundary; K/J Cretaceous/Jurassic boundary; CENO., Cenomanian; MJ, within the Middle Jurassic section; LJ, near the base of the Lower Jurassic(?) section. T marks a thin transgression unit. See figure 71 for location. 
figure 85 spans the west-central part of the basin. Beneath the subhorizontal, parallel arrangement of reflectors above an irregular seismic basement is a second set of reflectors tilted at a low angle. It is important to distinquish between the horizontal reflectors and those with a low-angle tilt, because they represent the two main kinds of deposits in the basin: synrift and postrift sedimentary rocks. The boundary between these two reflectors is interpreted to be Falvey's (1974) breakup unconformity, which resulted from the change in tectonism from block-faulting to broad crustal extension as the thinned crustal foundations of the basin sank during the separation of Africa from North America. The key unconformity is best developed in the area where platforms and basins meet. Within the central part of the main basin, the deposits are comformable.

\section{RIFT DEPOSITS}

The acoustic character of the sediments beneath the breakup unconformity can be seen most clearly beneath the landward half of Georges Bank. As shown by part of line 18 (fig. 86) across the eastern side of the bank (fig. 2, Schlee and Klitgord, this volume), seismic basement appears at slightly less than $2-1 / 2$ seconds two-way traveltime around shotpoint 1360 , drops to slightly more than 3 seconds in the central part of the profile, and then rises again to 2-1/2 seconds around shotpoints 1800-1900 (fig. 86). Reflectors dip gently to the northwest (left) beneath a probable unconformity (arrow, fig. 86) within a graben $15 \mathrm{~km}(9.3 \mathrm{mi})$ across. These reflectors are inferred to be part of a rift sequence that formed prior to the main phase of basin subsidence (parallel reflectors above the unconformity).

The character of reflectors within the rift sequence changes across the main basin. On line 18, more or less continuous reflectors that show strong acoustic reflectivity are interpreted to be marine shelf deposits of interbedded carbonate and evaporite rocks. On two other profiles (figs. 84 and 85), inferred rift deposits display similar reflector characteristics. Yet on the northwestward continuation of profiles 18 and 20, equivalent reflectors become discontinuous, and their amplitude is variable; both charactistics are indicative of a nonmarine clastic sedimentary sequence, similar to the section drilled in the lowest part of the COST No. G-1 well. For line 20 bordering the Long Island platform, the reflectors below horizon LJ (correlated with the breakup unconformity) are areally restricted by irregular highs in seismic basement (fig. 85). Seismic reflectors are moderately continuous to discontinuous and show a wide range of seismic amplitude and a splayed arrangement. The sequence is interpreted to consist of interbedded marine (carbonate-evaporite rock) and nonmarine

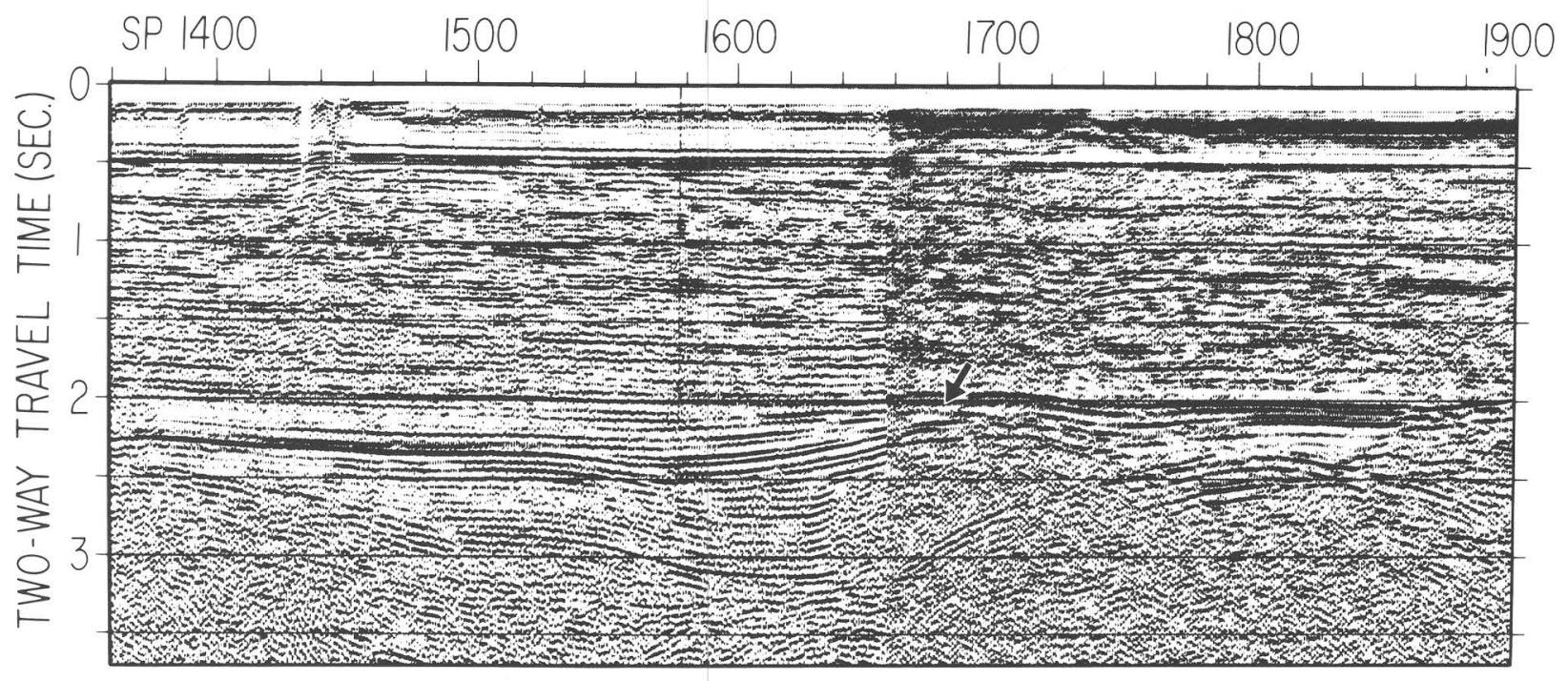

FIGURE 86.-A part of seismic line 18 between shotpoints 1360 and 1900 . Notice conspicuous unconformity (arrow) forming the upper boundary of inferred rift deposits within a graben. See figure 71 for location. 
clastic rocks that filled a rift prior to continental separation. Basement rocks are not obvious on BGR line 209 (fig. 84), probably because they are masked by the thick beds of limestones and anhydrite encountered in the lower part of the COST No. G-2 hole. BGR line 209 crosses the site of the COST No. G-2 well, where the deepest rock drilled was halite, which is of unknown age but probably correlates with the Argo Formation (Early Jurassic? to Late Triassic?) on the Scotian margin (Given, 1977; Barss and others, 1979; Poag, this volume). Reflectors associated with horizon LJ (Lower Jurassic?) are bowed-up areas of inferred carbonate accretion (possible reef). The largest of these, at shotpoint 680 (fig. 84), is $8 \mathrm{~km}$ (5 mi) across and appears to have been built over a basement high which can be seen on crossline 33. Between these bowed-up areas reflectors are horizontal and are thought to represent marine shelf deposits that accumulated over the central southern part of the basin.

\section{EARLY POSTRIFT DEPOSITS}

Above the breakup unconformity, the character of seismic reflectors varies within the basins. On the western flank of the LaHave platform, there are a few moderately continuous reflectors and many discontinuous ones of low to high seismic amplitude. This pattern of reflectors indicates a mixed marine and nonmarine sequence similar to the interbedded sandstone, shale, and limestone sampled in the COST No. G-1 well.

On BGR line 209, reflectors are parallel and weakly to strongly continuous. The zone of low continuity parallel reflectors between horizons MJ and LJ (Middle Jurassic and Lower Jurassic? on fig. 84) is interbedded limestone and anhydrite and a few beds of sandstone and siltstone. Reflector continuity and amplitude within this interval (MJ-LJ) increases to the southeast, indicating density contrasts between groups of strata that are not evident on BGR line 209 near the site of the COST No. G-2 well. The upper part of the early postrift section (to horizon UJ) shows the interfingering of probable alluvial and sublittoral coastal deposits and carbonate shelf deposits. A zone of weakly continuous, low-amplitude reflectors extends to the southeast (to the right on fig. 84) before changing acoustic character. In the COST No. G-2 well, rocks equivalent to this interval are gray sandstone, shale, limestone, and a few thin streaks of coal (Scholle, Schwah, and Krivoy, 1980; Simonis, 1980), thought to have been deposited in water depths of less than $30 \mathrm{~m}$ (100 ft) (Bielak and Simonis, 1980; Srholle, Schwab, and Krivoy, 1980).

Line 20 (fig. 85) displays some of the same changes in reflector characteristics noted in BGR line 209. The profile between horizons LJ and MJ is marked by strong high-amplitude, continuous reflectors. They continue to the southeast (to the right on fig. 85) where individual reflectors in foreset arrangement climb to the right, indicating that the margin in this area prograded snaward during the Jurassic. Between horizons MJ and UJ (Middle Jurassic and Upper Jurassic) there are less continuous and variable-amplitude reflectors which become even more prevalent to the northwest. As on BGR line 209, these zcres of discontinuous variable-amplitude reflectors extend as tongues from the northwest. The moderate- to low-continuity reflectors are interpreted to be sequences of nonmarine sandstones and shale that change laterally to mixed littoral and inner-shelf sediments. One of these tongues above horizon UJ projects well into the basin (shotpoint 2400, fig. 85) and is in an interval in which a few reflectors appear to be moderately continuous; these zones of continuous ref actors are interpreted to be marine shelf deposits laid down during transgressive phases of margin sedimentation (T-T symbol, fig. 85). Seaward (to the right) of this uppermost tongue (shotpoint 2400), reflectors are faint and dip seaward at a low angle, an arrangement that probably indicates a deltaic progradation of the shelf in this area during the Early Cretaceous. The pat'ern of outbuilding is similar to that described by Jansa and Wade (1975b) for the Early Cretaceous Missisauga Formation on the northern Scotian margin, although sediments there are thicl'er.

\section{LATE POSTRIFT DEPOSITS}

Cretaceous and younger sedimentary rocks make up the third broad group of dist'nctive reflectors beneath Georges Bank (figs. 84 and 85 ). They occupy the upper 1.2 seconds (twro-way traveltime) of the seismic records and are characterized by thin zones of fairly continuous reflectors of moderate amplitude, usually one or two wavelets thick, separated by thicker intervals of weakly continuous reflectors. Toward the outer 
part of the shelf are faint reflectors arranged in broad foresets. The difference in acoustic character between this group of reflectors and the underlying group is the absence of the tonguelike, discontinuous reflectors of variable amplitude.

In the COST No. G-2 well, this youngest group of reflectors is produced by a section of interbedded claystone, siltstone, sandstone, and a few thin beds of limestone of Barremian, Aptian, Cenomanian, and Coniacian Ages (Simonis, 1980; Scholle, Schwab, and Krivoy, 1980; Poag, this volume). Some of the limestone beds can be correlated with the persistent thin zone of reflectors described on BGR line 209; one group of strong reflectors marked by the symbol $0-0-0$ on figure 84 , is thought to correlate with the $O$ marker delineated in wells on the Scotian margin. The 0 marker off eastern Canada is a zone of thin Barremian limestone beds approximately $1.6 \mathrm{ft}(0.5 \mathrm{~m})$ thick within the Missisauga Formation (McIver 1972; fig. 4 of Given 1977).
Rocks from the COST Nos. G-1 and G-2 wells suggest a change in environment from shoreline conditions in the Early Cretaceous to shorelinemarine shelf conditions in the middle Cretaceous. Middle to outer shelf conditions existed at the COST No. G-2 well during the Late Cretaceous and early Tertiary (Bielak and Simonis, 1980; Scholle, Krivoy, and Hennessy, 1980; Scholle, Schwab, and Krivoy, 1980; Lachan?e and others, 1980; Poag, this volume). There are hiatuses in the COST Nos. G-1 and G-2 wells (see Poag, this volume) between the Barremian and Hauterivian, the Aptian and Cenomanian, the Ceromanian and Turonian, the Turonian and Coniarian, and the Santonian and Tertiary. Some of $t$ ? unconformities in the Cretaceous seem to be associated with marine transgressions inferred from thin zones of continuous reflectors in the BarremianHauterivian (fig. 84; 0-0-0) and the Cenomanian. There are hiatuses in other areas of the Atlantic Continental Shelf. At the COST No. B-3 well in

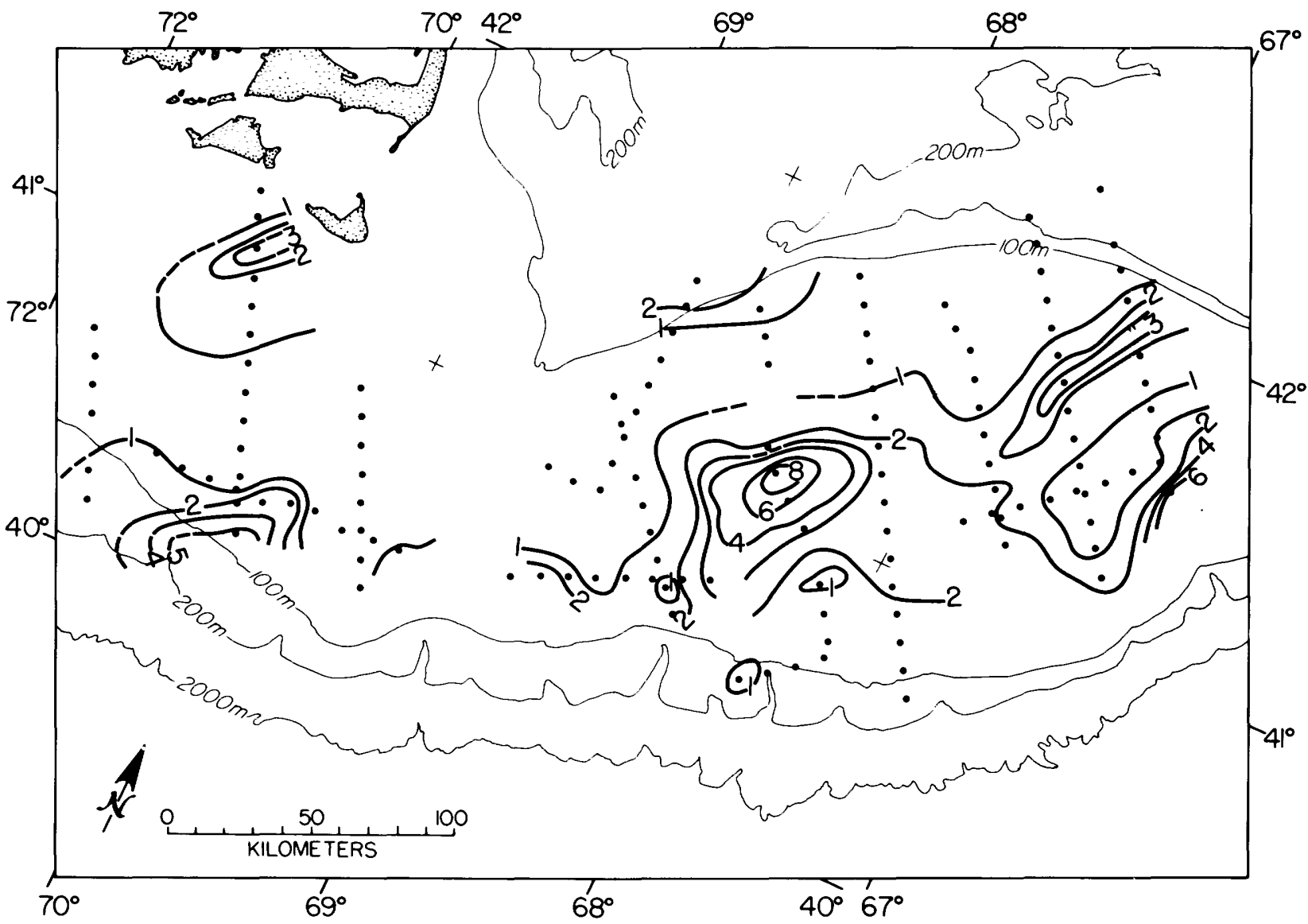

Figure 87.-Isopach map of synrift deposits in the Georges Bank basin. Contours are in kilometers, and dots indicate data points obtained from spot calculations along the grid of seismic-reflection profiles. 
the Baltimore Canyon trough, unconformities were detected between rocks of the Hauterivian and Barremian, the late Cenomanian and Turonian, the early Turonian and Coniacian, the Late Cretaceous and Eocene, and the late Eocene and late Oligocene (Poag, 1980b). In the Scotian margin wells, Ascoli (1976) lists major hiatuses in rocks of Berriasian, Aptian-early Albian, Cenomanian-Turonian, and Maestrichtian-late Eocene age. These intervals of widespread erosion during the Barremian, Cenomanian, and Late Cretaceous-early Tertiary indicate numerous short-term changes in sea level on the Atlantic margin and support the generalized coastal onlap-offlap curve of Vail and others (1977). The occurrence of marine shelf conditions in Late Cretaceous-early Tertiary time that resulted in similar seismic characteristics on widely spaced profiles is further evidence of a widespread marine transgression (Pitman, 1978; Vail and others, 1977) that affected continental margins bordering most of the world's oceans.

\section{BASIN GEOMETRY OF SEDIMENTARY FILL}

As noted by Schlee and Klitgord (this volume) the Georges Bank basin is a collection of rmaller subbasins (fig. 73). Interpretations from a grid of multichannel seismic reflection profiles s'iggest that the area has been built in rift phase and postrift phase (figs. 87 and 88 ).

Sediments of the rift phase are thick, irregularly distributed, and areally restricted to several elongate subbasins bordering the platforms. The subbasins have a northeast trend and contrin 1 to $3 \mathrm{~km}(3,300$ to $9,800 \mathrm{ft})$ of probable exrliest Jurassic and older red beds, limestones, and evaporites. The thickest rift deposits are under the south-central part of the bank in th? Yarmouth sag and in the main basin, where as much

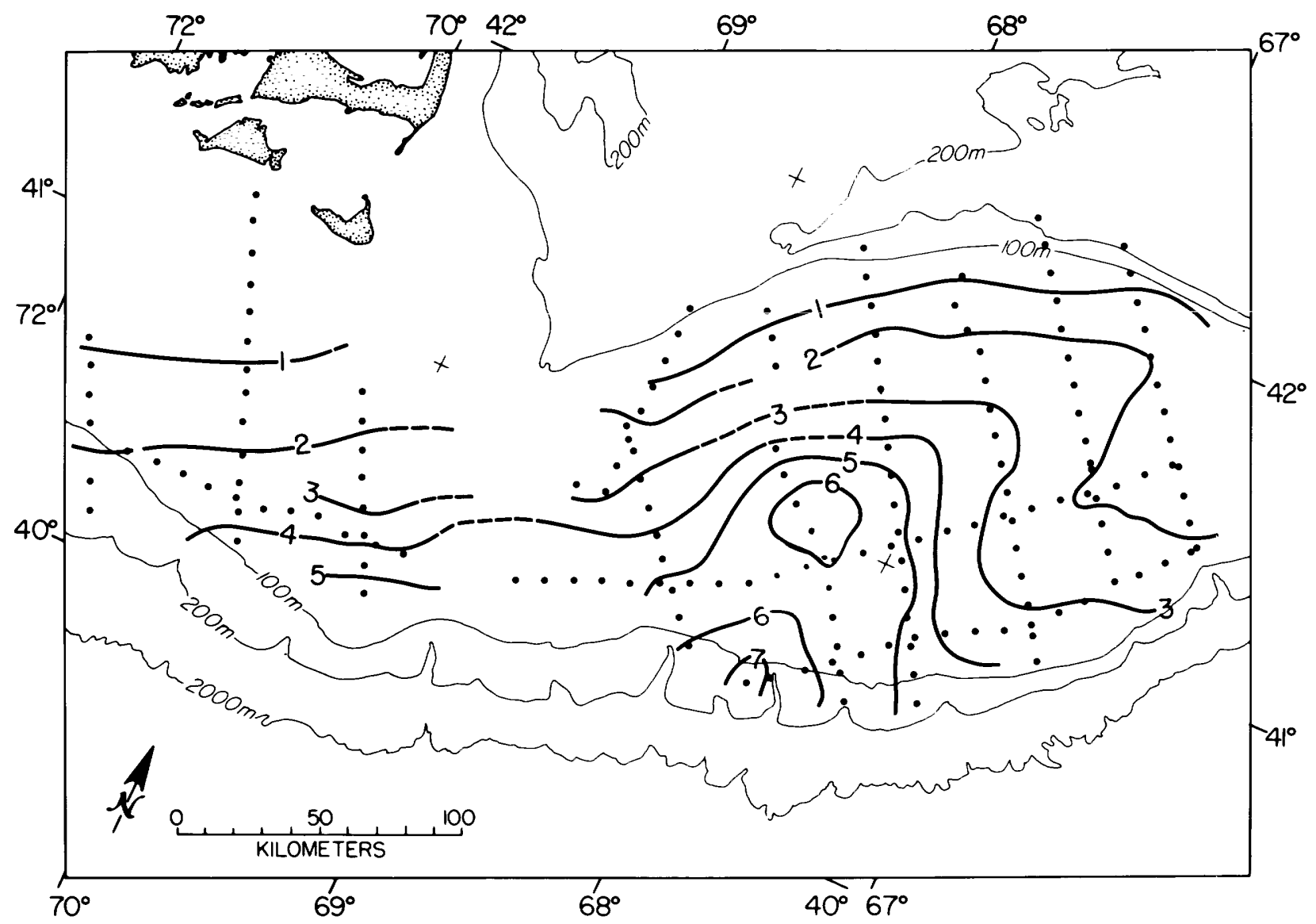

FIGURE 88.-Isopach map of postrift sedimentary section (Jurassic and Cretaceous only) for the Georges Banl: basin. Contours are in kilometers, and dots indicate data points obtained from spot calculations along the grid of seismic-reflection profiles. 
as 6 to $8 \mathrm{~km}(20,000$ to $26,000 \mathrm{ft})$ of sediment appears to be present (fig. 87). During the postrift phase of basin history the pattern of subsidence changed from narrow rifts to a broad subsiding area that encompassed the earlier formed rifts and had a sedimentary blanket as much as 6 to $7 \mathrm{~km}(20,000$ to $23,000 \mathrm{ft})$ thick (fig. 88). Large amounts of both rift and postrift sediments accumulated in the south-central part of the Georges Bank marking this area as the main basin. Much less sediment ( 1 to $2 \mathrm{~km} ; 3,300$ to $6,600 \mathrm{ft}$ ) accumulated on the landward periphery of the set of subbasins, even above earlier formed rifts where 2 to $3 \mathrm{~km}(6,600$ to $9,900 \mathrm{ft})$ of sediment was deposited earlier. A comparison of the two isopach maps (figs. 87 and 88 ) indicates that subsidence was rapid and localized at the beginning of basin formation, but slowed and covered a larger area in the late Mesozoic.

The postrift basin geometry was controlled by the formation of a continental shelf, slope, and rise as the new Atlantic ocean basin was created to the east. The buildup of a carbonate bank-reef complex near the shelf break trapped a thick accumulation of sediments on the shelf during the Jurassic and Early Cretaceous (Schlee and others, 1979). This shelf edge formed the seaward edge of the series of coalescing Atlantic marginal basins and its position has varied through time (Grow, Mattick, and Schlee, 1979; Schlee and others, 1979). During the Cretaceous, the overall rate of sediment accumulation decreased on the shelf, and there may have been a slight landward retreat of the shelf edge (Schlee and others, 1976, 1979; Uchupi and others, 1977). In the Cenozoic, the major realm of sedimentation was offshore (Tucholke and Mountain, 1979) and only a thin veneer accumulated on the shelf (Schlee and others, 1976; Austin and others, 1980).

The location of the shelf edge during the Jurassic is not clearly defined but the seismic and magnetic evidence suggest a small seaward progradation on the western side of Georges Bank (Mattick and others, 1981), and a landward retreat on the eastern side. As already mentioned, the arrangement of reflectors on line 20 suggests a seaward-prograding carbonate sequence (fig. 85) similar to that seen in the Baltimore Canyon trough (Grow, 1980). On the profiles east of line 20 , the retreat or cutting-back of the shelf during the Jurassic is suggested by the buried benches that form ascending steps landward (fig. 82). Our estimates of the location of the Early Jurassic shelf edge (east of line 20) put it consistently beneath the landward edge of the FCMA (fig. 73), suggesting that a common structural control for the shelf edge and the ECMA derreloped during the earliest stages of the margin dovelopment.

\section{TECTONIC HISTORY}

The tectonism associated with the rifting and continued separation of Africa from North America provided the dominant cc ntrol for basin development and the sedimentar"' wedge construction. The rate of crustal subsidence on different parts of the margin was prohably strongly influenced by the early tectonic history (Steckler and Watts, 1978; McKenzie, 1978: Royden and others, 1980). The distribution of the numerous subbasins and the accumulation history of the sedimentary fill provide the basic data to determine subsidence rates, from which can be inferred thermal history (Royden and others, 1980) and tectonic history.

\section{PALEgEOGRAPHIC RECONSTRIICTION}

Prior to Early Jurassic time (fig. 89A), northwest Africa was adjacent to the Georges Bank region (Bullard and others, 1965; LePichon and others, 1977; Klitgord and Schouten, 1980). The locus of rifting during the Late Triassic and Early Jurassic suggests that the region now occupied by Georges Bank lay in a shear zone between the Triassic grabens in New Jersey ard Connecticut and those in Northwest Africa and the Iberian Peninsula (Van Houten, 1977; M anspeizer and others, 1978). As a result, numarous grabens formed in the Georges Bank region in the latest Triassic or earliest Jurassic (Ballard and Uchupi, 1972). During the earliest stages of rifting and continental drift, crustal blocks formed by offsets just south of Georges Bank and just southeast of the southern tip of Nova Scotia along the breakup edge (fig. $89 B$ ) probably restricted water circulation. As the continents continued to drift apart, these ocean basins merged to form the early Atlantic Ocean basin. The restricted water circulation in the Middle and Early Jurassic led to salt deposition. Thick salt accumulations to the north of the offset off the southern tip of Nova Scotia may account for the pervarive diapirism north of Georges Bank. 

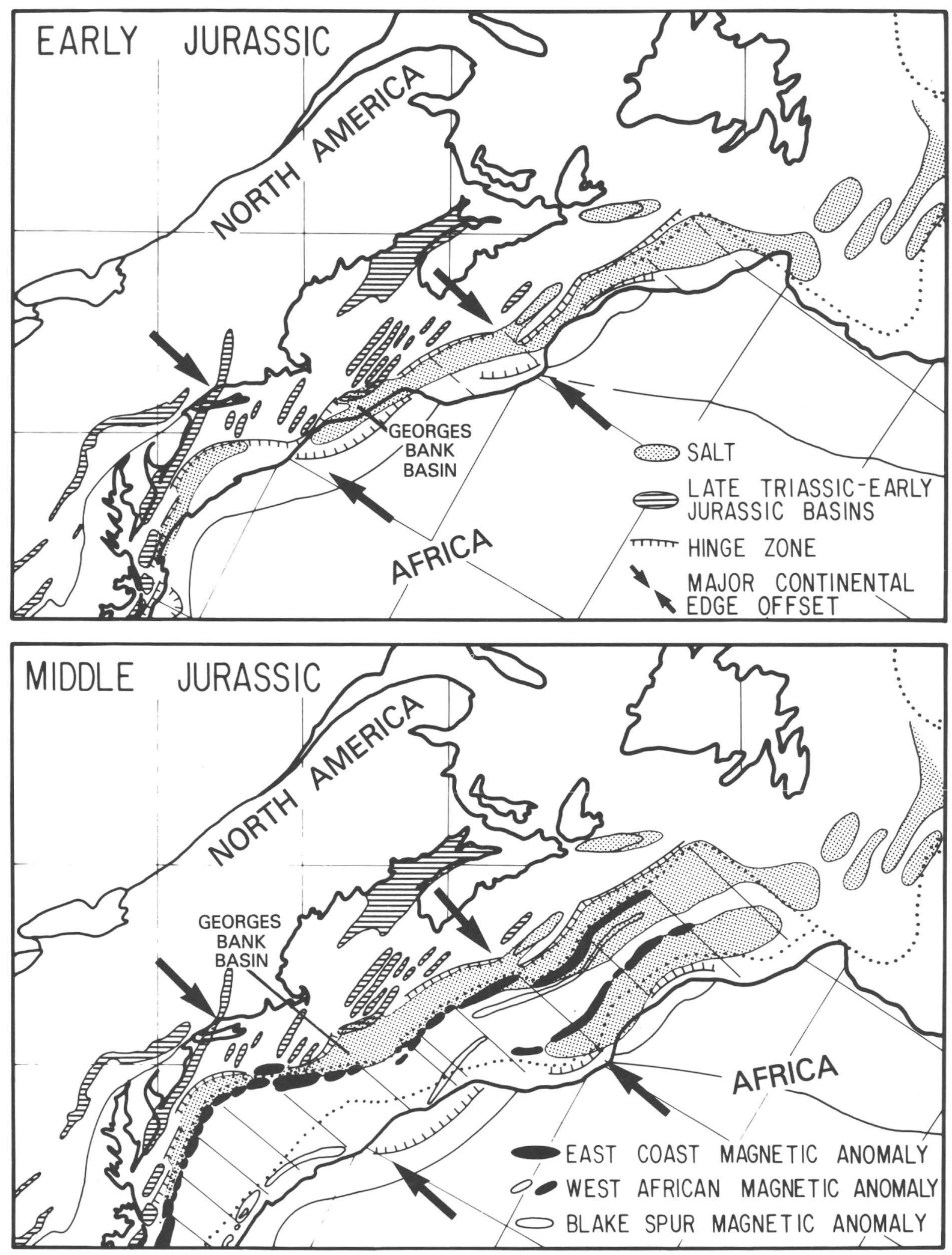

Figure 89.-Reconstructions of the Atlantic Ocean during the Early and Middle Jurassic. Note the possible barriers to water circulation during the early period of ocean opening just to the northeast and just to the southwest of the Georges Bank basin. The locations of Lower Jurassic(?) and Upper Triassic(?) salt deposits are indicated. From Klitgord and Schouten (1980). 


\section{TECTONIC STAGES}

The development of the Georges Bank basin began with the rifting of Paleozoic or older crust during the Late Triassic as at least three or four graben-like, northeast-oriented subbasins formed along the edge of the Long Island-Gulf of Mexico platform. Their trend was parallel to the landward edges of the Carolina trough, the Baltimore Canyon trough, and the Scotian basin. Prerift and synrift sediments filled these subbasins, which were tilted by later tectonic activity on the borders of the structures. As the two continents began to separate, the intrusion of igneous rock probably altered and broadened what now forms the main basin seaward of the Yarmouth arch (fig. 73). The restricted oceanic circulation at this time (late rifting stage to early drifting stage) would have resulted in evaporite deposition over much of the region.

At the end of the Early Jurassic, a new ocean basin was beginning to form. The sediment fill which had been previously trapped within the subsiding marginal subbasins, eventually spilled over into the ocean basin forming a continental shelf, slope, and rise. A less restricted basin circulation at this time probably facilitated the building of a broad carbonate platform and is marked in the stratigraphic data by the breakup unconformity. As crust cooled, subsidence was greatest near the earlier igneous intrusions and slower near the edges of the old platforms, resulting in increased subsidence to the southeast away from the Long Island platform and the Gulf of Maine, and to the southwest away from the LaHave platform. This pattern of Early and Middle Jurassic differential subsidence can be seen in the undulating pattern of the breakup unconformity above the synrift sediments. The breakup unconformity dips gently seaward over large distances but drops rapidly within a number of narrow zones, giving it a stair step appearance.

During the Middle and Late Jurassic, the infilling of sediments continued on a rapidly subsiding shelf while a thin wedge of sediments accumulated on the slope and rise. The position of the shelf edge changed during this time as sea level fluctuated (Vail and others, 1977). Numerous subbasins coalesced into a broader basin beneath the south-central Georges Bank; its extension to the northeast was divided by the Yarmouth arch into a shallower landward limb (the Yarmouth sag) and a deeper seaward limb (the Scotian basin). By the Cretaceous, shelf sediment accumulation had slowed and the accumulation pattern was more uniform over the whole shelf, no longer reflecting the deeper basement structures.

The Cenozoic tectonic history of Georges Bank has most likely been one of local and regional response to forces such as sea level fluctuation, sediment loading, and ice sheet loading and rebound. The subsidence from crustal cooling was negligible by then (Steckler and Watts, 1978), and only a thin veneer of sediments accumulated on the shelf. The shallowest of the rift subbasins identified from seismic data, Step \#1, lies along the northern edge of the bank and may have controlled its location. The shelf break was cut back as a result of erosion associated with the continuing sea level fluctuations. Evidence for Cenozoic tectonic activity, aside from slumping near the shelf break, is minimal, although Uchupi and others (in press) have found evidence of possible faulting near the northeast channel.

\section{TECTONIC SETTINGS OF THE COST NOS. G-1 AND G-2 WELLS}

The COST Nos. G-1 and G-2 wells are only about $65 \mathrm{~km}(40.4 \mathrm{mi})$ apart but the basement beneath them may be significantly different. The COST No. G-1 well was drilled on a small basement high adjacent to the Yarmouth sag, which we have inferred to be part of a Triassic or older graben system. This area remained well landward of the shelf edge throughout its history. The COST No. G-2 well lies seaward of this small basement high, and basement beneath the well may have been intruded by Lower Jurassic igneous rocks associated with continental breakup. Both wells were drilled in what probably was part of the early rift basin system, which included sites of salt accumulation. In contrast to the G-1 well, the G-2 well is located in a region that was close enough to the shelf edge throughout its history to record significant facies changes associated with shelf margin migrations. 


\section{Conclusions}

1. The COST No. G-1 well drilled through $16,071 \mathrm{ft}(4,898 \mathrm{~m})$ of sedimentary rocks in the Georges Bank of the North Atlantic Outer Continental Shelf. Seismic correlation with other cored sites on the continental shelf suggests the presence of Tertiary strata above $1,030 \mathrm{ft}(314 \mathrm{~m})$, which are disconformable over Cretaceous (santonian) rocks. Foraminifers, calcareous nannofossils, and palynomorphs indicate that the rocks are Cretaceous from 1,030 to $5,400 \mathrm{ft}$ (314 to $1,646 \mathrm{~m})$ and Late Jurassic in age from 5,400 to $10,100 \mathrm{ft}(1,646$ to $3,079 \mathrm{~m})$. A $\mathrm{K} / \mathrm{Ar}$ date of $550 \mathrm{~m} . \mathrm{y}$. for a phyllite from $16,050 \mathrm{ft}(4,892 \mathrm{~m})$ indicates the well bottomed in Cambrian strata.

2. No rocks were recovered from the COST No. G-1 well above 1,030 ft (314 m), but Eocene calcareous nannofossils and foraminifers in the uppermost samples suggest the presence of an Eocene limestone that appears on reflection profiles and in conventional cores. Down to $9,900 \mathrm{ft}(3,018 \mathrm{~m})$ the strata are coarse-grained unconsolidated sands and loosely cemented sandstones with beds of gray shale, lignite, and coal. From 9,900 to $12,400 \mathrm{ft}(3,780$ to $3,018 \mathrm{~m})$ the strata are predominantly gray shale, sandstone, limestone, and dolomite. There are predominantly red shales, sandstones, and conglomerates below $12,400 \mathrm{ft}(3,780 \mathrm{~m})$ down to $15,600 \mathrm{ft}(4,755 \mathrm{~m})$. Below this are black graphitic slate, phyllite, schist, metadolomite, and metaquartzite.

3. The COST No. G-2 well (drilled $42 \mathrm{mi}(68 \mathrm{~km})$ east of COST No. G-1) penetrated $21,874 \mathrm{ft}$ $(6,668 \mathrm{~m})$ of sedimentary rocks. Conventional cores and seismic correlation indicated that above $1,300 \mathrm{ft}(396 \mathrm{~m})$ are Tertiary strata, which lie unconformably over Cretaceous (Santonian) rocks. The microfossils indicate that Cretaceous strata extend from $1,300 \mathrm{ft}(396 \mathrm{~m})$ to $5,920 \mathrm{ft}(1,804 \mathrm{~m})$ and that Late Jurassic age strata occur from 5,920 to $10,100 \mathrm{ft}(1,804$ to $3,079 \mathrm{~m})$.
Below this depth, the rocks contain few microfossils and are tentatively dated as Middle and Early Jurassic. The well bottomed in rocks tentatively assigned a Late Triassic age.

4. No rocks younger than Santonian (Cretaceous) were recovered at the G-2 site, but rich foraminiferal assemblages from the uppermost sample suggest the presence of Eocene and younger limestones down to $1,300 \mathrm{ft}$ $(396 \mathrm{~m})$. From 1,300 to $4,000 \mathrm{ft}$ (396 to $1,219 \mathrm{~m})$ are unconsolidated sands, sandstones, and calcareous shales. From 4,000 to $13,500 \mathrm{ft}(1,219$ to $4,115 \mathrm{~m})$ are limestones with interbedded sandstones, and from 13,500 to $21,830 \mathrm{ft}(4,115$ to $6,654 \mathrm{~m})$ are alternating beds of limestone, anhydrite, and dolomite. The bottom $40 \mathrm{ft}(12 \mathrm{~m})$ of section contains salt and anhydrite.

5. The oldest sedimentary rocks at the COST Nos. G-1 and G-2 sites are post-rift Jurassic (possibly Late Triassic) evaporitic and terrigenous deposits. Through the Jurassic and Cretaceous the depositional environment varied between near-shore subaerial to sublittoral and inner to outer shelf conditions. Through the Cretaceous the water was deeper over the G-2 site than over the G-1 site, but shelf conditions prevailed at both until the Paleogene, when slope conditions are inferred.

6. Above $10,000 \mathrm{ft}(3,048 \mathrm{~m})$ in the COST No. G-1 well, porosities range from 15 to 33 percent and average 26 percent; below this depth the average porosity is 16 percent. In the COST No. G-2 well above $10,000 \mathrm{ft}(3,048 \mathrm{~m})$, porosities range from 15 to 39 percent and average 24 percent; below this depth the average value is 12 percent. The permeabilities are highly variable in both wells: in G-1 0.1 to $8,600 \mathrm{mD}$ above $9,000 \mathrm{ft}(2,733 \mathrm{~m})$ and 0.1 to $16 \mathrm{mD}$ below; in G-2 0.1 to $7,100 \mathrm{mD}$ above $10,000 \mathrm{ft}(3,048 \mathrm{~m})$ and 0.1 to $0.2 \mathrm{mD}$ below. 
7. The present-day geothermal gradients are $1.26^{\circ} \mathrm{F} / 100 \mathrm{ft}\left(22.3^{\circ} \mathrm{C} / \mathrm{km}\right)$ for the COST No. G-1 well and $1.34^{\circ} \mathrm{F} / 100 \mathrm{ft}\left(24.4^{\circ} \mathrm{C} / \mathrm{km}\right)$ for the COST No. G-2 well. The temperature gradient at the COST No. G-2 well is the highest yet measured on the Atlantic margin.

8. Measurements of vitrinite reflectance, color alteration of visible organic matter, and various organic geochemical properties indicate that the Tertiary and Cretaceous strata of both wells appear to have poor petroleum source-rock potential because the organic matter is thermally immature and the total organic carbon contents are less that 1 percent. The Jurassic rocks may have poor-to-fair potential for gas generation. The Jurassic hydrocarbons are thermally mature, but the average organic carbon contents are also less that 1 percent, and the organic matter is largely of terrestrial origin.

\section{REFERENCES CITED}

Allemann, F., Catalano, R., Fares, F., and Remane, J., 1971, Standard calpionellid zonation (Upper TithonianValanginian) of the western Mediterranean province: Proceedings of the Second International Conference on Planktonic Microfossils, Rome, 1970, v. 2, p. 1337-1340.

Amato, R. V., and Bebout, J. W., eds., 1980, Geologic and operational summary, COST No. G-1 well, Georges Bank area, North Atlantic OCS: U.S. Geological Survey OpenFile Report 80-268, 112 p.

Amato, R. V., and Simonis, E. K., eds., 1980, Geologic and operational summary, COST No. G-2 well, Georges Bank area, North Atlantic OCS: U.S. Geological Survey OpenFile Report 80-269, 116 p.

Angevine, C. L., and Turcotte, D. L., 1981, Thermal subsidence and compaction in sedimentary basins-Application to Baltimore Canyon trough: American Association of Petroleum Geologists Bulletin, v. 65, p. 219-225.

Ascoli, P., 1976, Foraminiferal and ostracod biostratigraphy of the Mesozoic-Cenozoic, Scotian shelf, Atlantic Canada, in Schafer, C. T., and Pelletier, B. R., eds., First International Symposium on Benthonic Foraminifera of Continental Margins: Maritime Sediments Special Publication 1, pt. B, p. 653-677.

Austin, J. A., Uchupi, E., Schaughnessy, D. R., III, and Ballard, R. D., 1980, Geology of New England passive margin: American Association of Petroleum Geologists Bulletin, v. 64, no. 4., p. 501-526.

Baker, D. R., 1972, Organic geochemistry and geologic interpretations, in Billings, G. K., Garrels, R. M., and Lewis, J. E., Paper on low-temperature geochemistry: Journal of Geological Education, v. 20, p. 221-224.
Baker, D. R., and Claypool, G. E., 1970, Effects of incipient metamorphism on organic matter in mudrock: American Association of Petroleum Geologists Bulletin, v. 54, no. 3, p. 456-467.

Ballard, R. D., 1975, Triassic rift structure in Gulf of Maine: American Association of Petroleum Geologists Bulletin, v. 59 , no. 7, p. 1041-1072.

Ballard, R. D., and Uchupi, Elazar, 1972, Carboniferous and Triassic rifting-A preliminary outline of the tectonic history of the Gulf of Maine: Geological Society America Bulletin, v. 83, no. 8, p. 2285-2302.

Barss, M. S., Bujak, J. P., and Williams, G. L., 1979, Palynological zonation and correlation of sixty-seven wells, eastern Canada: Canada Geological Survey Paper $78-24,118 \mathrm{p}$.

Bartenstein, Helmut, 1974, Lenticulina (Lenticulina) nodosa (Reuss 1863) and its subspecies-Worldwide index foraminifera in the Lower Cretaceous: Eclogae Geologicae Helvetiae, v. 67, p. 539-562.

Bartenstein, Helmut, Bettenstaedt, Franz, and Kovatcheva, Todorka, 1971, Foraminiferen des bulgarischen Barrême, ein Beitrag zur weltweiden Unterkreide-Stratigraphie: Neues Jahrbuch für Geologie und Paläontologie, v. 139, no. 2 , p. $125-162$.

Bebout, J. W., 1980, Biostratigraphy, in Amato, R. V., and Simonis, E. K., eds., Geologic and operational summary, COST No. G-2 well, Georges Bank Area, North Atlantic OCS: U.S. Geological Survey Open-File Report 80-269, p. 20-32.

Behrendt, J. C., and Klitgord, K. D., 1979, High resolution aeromagnetic anomaly map of the U.S. Atlantic continental margin: U.S. Geological Survey Geophysical Investigations Map GP-931, scale 1:1,000,000.

Benson, W. E., and others, 1976, Deep-Sea drilling in the North Atlantic: Geotimes, v. 21, no. 2, p. 23-26.

Berggren, W. A., and Van Couvering, J. A., 1974, The late Neogene-Biostratigraphy, geochronology, and paleoclimatology of the last 15 million years in marine and continental sequences: Palaeogeography, Palaeoclimatology, Palaeoecology, v. 16, p. 1-216.

Bielak, L. E., and Simonis, E. K., 1980, Paleoenvironmental analysis, in Amato, R. V., and Simonis, E. K., eds., Geologic and operational summary, COST No. G-2 well, Georges Bank area, North Atlantic OCS: U.S. Geological Survey Open-File Report 80-269, p. 29-32.

Blow, W. H., 1969, Late middle Eocene to Recent planktonic foraminiferal biostratigraphy, in Proceedings of the First International Conference on Planktonic Microfossils, Geneva, 1967: Leiden, Netherlands, E. J. Brill, v. 1, p. 199-421.

Bostick, N. H., Cashman, S. M., McCulloh, T. H., and Waddell, C. T., 1978, Gradients of vitrinite reflectance and present temperature in the Los Angeles and Ventura basins, California, in Oltz, D. F., ed., A symposium in geochemistry-Low temperature metamorphism of kerogen and clay minerals: Los Angeles, Society of Economic Paleontologists and Mineralogists, Pacific Section, p. 65-79.

Bukry, David, 1973, Low-latitude coccolith biostratigraphic zonation, in Edgar, N. T., Saunders, J. B., and others, eds., Initial reports of the Deep Sea Drilling Project, v. 15: Washington, D.C., U.S. Government Printing Office, p. $685-703$. 
Bukry, David, 1975, Coccolith and silicoflagellate stratigraphy, northwestern Pacific Ocean, Deep Sea Drilling Project, Leg 32, in Larson, R. L., Moberly, R., and others, eds., Initial Reports of the Deep Sea Drilling Project, v. 32: Washington, D.C., U.S. Government Printing Office, p. 677-701.

Bullard, E. C., Everett, J. E., and Smith, A. G., 1965, Fit of the continents around the Atlantic, in Blackett, P. M. S., Bullard, E. C., and Runcorn, S. K., eds., A symposium on continental drift: Royal Society of London, Philosophical Transactions, Series A, v. 258, p. 41-75.

Bush, P. R., 1970, A rapid method for the determination of carbonate carbon, and organic carbon: Chemical Geology, v. 6, p. $52-62$.

Claypool, G. E., and Baysinger, J. P., 1978, Thermal analysis/pyrolysis of Cretaceous sapropels, DSDP Leg 44, Hole 391C, Blake-Bahama basin, in Benson, W. E., and Sheridan, R. E., eds., Initial reports of the Deep Sea Drilling Project, v. 44: Washington, D.C., U.S. Government Printing Office, p. 635-638.

Claypool, G. E., Love, A. H., and Maughan, E. K., 1978, Organic geochemistry, incipient metamorphism, and oil generation in black shale members of Permian Phosphoria Formation, Western Interior United States: American Association of Petroleum Geologists Bulletin, v. 62, p. $98-120$.

Claypool, G. E., Lubeck, C. M., Baysinger, J. P., and Ging, T. G., 1977, Organic geochemistry, in Scholle, P. A., ed., Geological studies on the COST No. B-2 well, U.S. MidAtlantic Outer Continental Shelf area: U.S. Geological Survey Circular 750, p. 46-59.

Claypool, G. E., and Reed, P. R., 1976, Thermal-analysis technique for source-rock evalation-Quantitative estimate of organic richness and effects of lithologic variation: American Association of Petroleum Geologists Bulletin, v. 60, p. 608-612.

Degens, E. T., 1969, Biogeochemistry of stable carbon isotopes, chap. 12 of Eglinton, G., and Murphy, M. T., eds., Organic geochemistry, methods and results: Heidelberg, Springer Verlag, p. 304-329.

Ditty, P. S., 1980, Seismic velocity and correlations, in Amato, R. V., and Bebout, J. W., eds., Geologic and operational summary, COST No. G-1 well, Georges Bank area, North Atlantic OCS: U.S. Geological Survey OpenFile Report 80-268, p. 59-67.

Dow, W. G., 1977, Kerogen studies and geological interpretations: Journal of Geochemical Exploration, v. 7, p. 79-99.

Eliuk, L. S., 1978, The Abenaki Formation, Nova Scotia shelf, Canada-A depositional and diagenetic model for a Mesozoic carbonate platform: Bulletin Canadian Petroleum Geology, v. 26, no. 4, p. 424-514.

Espitalie, J., Madec, M., and Tissot, B., 1977, Source rock characterization method for petroleum exploration: Offshore Technology Conference, 9th, Houston, Tex., May 2-5, 1977, Proceedings, v. 3, p. 439-441.

Falvey, D. A., 1974, The development of continental margins in plate tectonic theory: Australian Petroleum Exploration Association Journal, v. 14, p. 95-106.

Folger, D. W., Hathaway, J. C., Christopher, R. A., Valentine, P. C., and Poag, C. W., 1978, Stratigraphic test well, Nantucket Island, Massachusetts: U.S. Geological Survey Circular 773, 28 p.
Galimov, E. M., 1973, Izotopy ugleroda v neftegazovoy geologii: Moscow, Izdatel'stvo Nedra, 384 p. English translation, 1975, Carbon isotopes in oil-gas geology, 395 p., available from U.S. Department of Commerce, National Technical Information Service, Springfield, VA 22161 , as rept. no. NASA TT F-682.

$1980, \mathrm{C}^{13} / \mathrm{C}^{12}$ in kerogen, chap. 9 of Durand, Bernard, ed., Kerogen, insoluble organic matter from sedimentary rocks: Paris, Techi, p. 271-300.

Gibson, T. G., Hazel, J. E., and Mello, J. F., 1968, Fossiliferous rocks from submarine canyons off northeastern United States: U.S. Geological Survey Professional Paper 600-D, p. D222-D230.

Given, M. M., 1977, Mesozoic and early Cenozoic geology of offshore Nova Scotia: Bulletin of Canadian Petroleum Geology, v. 25, p. 63-91.

Gradstein, F. M., Williams, G. L., Jenkins, W. A. M., and Ascoli, P., 1975, Mesozoic and Cenzoic stratigraphy of the Atlantic continental margin, eastern Canada, in Yorath, C. J., Parker, E. R., and Glass, D. J., eds., Canada's continental margins and offshore petroleum exploration: Canadian Society of Petroleum Geologists, Memoir 4, p. 103-131.

Grow, J. A., 1980, Deep structure and evolution of the Baltimore Canyon Trough in the vicinity of the COST No. B-3 well, in Scholle, P. A., ed., Geological studies of the COST No. B-3 well, United States Mid-Atlantic Continental Slope: U.S. Geological Survey Circular 833, p. 117-126.

Grow, J. A., Bowin, C. O., and Hutchinson, D. R., 1979, The gravity field of the U.S. Atlantic continental margin: Tectonophysics, v. 59, p. 2752.

Grow, J. A., Bowin, C. O., Hutchinson, D. R., and Kent, K. M., 1976, Preliminary free-air gravity anomaly map along the Atlantic continental margin between Virginia and Georges Bank: U.S. Geological Survey Miscellaneous Field Studies Map MF-795, Scale 1:1,200,000.

Grow, J. A., Mattick, R. E., and Schlee, J. S., 1979, Multichannel seismic depth sections and interval velocities over Outer Continental Shelf and upper continental slope between Cape Hatteras and Cape Cod, in Watkins, J. S., Montadert, Lucien, and Dickerson, P. W., eds., Geological and geophysical investigations of continental margins: American Association of Petroleum Geologists Memoir 29, p. 65-83.

Grow, J. A., and Schlee, J. S., 1976, Interpretation and velocity analysis of U.S. Geological Survey multichannel reflection profiles 4,5 , and 6 , Atlantic Continental Margin: U.S. Geological Survey Miscellaneous Field Studies Map MF-808.

Grow, J. A., and Sheridan, R. E., 1981, Deep structure and evolution of the continental margin off the eastern United States, in Geology of continental margins: International Geological Congress, 26th, Paris, July 7-17, 1980, Colloque C3 (Oceanologica Acta, no. SP, supp. to v. 4), p. 11-19.

Hardenbol, J., and Berggren, W. A., 1978, A new Paleogene numerical time scale, in Cohee, G. V., Glaessner, M. F., and Hedberg, H. D., eds., Contributions to the geologic time scale: American Association of Petroleum Geologists, Studies in Geology no. 6, p. 213-234. 
Hathaway, J. C., Poag, C. W., Valentine, P. C., Miller, R. E., Schultz, D. M., Manheim, F. T., Kohout, F. A., Bothner, M. H., and Sangree, D. A., 1979, U.S. Geological Survey core drilling on the Atlantic Shelf: Science, v. 206, no. 4418, p. 515-527.

Hathaway, J. C., Schlee, J. S., Poag, C. W., Valentine, P. C., Weed, E. G. A., Bothner, M. H., Kohout, F. A., Manheim, F. T., Schoen, R., Miller, R. E., and Schultz, D. M., 1976, Preliminary summary of the 1976 Atlantic Margin Coring Project of the U.S. Geological Survey: U.S. Geological Survey Open-File Report 76-844, 217 p.

Haworth, R. T., and MacIntyre, J. B., 1975, The gravity and magnetic field of Atlantic offshore Canada: Canada Geological Survey Paper 75-9 (Canada Hydrographic Service Marine Science Paper no. 16), 22 p.

Heise, B. A., and Jackson, D. S., 1980, Geothermal gradient, in Amato, R. V., and Simonis, E. K., eds., Geologic and operational summary, COST No. G-2 well, Georges Bank area, North Atlantic OCS: U.S. Geological Survey OpenFile Report 80-269, p. 53-55.

Hollister, C. D., Ewing, J. I., Habib, D., Hathaway, J. C., Laucelot, Y., Luterbacher, H. P., Paulus, F. J., Poag, C. W., Wilcoxon, J. A., and Worstell, P., 1972, Site 107-Upper continental rise: in Hollister, C. D., and Ewing, J. I.: Washington, D. C. U.S. Government Printing Office, Initial Reports of the Deep-Sea Drilling Project, v. 11 p. 351-356.

Hunt, J. M., 1967, The origin of petroleum in carbonate rocks, in Bissell, H. J., and Fairbridge, R. W., eds., Carbonate rocks: New York, Elsevier, p. 225-251.

1974, Hydrocarbon and kerogen studies, in van der Borch, C. C., and others, eds., Initial Reports of the Deep Sea Drilling Project, v. 22: Washington, D.C., U.S. Government Printing Office, p. 673-675.

1978, Characterization of bitumens and coals: American Association of Petroleum Geologists Bulletin, v. 62, p. 301-303.

1979, Petroleum geochemistry and geology: San Francisco, W. H. Freeman and Co., 617 p.

International Biostratigraphers, Inc., 1976, Biostratigraphy of the Ocean Production Company COST G-1 Georges Bank test: Houston, Texas, International Biostratigraphers, Inc., 16 p.

1977, Biostratigraphy of the Ocean Production Company COST G-2 Georges Bank test: Houston, Texas, International Biostratigraphers, Inc., 18 p.

Jackson, D. S., and Heise, B. A., 1980, Geothermal gradient, in Amato, R. V., and Bebout, J. W., eds., Geologic and operational summary, COST No. G-1 well, Georges Bank area, North Atlantic OCS: U.S. Geological Survey OpenFile Report 80-268, p. 79-81.

Jansa, L. F., Enos, Paul, Tucholke, B. E., Gradstein, F. M., and Sheridan, R. E. 1979, Mesozoic-Cenozoic sedimentary formations of the North American Basin; western North Atlantic, in Talwani, Manik, Hay, William, and Ryan, W. B. F., eds., Deep drilling results in the Atlantic Ocean-Continental margins and paleoenvironment: Washington, American Geophysical Union, Maurice Ewing Series 3, p. 1-57.

Jansa, L. F., Ramane, J., and Ascoli, P., 1980, Calpionellid and foraminiferal-ostracod biostratigraphy at the Jurassic-Cretaceous boundary, offshore eastern Canada: Rivista Italiana Paleontologia e Stratigrafia, v. 86, p. 67-126.
Jansa, L. F., and Wade, J. A., 1975a, Geology of the continental margin off Nova Scotia and Newfoundland, in van der Linden, W. J. M., and Wade, J. A., eds., Offshore geology of eastern Canada, v. 2, Regional geology: Geological Survey of Canada Paper 74-30, p. 51-105.

1975b, Paleogeography and sedimentation in the Mesozoic and Cenozoic, southeastern Canada, in Yorath, C. J., Parker, E. R., and Glass, D. J., eds., Canada's continental margins and offshore petroleum exploration: Canadian Society of Petroleum Geologists, Memoir 4, p. 79-102.

Judkins, T. W., Simonis, E. K., and Heise, B. A., 1980, Correlation with other wells, in Amato, R. V., and Simonis, E. K., eds., Geological and operational summary, COST No. G-2 well, Georges Bank Area, North Atlantic OCS: U.S. Geological Survey Open-File Report 80-269, p. 33-36.

Kane, M. F., Yellin, M. J., Bell, K. G., and Zietz, Isidore, 1972, Gravity and magnetic evidence of lithology and structure in the Gulf of Maine region: U.S. Geological Survey Professional Paper 726-B, 22 p.

Klitgord, K. D., and Behrendt, J. C., 1977, Aeromagnetic anomaly map of the U.S. Atlantic continental margin: U.S. Geological Survey Miscellaneous Field Studies Map MF-913, 2 sheets, scale 1:1,000,000.

1979, Basin structure of the U.S. Atlantic continental margin, in Watkins, J. S., Montadert, L., and Dickerson, P. W., eds., Geological and geophysical investigations of continental margins: American Association of Petroleum Geologists Memoir 29, p. 85-112.

Klitgord, K. D., and Grow, J. A., 1980, Jurassic seismic stratigraphy and basement structure of western North Atlantic magnetic quiet zone: American Association of Petroleum Geologists Bulletin, v. 64, no. 10, p. $1658-1680$.

Klitgord, K. D., and Schouten, Hans, 1980, The U.S. Atlantic continental margin, fracture zones and basement structures: International Geological Congress, 26th, Paris, France, July 7-17, 1980, Resumes/Abstracts, v. 3 , p. 1344 .

Lachance, D. J., 1980, Lithology, in Amato, R. V., and Bebout, J. W., eds., Geologic and operational summary, COST No. G-1 well, Georges Bank area, North Atlantic OCS: U.S. Geological Survey Open-File Report 80-268, p. 16-22.

Lachance, D. J., and Amato, R. V., 1980, Core descriptions and analyses, in Amato, R. V., and Bebout, J. W., eds., Geologic and operational summary, COST No. G-1 well, Georges Bank area, North Atlantic OCS: U.S. Geological Survey Open-File Report 80-268, p. 27-38.

Lachance, D. J., Bebout, J. W., and Bielak, L., 1980, Depositional environments, in Amato, R. V., and Bebout, J. W., eds., Geological and operational summary, COST No. G-1 well, Georges Bank area, North Atlantic OCS: U.S. Geological Survey Open-File Report 80-268, p. 53-58.

LePichon, Xavier, Sibuet, J. C., and Francheteau, Jean, 1977, The fit of the continents around the North Atlantic Ocean: Tectonophysics, v. 38, p. 169-209.

Lewis, R. S., and Sylvester, R. E., 1977, Shallow sedimentary framework of Georges Bank: American Association of Petroleum Geologists Bulletin, v. 61, p. 808.

Lloyd, A. J., 1962, Polymorphinid, miliolid and rotaliform foraminifera from the type Kimmeridgian: Micropaleontology, v. 8, no. 3, p. 369-383. 
Lopatin, N. V., 1976, K opredeleniyu vliyaniya temperatury i geologicheskogo vremini na katageneticheskiye protsessy uglefikatsii i neftegazoobrazovaniya [Determination of the influence exerted by temperature and geologic time upon catagenic processes of coalification and oil and gas formation], in Vassoyevich, N. B., and Timofeyev, P. P., eds., Issledovaniya organicheskogo veshchestva sovremennykh $\mathrm{i}$ iskopayemykh osadkov: Moscow, Izdatel'stvo Nauka, p. 361-366.

Louis, M. C., and Tissot, B. P., 1967, Influence de la temperature at de la pression sur la formation des hydrocarbures dans les argiles a kerogene: World Petroleum Congress, 7th, Mexico, 1967, Proceedings, v. 2, p. 47-60.

Malinowski, M. J., 1980, Core descriptions and analyses, in Amato, R. V., and Simonis, E. K., eds., Geologic and operational summary, COST No. G-2 well, Georges Bank area, North Atlantic OCS: U.S. Geological Survey OpenFile Report 80-269, p. 57-76.

Manspeizer, Warren, Puffer, J. H., and Cousminer, H. L., 1978, Separation of Morocco and eastern North America-A Triassic-Liassic stratigraphic record: Geological Society of America Bulletin, v. 89, p. 901-920.

Mattick, R. E., and Bayer, K. C., 1980, Geologic setting and hydrocarbon exploration activity, in Scholle, P. A., ed., Geological studies of the COST No. B-3 well, United States Mid-Atlantic continental slope area: U.S. Geological Survey Circular 833, p. 4-12.

Mattick, R. E., Foote, R. Q., Weaver, N. L., and Grim, M. S., 1974, Structural framework of the U.S. Atlantic Outer Continental Shelf north of Cape Hatteras: American Association of Petroleum Geologists Bulletin, v. 58, p. $1179-1190$.

Mattick, R. E., Girard, O. W., Jr., Scholle, P. A., and Grow, J. A., 1978, Petroleum potential of U.S. Atlantic slope, rise, and abyssal plain: American Association of Petroleum Geologists Bulletin, v. 62, no. 4, p. 592-608, 8 figs.

Mattick, R. E., Schlee, J. S., and Bayer, K. C., 1981, The geology and hydrocarbon potential of the Georges Bank-Baltimore Canyon area, in Kerr, J. W., and Fergusson, A.J., eds., Canadian Atlas of North American Borderlands: Canadian Society of Petroleum Geologists Memoir 7, p. 461-486.

McIver, N. L., 1972, Cenozoic and Mesozoic stratigraphy of the Nova Scotia Shelf: Canadian Journal of Earth Sciences, v. 9, p. 54-70.

McKenzie, Dan, 1978, Some remarks on the development of sedimentary basins: Earth and Planetary Science Letters, v. 40, p. 25-32.

Miller, R. E., Schultz, D. M., Claypool, G. E., Smith, M. A., Lerch, H. E., Ligon, D., Gary, C., and Owings, D. K., 1979, Organic geochemistry, in Scholle, P. A., ed., Geological studies of the COST GE-1 well, United States South Atlantic Outer Continental Shelf area: U.S. Geological Survey Circular 800, p. 74-92.

Miller, R. E., Schultz, D. M., Claypool, G. E., Smith, M. A., Lerch, H. E., Ligon, D., Owings, D. K., and Gary, C., 1980, Organic geochemistry, in Scholle, P. A., ed., Geological Studies of the COST No. B-3 well, United States Mid-Atlantic Continental Slope area: U.S. Geological Survey Circular 833, p. 85-104.
Oldale, R. N., Hathaway, J. C., Dillon, W. P., Hendricks, J. D., and Robb, J. M., 1974, Geophysical observations on the northern part of the Georges Bank and adjacent basins of the Gulf of Maine: American Association of Petroleum Geologists Bulletin, v. 58, no. 12, p. 2411-2427.

Pessagno, E. A., Jr., 1967, Upper Cretaceous planktonic foraminifera from the western Gulf Coastal Plain: Palaeontographica Americana, v. 5, p. 245-445.

Peterson, R. A., Fillipone, W. R., and Coker, F. B., 1955, The synthesis of seismograms from well log data: Geophysics, v. 20, p. 516-538.

Pitman, W. C., III, 1978, Relationship between eustacy and stratigraphic sequences of passive margins: Geological Society of America Bulletin, v. 89, no. 9, p. 1389-1403.

Poag, C. W., 1978, Stratigraphy of the Atlantic Continental Shelf and Slope of the United States: Annual Review of Earth and Planetary Sciences, v. 6, p. 251-280.

1980a, Foraminiferal stratigraphy and paleoecology, in Mattick, R. E., and Hennessy, J. L., eds., Structural framework, stratigraphy, and petroleum geology of the area of Oil and Gas Lease Sale No. 49 on the U.S. Atlantic Continental Shelf and Slope: U.S. Geological Survey Circular 812, p. 35-48.

$1980 \mathrm{~b}$, Foraminiferal stratigraphy, paleoenvironments, and depositional cycles in the outer Baltimore Canyon trough, in Scholle, P. A., ed., Geological studies of the COST No. B-3 well, United States Mid-Atlantic Continental Slope area: U.S. Geological Survey Circular 833, p. 44-65.

Poag, C. W., and Hall, R. E., 1979, Foraminiferal biostratigraphy, paleoecology, and sediment accumulation rates, in Scholle, P. A., ed., Geological studies of the COST GE-1 well, United States South Atlantic Outer Continental Shelf area: U.S. Geological Survey Circular 800 , p. 49-63.

Pusey, W. C., III, 1973, The ESP-kerogen method-How to evaluate potentiai gas and oil source rocks: World Oil, v. 176, no. 5 (April 1), p. 71-75.

Rabinowitz, P. D., 1974, The boundary between oceanic and continental crust in the western North Atlantic, in Burk, C. A., and Drake, C. L., eds., The geology of continental margins: New York, Springer-Verlag, p. 67-84.

Rabinowitz, P. D., and LaBreque, J. L., 1977, The isostatic gravity anomaly-Key to the evolution of the oceancontinent boundary at passive continental margins: Earth and Planetary Science Letters, v. 35, p. 145-150.

Robbins, E. I., and Rhodehamel, E. C., 1976, Geothermal gradients help predict petroleum potential of Scotian shelf: Oil and Gas Journal, v. 74, no. 9 (March 1), p. 143-145.

Royden, Leigh, Sclater, J. G., and von Herzen, R. P., 1980, Continental margin subsidence and heat flow-Important parameters in formation of petroleum hydrocarbons: American Association of Petroleum Geologists Bulletin, v. 64, p. 173-187.

Ryan, W. B. F., Cita, M. B., Miller, E. L., Hanselman, D., Nesteroff, W. D., Hecker, B., and Nibblelink, M., 1978, Bedrock geology in New England Submarine Canyons: Oceanologica Acta, v. 1, p. 233-254.

Sawyer, D. S., Swift, A., and Sclater, J. G., and Toksoz, M. N., Extensional model for the subsidence of the northern United States Atlantic continental margin: Geology [in press]. 
Schlee, J. S., Behrendt, J. C., Grow, J. A., Robb, J. M., Mattick, R. E., Taylor, P. T., and Lawson, B. J., 1976, Regional framework off northeastern United States: American Association of Petroleum Geologists Bulletin, v. 60, no. 6, p. 926-951.

Schlee, J. S., Dillon, W. P., and Grow, J. A., 1979, Structure of the continental slope off the eastern United States, in Doyle, L. J., and Pilkey, O. H., eds., Geology of continental slopes: Society Economic Paleontologists and Mineralogists Special Paper 27, p. 95-118.

Schlee, J. S., and Jansa, L. F., 1981, The paleoenvironment and development of the eastern North American continental margin, in Geology of continental margins: International Geological Congress, 26th, Paris, July 7-17, 1980, Colloque C3 (Oceanologica Acta, no. SP, supp. to v. 4), p. 71-80.

Scholle, P. A., 1977a, Data summary and petroleum potential, in Scholle, P. A., ed., Geological studies on the COST No. B-2 well, U.S. Mid-Atlantic Outer Continental Shelf area: U.S. Geological Survey Circular 750, p. 8-14.

ed., 1977b, Geological studies on the COST No. B-2 well, U.S. Mid-Atlantic Outer Continental Shelf area: U.S. Geological Survey Circular 750, 71 p.

ed., 1979, Geological studies of the COST GE-1 well, United States South Atlantic Outer Continental Shelf area: U.S. Geological Survey Circular 800,114 p.

1980, Geological studies of the COST No. B-3 well, United States Mid-Atlantic Continental Slope area: U.S. Geological Survey Circular 833, 132 p.

Scholle, P. A., Krivoy, H. L., and Hennessy, J. L., 1980, Summary chart of geological data from the COST No. G-1 well, U.S. North-Atlantic Outer Continental Shelf: U.S. Geological Survey Oil and Gas Investigations Chart OC-104, 1 sheet.

Scholle, P. A., Schwab, K. A., and Krivoy, H. L., 1980, Summary chart of geological data from the COST No. G-2 well, U.S. North Atlantic Continental Shelf: U.S. Geological Survey Oil and Gas Investigations Chart OC- 105,1 sheet.

Sengbush, R. L., Lawrence, P. L., and McDonal, F. J., 1961, Interpretation of synthetic seismograms: Geophysics, v. 26, p. $45-58$.

Sheridan, R. E., Grow, J. A., Behrendt, J. C., and Bayer, K. C., 1979, Seismic refraction study of the continental edge off the eastern United States: Tectonophysics, v. 59, $1-26$.

Simonis, E. K., 1979, Petroleum potential, in Amato, R. V., and Simonis, E. K., eds., Geological and operational summary, COST No. B-3 well, Baltimore Canyon trough area, Mid-Atlantic OCS: U.S. Geological Survey OpenFile Report 79-1159, p. 100-105.

1980, Lithologic description, in Amato, R. V., and Simonis, E. K., eds., Geologic and operational summary, COST No. G-2 well, Georges Bank area, North Atlantic OCS: U.S. Geological Survey Open-File Report 80-269, p. 14-19.

Smith, M. A., 1980, Geochemical analysis, in Amato, R. V., and Simonis, E. K., eds., Geologic and operational summary, COST No. G-2 well, Georges Bank area, North Atlantic OCS: U.S. Geological Survey Open-File Report 80-269, p. 77-99.
Smith, M. A., and Shaw, D. R., 1980, Geochemical analysis, in Amato, R. V., and Bebout, J. W., eds., Geologic and operational summary, COST No. G-1 well, Georges Bank area, North Atlantic OCS: U.S. Geological Survey OpenFile Report 80-268, p. 82-91.

Stahl, W. J., 1978, Source rock-crude oil correlation by isotopic type curve: Geochimica et Cosmochimica Acta, v. 42 , p. $1573-1577$.

Stainforth, R. M., Lamb, J. L., Luterbacker, Hanspeter, Beard, J. H., and Jeffords, R. M., 1975, Cenozoic planktonic foraminiferal zonation and characteristics of index forms: University of Kansas Paleontological Contributions, art. 62, p. 1-162e; Appendix, p. 163-425.

Steckler, M. S., and Watts, A. B., 1978, Subsidence of the Atlantic-type continental margin of New York: Earth and Planetary Science Letters, v. 41, p. 1-13.

Steinkraus, W. E., 1980, Biostratigraphy, in Amato, R. V., and Bebout, J. W., eds., Geologic and operational summary, COST No. G-1 well, Georges Bank area, North Atlantic OCS: U.S. Geological Survey Open-File Report 80-268, p. 39-52.

Swetland, P. J., Patterson, J. M., and Claypool, G. E., 1978, Petroleum source-bed evaluation of Jurassic Twin Creek Limestone, Idaho-Wyoming thrust belt: American Association of Petroleum Geologists Bulletin, v. 62, p. 1075-1080.

Talwani, Manik, and Eldholm, Olav, 1973, Boundary between continental and oceanic crust at the margin of rifted continents: Nature, v. 241, p. 325-330.

Taner, M. T., and Koehler, F., 1969, Velocity spectra digital computer derivation and applications of velocity functions: Geophysics, v. 34, p. 792-812.

Taylor, P. T., Zietz, Isidore, and Dennis, L. S., 1968, Geologic implications of aeromagnetic data for the eastern continental margin of the United States: Geophysics, v. 33, p. 755-780.

Tissot, B., Demaison, G., Masson, P., Delteil, J. R., and Combaz, A., 1980, Paleoenvironment and petroleum potential of Middle Cretaceous black shales in Atlantic basins: American Association of Petroleum Geologists, Bulletin, v. 64, p. 2051-2063.

Tissot, B., Deroo, G., and Herbin, J. P., 1979, Organic matter in Cretaceous sediments of the North Atlantic-Contribution to sedimentology and paleogeography, in Talwani, Manik, Hay, William, and Ryan, W. B. F., eds., Deep drilling results in the Atlantic Ocean-Continental margins and paleoenvironments: Washington, American Geophysical Union, Maurice Ewing Series 3, p. 362-374.

Tissot, B., Durand, B., Espitalie, J., and Combaz, A., 1974, Influence of nature and diagenesis of organic matter in formation of petroleum: American Association of Petroleum Geologists Bulletin, v. 58, no. 3, p. 499-506.

Tissot, B. P., and Welte, D. H., 1978, Petroleum formation and occurrence, a new approach to oil and gas exploration: New York, Springer-Verlag, $538 \mathrm{p}$.

Tucholke, B. E., 1979, Relationships between acoustic stratigraphy and lithostratigraphy in the western North Atlantic basin, in Tucholke, B. E., and Vogt, P. R., and others, Initial reports of the Deep Sea Drilling Project: Washington, U.S. Government Printing Office, v. 43, p. 827-846. 
Tucholke, B. E., and Mountain, G. S., 1979, Seismic stratigraphy, lithostratigraphy and paleosedimentation patterns in the North American Basin, in Talwani, Manik, Hay, William, and Ryan, W. B. F., eds., Deep drilling results in the Atlantic Ocean-Continental margins and paleoenvironment: Washington, American Geophysical Union, Maurice Ewing Series 3, p. 58-86.

Tucholke, B. E., and Vogt, P. R., 1979, Western North Atlantic-Sedimentary evolution and aspects of tectonic history, in Tucholke, B. E., Vogt, P. R., and others, 1979, Initial reports of the Deep Sea Drilling Project: Washington, U.S. Government Printing Office, v. 43, p. 791-825.

Uchupi, Elazar, 1966, Structural framework of the Gulf of Maine: Journal of Geophysical Research, v. 71, p. 3013-3028.

Uchupi, Elazar, Austin, J. A., Jr., and Gever, D. H., PreCenozoic faulting in the eastern end of Georges Bank: [in press].

Uchupi, Elazar, Ballard, R. D., and Ellis, J. P., 1977, Continental Slope and upper rise off western Nova Scotia and Georges Bank: American Association of Petroleum Geologists Bulletin, v. 61, p. 1483-1492.

U.S. Naval Oceanographic Office, 1966, Total magnetic intensity aeromagnetic survey 1964-1966-U.S. Atlantic coastal region: Washington, D.C., U.S. Naval Oceanographic Office, 15 sheets, scale 1:500,000.

Vail, P. R, and Mitchum, R. M., Jr., 1979, Global cycles of relative changes of sea level from seismic stratigraphy, in Watkins, J. S., Montadert, L., and Dickerson, P. W., Geological and geophysical investigations of continental margins: American Association of Petroleum Geologists Memoir 29, p. 469-472.

Vail, P. R., Mitchum, R. M., Jr., Todd, R. G., Widmier, J. M., Thompson, S., III, Sangree, J. B., Bubb, J. N., and Hatelid, W. G., 1977, Seismic stratigraphy and global changes of sea level, in Payton, C. E., ed., Seismic stratigraphy-Applications to hydrocarbon exploration: American Association of Petroleum Geologists Memoir 26 , p. 49-212.

Valentine, P. C., 1980, Calcareous nannofossil biostratigraphy, paleonvironments, and post-Jurassic continental margin development, in Scholle, P. A., ed., Geological studies of the COST No. B-3 well, United States MidAtlantic continental slope area: U.S. Geological Survey Circular 833, p. 67-83.

1981, Continental margin stratigraphy along U.S. Geological Survey seismic line 5-Long Island platform and western Georges Bank basin: U.S. Geological Survey Miscellaneous Field Studies Map MF-857.
Valentine, P. C., Uzmann, J. R., and Cooper, R. A., 1980, Geology and biology of Oceanographer submarine canyon: Marine Geology, v. 38, p. 283-312.

van Hinte, J. E., 1976a, A Jurassic time scale: American Association of Petroleum Geologists Bulletin, v. 60, p. 489-497.

1976b, A Cretaceous time scale: American Association of Petroleum Geologists Bulletin, v. 60, p. 498-516.

Van Houten, F. B., 1977, Triassic-Liassic deposits of Morocco and eastern North American-Comparison: American Association of Petroleum Geologists Bulletin, v. 61, p. 79-99.

Vassoyevich, N. B., Korchagina, Yu. I., Lopatin, N. V., and Chernyshev, V. V., 1970, Glavanaya faza nefteobrazovaniya [Principal phase of oil formation]: Moskovskogo Universiteta Vestnik, Series 4, Geologii, v. 24, no. 6, p. 3-27; English translation in International Geology Review, v. 12, no. 11, p. 1276-1296.

Wade, J. A., 1977, Stratigraphy of Georges Bank basinInterpretation from seismic correlation to the western Scotian Shelf: Canadian Journal Earth Science, v. 14, no. 10, p. 2274-2283.

Waetjan, H. H., 1980, Seismic velocity and reflection correlation, in Amato, R. V., and Simonis, E. K., eds., Geologic and operational summary, COST No. G-2 well, Georges Bank area, North Atlantic OCS: U.S. Geological Survey Open-File Report 80-269, p. 37-44.

Waples, D. W., 1980, Time and temperature in petroleum formation-Application of Lopatin's method to petroleum exploration: American Association of Petroleum Geologists Bulletin, v. 64, p. 916-926.

Watts, A. B., and Steckler, M. S., 1979, Subsidence and eustasy at the continental margin of eastern North America, in Talwani, Manik, Hay, William, and Ryan, W. B. F., eds., Deep drilling results in the Atlantic Ocean-Continental margins and paleoenvironment: Washington, American Geophysical Union, Maurice Ewing Series 3, p. 218-234.

Weed, E. G. A., Minard, J. P., Perry, W. J., Jr., Rhodehamel, E. C., and Robbins, E. I., 1974, Generalized prePleistocene geologic map of the northern United States continental margin: U.S. Geological Survey Miscellaneous Geologic Investigations Map I-861, scale $1: 1,000,000$.

Worzel, J. L., and Shurbet, G. L., 1955, Gravity anomalies at continental margins: National Academy of Sciences, Proceedings, v. 41, p. 458-469.

Yen, T. F., 1972, Terrestrial and extraterrestrial stable organic molecules, in Landel, R. F., and Rembuum, A., eds., Chemistry in space: New York, Elsevier, p. 105-153. 
